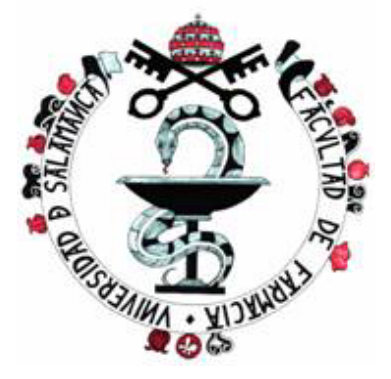

\title{
LA VIA DE RAS EN \\ UN MODELO DE FIBROSIS \\ RENAL EXPERIMENTAL
}

\section{M $^{\mathbf{a}}$ Teresa Grande Rodríguez 2009}

Director: José Miguel López Novoa 

Memoria presentada por $M^{a}$ Teresa Grande Rodríguez para la obtención del Grado de Doctor por la Universidad de Salamanca

Salamanca, de Marzo de 2009

Fdo. $M^{a}$ Teresa Grande Rodríguez 



\section{DEPARTAMENTO DE FISIOLOGÍA Y}

FARMACOLOGÍA

VNIVERSIDAD

DSALAMANCA

DR. D. RAFAEL JIMÉNEZ FERNÁNDEZ, DIRECTOR DEL DEPARTAMENTO DE FISIOLOGÍA Y FARMACOLOGÍA DE LA UNIVERSIDAD DE SALAMANCA

\section{CERTIFICA:}

Que el presente trabajo, elaborado por la Lda. M $\mathrm{M}^{\mathrm{a}}$ Teresa Grande Rodríguez para optar al Grado de Doctor, con el título: “LA VIA DE RAS EN UN MODELO DE FIBROSIS RENAL EXPERIMENTAL", ha sido realizado bajo la dirección del Doctor D. José Miguel López Novoa, en el Departamento de Fisiología y Farmacología de la Universidad de Salamanca.

Y para que así conste, expido y firmo el presente certificado en Salamanca, a de Marzo de 2009 

DR. D. JOSÉ MIGUEL LÓPEZ NOVOA, PROFESOR CATEDRÁTICO DE FISIOLOGÍA DEL DEPARTAMENTO DE FISIOLOGÍA Y FARMACOLOGÍA DE LA UNIVERSIDAD DE SALAMANCA.

\section{CERTIFICA:}

Que el presente trabajo, titulado "LA VIA DE RAS EN UN MODELO DE FIBROSIS RENAL EXPERIMENTAL" presentado por Dña. $\mathbf{M}^{\mathbf{a}}$ Teresa Grande Rodríguez para optar al Grado de Doctor, ha sido realizado bajo mi dirección en el Departamento de Fisiología y Farmacología de la Universidad de Salamanca, y considero que cumple las condiciones necesarias, autorizando su presentación a fin de que pueda ser defendido ante el tribunal correspondiente.

Y para que así conste, expide y firma el presente certificado en Salamanca, a de Marzo de 2009 

Este trabajo ha sido financiado por el Ministerio de Ciencia y Tecnología a través de los proyectos SAF2003-04177 y SAF2007-63893, el Instituto Carlos III a través del proyecto RETIC (RedIn-Ren) RD/006/0016, la Junta de Castilla y León mediante los proyectos SA001/C05 y SAN191/SA04/06 y la Fundación Renal Iñigo Álvarez de Toledo. 

Esta memoria ha sido fruto del trabajo de muchas personas, por eso quiero aprovechar este espacio para expresar mi más sincero aprecio por ellos.

En primer lugar y porque este trabajo no habría sido posible sin su dirección, su supervisión y diseño, a mi director, Dr. José Miguel López-Novoa. Gracias por darme la oportunidad de trabajar en tu equipo, por tu ayuda, tu paciencia, tus consejos, y sobretodo, por transmitirme tu entusiasmo por la investigación. Para mi ha sido un honor realizar este trabajo bajo su dirección.

También agradezco al Dr. Fernando Pérez-Barriocanal todo su apoyo, por confiar en mí, por sus consejos y su optimismo, por su profesionalidad e interés.

Al Dr. Miguel Arévalo, quien ha participado muy activamente en este trabajo, por su gran profesionalidad y por su gran calidad humana, y por supuesto a Guti, por su experta dedicación en las técnicas histológicas. También quiero agradecer este trabajo a la Dra. Ana I Morales, por sus consejos, su apoyo y por ser tan cercana. A la Dra. Alicia Rodríguez-Barbero por prestarme ayuda siempre que lo he necesitado y por sus ánimos, y al Dr. Francisco López-Hernández.

Este trabajo comenzó hace unos años, en la compañía de Ana, quién me enseñó el mundo del western y algunas manías, de Neil (escocés, que no inglés, de quien aprendí mucho) y de Annette, (compendio de técnicas de laboratorio). Y con el resto del grupo, Juana (\& Roberto), Marta (de nuevo aqui), Mirjana, César y Dele, con los que sigo teniendo contacto y tengo muy buenos recuerdos de ellos.

Quiero darles las gracias a mis amigos del laboratorio, a Penélope, una gran amiga y una gran compañera, por toda la ayuda que me has prestado, por alegrarte de mis éxitos y animarme en los fracasos, por nuestros cafeses, nuestros congresos, bailes, cursos, ratas, ratones y westerns, en fin, por lo bien que nos lo hemos pasado. A Begoña, porque me has enseñado y ayudado mucho, por estar siempre ahí, por ser tan dulce, por Daniela, por ser como eres, no cambies nunca. A Rodri (Dr. Morchón), por demostrarme que eres un amigo de los de verdad, por hacerme reír tanto (y enfadar), por ser tan sincero conmigo, por escucharme. A Laura, por lo bien que lo hemos pasado, por estar a mi lado, por estar siempre dispuesta para ayudar. A Soraya (Dra. Velasco), me 
quedo con los buenos ratos que hemos vivido juntas y todos los momentos que nos hemos apoyado, reído, soñado e imaginado juntas. Gracias también a mis compañeros de laboratorio: Rebeca (investigating USA), Yaremi (ya tu sabes), Lucia (super genotipadora), Andrea (sin imitaciones), Isabel (compi de prácticas y de Ras), Ma José, Sandra, Omar, Miguel, Bárbara, María, Nieves y Carlos. A mis excompañeros: Gabriela y Fernando Dorado.

También quiero dar las gracias al Dr. Vincent Sauzeau, a Alex Núñez y al Dr. García Criado, por nuestras charlas tan amenas y por vuestra ayuda desinteresada. Gracias también por la ayuda prestada por todo el laboratorio de patología del CIC, en especial a Teresa, Verónica, Montse y Susana.

Muchas gracias a todo el personal del servicio de experimentación animal, en especial a Luis Muñoz, a Álvaro y a Carmen. No sin olvidarme de quienes hacen posible que yo haga mis experimentos cuidando día tras día de los ratoncines, a Jose Fernando, Juan, Jorge, Narci y Elena. Por supuesto a Luisa, por tu compañía durante aquellas tardes que se alargaban de más.

A mis amigos, Isabel, Roberto y María (IE),y Esther ( $y$ fir). Por lo bien que nos lo hemos pasado juntos durante tantos y tantos ratos. Gracias.

Y por último, a los más importantes. Quiero agradecer a mi familia el inmenso amor que me han demostrado siempre, día tras día. A mi padre, por todo lo que representa para mí, por enseñarme a esforzarme y a trabajar con energía. A mi madre, porque es un modelo en el que inspirarme cada día y porque sin ti nada sería posible. A mi hermano por ser mi otro yo. A mis abuelas y abuelos (os llevo en el corazón). A toda mi familia.

Muchas Gracias. 
"Existe al menos un rincón del universo que con toda seguridad puedes mejorar, y eres tú mismo".

Aldous Huxley 



\section{A mi familia}




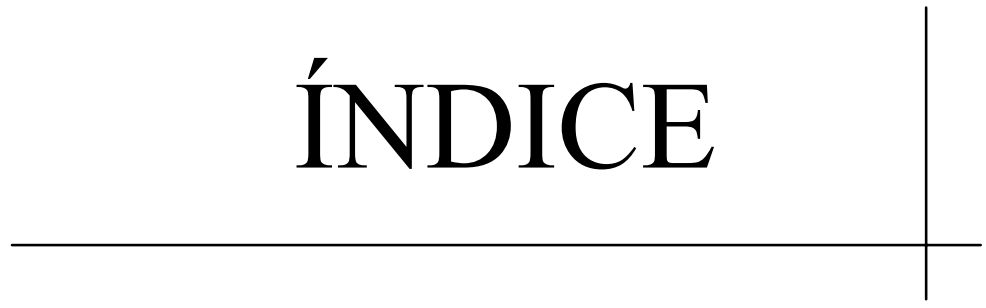



Las isoformas de Ras en la nefropatía obstructiva

Therapeutical relevance of MAP-kinase inhibitors in renal diseases: Current knowledge and Future Clinical Perspectives

Myofibroblast activation in obstructive nephropathy. A new therapeutic target

Role of inflammation in tubulo-interstitial damage associated to obstructive nephropathy

Extracellular matrix deposition and apoptosis during obstructive nephropathy

\section{RESULTADOS Y DISCUSIÓN}

Activation of Erk1/2 and Akt following unilateral ureteral obstruction

Contribution of Angiotensin II and Ras signalling pathway activation to early renal interstitial changes induced by obstructive nephropathy in mice

Targeted genomic disruption of H-ras and N-ras has no effect on early renal changes after unilateral ureteral ligation

Targeted genomic disruption of H-Ras decreases renal fibrosis and myofibroblast activation after unilateral ureteral obstruction in mice

$\mathrm{K}$-ras is involved in renal cell apoptosis and proliferation induced by unilateral ureteral obstruction in mice

Papel de la isoforma K-ras4A en la fibrosis tubulointersticial inducida por la obstrucción ureteral en ratón 
ABREVIATURAS 

ACE: Enzima convertidora de angiotensina.

Akt: Oncogén aislado de tumores producidos por el retrovirus murino AKT8.

Ang II: Angiotensina II.

APS: Persulfato amónico.

$\mathbf{A T}_{1}$ : Receptor tipo 1 de angiotensina II.

$\mathbf{A T}_{2}$ : Receptor tipo 2 de angiotensina II.

BAD: Inductor de muerte asociado a Bcl-2; Bcl-2-associated death promoter.

BMP: Bone morphogenic proteins.

BSA: Albúmina bovina sérica.

CBF-A: CArG box-binding factor-A.

COX: Ciclooxigenasa.

CRF: Enfermedad Renal Crónica; Chronic Renal Failure.

CTGF: Factor de crecimiento de tejido conjuntivo; Connective tissue growth factor.

Cys: Cisteína.

DAB: 3,3'-diaminobenzidina.

DAG: Diacilglicerol.

ECA: Enzima convertidora de angiotensina.

ECL: Intensificador de quimioluminiscencia; Enhanced Chemiluminescent.

ECM: Matriz Extracelular; Extracellular Matrix.

EDTA: Ácido etileno diamino tetracético.

EEM: Error estándar de la media.

EGF: Factor de crecimiento epidérmico; Epidermal growth factor.

Elk-1: Gen similar a Ets; Ets-like gene 1.

EMT: Ephitelial Mesenchymal Transition.

eNOS: Sintasa de óxido nítrico endotelial.

ERK: Proteína kinasa regulada por señales extracelulares; Extracellular signal-regulated protein kinase.

FGF: Fibroblast growth factor.

FSP-1: Fibroblast specific protein-1

FST-1: Fibroblast transcription site-1.

FTI: Inhibidores de farnesil transferasa.

GAG: Glucosaminoglucanos.

GAPs: Proteínas activadoras de GTPasas; Guanosine triphosphatase activating proteins. 
GBM: Glomerular basement membrane.

GDP: Guanosina 5'difosfato.

GEFs: Proteínas intercambiadoras de nucleótidos de guanina; Guanine nucleotide exchange factors.

Grb2: Proteína de unión a receptores de factores de crecimiento 2; Growth factor receptor binding protein 2.

GSK-3ß: Glycogen synthase kinase $3 \beta$.

GTP: Guanosina 5'trifosfato.

GTPasa: Guanosina trifosfatasa.

HEPES: ácido N-(2-hidroxietil)piperazina-N'-(4-butasulfónico).

HGF: Hepatocyte growth factor.

HIF-1: Hypoxia inducible factor-1.

HO-1: Heme oxigenase-1.

HPR: Peroxidasa de rábano picante; Horse-radish peroxidase.

HSP27: Heat-shock protein 27

ICAM: Intercellular adhesion molecule-1.

IECAs: Inhibidores de la ECA.

IGF: Factor de crecimiento tipo insulina; Insulina-like growth factor.

IH: Inmunohistoquímica.

IKK: I kappaB kinasa

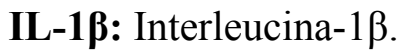

ILK: Integrin-linked kinase.

JNK: Kinasa N-terminal de jun; Jun $\mathbf{N}$-terminal kinase.

kDa: Kilodalton.

KO: Knock out.

L: Riñón ligado.

MAPKKs: MAPK de kinasas.

MAPKs: Proteínas kinasas activadas por mitógenos; Mitogen-activated protein kinases.

MC: Mesangial cell.

MCP-1: Monocyte chemoattractant protein-1.

MCS-F: Macrophage colony-stimulating factor-1.

MEK: kinasa MAPK/ERK.

MIF: Macrophage migratory inhibitory factor. 
MLB: Tampón de lisis con magnesio; Magnesium-containing Lysis Buffer.

MMP: Matrix metalloproteinases.

NF-кB: Factor nuclear kappa B; Nuclear Factor kappa B

NL: Riñón no ligado.

NO: Riñón no obstruido.

O: Riñón obstruido.

OPN: Osteopontin.

OUU: Obstrucción ureteral unilateral.

p70 $^{\text {S6K }}$ : Proteína S6 kinasa ribosomal.

PAI: Inhibidor de la activación de plasminógeno; Plasminogen activator inhibitor.

PAN: puromycin aminonucleoside.

PBS: Solución salina tamponada con fosfatos.

PDGF: Factor de crecimiento derivado de plaquetas; Platelet-derived growth factor.

PDKs: Kinasas dependientes de fosfoinositoles.

PGE: Prostaglandina E.

PI: Fosfatidilinositol.

PI3K: Fosfatidilinositol-3-kinasa.

PIP $_{2}$ : Fosfatidil-inositol-4,5-bisfosfato

$\mathbf{P I P}_{3}$ : Inositol-1,4,5-trifosfato.

PKB: Proteína kinasa B.

PLA2: Fosfolipasa $\mathrm{A}_{2}$

PLC: Fosfolipasa C.

PLD: Fosfolipasa D.

PMSF: Fluoruro de fenil metil sulfonilo.

Rab: Ras-like proteins in brain.

Raf: Factor activado por ras; ras activated factor.

Ran: Ras-like nuclear.

Ras: Oncogén aislado de sarcomas murinos inducidos por virus; Retrovirus associated sequences.

RBD: Dominio de unión a Ras; Ras Binding Domain.

Rho: Ras homologous.

ROCK: Rho-associated coiled coil-containing protein kinase.

SDS: Dodecil sulfato sódico. 
SEM: Error stándard de la media.

Ser: Serina.

Shc: Colágeno homólogo a Src; Src-homology collagen protein

SO: Sham operated kidneys.

Sos: Son of sevenless.

Src: Oncogén derivado del virus de sarcoma de Rous.

SRF: Factor de respuesta sérica; Serum response factor.

TBM: Tubular basement membrane.

TEMED: N,N,N',N'-tetrametildiamina.

TFG: Tasa de filtración glomerular.

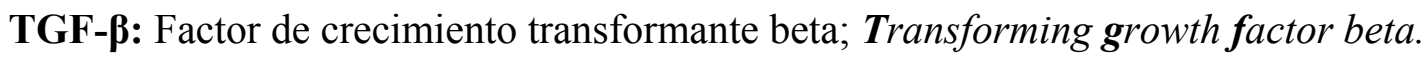

TK: Tirosina kinasa.

TNF- $\alpha$ : Factor de necrosis tumoral alfa.

tPA: tissue Plasminogen activator.

Tris: Tris hidroximetil amino metano.

TTBS: Solución salina con tween tamponada con tris.

TXA $\mathbf{A}_{2}$ : Tromboxano $\mathrm{A}_{2}$.

TXs: Tromboxanos.

uPAR: Receptor urokinase-type plasminogen activator.

UUO: Unilateral ureteral obstruction.

VCAM: Vascular cell adhesion molecule-1.

VEGF: Factor de crecimiento vascular endotelial; Vascular endotelial growth factor.

WB: Western blot.

a-SMA: Alfa-actina de músculo liso vascular; Alpha-smooth muscle actin.

3d: 3 días.

15d: 15 días. 


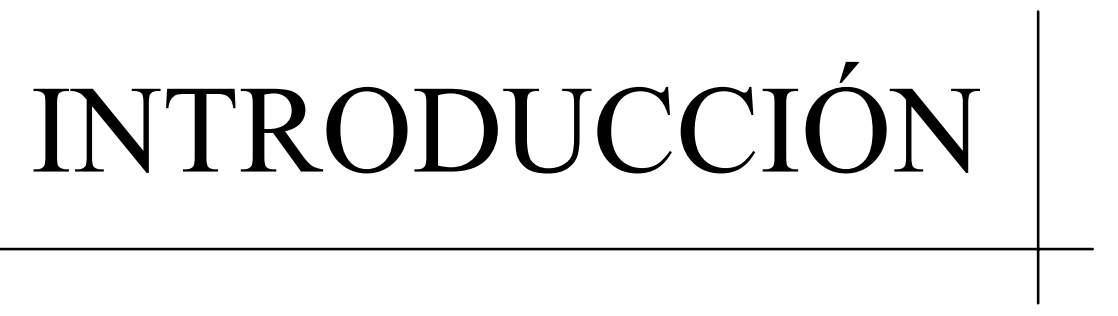





\section{GENERALIDADES}

La fibrosis renal es una característica común de la enfermedad renal crónica independientemente de su etiología. Numerosas citoquinas involucradas en el desarrollo de la fibrosis renal activan Ras. Las diferentes isoformas de Ras regulan numerosos procesos celulares a través de la activación de sus efectores. El papel de las isoformas de Ras en la nefropatía obstructiva está comentado en forma de Editorial (Artículo I). A continuación se ha revisado la relevancia terapéutica de los inhibidores de las MAPKinasas en las enfermedades renales (Artículo II). La obstrucción ureteral unilateral es un modelo experimental de fibrosis tubulointersticial ampliamente utilizado porque mimetiza de forma acelerada los diferentes estados de la nefropatía obstructiva. Se han realizado tres revisiones bibliográficas sobre este modelo experimental, centrándonos primero en la activación de los miofibroblastos observada durante la obstrucción ureteral (Artículo III) a continuación el papel de la inflamación en este modelo experimental de nefropatía obstructiva (Artículo IV) y por último hemos revisado la acumulación de matriz extracelular y la apoptosis observada en la obstrucción ureteral (Artículo V). 


\section{Artículo I}

\section{Editorial}

\section{"Las isoformas de ras en la nefropatía obstructiva"}

M. Teresa Grande and José M. López-Novoa

Nefrología (enviado) 


\section{LAS PROTEINAS RAS}

Las proteínas Ras son pequeñas proteínas monoméricas, con actividad GTPasa muy conservadas a lo largo de la evolución de todos los organismos eucariotas. Estas pequeñas proteínas ejercen gran variedad de funciones celulares como son la regulación de la expresión génica, proliferación celular, migración, organización del citoesqueleto, tráfico intracelular de vesículas y transporte de proteínas entre el núcleo y el citoplasma ${ }^{1}$.

Los genes ras se descubrieron en los años 60 como elementos del virus de la cepa Harvey y Kirsten que producía sarcomas en roedores recién nacidos ${ }^{2,3}$. A principios de los 80 se identificaron distintos alelos mutados de genes ras como oncogenes dominantes presentes en un gran porcentaje de tumores sólidos. En mamíferos las células poseen tres genes cuya estructura y función es muy parecida: $\mathrm{H}$ ras, K-ras y N-ras. Están compuestos por cinco exones codificantes y un exón 5' no codificante, y difieren muy poco en el tamaño y en la secuencia de intrones. Los genes K-ras tienen dos splicing alternativos para el cuarto exón codificante: 4A y 4B, dando lugar a dos proteínas que difieren en 25 aminoácidos del extremo carboxilo terminal ${ }^{4}$. Los genes ras codifican proteínas de 189 aminoácidos (N-Ras, H-Ras y K-Ras4A) y de 188 aminoácidos (K-Ras4B). Las proteínas Ras tienen un alto grado de homología en sus primeros 164 aminoácidos, siendo idénticas en los primeros 86 aminoácidos y con un 79\% de homología en los 78 residuos restantes. Sin embargo, entre los aminoácidos 165 y 185, llamada región heterogénea, son completamente distintas en los 20 aminoácidos carboxilo terminales, a excepción de los 4 aminoácidos del extremo carboxiterminal donde la secuencia Cys186-A-A-X-COOH, (también denominado motivo CAAX, donde $\mathrm{C}$ es una cisteína, $\mathrm{A}$ es un aminoácido alifático y $\mathrm{X}$ un aminoácido cualquiera) está presente en todos los miembros de $\operatorname{Ras}^{5}$ y esta secuencia CAAX, es una señal para el procesamiento por enzimas que añaden un grupo prenilo (farnesilo o geranilgeranilo), facilitando el anclaje de la proteína Ras a la membrana. La heterogeneidad en esta secuencia de 25 aminoácidos ha llevado a que esta zona se llame región hipervariable y se piensa que la variación que existe en esta región debe tener algún efecto funcional ${ }^{6}$. Las diferencias de la región hipervariable en la secuencia primaria de las proteínas Ras determinan distintas modificaciones post-transduccionales y diferencias en el tráfico y situación en la membrana plasmática que, en último término, producen diferencias en la actividad biológica determinada por su localización 
con moléculas que regulan la actividad de Ras como los receptores tirosina quinasa (RTK) o moléculas efectoras de Ras como PI $3 \mathrm{~K}^{7-9}$. Además, mientras la falta de H-Ras y N-Ras no afecta en el desarrollo vital del ratón, K-Ras sí parece ser fundamental para el desarrollo del ratón ya que la deficiencia de K-ras produce la muerte de los embriones ${ }^{10-12}$.

Las proteínas Ras de mamíferos se localizan en la superficie interna de la membrana plasmática ${ }^{13,14}$ localizándose en caveolas o en rafts, regiones lipídicas ricas en colesterol, o en zonas desorganizadas de la membrana ${ }^{15}$ dependiendo de las modificaciones postraduccionales. Así, se sabe que H-Ras está localizada en islotes lipídicos, mientras que K-Ras se localiza en zonas desorganizadas de la membrana ${ }^{16,17}$.

Una vez localizadas en la membrana, las proteínas Ras alternan un equilibrio entre la forma inactiva, unida a GDP, y la forma activa, unida a GTP, que le permite interaccionar con las moléculas efectoras y ejercer sus funciones celulares.

\section{EFECTORES DE LA ACTIVACIÓN DE RAS}

La proteína activada Ras media en la proliferación celular a través de la estimulación de MAPKs (mitogen-activated protein Kinases), activando mediante la serina-treonina quinasa Raf a la proteína ERK1y ERK2, también conocidas como p44y p42- MAPK. La activación de las MAPK en respuesta a estímulos controla la expresión de genes, el metabolismo celular y funciones del citoesqueleto, contribuyendo a la regulación de procesos celulares tan complejos como la migración, la mitogénesis, la diferenciación o la supervivencia celular ${ }^{18}$.

Otra ruta de señalización estimulada por Ras es la vía de la proteína quinasa $B$ (PKB), o Akt mediante la activación de la PI3K. Akt regula la expresión de numerosos genes, induce la síntesis proteica, promueve la supervivencia celular y protege a las células de la apoptosis. Akt ejerce su efecto anti-apoptótico mediante fosforilación de numerosos substratos reduciendo su actividad como BAD, caspasa 9, factores de transcripción como el forkhead factor FKHR1, o E2F, y la quinasa IKK que regula al factor de transcripción NF- $\mathrm{KB}^{19}$.

\section{PAPEL DE LA ACTIVACIÓN DE RAS EN LA PATOLOGÍA RENAL}

La fibrosis renal tiene un papel fundamental en el desarrollo de las enfermedades renales. Existen numerosas citoquinas que activan Ras como Angiotensina II, factor de crecimiento transformante $\beta$ (TGF- $\beta$ ), factor de crecimiento derivado de las plaquetas 
(PDGF), factor de crecimiento epidérmico (EGF), endotelina y trombina y que se encuentran aumentadas en la fibrosis renal y en numerosos modelos experimentales de fibrosis renal ${ }^{20}$. Además la administración de inhibidores de la activación de Ras como los inhibidores de la farnesilación o las estatinas en modelos experimentales de daño renal, disminuyen el daño glomerular, la aterosclerosis y la proliferación. También la administración de inhibidores de la activación de ERK disminuyen el daño renal observado en modelos de glomerulonefritis y de la enfermedad poliquística renal. Se ha encontrado activación de Akt en ratas diabéticas, en modelos de glomeruloesclerosis y de isquemia/reperfusión renal donde la inhibición de la activación de Akt mejora el daño renal ${ }^{20}$.

\section{PAPEL DE LA ACTIVACIÓN DE RAS EN LA NEFROPATIA OBSTRUCTIVA.}

La mayor parte de los estudios que analizan los mecanismos conducentes al daño renal en la nefropatía obstructiva se han realizado en modelos de obstrucción ureteral unilateral en ratas y ratones. La obstrucción ureteral unilateral consiste en una obstrucción aguda y completa del uréter que mimetiza de forma acelerada los diferentes estados de la nefropatía obstructiva dando lugar a fibrosis tubulointersticial. La característica patológica principal del riñón obstruido son las alteraciones tubulointersticiales donde se detecta infiltración de células, apoptosis y proliferación de células tubulares e intersticiales, acumulación de (mio)fibroblastos, atrofia tubular y fibrosis intersticial. Además también se observan alteraciones hemodinámicas, aumento del estrés oxidativo, inflamación e infiltración de leucocitos. La fibrosis intersticial se debe a un aumento de la deposición de la matriz extracelular intersticial por aumento de colágenos, sobre todo I, III y IV, y de fibronectina. Este incremento en la deposición de matriz extracelular se debe al aumento en la población renal de fibroblastos, los cuales provienen de múltiples orígenes ${ }^{21,22}$ : i) células hematopoyéticas, ii) activación de fibroblastos intersticiales residentes iii) células tubulares que se transforman vía transición epitelio-mesenquimal.

Numerosos factores están implicados en la transducción de señales que conllevan al desarrollo de la fibrosis tubulointersticial en la obstrucción ureteral como TGF- $\beta$, activación de NF- $\kappa \mathrm{B}, \mathrm{TNF}-\alpha$, angiotensina II, factores de crecimiento, moléculas de adhesión y quimiocinas. Por su parte, Ras, a través de sus efectores, juega un papel muy importante en la transducción de señales en el riñón de factores como angiotensina $\mathrm{II}^{23}$ y TGF-beta ${ }^{20}$. 
Ras se expresa en el riñón y existe una expresión específica de las isoformas de Ras tanto en el riñón normal como en el riñón dañado tras la obstrucción ureteral ${ }^{24}$. En el riñón de ratón parece que N-Ras y K-Ras se expresan en la corteza interna y en la médula, mientras que H-Ras solo se localiza en la médula. En el riñón humano, N-Ras se localiza específicamente en células epiteliales tubulares, mientras que K-Ras y H-Ras se expresan en células mesangiales, células intersticiales y tubulares ${ }^{25}$. La obstrucción ureteral produce en el riñón obstruido un aumento en la expresión de las 3 isoformas de Ras, tanto en intensidad como en área ocupada. En el riñón obstruido N-Ras y K-Ras se expresan en la zona tubulointersticial de la corteza y médula, mientras que la expresión de H-Ras es granular en las células tubulares pero no en células intersticiales ${ }^{24}$. En estudios previos hemos observado la activación de Ras y de sus efectores tras la obstrucción ureteral, demostrando además una relación entre la activación de los efectores de Ras, ERK y Akt, con los cambios tempranos observados tras la obstrucción ureteral. Precisamente, la activación de ERK está relacionada con la proliferación celular, la apoptosis y la activación de fibroblastos y la activación de Akt está relacionada con la proliferación, la activación de fibroblastos y la producción de matriz extracelular observados después de 3 días de obstrucción ureteral ${ }^{26}$. También se conocen distintas funciones de las isoformas de Ras en estudios llevados a cabo en fibroblastos renales. Por ejemplo H-Ras y N-Ras están involucrados en la producción de matriz extracelular y en la proliferación ${ }^{27}$ y se ha demostrado que K-Ras está implicado también en la regulación de la proliferación celular de fibroblastos renales ${ }^{28}$. Teniendo en cuenta toda la información que existe sobre Ras y la nefropatía obstructiva, sería importante conocer qué posible papel diferencial tiene la activación de las diferentes isoformas de Ras (N-Ras, H-Ras y K-Ras) en el desarrollo de la patología renal asociada a la obstrucción ureteral para estudiar cuales son los mecanismos de regulación que llevan a la pérdida de la función renal y conocer posibles dianas terapéuticas para prevenir el desarrollo de la enfermedad renal durante la obstrucción ureteral. 


\section{Bibliografía}

1. Barandier $\mathrm{C}$, Ming XF, Yang Z. Small G proteins as novel therapeutic targets in cardiovascular medicine. News Physiol Sci 2003; 18:18-22.

2. Harvey JJ. An unidentified virus which causes the rapid production of tumors in mice. Nature 1964; 204: 1104-1105.

3. Kirsten WH, Mayer LA. Morphologic responses to a murine erythroblastosis virus. J Natl Cancer Inst 1967; 39: 311-335.

4. Barbacid M. Ras genes. Annu Rev Biochem 1987; 56: 779-828.

5. Santos E, Nebreda AR. Structural and functional properties of ras proteins. Faseb $J$ 1989; 3: 2151-2163.

6. Ellis CA, Clark G. The importance of being K-Ras. Cell Signal 2000; 12: 425-434.

7. Ehrhardt A, David MD, Ehrhardt GR, Schrader JW. Distinct mechanisms determine the patterns of differential activation of H-Ras, N-Ras, K-Ras 4B, and M-Ras by receptors for growth factors or antigen. Mol Cell Biol 2004; 24: 6311-6323.

8. Hamilton M, Wolfman A. Ha-ras and N-ras regulate MAPK activity by distinct mechanisms in vivo. Oncogene 1998; 16: 1417-1428.

9. Hancock JF. Ras proteins: different signals from different locations. Nat Rev Mol Cell Biol 2003; 4: 373-384.

10. Esteban LM, Vicario-Abejon C, Fernandez-Salguero P, Fernandez-Medarde A, Swaminathan N, Yienger K, Lopez E, Malumbres M, McKay R, Ward JM, Pellicer A, Santos E. Targeted genomic disruption of H-ras and N-ras, individually or in combination, reveals the dispensability of both loci for mouse growth and development. Mol Cell Biol 2001; 21: 1444-1452.

11. Johnson L, Greenbaum D, Cichowski K, Mercer K, Murphy E, Schmitt E, Bronson RT, Umanoff H, Edelmann W, Kucherlapati R, Jacks T. K-ras is an essential gene in the mouse with partial functional overlap with N-ras. Genes Dev 1997; 11: 24682481.

12. Koera K, Nakamura K, Nakao K, Miyoshi J, Toyoshima K, Hatta T, Otani H, Aiba A, Katsuki M. K-ras is essential for the development of the mouse embryo. Oncogene 1997; 15: 1151-1159.

13. Inouye K, Mizutani S, Koide H, Kaziro Y. Formation of the Ras dimer is essential for Raf-1 activation. $J$ Biol Chem 2000; 275: 3737-3740.

14. Santos E, Nebreda AR, Bryan T, Kempner ES. Oligomeric structure of p21 ras proteins as determined by radiation inactivation. J Biol Chem 1988; 263: 98539858.

15. Hancock JF, Paterson H, Marshall CJ. A polybasic domain or palmitoylation is required in addition to the CAAX motif to localize p21 ras to the plasma membrane. Cell 1990; 63: 133-139.

16. Prior IA, Harding A, Yan J, Sluimer J, Parton RG, Hancock JF. GTP-dependent segregation of H-ras from lipid rafts is required for biological activity. Nat Cell Biol 2001; 3: 368-375.

17. Roy S, Luetterforst R, Harding A, Apollini A, Etheridge M, Stang E, Rolls B, Hancock JF, Parton RG. Dominant-negative caveolin inhibits H-ras function by disrupting cholesterol-rich plasma membrane domains. Nat Cell Biol 1999, 1: 98105. 
18. Dhanasekaran N, Premkumar Reddy E. Signaling by dual specificity kinases. Oncogene 1998; 17: 1447-1455.

19. Kim D, Chung J. Akt: versatile mediator of cell survival and beyond. J Biochem Mol Biol. 2002 Jan 31;35(1):106-15.

20. Martínez-Salgado C, Rodríguez-Peña AB, López-Novoa JM. Involvement of small Ras GTPases and their effectors in chronic renal disease. Cell Mol Life Sci 2008; 65: 477-492.

21. Strutz F, Zeisberg M. Renal fibroblasts and myofibroblasts in chronic kidney disease. J Am Soc Nephrol 2006; 17: 2992-2998.

22. Strutz F. How many different roads may a cell walk down in order to become a fibroblast? J Am Soc Nephrol 2008; 19: 2246-2248.

23. Muthalif MM, Karzoun NA, Gaber L, Khandekar Z, Benter IF, Saeed AE, Parmentier JH, Estes A, Malik KU. Angiotensin II-induced hypertension: contribution of Ras GTPase/Mitogen-activated protein kinase and cytochrome P450 metabolites. Hypertension 2000; 36: 604-60.

24. Rodríguez-Peña AB, Santos E, Arévalo M, López-Novoa JM. Activation of small GTPase Ras and renal fibrosis. J Nephrol 2005; 18: 341-349.

25. Kocher HM, Moorhead J, Sharpe CC, Dockrell ME, Al-Nawab M, Hendry BM. Expression of Ras GTPases in normal kidney and in glomerulonephritis. Nephrol Dial Transplant 2003; 18:2284-2292.

26. Rodríguez-Peña AB, Grande MT, Eleno N, Arévalo M, Guerrero C, Santos E, López-Novoa JM. Activation of Erk1/2 and Akt following unilateral ureteral obstruction. Kidney Int 2008; 74: 196-209.

27. Martínez-Salgado C, Fuentes-Calvo I, García-Cenador B, Santos E, López-Novoa JM. Involvement of $\mathrm{H}$ - and N-Ras isoforms in transforming growth factor-beta1induced proliferation and in collagen and fibronectin synthesis. Exp Cell Res 2006; 312: 2093-2106.

28. Sharpe CC, Dockrell ME, Scott R, Noor MI, Cowsert LM, Monia BP, Hendry BM. Evidence of a role for Ki-RAS in the stimulated proliferation of human fibroblasts. J Am Soc Nephrol 1999; 10: 1186-1192. 
Artículo II

Revisión

"Therapeutical Relevance of MAP-kinase Inhibitors in Renal Diseases: Current Knowledge and Future Clinical Perspectives"

M. Teresa Grande and José M. López-Novoa

Current Medicinal Chemistry, 2008, 15, 2054-1070 


\title{
Therapeutical Relevance of MAP-Kinase Inhibitors in Renal Diseases: Current Knowledge and Future Clinical Perspectives
}

\author{
M.Teresa Grande and José M. López-Novoa* \\ Instituto "Reina Sofia" de Investigación Nefrológica, Departamento de Fisiología y Farmacología, Universidad de \\ Salamanca, Salamanca, Spain, Red Cooperativa de Investigación Renal del Instituto Carlos III (RedinRen). Salamanca, \\ Spain
}

Abstract: Renal failure, both acute and chronic, represents an important health problem by its social, sanitary and economic aspects. Mitogen-activated protein kinases (MAPK) are a family of mediators involved in the transduction of extracellular stimuli to in tracellular responses. The best studied members of this family are extracellular signal-regulated kinases 1 and 2 (ERK1 and ERK2), Jun $\mathrm{NH}_{2}$-terminal kinase (JNK), p38 kinase and extracellular signal regulated kinases 5 (ERK5) also known as big MAP Kinase 1 (BMK1). MAPKs plays a role in regulating renal function and all these pathways have been demonstrated to be activated in many "in vivo" and cellular models or renal failure. As MAP kinases are key regulators in the control of cell proliferation and cell death, many more or less specific in hibitors of these pathways are being developed for the treatment of tumors. The purpose of this review is to examine the data available on the role of MAPKs activation in "in vivo" models of renal failure, as well as in different renal cell types (especially in mesangial cells, podocytes, tubular epithelial cells and fibroblasts) subjected to stress or damage. We have also reviewed the effect of MAPKs inhibition on renal damage, both "in vivo" and "in vitro". Data collected allow to suggest that therapy of chronic and acute renal disease with MAPKs inhibitors is a promising therapeutic area, although much more basic and clinical studies are necessary before this kind of therapy can be used in the everyday clinic.

Keywords: Acute renal failure, chronics renal failure, MAPkinase, ERK, JNK, p38kinase, fibroblasts, mesangial cells, podocytes, tubular epithelial cells.

\section{GENERAL CHARACTERISTICS OF RENAL DISEASE}

\subsection{Definitions and Pathogenesis of Renal Failure}

Renal failure is defined as a decline in the kidneys' excretory function, as a consequence of damage to this organ. Renal failure can be classified as acute or chronic renal failure.

Acute renal failure (ARF) is defined conceptually as a rapid (hours to weeks) and usually reversible decline in GFR [1]. The causes of ARF can be grouped into three major categories: decreased renal blood flow (pre-renal causes), direct renal parenchymal damage (intrinsic renal causes), and obstruction of the urine ways (post-renal or obstructive causes). Pre-renal failure is associated to hypotension, treatment with drugs such as diuretics, non-steroidal antiinflammatory drugs or cyclo-oxygenase 2 inhibitors, and angiotensin converting enzyme inhibitors or angiotensin II (Ang-I) receptor antagonists, in settings such as renal artery stenosis. Overall, the most common cause of ARF is acute tubular necrosis. Postoperative acute tubular necrosis accounts for up to $25 \%$ of cases of hospital-acquired ARF, mostly resulting from prerenal causes. Another common cause of hospital-acquired ARF is acute radiocontrast nephropathy. Other causes are administration or casual ingestion of toxic drugs or substances such as aminoglycoside antibiotics, antitumoral agents (cisplatin), compounds containing mercury or lead, or other toxic products with largely renal excretion.

*Address correspondence to this author at the Departamento de Fisiología y Farmacología, Universidad de Salam anca, Avda. Campo Charro sin, 37007 Salamanca, Spain; Tel: (+34) 923294472 ; Fax: (+34) 923294669 E-mail: jmlnovoa@usal.es
Chronic renal failure (CRF) is a pathological, irreversible and progressive loss of renal function. CRF result from avariety of causes such as diabetes (from 25 to $40 \%$ or more), hypertension (about 15\%), nephritis (glomerulonephritis or interstitial nephritis), inflammatory and infiltrative diseases, polycystic kidney disease, autoimmune diseases (i.e. systemic lupus erythematosus), and other minor causes. These diseases evolve towards a chronic, progressive and irreversible renal dysfunction, characterized by renal fibrosis, and renal replacement therapy (RRT) including hemodialysis, peritoneal dialysis or renal transplant, becomes compulsory to prevent the patients' death [2]. CRF pathogenesis is characterized, with independence of the original disease, by a progressive nephron loss due to tubular cell deletion, an excessive deposition of ECM in the glomeruli and tubular interstitium, and renal vasculature alterations [3]. Moreover, the degree of renal lesion and the risk of progression closely correlate with the extent of tubulointerstitial fibrosis, regardless of etiology [4]. In addition, as a consequence of the increasing renal dysfunction, there are several compensatory responses including hypertension, hyperfiltration and peripheral or renal sympathetic hyperactivity which may also contribute to the progressive renal damage characteristic of CRF [5].

The development of effective and curative therapies for CRF depends on the detailed understanding of the cellular and molecular mechanisms responsible for renal damage and failure progression.

\subsection{Epidemiology}

In different studies, incidence rates of ARF vary from 0.9 to $20 \%$ and mortality rates between 25 to $80 \%$. These discrepancies are caused by large differences in the definition of ARF, variability between patients, and different experience between hospitals in the treatment of ARF and its concomi- 
tant pathologies [6]. In a large, multicenter study [7], patients who were discharged with a diagnosis of ARF had a ten times higher mortality rate $(26 \%)$ than overall hospital mortality [7]. In addition to high mortality, ARF increases in a substantial way the hospital stay duration and the cost of treatment [8].

Incidence and prevalence numbers on total CRF patients are very variable among countries, being the incidence of end-stage renal failure about 320 people per million (ppm) in the USA, about $250 \mathrm{ppm}$ in Japan, about $150 \mathrm{ppm}$ in the India, whereas in Canada is about $140 \mathrm{ppm}[9,10]$.

\section{MAJOR CELL TYPES INVOLVED IN RENAL DIS- EASES}

Almost all the cell types present in the kidney are involved in either ARF or CRF. However, the most studied cells in these circumstances are mesangial cells, podocytes, tubular epithelial cells and fibroblasts, and we will focus specifically on the role of these cell types. It should be noted that we only mention resident cell types, and we have excluded inflammatory cells, although they play a major role in renal disease.

\subsection{Mesangial Cells}

Mesangial cells are specialized pericytes placed in the core of glomerular capillary tuft, that serve as physical support for capillary loops and also regulate glomerular function, as they are able to contract in response to several agonists, thus modifying glomerular architecture and, consequently, ultrafiltration surface and ultrafiltration coefficient. Another characteristic of the glomerular mesangial cells is their ability to produce large amounts of extracellular matrix (ECM) proteins $[11,12]$.

\subsection{Podocytes}

Podocytes or glomerular visceral epithelial cells are highly differentiated glomerular endothelial pericytes that cover the glomerular basal membrane (GBM) of glomerular capillaries by the urinary space. Podocytes show an abundantly rich actin cytoskeleton and an arborized appearance with multiple interdigitating foot processes. This complex architecture is required for maintaining the selective filter properties restricting the passage to the urine of plasma macromolecules, the synthesis and maintenance of the GBM and the structural support to the glomerular tuft. Disruption or alterations of the complex structure of podocytes and GBM result in reduction of glomerular filtration rate and/or increased protein filtration [13].

\subsection{Epithelial Tubular Cells}

Epithelial tubular cells are the most abundant cell types in the kidneys and they are responsible for reabsorption and/or secretion of water, electrolytes and other organic molecules. These cells are easily damaged by renal ischemia or hypoxia and by endogenous and exogenous toxic products, which are concentrated in the tubular fluid. This explains tubular necrosis after renal ischemia and toxic renal failure.

Tubular epithelial cells also contribute to CRF in two different ways: epithelial cells release cytokines and growth factors in response to presence of excessive amounts of protein in the filtered tubular fluid. These cytokines and growth factors are responsible for initiating or contributing to kidney damage that will lead to CRF [14]. In addition, tubular cells suffers the so called epithelial-to-mesenchymal transition (EMT) in which they are transformed in myofibroblasts, the main source for extracellular matrix in chronic kidney diseases [15]. However, although EMT has been extensively proven "in vitro", its occurrence in human renal disease has not been definitely demonstrated.

\subsection{Fibroblasts}

Fibroblasts and dendritic cells represent the bulk of interstitial cells in the cortex. In healthy animals, fibroblasts are the most abundant interstitial cells in the cortex, whereas fibroblasts are less abundant in the medulla, and there are few, if any, myofibroblasts. Renal fibroblasts play a major functional role in the normal and pathological function of the kidney, as they synthesize many of the constituents of the fibrillar ECM, [16] and they are also a major source of ECM-degrading proteases such as matrix metalloproteinases

Table 1. Scheme of the MAP-Kinase Signalling Pathways

\begin{tabular}{|c|c|c|c|c|}
\hline Extracellular Stimuli & $\begin{array}{l}\text { Growth Factors } \\
\text { Mitogens GPCR }\end{array}$ & \multicolumn{2}{|c|}{$\begin{array}{l}\text { Stress } \\
\text { Inflammatory CytokinesGrowth Factors, GPCR }\end{array}$} & $\begin{array}{c}\text { Stress } \\
\text { Growth Factors Mitogens, GPCR }\end{array}$ \\
\hline $\begin{array}{l}\text { Small GTPases or G- } \\
\text { proteins }\end{array}$ & Ras & \multicolumn{2}{|c|}{ Rac,-1, Rho A, Rho B Cdc 42} & $?$ \\
\hline MAPKKK & $\begin{array}{l}\text { Raf, Mos, Tpl2 } \\
\text { MEKK1, MEKK3 }\end{array}$ & $\begin{array}{l}\text { MEKK1-5, MLK3 } \\
\text { Assk } 1 \text {, Dlk, Lzk }\end{array}$ & $\begin{array}{c}\text { MLK3, Tak1 } 1 \\
\text { Dlk, Assk 1, MEKK4 }\end{array}$ & $\begin{array}{l}\text { MEKK2, MEKK3 } \\
\text { Raf }\end{array}$ \\
\hline MAPKK & MKK 1, MKK2 & $\mathrm{MKK} 4, \mathrm{MKK} 7$ & MKK3, MKK6 & MKK5 \\
\hline MAPK & ERK 1, ERK2 & JNK 1, JNK 2, JNK 3 & $\mathrm{p} 38 \mathrm{\alpha}, \mathrm{p} 38 \beta, \mathrm{p} 38 \gamma, \mathrm{p} 38 \mathrm{z}$ & ERK5 \\
\hline MAPKAP & $\begin{array}{c}\text { Rsk } 1-4 \\
\text { Mnk 1, Mnk2 } \\
\text { Msks } 1, \text { Msls2 }\end{array}$ & Mk2 & $\begin{array}{l}\text { Mnk } 1-3 \\
\text { Msk } 1-2 \\
\text { Mk } 1,2,3,5\end{array}$ & $?$ \\
\hline Substrates & $\begin{array}{l}\text { Sap 1, Elk 1, MAF-A } \\
\text { p53, c-myc, c-fos } \\
\text { Smad 1,2,3,4 }\end{array}$ & $\begin{array}{c}\text { c-jun, ATF-2, Elk- } 1,3 \\
\text { p53, c-myc, HSF-1, IRS-1 } \\
\text { NFAT4, DPC4, Shc }\end{array}$ & $\begin{array}{l}\text { MEF-2, ATF-2, c-fos } \\
\text { Elk-1, Hsp-25, Hsp-27 } \\
\text { CHOP, c-jun }\end{array}$ & $\begin{array}{l}\text { MEF-2, c-fos, Fra-1 } \\
\text { c-myc, c-jum, Ets-1 } \\
\text { Sap-1, CREB }\end{array}$ \\
\hline
\end{tabular}


(MMP), maintaining ECM homeostasis via regulation of ECM turnover [17]. In diseased kidneys, myofibroblasts are more abundant and derives from resident fibroblasts or from EMT, although other surces susch as vascular smooth muscle cells have been also suggested [18]. Myofibroblasts migrate, proliferate and produce large quantities of ECM, which contributes to repair of damaged tissues, but also to pathological fibrosis.

\section{MITOGEN ACTIVATED PROTEIN (MAP) KINASES}

Mitogen-activated protein kinases (MAPK) are important mediators involved in the transduction of extracellular stimuli to intracellular responses [19]. A general cascade pattern of activation is observed for all MAPKs (including ERKs, Jun kinase and p38 kinase). The typical MAPK pathway consists of a MAPK, its upstream activator (MAPK kinase: $\mathrm{MKK}$ ), and a further upstream activator (MAPK kinase kinase: MKKK) (Table 1).

MAPKs can be divided into at least three broad families on the basis of sequence similarity, upstream activators, and to a lesser extent, substrate specificity. The classic extracellular signal-regulated kinases (ERKs; ERK1 and ERK2) were identified in the context of growth factor-related signaling, whereas the Jun $\mathrm{NH}_{2}$-terminal kinase (JNK) and p38 families were described in the setting of cell response to stress and inflammation. Recently, additional MAPK families have been identified, of which only ERK 5 thus far has clearly delineated upstream activators and downstream effectors.

Map kinase kinases (MAPKKs, MKKs or MEKs) exhibit relative specificity for the Map kinase proteins that they phosphorylate. MKK1 and MKK2 phosphorylate Erk kinases in the Thr-Glu-Tyr motif; MKK3, MKK4, and MKK6 phosphorylate p38 kinases in the Thr-Gly-Tyr motif, while MKK 4 and MKK 7 regulate dual phosphorylation of JNK kinases in the Thr-Pro-Tyr motif. Another member of the MAPKK family of kinases is MKK5, which selectively phosphorylates the Thr-Glu-Tyr motif in Erk5/BMK-1 (Table 2).

The activation of MAPKKs is regulated by other upstream serine-threonine kinases, called MAPKK kinases (MAPKKKs), which phosphorylate the MAPK kinases (MAPKKs) on specific serine residues. Thus, there is a serial activation of serine-threonine and dual specificity kinases, ultimately leading to induction of the kinase domains of Map kinases and activation of downstream pathways. Several serine-threonine kinases have been implicated in acting as MAPKKKs for the different groups of Map kinase pathways. In the case of the Erk1/2 pathway, the family of Raf kinases, as well as Mos and Tpl2, acts as MAPKKKs. On the other hand, the different MAPKKs that regulate activation of the JNK and p38 kinases include mixed-lineage kinases (MLK1, MLK2, MLK3, Dlk, and Lzk), MEKK kinases (MEKK1, MEKK2, MEKK3, and MEKK4), Tak1, Ask1, Ask2, and Tpl-2. MAPKKs for the ERK-5 pathway include MEKK2, MEKK3, and kinases of the Raf family (Table 1).

The direct downstream MAP-kinases substrate, comprehensively called the MAPKactivated protein kinase (MAPKAPK) family, can be categorized into four subfamilies, the Rsks (p90 ribosomal S6 kinases), MK, Mnk (MAPK signalintegrating kinases/MAPK-interacting kinases), and Msk (mitogen- and stress-activated protein kinase) families. The Rsks (Rsk1, Rsk2, and Rsk3) are activated specifically by ERKs, whereas the MKs (MK2/MAPKAPK2, MK3/ MAPKAPK $3 / 3 \mathrm{pK}$, and MK5/PRAK) are activated mainly by p38 MAPK in vivo. In contrast, the Mnks (Mnk1 and Mnk2) and Msks (Msk1 and Msk2) are targeted in vivo by both the ERK and p38 MAPK pathways, resulting in the activation of Mnks and Msks by a broad spectrum of extracellular stimuli (Table 1).

A single stimulus can activate several MAPKs. Still, each family of MAPKs is nonetheless activated in a relatively specific fashion by a subset of MKKs. For example, ERK1/2 is activated by both MAPK/ERK kinase MEK1 and MEK2, whereas JNKs are activated primarily by MKK 4 and MKK7 and $\mathrm{p} 38$ is activated by MKK 3 and MKK 6 . In contrast, the relationship between individual MKKs and their upstream MKKKs is less clear. Members of the Raf family specifically activate the ERK1/2-directed MKKs, MKK1, and MKK2, although there is considerable cross-talk among the parallel cascades at the level of MKKKs. A further level of complexity is contributed by the expanding range of activators of MKKKs, including MKKKKs and small GTP-binding proteins [20].

MAP kinase pathways play a major role at regulating many renal functions [21]. Alteration of MAP kinase pathways seems to be also involved in the genesis and progression of several models of chronic renal disease as described later in this section. An important interest of these pathways as possible targets to prevent or revert chronic or acute renal diseases is that, due to the relevance of these pathways in tumor growth and metastasis, a great amount of drugs have

Table 2. Specificity of Different MAP Kinase Kinases (Mapkks) to Phosphorylate the Specific Motifs of the Different Map Kinases

\begin{tabular}{|c|c|c|c|c|c|c|c|}
\hline & MKK1 & MKK2 & MKK3 & MKK4 & MKK5 & MKK6 & MKK7 \\
\hline \hline Motif & Thr-Glu-Tyr & Thr-Glu-Tyr & Thr-Gly-Tyr & Thr-Gly-Tyr, Thr-Pro-Tyr & Thr-Pro-Tyr & Thr-Glu-Tyr & Thr-Gly-Tyr \\
\hline Erk & + & + & - & - & - & - & - \\
\hline p38 & - & - & + & + & - & + & - \\
\hline JNK & - & - & - & + & - & - & + \\
\hline Erk5 & - & - & - & - & + & - & + \\
\hline
\end{tabular}

+: Map kinase is phosphorylated/activated by the correspondent MKK; - Map kinase is not phosphorylated/activated for the correspondent MKK. 
been developed with the purpose to inhibit MAP kinase cascades. In the present article, we will revise the possible involvement of MAP kinases in the genesis and/or progression of renal disease, and the potential therapeutic opportunities based in the specific blockade of these pathways.

\subsection{Extracellular Signal-Regulated Kinases 1 and 2 (ERK1/2)}

\subsubsection{Overview of the ERK1/2 Kinase Pathways}

Principal mammalian ERKs, ERK1 (p44) and ERK2 (p42), are activated by the MEK1 and MEK2 "dualspecificity" (Ser/Thr and Tyr) kinases that phosphorylate the TEY motif specific for ERKs. Effectors of activated ERK include transcription factors such as Elk-1, Ets 1, Sap1, m$\mathrm{Myc}$, signal transducers and activators of transcription proteins (STAT), adapter proteins (Sos), enzymes (p90 ribo- somal S6 kinases (Rsk 1-4) phospholipase $A_{2}$ ), and cell surface EGF and estrogen receptors [22]. The p90 ribosomal S6 kinase (Rsk) family seems to play a major role in transducing ERK $1 / 2$ signaling. This family comprises four mammalian serine/threonine kinases (Rsk1-4). Rsk1 and Rsk2 were recently shown to phosphorylate ribosomal protein S6 in response to Ras/extracellular signal-regulated kinase (ERK) pathway activation. Mitogenic stimulation of the Ras/ERK pathway leads to the activation of Rsk1. Rsk1 seems to be a multifunctional ERK effector because it participates in various cellular processes, including nuclear signaling. Rsk1 was found to regulate several transcription factors, including SRF, c-Fos, and Nur77. Additional nuclear factors have been shown to be regulated by Rsk1, including MITF, estrogen receptor- $\alpha$ nuclear factor (NF)-ATc4 and ER81. Rsk1 was shown to interact with the transcriptional coactivator CREBbinding protein (CBP), which, interestingly, binds many
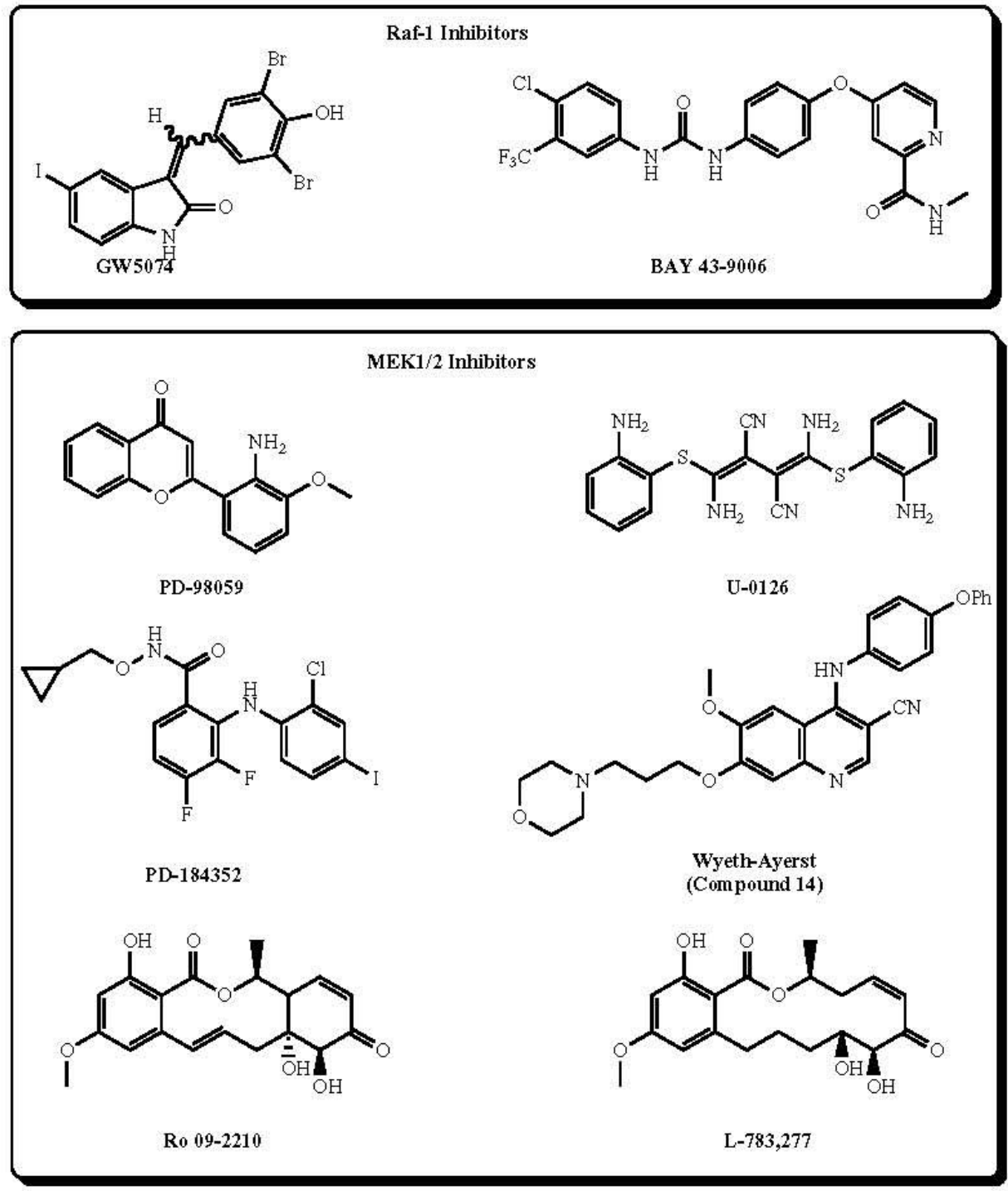

Fig. (1). Chemical structures of the most used ERK $1 / 2$ pathway inhibitors. 
transcription factors known to be regulated by Rskl. On the basis of the nature of its substrates, Rskl seems to regulate immediate early gene products, such as c-Fos, which promotes the expression of cyclin D1 during the G0/G1 transition to $\mathrm{S}$ phase. Other proteins through which Rsk1 may stimulate proliferation include the cyclin-dependent kinase (CDK) inhibitor $\mathrm{p} 27^{\text {lapl }}$, (Rsk1 blocks the inhibition of the cyclin D1/CDK 4 complex by the CDK inhibitor $\mathrm{p} 27^{\text {lapl}}$ ) the $\mathrm{Na}^{+} / \mathrm{H}^{+}$exchanger NHE-1 and the kinase GSK3 [Roux PP. Rsk1: UCSD-Nature MoleculePages http://www.signalinggateway.org/molecule/ consulted online: March 10, 2008].

From a physiological perspective, ERK signaling has been implicated in mitogenesis, cell survival and differentiation [23]. ERK1 and ERK2, the MKKK, Raf-1, the MKK, MEK, and the ERK effector, p90 S6 kinases (Rsks) are all expressed in nephron segments [24].

\subsubsection{Inhibition of ERK1/2 Pathway}

Experimental elucidation of the role of ERK signaling activation in renal function and disease has been facilitated by the early discovery of pharmacological inhibitors of ERK action, mainly PD-98059 and U-0126 whose structures are shown in Fig. (1). Both inhibitors appear to indirectly block ERK signaling through inhibition of its immediate upstream activators, MEK1 and MEK2 [25]. Although these compounds seems to be rather selective as none of them significantly inhibits the activity of a large panel of protein kinases which includes ERK1, JNK1 and p38 MAP kinases in an in vitro assay. However, specificity of these inhibitors is only relative because PD-98059 is also a potent inhibitor of cyclooxygenase-1 and -2 [26]. A more recently described highly MEK1-specific derivative of PD-98059, PD-184352 (Fig. 1), has been shown to have an enhanced bioavailability and to be functional in vivo, [25]. A series of 3-cyano-4- (phenoxyanilino)-quinolines has been developed as MEK inhibitors by Wyeth- Ayerst [27]. The mechanism of action of these compounds as MEK inhibitors has not been reported. The most potent, Compound 14 (Fig. 1) inhibits MEK1 activity in vitro and shows anti-proliferative properties. Several resorcylic acid lactones isolated from microbial extracts display potent inhibitory activity toward MEK. For instance, Ro 09-2210, isolated from a fungal broth $\mathrm{FC2} 2506$, and L-783,277, purified from organic extracts of Phoma sp. Inhibit MEK1 activity in vitro (Fig. 1). Unlike PD98059, U0126 and PD184352, these compounds are competitive with ATP, and the inhibition is irreversible. These compounds are also effective in cell-based assays, e.g., Ro 09 . 2210 inhibits phorbol ester-induced activation of AP1, while L-783,277 inhibits the growth of several epithelial tumors. Others inhibitors of Raf-1 have been also developed; they are GW5074 and BAY 43-9006 (Fig. 1). So far, no specific and potent inhibitors of ERK1/2 have been reported. Recently, purvalanol, one of the most potent cyclin-dependent kinase (CDK) inhibitors to date, has been shown to target also ERK1 and ERK2 [25]. Thus, the anti-proliferative property of purvalanol is mediated by the inhibition of both ERK $1 / 2$ and CDKs. A scheme of the place of action of the inhibitors above mentioned on the ERK1/2 kinase cascade is shown in Fig. (2).

\subsubsection{ERK1/2 Activation in Experimental Models of Renal Disease}

ERK1/2 activation and MEK upregulation have been reported in the glomeruli of rats with experimental proliferative anti-glomerular basement membrane glomerulonephritis [28]. ERK activation has been also reported in the anti-Thyl nephritis, a model of progressive mesangioproliferative glomerulonephritis $[29,30]$. Renal ERK activation has been also reported in an experimental model of obstructive dam-

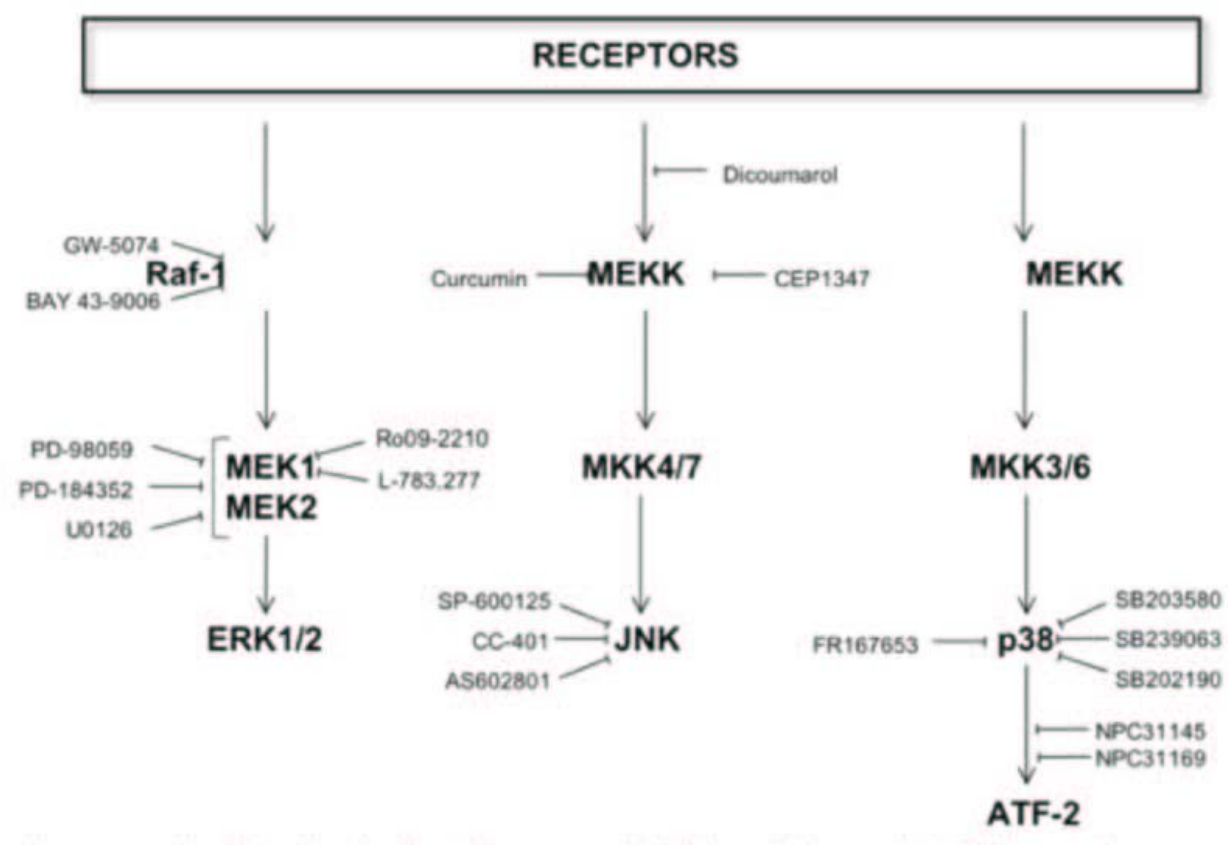

Fig. (2). Schematic representation of the sites of action of the most used inhibitors of the several MAP kinase pathways. 
age induced unilateral ureteral ligation in rats [31]. This ERK activation has been related to tubular proliferation in the obstructed kidney [32]. Activation of ERK precedes tubulointerstitial injury in this model, indicating that the ERK pathway may be involved in the proliferation of renal tubular epithelial cells and interstitial cells that occurs in this model $[31,32]$. ERK has been reported to be activated in the epithelial tubular cells of the cysts in a mice model of genetic polycystic kidney disease, whereas it was not activated in the tubules with normal appearance [33]. ERK activation has been also demonstrated in several models of kidney disease such as diabetic nephropathy [34,35], subacute glomerular injury induced by salt loading in the Dahl salt-sensitive rat [36], Ang-II-induced hypertensive renal disease [37] or cisplatin-induced tubular damage [38]. In addition, increased ERK1/2 activation has been observed in the kidneys of cadmium-intoxicated rats, probably as a consequence of the small GTPase RAS activation [39].

\subsubsection{ERK Activation In Renal Cells}

\subsubsection{ERK Activation in Mesangial Cells}

Mesangial cell proliferation is a characteristic hallmark of most types of chronic glomerular diseases, at least during an initial phase (see above, section 2.1). ERK activation seems to play a major role in the control of mesangial cell proliferation. ERK $1 / 2$ are activated in mesangial cells by a great number of stimuli with proliferative effect [40-49] (Table 3). Physical stimuli such as hyperglycemia [34], cyclic two-dimensional mechanical stretch and relaxation [50,51], elevated hydrostatic pressure [52] and collagen gel three-dimensional contraction [53] are also able to activate ERK in mesangial cells. The effect of some of these effectors on mesangial ERK activation is likely Ras dependent, as evidenced by its sensitivity to the inhibitors of hydroxymethylglutaryl-CoA reductase, which blocks prenyl synthesis and thus, the prenylation of Ras, necessary for its activation [21]. However, it should be taken into account that HMG-CoA reductase inhibitors also prevent the activation of other small GTPases, such as Rho. By opposite there are also several stimuli that are able to functionally antagonize ERK signal- ing in cultured mesangial cells. These stimuli include vasodilators and other substances (Table 3) [54-59]. A number of these inhibitory events appear to be mediated through the action of cyclic nucleotide monophosphate (e.g., cAMP and cGMP) second-messenger system s.

In addition some stimuli are not only able to regulate ERK activation, but also they may directly regulate abundance of MAPK cascade constituents. For example, in addition to increasing ERK activity, TGF- $\beta 2$ [60], IL-1 [61], endothelin-1 [62], PDGF [62], and fetal bovine serum [63] also increased the abundance of mRNA coding for the ERK activator MEK in mesangial cells. Similarly, in addition to activating ERK, PDGF stimulates ERK synthesis [64]. By opposite, a prostacyclin analog increases expression of the ERK-directed phosphatase MKP-1 and thereby potentially antagonizes MAPK signaling in the mesangium [65]. In general, pharmacological inhibition of the ERK pathway results in a decrease of serum or agonist-induced mesangial cell proliferation, thus supporting the notion that ERK-1/2 activation plays a major role in mesangial cell proliferation [21].

Chronic glomerular diseases are also characterized by increased extracellular matrix synthesis by mesangial cells, which results in mesangial matrix expansion and glomerulosclerosis. Most of the substances that activate ERK in mesangial cells also increase extracellular matrix synthesis. This occurs for insulin [42], vascular endothelial growth factor (VEGF) [43], endothelin [66], Ang-II [42,66], bradykinin [67], serotonin [46], high glucose and AGES [68]. TGF- $\beta 1$ seems to play a central role in stimulating ECM synthesis by mesangial cells [69] and it activates the ERK1/2 pathway in cultured mesangial cells $[42,70]$. Furthermore, physical stimuli such as osmotic stress [34,71], and mechanical stretch and relaxation $[50,71]$ activate both ERK1/2 and extracellular matrix synthesis by mesangial cells. Thus, there are enough evidence suggesting a major role for ERK $1 / 2$ activation plays in the increased mesangial proliferation and exaggerated extracellular matrix synthesis that are characteristic of most chronic glomerular diseases.

Table 3. Stimuli Regulating MAP Kinases Activation in Mesangial Cells

\begin{tabular}{|c|c|c|c|c|c|c|c|c|c|}
\hline \multicolumn{4}{|c|}{ ERK1/2 } & \multicolumn{4}{|c|}{$\underline{\text { INK }}$} & \multirow{2}{*}{\multicolumn{2}{|c|}{$\frac{\underline{\mathrm{P} 38}}{\text { Activation }}$}} \\
\hline \multicolumn{2}{|c|}{ Activation } & \multicolumn{2}{|l|}{ Inhibition } & \multicolumn{2}{|c|}{ Activation } & \multicolumn{2}{|c|}{ Inhibition } & & \\
\hline $\begin{array}{l}\text { PDGF } \\
\text { EGF } \\
\text { Insulin } \\
\text { VEGF } \\
\text { TGF- } 11 \\
\text { Endothelin } \\
\text { Ang-II } \\
\text { Bradylinin } \\
\text { Lysophosphatidic } \\
\text { acid } \\
\text { Serotonin } \\
\text { ATP } \\
\text { Vasopressin } \\
\text { CD53 tetraspanin } \\
\text { antigen } \\
\text { High glucose }\end{array}$ & $\begin{array}{l}{[40,41]} \\
{[41]} \\
{[42]} \\
{[43]} \\
{[44]} \\
{[40]} \\
{[42]} \\
{[45]} \\
{[41]} \\
{[46]} \\
{[47]} \\
{[48]} \\
{[49]} \\
{[34]}\end{array}$ & $\begin{array}{l}\text { Tryptophan derivative } \\
\text { Prostaglandin analogs } \\
\text { Dopam ine } \\
\text { Atrial natriuretic peptide } \\
\text { Nitric oxide } \\
\text { Adrenomedullin } \\
\text { Heparin } \\
\text { High glucose } \\
\text { Phosphodiesterase inhibitors } \\
\text { cAMP and cGMP analogs }\end{array}$ & \begin{tabular}{|l}
{$[54]$} \\
{$[56]$} \\
{$[55]$} \\
{$[56,51]$} \\
{$[56]$} \\
{$[57]$} \\
{$[58]$} \\
{$[59]$} \\
{$[56]$}
\end{tabular} & $\begin{array}{l}\text { Ang-II } \\
\text { Endothelin } \\
\text { ATP } \\
\text { Nitric oxide } \\
\text { Docosahexaenoic } \\
\text { acid } \\
\text { TNF- } \alpha \\
\text { IL-1B } \\
\text { PDGF-BB } \\
\text { Gentamicin } \\
\text { Celecoxib }\end{array}$ & \begin{tabular}{|l}
{$[110]$} \\
{$[111]$} \\
{$[112]$} \\
{$[113]$} \\
\\
{$[114]$} \\
{$[115]$} \\
{$[116,117]$} \\
{$[118]$} \\
{$[119]$} \\
{$[120]$}
\end{tabular} & $\begin{array}{l}\text { PGE1 } \\
\text { BMP7 } \\
\text { Retinoic acid } \\
\text { Quercetin }\end{array}$ & $\begin{array}{l}{[124]} \\
{[125]} \\
{[126]} \\
{[127]}\end{array}$ & $\begin{array}{l}\text { Ang-II } \\
\text { TGF- } \beta 1 \\
\text { AGEs } \\
\text { Cadmium } \\
\text { Oxidative stress }\end{array}$ & $\begin{array}{l}{[123]} \\
{[44,179} \\
{[180]} \\
{[181]} \\
{[182]}\end{array}$ \\
\hline
\end{tabular}


Glomerular inflammation is another manifestation of renal damage. Ciclooxigenase-2 (COX-2), a key mediator of renal inflammation is induced by several cytokines, including TGF- $\beta 1$. Recently, it has been dem onstrated that ERK1/2 activation plays a major role in TGF- $\beta 1$-induced COX-2 expression and activity in mesangial cells [44].

In general, pharmacological inhibition of the ERK pathway with UO126 or PD184352 results in a decrease of serum or agonist-induced proliferation and EMC synthesis by cultured mesangial cells $[21,44,68]$.

\subsubsection{ERK Activation in Tubular Cells}

ERK activation in tubular epithelial cells has been reported for EGF [24], hepatocyte growth factor [72], bradykinin [73], Ang-II [24], epinephrine [74], endothelin [24], lactosylceramide, a lipid mediator increased in polycystic kidney disease tissue [75], arachidonic acid [76], advanced glycation end-products, nonenzymatically modified macromolecules associated with hyperglycemia and diabetes mellitus [77], and ATP depletion [78]. Increased osmolality also activates ERK in epithelial tubular cells [79]. Nephrotoxicants such as cisplatin have also been shown to activate ERK and induce apoptosis in tubule cells both in vitro [38] and in vivo [80]. The immunosupressor cyclosporine $\mathrm{A}$ induces cell death and ERK activation in a mice proximal tubular cell line [81]. In addition, inhibition of ERK activation with UO126 or PD98959 prevents cyclosporine A-induced ERK $1 / 2$ activation in mice tubular cells, but not cyclosporineinduced cell death, thus indication that ERK activation is not involved in cyclosporine A toxicity [81]. In tubular renal proximal cells, ERK mediates the stimulation by angiotensin II of the $\mathrm{Na}^{+}-\mathrm{HCO}_{3}{ }^{-}$cotransport in the proximal tubule, and the subsequent sodium reabsorption [82].

\subsubsection{ERK Activation in Fibroblasts}

The MEK/ERK pathway may play a role in TGF- 3 mediated ECM synthesis. It has been described that ERK1/2 activation inhibits collagen type I synthesis in human skin fibroblasts after mitogenic stimulation [83]. In agreement, the lack of $\mathrm{H}$ - and $\mathrm{N}$-Ras isoforms induces a reduction in ERK activation, together with an increase in fibronectin and collagen expression [84]. Furthermore, Stratton et al. [85] reported that activation of the Ras/MEK/ERK pathway is required for the induction of connective tissue growth factor (CTGF) by TGF- $\beta 2$, and that the in vitro and in vivo antifibrotic effects of prostacyclin derivatives were due to inhibition of the Ras/MEK/ERK pathway, suggesting that specific inhibition of this pathway in fibroblasts might prevent fibrosis. ERK $1 / 2$ activation seems to play also a key role in the control of renal interstitial fibroblast proliferation, that is a key event in the genesis of tubulo-interstitial fibrosis [86]. Furtherm ore, inhibition of ERK activation reduces fibroblast proliferation [84]. In vitro models of oxidative renal injury demonstrated a role for ERK activation in apoptosis of renal fibroblasts [87] but not in tubular epithelium where it promoted cell survival [88].

TGF- $\beta$ also stimulates proliferation of fibroblasts [89]. A role for Ras proteins in the effect of TGF- $\beta$ has also been proposed. In fact, cell proliferation and PCNA expression in response to TGF- $\beta 1$ are diminished in $\mathrm{H}-\mathrm{ras}^{-1} \mathrm{~N}-\mathrm{ras}^{\gamma-}$ fibroblasts. This reduction may be in part related to the lower
ERK phosphorilation observed in $\mathrm{H}-\mathrm{ras}^{-1} / \mathrm{N}-\mathrm{ras}^{-/}$fibroblasts compared with control cells [84]. These data suggest that ERK activation might be involved, at least in part, in the stimulation of proliferation induced by TGF- $\beta 1$. In most of the studies, blockade of ERK activation with UO126 clearly reduces the effects of TGF- $\beta 1$ on cultured fibroblast proliferation and ECM synthesis [84,85].

\subsubsection{ERK Activation and Epithelial-Mesen chymal Transi- tion}

Tubular EMT can be induced by TGF- $\beta 1$ [ 900 , advancedglycation end products [91], and Ang- $[$ [92] and all these substances activate ERK1/2 in tubular epithelial cells. However, TGF- $\beta 1$ is probably the key inducer of EMT because TGF- $\beta 1$ signaling is sufficient to induce EMT in cultured epithelial cells [90]. The intracellular signaling responsible for TGF- $\beta$-induced EMT includes activation of ERK $1 / 2$ [93, 94], p38 MAPK [95], and JNK [96]. ERK activation seems to be a necessary step in the induction of EMT $[97,98]$. Furthermore, inhibition of ERK activation with U0126 or PD 98959 prevents TGF- $\beta 1$-induced EMT [ 94,98$]$.

\subsubsection{Effects of ERK-Inhibition on Renal Damage}

Inhibition of ERK with UO126 results in amelioration of the renal damage in a rat model of experimental mesangioproliferative glomerulonephritis by suppressing the proliferation of mesangial cells [30], whereas ERK inhibition with PD184352 slows the progression of renal disease in DBA/2-pcy/pcy (pcy) mice, a murine model of polycystic kidney disease [34]. In the unilateral ureteral obstruction model of tubulointerstitial fibrosis in mice, the inhibition of ERK1/2 activation by administration of U0126 led to reduced interstitial levels of both fibroblast-myofibroblast markers alpha-smooth muscle actin and vimentin which were induced by obstruction [99]. Moreover, in the same model, administration of ERK $1 / 2$ inhibitor UO126 diminished the number of tubules and interstitial cells suffering apoptosis in obstructed kidneys [99]. Administration of the MEK inhibitor, U0126 is able to partially protect the kidney against the tubular damage induced by cisplatin, both in vitro [38] and in vivo [80], most probably preventing cisplatin-induced tubular apoptosis.

\subsubsection{Conclusion}

According to the information shown above, it can be suggested that activation of ERK triggers a lot of effects in renal cells (Table 4) including proliferation of mesangial cells and fibroblasts cells, which are responsible for extracellular matrix synthesis and deposition, characteristic of chronic renal disease. ERK activation seems also to be involved in EMT and in tubular apoptosis in several models of renal failure. Thus, pharmacological inhibition of this pathway can offer a new approach to treat these alterations in chronic renal diseases. However, ERK1/2 activation seems to be necessary for tubular cell proliferation, which is a necessary event to recover from acute tubular necrosis, and thus, these treatments could worsen the curse of those reversible pathologies whose recovery need tubular reepithelization. In addition, ERK $1 / 2$ activation seems also to regulate sodium transport. Thus, ERK inhibition could also modify tubular reabsorption. 


\section{2. c- jun $\mathrm{NH}_{2}$-Terminal Kinase (JNK)}

\subsubsection{Physiological Role of JNK Pathway}

Members of the JNK family (also known as stressactivated protein kinase-1 or SAPK1) are generally responsive to events that induce cell stress, such as hypertonicity, ultraviolet light, heat shock, and proinflammatory cytokines. These kinases include the widely expressed JNK1 (also known as p46 or SAPK1 gamma) and JNK2 (also known as p54 or SAPK1 alpha), as well as the brain-specific JNK3 (also known as p49 or SAPK1 beta). JNK1 and JNK2 are subject to alternative splicing, giving rise to $46-$ and $54-\mathrm{kDa}$ protein products. To achieve activation, JNKs undergo MKK-mediated dual phosphorylation at their TPY motifs. Effectors of the JNK family are mainly transcription factors such as c-Jun, Elk-1, ATF-2, DPC4, NFAT4, and p53 (Fig. 1). Activation of JNKs in vivo appears to play a role in inflammation, tum origenesis, and apoptosis [100].

\subsubsection{Inhibition of JNK Pathway}

Rather specific pharmacological inhibition of JNK activation and JNK-dependent signaling can be achieved by using curcumin, an inhibitor of activator protein-1 (AP-1) and nuclear factor-KB [101], or the quinone reductase inhibitors dicoumarol and menadione [102]. Another inhibitor of the JNK pathway, CEP1347 (KT7515) (Fig. 3), has been described [103]. CEP1347 inhibit members of the mixed lineage kinase (MLK) family, MLK1 (Mitogen-activated protein kinase kinase kinase 9; MAPKKK9), MLK2 (Mitogen-activated prote in kinase kinase kinase 10 ; MAPKKK10) and MLK3 (Mitogen-activated protein kinase kinase kinase 11; MAPKKK11), that are upstream activators of the JNK pathway. This represents an initial attempt to specifically target the JNK pathway via inhibition of selected MAPKKKs upstream of JNKs. The most specific inhibitor seems to be SP600125 (Fig. 3), a reversible ATPcompetitive inhibitor [104]. JNK inhibitors from Celgene (CC-401; Celgene, San Diego, CA, USA) and Serono (AS602801; Serono, Geneva, Switzerland) are currently undergoing phase 1 clinical trials, but its formulas and mechanisms of action have not been released. A scheme of the actions of the different inhibitors on the specific JNK kinase cascade is shown in Fig. (2).

\subsubsection{JNK Activation in Experimental Models of Renal Damage}

Renal JNK activation has been described in proliferative anti-glomerular basement membrane glomerulonephritis in rats [28], and in mesangial proliferative glomerulonephritis induced by anti-thymocyte serum in rats $[29,105]$. In this model, prednisolone therapy, which improved proteinuria and glomerular hypercellularity, also blocked the increment in JNK activation [104]. JNK activation has been also reported in the Dahl salt-sensitive hypertensive rat [36].

Table 4. Functions of Mapkinases Activation in Renal Cells

\begin{tabular}{|c|c|c|c|}
\hline Renal Cells & MAPK & Effects & References \\
\hline \multirow{3}{*}{ Mesangial cells } & ERK activation & $\begin{array}{l}\text { Cell proliferation } \\
\text { ECM synthesis }\end{array}$ & $\begin{array}{l}{[40-48]} \\
{[42-44,46,50,66-70]}\end{array}$ \\
\hline & JNK activation & $\begin{array}{l}\text { Control of mesangial cell proliferation } \\
\text { LDL signaling leading to CTGF and collagen I expression }\end{array}$ & $\begin{array}{l}{[121,122]} \\
{[128]}\end{array}$ \\
\hline & P38 activation & $\begin{array}{l}\text { Production of thrombospondin-1 } \\
\text { MCP-1 expression } \\
\text { Fibronectin and Collagen expression } \\
\text { AGE-induced iNOS expression and NO production } \\
\text { Mesangial cell contraction induced by cadm ium }\end{array}$ & $\begin{array}{l}{[123]} \\
{[184]} \\
{[183]} \\
{[180]} \\
{[182]}\end{array}$ \\
\hline \multirow{3}{*}{$\begin{array}{l}\text { Epithelial tubular } \\
\text { cells }\end{array}$} & ERK activation & $\begin{array}{l}\text { Apoptosis induced by cisplatin } \\
\text { Cell death induced by cyclosporine } \mathrm{A} \\
\text { Epithelial-to-mesenchymal transition }\end{array}$ & $\begin{array}{l}{[38,80]} \\
{[81]} \\
{[93,94]}\end{array}$ \\
\hline & JNK activation & $\begin{array}{l}\text { Toxicant-induced epithelial cell apoptosis } \\
\text { Epithelial-to-mesenchymal transition } \\
\text { EGF-induced cell dedifferentiation }\end{array}$ & $\begin{array}{l}{[137-140]} \\
{[142]} \\
{[177]}\end{array}$ \\
\hline & P38 activation & $\begin{array}{l}\text { Epithe lial-to-mesenchymal transition } \\
\text { Angiotensinogen gene expression } \\
\text { Production of thrombospondin-1 } \\
\text { Apoptosis } \\
\text { MCP-1 production }\end{array}$ & $\begin{array}{l}{[122]} \\
{[168]} \\
{[171]} \\
{[136,174-176]} \\
{[178]}\end{array}$ \\
\hline \multirow{2}{*}{ Fibroblasts } & ERK activation & $\begin{array}{l}\text { ECM synthesis } \\
\text { Proliferation induced by T GF- } \beta 1\end{array}$ & $\begin{array}{l}{[83-85]} \\
{[84,89]}\end{array}$ \\
\hline & P38 activation & Production of thrombospondin-1 & {$[171]$} \\
\hline Podocytes & P38 activation & $\begin{array}{l}\text { Apoptosis } \\
\text { VEGF production } \\
\text { ECM synthesis } \\
\text { Actin organization }\end{array}$ & $\begin{array}{l}{[155]} \\
{[156]} \\
{[158]} \\
{[151,153,159-163]}\end{array}$ \\
\hline
\end{tabular}



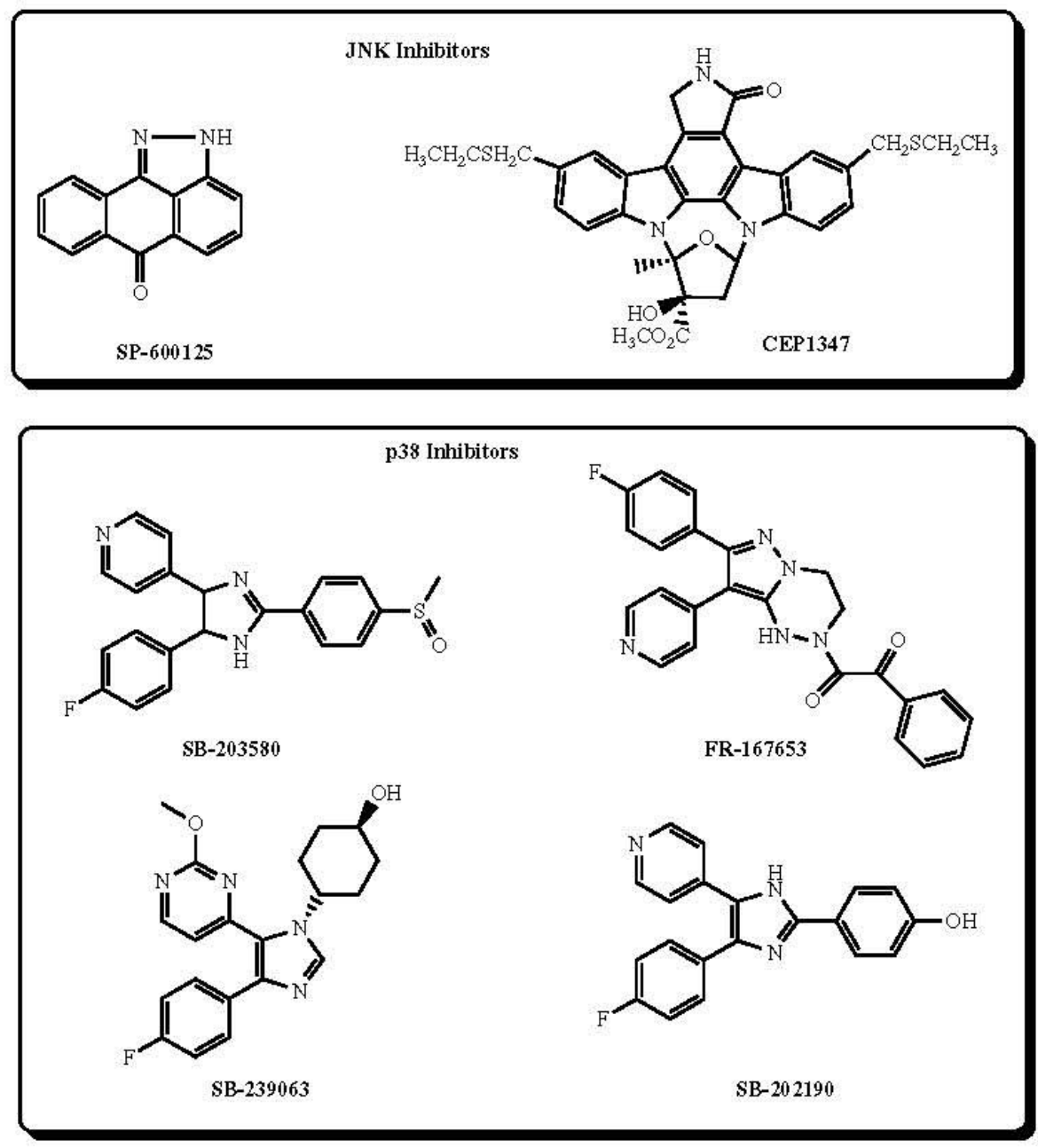

Fig)

Chemical structures of the most used JNK and $\mathrm{p} 38$ pathways inhibitors.

JNK activation has been also reported in acute models of renal damage such as renal ischemia-reperfusion [106,107]. In this model, activation (enhanced DNA binding) of the MAPK-responsive transcription factors, c-Jun and ATF-2 have been also reported [78]. The ischemia-associated activation of JNK may be ameliorated by systemic administration of substances with antioxidant properties [106, 107]. Renal JNK activation was also observed in the acute renal injury induced by glycerol [108]. The exogenous application of heat stress also increased JNK activation in mouse kidney [109].

\subsubsection{JNK Activation in Mesangial Cells}

JKK is activated in mesangial cells by agonists of $\mathrm{G}$ protein-coupled receptors proinflammatory cytokines [110$118]$, and several drugs $[119,120]$ (Table 3 ). JNK activation has been observed in mesangial cells undergoing hypertrophy $[121,122]$. Infection of MC with a dominant negative form of ERK and JNK inhibited PDGF-BB-induced increase mesangial cell proliferation, thus suggesting that JNK pathway activation is involved in mesangial cell proliferation
[118]. Furthermore, in human mesangial cells, Ang-IIinduced thrombospondin-1 production (an obligatory step on activation of latent TGF-betal by Ang-II) is dependent on JNK signaling [123].

There are also several substances that are able to antagonize JNK signaling in mesangial cells (Table 3) [124-127]. Inhibition of JNK in mesangial cells with SP 600125 suppressed LDL-induced TGF- $\beta$, CTGF, and collagen I expression, thus suggesting that JNK pathway and TGF- $\beta 1$ play a key role in LDL signaling leading to CTGF and collagen I expression [128]. Treatment with the JNK-selective blocker, SP600125 almost completely prevented the proliferative effect of Ang-II in cultured human mesangial cells, thus suggesting that JNK activation mediates this proliferative effect [122]. In addition, celecoxib-induced HO-1 expression in mesangial cells was attenuated by pretreatment of the cells with SP 600125, but not by SB203580 (a specific p38 MAPK inhibitor), or PD98059 (a specific MEK inhibitor), thus suggesting that celecoxib-induced HO-1 expression in mesangial cells may be mediated by the JNK activation [120]. In cultured human mesangial cells, peptides contain- 
ing arginine-glycine-aspartic acid (RGD) motifs, commonly found on the binding sites of extracellular matrix to integrins, increase the expression and function of soluble guanylate cyclase (sGC), and the effect of RGDS on sGC protein content was completely abolished by treating the cells with JNK inhibitors, curcum in and SP600125 [129].

From all the above described data, it can be deduced that JNK activation plays a major role in mesangial cell functional alterations (proliferation, ECM synthesis and inflammation) involved in acute and chronic renal glomerular diseases.

\subsubsection{JNK Activation in Epithelial Tubular and Other Kidney Cells}

After urinary obstruction, tubular epithelial cells become subject to both hypotonicity and cyclic stretch [130] and it has been proposed that these mechanical forces are responsible for renal epithelial cells apoptosis [131], a characteristic feature of kidney damage resulting from UUO [131]. Hypertonicity or hypotonicity activates JNK in renal epithelial cells in culture [132-134]. Hypertonicity activated JNK2 but not JNK1 in inner medullary collecting duct cells and inhibition of the JNK2 pathway through the trasfection of a dominant negative form of JNK2 increased the proapoptotic effect of hypertonicity [135], suggesting a protective role of JNK against osmolarity-induced apoptosis. On the contrary, stretch induced apoptosis and JNK activation, and inhibition of this pathway reduced the degree of stretch-induced apoptosis [136].

Nephrotoxic drugs and oxidative stress inducers including arachidonic acid [137] cadmium [138], oxygen free radicals [139] or 1,2-(dichlorovinyl)-L-cysteine (DCVC) [140] resulted in JNK activation, cell apoptosis and detachment from the substrate, whereas inhibition of JNK with SP600125 maintained cell adhesion as well as protection against apoptosis [140], thus suggesting that JNK activation mediates toxicant-induced epithelial cell apoptosis.

Other effects involving JNK activation in tubular cells are thrombin-stimulated PAI-1 expression [141], and epithelial-to-mesenchymal transition (EMT). Some epithelial cells undergo EMT when plated in collagen type 1, and this coincides with JNK activation. Dominant inhibitory Rac1 (RacN17) or inhibition of JNK signaling with SB600125 prevented collagen I-induced EMT [142].

An explanation for these opposing roles of JNK in the same pathological scenario needs to be further elucidated. It should be noted that JNK can participate both in cell survival and apoptosis, depending on the cell type, the stimulus and the circumstances [143].

\subsubsection{Conclusion}

JNK activation seems to be involved in a great variety of physiological functions and processes characteristics of renal damage, (Table 4), such as mesangial cell proliferation, increased extracellular matrix synthesis, tubular cell apoptosis and EMT. Thus, the inhibition of JNK activation represents a novel therapeutic target for the treatment of chronic renal diseases. However, JNK activation is involved in many physiological processes throughout the organism. For instance, JNK activation participates in proliferative and apop- totic signaling in tubular cells. In some instances it is difficult to ascertain whether these effects participate in defensive and repair responses or in deleterious actions.

Accordingly, indiscriminate inhibition of JNK with therapeutic purposes needs to be much further evaluated in vivo and in the preclinical and clinical scenarios.

\section{3. p38 Kinase}

\subsubsection{Overview of 38 Kinase Pathways}

The p38, also known as stress-activated protein kinase- 2 (SAPK2) is a ubiquitous, conserved protein kinase. The p38 family includes four isozymes ( $\alpha$ through $\delta$ ), subjected to dual phosphorylation at the TGY motif, primarily by MKK3 and MKK 6. Members of the 38 family are generally but not exclusively responsive to environmental stressors. Effectors of the p38 family include both transcription factors such as ATF-2, Elk-1, CHOP/Gadd153, Max, MEF2C, and enzymes such as MAPKAP kinase (Fig. 1). Although its precise function remains controversial, p38 MAPK is particularly involved in the inflammatory process, and its activation is required for regulation of transcriptional activation of inflammatory cytokine genes including IL-1 $\beta$ and TNF- $\alpha$ [144].

\subsubsection{Inhibition of p 38 Kinase}

Knowledge on the functional role of p38 signaling has been facilitated, among other tools, by the availability of several synthetic inhibitors among which the most used is SB203580 (Fig. 3), which inhibits most, but not all of the p38 isozymes with relatively high specificity [145]. However, SB203580 also inhibits cyclooxygenase- 1 and -2 and thromboxane synthase [25]. Other inhibitors are FR167653, SB239063, and SB202190 (Fig. 3). Specific inhibitors of the p38 $\alpha$ isozyme, NPC31145 and NPC31169, have been also developed $[146,147]$. They do not block phosphorylation of p38 $\alpha$, but inhibit the ability of phosphorylated-p38 $\alpha$ (p-p38 $\alpha)$ to phosphorylate its downstream targets such as activated transcription factor-2 (ATF-2). A scheme of the place of action of these inhibitors on the p-38 kinase cascade is shown in Fig. (2).

\subsection{3. p38 Kinase Activation in vivo Models of Renal Dis-} ease

In a model of primary mesangial proliferative glomerulonephritis induced by anti-Thyl serum, activation of $\mathrm{p} 38$ has been reported to occur some days later than ERK activation [29]. Homozygous Ren2 transgenic rats (expressing the mouse Ren2 gen) are characterized by renal fibrosis, and increased $\mathrm{p} 38$ activation $[148,149]$. In rats subject to a hemorrhagic hypotensive shock, p38 MAPK activation increased immediately after hemorrhage and decreased with time. This was accompanied by TNF- $\alpha$ and $\Pi-1 \beta$ overexpression, inflammation and renal dysfunction [150].

In human podocyte injury diseases, an increased phosphorylation of p38 MAPK was observed in podocytes [151]. Furthermore, in rat puromycin aminonucleoside (PAN) nephropathy and mouse adriamycin (ADR) nephropathy, p38 MAPK phosphorylation was marked but transient, preceding overt proteinuria. In rats with streptozotocin-induced diabetes, p38 activation has been also observed [152]. Renal 
ischemia-reperfusion was associated with renal p38 activation [153].

\subsection{4.p38 Kinase Activation and Podocyte Damage}

Podocyte loss is a key event leading to glomerulosclerosis [154, and section 2.2]. Critical pathological events affecting podocytes are cell death, mainly by apoptosis, increased production of mediators with auto and paracrine actions and ECM components and actin filament depolymerization, leading to cytoskeleton reorganization, cell detachment and fo ot process effacement.

p38 activation has been implicated in TGF- $\beta$-induced cultured podocyte apoptosis [155]. Incubation of cultured podocytes with Ang-II increased both phosphorylation of p38 and MKK3/6 and VEGF production. [156]. In addition, podocytes exposure to high glucose stimulates the expression of VEGF which in turn induces collagen $\alpha 3 I V$ production, acting downstream of TGF- $\beta 1$ [157].

Podocyte ECM synthes is is also regulated by $\mathrm{p} 38$ activation. Exposure of podocytes to high glucose stimulates p38 and hsp 25 phosphorylation and collagen IV $\alpha 5$ expression via a 12-lip oxygenase-dependent pathway [158], and maintains actin cytoskeleton [159].

Also in cultured podocytes, PAN and oxidative stress induce $\mathrm{p} 38$ phosphorylation along with actin reorganization [151]. However, mechanical stretch induces upregulation of cyclooxygenase-2 and prostaglandin EP4 receptor in a p38 MAPK-dependent manner, which may facilitate actin depolymerization [159]. These opposing effects of p38 on actin organization suggest a strong dependency on the cellular circumstance evoked by the action of a specific combination of stimuli. Specific p38 MAPK substrates that may be responsible for mediating actin depolymerization include transcriptional factors such as activating transcription factor 2 (ATF-2), C/EBP homologous protein (CHOP), Elk-1, myocyte enhancer factors 2A (MEF2A) and 2C (MEF2C), and Max, which can be phosphorylated and activated by $\mathrm{p} 38$ [160]. p38 can also activate MAPK-activated protein kinases 2 and 3, which in turn phosphorylate small heat-shock protein 27 (hsp 27) which plays a major role in actin filament dynamics regulated by $\mathrm{p} 38$ MAPK $[161,162]$. In addition, p38 activation phosphorylates heat shock prote in 25 (hsp25), stabilizing fibrillar actin and preventing cleavage to globular actin. Actin filament is a major constituent of foot processes, and depolymerization of actin filaments leads to foot process effacement [163]. Because actin filaments interact with components of slit diaphragm and with integrins, depolymerized actin filaments may facilitate the loss of adhesive interactions, leading to disruption of slit diaphragm and detachment from GBM [163], a major characteristic of chronic glomerular damage.

The addition of the p38 inhibitor SB203580 to cultured podocytes led to a marked inhibition of the increased VEGF mRNA and protein production induced by Ang-II in a dosedependent manner [156]. These results suggest that the production of VEGF induced by Ang-II in podocytes is mediated, in part, through the activation of the p38 MAPK pathway. In cultured podocytes, FR 167653 inhibits PAN and oxidative stress-induced p38 phosphorylation along with actin reorganization [151]. Inhibition of $\mathrm{p} 38$ activation by
SB202190 in cultured podocytes diminishes high glucoseinduced p38 and hsp 25 phosphorilation, and alters the ratio between fibrillar and globular actin [152].

\subsection{5. p38 Kinase and Renal Tubular Epithelial cells Dam- age}

Both p38 and ERK activation seems to participate in TGF- $\beta$-induced EMT in proximal tubular NRK-52E cell line [93]. However, IL-1 $\beta$-induced EMT in the HK-2 human renal proximal tubular cell line is mediated by p 38 and JNK but not ERK activation [164].

In cultured thick ascending limb cells, p38 activation mediates nitric oxide-induced ciclooxigenase- 2 upregulation [165]. Exposure of MDCK cells to proinflammatory cytokines TNF $\alpha$ and IFN $\gamma$ resulted in a marked p38 activation and a sustained elevation of paracellular permeability without significantly induction of MDCK cell apoptosis [166], suggesting that downstream effectors of $\mathrm{p} 38$ signaling pathways mediate the $\mathrm{TNF} \alpha / \mathrm{IFN} \gamma$-induced functional reorganization that modulates MDCK cell barrier function.

Ang-II stimulates p38 activation in primary cultures of rat proximal tubular cells and this fact seems to mediate increased TGF- $\beta 1$ secretion [167]. TGF- $\beta 1$ stimulates angiotensinogen gene expression in proximal tubule cells and this effect seems to be mediated by $\mathrm{p} 38$ activation [168]. In addition, TGF- $\beta 1$ is also able to induce in epithelial cells the production of thrombospondin-1 (TSP-1) a potent profibrotic and antiangiogenic substance in the kidney and in other tissues $[169,170]$. TGF- $\beta 1$ is able to activate p38 in the rat proximal tubular cell line NRK52E and in mouse fibroblasts and TGF- $\beta 1$-dependent TSP-1 expression is dependent on $p$ 38 activation [171].

Hypertonic stress activates of $\mathrm{p} 38$ in several types of cultured epithelial cells $[132,133,172,173]$. p38-mediated tubule cell apoptosis has been demonstrated to occur upon the action of TGF- $\beta 1$ [174] and mechanical stretch [136]. Treatment of LLC-PK1 cells with the nephrotoxicants 1,2(dichlorovinyl)-L-cysteine (DCVC), 2,3,5-Tris-(glutathionS-yl)hydroquinone (TGHQ), or $\mathrm{H}_{2} \mathrm{O}_{2}$ resulted in p38 activation, increased $\mathrm{Hsp} 27$ phosphorylation and apoptosis $[175,176]$, suggesting that $\mathrm{p} 38$ activation contributes to $\mathrm{H}_{2} \mathrm{O}_{2}$ , DCVC and TGHQ-induced cell death.

Epidermal growth factor (EGF) plays a major role in renal proximal tubular cell dedifferentiation, a prerequisite for regenerative proliferation and migration after renal injury, and thus, for recovery from tubular necrosis. When proximal tubular cells are subjected to an oxidant injury, both the EGF receptor, MKK3, and $\mathrm{p} 38$ become activated. Accordingly, it is likely that $\mathrm{p} 38$ pathway activation mediates EGF receptor activation after oxidant injury [177].

In renal tubular cells, p38 inhibition with SB202190 reduces the expression of the proinflammatory cytokine MCP1 as well the TGF- $\beta 1$-induced procollagen I $\alpha 1$ expression induced by albumin [178]. Pharmacological inhibition of $\mathrm{p} 38$ signaling with SB202190 blocked the deleterious effects of the pro inflammatory cytokines on epithelial barrier function [166]. Blocking p38 with SB 203589 and NPC31169 inhibited TGF- $\beta 1$-induced TSP- 1 mRNA and protein expression in the rat proximal tubular cell line NRK52E and in mouse fibroblasts suggesting that TSP-1 expression in response to 
TGF- $\beta 1$ is regulated by $p 38$ [171]. Furthermore, inhibition of the p38 pathway activation by SB202190 and SB-203580 blunted Hsp 27 phosphorylation and protected LLC-PK 1 cells from $\mathrm{H}_{2} \mathrm{O}_{2}$, DCVC and TGHQ-induced cell death $[175,176]$, indicating that $\mathrm{p} 38$ activation contributes to $\mathrm{H}_{2} \mathrm{O}_{2}$ and TGHQ-induced cell death. Although both $\mathrm{p} 38$ and JNK were activated in this epithelial cell line by DCVC, only inhibition of p38 with SB203580 reduced Hsp27 phosphorylation, which was associated with accelerated reorganization of focal adhesions, cell detachment, and more apoptosis, thus suggesting that early $\mathrm{p} 38$ activation by the toxic is a defense mechanism that results in a rapid phosphorylation of $\mathrm{Hsp} 27$, a requirement for proper maintenance of cell adhesion, thus partially protecting against renal epithelial cell apoptosis [140]. In contrast, inhibition of JNK with SP600125 maintained cell adhesion as well as protection against apoptosis, thus suggesting that JNK activation mediates toxicantinduced epithelial cell apoptosis [140]. Inhibition of p38 with SB203580 or adenoviral overexpression of a dominant negative $\mathrm{p} 38$ form or its upstream activator, MKK3, inhibits EGF receptor blocked renal proximal tubular cells dedifferentiation, which results in delayed recovery of acute tubular necrosis [177].

\subsection{6.p38 Kinase and Mesangial Cell Activation}

In cultured mesangial cells, p38 is activated by many substances, including hormones, cytokines, heavy metals and oxidant stress (Table 3). TGF-beta1-induced production of fibronectin, type I and type IV collagen in cultured rat mesangial cells is also mediated by p38 activation $[179,183]$. TGF- $\beta 1$ also induces COX- 2 expression in human mesangial cells whereas p38 MAPK inhibition with SB203580 blunts TGF-beta1-induced COX-2 overexpression [44]. TGF-beta1 also increased the expression of the pro-inflammatory cytokine MCP-1 in a time- and dose-dependent in a rat mesangial cell line, and this effect required the activation of $\mathrm{p} 38$ [183]. In mesangial cells, either the p38 inhibitor SB-203580 or the JNK inhibitor SP-600125, but not the ERK1/2 inhibitor PD98059 significantly reduced Ang-II-induced TSP-1 production, suggesting that ANG II-induced TSP-1 production is dependent on p38 MAPK and JNK signaling [123]. In mesangial cells, incubation with the p38 inhibitor SB203580 suppressed AGE-induced iNOS expression and nitrite release. Cadmium-induced mesangial cell contraction, p38 MAP kinase activation, increased hsp 25 phosphorylation and association of hsp 25 with microfilaments were inhibited by the specific p38 inhibitor SB203580 and by expression of a catalytically inactive mutant of p38 [181].

\subsubsection{Effects of 38 Inhibition on Renal Disease}

Pharmacological inhibition of p38 kinase has proven to partially prevent renal damage and to preserve renal function in different animal models of nephropathy. Stambe et al. [146] and Wada et al. [185] reported that the p38 inhibitor NPC3 1145 blocked early neutrophil and platelet infiltration in the anti-glomerular basement membrane (GBM) nephritis model in rats and this was associated with less proteinuria and preserved renal function., Iwata and colleagues also reported that chronic administration of the p38 MAPK inhibitor FR167653 in a lupus model in mice inhibited the autoimmune response leading to a reduction in renal injury and renal function preservation [186]. Treatment of Ren2 transgenic rats with the p38 inhibitor SB239063 strongly reduced renal osteopontin, alpha-smooth muscle actin and collagen type III expression and tubulointerstitial fibrosis $[148,149]$.

In rats with puromycin aminonucleoside (PAN) nephropathy and mouse adriamycin (ADR) nephropathy, both nephropathies characterized by a marked podocyte damage, pretreatment with FR167653 completely inhibited p38 MAPK activation, prevented the occurrence of proteinuria, and markedly ameliorated podocyte injury. Furthermore, early treatment with FR 167653 effectively prevented glomerulosclerosis and renal dysfunction in the chronic phase of ADR nephropathy, suggesting that p38 MAPK might be a potential target for therapeutic intervention in proteinuric glomerulopathies [151].

In rats subject to a hemorrhagic hypotensive shock, pretreatment of the animals with a specific inhibitor of $\mathrm{p} 38$ MAPK activation, FR167653, attenuated TNF- $\alpha$ and IL-1 $\beta$ overexpression, inflammation and renal dysfunction consequent to the hypotensive shock, although the primary hypotensive state was maintained [150]. Blockade of $\mathrm{p} 38$ with FR167653 ameliorated renal ischemia/reperfusion injury [187]. Tubule-targeted, intracellular delivery of the p38 inhibitor SB202190 also reduced kidney damage after experimental renal ischemia/reperfusion in rats [178].

Only in the rat $5 / 6$ nephrectomy model of CRF did treatment with the p38 $\alpha$ inhibitor NPC31169 result in worsened renal function, more proteinuria, and more severe glomerulosclerosis and tubulointerstitial injury. p38 inhibition resulted in marked cell proliferation in these rats, with more proliferating tubular cells, myofibroblasts, and macrophages. Still, p38 suppression with NPC31169 resulted in less tubular cell apoptosis [147].

\subsubsection{Conclusions}

From the above reviewed data, we can conclude that $\mathrm{p}-38$ is activated in most models of chronic renal damage in and in acute inflammatory renal damage. The reported functions of p38 activation in renal cells are summarized in Table 4 . In general terms, blockade of $\mathrm{p} 38$ may be beneficial in severe and acute inflammatory renal diseases in which there are high levels of proinflammatory cytokines (such as IL-1 $\beta$ and TNF- $\alpha$ ). In contrast, the chronic models of renal failure are most associated to platelet-derived growth factor-associated mesangial cell proliferation and TGF- $\beta$-associated fibrosis [188] whereas TNF- $\alpha$ expression was minimal. Because lowgrade chronic inflammation is known to suppress normal cell growth, one might speculate that blocking p38-mediated inflammation may stimulate a proliferative response, which in this model is deleterious. However p38 activation may also facilitate actin depolymerization and podocyte loss, and this is a key event leading to glomerulosclerosis. Thus, these pathological events would benefit from pharmacological p38 inhibition. However, in pathological situations that require reepithelization, EGF-dependent epithelial cell dedifferentiation, a necessary event for acute tubular necrosis recovery, depends on p-38 activation. In this case, pharmacological blockade of p38 activation would delay or hamper tubular recovery. 


\subsection{Extracellular Signal-Regulated Kinase 5 (ERK-5)}

Another more recently discovered MAPK, the extracellular signal-regulated kinase 5 (ERK5) also known as big MAP Kinase 1 (BMK1), has been involved in the regulation of cell proliferation, apoptosis and responses to physical stimuli [189]. ERK5 was identified as a MAPK family member with a large $\mathrm{COOH}$ terminal domain and a unique loop-12 sequence that shares the TEY activation motif with ERK1/2 $[189,190]$. In addition to the core catalytic domain, ERK 5 contains an approximately 400 amino acid C-terminal extension containing a transcriptional activation domain, and a region that interacts with the myocyte enhancer factor- 2 (MEF2) family of transcription factors. Furthermore, ERK5 can phosphorylate some MEF2 proteins leading to upregulation of the immediate early response gene $c$-jun $[191,192,193]$. In common with ERK1 and ERK2, ERK5 requires phosphorylation at the conserved TEY motif within its activation loop for full activity [191]. ERK5 is phosphorylated and activated by an upstream MAPK kinase called MEK $5[190,191]$. ERK 5 has been reported to be activated by oxidative stress [194], serum and certain growth factors such as EGF [195].

To the present, no specific ERK-5 inhibitors have been described, although UO126 PD 98059 , classical inhibitors of MEK activity, also blocks ERK5 activation.

\subsubsection{ERK5 Activation and Kidney Damage}

Information about the role of ERK5 on renal diseases is very scarce. ERK 5 and ERK $1 / 2$ but not $\mathrm{p} 38$ has been reported to be activated in the glomeruli of Otsuka Long Evans Tokushima Fatty rats, a model of type 2 diabetes mellitus which shows diabetic nephropathy [196]. High glucose plus high raffinose cause mesangial cell proliferation and a rapid and significant activation of ERK-5. MEK inhibitors, U0126 and PD 98059 , both inhibit ERK 5 activation by high glucose in a concentration-dependent manner [196]. Transfection of a dominant-negative form of MEK5, the upstream regulator of ERK5, abolished mesangial cell proliferation stimulated by high glucose thus suggesting that ERK5-mediated mesangial cell growth may be involved in the pathogenesis of diabetic nephropathy [196]. Some other mediators of acute and chronic renal failure such as Ang-II, endothelin I, platelet activating factor, TGF- $\beta 1$ and EGF are also able of activate ERK-5 [197]. Even more important, transfection of a dominant-negative form of ERK-5 resulted in a significant decrease in EGF-induced mesangial cell contraction and proliferation [197]. Finally, it has been reported that ERK5 activation is required for EGF-dependent morphogenesis of renal tubular structure [198].

\subsubsection{Conclusions}

The data available on the role of ERK5/BMK1 in the genesis of renal disease or in renal cell damage is too scarce to obtain conclusions on the pathophysiological role of this signaling pathway, and on the therapeutic possibilities posed by its manipulation.

\section{CLINICAL PERSPECTIVES, LIMITATIONS AND CAUTIONS}

As previously reported, many chemicals have been developed to block MAP kinase and other protein kinase path- ways, mainly with the purpose to treat diverse types of tumors. As experimental data above reviewed demonstrate in many "in vivo" and cellular systems that MAP kinase inhibition, can prevent or slow the development of many of the changes associated to CRF or ARF, in can be suggested that administration of MAP kinase inhibition can represent a new therapeutical tool to fight against renal disease. However, at the present, this kind of therapies shows many limitations.

First, although the effects of all these kinase inhibitors have been well tested in cellular models of renal disease, or even in animal models of the disease, its application to humans is still in the first phases of development, for most of them. There are many of these drugs that are in active processes of clinical application. Some of them have recently been approved for selective, restricted clinical use or are awaiting approval, including: Dasatinib, Imatinib, Lapatinib, Nilotinib, Panitumumab, and Sunitinib. Most of these drugs are inhibitors of kinase activity of VEGF and/or EGF receptors, but recently, Sorafenib (previously known as BAY 43 $9006)$, a multikinase inhibitor specially designed to target the RAF-MEK-ERK pathway has been approved for its use in the treatment of patients with advanced renal cell carcinoma and it has been commercialized with the name of Nexavar by Bayer Pharmaceuticals [199].

Some other kinase inhibitors are now in Phase III, including Motesanib and Pazopanib, (inhibitors of VEGF and PDGF receptors), Aflibercept, Vandetanib (VEGF and EGF receptors), Cediranib, BIBW-2992 (EGFR and HER2 inhibitors), Enzastaurin and Ruboxistaurin (PKC-beta and PI3K/AKT), Deforolimus (mTOR), Lestaurtinib (FMS-like tyrosine kinase 3 inhibitor), Alvocidib (CDK inhibitor). Among kinase inhibitors now in Phase II, there are some p38 MAP kinase inhibitors: (VX-702, SCIO-469, Pamapimod, 681323 and $856553, \mathrm{KC}-706)$ as well as MEK Inhibitors (PD-325901 and ARRY-142886) and PI3K or Akt inhibitors (Triciribine, Perifosine and INCB-18424). MEK1/2 inhibitor PD184352 is currently being evaluated in Phase I clinical trials. JNK inhibitors from Celgene (CC-401; Celgene, San Diego, CA, USA) and Serono (AS602801; Serono, Geneva, Switzerland) are currently undergoing phase 1 clinical trials.

Another major problem of the therapy with proteinkinase inhibitors is the undesired inhibitor effects on other kinases different to the kinase targeted, as their close structural similarities can make difficult to achieve specificity for a particular kinase, thus potentially leading to unwanted side effects. A very significant example of the lack of selectivity of protein kinases has been recently reported by Bain et al. [200]. They have assessed the specificities of 65 compounds reported to be relatively specific inhibitors of protein kinases against a panel of $70-80$ protein kinases. Their results have further emphasized the need for considerable caution in using small-molecule inhibitors of protein kinases to assess the physiological roles of these enzymes or specifically inhibit a particular protein kinase, as despite being widely used, many of the compounds that they analyzed were too non-specific for obtaining useful conclusions. On the basis of this information, they recommend the use of the following small-molecule inhibitors for specific MAP kinase inhibitors: SB 203580/SB202190 to inhibit p38 MAPK isoforms, and PD 184352 or PD 0325901 to inhibit MKK1 (MAPK 
kinase-1) or MKK1 plus MKK5, and thus inhibit ERK1/2 ad ERK5 activation,

However, it is possible to re-design protein-kinase inhibitors in order to eliminate undesired inhibitory effects. For instance, the kinase inhibitor imatinib has been highly successful in the treatment of both chronic myelogenous leukaemia (CML) and gastrointestinal stromal tumours (GIST). However, treatment with imatinib has been reported to cause severe, cardiotoxicity, although in a low number of cases. Fernández et al. have reported the possibility of reengineering imatinib to alter its kinase inhibition profile to specifically target GISTs, while reducing its toxic effects on the heart [201]. The authors aimed to redesign imatinib, focusing its specificity on C-Kit kinase inhibition, which is the therapeutic target for GIST treatment, while reducing its effect on the kinase $\mathrm{BCR}-\mathrm{ABL}$, which is the therapeutic target for CML but it has also been linked to the cardiovascular side effects of the drug. In addition, they aimed to promote also the inhibition of JNK1, as it has been reported that JNK activation mediates the adverse effects of imatinib on heart cells [202]. Using structural and molecular dynamics analysis, they predicted that addition of a methyl group to imatinib to form the reengineered compound, that was called WBZ-4, would promote dehydration of the C673-G676 residue pair upon binding to $\mathrm{C}$-Kit and stabilize the complex, while impeding any association of WBZ-4 with BCR-ABL. Surprisingly, this small modification increased the inhibitory activity of WBZ-4 on JNK 1 activation [201]. To prove the in vivo efficiency of this new compound, they assayed it in a mouse model of GIST. In this model, WBZ-4 was shown to decrease tumor volume and weight to a similar extent to that observed with imatinib, but in contrast to imatinib, WBZ-4 did not affect left-ventricular cardiac function. JNK1/2 activation induced by WBZ-4 in mouse cardiomyocytes was lower to that induced by imatinib, thus explaining the lower cardiotoxicity of WBZ-4 compared with imatinib [201]. This approach might also be applied to engineer the specificity of other kinase inhibitors with undesirable side-effects with the aim of creating safer and more effective drugs. In this case, it should be possible to use in chronic renal disease some of the MAP kinase inhibitors that, at the present, show toxic effects.

A further major limitation for the use of MAP kinase inhibitors in the treatment of renal failure is that, what is positive for certain aspect of renal damage can be negative for other aspect. For instance, under several stress circumstances, renal cell viability or tubular reepithelization depends on the sustained activation of some MAP kinases such as ERK or p38, and their inhibition was associated with cell death or lack of recovery after ischemia/reperfusion $[140,177,203]$. This suggests that activation of these kinases may be involved in the repairing processes during ischemia/reperfusion, regulating cell proliferation, apoptosis ad differentiation. Furthermore, podocyte survival also requires ERK activation [204]. For these reasons, it has to be considered that the inhibition of MAP kinase signaling pathways may be therapeutic, but in some pathophysiological circumstances it may also inhibit the repairing processes, thus impairing or delaying the recovery of renal function. In addition, MAP kinase activation can regulate physiological functions of the kidney, such as tubular transport [82] and MAP kinase inhibition could thus impair these physiological functions.

As a final conclusion, although there are many experimental data derived from both "in vivo" and "in vitro" models of renal damage suggesting that with MAP kinase inhibitors is a promising area of therapy for renal failure, supporting data from further experimental models of kidney disease and large clinical trials on the use of these drugs on chronic or acute renal disease with careful analysis of possible adverse reactions or undesired side effects are required before they can be used in the every day clinical setting.

\section{ACKNOWLEDGEMENTS}

Studies from the Authors' Laboratory have been supported by grants from Span ish Ministerio de Ciencia y Tecnologia (BFU2004-00285/BFI, SAF 2003-04177; and SAF 2007-63893) Instituto de Sahud Carlos III, (RETIC RedInRen RD/0016), Junta de Castilla y León (SA 001/C05), and Instituto Reina Sofia de Investigación Nefrológica.

\section{REFERENCES}

[1] Lameire, N.; Van Biesen, W; Vanholder, R. Lancet, 2005, 365, 417.

[2] Remuzzi, G.; Benigni, A.; Remuzzi, A. J. Clin. Invest., 2006, 116, 288

[3] Bohle, A.; Muller, G.A.; Wehrmann, M.; Mackensen-Haen, S.; Xiao, J.C. Kidney Int. Suppl., 1996, 54, S2.

[4] Nath, K.A. Am. J. Kidney Dis., 1992,20,1.

[5] Koom ans, H.A.; Blankestijn, P.J.; Joles, J.A. J. Am. Soc. Nephrol., $2004,15,524$

[6] Lameire, N.; Van Biesen, W.; Vanholder, R. J. Am. Soc. Nephrol., $2006,17,923$.

[7] Liangos, O.; Wald, R.; O'Bell, J.W.; Price, L.; Pereira, B.J.; Jaber, B.L. Clin. J. Am. Soc. Nephrol, 2006, I, 43.

[8] Chertow, G.M.; Burdick, E.; Honour, M.; Bonventre, J.V.; Bates, D.W. J. Am. Soc. Nepirol., 2005, 10,3365.

[9] Garg, A.X.; Kiberd, B.A.; Clark, W. F. Haynes, R.B.; Clase, C.M. Kidney Int., 2002, 61, 2165.

[10] Go, A.S; Chertow, G.M.; Fan, D.; McCulloch, C.E.; Hsu, C.Y. $N$. Engl. J. Med., 2004, 35I, 1296 .

[11] [11] López-Novoa, J.M.; de Arriba, G.; Barrio, V; RodriguezPuyol, D. Eur. J. Pharmacol., 1987, 134, 365.

[12] Olivera, A.; Lopez-Novoa, J.M. Br. J. Pharmacol. 1992, 107,341.

[13] Shanlkland, S.J. Kidney Int, 2006, 69,2131.

[14] Eddy, AA. Am. J. Kidney Dis., 2001, 37, \$25

[15] Iwano, M.; Plieth, D.; Danoff, T.M.; Xue, C; Okada, H.; Neilson, E. G. J. Cin. Invest., 2002, 110,341.

[16] Tomasek, J.J.; Gabbiani, G.; Hinz, B.; Chaponnier, C.; Brown, R.A. Nat. Rev. Mol. Cell Biol, 2002, 3,349.

[17] Simian, M.; Hirai, Y.; Navre, M.; Werb, Z.; Lochter, A.; Bissell, M.J. Development, 2001, I28,3117.

[18] Strutz, F, Zeisberg, M. J. Am. Soc. Nephrol, 2006, I7, 2992.

[19] Chang, L.; Karin, M. Nature, 2001, 410,37.

[20] Garrington, T. P.; Johnson, G.L. Curr. Opin. Cell Biol., 1999, H, 211.

[21] [21]. Tian, W; Zhang, Z; Cohen, D.M. Am. J. Physiol Renal Physiol, 2000,270,593.

[22] Rubinfeld, H.; Seger, R. Mol. Biotechnol., 2005,31, 151

[23] Ishii, Y.; Sals ai, S.; Honma, Y. Leuk. Res., 2001, 25, 813.

[24] Terada, Y.; Yamada, T.; Talsayama, M.; Nonoguchi, H.; Sasalki, S.; Tomita, K.; Marumo, F. J.Am. Soc. Nephrol., 1995, 6, 1565.

[25] Kohno, M.; Pouyssegur, J. Prog. Cell Cycle Res., 2003, 5, 219.

[26] Borsch-Haubold, A.G.; Pasquet, S.; Watson, S.P. J. Biol. Chem., $1998,273,28766$

[27] Zhang, N.; Wu, B.; Powell, D.; Wissner, A.; Floyd, M.B.; Kovacs, E. D.; Toral-Barza, L.; Kohler, C. Bioorg. Med. Chem. Lett., 2000, 
10,2825.

[28] Bolsemeyer, D.; Guglielmi, K.E.; McGinty, A.; Sorokin, A.; Lianos, E.A.; Dunn, M.J. J. Clin. Invest., 1997, 100, 582

[29] Bolsemeyer, D.; Ostendorf, T.; Kunter, U.; Lindemann, M.; Kramer, H.J.; Floege, J. J. Am. Soc. Nephrol., 2000, II, 232

[30] Bokemeyer, D.; Panek, D.; Kramer, HJ.; Lindemann, M.; Kitahara M.; Boor, P.; Kerjaschlki, D.; Trzaslsos, JM.; Floege, J.; Ostendorf, T. J. Am. Soc. Nephrol., 2002, 13,1473 .

[31] Pat, B.; Yang, T.; Kong, C; W Watters, D.; Johnson, D. W.; Gobe, G. Kidney Int, 2005, 67,931.

[32] Masalsi, T.; Foti, R.; Hill, P.A.; Ilezumi, Y.; Atlsins, R.C.; NilsolicPaterson, D.J. Kidney Int, 2003, 63, 1256.

[33] Omori, S.; Hida, M.; Fujita, H.; Talsahashi, H.; Tanimura, S.; Kohno, M.; A.wazu, M. J. Am. Soc. Nephrol, 2006, 17, 1604.

[34] Haneda, M.; Aralki, S.; Togawa, M.; Sugimoto, T.; Isono, M. Kiklkawa, R. Diabetes, $1997,46,847$.

[35] Feliers, D.; Duraisamy, S.; Faullkner, J.L.; Duch, J.; Lee, A.V.; Abboud, H.E.; Choudhury, G.G.; Kasinath, B.S. Kidney Int., 2001 60,495 .

[36] Hamaguchi, A.; Kim, S.; Izumi, Y.; I wao, H. J. Am. Soc. Nephrol. $2000,11,39$.

[37] Hamaguchi, A.; Kim, S.; Yano, M.; Yamanalsa, S.; Iwao, H. J. Am. Soc. Nephrol, $1998,9,372$.

[38] Arany, I.; Megyesi, JK.; Kaneto, H.; Price, PM.; Safirstein, RL. Am. J. Physiol. Renal Physiol., 2004, 287, 543

[39] Sánchez-González, P; Vicente-Sânchez, C.; Pérez-Barriocanal, F.; López-Novoa, J.M.; Morales, A.I. Toxicol. Lett., 2006, 164, 112.

[40] Schramek, H.; Schumacher, M.; Pfaller, W. Am. J. Physiol. Renal Finid Electrolyte Physiol., 1996, 271, 423.

[41] Inoue, C.N.; Ko, Y.H.; Guggino, W.B.; Forster, H.G.; Epstein, M. Proc. Soc. Exp. Biol. Med., 1997, 216, 370.

[42] Anderson, P.W.; Zhang, X.Y.; Tian, J.; Correale, J.D.; Xi, X.P.; Yang, D.; Graf, K.; Law, R.E.; Hsueh, W.A. Kidney Int., 1996, 50, 745 .

[43] Amemiya, T.; Sasamura, H.; Mifune, M.; Kitamura, Y.; Hirahashi, J.; Hayashi, M.; Saruta, T. Kidney Int., 1999, 56, 2055.

[44] Rodríguez-Barbero, A.; Dorado, F; Velasco, S.; Pandiella, A.; Banas, B.; Lopez-Novoa, J.M. Kidney Int., 2006, 70,901.

[45] El-Dahr, S.S.; Dipp, S.; Baricos, W.H. Am. J. Physiol Renal Physiol, 1998, 275, 343.

[46] Grewal, J.S.; Mukhin, Y.V.; Garnovskaya, M.N.; Raymond, J.R. Greene, E. L. Am. J. Phosiol. Renal Physiol, 1999, 276, 922.

[47] Huwiler, A.; Pfeilschifter, J. Br. J. Pharmacol, 1994, II3, 1455

[48] Kusalsa, I.; Ishikawa, S.E.; Higashiyama, M.; Saito, T.; Nagasalka, S. Endocrinology, 1996, 137, 5421

[49] Yunta, M.; Rodriguez-Barbero, A.; Arevalo, M.A.; Lopez-Novoa J.M.; Lazo, P.A. Kidney Int., 2003, 63, 534.

[50] Ishida, T.; Haneda, M.; Maeda, S.; Koya, D.; Kikkawa, R. Diabetes, $1999,48,595$.

[51] Ingram, A.J.; James, L.; Ly, H.; Thai, K.; Cai, L.; Scholey, J.W. Kidney Int, 2000,58, 1067 .

[52] Kawata, Y.; Mizulsami, Y.; Fujii, Z.; Salsumura, T.; Yoshida, K.; Matsuzalsi, M. J. Bio.l Chem., 1998, 273, 16905 .

[53] Zent, R.; A ilenberg, M.; Silverman, M. Exp. Cell Res, 1998, 240, 134.

[54] Ikeda, M.; Ikeda, U.; Shimada, K.; Fujita, N.; Okada, K.; Saito, T.; Minota, S.; Kano, S. Eur. J. Pharmacol, 1997, 324, 283.

[55] Yasunari, K.; Kohno, M.; Kano, H.; Yolsolsawa, K.; Minami, M. Yoshilsawa, J. Hypertension, 1997, 29, 350.

[56] Haneda, M.; Aralki, S.; Sugimoto, T.; Togawa, M.; Koya, D.; Kiklkawa, R. Kidney Int, 1996,50,384.

[57] Miralem, T.; Templeton, D.M. Biochem. J., 1998, 330,651.

[58] Matsuo, H.; Yam asalki, H.; Matsumoto, K.; Uotani, S.; Yamaguchi, Y.; Alsazawa, S.; Yamashita, S.; Nagataki, S. Biochem. Biophys. Res. Commun, 1996, 226,746.

[59] Matousovic, K.; Grande, J.P.; Chini, C.C.; Chini, E.N.; Dousa, T.P. J. Clin. Invest., $1995,96,401$.

[60] Huwiler, A.; Pfeilschifter, J. FEBS Lett, 1994, 14, 255,

[61] Huwiler, A.; Pfeilschifter, J. FEBS Lett., 1994, I5, 135

[62] Schramek, H.; Sorolsin, A.; Watson, R.D.; Dunn, M.J. J. Cardiovasc. Pharmacol., 1995, 26, 95 .

[63] Schramek, H.; Schumacher, M.; Wilflingseder, D.; Oberleithner, H.; Pfaller, W. Am. J. Physiol. Cell Physiol., 1997, 272,383.

[64] Huwiler, A.; Fabbro, D.; Pfeilschifter, J. Eur. J. Biochem., 1995,
227,209 .

[65] Togawa, M.; Haneda, M.; Araki, S.; Sugimoto, T.; Isono, M.; Hidalsa, H.; Yasuda, H.; Kashiwagi A.; Kilklkawa, R. Eur. J. Pharmacol, 1997, 336, 291 .

[66] Gomez-Garre, D.; Ruiz-Ortega, M.; Ortego, M.; Largo, R.; LopezArmada, M.J.; Plaza, J.J.; Gonzalez, E.; Egido, J. Hypertension, $1996,27,885$.

[67] Tan, Y.; Wang, B.; Keum, J.S.; Jaffa, A.A. Am. J. Physiol. Renal Physiol., 2005, 288, 483 .

[68] Lin, C.L.; Wang, F.S.; Kuo, Y.R.; Huang, Y.T.; Huang, H.C.; Sun, Y.C.; Kuo, Y.H. Kidney Int., 2006, 69, 1593.

[69] Border, W.A.; Noble, N.A. Kidney Int., 1997, 51, 1388.

[70] Guo, B.; Inolki, K.; Isono, M.; Mori, H.; Kanasalki, K.; Sugimoto, T.; Akiba, S.; Sato, T.; Yang, B.; Kiklsawa, R.; Kashiwagi, A.; Koya, D. Kidney Int, 2005, 68,972.

[71] Riser, B.L.; Cortes, P.; Yee, J.; Sharba, A.K.; Asano, K.; Rodriguez-Barbero, A.; Narins, R.G. J. Am. Soc. Nephrol., 1998, 9, 827.

[72] Tanimura, S.; Chatani, Y.; Hoshino, R.; Sato, M.; Watanabe, S.; Kataoka, T.; Nals amura, T.; Kohno, M. Oncogene, 1998, 17, 57.

[73] Lal, M.A.; Proulx, P.R.; Hebert, R.L. Am. J. Physiol. Renal Physiol, 1998, 274, 728.

[74] Cussac, D.; Schaals, S.; Gales, C.; Flordellis, C.; Denis, C.; Paris, H. Am. J. Physiol. Renal Physiol, 2002, 282, 943.

[75] Chatterjee, S.; Shi, W.Y.; Wilson, P.; Mazumdar, A. J. Lipid. Res., $1996,37,1334$.

[76] Dulin, N.O.; Sorokin, A.; Douglas, J.G. Hypertension, 1998, 32, 1089 .

[77] Simm, A.; Munch, G.; Seif; F.; Schenk, 0.; Heidland, A.; Richter, H.; Vamvalsas, S.; Schinzel, R. FEBS Lett., 1997, 410,481.

[78] Moroolsa, H.; Bonventre, J.V.; Pombo, C.M.; Kyrialsis, J.M.; Force, T. J. Biol. Chem., $1995,270,30084$

[79] Kramer, H.J.; Hashemi, T.; Backer, A.; Bokemeyer, D. Kidney Blood Press. Res., 2002,25,65.

[80] Jo, S.K.; Cho, W.Y.; Sung, S.A.; Kim, H.K.; Won, N.H. Kidney Int., 2005, 67, 458 .

[81] Sarró, E., Tornavaca, O., Plana, M., Meseguer, A., Itarte, E. Kidney Int., 2008, 73,77.

[82] Li, Y.; Yamada, H.; Kita, Y.; Kunimi, M.; Horita, S.; Suzuki, M.; Endo, Y.; Shimizu, T.; Selki, G.; Fujita, T. J. Am. Soc. Nephrol., $2008,19,252$.

[83] Reunanen, N.; Foschi, M.; Han, J.; Cari, V.K. J. Biol. Chem., 2000, 275,34634

[84] Martínez-Salgado, C.; Fuentes-Calvo, I.; García-Cenador, B.; Santos, E.; López-Novoa, J.M. Exp. Cell Res., 2006,312, 2093.

[85] Stratton, R.; Rajkumar, V.; Ponticos, M.; Nichols, B.; Shiwen, X.; Black, C.M. A braham, D.J.; Leask, A EASEB J, 2002, 16, 1949.

[86] Heeg, M.H.; Koziolek, M.J.; Vaslso, R.; Schaefer, L.; Sharma, K.; Muller, G.A.; Strutz, F. Kidney Int., 2005, 68, 96.

[87] Pat, B.K.; Cuttle, L.; Watters, D.; Yang, T.; Johnson, D.W.; Gobe, G.C. Nephrologv (Carlton), 2003, 8, 196

[88] Di Mari, J.F.; Davis, R.; Safirstein, R.L. Am. J. Physio l, 1999, 277, 195.

[89] Werner, S.; Grose, R. Physiol. Rev., 2003, 83, 835

[90] Bottinger, E. P.; Bitzer, M.J. Am. Soc. Nephrol, 2002, 13, 2600 ,

[91] Li, J.H.; Wang, W.; Huang, X.R.; Oldfield, M.; Schmidt, A.M.; Cooper, M.E.; Lan, H.Y. Am. J. Pathol., 2004, 164, 1389.

[92] Wang, W.; Huang, X.R.; Canlas, E.; Oka, K.; Truong, L.D.; Deng, C.; Bhowmick, N.A.; Ju, W.; Bottinger, E. P.; Lan, H.Y. Circ. Res., 2006, 98,1032

[93] Rhyu, D. Y.; Yang, Y.; Ha, H.; Lee, G.T.; Song, J.S.; Uh, S.T.; Lee, H.B. J. Am. Soc. Nephrol, 2005, 16,667.

[94] Janda. E.; Lehmann, K.; Killisch, I.; Jechlinger, M.; Herzig, M.; Downward, J.; Beug, H.; Grunert, S. J. Cell Biol., 2002, 156, 299.

[95] Bhowmick, N.A.; Zent, R.; Ghiassi, M.; McDonnell, M.; Moses, H.L. J. Biol. Chem., 2001, 14, 276, 46707

[96] Hocevar, B.A.; Brown, T. L.; Howe, P.H. EMBO J., 1999, 18, 1345.

[97] Schramek, H.; Feifel, E.; Marschitz, I.; Golochtchapova, N.; Gstraunthaler, G.; Montesano, R. Am. J. Physiol. Cell Physiol., $2003,285,652$.

[98] Xie, L.; Law, B.K.; Chytil, A.M.; Brown, K.A.; Aalsre, M.E.; Moses, H.L. Neoplasia, 2004, 6, 603.

[99] Rodriguez-Pena, A,; Grande, M.T.; Eleno, N.; Arévalo, M.; Guerrero, C.; Santos, E; López-Novoa, J.M. Kidney Int, 2008 (in press)

[100] Nishina, H.; Nalkagawa, K.; Azuma, N.; Katada, T. J. Biol. Regul. 
Homeost. Agents., 2003, I7, 295 .

[101] Chen, Y.R.; Tan, T.H. Oncogene, 1998, 17, 173

[102] Cross, J.V; Deals, J.C.; Rich, E.A.; Qian, Y; Lewis, M.; Parrott L.A.; Mochida, K.; Gustafson, D.; Vande Pol, S.; Templeton, D.J. J. Biol. Chem., 1999, 274, 31150

[103] Maroney, A.C., Finn, J. P., Connors, T.J., Durkin, J.T., Angeles, T., Gessner, G., Xu, Z., Meyer, S.L., Savage, M.J., Greene, L.A., Scott, R.W., Vaught, J.L. J. Biol. Chem., 2001, 276, 25302.

[104] Bennett, B.L.; Sasalki, D. T.; Murray, B.W.; O'Leary, E.C.; Salkata S.T.; Xu, W. Proc. Natl. Acad Sci. USA, 2001, 98, 13681

[105] Seto, M.; Kim, S.; Yoshifusa, H.; Nalsamura, Y.; Masuda, T. Hamaguchi, A.; Yamanalsa, S.; Iwao, H. J. Am. Soc. Nephrol., $1998,9,1367$.

[106] Di Mari, J.; Megyesi, J.; Udvarhelyi, N.; Price, P.; Davis, R.; Safirstein, R. Am. J. Physiol. Renal Physiol., 1997, 272, 292.

[107] Kunduzova, O.R.; Bianchi, P.; Pizzinat, N.; Escourrou, G.; Seguelas, M.H.; Parini, A.; Cambon, C. FASEB J., 2002, I6, 1129.

[108] Ishizuka, S.; Yano, T.; Hagiwara, K.; Sone, M.; Nihei, H.; Ozasa H.; Horikawa, S. Biochem. Biophys. Res. Común., 1999, $254,88$.

[109] Hu, Y.; Metzler, B.; Xu, Q.J. Biol. Chem., 1997, 272,9113.

[110] Huwiler, A.; van Rossum, G.; Wartmann, M.; Pfeilschifter, J. Eur 7. Pharmacol., 1998, 343,297.

[111] Araki, S.; Haneda, M.; Togawa, M.; Kiklkawa, R. Kidney Int, $1997,51,631$

[112] Huwiler, A.; van Rossum, G.; Wartmann, M.; Pfeilschifter, J. Br. J. Pharmacol, 1997, 120,807

[113] Pfeilschifter, J.; Huwiler, A. FEBS Lett, 1996, 396,67.

[114] Yusufi, A.N.; Cheng, J.; Thompson, M.A.; Wallser, H.J.; Gray, C.E.; Warner, G.M.; Grande, J.P. J. Lab. Clin. Med., 2003, I4I, 318.

[115] Guo, Y.L.; Baysal, K.; Kang, B.; Yang, L.J.; Williamson, J.R. J. Biol. Chem., 1998, 273, 4027 .

[116] Uciechowski, P.; Salklatvala, J.; von der Ohe, K.; Resch, M.; Szamel, M.; Kracht, J. FEBS Lett, 1996, 394, 273.

[117] Wilmer, W.A.; Tan, L.C.; Dickerson, J.A.; Danne, M.; Rovin, B.H. J. Biol. Chem., 1997, 272, 10877

[118] Kawano, H.; Kim, S.; Ohta, K.; Nalsao, T.; Miyazalki, H.; Nalsatani, T. ; Iwao, H. J. Am. Soc. Nephrol, 2003, 14, 584

[119] Martinez-Salgado, C.; Rodriguez-Barbero, A.; Eleno, N.; LopezNovoa, J.M. Life Sci, 2005, 77, 2285

[120] Hou, C.C.; Hung, S.L.; Kao, S.H.; Chen, T.H.; Lee, H.M. Ann. N. Y. Acad. Sci., 2005, 1042, 235

[121] Goruppi, S.; Bonventre, J.V.; Kyriakis, J.M. EMBO J., 2002, 2I, 5427 .

[122] Zhang, A.; Ding, G.; Huang, S.; Wu, Y.; Pan, X.; Guan, X.; Chen, R.; Yang, T. Am. J. Physiol. Renal Physiol, 2005, 288, 1118 .

[123] Naito, T.; Masalsi, T.; Nikolic-Paterson, D.J.; Tanji, C.; Yorioka N.; Kohno, N. Am. J. Physiol. Renal Physiol, 2004, 286, 278.

[124] Kishida, M.; Uralsaze, M.; Talsata, M.; Nobata, Y.; Yamamoto, N.; Temaru, R.; Sato, A.; Yamazalsi, K.; Nalsamura, N.; Kobayashi, M. Exp. Clin. Endocrinol. Diabetes, 2005, 113,365

[125] Lee, M.J.; Yang, C.W.; Jin, D.C.; Chang, Y.S.; Bang, B.K.; Kim, Y.S. J.Immunol, 2003, 170,2557

[126] Moreno-Manzano, V.; Ishikawa, Y.; Lucio-Cazana, J.; Kitamura M. J. Biol. Chem., 1999, 16,274, 20251

[127] Ishilkawa, Y.; Kitamura, M. Kidney Int., 2000, 58, 1078.

[128] Sohn, M.; Tan, Y.; Klein, R.L.; Jaffa, A.A. Kidney Int., 2005, 67 1286.

[129] Diez-Marques, M.L.; Ruiz-Torres, M.P.; Griera, M.; Lopez-Ongil, S.; Saura, M.; Rodriguez-Puyol, D.; Rodriguez-Puyol, M. Cardiovasc. Res., $2006,69,359$.

[130] Ricardo, S.D.; Ding, G.; Eufemio, M.; Diamond, J.R. Am. J. Physiol, 1997, 272,789.

[131] Cachat, F.; Lange-Sperandio, B.; Chang, A.Y.; Kiley, S.C.; Thom hill, B.A.; Forbes, M.S.; Chevalier, R.L. Kidney Int., 2003, 63, 564.

[132] Berl, T.; Siriwardana, G.; Ao, L.; Butterfield, L.M.; Heasley, L.E Am. J. Physiol. Renal Physiol, 1997, 272, 305.

[133] Zhang, Z.; Cohen, D.M. Am. J. Physiol. Renal Fluid Electrolyte Physiol., 1996, 27I, 1234.

[134] Zhang, Z.; Yang, X.Y,; Cohen, D.M. Am. J. Physiol. Cell Physiol, $1998,275,1104$.

[135] Wojtaszel,, P.A.; Heasley, L.E.; Siriwardana, G.; Berl, T. J. Biol Chem., 1998, 273, 800

[136] Nguyen, H.T.; Hsieh, M.H.; Gaborro, A.; Tinloy, B.; Phillips, C.;
Adam, R.M. Nephron. Exp. Nephrol., 2006, 102, 49

[137] Cui, X.L.; Douglas, J.G. Proc. Natl. Acad. Sci. USA, 1997, 94, 3771.

[138] Matsuoka, M.; Igisu, H. Biochem. Biophys. Res. Commun, 1998, $251,527$.

[139] Wang, L.; Matsushita, K. ; Aralki, I.; Talseda, M. Nephron, 2002, 91 , 142.

[140] De Graauw, M.; Tijdens, I.; Cramer, R.; Corless, S.; Timms, J.F; van de Water, B. J. Biol. Chem., 2005, 280,29885.

[141] Pontrelli, P.; Ranieri, E; Ursi, M.; Ghosh-Choudhury, G.; Gesualdo, L.; Paolo Schena, F.; Grandaliano, G. Kidney Int, 2004, 65, 2249

[142] Shintani, Y.; Wheelock, M.J.; Johnson, K.R. Mol. Biol. Cell, 2006, I7, 2963.

[143] Chen, Y.R.; Wang, X.; Templeton, D.; Davis, R.J.; Tan, T.H. J. Biol. Chem., 1996,27I, 31929.

[144] Herlaar, E.; Brown, Z. Mol. Med. Today, 1999, 5, 439.

[145] Jiang, Y.; Gram, H.; Zhao, M.; New, L.; Gu, J.; Feng, L.; Di Padova, F.; Ulevitch R.J.; Han, J. J. Biol. Chem., 1997, 272, 30122.

[146] Stambe, C.; Atkins, R.C.; Tesch, G.H.; Kapoun, A.M.; Hill, P.A.; Schreiner, G.F.; Nikolic-Paterson, D.J. J. Am. Soc. Nephrol, 2003, 14, 338 .

[147] Ohashi, R.; Nalkagawa, T.; Watanabe, S.; Kanellis, J.; Almirez, R. G.; Schreiner, G.F.; Johnson, R.J. A m. J. Pathol, 2004, 164, 477.

[148] De Borst, M.H.; Navis, G.; de Boer, R.A.; Huitema, S.; Vis, L.M.; van Gilst, W. H.; van Goor, H. Lab. Invest., 2003, 83, 1761.

[149] De Borst, M.H.; van Timmeren, M.M.; Vaidya, V.S.; Van Dalen, M.B.; Kramer, A.B.; Schuurs, T.A.; Bonventre, J.V.; Navis, G.; van Goor, H. Am. J. Physiol. Renal Physiol., 2007, 292, 313.

[150] Sato, H.; Tanalsa, T.; Kasai, K.; Kita, T.; Tanaka, N. Shock, 2005, 24,488 .

[151] Koshilsawa, M.; Mulsoyama, M.; Mori, K.; Suganami, T.; Sawai, K.; Yoshioka, T.; Nagae, T.; Yolsoi, H.; Kawachi, H.; Shimizu, F, Sugawara, A.; Nalsao, K. J. Am. Soc. Nephrol, 2005, 16, 2690.

[152] Dai, T.; Natarajan, R.; Nast, C.C.; LaPage, J.; Chuang, P.; Sim, J.; Tong, L.; Chamberlin, M.; Wang, S.; Adler, S.G. Kidney Int., 2006, 60,806 .

[153] Yin, T.; Sandhu, G.; Wolfgang, C.D.; Burrier, A.; Webb, R.L.; Rigel, D. F.; Hai, T.; Whelan, J. J. Biol. Chem., 1997,272, 19943.

[154] Kriz, W. Gretz, N.; Lemley, K. V. Kidney Int., 1998, 54, 687.

[155] Schiffer, M.; Bitzer, M.; Roberts, I.S.; Kopp, J.B.; ten Dijke, P.; Mundel P.; Bottinger, E. P. J. Ciin. Invest, 2001, 108, 807.

[156] Kang, Y.S.; Park, Y.G.; Kim, B.K.; Han, S.Y.; Jee, Y.H.; Han, K.H.; Lee, M.H.; Song, H.K.; Cha, D.R.; Kang, S.W.; Han, D.S. J. Mol. Endocrinol., 2006, 36,377.

[157] Chen, S.; Kasama, Y.; Lee, J.S.; Jim, B.; Martin, M.; Ziyadeh, F.N. Diabetes, 2004, 53, 2939.

[158] Kang, S.W.; Natarajan, R.; Shahed, A.; Nast, C.C.; Mundel, P.; Kashtan, C.; Adler, S.G. J. Am. Soc. Nephrol, 2003, 14, 3178.

[159] Martineau, L.C.; McVeigh, L.I.; Jasm in, B.J.; Kennedy, C.R. Am J. Physiol. Renal Physiol, 2004, 286,693.

[160] Zhu, T.; Lobie, P.E. J. Biol. Chem., 2000, 275, 2103.

[161] Guay, J.; Lambert, H.; Gingras-Breton, G.; Lavoie, J.N.; Huot, J.; Landry, J. J. Cell Sci, 1997, 110,357.

[162] Smoyer, W.E.; Ransom, R.F. FASEB J., 2002, 16, 315

[163] Mundel, P.; Shankland, S.J. J. Am. Soc. Nephrol, 2002, 13, 3005.

[164] Zhang, M.; Tang, J.; Li, X. Nephron. Exp. Nephrol., 2005, 99, 68.

[165] Cheng, H.F.; Zhang, M.Z.; Harris, R.C. Am. J. Physiol. Renal Physiol, 2006, 290, 1391.

[166] Patrick, D.M.; Leone, A.K.; Shellenberger, J.J.; Dudowicz, K.A.; King, J.M. BMC Physiol, 2006, 0,2 .

[167] Su, Z.; Zimpelmann, J.; Burns, K.D. Kidney Int., 2006, 60,2212.

[168] Brezniceanu, M.L.; Wei, C.C.; Zhang, S.L.; Hsieh, T.J.; Guo, D. F.; Hebert, M.J.; Ingelfinger, J.R.; Filep, J.G.; Chan, J.S. Kidney Int., $2006,60,1977$.

[169] Bornstein, P. J. Clin. Invest., 2001, J07, 929

[170] Hugo, C.; Shankland, S.J.; Pichler, R.H.; Couser, W.G.; Johnson, R.J. Kidney Int., 1998, 53,302.

[17 1] Nakagawa, T.; Lan, H.Y.; Glushak ova, O.; Zhu, H.J.; Kang, D.H.; Schreiner, G.F.; Bottinger, E.P.; Johnson, R.J.; Sautin, Y.Y. J. Am. Soc. Nephrol, 2005, 10,899.

[172] Watts, B.A. III.; Di Mari, J.F.; Davis, R.J;; Good, D.W. Am. J. Physiol. Renal Physiol., 1998,275, 478

[173] Padda, R.; Wamsley-Davis, A.; Gustin, M.C.; Ross, R.; Yu, C.; 


\section{Map Kinase Inhibitors in Renal Disease}

Sheilkh-Hamad, D. Am. J. Physiol. Renal Physiol., 2006, $291,874$.

[174] Yu, L.; Hebert, M.C.; Zhang. Y.E. EMBO J., 2002, 21,3749.

[175] Ramachandiran, S.; Huang, Q.; Dong, J.; Lau, S.S.; Monks, T.J. Chem. Res. Toxicol., 2002, 15, 1635.

[176] Dong, J.; Ramachandiran, S.; Tikoo, K.; Jia, Z.; Lau, S.S.; Monks, T.J. Am. J. Phosiol. Renal Physiol., 2004, 287, 1049.

[177] Zhuang, S.; Yan, Y.; Han, J.; Schnellmann, R.G. J. Biol. Chem. $2005,280,21036$.

[178] Prakash, J.; Sandovici, M.; Saluja, V.; Lacombe, M.; Schaapveld, R.Q.; de Borst, M.H.; van Goor, H.; Henning, R.H.; Proost, J.H. Moolenaar, F; Keri, G.; Meijer, D.K.; Poelstra, K.; Kol, R.J. J. Pharmacol. Exp. Ther, 2006, 319,8 .

[179] Jiang, T.; Che, Q.; Lin, Y.; Li, H.; Zhang, N. Nephrology (Car Iton), 2006, $H, 105$.

[180] Chang, P.C.; Chen, T.H.; Chang, C.J.; Hou, C.C.; Chan, P.; Lee, H.M. Kidney Int, 2004, 65, 1664

[181] Hirano, S.; Sun, X.; DeGuzman, C.A.; Ransom, R.F.; McLeish, K.R.; Smoyer, W.E.; Shelden, E.A.; Welsh, M.J.; Benndorf, R. Am. J. Physiol. Renal Physiol, 2005,288, 1133.

[182] Huot, J.; Lambert, H.; Lavoie, J.N.; Guimond, A.; Houle, F.; Landry, J. Eur. J. Biochem., 1995, 227, 416.

[183] Wang, L.; Kwak, J.H.; Kim, S.I.; He, Y.; Choi, M.E. J. Biol. Chem., $2004,270,33213$.

[184] Cheng, J.; Diaz Encarnacion, M.M.; Warner, G.M.; Gray, C.E.; Nath, K.A.; Grande, J. P. Am. J. Physiol. Cell Physiol, 2005, 289 , 959.

[185] Wada, T.; Furuichi, K.; Salsai, N.; Hisada, Y.; Kobayashi, K.; Mulsaida, N.; Tomosugi, N.; Matsushima, K.; Yokoyama, H. Am.J. Kidney Dis., 2001, 38, 1169

[186] Iwata, Y.; Wada, T.; Furuichi, K.; Salkai, N.; Matsushima, K.; Yoloyama, H.; Kobayashi, K. J. Am. Soc. Nephrol., 2003, I4, 57.

[187] Furuichi, K.; Wada, T.; Iwata, Y.; Salsai, N.; Yoshimoto, K.; Kobayashi, K.K.; Mulkaida, N.; Matsushima, K.; Yolkoyama, H. Nephrol Dial. Transplant, 2002, 17,399.

[188] Floege, J.; Burns, M.W.; Alpers, C.E; Yoshimura, A.; Pritzl, P.; Gordon, K.; Seifert, RA.; Bowen-Pope, D. F.; Couser, W.G.; Johnson, R.J. Kidney Int., 1992, 41,297.
Current Medicinal Chemistry, 2008 Vol 15, No. 202070

[189] Lee, J.D.; Ulevitch, R.J.; Han, J. Biochem. Biophys. Res. Commun, $1995,213,715$

[190] Zhou, G.; Bao, Z.Q.; Dixon, J.E. J. Biol. Chem., 1995, 270, 12665.

[191] Kato, Y.; Kravchenlso, V.V.; Tapping, R.I.; Han, J.; Ulevitch, R.J.; Lee, J.D. EMBO J., 1997, 16, 7054.

[192] Kasler, H.G.; Victoria, J.; Duramad, O.; Winoto, A. Mol. Cell Biol., $2000,20,8382$

[193] Barsyte-Lovejoy, D.; Galanis, A.; Clancy, A.; Sharrocks, A.D. Biochem. J., 2004, 381, 693.

[194] Abe, J.; Kusuhara, M.; Ulevitch, R.J.; Berk, B.C.; Lee JD. J. Biol. Chem., 1996, 27I, 16586

[195] Kato, Y.; Tapping, R.I.; Huang, S.; Watson, M.H.; Ulevitch, R.J.; Lee, J.D. Nature, 1998, 395,713.

[196] Suzalki, Y.; Yoshizumi, M.; Kagami, S.; Nishiyama, A.; Ozawa, Y.; Kyaw, M.; Izawa, Y.; Kanematsu, Y.; Tsuchiya, K.; Tamalki, T. Kidney Int., 2004, 65, 1749.

[197] Dorado, F.; Velasco, S.; Esparis-Ogando, A.; Pericacho, M.; Pandiella, A.; Silva, J.; López-Novoa, JM.; Rodríguez-Barbero, A.; Nephrol. Dial. Transplant, 2008, (in press).

[198] Karihaloo, A.; O'Rourke, D.A.; Nickel, C; Spolses, K.; Cantley, L. G. J. Biol. Chem., 2001, 276, 9166.

[199] Wilhelm, S.; Carter, C.; Lynch, M.; Lowinger, T.; Dumas, J.; Smith, R.A.; Schwartz.; B.; Simantov, R.; Kelley, S. Nat. Rev. Drug. Discov, 2006, 5,835.

[200] Bain, J; Plater, L; Elliott, M; Shapiro, N; Hastie, C.J.; McLauchlan, H.; Klevernic, I.; Arthur, J.S.; Alessi, D.R.; Cohen, P. Biochem. J., $2007,408,297$

[201] Fernández, A., Sanguino, A., Peng, Z., Ozturk, E, Chen, J., Crespo, A., Wulf, S., Shavrin, A., Qin, C., Ma, J., Trent, J., Lin, Y., Han, H.D., Mangala, L.S., Bankson, J.A., Gelovani, J., Samarel, A., Bormmann, W., Sood, A.K., Lopez-Berestein, G. J. Clin. Invest., 2007, 117,4044

[202] Demetri, G.D. J. Clin. Invest., 2007, $117,3650$.

[203] Arany, I,; Megyesi, J.K.; Nelkin, B.D.; Safirstein, R.L. Kidney Int., 2006, 70,669.

[204] Bijian, K.; Talsano, T.; Papillon, J.; Khadir, A.; Cybulsky, A.V. Am. J. Physiol. Renal Physiol, 2004, 286, 255. 
Artículo III

Revisión

"Myofibrobast Activation in Obstructive Nephropathy. A New Therapeutic Target?"

M. Teresa Grande and José M. López-Novoa Nature Nephrology Reviews (aceptado) 


\section{SUMMARY}

Obstructive nephropathy is a major cause of renal failure, particularly in newborns and children. After urinary tract obstruction, and under the influence of mechanical forces and cytokines such as TGF- $\beta$, PDGF, FGF, ED-A splice variant of fibronectin activin $\mathrm{A}$ and other chemokines produced by tubular and infiltrated interstitial cells, resident fibroblasts undergo transformation to activated fibroblasts or to myofibroblasts. Myofibroblasts can also derive from pericytes or from endothelial cells. In addition, selected tubular epithelial cells change the phenotype to fibroblast like-mesenchymal cells in a process called epithelial-mesenchymal transition (EMT) that is characterized by downregulation of epithelial marker proteins such as E-cadherin, ZO-1 and cytokeratin, loss of cell-to-cell adhesion, finally, upregulation of mesenchymal markers including vimentin, $\alpha$-SMA and fibroblast-specific protein-1, basement membrane degradation and migration to the interstitial compartment. All this process is strictly regulated by several signaling pathways including activation of the small GTPases of the Ras family, MAP-kinases, PI3-Kinase/Akt, GSK-3 $\beta$, ILK/PINCH， NFאB， Smads, and many others. Myofibroblasts proliferate and produce great amounts of extracellular matrix components that accumulate in the tubular interstitium, which together with tubular atrophy, leads to interstitial fibrosis. The molecular mechanisms leading to myofibroblast activation and EMT seems to be a promising target to prevent or even reverse interstitial fibrosis and reduced renal function associated to obstructive nephropathy.

KEYWORDS: epithelial-to-mesenchymal transition, fibroblasts, obstructive nephropathy, obstructive uropathy, ureteral obstruction.

\section{REVIEW CRITERIA}

The Pub-Med database and major nephrology journals were the primary sources for this review, focusing on papers published in the past 5 years (2004-2008) that described the mechanisms of fibroblast activation in experimental models of obstructive nephropathy, mainly rodent models of unilateral ureteral obstruction although in some cases, some complementary in vitro data has been also revised. When necessary, older papers with very relevant data are also quoted. 


\section{INTRODUCTION}

End-stage renal disease is a common functional and histological feature of progressive renal diseases, characterized by loss of glomerular and peritubular capillary architecture, cell proliferation, and diffuse extracellular matrix accumulation leading to tubular atrophy, and progressive fibrosis. Depending on the pathology, extracellular matrix accumulation may occur either in the glomeruli (glomerulosclerosis), or in the tubular interstitium (tubulointerstitial fibrosis). Tubulointerstitial fibrosis is characterized by the accumulation of extracellular matrix (ECM) components including collagen types I, III, and IV, as well as proteoglycans and fibronectin. Interstitial fibrosis seems to be a morphologic hallmark of chronic renal disease. In particular, many studies have determined that the extent of tubulointerstitial involvement correlates better with renal function deterioration than glomerular changes do, thus the extent of damaged tubulointerstitial area in any given renal biopsy has important implications for the renal prognosis of the patient (summarized in $^{1,2}$ ). Furthermore, interstitial fibrosis is a component of normal structural changes in the aging kidney ${ }^{3}$ and it is a hallmark of the chronic allograft nephropathy, the most common cause of kidney transplant failure within a decade after transplantation. ${ }^{4}$ Tubulointerstitial fibrosis is also a major structural component of obstructive nephropathy, the first primary cause $(22,9 \%)$ of chronic renal failure (CRF) in children, according to data of The North American Pediatric Renal Transplant Cooperative Study (NAPRTCS). ${ }^{5}$

The experimental model of unilateral ureteral obstruction (UUO) in rat and mouse have become the standard model to better understand the causes and mechanism of nonimmunological tubulointerstitial fibrosis, as it is a normotensive, nonproteinuric, nonhyperlipidemic model, without any apparent immune or toxic renal insult. The UUO consists of an acute obstruction of one of the ureters, and depending on the time of obstruction, this model mimics the different stages of obstructive nephropathy leading to tubulointerstitial fibrosis ${ }^{2}$ without compromising the animal's life, because the contralateral kidney maintains its function, or even increases its function due to compensatory functional and anatomic hypertrophy. UUO is characterized by a series of functional and structural changes, including a decrease in renal blood flow and glomerular filtration rate, alterations in tubular transport, increased oxidative stress, tubular atrophy and apoptosis, leukocyte infiltration, inflammation, fibroblast activation and proliferation, and interstitial 
fibrosis (Figure 1). Some of these features have been recently reviewed in this Journal. ${ }^{6}$ The purpose of the present review is to revise the most recent advances on the mechanisms involved in myofibroblasts activation in experimental UUO. We have reviewed mainly data obtained from in vivo models, although in some cases, some complementary in vitro data has been also included.

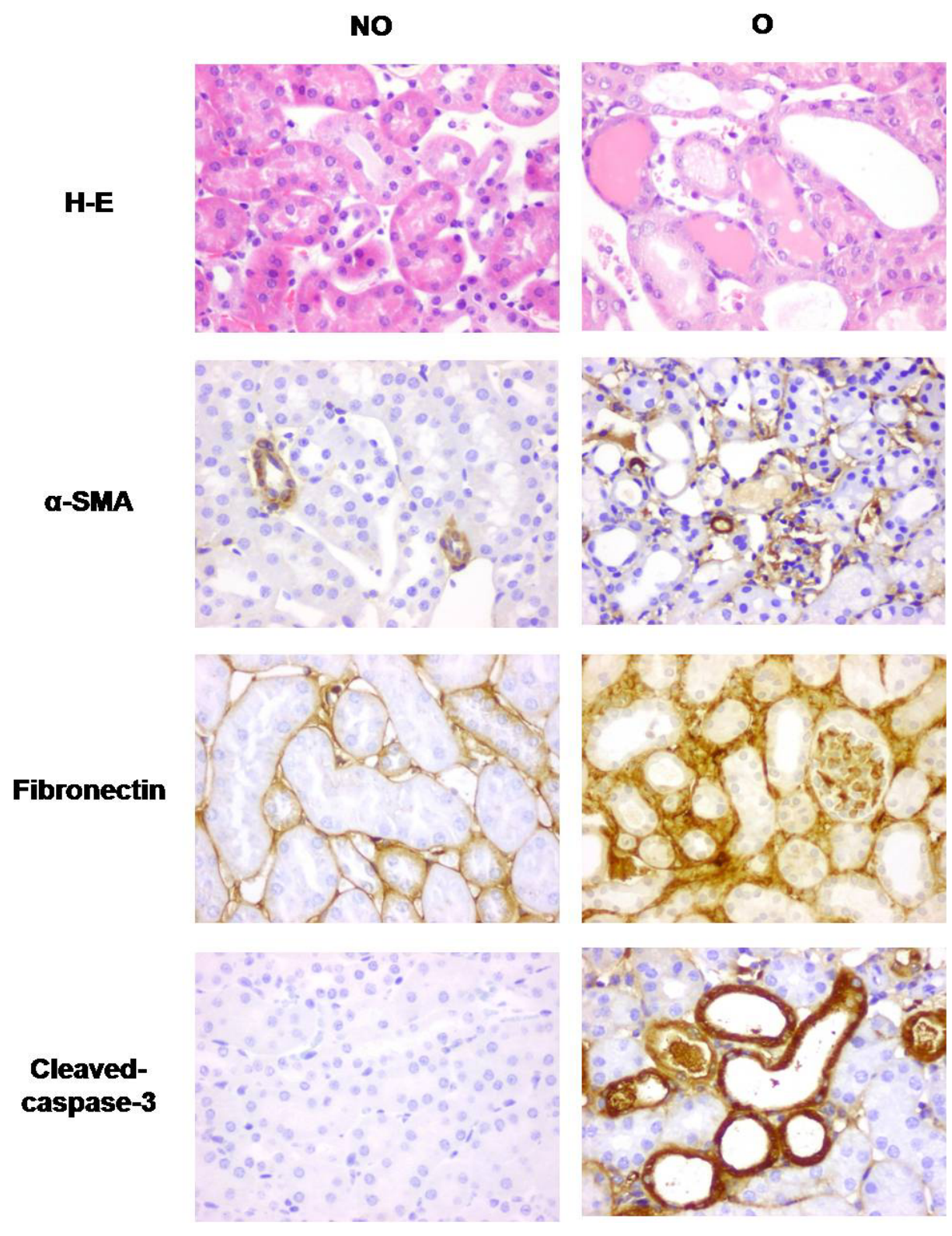

Figure 1: Characteristic histological alterations in obstructed $(\mathrm{O})$ and non obstructed (NO) kidneys after UUO in mice. Hematoxilin-eosin (HE) staining reveals tubular dilatation and simplification of the epithelial cells in some tubules. $\alpha$-smooth muscle actin ( $\alpha$-SMA) staining appears only in the blood vessel wall in the non-obstructed kidney, but in the obstructed kidney, many $\alpha$-SMA-stained cells are scattered in the interstitial space. Fibronectin staining was limited to the tubular basement membranes in the non obstructed kidney, whereas in the obstructed kidney, large amounts of fibronectin appear in the interstitial space. Collagen I staining was absent in the non obstructed kidney, whereas strong collagen I staining is observed in the interstitial space in the obstructed kidney. 


\section{FIBROBLAST ACTIVATION AFTER UUO}

Interstitial cells in the kidney are a heterogeneous population including fibroblasts, dendritic cells and lymphocyte-like cells. Long-term activation of fibroblasts results in massive proliferation and excessive ECM accumulation. Activated fibroblasts and myofibroblasts, cells with fibroblasts appearance but also expressing myocite markers, such as $\alpha$-smooth muscle actin ( $\alpha$-SMA), play a key role in the genesis of interstitial fibrosis during ureteral obstruction. ${ }^{7}$ It has been shown that interstitial fibroblasts in kidney fibrosis derive from several sources ${ }^{7,8}$ (figure 2). One source of activated fibroblasts are bone marrow derived cells, although these bone-marrow derived myofibroblasts or fibroblasts do not seem to participate significantly in collagen synthesis after UUO. ${ }^{9}$ The activation of resident interstitial fibroblasts seems to play also a critical role in fibrosis during UUO. ${ }^{10}$ Vascular pericytes have been also proposed as responsible for interstitial fibrosis, as they migrate and differentiate into myofibroblasts as a result of vascular injury or vascular factors after UUO. ${ }^{11}$ Endothelial cells can also contribute to the appearance of fibroblasts during kidney fibrosis via a process called endothelial-to-mesenchymal transition. ${ }^{12}$ Finally, numerous studies report that transformation of tubular cells via epithelial-mesenchymal transition (EMT) are the origin of myofibroblast in the obstructed kidneys after UUO. ${ }^{7,13}$

Thus, there are several sources of activated fibroblasts and myofibroblasts in the interstitial space of obstructed kidneys, but the relevance of each source seems to depend on the time of study after obstruction. EMT -derived myofibroblasts have been suggested to appear after 7 days of UUO and thereafter whereas resident fibroblasts and perivascular pericytes are a major source of activated fibroblasts and myofibroblasts in the first stage of obstruction as they have been reported to appear in the first hours after $\mathrm{UUO}^{11}$.

\section{LOCAL INTERSTITIAL FIBROBLAST ACTIVATION}

Differentiation of fibroblast into myofibroblasts represents a beneficial event during wound healing and tissue repair but it results harmful when becomes excessive as occurs in fibrotic diseases. In fact, the number of interstitial myofibroblasts correlates closely with tubulointerstitial fibrosis and progressive renal failure. ${ }^{14}$ This differentiation into myofibroblast seems to be regulated by both mechanical and chemical microenvironments factors. 


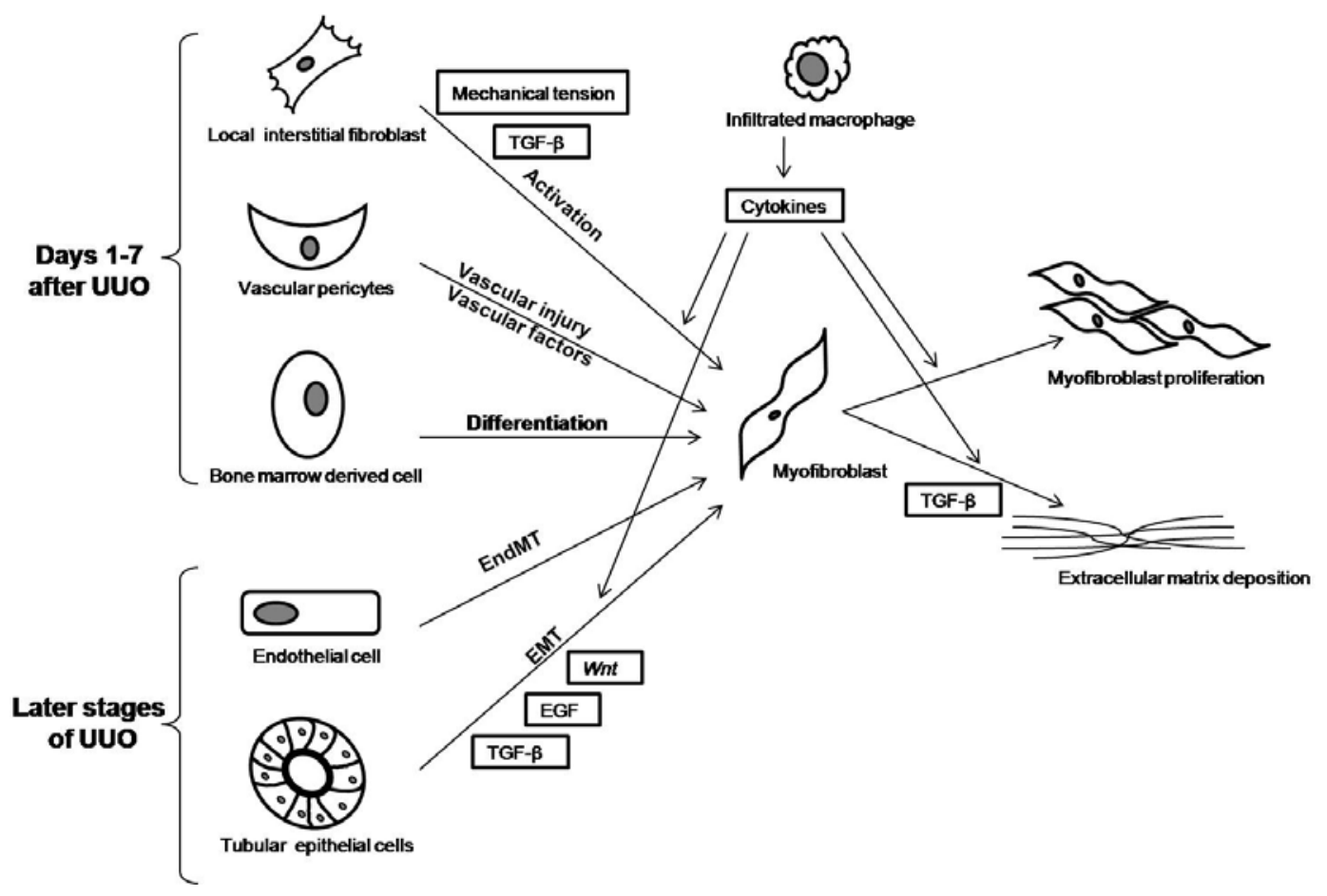

Figure 2. Origin and time-course of myofibroblasts in the obstructed kidney. Interstitial myofibroblasts derive in the first 7 days of UUO from activation of local resident fibroblasts by mechanical stretch or cytokines such as TGF- $\beta$ or macrophage-produced cytokines, by differentiation of bone-marrow-derived cells and by vascular pericytes induced by vascular injury and vascular factors. In larger stages, myofibroblasts derive from epithelial-to-mesenchymal transition (EMT), modulated by many cytokines and by Endothelial-to-mesenchymal transition (EndMT) from endothelial cells. Myofibroblasts proliferate and produce extracellular matrix.

Identification of fibroblasts has become complicated as there is no a single protein that is neither always nor exclusively expressed in all fibroblasts. Expression of fibroblasts markers depends on the origin and functional stage of the cell. Fibroblast specific protein 1 (FSP1), ecto-5'-nucleotidase, vimentin and $\alpha$-smooth muscle actin ( $\alpha$-SMA) are the activated fibroblasts markers most frequent used. FSP1, also known as small cytoplasmic calcium-binding protein S100A4, has been widely used as fibroblast marker but the fact that only few cells are positive for FSP1/S100A4 in healthy kidneys suggests that not all fibroblast population express this protein. ${ }^{15}$ Another marker used for fibroblast identification has been ecto- $5^{\prime}$ nucleotidase ( $\left.5^{\prime} \mathrm{NT}\right)$ expression, ${ }^{16}$ but it has been also found in the apical membrane of proximal tubular cells. ${ }^{17}$ The intermediate filament protein vimentin is regarded as a marker for cells of mesenchymal origin and is expressed in migrating cells. $\alpha$-SMA is marker of smooth muscle cells and also of cells from mesenchymal origin. Both, vimentin and $\alpha$-SMA, have been frequently used as markers of myofibroblasts. 
In normal kidneys, cortical interstitial fibroblast have been identified by their expression of $5^{\prime} \mathrm{NT}$, but no co-expression of $5^{\prime} \mathrm{NT}$ and $\alpha$-SMA was observed. ${ }^{15}$ However, some cells expressing both $5^{\prime} \mathrm{NT}$ and $\alpha$-SMA were observed 1 day after ureteral obstruction, and become more frequent up to fourth day. At this time, neither cells double positive for FSP 1 and $\alpha$-SMA nor for FSP 1 and $5^{\prime} \mathrm{NT}$ in tubular cells were observed in the obstructed kidneys. ${ }^{10,16}$ This results suggest that FSP1 positive cells are not myofibroblasts, and it has been suggested that these cells are leukocytes ${ }^{10}$ or macrophages. ${ }^{11}$ Co-expression of $5^{\prime} \mathrm{NT}$ and $\alpha$-SMA suggest that at least up to day fourth after UUO, myofibroblasts seems to derive from activation of resident fibroblast whereas the lack of co-expression of $5^{\prime} \mathrm{NT}$ or $\alpha$-SMA with FSP1/S100A4 suggests that FSP-1/S100A4 is not a exclusive fibroblast marker as have been reported that FSP-1/S100A4 also co-localizes with macrophages markers. ${ }^{18}$ To our knowledge, the co-expression of vimentin with either $\alpha$-SMA, $5^{\prime}$ NT nor FSP1/S100A4 has not been reported.

One of the microenvironmental factor responsible of fibroblast activation is mechanical tension (figure 2), which has been reported to induce $\alpha$-SMA expression in fibroblast, whereas tension release reduced $\alpha$-SMA expression. Moreover, when fibroblasts were subjected to mechanical tension, contractility correlated with the level of $\alpha$-SMA. ${ }^{19}$ Renal fibroblast subjected to cyclic stretch, to mimic the changes in intrarenal pressure in UUO, produced collagen, laminin, fibronectin and TGF- $\beta .^{20}$

However, mechanical stress is not the only environmental factor able to upregulate $\alpha$-SMA production. Cytokines such as TGF- $\beta,{ }^{21}$ PDGF, ${ }^{22}$ FGF, ${ }^{23}$ and ED-A splice variant of fibronectin are also involved in fibroblast activation and proliferation. ${ }^{24}$ Also chemokines, derived from infiltrating leukocytes, have been reported to be involved in regulating fibroblast activation. ${ }^{25}$ TGF- $\beta$ seems to be the major growth factor directly promoting myofibroblast development by inducing expression of $\alpha$-SMA. ${ }^{21}$ UUO induce TGF- $\beta$ overexpression and activation of the Smad pathway, which transmits the signaling of TGF- $\beta$ from cell membrane to the nucleus. Overexpression of latent TGF- $\beta$ reduced the UUO-induced $\alpha$-SMA positive cells as well as inhibited the smad2/3 activation observed after UUO. ${ }^{26}$ Furthermore, blockade or elimination of smad2/3 pathway reduces interstitial fibrosis after UUO. ${ }^{27}$ Also Smad transcriptional co-repressors, SnoN and Ski, are downregulated during obstructive nephropathy, exhibiting additive effect in abrogating the profibrotic actions of TGF- $\beta$. Moreover, inhibition of degradation of SnoN abolished TGF- $\beta$ - 
mediated $\alpha$-SMA and fibronectin induction. ${ }^{28,29}$ These results suggest TGF- $\beta$ promotes fibroblast activation through Smad signaling pathway.

Activin A, a member of the TGF- $\beta$ superfamily, seems to be also involved in fibroblast activation. The expression of activin A was found upregulated in kidneys after UUO. ${ }^{30}$ Activin A did not induced EMT in tubular epithelial cells but it promoted cell proliferation, induced the expression of $\alpha$-SMA, and enhanced the expression of type I collagen mRNA in renal fibroblasts. Both administration of follistatin, an inhibitor of activin effects, or overexpression of activin mutant receptor, reduced the proliferation rate and suppressed the expression of type I collagen. TGF- $\beta$ induced the expression of activin A. In contrast, blockade of activin signaling reduced TGF- $\beta$ effects such as type I collagen synthesis. These results suggest that activin $\mathrm{A}$ is a potent inducer of fibroblast activation in the kidney. ${ }^{30}$

In conclusion, regardless of the difficulty in identifying fibroblasts, it seems that the activation of local fibroblasts is regulated by both mechanical stretch and cytokines, especially TGF- $\beta$, but also by other cytokines derived from damaged tubular epithelial cells and infiltrating macrophages.

\section{EPITHELIAL-MESENCHYMAL TRANSITION}

As above stated, it has been suggested that during renal fibrosis, tubular epithelial cells can obtain a mesenchymal phenotype, in which the cell morphology changes from a cuboidal to a fibroblastic shape, and cells acquire an enhanced migratory faculty permitting them to transit from the renal tubular microenvironment into the interstitial space, where they contribute to extracellular matrix accumulation. This process is called epithelial-mesenchymal transition (EMT). During EMT epithelial characteristics are lost and mesenchymal phenotype appears. EMT in epithelial cells is characterized by the disruption of epithelial junctional complexes and the subsequent loss of cell polarity. ${ }^{31}$ These actions are accompanied by morphological changes to a fibroblastoid morphology, downregulation of epithelial marker proteins such as E-cadherin, ZO-1 and cytokeratin, and finally, upregulation of mesenchymal markers including vimentin, $\alpha$-SMA and FSP-1. ${ }^{7}$ Finally, the cell is also able to degrade the basal membrane and to acquire the capacity to migrate from the tubular to the interstitial space, where it obtains its final myofibroblast morphology (Figure 3). Although several in vivo studies have demonstrated the 
existence of EMT in the UUO model, the most conclusive evidence of EMT in this model came from a landmark study by Iwano et al. using genetically tagged proximal tubular epithelial cells, demonstrating that up to $36 \%$ of all matrix producing cells within the tubulointerstitial space may be of tubular epithelial origin. ${ }^{32}$ However, the contribution of EMT to the formation of myofibroblasts may be less in other experimental models. ${ }^{33}$

In addition to differentiated tubular epithelial cells, renal progenitor tubular cells (RPC) seem to be also involved in EMT. In the normal kidney RPC has been reported to be scattered among the tubular epithelial cells, whereas many RPC were observed in the interstitum of obstructed kidneys 3 days after obstruction and thereafter. By opposite no RPC were detected in the interstitium in contralateral kidneys after UUO. Thus RPC, which are localized in tubules of the normal kidneys, proliferated, migrated into the interstitium, and transdifferentiated into fibroblast-like cells in the UUO model, suggesting that RPC might be a main population undergoing EMT in diseased kidneys. ${ }^{34}$
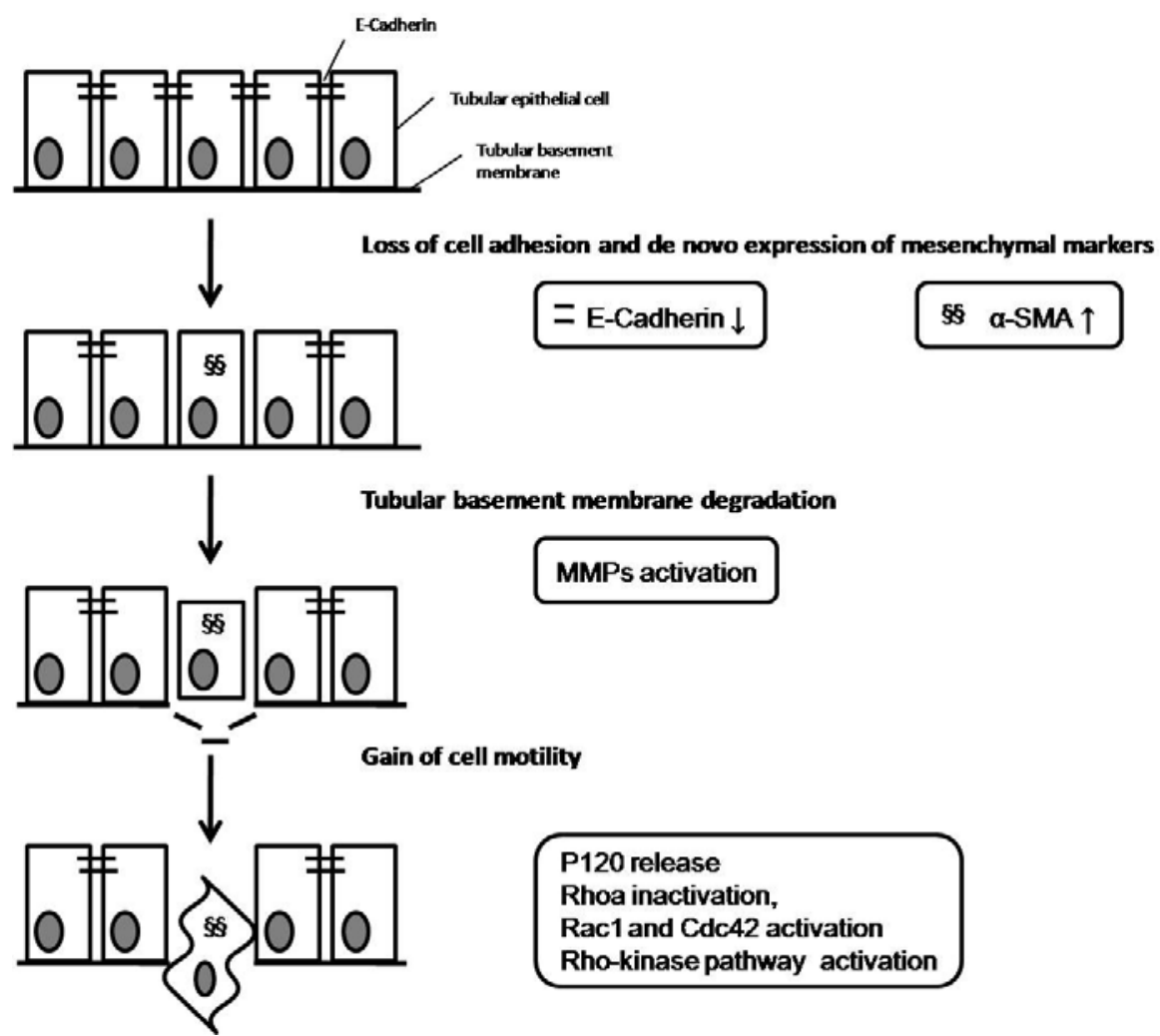

Figure 3. Steps involved in epithelial-to-mesenchymal transition (EMT). EMT has three major steps: Loss of cell adhesion and de novo expression of mesenchimal markers such as $\alpha$ smooth muscle actin ( $\alpha$-SMA), tubular basement membrane degradation due to increased activity of selective metalloproteinases (MMPs), and gain of cell motility, which allow the cell to migrate from the tubular to the interstitial space. 
Although the role of EMT in interstitial fibrosis associated to urinary obstruction has received much attention in the last years, and much studies on EMT have been published using in vitro techniques or in animal models of urinary obstruction, to our knowledge EMT has not been observed in the human obstructive disease. There are studies on EMT performed in biopsies from patients with diabetic nephropathy ${ }^{35}$ IgA nephropathy, ${ }^{36}$ lupus nephritis, ${ }^{37}$ and chronic allograft dysfunction, ${ }^{38}$ using mesenchymal marker proteins such as $\alpha$-SMA vimentin or FSP1/S100A4 as markers of EMT, because these markers does not appears in the tubular interstitium in normal kidneys. In these studies, the expression of these mesenchymal marker proteins in tubular epithelial cells was well correlated with renal function in IgA nephropathy, lupus nephritis and chronic allograft failure. For instance, in biopsies from kidneys with chronic allograft failure, it has been observed the loss of epithelial markers (E-cadherin, cytokeratin, ZO-1), new expression of mesenchymal markers (vimentin, S100A4, $\alpha$-SMA) and a collagen synthesis marker (HSP-47) have been reported. ${ }^{39}$ However, a very recent study suggest that EMT does not play a major role in the development of early allograft fibrosis. ${ }^{40}$ Recently, in a fetal non-human primate model of UUO, disruption of E-cadherin with concomitant de novo expression of basolateral vimentin in the obstructed kidney has been reported. $^{41}$

Although most studies about cellular and molecular mechanisms involved in EMT are based on in vitro studies there are also some studies that have analyzed the mechanisms of EMT in the obstructed kidney during UUO. ${ }^{25,42}$ Next we will review what has been documented about the mechanisms of EMT in the UUO model in in vivo studies.

\section{LOSS OF EPITHELIAL CELL ADHESION AND DE NOVO EXPRESSION OF MESENCHYMAL MARKERS DURING EMT}

Adherens and tight junctions are intercellular junctions crucial for epithelial adhesion. Adherens junctions are formed by E-cadherin whose intracellular domain binds to $\beta$-catenin, which binds to $\alpha$-catenin, which in turn interacts with actin. This catenin-mediated anchorage of E-cadherin to the actin cytoskeleton is required for strong cell-cell adhesion (Figure 4). Occludin and the members of the family of claudin proteins are the major constituents of tight junctions. Occludin and claudins 
are connected to the actin filaments through cytoplasmic adaptor protein, zonula occludens protein-1 (ZO-1) (Figure 4). During UUO in the obstructed kidney it has been observed a loss of E-cadherin on day 7 and 14 after UUO in rats ${ }^{43}$ and also a loss of ZO-1 induced by TGF- $\beta$ in tubular epithelial cells ${ }^{44}$ and an increased expression of $\beta$-catenin on day 7 after UUO in mice. ${ }^{45}$

Loss of intercellular epithelial adhesion molecules such as E-cadherin and ZO-1 is characteristic of the EMT process, but EMT also involves de novo expression of mesenchymal markers such as vimentin, $\alpha$-SMA and FSP-1/S100A4, whose expression is increased in the obstructed kidneys after UUO (figure 3 ). ${ }^{34}$ The lost of E-cadherin and the expression of mesenchymal markers seem to be coupled processes, as, in the obstructed kidney of the UUO model in mice, the loss of Ecadherin has been correlated with the novo expression of $\alpha$-SMA. ${ }^{46}$ In fact, as later described, many of the transcription factors upregulated during EMT acts as downregulators of E-cadherin expression and up-regulators of these mesenchymal markers. However, the expression of EMT markers seems to depend not only on the time after obstruction but also on the species as a recent study performed in rats showed increased E-cadherin expression after 3 and 10 days of obstruction ${ }^{47}$. Transcriptional factors involved in EMT

Several distinct transcription factors have been found to be involved in the induction of EMT programs in epithelial cells. These include Snail, Slug, Twist, ZEB1 and ZEB2/Sip1.

Snail (Snail1) and Slug (Snail2), two zinc-finger transcription factors known to bind E-box elements, are potential repressors of E-cadherin transcription which have been reported to increase in the obstructed kidney after UUO. ${ }^{25,48}$ Moreover, Snaill activates the transcription of genes associated with mesenchymal differentiation, such as vimentin and fibronectin. Indeed, Snail activation is sufficient to induce EMT and spontaneous kidney fibrosis in adult transgenic mice. ${ }^{49}$

Twist transcription factor is a basic-helix-loop-helix transcription factor and represses transcription from the E-cadherin promoter via the E-boxes that are also targeted by Snail and SIP1. Expression of Twist in MDCK kidney epithelial cells led to decrease of adherens junctions proteins such as E-cadherin, $\alpha$-catenin, $\beta$-catenin, and $\gamma$-catenin and the expression of fibroblast markers including fibronectin, vimentin, $\alpha$-SMA and N-cadherin was strongly induced. ${ }^{50}$ Twist mRNA was increased in the obstructed kidneys after UUO, some tubular cells coexpressed Twist 
and FSP1 that indicated Twist is involved in tubular EMT of obstructed kidneys and massive coexpression of Twist and $\alpha$-SMA was observed in interstitial spaces of UUO kidneys. ${ }^{42}$

\section{ZEB1 (TCF8/deltaEF1) and ZEB2 (Smad-interacting protein 1} [SIP1]/ZFXH1B), two members of the ZEB family, have also emerged as key factors that regulate E-cadherin and the induction of EMT in in vitro sudies. ${ }^{51}$ Both, ZEB1 and ZEB2, have been reported to be strong suppressors of E-cadherin expression and at the same time, ZEB2 has been shown to directly activate the vimentin promoter by an unknown mechanism as revealed in vitro studies. ${ }^{52}$ Relationship between these transcription factors and epithelial or mesenchimal phenotype markers is shown in table 1.

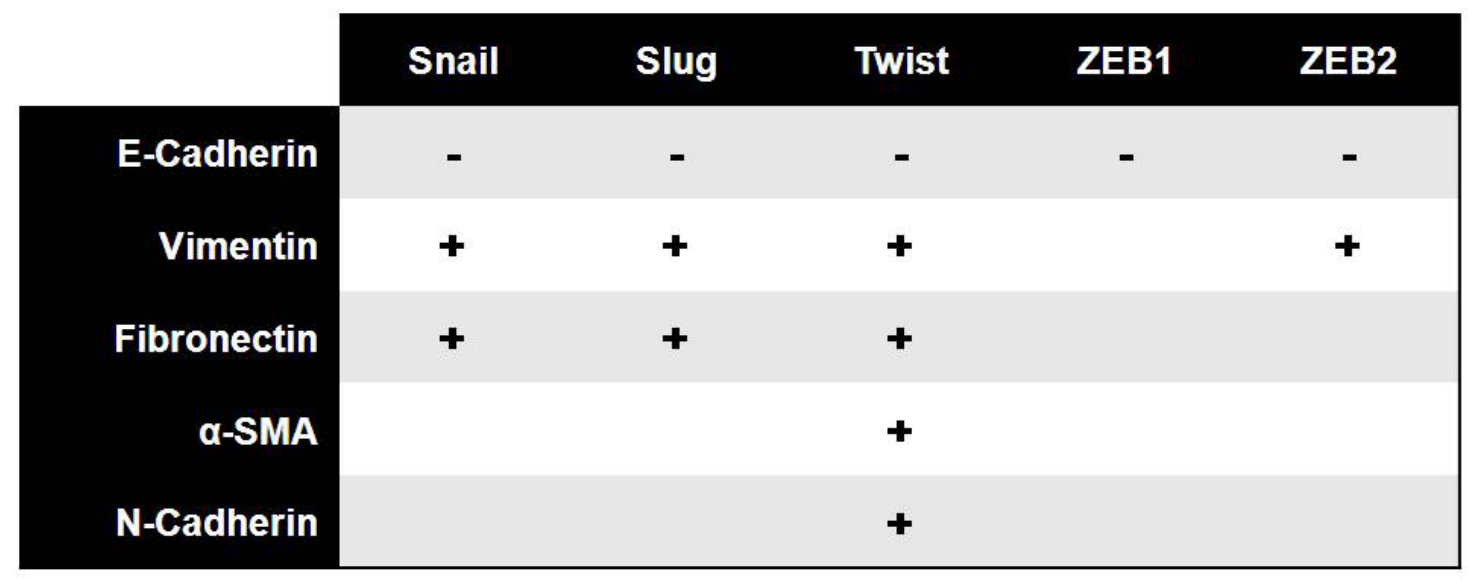

Table 1: Transcription factors involved in regulation of epithelial-mesenchymal transition markers. $(+)$ upregulated, (-) downregulated

Regulation of transcriptional factors involved in EMT

Activation of transcriptional factors involved in EMTcan be initiated by at least two different ways: ligand-inducible receptor kinase activation and Wnt/Frizzled signals in the surface of the cell.

Injury to the kidney is associated with the release by damaged or infiltrating cells of growth factors such as TGF- $\beta$, EGF, and FGF-2 that bind epithelial receptors with ligand-inducible intrinsic kinase activity. As a result of ligand-inducible receptor kinase activation there is a downstream engagement of several signaling pathways, such as the Smad pathways or GTPases from the Ras superfamily. A proof of the role of small GTP-ase Ras activation in EMT induced by ureteral obstruction in mice derivates from unpublished studies from our laboratory showing that in mice lacking H-Ras, ureteral obstruction induced a lower expression of $\alpha$-SMA, vimentin, 
FSP-1 and snail than in WT mice, thus reduced EMT in H-rasKO mice (Grande MT and Lopez-Novoa JM, unpublished results). Raf-MAP kinase pathway activation leads to the induction of the snail promoter ${ }^{53}$ and slug expression ${ }^{54}$ regulating repression of E-cadherin. ${ }^{55}$ Ras also activated the PI3K/Akt pathway, which in turns regulates the activity of glycogen synthase kinase- $3 \beta$ (GSK-3 $\beta$ ) as GSK-3 $\beta$ activity is inhibited by phosphorylation via the PI3K/Akt signaling. ${ }^{56}$ GSK-3 $\beta$ has been demonstrated to regulate the Snaill level by regulating the degradation of Snaill protein. The level of the phosphorylated inactive form of GSK-3 $\beta$ was found to be increased in the tubular epithelial cells of the obstructed kidney after UUO, and the elevated level of GSK-3 $\beta$ phosphorylation correlated with Snaill accumulation, since this inactive form cannot recruit a protein degradation system for Snail1. ${ }^{48}$ The PI3K/Akt pathway has been reported to be activated in the obstructed kidney after UUO. ${ }^{57}$ (Figure 4).

In the obstructed kidney, others signals, in addition to the ligand-inducible receptor kinase activation, are also regulating transcriptional factors required for EMT. One of these signals is promoted by Wnt genes which code for secreted proteins that associate with the cell surface and are capable of signaling via members of a family of receptors named Frizzled. In response to a Wnt/Frizzled signal, GSK-3 activity is inhibited and thus $\beta$-catenin is not phosphorylated. Not phosphorylated $\beta$ catenin is the stabilized form of $\beta$-catenin and it is transported into the nucleus, where it can participate with Lef/TCF (lymphoid enhancer binding factor/T-cell factor) in the transcriptional induction of genes that are required for EMT. ${ }^{58}$ (Figure 4) This Wnt signaling pathway has been reported to be activated in the obstructed kidney 7 days after UUO. ${ }^{45}$

Once initiated cell surface signals, numerous factors are involved in the regulation of transcriptional factors, such as HSP27, NF- $\mathrm{BB}$ activation, integrinlinked kinase and Smads signaling pathways.

HSP27 is also involved in the pathogenesis of TGF- $\beta$-induced EMT and chronic tubulointerstitial fibrosis. It has been reported that UUO resulted in significant upregulation of TGF- $\beta, \alpha$-SMA, total and phosphorylated HSP27. The induction of HSP27 overexpression by transient transfection significantly increased E-cadherin while decreasing E-cadherin repressor Snail levels. These results suggest that HSP27 overexpression may delay injury by upregulating E-cadherin through downregulation of Snail. ${ }^{59}$ 


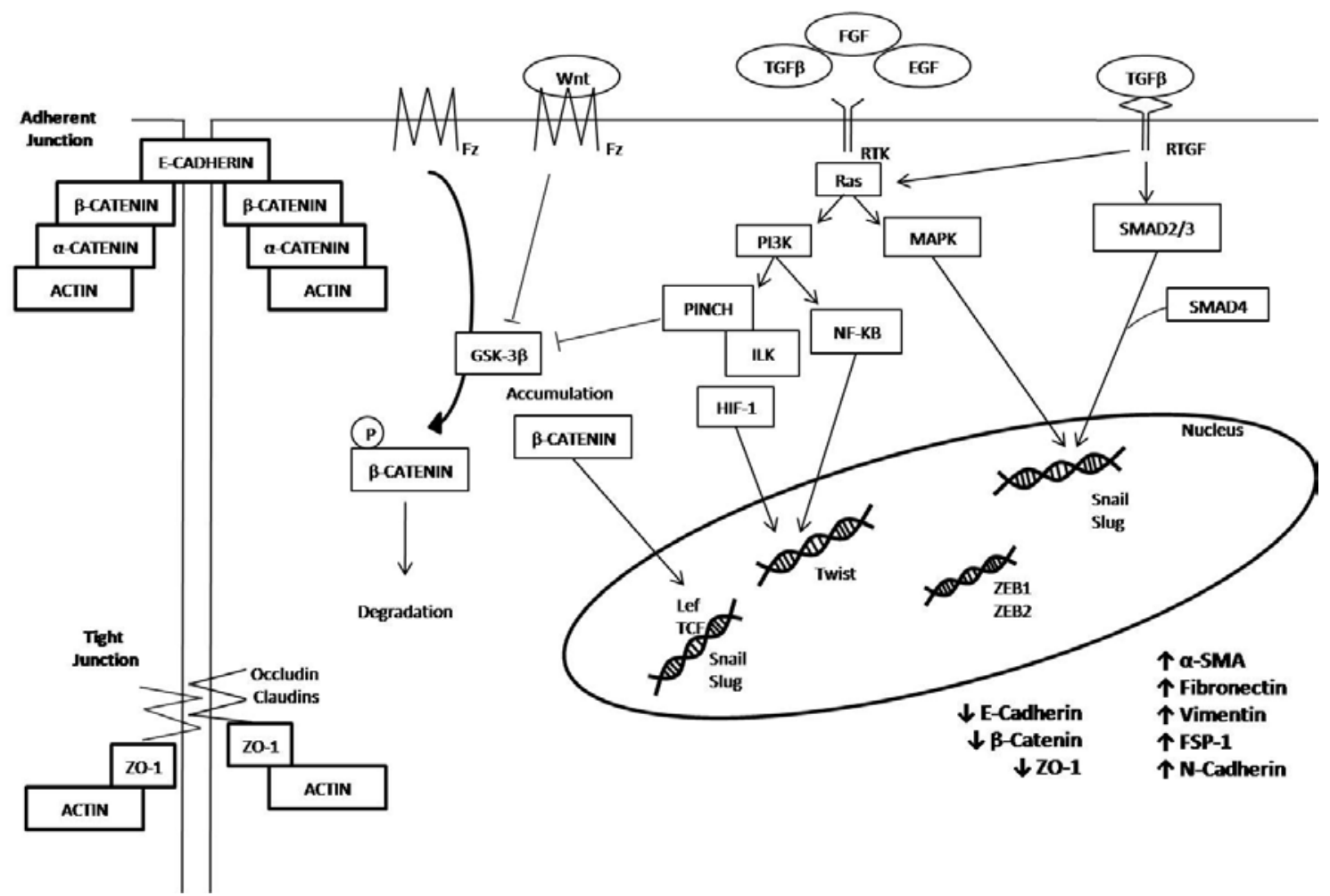

Figure 4. Schematic review of the major factors involved in epithelial-to-mesenchymal transition (EMT). EMT is characterized by disruption of the cell-to cell attachment (adherent junctions and thigh junctions), decrease of the expression of molecules involved in cell-to cell attachment, such as E-cadherin, $\beta$-catenin and ZO-1, and overexpression of myofibroblasts markers such as $\alpha$-smooth muscle actin ( $\alpha$-SMA), vimentin, FSP1 and N-cadherin. EMT is induced by several cytokines such as TGF- $\beta$, EGF, FGF or Wnt, using many signaling pathways such as smads, small GTPases of the Ras family, PI3K/Akt, MAP kinases, and ILK/PINCH, ant the activation of transcription factors such as NFKB, HIF, Lef, TCF, Snail, Slug, Twist, and ZEB1 and ZEB2.

The transcription factor NF- $\mathrm{kB}$ has been reported to be an essential regulator of EMT, and it has been suggested that the cooperation of Ras and TGF- $\beta$ depends on NF-kB activity, probably via Akt signaling. ${ }^{60}$ Twist proteins are also induced by cytokine signaling pathway that requires $\mathrm{NF}-\kappa \mathrm{B}$ activation $^{61}$ and by hypoxia inducible factor-1, HIF-1. ${ }^{62}$ Moreover, an in vitro study revealed that over-expression of the constitutively active p65 subunit of NF- $\kappa \mathrm{B}$, specifically suppressed E-cadherin expression and induced the expression of the mesenchymal gene vimentin as well as

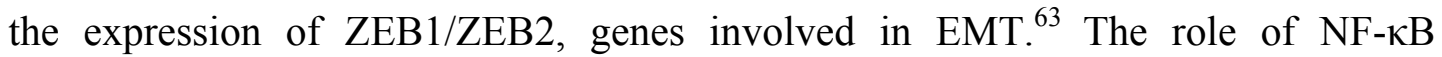
functions in the regulation of master genes that repress the epithelial phenotype, and the roles of NF-kappaB in control of mesenchymal genes have been previously review. ${ }^{64}$ 
Other signaling pathway involved in EMT is the integrin-linked kinase (ILK). ILK is a multifunctional intracellular effector of cell-matrix interactions and regulates many cellular processes, including growth, proliferation, survival, differentiation, migration, invasion and angiogenesis. ${ }^{65}$ ILK is an intracellular serine/threonine protein kinase that interacts with the cytoplasmic domains of $\beta$ integrins and numerous cytoskeleton-associated proteins. ILK, isoforms of the adaptor proteins PINCH (particularly interesting Cys-His-rich protein), and parvin form the IPP complex in the cytoplasm that has been implicated in the control of signaling pathways through both phosphorylation of downstream targets (most notably AKT and GSK3) and binding to upstream effectors of the Jun N-terminal kinase (JNK) signalling pathway and regulators of small-molecular-weight GTPases. ${ }^{66}$ There are convincing data suggesting that ILK is involved in EMT during renal interstitial fibrogenesis. Thus, ILK expression is specifically induced in renal tubular epithelial cells in response to TGF- $\beta 1$ treatment in vitro and after obstructive or diabetic injury in vivo. ${ }^{67}$ After UUO in mice, PINCH-1 expression increased in a time-dependent manner, and PINCH-1 through its interaction with ILK, plays an important role in regulating TGF- $\beta$-mediated EMT. ${ }^{44}$

Using in vitro approaches, it has been reported that Smads regulates TGF- $\beta$ induced EMT through phosphorylation of $\operatorname{Smad} 2 / 3$, which are then imported into the nucleus with Smad4. ${ }^{68,69,70}$ Mice lacking Smad3 presented a decreased expression of EMT markers in the obstructed kidney after UUO, suggesting a key role of Smad signaling pathway in TGF- $\beta$-induced EMT. ${ }^{71}$ In vitro studies have also reported that nuclear Smads acts as cofactors for other transcriptional proteins regulating nuclear gene activity, such as nuclear import of Lef/TCF which participates in transcriptional induction of genes that are required for EMT. ${ }^{72}$ Transcription factors such as $\mathrm{ZEB}^{73}$ and Snail $^{74}$ are regulated by TGF- $\beta$ through Smads pathway.

Inhibitor of differentiation-1 (Id1), a dominant negative antagonist of the basic helix-loop-helix transcription factors, was found to be induced rapidly in human proximal tubular epithelial cells after TGF-beta1 treatment. This induction of Id1 depended on intracellular Smad signaling. Ectopic expression of Id1 suppressed epithelial E-cadherin and zonula occludens- 1 expression. ${ }^{75}$ In in vivo studies in mice, Id1 was found to be induced exclusively in the degenerated, dilated renal tubular epithelium from 1 day after UUO, and this increase was sustained until 14 days after UUO. $^{75}$ 
As a conclusion, multiple extracellular stimuli have been shown to induce EMT by activating several major signaling pathway, including Wnt, tyrosin kinaseRas signaling, ILK complexes and TGF- $\beta$-Smad signaling, which regulate transcriptional factors that trigger EMT. However, how such distinct signaling pathways orchestrate the complex cellular events that facilitate EMT is not well understood. FSP1/S100A4 has been also suggested to be not only a marker of EMT, but also a factor involved in the transition from epithelium to myofibroblasts. This hypothesis is based in the fact that fibroblasts produced by EMT express a gene encoding FSP1 which is regulated by a promoter element called fibroblast transcription site-1 (FTS-1) which forms a complex with another two transcriptional proteins called the CArG box-binding factor-A (CBF-A) and the KRAB-associated protein 1 (KAP-1). This complex has been reported to be an activator of genes encoding the EMT proteome and suggests that it is an early proximal regulator in the molecular program leading to fibroblast formation. FSP1 and these two proteins of the FTS-1 complex, CBF-A and KAP-1, were found to be upregulated in the obstructed kidney after 12 days of UUO in mice. ${ }^{76}$ Furthermore, the in vitro overexpression of FSP1 cDNA in tubular epithelium is accompanied by conversion to a mesenchymal phenotype fibroblast-like appearance, a reduction in cytokeratin, and new expression of vimentin. ${ }^{46}$

\section{TUBULAR \\ BASEMENT \\ MEMBRANE \\ DEGRADATION:}

\section{METALLOPROTEINASES}

Tubular epithelial cells (TECs) interact via their basal side with tubular basement membranes (TBM), which clearly separate the tubular compartment from the interstitial compartment. The current paradigm for EMT during renal fibrosis postulates those TECs lose contact with adjacent cells and the TBM, and transit through the TBM into the renal interstitium, acquiring migratory capacity to move into the interstitial matrix. (Figure 3). A proof of the importance of basement membrane degradation in EMT is the observation that preservation of tubular basement membrane (TBM) integrity in $t P A^{-/}$mice induce blockade of tubular EMT and protects the kidney from developing fibrotic lesions after obstructive injury. ${ }^{77}$ Initially it seems that TBM architecture is degraded by zinc-dependent endopeptidases known as matrix metalloproteinases (MMPs). MMP9 has been reported to appeared at day 3 after UUO and its activity increased until day 6 , from 
which begins to decrease its activity, and this decrease is also accompanied by the emergence of tissue inhibitor of metalloproteinase-1 (TIMP1) which have been reported to promote renal interstitial fibrosis. ${ }^{78}$ Others MMPs have been reported to appear shortly after UUO, including MMP2 ${ }^{79}$ and MMP7. ${ }^{80}$ These results suggest that early after UUO and around the epithelial cells that will suffer EMT, basement membranes as well as extracellular matrix are degraded by increased MMPs activity (Figure 3). It should be noted that after long-term UUO and in the interstitial space, MMPs activity is inhibited promoting extracellular matrix accumulation. A recent study relates the structural and functional integrity of the TBM with interactions between MMP9 and TIMP1, ${ }^{81}$ suggesting a key role of MMPs in the first stage of EMT.

\section{GAIN OF CELL MOTILITY}

Motility is a characteristic of the cells suffering EMT, as it is required to move from the tubular to the interstitial compartment. Cell motility is a high regulated process in which many factors are involved.

p120 catenin is a cadherin-associated protein that promotes the invasiveness of E-cadherin-deficient by increasing cell motility. ${ }^{82}$ p120 catenin, binds the intracellular cadherin domain tail of E-cadherin at the juxtamembrane domain, whereas $\beta$-catenin binds the distal domain near the C-terminus. p120 catenin is thought to promote cell motility through modulating activities of Rho GTPases in the cytoplasm. Disruption of E-cadherin- $\beta$-catenin binding leads p120 catenin stranded in the cytoplasm that is not bound to cadherin inhibits the activity of RhoA by acting as a GDI and sequestering RhoA in its inactive form, and, consequently inhibiting the formation of stress fibers and focal adhesion, Cytosolic p120-catenin subsequently activates Rac1 (filopodia) and Cdc42 (lamellipodia) by inactivating RhoA. The result would be an increased motility. Note that cadherin family members differentially bind p120-catenin and as a result might have different influences on RhoGTPase activity. Indeed, VE-cadherin and N-cadherin have different affinities for p120-catenin, as do R-cadherin and E-cadherin. ${ }^{82}$ p120 catenin increase can also result in its translocation to the nucleus, where it associates with the transcription factor Kaiso and modulates gene expression. ${ }^{83}$ In highly differentiated colon carcinoma cells (LIM1863 cells) EMT occurs within 24 hours following stimulation with TGF- $\beta$ and TNF- $\alpha$. During the EMT, the localization p120 catenin shifts from 
cell-cell junctions to the cytoplasm, where it forms a complex with RhoA that is associated with a marked decrease in RhoA activation coincident with E-cadherin loss during the EMT. ${ }^{84}$ It is necessary to mention that most of these studies have been performed on cancer cell lines and, to our knowledge, expression and localization of p120 has not been studied in the UUO model. RhoA expression and activation has been reported not to differ between obstructed and contralateral kidneys after 4 days of UUO, whereas RhoB and RhoC were up-regulated after UUO. ${ }^{85}$ The actions of Rho are mediated by downstream Rho effectors such as Rhoassociated coiled-coil forming protein kinase (ROCK). The administration of a specific inhibitor of ROCK, diminished $\alpha$-SMA expression after UUO, suggesting that Rho-ROCK signaling pathway plays an important role in the regulation of EMT. In addition, ROCK inhibition also decreases cell motility. ${ }^{85}$ To our knowledge, neither Cdc42 nor Rac1 role in cell motility has been studied in in vivo models of UUO. However, there are in vitro data suggesting a role for RhoA, Cdc42 and Rac1 in EMT. Human proximal tubular epithelial cells (HK2 cells) undergo EMT in response to activated PBMC conditioned medium (aPBMC-CM), aPBMC-CM induces a rapid activation of RhoA, Rac1, and Cdc42 activity in HK2 cells. Moreover, infection with adenovirus expressing constitutively active RhoA, Rac1, and Cdc42 significantly increased the expression of fibronectin and downregulated expression of E-cadherin and K19. ${ }^{86}$ Constitutively active RhoA activated the Rho kinase and its downstream effectors, whereas constitutively active Rac1 and Cdc42 activated the P21-activated protein kinase in epithelial cells. ${ }^{86}$ These results suggest that the activation of RhoA, Rac1, and $\mathrm{Cdc} 42$ and their downstream effectors, induces to HK2 cells to EMT, thus suggesting that activation of small Rho-GTPases is a key step in the mechanism of EMT and probably contributes to tubulointerstitial fibrosis. Furthermore, cells induced to undergo EMT by TGF $\beta 3$ demonstrate increased motility when seeded on fibronectin and display a rapid activation of RhoA followed by a gradual downregulation of $\mathrm{Cdc} 42$ and Rac3 activity. ${ }^{87}$ The induced expression of a fast-cycling RhoA mutant (RhoA F30) stimulates the formation of stress fibers and spreading, and therefore the generation of mesenchymal phenotype whereas the inactivation of the Rho effector Rho-kinase, prevents from TGF $\beta 3$ induced EMT. ${ }^{87}$ 
These results suggest that rapid activation of the RhoA/Rho-kinase pathway and subsequently reorganization of the actin cytoskeleton is necessary in increased cell motility characteristic of EMT, during ureteral obstruction.

\section{MYOFIBROBLAST ACTIVATION PATHWAYS AS A TARGET FOR OBSTRUCTIVE NEPHROPATHY THERAPY.}

Since EMT is a developmental process crucial for metastasis of tumors, ${ }^{88}$ and the molecules involved in EMT represent potential targets for pharmacological agents for the control of metastatic spread in the treatment of malignancies, a tremendous research effort is being done to find therapies that prevent this process. For instance, kinases have been an attractive target for therapeutic intervention in many diseases, including renal diseases and cancer. ${ }^{89}$ For instance, we have reported that Erk1/2 inhibition or PI3K/Akt inhibition pathways resulted in decreased renal fibrosis and reduced expression of EMT markers after UUO in mice. ${ }^{57}$ Kinases recognize distinct substrates among others through subtle differences in their catalytic structures. These differences allow the development of relatively selective inhibitors. The diversity and the size of the kinome (comprising more than 500 kinases) challenge the development of truly selective inhibitors. Typically drug discovery efforts have focused on developing compounds that are specific for a particular target kinase in order to prevent metastasis without interrupt normal cell functions. ${ }^{90}$ However, inhibitors with broader specificity may offer an improved therapeutic benefit. Activation of the phosphatidylinositol 3' kinase (PI3K)/AKTGSK-3 $\beta$ axis is emerging as a central feature of $\mathrm{EMT}^{91}$ but tyrosine kinases are also involved. For instance, Apsel et al. ${ }^{92}$ identify compounds that inhibit both protein tyrosine kinases and lipid PI3Ks, both of which are well known as potent oncoproteins. In another example of the use of anticancer drugs to treat other diseases, administration of the multi-tyrosine kinase inhibitor, Imatinib, primarily used to treat chronic myeloid leukaemia, to non-obese diabetic (NOD) mice, a model of spontaneous diabetes, prevented the appearance of the disease in more than $80 \%$ of the mice. ${ }^{93}$ Indeed, Sunitinib, another approved multikinase inhibitor, induced remission in $100 \%$ of mice following just 1 week of therapy. ${ }^{93}$ Thus, targeting specific signaling pathways with drugs developed for cancer treatment could be a new therapeutical strategy to prevent myofibroblast activation and the subsequent interstitial fibrosis in obstructive nephropathy. EMT-related signal transduction 
cascades, such as TGF- $\beta / \mathrm{Smad}^{71}$ and TGF- $\beta / \mathrm{ILK}^{44}$ are also potential future targets to prevent or treat unfavorable renal tissue fibrosis. Furthermore, EMT can be a reversible process, as both EMT and the reverse, mesenchymal-epithelial transition, occur repeatedly during normal embryonic development. In fact, bone morphogenic protein-7 (BMP-7) a member of the TGF- $\beta$ superfamily, is not only able to reverse renal fibrosis and myofibroblast accumulation in mice with nephrotoxic serum nephritis a model of progressive chronic renal injury, and to prevent TGF- $\beta$-induced EMT, ${ }^{94}$ but it is able to induce the acquisition of E-cadherin expression and decreased motility in cultures of adult renal fibroblasts indicating that true mesenchymal-to-epithelial transition (MET) might be achieved. ${ }^{95}$ Thus, targeting signaling pathways involved in myofibroblast activation and EMT appears as a promising strategy to prevent and even reverse interstitial fibrosis in obstructive nephropathy.

\section{CONCLUSIONS}

Although UUO does not exactly mimics the changes occurring in the kidney during human obstructive nephropathy, it seems to be a very useful model to investigate the cellular and molecular mechanisms leading to interstitial fibrosis as well as possible therapies to prevent or even to reverse renal damage associated to urinary tract obstruction. Either activated fibroblasts or myofibroblasts recruitment from resident fibroblasts, pericytes, endothelial cells or bone marrow-derived circulating cells, or produced by epithelial-to-mesenchymal transition play a key role in the genesis of in interstitial fibrosis induced by urinary obstruction. Thus, strategies devoted to target the molecular processes leading to myofibroblasts activation are among the more promising candidates for the therapy of obstructive nephropathy. 


\section{KEY POINTS}

- A leading cause of chronic renal failure in children, obstructive nephropathy is characterized by inflammation, tubular atrophy and interstitial fibrosis.

- Tubulointerstitial fibrosis is the common end-stage of many progressive renal diseases, characterized by loss of glomerular and peritubular capillary architecture, cell proliferation, and diffuse extracellular matrix accumulation. Unilateral ureteral obstruction (UUO) has been the most used method to study the cellular and molecular mechanisms leading to interstitial fibrosis.

- Either activated fibroblasts or myofibroblasts recruitment from resident fibroblasts, pericytes, endothelial cells or bone marrow-derived circulating cells, or produced by epithelial-to-mesenchymal transition are major processes in the genesis and progression of fibrosis damage.

- Research using rodent models of UUO and in vitro studies in the past 5 years has shed new light on the molecular mechanisms underlying these processes.

- Myofibroblast activation and EMT are induced by mechanical forces and cytokines such as TGF- $\beta$, PDGF, FGF, ED-A splice variant of fibronectin activin $\mathrm{A}$ and other chemokines produced by tubular and infiltrated interstitial cells.

- EMT is strictly regulated by several signaling pathways including activation of the small GTPases of the Ras and Rho family, MAP-kinases. PI3Kinase/Akt, GSK-3 $\beta$, ILK/PINCH, NFאB, Smads, and many others.

- The in depth knowledge of molecular mechanisms responsible of these processes is essential to develop pharmacological strategies for preventing or even reversing interstitial fibrosis associated to obstructive nephropathy. 


\section{Glossary terms:}

Epithelial-mesenchimal-transition (EMT): phenomenon by which epithelial cells can obtain a mesenchymal phenotype, with changes in cell morphology and acquisition of migratory properties allowing them to move into the interstitial space.

Intercellular junctions: Cell-to cell binding structures that are crucial for epithelial adhesion and function, and that maintains cell polarity.

Transcription factors: intracellular proteins that regulates gene expression by binding to specific sequences of DNA (promoters) and modulating transcription into RNA.

\section{Acknowledgments}

The author's studies have been supported by grants from Ministerio de Educación, Turismo y Deportes (BFU2004-00285/BFI, and SAF2007-63893), Junta de Castilla y León (SA 001/C05), and Instituto de Salud Carlos III, (RETIC RedIn- Ren RD/0016). Photomicrographs (Figure 1) were produced by Prof. Miguel Arévalo, Department of Human Anatomy and Histology, University of Salamanca.

\section{Competing interests}

The authors declared they have no competing interests. 


\section{References}

1 Bohle A et al. (1994) On the pathogenesis of chronic renal failure in primary glomerulopathies: a view from the interstitium. Exp Nephrol 2: 205-210

2 Manucha W (2007) Biochemical-molecular markers in unilateral ureteral obstruction. Biocell 31: 1-12

3 Lopez-Novoa JM (2008) The mechanisms of age-associated glomerular sclerosis. In The aging kidney in health and disease, 113-126 (Eds Macias-Nuñez JF et al.) New York: Springuer science

4 Joosten SA et al. (2005) Chronic renal allograft rejection: pathophysiologic considerations. Kidney Int 68: 1-13

5 Smith JM et al. (2007) Contributions of the Transplant Registry: The 2006 Annual Report of the North American Pediatric Renal Trials and Collaborative Studies (NAPRTCS). Pediatr Transplant 11: 366-373

6 Chevalier RL (2006) Obstructive nephropathy: towards biomarker discovery and gene therapy. Nat Clin Pract Nephrol 2: 157-168

7 Strutz F and Zeisberg M (2006) Renal fibroblasts and myofibroblasts in chronic kidney disease. J Am Soc Nephrol 17: 2992-2998

8 Strutz F (2008) How many different roads may a cell walk down in order to become a fibroblast? J Am Soc Nephrol 19: 2246-2248

9 Roufosse C et al. (2006) Bone marrow-derived cells do not contribute significantly to collagen I synthesis in a murine model of renal fibrosis. J Am Soc Nephrol 17: 775-782

10 Picard N et al. (2008) Origin of renal myofibroblasts in the model of unilateral ureter obstruction in the rat. Histochem Cell Biol 130: 141-155

11 Lin SL et al. (2008) Pericytes and perivascular fibroblasts are the primary source of collagen-producing cells in obstructive fibrosis of the kidney. Am J Pathol 173: $1617-1627$

12. Zeisberg EM et al. (2008) Fibroblasts in kidney fibrosis emerge via endothelialto-mesenchymal transition. J Am Soc Nephrol 19: 2282-2287

13 Zeisberg M and Kalluri R (2008) Fibroblasts emerge via epithelial-mesenchymal transition in chronic kidney fibrosis. Front Biosci 13: 6991-6998

14 Qi W et al. (2006) The renal cortical fibroblast in renal tubulointerstitial fibrosis. Int J Biochem Cell Biol 38: 1-5 
15 Le Hir M et al. (2005) Characterization of renal interstitial fibroblast-specific protein 1/S100A4-positive cells in healthy and inflamed rodent kidneys. Histochem Cell Biol 123: 335-346

16 Kaissling B and Le Hir M (2008) The renal cortical interstitium: morphological and functional aspects. Histochem Cell Biol 130: 247-262

17 Vekaria RM et al. (2006) Immunolocalization of ectonucleotidases along the rat nephron. Am J Physiol Renal Physiol 290: F550-F560

18 Inoue $\mathrm{T}$ et al. (2005) Antibodies against macrophages that overlap in specificity with fibroblasts. Kidney Int 67: 2488-2493

19 Desmouliere A et al. (2005) Tissue repair, contraction, and the myofibroblast. Wound Repair Regen 13: 7-12

20 El Chaar M et al. (2005) Cyclooxygenase-2 inhibitor decreases extracellular matrix synthesis in stretched renal fibroblasts. Nephron Exp Nephrol 100: e150-e155 21 Wang W et al. (2005) Transforming growth factor-beta and Smad signalling in kidney diseases. Nephrology (Carlton) 10: 48-56

22 Eitner F et al. (2008) PDGF-C is a proinflammatory cytokine that mediates renal interstitial fibrosis. J Am Soc Nephrol 19: 281-289

23 Strutz F et al. (2000) Basic fibroblast growth factor expression is increased in human renal fibrogenesis and may mediate autocrine fibroblast proliferation. Kidney Int 57: 1521-1538

24 Hinz B (2006) Masters and servants of the force: the role of matrix adhesions in myofibroblast force perception and transmission. Eur J Cell Biol 85: 175-181

25 Lange-Sperandio B et al. (2007) Leukocytes induce epithelial to mesenchymal transition after unilateral ureteral obstruction in neonatal mice. Am J Pathol 171: $861-871$

26 Huang XR et al. (2008) Mice overexpressing latent TGF-betal are protected against renal fibrosis in obstructive kidney disease. Am J Physiol Renal Physiol 295: F118-F127

27 Sato M et al. (2003) Targeted disruption of TGF-beta1/Smad3 signaling protects against renal tubulointerstitial fibrosis induced by unilateral ureteral obstruction. $J$ Clin Invest 112: 1486-1494

28 Tan $\mathrm{R}$ et al. (2006) Downregulation of SnoN expression in obstructive nephropathy is mediated by an enhanced ubiquitin-dependent degradation. J Am Soc Nephrol 17: 2781-2791 
29 Fukasawa $\mathrm{H}$ et al. (2006) Ubiquitin-dependent degradation of SnoN and Ski is increased in renal fibrosis induced by obstructive injury. Kidney Int 69: 1733-1740 30 Yamashita S et al. (2004) Activin A is a potent activator of renal interstitial fibroblasts. J Am Soc Nephrol 15: 91-101

31 Lee DB et al. (2006) Tight junction biology and kidney dysfunction. Am J Physiol Renal Physiol 290: F20-F34

32 Iwano $\mathrm{M}$ et al. (2002) Evidence that fibroblasts derive from epithelium during tissue fibrosis. J Clin Invest 110: 341-350

33 Faulkner JL et al. (2005) Origin of interstitial fibroblasts in an accelerated model of angiotensin II-induced renal fibrosis. Am J Pathol 167: 1193-1205

34 Yamashita S et al. (2005) Involvement of renal progenitor tubular cells in epithelial-to-mesenchymal transition in fibrotic rat kidneys. J Am Soc Nephrol 16: 2044-2051

35 Rastaldi MP et al. (2002) Epithelial-mesenchymal transition of tubular epithelial cells in human renal biopsies. Kidney Int 62: 137-146

36 Nishitani Y et al. (2005) Fibroblast-specific protein 1 is a specific prognostic marker for renal survival in patients with IgAN. Kidney Int 68: 1078-1085

37 Rossini M et al. (2005) Immunolocalization of fibroblast growth factor-1 (FGF1), its receptor (FGFR-1), and fibroblast-specific protein-1 (FSP-1) in inflammatory renal disease. Kidney Int 68: 2621-2628

38 Hertig A et al. (2006) Risk factors for early epithelial to mesenchymal transition in renal grafts. Am J Transplant 6: 2937-2946

39 Vongwiwatana A et al. (2005) Epithelial to mesenchymal transition during late deterioration of human kidney transplants: the role of tubular cells in fibrogenesis. Am J Transplant 5: 1367-1374

40 Vitalone MJ et al. (2008) Epithelial-to-mesenchymal transition in early transplant tubulointerstitial damage. J Am Soc Nephrol 19: 1571-1583

41 Butt MJ et al. (2007) Collecting duct epithelial-mesenchymal transition in fetal urinary tract obstruction. Kidney Int 72: 936-944

42 Kida Y et al. (2007) Twist relates to tubular epithelial-mesenchymal transition and interstitial fibrogenesis in the obstructed kidney. J Histochem Cytochem 55: 661673

$43 \mathrm{Wu}$ MJ et al. (2006) Rapamycin attenuates unilateral ureteral obstruction-induced renal fibrosis. Kidney Int 69: 2029-2036 
$44 \mathrm{Li} \mathrm{Y}$ et al. (2007) PINCH-1 promotes tubular epithelial-to-mesenchymal transition by interacting with integrin-linked kinase. J Am Soc Nephrol 18: 25342543

45 Surendran K et al. (2005) Wnt-dependent beta-catenin signaling is activated after unilateral ureteral obstruction, and recombinant secreted frizzled-related protein 4 alters the progression of renal fibrosis. J Am Soc Nephrol 16: 2373-2384

46 Liu Y (2004) Epithelial to mesenchymal transition in renal fibrogenesis: pathologic significance, molecular mechanism, and therapeutic intervention. $J \mathrm{Am}$ Soc Nephrol 15: 1-12

47 Docherty NG et al. (2009) Increased E-cadherin expression in the ligated kidney following unilateral ureteric obstruction. Kidney Int 75: 205-213

48 Yoshino J et al. (2007) Snail1 is involved in the renal epithelial-mesenchymal transition. Biochem Biophys Res Commun 362: 63-68

49 Boutet A et al. (2006) Snail activation disrupts tissue homeostasis and induces fibrosis in the adult kidney. EMBO J 25: 5603-5613

50 Yang $\mathrm{J}$ et al. (2004) Twist, a master regulator of morphogenesis, plays an essential role in tumor metastasis. Cell 117: 927-939

51 Peinado $\mathrm{H}$ et al. (2007) Snail, Zeb and bHLH factors in tumour progression: an alliance against the epithelial phenotype? Nat Rev Cancer 7: 415-428

52 Park SM et al. (2008) The miR-200 family determines the epithelial phenotype of cancer cells by targeting the E-cadherin repressors ZEB1 and ZEB2. Genes Dev 22: 894-907

53 Horiguchi K et al.: Role of Ras signaling in the induction of snail by TGF-beta. $J$ Biol Chem, in press

54 Choi J et al. (2007) Transforming growth factor-betal represses E-cadherin production via slug expression in lens epithelial cells. Invest Ophthalmol Vis Sci 48: $2708-2718$

55 Thiery JP and Sleeman JP (2006) Complex networks orchestrate epithelialmesenchymal transitions. Nat Rev Mol Cell Biol 7: 131-142

56 Qiao M et al. (2008) Metastasis and AKT activation. Cell Cycle 7: 2991-2996

57 Rodriguez-Pena $\mathrm{AB}$ et al. (2008) Activation of Erk1/2 and Akt following unilateral ureteral obstruction. Kidney Int 74: 196-209 
58 Jiang YG et al. (2007) Role of Wnt/beta-catenin signaling pathway in epithelialmesenchymal transition of human prostate cancer induced by hypoxia-inducible factor-1alpha. Int J Urol 14: 1034-1039

59 Vidyasagar A et al. (2008) HSP27 is involved in the pathogenesis of kidney tubulointerstitial fibrosis. Am J Physiol Renal Physiol 295: F707-F716

60 Huber MA et al. (2004) NF-kappaB is essential for epithelial-mesenchymal transition and metastasis in a model of breast cancer progression. $J$ Clin Invest 114: $569-581$

61 Pham CG et al. (2007) Upregulation of Twist-1 by NF-kappaB blocks cytotoxicity induced by chemotherapeutic drugs. Mol Cell Biol 27: 3920-3935

62 Peinado H and Cano A (2008) A hypoxic twist in metastasis. Nat Cell Biol 10: 253-254

63 Chua HL et al. (2007) NF-kappaB represses E-cadherin expression and enhances epithelial to mesenchymal transition of mammary epithelial cells: potential involvement of ZEB-1 and ZEB-2. Oncogene 26: 711-724

64 Min C et al. (2008) NF-kappaB and epithelial to mesenchymal transition of cancer. J Cell Biochem. 104: 733-744

65 McDonald PC et al. (2008) Integrin-linked kinase--essential roles in physiology and cancer biology. J Cell Sci 121: 3121-3132

66 Legate KR et al. (2006) ILK, PINCH and parvin: the tIPP of integrin signalling. Nat Rev Mol Cell Biol 7: 20-31

$67 \mathrm{Li}$ Y et al. (2003) Role for integrin-linked kinase in mediating tubular epithelial to mesenchymal transition and renal interstitial fibrogenesis. J Clin Invest 112: 503-516 68 Deckers M et al. (2006) The tumor suppressor Smad4 is required for transforming growth factor beta-induced epithelial to mesenchymal transition and bone metastasis of breast cancer cells. Cancer Res 66: 2202-2209

69 Phanish MK et al. (2006) The differential role of Smad2 and Smad3 in the regulation of pro-fibrotic TGFbetal responses in human proximal-tubule epithelial cells. Biochem J 393: 601-607

70 Runyan CE et al. (2005) The role of internalization in transforming growth factor beta1-induced Smad2 association with Smad anchor for receptor activation (SARA) and Smad2-dependent signaling in human mesangial cells. J Biol Chem 280: 83008308 
71 Inazaki $\mathrm{K}$ et al. (2004) Smad3 deficiency attenuates renal fibrosis, inflammation, and apoptosis after unilateral ureteral obstruction. Kidney Int 66: 597604

72 Nawshad A et al. (2005) Transforming growth factor-beta signaling during epithelial-mesenchymal transformation: implications for embryogenesis and tumor metastasis. Cells Tissues Organs 179: 11-23

73 Postigo AA et al. (2003) Regulation of Smad signaling through a differential recruitment of coactivators and corepressors by ZEB proteins. EMBO J 22: 24532462

74 Zavadil J and Bottinger EP (2005) TGF-beta and epithelial-to-mesenchymal transitions. Oncogene 24: 5764-5774

$75 \mathrm{Li}$ Y et al. (2007) Tubular epithelial cell dedifferentiation is driven by the helixloop-helix transcriptional inhibitor Id1. J Am Soc Nephrol 18: 449-460

76 Venkov CD et al. (2007) A proximal activator of transcription in epithelialmesenchymal transition. J Clin Invest 117: 482-491

77 Yang, J et al. (2002) Disruption of tissue-type plasminogen activator gene in mice reduces renal interstitial fibrosis in obstructive nephropathy. J. Clin. Invest 110: $1525-1538$

78 Cai G et al. (2008) Tissue inhibitor of metalloproteinase-1 exacerbated renal interstitial fibrosis through enhancing inflammation. Nephrol Dial Transplant 23: $1861-1875$

79 Nishida $\mathrm{M}$ et al. (2007) MMP-2 inhibition reduces renal macrophage infiltration with increased fibrosis in UUO. Biochem Biophys Res Commun 354: 133-139

80 Surendran K et al. (2004) Matrilysin (MMP-7) expression in renal tubular damage: association with Wnt4. Kidney Int 65: 2212-2222

81 Xue H et al. (2008) [Role of MMP-9 and TIMP-1 in renal tubular epithelialmyofibroblast transdifferentiation]. Sichuan Da Хие Хие Baо Yi Хие Ban 39: 34-38 82 Yanagisawa M et al. (2008) A p120 catenin isoform switch affects Rho activity, induces tumor cell invasion, and predicts metastatic disease. J Biol Chem 283: 18344-18354

83 Cavallaro U and Christofori G (2004) Cell adhesion and signalling by cadherins and Ig-CAMs in cancer. Nat Rev Cancer 4: 118-132 
84 Bellovin DI et al. (2005) Altered localization of p120 catenin during epithelial to mesenchymal transition of colon carcinoma is prognostic for aggressive disease. Cancer Res 65: 10938-10945

85 Moriyama T and Nagatoya K (2004) The Rho-ROCK system as a new therapeutic target for preventing interstitial fibrosis. Drug News Perspect 17: 29-34

86 Patel S et al. (2005) RhoGTPase activation is a key step in renal epithelial mesenchymal transdifferentiation. J Am Soc Nephrol 16: 1977-1984

87 Kaartinen V et al. (2002) TGFbeta3-induced activation of RhoA/Rho-kinase pathway is necessary but not sufficient for epithelio-mesenchymal transdifferentiation: implications for palatogenesis. Int J Mol Med 9: 563-570

88 Guarino $\mathrm{M}$ et al. (2007) The role of epithelial-mesenchymal transition in cancer pathology. Pathology 39: 305-318

89 Grande MT and Lopez-Novoa JM (2008) Therapeutical relevance of MAP-kinase inhibitors in renal diseases: current knowledge and future clinical perspectives. Curr Med Chem 15: 2054-2070

90 Fernandez A et al. (2007) An anticancer C-Kit kinase inhibitor is reengineered to make it more active and less cardiotoxic. J Clin Invest 117: 4044-4054

91 Larue L and Bellacosa A (2005) Epithelial-mesenchymal transition in development and cancer: role of phosphatidylinositol 3' kinase/AKT pathways. Oncogene 24: 7443-7454

92 Apsel B et al. (2008) Targeted polypharmacology: discovery of dual inhibitors of tyrosine and phosphoinositide kinases. Nat Chem Biol 4: 691-699

93 Louvet C et al. (2008) Tyrosine kinase inhibitors reverse type 1 diabetes in nonobese diabetic mice. Proc Natl Acad Sci U S A 105: 18895-18900

94 Zeisberg M et al. (2003) BMP-7 counteracts TGF-beta1-induced epithelial-tomesenchymal transition and reverses chronic renal injury. Nat Med 9: 964-968

95 Zeisberg M et al. (2005) Bone morphogenic protein-7 induces mesenchymal to epithelial transition in adult renal fibroblasts and facilitates regeneration of injured kidney. J Biol Chem 280: 8094-8100 


\section{Artículo IV}

\section{Revisión}

\section{"Role of Inflammation in Túbulo-interstitial Damage Associated to Obstructive Nephropathy"}

M. Teresa Grande, Fernando Pérez-Barriocanal and José M. López-Novoa Nephrology Dialysis Transplantation (enviado) 


\begin{abstract}
Obstructive nephropathy is characterized by an inflammatory state in the kidney, that is promoted by cytokines and growth factors produced by damaged tubular cells, infiltrated macrophages and accumulated myofibroblasts. This inflammatory state contributes to tubular atrophy and interstitial fibrosis characteristic of obstructive nephropathy. Accumulation of leukocytes, especially macrophages and $T$ lymphocytes, in the renal interstitium is strongly associated to the progression of renal injury. Proinflammatory cytokines, NF- $\kappa \mathrm{B}$ activation, adhesion molecules, chemokines, growth factors, $\mathrm{NO}$ and oxidative stress contribute in different ways to progressive renal damage induced by obstructive nephropathy, as they induce leukocytes recruitment, tubular cell apoptosis and interstitial fibrosis. Increased angiotensin II production, increased oxidative stress and high levels of proinflammatory cytokines contribute to NF- $\mathrm{KB}$ activation which in turn induce the expression of adhesion molecules and chemokines responsible for leukocyte recruitment and iNOS and cytokines overexpression, which aggravates the inflammatory response in the damaged kidney. In this manuscript we revise the different events and regulatory mechanisms involved in inflammation associated to obstructive nephropathy.
\end{abstract}

\title{
Key words
}

Leukocyte recruitment, Macrophage infiltration, NF- $\kappa \mathrm{B}$ activation, Ureteral obstruction. 


\section{Introduction}

Obstructive nephropathy due to congenital or acquired urinary tract obstruction is the first primary cause of chronic renal failure (CRF) in children, according to data of The North American Pediatric Renal Transplant Cooperative Study (NAPRTCS) [1]. Obstructive nephropathy is also a major cause of renal failure in adults $[2,3]$.

The renal consequences of chronic urinary tract obstruction are very complex, and lead to renal injury and renal insufficiency. Despite numerous clinical and experimental studies over the past several decades, the evaluation and management of obstructive nephropathy remains challenging. The experimental model of unilateral ureteral obstruction (UUO) in rat and mouse has become the standard model to understand the causes and mechanisms of nonimmunological tubulointerstitial fibrosis. This is because it is normotensive, nonproteinuric, nonhyperlipidemic, and without any apparent immune or toxic renal insult. The UUO consists of an acute obstruction of one of the ureter that mimics the different stages of obstructive nephropathy leading to tubulointerstitial fibrosis without compromising the life of the animal, because the contralateral kidney maintains or even increases its function due to compensatory functional and anatomic hypertrophy $[2,3]$

The evolution of renal structural and functional changes following urinary tract obstruction in these models has been well described. The first changes observed in the kidney are hemodynamic, beginning with renal vasoconstriction mediated by increased activity of the renin-angiotensin system and other vasoconstrictor systems [4]. Epithelial tubular cells are damaged by the stretch secondary to tubular distension and the increased hydrostatic pressure into the tubules due to accumulation of urine in the pelvis and the retrograde increase of interstitial pressure. This is followed by an interstitial inflammatory response initially characterized by macrophage infiltration. There is also a massive myofibroblasts accumulation in the interstitium. These myofibroblasts are formed by proliferation of resident fibroblasts, from bone marrow-derived cells, from pericyte infiltration, as well by epithelialmesenchymal transformation (EMT), a complex process by which some tubular epithelial cells acquire mesenchymal phenotype and become activated myofibroblasts [5]. 
Damaged tubular cells, interstitial macrophages and myofibroblasts produce cytokines and growth factors that promote an inflammatory state in the kidney, induce tubular cell apoptosis and provoke the accumulation of extracellular matrix. The end-result of severe and chronic obstructive nephropathy is a progressive renal tubular atrophy with loss of nephrons accompanied by interstitial fibrosis. Thus interstitial fibrosis is the result of these processes in a progressive and overlapping sequence. The evolution of renal injury in obstructive nephropathy shares many features with other forms of interstitial renal disease such as acute renal failure, polycystic kidney disease and renal transplant rejection. The final fibrotic phase is very similar to virtually all progressive renal disorders, including glomerular disorders and systemic diseases such as diabetes or hypertension [4].

Tubulointerstitial fibrosis seems to be a morphologic hallmark of chronic renal disease, and also its extent is strongly correlated with the decline of the glomerular filtration rate in patients with chronic renal disease [6]. Furthermore, interstitial fibrosis is a component of normal structural changes in the aging kidney [7] and it is a hallmark of the chronic allograft nephropathy, the most common cause of kidney transplant failure within a decade after transplantation [8].

In this review we will analyze the role of inflammation on renal damage associated to obstructive nephropathy, and the cellular and molecular mechanisms involved in the genesis of these processes. As later described, the inflammatory process, through the release of cytokines and growth factors, results in the accumulation of interstitial macrophages, which in turn also release more cytokines and growth factors that contribute directly to tubular apoptosis and interstitial fibrosis [9].

Most of the information used in the present review has been obtained using UUO models in rats and mice, although many interesting data has been derived from studies using cell culture techniques.

\section{Urinary obstruction induces an inflammatory state in the kidney}

In Sprague-Dawley rats subjected to chronic neonatal UUO (from 2 to 12 days), microarray analysis revealed that the mRNA expression of multiple immune modulators, including krox24, interferon-gamma regulating factor-1 (IRF-1), monocyte chemoattractant protein-1 (MCP-1), interleukin-1 $\beta$ (IL-1 $\beta$ ), 
CCAAT/enhancer binding protein $(\mathrm{C} / \mathrm{EBP}), \mathrm{p} 21, \mathrm{c}-\mathrm{fos}$, c-jun, and $\mathrm{pJunB}$, were significantly increased in obstructed compared to sham-operated kidneys, thus suggesting that UUO induces a pro-inflammatory environment [10]. This environment is characterized by up-regulation of inflammatory cytokines and factors that favors leukocyte infiltration. Other cytokines with different functions are also differentially regulated after UUO, and will contribute to the regulation of inflammation and interstitial infiltration. Thus, in the present review we will analyze the data available about the mechanisms involved in this inflammatory state, including nuclear factor $\kappa \mathrm{B}(\mathrm{NF}-\kappa \mathrm{B})$ activation, increased oxidative stress, interstitial cell infiltration, and production of proinflammatory cytokines and other growth factors with inflammatory or anti-inflammatory properties, in the renal damage after UUO.

\section{NF- $\kappa$ B activation.}

$\mathrm{NF}-\kappa \mathrm{B}$ is a ubiquitous and well-characterized transcription factor responsible for the regulation of complex phenomena, with a pivotal role in controlling cell signalling in the body under certain physiological and pathological conditions. Among other functions, NF- $\kappa \mathrm{B}$ controls the expression of genes encoding proinflammatory cytokines (e. g., IL-1, IL2, IL-6, TNF- $\alpha$, etc.), chemokines (e. g., IL-8, MIP-1 $\alpha$, MCP-1, RANTES, eotaxin, etc.), adhesion molecules (e. g., ICAM, VCAM, E-selectin), inducible enzymes (COX-2 and iNOS), growth factors, some of the acute phase proteins, and immune receptors, all of which play critical roles in controlling most inflammatory processes $[11,12]$. Thus, NF- $\mathrm{kB}$ occupies a central position in the regulation of inflammation (Figure 1).

NF- $\kappa \mathrm{B}$ is activated by several cytokines such as IL- $1 \beta, \mathrm{TNF}-\alpha$, by oxidative stress and by other molecules such as Ang II [13]. NF- $\kappa B$ is activated very early following UUO [14] and it is maintained activated during at least 7 days after UUO [15]. Furthermore, inhibition of NF- $\kappa \mathrm{B}$ activation decreases apoptosis and interstitial fibrosis in rats with UUO [16]. NF- $\mathrm{B}$ inhibition also diminishes monocyte infiltration and inflammation gene overexpression after UUO [15]. The administration of a proteasome inhibitor to maintain levels of $\mathrm{I}-\mathrm{\kappa B}$, an endogenous inhibitor of NF- $\kappa \mathrm{B}$, reduces renal fibrosis and macrophage influx following UUO [17]. 
Renal cortical TNF- $\alpha$ levels increases early after UUO, whereas TNF- $\alpha$ neutralization with a pegylated form of soluble TNF receptor type 1 significantly reduced obstruction-induced TNF- $\alpha$ production, as well as NF- $\kappa$ B activation, I $\mathrm{B}$ degradation, angiotensinogen expression, and renal tubular cell apoptosis, thus

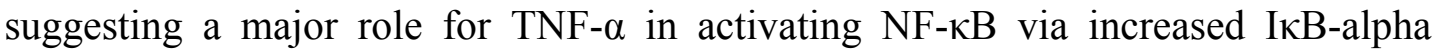
phosphorylation [18].

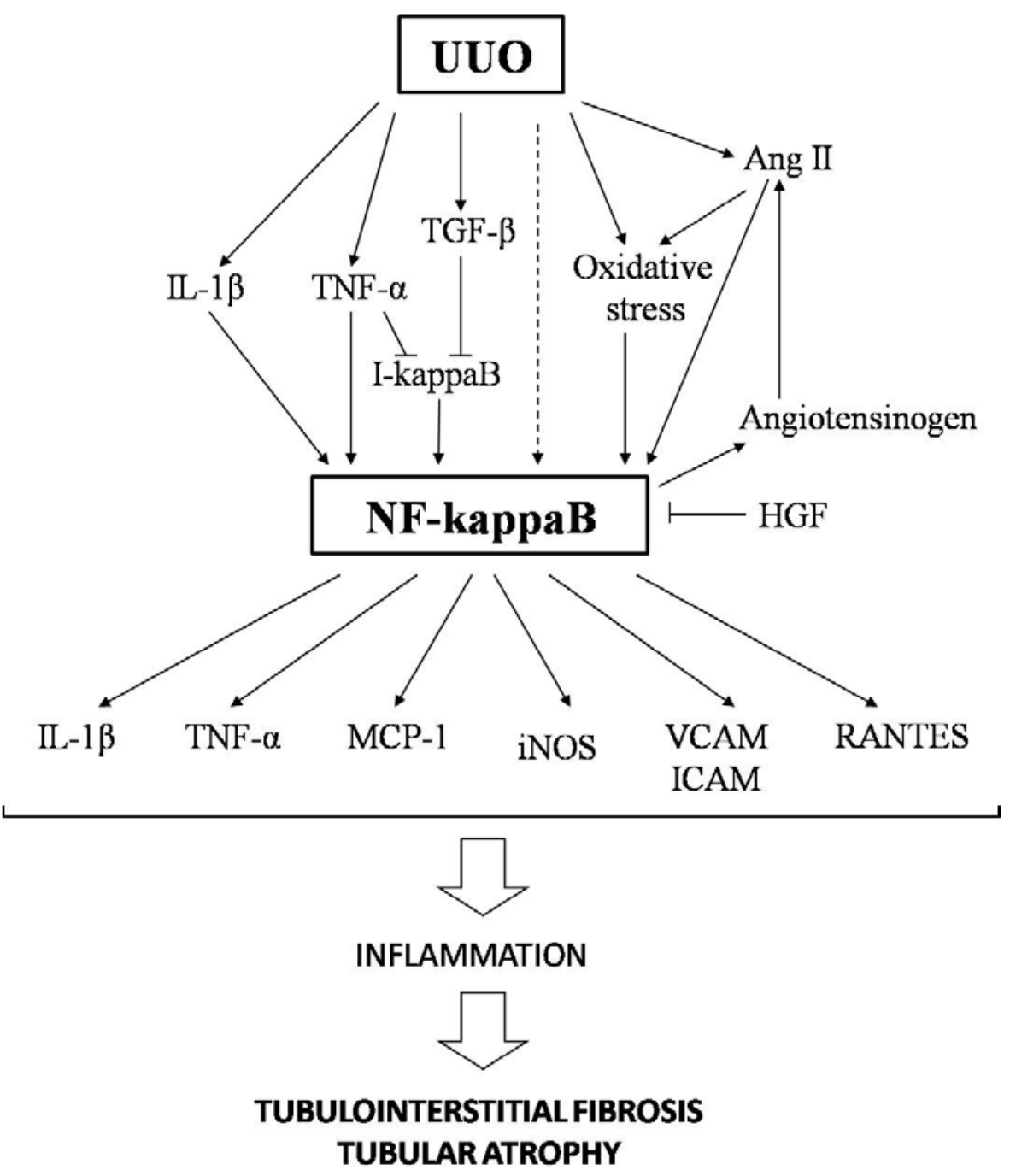

Figure 1. Schematic representation of some of the signaling intermediates potentially involved in regulation of inflammatory response after UUO. UUO induces IL-1 $\beta$ and TNF- $\alpha$ expression, leading to NF- $\kappa B$ activation. Also, UUO also induces both oxidative stress and increased Angiotensin II (Ang II) levels. Ang II also activate the transcription factor $\mathrm{NF}-\kappa \mathrm{B}$, both directly and indirectly, by promoting oxidative stress, which in turns activate Ang II by regulating angiotensinogen expression. TGF- $\beta$ activates NF- $\kappa$ B through I- $\kappa B$ inhibition, a mechanism shared by TNF- $\alpha$. NF- $\kappa B$ activation concludes in IL-1 $\beta$ and TNF- $\alpha$ expression enhancing NF- $\kappa B$ activation. Also $\mathrm{NF}-\mathrm{\kappa B}$ controls the expression of genes encoding pro-inflammatory cytokines, adhesion molecules and iNOS. 
In addition, curcumin, a phenolic compound with anti-inflammatory properties, has revealed protective action against interstitial inflammation in obstructive nephropathy by inhibition of the NF-kB-dependent pathway [19]. HGF has also been reported to inhibit renal inflammation, proinflammatory chemokine expression and renal fibrosis in UUO models. The anti-inflammatory effect of HGF is mediated by disrupting nuclear factor NF- $\mathrm{KB}$ signaling, as later will be described [20].

NF- $\kappa \mathrm{B}$ can be also activated by oxidative stress. The administration of antioxidant peptides to rats that suffered UUO was associated to a lower activation of $\mathrm{NF}-\kappa \mathrm{B}$, and significantly attenuated the effects of ureteral obstruction on all aspects of renal damage associated to UUO [21]. Thus, oxidative stress seems to play also a major role in the UUO-associated inflammation.

\section{Oxidative stress}

Oxidative stress has been implicated in the pathogenesis of various forms of renal injury [22]. Oxidative stress is also a major activator of the NF- $\kappa \mathrm{B}$ and thus, and inductor of an inflammatory state [23] (Figure 1). There are several evidences that increased oxidative stress is involved in renal inflammatory damage after UUO. Reactive oxygen species are significantly increased in the chronically obstructed kidney [24]. A high correlation was observed between the rates of free radical oxidation markers in the obstructed kidney tissue and in plasma [25]. Superoxide anion and hydrogen peroxide production increase significantly in the obstructed kidney [26]. After 5 days of obstruction, it has been reported a slight increase on renal cortex NADPH oxidase activity (a major source for superoxide production) whereas after 14 days of obstruction, a high increase on NADPH oxidase activity was observed. In addition, decreased superoxide dismutase activity were demonstrated following 14 days of obstruction whereas no differences were noticed on the antioxidant level after 5 days of kidney obstruction [27].

Increased Ang II production, accumulation of activated phagocytes in the interstitial space and elevation of medium-weight molecules have been involved as responsible for the increased oxidative stress [28] after UUO. UUO also generate increased levels of carbonyl stress, and subsequently advanced glycation endproducts (AGEs), and nitration adduct residues, both contributing to the progression 
of renal disease in the obstructed kidney $[29,30]$. The products of lipid peroxidation have been also found increased in both plasma and obstructed kidney after UUO [31] Carboxymethyl-lysine, a marker for accumulated oxidative stress, was found to be increased in the interstitium of UUO kidney [24]. Furthermore, heme oxygenase-1 (HO-1) expression, a sensitive indicator of cellular oxidative stress, was also induced as early as 12 hours after ureteral obstruction [24]. All this results suggest that the injured tissue after UUO show sufficient oxidative stress markers as to ensure that oxidative stress is involved in the pathogenesis of UUO. In the other hand, levels of the antioxidant enzyme catalase and copper-zinc superoxide dismutase, which prevent free radical damage, are lower in the obstructed kidney compared with the contralateral unobstructed kidney [26].

The interstitial infiltration of macrophages following UUO is inhibited by endogenous antioxidant compounds, such as retinoids, and the administration of isotretinoin, a retinoid agonist, reduces renal macrophage infiltration in rats with UUO [32].

In short, oxidative stress markers increase in the kidney during UUO and levels of enzymes that prevent the oxidative damage are diminished in the obstructed kidney. All these data suggest that oxidative stress is increased in the obstructed kidney, and that increased oxidative stress plays a role in inducing an inflammatory state and in deteriorating the renal function of the obstructed kidney.

\section{Proinflammatory cytokines in urinary obstruction}

\section{TNF- $\alpha$ and IL-1}

The prototypical pro-inflammatory cytokines, TNF- $\alpha$ and interleukin-1 (IL1), play a major role in the recruitment of inflammatory cells in the obstructed kidney [33-35]. Both TNF- $\alpha$ [36] and IL-1 [10,35] expression have been found augmented after renal obstruction. Also the synthetic vitamin D analogue paricalcitol reduced infiltration of $\mathrm{T}$ cells and macrophages accompanied by a decreased expression of TNF- $\alpha$ in the obstructed kidney [37] and TNF- $\alpha$ neutralization reduced the degree of apoptotic renal tubular cell death although it did not prevent renal apoptosis completely, suggesting that other signaling pathways may contribute to obstructioninduced renal cell apoptosis [36]. The IL-1 receptor antagonist (IL-1ra) administration in mice with UUO inhibited IL-1 activity and subsequently decreased 
the infiltration of macrophages, the expression of ICAM-1 and the presence of alphasmooth muscle actin (a marker of myofibroblasts) [35].

\section{Angiotensin II}

Angiotensin II (Ang II) behaves in the kidney as a proinflammatory cytokine, as it regulates a number of genes associated with progression of renal disease. The regulation of gene expression by Ang II occurs through changes in the activity of transcription factors within the nucleus of target cells. In particular, several members of the NF- $\mathrm{BB}$ family of transcription factors are activated by Ang II, which in turn fuels at least two autocrine reinforcing loops that amplify Ang II and TNF- $\alpha$ formation [38], and thus, it is not surprisingly the interrelation between Ang II and proinflammatory cytokines effects in the interstitial cell infiltration after UUO. Many studies have demonstrated that obstructive nephropathy leads to activation of the intrarenal renin-angiotensin system [4, 39, 40]. This system is also activated in animal models of UUO. Ang II has a central role in the beginning and progression of obstructive nephropathy, both directly, and indirectly by stimulating production of molecules that contribute to renal injury. Following UUO, Ang II activates NF- $\mathrm{B}$, a transcription factor that promotes the expression of proinflammatory genes [14]. In turn, the angiotensinogen gene is stimulated by activation of NF- $\kappa \mathrm{B}$ [41] (Figure 1). In relation to the inflammatory process, AT1 regulates several proinflammatory genes, including cytokines (interleukin-6 [IL-6]), chemokines (monocyte chemoattractant protein 1 [MCP-1]), and adhesion molecules (vascular cell adhesion molecule 1 [VCAM-1]) [42], but others, as the chemokine RANTES, are regulated by AT2 [43]. Some evidence suggests that AT2 participates in the inflammatory response in renal and vascular tissues [42, 43, 44]. In vivo and in vitro studies have shown that Ang II activates NF- $\mathrm{kB}$ in the kidney, via both AT1 and AT2 receptors $[45,46]$.

Most studies have focused on the role of AT1 receptor activation on kidney inflammation after UUO. For instance, inhibition or inactivation of angiotensin AT1 receptors also reduces NF- $\kappa \mathrm{B}$ activation in the obstructed kidneys after UUO [47, 48]. Also AT1 blockade, partially decreased macrophage infiltration in the obstructed kidney $[15,47,49]$. Thus AT-1 activation seems to play a role in the OUU-associated inflammation. However, obstructed kidney in AT1 KO mice showed interstitial monocyte infiltration and NF- $\kappa \mathrm{B}$ activation, and both processes 
were abolished by AT2 blockade, suggesting that AT-2 activation plays also a major role in UUO-induced renal inflammation [15]. Simultaneous blockade of both AT1 and AT2 is able to completely prevent the inflammatory process after UUO [15], thus giving a further proof of the role of both receptors in the inflammatory state occurring after UUO. It should be noted that in wild-type mice reconstituted with marrow lacking the angiotensin AT1 receptor gene, UUO results in more severe interstitial fibrosis despite fewer interstitial macrophages [50]. This effect seems to be due to impaired phagocytic function of AT1 receptor-deficient macrophages [50]. This is a typical example of the fact that manipulation of a single molecule affecting more than one renal compartment could have opposite effects in different compartments.

Treatment with angiotensin converting enzyme (ACE) inhibitors greatly reduced the monocyte/macrophage infiltration in the obstructed kidney [51] but this reduction seems to be observed only in the short-term UUO, and 14 days after UUO ACE inhibitors did not decreased monocyte/macrophage infiltration, maybe because in late-stage UUO, infiltration is dependent on cytokines formation that is independent of Ang II [52].

Ang II also stimulates the activation of the small GTPase Rho, which in turn activates Rho-associated coiled-coil forming protein kinase (ROCK). Furthermore, inhibition of ROCK in mice with UUO significantly reduces macrophage infiltration and interstitial fibrosis [53].

\section{Other proinflammatory cytokines}

Macrophage migratory inhibitory factor (MIF) is a proinflammatory cytokine which regulates leukocyte activation and fibroblast proliferation but although it is increased in the obstructed kidney after ureteral obstruction, MIF deficiency did not affect interstitial macrophage and T cell accumulation induced by UUO [54], thus suggesting that there are other factors that are also involved.

\section{Interstitial cell infiltration}

It is now generally accepted that leukocyte infiltration and activation of interstitial macrophages play a central role in the renal inflammatory response to UUO [9]. The progression of renal injury in the obstructive nephropathy is closely associated with accumulation of leukocytes and fibroblasts in the damaged kidney. 
Leukocyte infiltration, especially macrophages and $\mathrm{T}$ lymphocytes, increases as early as 4 to 12 hours after ureteral obstruction and continues to increase over the course of days thereafter [55]. There are studies suggesting that lymphocyte infiltration does not seem to be required for progressive tubulointerstitial injury since immunocompromised mice with very low numbers of circulating lymphocytes showed the same degree of kidney damage after UUO [56]. However, macrophages are involved in the obstructed pathology $[55,57]$. In a neonatal model of UUO in mice, blocking leukocyte recruitment by using the chemokine receptor-1 antagonist BX471 protected against tubular apoptosis and interstitial fibrosis, as evidenced by reduced monocyte influx, a decrease in EMT, and attenuated collagen deposition [58]. In this model, EMT was rapidly induced within 24 hours after UUO along with up-regulation of the transcription factors Snaill and Snail2/Slug, preceding the induction of $\alpha$-SMA and vimentin. In the presence of BX471, the expression of chemokines, as well as of Snaill and Snail2/Slug, in the obstructed kidney was completely attenuated. This was associated with reduced macrophage and T-cell infiltration, tubular apoptosis, and interstitial fibrosis in the developing kidney. These findings provide evidence that leukocytes induce EMT and renal fibrosis after UUO [58].

The recruitment of leukocytes from the circulation is mediated by several mechanisms including the activation of adhesion molecules, chemoattractant cytokines and proinflammatory and profibrotic mediators (Figure 2).

\section{Adhesion molecules and leukocyte infiltration}

Adhesion molecules are cell surface proteins involved in binding with other cells or with extracellular matrix. Adhesion molecules such as selectins, vascular cell adhesion molecule 1 (VCAM-1), intercellular adhesion molecule 1 (ICAM-1) and integrins plays a major role in leukocyte infiltration in several physiological and pathological conditions. We will next review their role in leukocyte recruitment after UUO.

\section{Selectins}

Selectins and their ligands mediate the initial contact between circulating leukocytes and the vascular endothelium resulting in capture and rolling of leukocytes along the vessel wall [59]. There are three different selectins: E-selectin is 
expressed on endothelial cells, P-selectin on endothelial cells and platelets, and Lselectin on leukocytes. Whereas E-selectin expression is induced by inflammatory cytokines, P-selectin is rapidly mobilized to the surface of activated endothelium or platelets. L-selectin is constitutively expressed on most leukocytes. It has been reported that after ligation of the ureter, ligands for L-selectin rapidly disappeared from tubular epithelial cells and were relocated to the interstitium and peritubular capillary walls, where infiltration of monocytes and CD8(+) T cells subsequently occurred and mononuclear cell infiltration was significantly inhibited by neutralizing L-selectin, indicating the possible involvement of an L-selectin-mediated pathway [60]. In mice $\mathrm{KO}$ for $\mathrm{P}$ selectin, there is a marked decrease in macrophage infiltration [61]. In other study using mice with a triple null mutation for E-, P-, and L-selectin $\left(\mathrm{EPL}^{-/-}\right.$mice$)$, it has been reported that $\mathrm{EPL}^{-/-}$mice compared with wild type mice, showed markedly lower interstitial macrophage infiltration, collagen deposition and tubular apoptosis after ureteral obstruction [62]. Furthermore, tubular apoptosis showed a significant correlation with macrophage infiltration [62]. Targeted deletion of cerebroside sulfotransferase (which is necessary for the selectin-binding glycolipid) markedly diminishes apoptosis, tubular atrophy and interstitial fibrosis in mice with UUO [63].

\section{ICAM and VCAM}

Vascular cell adhesion molecule 1 (VCAM-1) and intercellular adhesion molecule 1 (ICAM-1) plays a major role in firm leukocyte adherence to vessel wall, a prerequisite for leukocyte diapedesis. VCAM-1 and ICAM-1 involvement in obstructive nephropathy have been also studied. Both ICAM and VCAM expression was observed to be increased in the obstructed kidney, but with a different time course. ICAM expression increased as early as 3 hours [64] and continued high after 90 days of obstruction, while VCAM expression increased later, 2 or 3 days after obstruction $[65,66]$. Chronic UUO in weanling rats upregulated renal interstitial expression of ICAM-1 and macrophage antigen 1 (Mac-1) [67]. Both VCAM and ICAM immunostaining was higher in the expanding interstitium, but lower in glomeruli in obstructed kidney compared with contralateral kidneys, and only ICAM immunostaining within the apical tubular epithelium increase in both cortical and medullary cross-sections [64]. Inhibition of ICAM-1 by intravenous administration of antisense oligonucleotides against ICAM-1 markedly reduced interstitial 
inflammation and extracellular matrix following UUO in mice [68]. Inhibition of IL1 by administration of genetically modified bone-marrow-derived vehicle cells containing an IL-1 receptor antagonist also reduced ICAM-1 expression and macrophage infiltration in mice with UUO [35], given a further support to the role of ICAM-1 expression as a key step in macrophage infiltration after UUO. No details of the role of PECAM in obstructive nephropathy have yet been reported to our knowledge.

Integrins and other molecules involved in leukocyte adhesion

Integrins are heterodimeric adhesion receptors consisting of noncovalently associated $\alpha$ and $\beta$ subunits. $\beta 1$-integrin interacts with LDL receptor-related protein 1 (LRP1) to mediate the activity of tPA as a fibrogenic cytokine in obstructed kidney [69]. $\beta 2$-integrins, mediate macrophage infiltration in obstructive nephropathy as, targeted deletion of $\beta 2$-integrins, reduces early macrophage infiltration following UUO in the neonatal rat [70]. $\beta 2$-integrins also mediate macrophage infiltration in obstructive nephropathy in weanling rats [67]. Also $\alpha v \beta 5$ integrin interacts with the receptor for urokinase-type plasminogen activator (uPAR or CD87), which in response to ureteral obstruction was significantly upregulated [71], a finding consistent with the fact that obstructed kidneys from uPAR-/- mice showed lower leukocytes and macrophages recruitment in the interstitium than WT mice [71].

Other molecules that participate in leukocyte recruitment have been identified, including junctional adhesion molecules (JAMs) which engage interactions with leukocyte 1 and 2 integrins [72]. JAM-C recognizes macrophage antigen-1 (Mac-1), a leukocyte integrin of particular interest because it has been reported to be the predominant leukocyte integrin involved in leukocyte recruitment after obstruction, and it is activated after UUO [67, 70].

\section{Chemokines involved in leukocyte infiltration}

Infiltrating cells are attracted by chemokines following a concentrationdependent signal towards the source of chemokines. Chemokines are categorized into four groups depending on the spacing of their first two cysteine residues. Thus CC chemokines (or $\beta$-chemokines) have two adjacent cysteines near their amino terminal end, whereas the two N-terminal cysteines of CXC chemokines (or $\alpha$-chemokines) are separated by one amino acid, $\mathrm{C}$ chemokines (or $\gamma$ chemokines) has only two 
cysteines; one N-terminal cysteine and one cysteine downstream. Finally CX3C chemokines (or $\delta$-chemokines) have three amino acids between the two cysteines.

CC chemokines, MCP-1 (monocyte chemoattractant protein-1) and RANTES (Regulated on Activation Normal T cell Expressed and Secreted), have been reported to increase progressively from 2 to 10 days after UUO [57, 73]. MCP-1 expression increases at 2 hours after obstruction, while RANTES and macrophage inflammatory protein 1 alpha (MIP-1 $\alpha$ ) expression are increased later, at day 5 after UUO [74]. Intramuscular injection of a mutant MCP-1 gene can block macrophage recruitment and reduce renal fibrosis following UUO [75]. Upregulation of MCP-1, in turn, is suppressed by HO-1. Targeted deletion of HO-1 in other models of renal injury significantly increases MCP-1 expression [76].

CC chemokines receptors, CCR1, CCR2 and CCR5 have been reported to be overexpressed after UUO [73]. Moreover, studies in CCR1 KO mice revealed that deletion of the CCR1 receptor attenuates leukocyte recruitment following UUO [77]. Something similar occurred with the inhibition of the CCR1 receptor [78]. However, this did not occur with CCR5, suggesting that only CCR1 is required for leukocyte recruitment and fibrosis after UUO [77]. Targeted deletion of the CCR2 gene or administration of CCR2 inhibitors reduced macrophage infiltration and interstitial fibrosis following UUO [79].

The synthetic vitamin D analogue paricalcitol reduced infiltration of T cells and macrophages in the obstructed kidney accompanied by a decreased expression of RANTES [37].

CXC chemokines are also involved in leukocyte recruitment in UUO, as it has been reported that interferon-gamma-induced protein-10 (IP-10), a CXC chemokine that is a potent chemoattractant for activated $\mathrm{T}$ lymphocytes, natural killer cells, and monocytes is overexpressed in obstructed kidneys [80]. Its receptor, CXCR3 was also found to be upregulated after UUO [81]. Also, targeted deletion of its receptor, CXCR3, or administration of an anti-IP-10-neutralizing monoclonal antibody promoted renal fibrosis, without affecting neither macrophage nor $\mathrm{T}$ cell infiltration in obstructed kidneys. [81], thus suggesting that blockade of contributes to renal fibrosis, possibly by upregulation of transforming growth factor-beta1 (TGF$\beta 1$ ), concomitant with downregulation of hepatocyte growth factor (HGF). Thus, 
overexpression of IP-10 and CXCR3 after UUO seems to serve as a protective mechanism against renal fibrosis.

\section{Growth factors involved in the regulation of leukocyte infiltration}

Growth factors are proteins capable of regulating a variety of cellular processes and typically act as molecules carrying information between cells. In the setting of a pro-inflammatory situation, growth factors regulate several steps of the inflammatory process.

TGF- $\beta 1$ is a pleiotropic cytokine involved in a wide range of pathophysiological processes. Many studies have reported an increase in TGF- $\beta 1$ content after UUO [57]. There is no doubt that TGF- $\beta 1$ plays a major role in stimulating ECM production after OUU. The profibrogenic effect of TGF- $\beta 1$ is achieved by a combination of inhibition of the degradation of matrix proteins by increased generation of proteinase inhibitors and by decreased expression of degradative proteins such as collagenase. The net effect of TGF-P on extracellular matrix is one of accumulation. Furthermore, TGF- $\beta 1$ is a chemoattractant for fibroblasts, and also stimulates fibroblast proliferation. Experimental studies, in a variety of renal disorders, have shown that the sustained aberrant expression of renal TGF- $\beta 1$ results in the pathological accumulation of extracellular matriz material in both the glomerulus and interstitial compartments. However this molecule has also several anti-inflammatory properties. First, TGF- $\beta$ has opposing actions than those of the proinflammatory cytokines IL-1 and TNF- $\alpha$ in glomerular diseases. Second, TGF- $\beta$ is a prominent macrophage deactivator acting against macrophage-mediated kidney injury [82]. By the opposite, TGF-P is known to be a strong chemoattractant for monocytes [83]. In agreement with this property, a significant correlation between interstitial macrophage number and cortical TGF- $\beta 1$ expression levels has been reported in the obstructed kidney [57]. The major origin of increase TGF- $\beta 1$ levels after UUO seems to be the infiltrated macrophages [57]. Thus machrophague infiltration seems to play a major role in UUO-induced interstitial fibrosis. In a model of mice that overexpress latent TGF- $\beta 1$ on skin, high levels of latent TGF- $\beta 1$ shows renoprotective effects as mice are protected against renal inflammation after UUO. This protection seems to be mediated by upregulation of renal Smad7, an

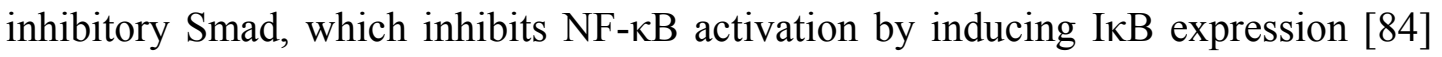
(Figure 1). Leptin has been suggested as a cofactor of TGF- $\beta$ activation in obstructed 
kidney after UUO and the blockade of leptin has been proposed as a therapeutic possibility to prevent or delay the fibrosis and inflammation observed in the obstructive nephropathy [85].

HGF is known to contribute to organogenesis and tissue repair through mitogenic, motogenic and morphogenic activities in the kidney [86]. Renal HGF levels increased rapidly after UUO, reaching a peak 3 days after obstruction. Seven days after UUO, HGF levels declined to half of those seen three days after UUO. Also the administration of exogenous HGF to mice with UUO produced a reduction in TGF- $\beta$ levels that may be achieved, at least in part, by suppression of macrophage infiltration, as has been observed that HGF suppress infiltration of macrophages in the obstructive nephropathy [87, 88]. HGF gene delivery inhibited interstitial infiltration of inflammatory $\mathrm{T}$ cells and macrophages, and suppressed expression of both RANTES and MCP-1 in a mouse model of obstructive nephropathy [21]. HGF inhibits renal inflammation and proinflammatory chemokine expression by disrupting nuclear factor $\mathrm{NF}-\mathrm{\kappa B}$ signalling through 2 different ways, 1) by preventing p65 NF- $\mathrm{kB}$ binding to the RANTES promoter and 2) by activating the phosphoinositide 3-kinase/Akt pathway, which led to the phosphorylation and inactivation of glycogen synthase kinase. Suppression of GSK-3 $\beta$ activity mimicked HGF and abolished RANTES expression [21].

Paricalcitol, as noted above, reduced infiltration of $\mathrm{T}$ cells and macrophages in the obstructed kidney and the mechanism by which it works seems to be the inhibition of RANTES expression by promoting vitamin D receptor-mediated sequestration of NF- $\kappa \mathrm{B}$ signaling [37].

The growth factor macrophage colony-stimulating factor-1 (M-CSF or CSF1) is important in promoting monocyte survival and activation to macrophages and it is produced by tubular epithelial cells and fibroblasts, whereas macrophages generate inflammatory cytokines that are dependent on M-CSF. M-CSF expression is regulated by NF- $\mathrm{KB}$ activation [89] and it has been reported that M-CSF expression is increased in the obstructed kidneys after UUO and that this increase is correlated with the macrophage recruitment induced in the obstructed kidney $[54,90]$. Targeted deletion of M-CSF in mice with UUO reduced interstitial macrophage infiltration, proliferation and activation, and significantly diminished tubular apoptosis [91] thus 
suggesting the key role of M-CSF regulating damage induced by macrophages during UUO.

Agonists of the adenosine receptor transiently reduced renal macrophage infiltration and inflammation in ischemic renal injury [92] and its mechanism of action is probably related with the inhibition by adenosine of M-CSF, although this item is not yet completely proven [93]. However, adenosine receptor agonists do not reduce renal inflammation and injury after UUO [92]. This might explained because the overwhelming stimulus provided by continued UUO cannot be reversed by this means of suppressing inflammation.

\section{Osteopontin and leukocyte infiltration in UUO}

Osteopontin (OPN) is a tubular-derived glycoprotein with macrophage chemoattractant properties. Numerous studies have investigated the role of OPN in tubulointerstitial macrophage accumulation in the kidney [94, 95]. Using OPN knockout mice, Persy et al. verified that OPN was a critical factor for interstitial macrophage accumulation after renal ischemia and reperfusion damage [96]. OPN is involved in the accumulation of macrophages within the renal cortex following UUO, as OPN expression increased 4-fold 1 day after UUO and persisted at this level for the 5-days duration of UUO, and this increase was found to be correlated with interstitial macrophage infiltration [97, 89]. Furthermore, targeted deletion of the OPN gene reduced macrophage infiltration and interstitial fibrosis in mice with UUO and enhanced tubular cells apoptosis. This suggests that OPN could play a different role in the tubular epithelial cells and the interstitium. Thus, OPN might contribute to renal interstitial injury and, at the same time, it might have a protective role on the tubular epithelial cells [98].

OPN is a major ligand of CD44 glycoproteins, and chronic UUO also increases tubular expression of the CD44 family of glycoproteins, which are generated by alternative splicing after transcription of a single gene. Targeted deletion of CD44 in mice with UUO reduces macrophage infiltration and interstitial fibrosis, but increases tubular apoptosis and tubular injury [99]. Thus, we can deduce that OPN has a dual role in obstructive nephropathy, with damaging effects on the renal interstitium and protective effects on the tubular epithelial cells. 
Ang II and losartan administration increased and decreased respectively OPN expression in the kidney, whereas angiotensinogen and AT1-receptor antisense inhibition inhibited OPN expression in tubular proximal cells $[100,101]$. This suggests that the increased levels of Ang II in the obstructed kidney, through AT1 receptor, up-regulated OPN expression and secretion by the proximal tubule, facilitating macrophage recruitment into the renal interstitium (Figure 2)

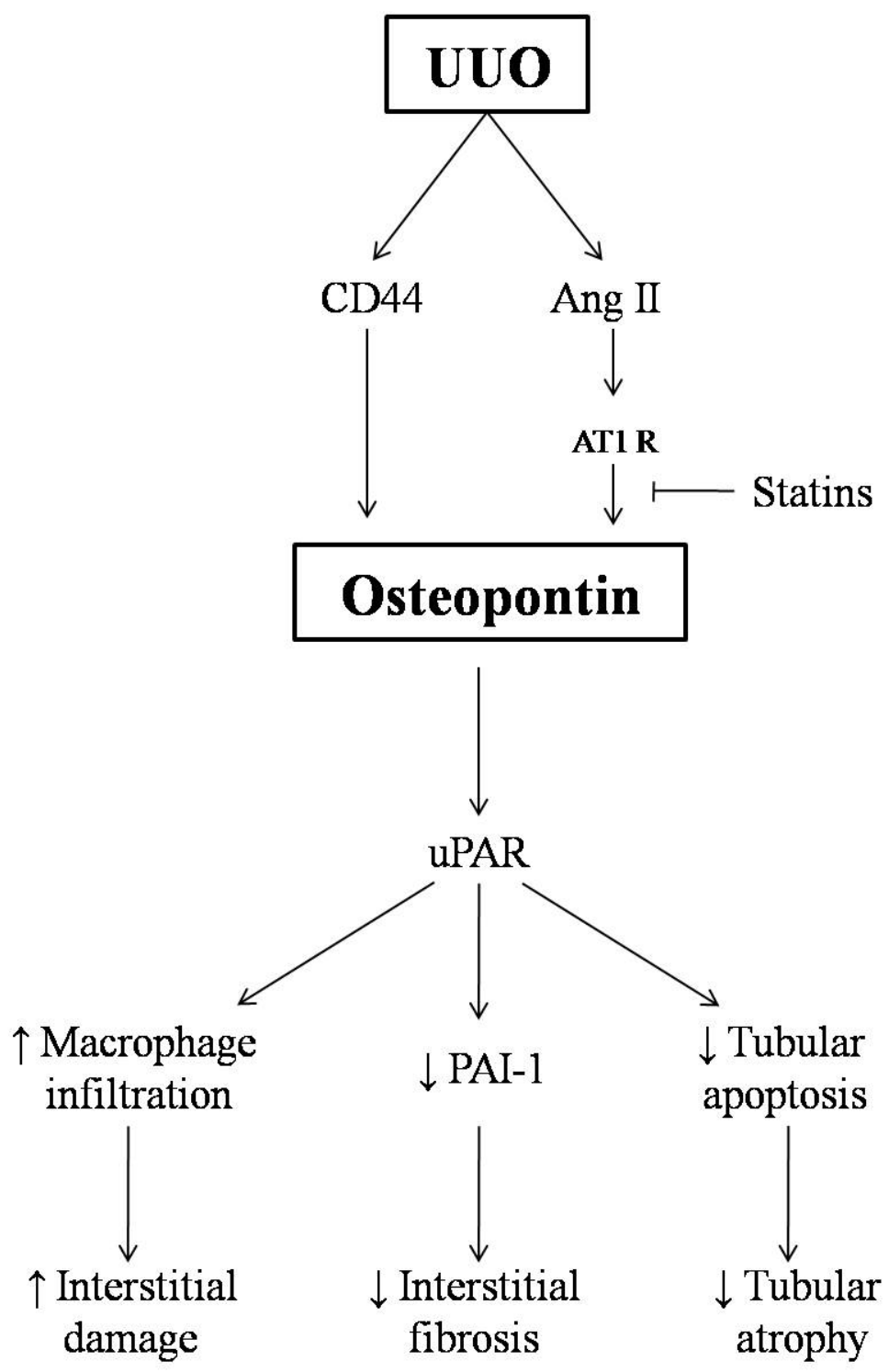

Figure 2. Schematic illustration of the Osteopontin signaling pathway and effects during obstructive nephropathy. UUO induces increased Angiotensin II (Ang II) levels which up-regulated Osteopontin (OPN) expression through AT1 receptor. This effect can be inhibited by statins. UUO also increases tubular expression of the CD44, a receptor of OPN. OPN actions are mediated by uPAR, which reduces tubular apoptosis and interstitial fibrosis through reduced plasminogen activator inhibitor-1 (PAI-1) and promotes macrophage infiltration in the obstructive nephropathy. 


\section{iNOS overexpression}

Inducible nitric-oxide synthase (iNOS) overexpression is a characteristic hallmark of the inflammatory state and activation of the transcription factor NF- $\kappa \mathrm{B}$ is thought to be essential for the induction of iNOS [107]. iNOS expression increases after UUO (Figure 1). Thus, 5 days after kidney obstruction there is an increased NO production and iNOS expression at transcriptional and post-transcriptional levels, whereas 14 days after obstruction, decreased endogenous NO production and lower iNOS expression at mRNA and protein levels were observed [27]. Tubular epithelial cells are probable the major source of $\mathrm{NO}$ as these cells are subjected to a high pressure or mechanical stretch as a result of ureteral obstruction. When cultured tubular epithelial cells are subjected to high pressure $(60 \mathrm{mmHg})$, there was an increase of iNOS expression, while endothelial NOS expression remained unchanged. Furthermore, the use of NF- $\mathrm{B}$ inhibitors was shown to prevent the increase in iNOS expression, thus suggesting the role of this pro-inflammatory pathway in the iNOS overexpression [108]. In obstructed neonatal rats, in vivo administration of L-Arginine, which activates NO production by iNOS, prevented renal damage. Opposite effects were obtained after nitro L-Arginine methyl ester (LNAME) treatment. These findings suggest that NO can produce resistance to obstruction-induced cell death in neonatal UUO [27]. Targeted deletion of inducible nitric oxide synthase (iNOS) in mice subjected to UUO increases renal macrophage infiltration and interstitial fibrosis, indicating that endogenous iNOS also serves to limit macrophage infiltration [109]. Administration of losartan to the UUO model in rats induced a down-regulation of iNOS, with persistent levels of eNOS in renal cortex of the obstructed kidney, thus suggesting that Ang II plays a major role in iNOS overexpression [110]. Liposome-mediated iNOS gene therapy improves renal function in rats with UUO [111] demonstrating that strategies to increase iNOS might be a powerful therapeutic approach in obstructive nephropathy [112].

\section{Conclusions and clinical perspectives}

In this review we have summarized the most important factors that have been involved in genesis and progression of the inflammatory damage induced by ureteral obstruction. These factors regulate cytokine and chemokines production, leukocyte/macrophage recruitment, interstitial inflammation, tubular cell apoptosis, 
and fibroblasts proliferation and activation (see table 1). NF- $\mathrm{BB}$ activation plays a central role in the inflammatory reaction after ureteral obstruction. Oxidative stress and renin-angiotensin II system seems to play a major role in activating NF- $\kappa B$ and they contribute also to the overexpression of pro-inflammatory cytokines in the obstructive nephropathy. As many therapeutic agents have been developed in the last years to control inflammation and NF- $\mathrm{KB}$ activation for the treatment of several diseases such as tumors [113], it can be postulated that this anti-inflammatory therapy could be useful to treat or prevent kidney damage during obstructive nephropathy [114]. Although there are many data in animal models, most of them reviewed in the present manuscript, demonstrating that anti-inflammatory treatment ameliorates renal damage in experimental models of obstructive nephropathy, clinical studies on these topics are almost absent in the literature. Thus, the antiinflammatory therapy to treat obstructive nephropathy, although promising, needs many clinical studies that prove to be successful in the clinical setting. 
Table 1. Summary effects of different molecules involved in inflammation in the obstructive nephropathy

\begin{tabular}{|c|c|}
\hline TNF- $\alpha$ & $\begin{array}{l}\text { Macrophage infiltration } \\
\text { Renal tubular cell death }\end{array}$ \\
\hline IL-1 & $\begin{array}{l}\text { ICAM expression } \\
\text { Macrophage infiltration } \\
\text { Fibroblast activation }\end{array}$ \\
\hline MIF & $\begin{array}{l}\text { Leukocyte activation } \\
\text { Fibroblast proliferation }\end{array}$ \\
\hline Ang II & Macrophage infiltration \\
\hline NF-kappaB & $\begin{array}{l}\text { Macrophage infiltration } \\
\text { Renal tubular cell apoptosis }\end{array}$ \\
\hline iNOS & $\begin{array}{l}\text { Resistance to cell death } \\
\text { Limit macrophage infiltration }\end{array}$ \\
\hline E,P,L Selectins & $\begin{array}{l}\text { Monocytes/macrophage and } \mathrm{T} \text { cell infiltration } \\
\text { Tubular apoptosis } \\
\text { Collagen deposition }\end{array}$ \\
\hline VCAM, ICAM & $\begin{array}{l}\text { Interstitial inflammation } \\
\text { Leukocyte infiltration }\end{array}$ \\
\hline$\beta$-integrins & $\begin{array}{l}\text { Macrophage infiltration } \\
\text { Mediates tPA activity as a fibrogenic cytokine }\end{array}$ \\
\hline JAMS & Leukocyte recruitment \\
\hline MCP-1, RANTES, MIP-1 $\alpha$ & Macrophage recruitment \\
\hline CCR1, CCR2 & $\begin{array}{l}\text { Leukocyte recruitment } \\
\text { Interstitial fibrosis }\end{array}$ \\
\hline IP-10 & Leukocyte recruitment \\
\hline TGF- $\beta$ & Macrophage infiltration \\
\hline HGF & $\begin{array}{l}\text { Supress macrophage infiltration } \\
\text { Inhibit chemokin expression }\end{array}$ \\
\hline M-CSF & $\begin{array}{l}\text { Macrophage infiltration, activation and proliferation } \\
\text { Tubular apoptosis }\end{array}$ \\
\hline OPN & $\begin{array}{l}\text { Macrophage infiltration } \\
\text { Interstitial fibrosis } \\
\text { Repress tubular cell apoptosis }\end{array}$ \\
\hline
\end{tabular}




\section{References}

1. Smith JM, Stablein DM, Munoz R, et al. Contributions of the Transplant Registry: The 2006 Annual Report of the North American Pediatric Renal Trials and Collaborative Studies (NAPRTCS). Pediatr Transplant 2007; $11: 366-73$.

2. Klahr S, Morrissey J. Obstructive nephropathy and renal fibrosis. Am J Physiol Renal Physiol 2002; 283:F861-75.

3. Klahr S. Obstructive nephropathy. Intern Med 2000; 39:355-61.

4. Chevalier RL. Obstructive nephropathy: towards biomarker discovery and gene therapy. Nat Clin Pract Nephrol 2006; 2:157-68.

5. Iwano M, Plieth D, Danoff TM, et al. Evidence that fibroblasts derive from epithelium during tissue fibrosis. J Clin Invest 2002; 110:341-50.

6. Bohle A, Muller GA, Wehrmann M, et al. Pathogenesis of chronic renal failure in the primary glomerulopathies, renal vasculopathies, and chronic interstitial nephritides. Kidney Int Suppl 1996; 54:S2-9.

7. Ruiz-Torres MP, Bosch RJ, O'Valle F, et al. Age-related increase in expression of TGF-betal in the rat kidney: relationship to morphologic changes. J Am Soc Nephrol 1998; 9:782-91.

8. Paul LC. Chronic allograft nephropathy: An update. Kidney Int 1999; 56:78393.

9. Chevalier RL. Pathogenesis of renal injury in obstructive uropathy. Curr Opin Pediatr 2006; 18:153-60.

10. Silverstein DM, Travis BR, Thornhill BA, et al. Altered expression of immune modulator and structural genes in neonatal unilateral ureteral obstruction. Kidney Int 2003; 64:25-35.

11. Nam NH. Naturally occurring NF-kappaB inhibitors. Mini Rev Med Chem 2006; 6:945-51.

12. Blackwell TS, Christman JW. The role of nuclear factor-kappa B in cytokine gene regulation. Am J Respir Cell Mol Biol 1997; 17:3-9.

13. Bauge C, Beauchef G, Leclercq S, et al. NFkappaB mediates IL-1beta-induced down-regulation of TbetaRII through the modulation of Sp3 expression. J Cell Mol Med 2008; 12:1754-66.

14. Morrissey JJ, Klahr S. Enalapril decreases nuclear factor kappa B activation in the kidney with ureteral obstruction. Kidney Int 1997; 52:926-33.

15. Esteban V, Lorenzo O, Ruperez M, et al. Angiotensin II, via AT1 and AT2 receptors and NF-kappaB pathway, regulates the inflammatory response in unilateral ureteral obstruction. J Am Soc Nephrol 2004; 15:1514-29.

16. Miyajima A, Kosaka T, Seta K, et al. Novel nuclear factor kappa B activation inhibitor prevents inflammatory injury in unilateral ureteral obstruction. J Urol 2003; 169:1559-63. 
17. Tashiro K, Tamada S, Kuwabara N, et al. Attenuation of renal fibrosis by proteasome inhibition in rat obstructive nephropathy: possible role of nuclear factor kappaB. Int J Mol Med 2003; 12:587-92.

18. Meldrum KK, Metcalfe P, Leslie JA, et al. TNF-alpha neutralization decreases nuclear factor-kappaB activation and apoptosis during renal obstruction. J Surg Res 2006; 131:182-8.

19. Kuwabara N, Tamada S, Iwai T, et al. Attenuation of renal fibrosis by curcumin in rat obstructive nephropathy. Urology 2006; 67:440-6.

20. Giannopoulou M, Dai C, Tan X, et al. Hepatocyte growth factor exerts its antiinflammatory action by disrupting nuclear factor-kappaB signaling. Am J Pathol 2008; 173:30-41.

21. Mizuguchi Y, Chen J, Seshan SV, et al. A novel cell-permeable antioxidant peptide decreases renal tubular apoptosis and damage in unilateral ureteral obstruction. Am J Physiol Renal Physiol 2008; 295:F1545-53.

22. Haugen E, Nath KA. The involvement of oxidative stress in the progression of renal injury. Blood Purif 1999; 17:58-65.

23. Heidland A, Sebekova K, Schinzel R. Advanced glycation end products and the progressive course of renal disease. Am J Kidney Dis 2001; 38:S100-6.

24. Kawada N, Moriyama T, Ando A, et al. Increased oxidative stress in mouse kidneys with unilateral ureteral obstruction. Kidney Int 1999; 56:1004-13.

25. Klahr S. Urinary tract obstruction. Semin Nephrol 2001; 21:133-45.

26. Ricardo SD, Ding G, Eufemio M, et al. Antioxidant expression in experimental hydronephrosis: role of mechanical stretch and growth factors. Am J Physiol 1997; 272:F789-98.

27. Manucha W, Valles PG. Cytoprotective role of nitric oxide associated with Hsp70 expression in neonatal obstructive nephropathy. Nitric Oxide 2008; 18:204-15.

28. Barinov EF, Barabadze EV, Zhdaniuk Iu I. [Dynamics and factors regulating the intensity of free radical processes during experimental supravesical block]. Vopr Med Khim 1992; 38:5-7.

29. Asami J, Odani H, Ishii A, et al. Suppression of AGE precursor formation following unilateral ureteral obstruction in mouse kidneys by transgenic expression of alpha-dicarbonyl/L-xylulose reductase. Biosci Biotechnol Biochem 2006; 70:2899-905.

30. Moriyama T, Kawada N, Nagatoya K, et al. Fluvastatin suppresses oxidative stress and fibrosis in the interstitium of mouse kidneys with unilateral ureteral obstruction. Kidney Int 2001; 59:2095-103.

31. Saborio P, Krieg RJ, Jr., Kuemmerle NB, et al. Alpha-tocopherol modulates lipoprotein cytotoxicity in obstructive nephropathy. Pediatr Nephrol 2000; 14:740-6.

32. Schaier M, Jocks T, Grone HJ, et al. Retinoid agonist isotretinoin ameliorates obstructive renal injury. J Urol 2003; 170:1398-402. 
33. Hashem RM, Soliman HM, Shaapan SF. Turmeric-based diet can delay apoptosis without modulating NF-kappaB in unilateral ureteral obstruction in rats. J Pharm Pharmacol 2008; 60:83-9.

34. Metcalfe PD, Leslie JA, Campbell MT, et al. Testosterone exacerbates obstructive renal injury by stimulating TNF-alpha production and increasing proapoptotic and profibrotic signaling. Am J Physiol Endocrinol Metab 2008; 294:E435-43.

35. Yamagishi H, Yokoo T, Imasawa T, et al. Genetically modified bone marrowderived vehicle cells site specifically deliver an anti-inflammatory cytokine to inflamed interstitium of obstructive nephropathy. J Immunol 2001; 166:609-16.

36. Misseri R, Meldrum DR, Dinarello CA, et al. TNF-alpha mediates obstructioninduced renal tubular cell apoptosis and proapoptotic signaling. Am J Physiol Renal Physiol 2005; 288:F406-11.

37. Tan X, Wen X, Liu Y. Paricalcitol inhibits renal inflammation by promoting vitamin D receptor-mediated sequestration of NF-kappaB signaling. J Am Soc Nephrol 2008; 19:1741-52.

38. Klahr S, Morrissey J. Comparative effects of ACE inhibition and angiotensin II receptor blockade in the prevention of renal damage. Kidney Int Suppl 2002:S23-6.

39. Harris RC, Martinez-Maldonado M. Angiotensin II-mediated renal injury. Miner Electrolyte Metab 1995; 21:328-35.

40. Chevalier RL. Molecular and cellular pathophysiology of obstructive nephropathy. Pediatr Nephrol 1999; 13:612-9.

41. Klahr S, Morrissey J. Angiotensin II and gene expression in the kidney. Am J Kidney Dis 1998; 31:171-6.

42. Ruiz-Ortega M, Rupérez M, Esteban V, et al. Modulation of angiotensin II effects, a potential novel approach to inflammatory and immune diseases. Curr Med Chem 2003; 2: 379-394.

43. Wolf G, Ziyadeh FN, Thaiss F, et al. Angiotensin II stimulates expression of the chemokine RANTES in rat glomerular endothelial cells. Role of the angiotensin type 2 receptor. J Clin Invest 1997; 100:1047-58.

44. Akishita $\mathrm{M}$, Horiuchi $\mathrm{M}$, Yamada $\mathrm{H}$, et al. Inflammation influences vascular remodeling through AT2 receptor expression and signaling. Physiol Genomics $2000 ; 2: 13-20$.

45. Ruiz-Ortega M, Lorenzo O, Ruperez M, et al. Systemic infusion of angiotensin II into normal rats activates nuclear factor-kappaB and AP-1 in the kidney: role of AT(1) and AT(2) receptors. Am J Pathol 2001; 158:1743-56.

46. Esteban V, Ruperez M, Vita JR, et al. Effect of simultaneous blockade of AT1 and AT2 receptors on the NFkappaB pathway and renal inflammatory response. Kidney Int Suppl 2003:S33-8.

47. Nakatani T, Tamada S, Asai $\mathrm{T}$, et al. Role of renin-angiotensin system and nuclear factor-kappaB in the obstructed kidney of rats with unilateral ureteral obstruction. Jpn J Pharmacol 2002; 90:361-4. 
48. Satoh M, Kashihara N, Yamasaki Y, et al. Renal interstitial fibrosis is reduced in angiotensin II type 1a receptor-deficient mice. J Am Soc Nephrol 2001; $12: 317-25$.

49. Kellner D, Chen J, Richardson I, et al. Angiotensin receptor blockade decreases fibrosis and fibroblast expression in a rat model of unilateral ureteral obstruction. J Urol 2006; 176:806-12.

50. Nishida M, Fujinaka H, Matsusaka T, et al. Absence of angiotensin II type 1 receptor in bone marrow-derived cells is detrimental in the evolution of renal fibrosis. J Clin Invest 2002; 110:1859-68.

51. Ishidoya S, Morrissey $\mathrm{J}$, McCracken $\mathrm{R}$, et al. Angiotensin II receptor antagonist ameliorates renal tubulointerstitial fibrosis caused by unilateral ureteral obstruction. Kidney Int 1995; 47:1285-94.

52. Turan $\mathrm{T}$, van Harten JG, de Water R, et al. Is enalapril adequate for the prevention of renal tissue damage caused by unilateral ureteral obstruction and/or hyperoxaluria? Urol Res 2003; 31:212-7.

53. Nagatoya K, Moriyama T, Kawada N, et al. Y-27632 prevents tubulointerstitial fibrosis in mouse kidneys with unilateral ureteral obstruction. Kidney Int 2002; 61:1684-95.

54. Rice EK, Nikolic-Paterson DJ, David JR, et al. Macrophage accumulation and renal fibrosis are independent of macrophage migration inhibitory factor in mouse obstructive nephropathy. Nephrology (Carlton) 2004; 9:278-87.

55. Diamond JR. Macrophages and progressive renal disease in experimental hydronephrosis. Am J Kidney Dis 1995; 26:133-40.

56. Shappell SB, Gurpinar T, Lechago J, et al. Chronic obstructive uropathy in severe combined immunodeficient (SCID) mice: lymphocyte infiltration is not required for progressive tubulointerstitial injury. J Am Soc Nephrol 1998; 9:1008-17.

57. Diamond JR, Kees-Folts D, Ding G, et al. Macrophages, monocyte chemoattractant peptide-1, and TGF-beta 1 in experimental hydronephrosis. Am J Physiol 1994; 266:F926-33.

58. Lange-Sperandio B, Trautmann A, Eickelberg O, et al. Leukocytes induce epithelial to mesenchymal transition after unilateral ureteral obstruction in neonatal mice. Am J Pathol 2007; 171:861-71.

59. Springer TA. Traffic signals for lymphocyte recirculation and leukocyte emigration: the multistep paradigm. Cell 1994; 76:301-14.

60. Shikata K, Suzuki Y, Wada J, et al. L-selectin and its ligands mediate infiltration of mononuclear cells into kidney interstitium after ureteric obstruction. J Pathol 1999; 188:93-9.

61. Naruse T, Yuzawa Y, Akahori T, et al. P-selectin-dependent macrophage migration into the tubulointerstitium in unilateral ureteral obstruction. Kidney Int 2002; 62:94-105.

62. Lange-Sperandio B, Cachat F, Thornhill BA, et al. Selectins mediate macrophage infiltration in obstructive nephropathy in newborn mice. Kidney Int 2002; 61:516-24. 
63. Ogawa D, Shikata K, Honke K, et al. Cerebroside sulfotransferase deficiency ameliorates L-selectin-dependent monocyte infiltration in the kidney after ureteral obstruction. J Biol Chem 2004; 279:2085-90.

64. Shappell SB, Mendoza LH, Gurpinar T, et al. Expression of adhesion molecules in kidney with experimental chronic obstructive uropathy: the pathogenic role of ICAM-1 and VCAM-1. Nephron 2000; 85:156-66.

65. Morrissey JJ, Klahr S. Differential effects of ACE and AT1 receptor inhibition on chemoattractant and adhesion molecule synthesis. Am J Physiol 1998; 274:F580-6.

66. Ricardo SD, Levinson ME, DeJoseph MR, et al. Expression of adhesion molecules in rat renal cortex during experimental hydronephrosis. Kidney Int 1996; 50:2002-10.

67. Takeda A, Fukuzaki A, Kaneto H, et al. Role of leukocyte adhesion molecules in monocyte/ macrophage infiltration in weanling rats with unilateral ureteral obstruction. Int J Urol 2000; 7:415-20.

68. Cheng QL, Chen XM, Li F, et al. Effects of ICAM-1 antisense oligonucleotide on the tubulointerstitium in mice with unilateral ureteral obstruction. Kidney Int 2000; 57:183-90.

69. $\mathrm{Hu} \mathrm{K}, \mathrm{Wu} \mathrm{C}$, Mars $\mathrm{WM}$, et al. Tissue-type plasminogen activator promotes murine myofibroblast activation through LDL receptor-related protein 1mediated integrin signaling. J Clin Invest 2007; 117:3821-32.

70. Lange-Sperandio B, Schimpgen K, Rodenbeck B, et al. Distinct roles of Mac-1 and its counter-receptors in neonatal obstructive nephropathy. Kidney Int 2006; 69:81-8.

71. Zhang G, Kim H, Cai X, et al. Urokinase receptor modulates cellular and angiogenic responses in obstructive nephropathy. J Am Soc Nephrol 2003; $14: 1234-53$.

72. Sircar M, Bradfield PF, Aurrand-Lions M, et al. Neutrophil transmigration under shear flow conditions in vitro is junctional adhesion molecule-C independent. J Immunol 2007; 178:5879-87.

73. Vielhauer V, Anders HJ, Mack M, et al. Obstructive nephropathy in the mouse: progressive fibrosis correlates with tubulointerstitial chemokine expression and accumulation of $\mathrm{CC}$ chemokine receptor 2- and 5-positive leukocytes. J Am Soc Nephrol 2001; 12:1173-87.

74. Kaneto H, Fukuzaki A, Ishidoya S, et al. [mRNA expression of chemokines in rat kidneys with ureteral obstruction]. Nippon Hinyokika Gakkai Zasshi 2000; 91:69-74.

75. Wada T, Furuichi K, Sakai N, et al. Gene therapy via blockade of monocyte chemoattractant protein-1 for renal fibrosis. J Am Soc Nephrol 2004; 15:940-8.

76. Pittock ST, Norby SM, Grande JP, et al. MCP-1 is up-regulated in unstressed and stressed HO-1 knockout mice: Pathophysiologic correlates. Kidney Int $2005 ; 68: 611-22$. 
77. Eis V, Luckow B, Vielhauer V, et al. Chemokine receptor CCR1 but not CCR5 mediates leukocyte recruitment and subsequent renal fibrosis after unilateral ureteral obstruction. J Am Soc Nephrol 2004; 15:337-47.

78. Anders HJ, Vielhauer V, Frink $M$, et al. A chemokine receptor CCR-1 antagonist reduces renal fibrosis after unilateral ureter ligation. J Clin Invest 2002; 109:251-9.

79. Kitagawa K, Wada T, Furuichi K, et al. Blockade of CCR2 ameliorates progressive fibrosis in kidney. Am J Pathol 2004; 165:237-46.

80. Crisman JM, Richards LL, Valach DP, et al. Chemokine expression in the obstructed kidney. Exp Nephrol 2001; 9:241-8.

81. Nakaya I, Wada T, Furuichi K, et al. Blockade of IP-10/CXCR3 promotes progressive renal fibrosis. Nephron Exp Nephrol 2007; 107:e12-21.

82. Kitamura M, Suto TS. TGF-beta and glomerulonephritis: anti-inflammatory versus prosclerotic actions. Nephrol Dial Transplant 1997; 12:669-79.

83. Wahl SM, Hunt DA, Wakefield LM, et al. Transforming growth factor type $\beta$ induces monocyte chemotaxis and growth factor production. Proc. Natl. Acad. Sci. USA 1987; 84: 5788-92,

84. Wang W, Huang XR, Li AG, et al. Signaling mechanism of TGF-betal in prevention of renal inflammation: role of Smad7. J Am Soc Nephrol 2005; $16: 1371-83$.

85. Kumpers $\mathrm{P}$, Gueler F, Rong S, et al. Leptin is a coactivator of TGF-beta in unilateral ureteral obstructive kidney disease. Am J Physiol Renal Physiol 2007; 293:F1355-62.

86. Balkovetz DF, Lipschutz JH. Hepatocyte growth factor and the kidney: it is not just for the liver. Int Rev Cytol 1999; 186:225-60.

87. Mizuno S, Matsumoto K, Nakamura T. Hepatocyte growth factor suppresses interstitial fibrosis in a mouse model of obstructive nephropathy. Kidney Int 2001; 59:1304-14.

88. Gao X, Mae H, Ayabe N, et al. Hepatocyte growth factor gene therapy retards the progression of chronic obstructive nephropathy. Kidney Int 2002; 62:123848.

89. Wardle EN. Nuclear factor kappaB for the nephrologist. Nephrol Dial Transplant 2001; 16:1764-8.

90. Tian S, Ding G, Jia R, et al. Tubulointerstitial macrophage accumulation is regulated by sequentially expressed osteopontin and macrophage colonystimulating factor: implication for the role of atorvastatin. Mediators Inflamm 2006; 2006:12919.

91. Lenda DM, Kikawada E, Stanley ER, et al. Reduced macrophage recruitment, proliferation, and activation in colony-stimulating factor-1-deficient mice results in decreased tubular apoptosis during renal inflammation. J Immunol 2003; 170:3254-62.

92. Lange-Sperandio B, Forbes MS, Thornhill B, et al. A2A adenosine receptor agonist and PDE4 inhibition delays inflammation but fails to reduce injury in 
experimental obstructive nephropathy. Nephron Exp Nephrol 2005; 100:e11323.

93. Xaus J, Valledor AF, Cardo M, et al. Adenosine inhibits macrophage colonystimulating factor-dependent proliferation of macrophages through the induction of p27kip-1 expression. J Immunol 1999; 163:4140-9.

94. Panzer U, Thaiss F, Zahner G, et al. Monocyte chemoattractant protein-1 and osteopontin differentially regulate monocytes recruitment in experimental glomerulonephritis. Kidney Int 2001; 59:1762-9.

95. Xie Y, Sakatsume M, Nishi S, et al. Expression, roles, receptors, and regulation of osteopontin in the kidney. Kidney Int 2001; 60:1645-57.

96. Persy VP, Verhulst A, Ysebaert DK, et al. Reduced postischemic macrophage infiltration and interstitial fibrosis in osteopontin knockout mice. Kidney Int $2003 ; 63: 543-53$.

97. Kaneto H, Morrissey J, McCracken R, et al. Osteopontin expression in the kidney during unilateral ureteral obstruction. Miner Electrolyte Metab 1998; 24:227-37.

98. Ophascharoensuk V, Giachelli CM, Gordon K, et al. Obstructive uropathy in the mouse: role of osteopontin in interstitial fibrosis and apoptosis. Kidney Int 1999; 56:571-80.

99. Rouschop KM, Sewnath ME, Claessen N, et al. CD44 deficiency increases tubular damage but reduces renal fibrosis in obstructive nephropathy. J Am Soc Nephrol 2004; 15:674-86.

100. Diamond JR, Kreisberg R, Evans R, et al. Regulation of proximal tubular osteopontin in experimental hydronephrosis in the rat. Kidney Int 1998; 54:1501-9.

101. Ricardo SD, Franzoni DF, Roesener CD, et al. Angiotensinogen and AT(1) antisense inhibition of osteopontin translation in rat proximal tubular cells. Am J Physiol Renal Physiol 2000; 278:F708-16.

102. Vieira JM, Jr., Mantovani E, Rodrigues LT, et al. Simvastatin attenuates renal inflammation, tubular transdifferentiation and interstitial fibrosis in rats with unilateral ureteral obstruction. Nephrol Dial Transplant 2005; 20:1582-91.

103. Park JK, Muller DN, Mervaala EM, et al. Cerivastatin prevents angiotensin IIinduced renal injury independent of blood pressure- and cholesterol-lowering effects. Kidney Int 2000; 58:1420-30.

104. Massy ZA, Guijarro C. Statins: effects beyond cholesterol lowering. Nephrol Dial Transplant 2001; 16:1738-41.

105. Sato N, Shiraiwa K, Kai K, et al. Mizoribine ameliorates the tubulointerstitial fibrosis of obstructive nephropathy. Nephron 2001; 89:177-85.

106. Yoo KH, Thornhill BA, Forbes MS, et al. Osteopontin regulates renal apoptosis and interstitial fibrosis in neonatal chronic unilateral ureteral obstruction. Kidney Int 2006; 70:1735-41.

107. Musial A, Eissa NT. Inducible nitric-oxide synthase is regulated by the proteasome degradation pathway. J Biol Chem 2001; 276:24268-73. 
108. Broadbelt NV, Stahl PJ, Chen J, et al. Early upregulation of iNOS mRNA expression and increase in NO metabolites in pressurized renal epithelial cells. Am J Physiol Renal Physiol 2007; 293:F1877-88.

109. Hochberg D, Johnson CW, Chen $\mathrm{J}$, et al. Interstitial fibrosis of unilateral ureteral obstruction is exacerbated in kidneys of mice lacking the gene for inducible nitric oxide synthase. Lab Invest 2000; 80:1721-8.

110. Manucha W, Oliveros L, Carrizo L, et al. Losartan modulation on NOS isoforms and COX-2 expression in early renal fibrogenesis in unilateral obstruction. Kidney Int 2004; 65:2091-107.

111. Ito $\mathrm{K}$, Chen $\mathrm{J}$, Khodadadian JJ, et al. Liposome-mediated transfer of nitric oxide synthase gene improves renal function in ureteral obstruction in rats. Kidney Int 2004; 66:1365-75.

112. Chevalier RL. Promise for gene therapy in obstructive nephropathy. Kidney Int 2004; 66:1709-10.

113. Wu JT, Kral JG. The NF-kappaB/IkappaB signaling system: a molecular target in breast cancer therapy. J Surg Res. 2005 Jan;123(1):158-69.

114. Tamada S, Asai T, Kuwabara N, et al. Molecular mechanisms and therapeutic strategies of chronic renal injury: the role of nuclear factor kappaB activation in the development of renal fibrosis. J Pharmacol Sci. 2006;100:17-21. 


\section{Artículo V}

\section{Revisión}

"Extracellular matrix deposition and apoptosis during obstructive nephropathy"

M. Teresa Grande, Fernando Pérez-Barriocanal, José M. López-Novoa The Open Urology and Nephrology Journal (enviado) 


\begin{abstract}
:
Obstructive nephropathy is associated to interstitial tubular fibrosis. The development of tubulointerstitial fibrosis is due to increased synthesis, deposition, and possibly reduced degradation of renal extracellular matrix components, especially collagens and non-collagenous proteins, such as laminin and fibronectin. Tubular epithelial cell apoptosis induces loss of functional nephrons, and plays also a major role in interstitial fibrosis induced by obstructive nephropathy. The effect of TGF- $\beta$ is regulated for other cytokines including hepatocyte growth factor, bone morphogenetic proteins, connective tissue growth factor and leptin. Tubulointerstitial cell infiltration, mostly macrophages, and release of proinflammatory cytokines, such as NF- $\mathrm{BB}$ and TNF- $\alpha$, stimulate tubular cell apoptosis during obstruction. Also TGF- $\beta$ and Angiotensin II regulate tubular cell apoptosis in obstructive nephropathy. The effect of TGF- $\beta$ on interstitial fibrosis and apoptosis is regulated for other cytokines including hepatocyte growth factor, bone morphogenetic proteins, connective tissue growth factor and leptin. Because increased extracellular matrix deposition and tubular cell apoptosis are major factors responsible for structural alterations observed in obstructive nephropathy, targeting their regulating factors could be an efficient approach for reducing renal lesions induced by urinary tract obstruction.
\end{abstract}




\section{INTRODUCTION}

Obstructive nephropathy due to congenital or acquired urinary tract obstruction is the first primary cause of chronic renal failure in children, but it is also a major cause of renal failure in adults [1]. The renal consequences of chronic urinary tract obstruction are very complex, and lead to renal injury and renal insufficiency. The end result of severe and chronic obstructive nephropathy is a progressive renal tubular atrophy with loss of nephrons due to tubular cell apoptosis, and interstitial fibrosis due to extracellular matrix accumulation in the tubular interstitium and the spaces where tubular atrophy has occurred. Despite numerous clinical and experimental studies over the past several decades, the evaluation and management of obstructive nephropathy remains challenging. The purpose of this review is to analyze in depth infiltration the cellular and molecular mechanisms involved in the genesis of interstitial fibrosis and tubular epithelial cell apoptosis associated to obstructive nephropathy. It should be noted that most of the data relative to fibrosis and apoptosis associated to obstructive nephropathy have been obtained in an experimental model, unilateral ureteral obstruction (UUO) in rats and mice. The UUO model has become the standard model to understand the causes and mechanisms of nonimmunological interstitial fibrosis. This is because it is normotensive, nonproteinuric, nonhyperlipidemic, and without any apparent immune or toxic renal insult. The UUO consists of an acute obstruction of one of the ureter that mimics the different stages of obstructive nephropathy leading interstitial fibrosis without compromising the life of the animal, because the contralateral kidney maintains or even increases its function due to compensatory functional and anatomic hypertrophy. Some other data have been also obtained for "in vitro" studies.

\section{RENAL FIBROSIS}

Renal fibrosis is the common end-point in all the chronic renal diseases, with independence on the origin of the disease. Fibrosis is also a phenomena characteristic of several diseases in other organs such as the lung (pulmonary fibrosis) or the liver (cirrhosis). The evolution of renal injury in obstructive nephropathy shares many features with other forms of interstitial renal disease such as acute renal failure, polycystic kidney disease and renal transplant rejection. The final fibrotic phase is very similar to virtually all progressive renal disorders, including glomerular disorders and systemic diseases such as diabetes or hypertension. The first part of this review will be 
devoted to study the mechanisms involved in renal fibrosis associated to obstructive nephropathy. However it should be noted that the evolution of renal injury in obstructive nephropathy shares many features with other forms of interstitial renal disease such as acute renal failure, polycystic kidney disease and renal transplant rejection. The final fibrotic phase is very similar to virtually all progressive renal disorders, including glomerular disorders and systemic diseases such as diabetes or hypertension.

\subsection{Increased ECM deposition}

Tissue fibrosis is a result of an imbalance between enhanced production and deposition and impaired degradation of extracellular matrix deposition components. Extracellular matrix is a complex and intricate network within which molecules are precisely organized. Most of the extracellular matrix molecules, collagens, glycoproteins and proteoglycans, share similar structural domains. Laminin, types IV and $\mathrm{V}$ collagens, entactin and fibronectin are localized in the normal kidney, with different distribution in the glomerular basement membranes, the mesangial matrix and tubular basement matrix [2].

The obstructive nephropathy is accompanied of interstitial fibrosis, interstitial expansion and tubular basement membrane thickening and collagen, fibronectin and heparin sulfate proteoglycan accumulation [3].

The obstructed kidney revealed increased deposition of type I and III collagen and type IV collagen, laminin, and fibronectin, normally associated with the basement membrane, were found both in a thickened basement membrane and in the interstitial space [4]. Also our studies supported increased fibronectin and type I collagen levels in the interstitium of the obstructed kidney after three days of ureteral obstruction with an intense staining in the tubulointerstitial space [5] and types I and IV collagens and TGF$\beta$ mRNA levels were also increased in the obstructed kidneys [6]. Increased extracellular matrix deposition can be based in increased synthesis or decreased degradation. Extracellular matrix degradation is carried out by several enzymes, including MMPs.

\subsection{Altered MMPs activity}

As commented above, MMPs play a critical role in the development of extracellular matrix deposition. Synthesis and degradation of extracellular matrix is 
regulated by the balance between MMPs and MMPs inhibitors. Among MMPs inhibitors, tissue inhibitors of metalloproteases (TIMPs) play a major role in regulating MMPs activity. MMP-2 (type IV collagenase) levels have been reported to be increased in the obstructed kidney [7] and the inhibition of MMP-2 accelerated the UUO-induced fibrosis in the obstructed kidney [8] whereas MMP-9 (type IV collagenase) was significantly decreased in the obstructed kidney probably through tissue inhibitor of metalloproteinase-1 (TIMP-1). However, whereas TIMP1-deficient mice do not show differences in the severity of interstitial fibrosis after UUO compared with control mice, overexpression of TIMP-1 has been reported to promote renal interstitial fibrosis [9]. These findings may be explained by compensation by other protease inhibitors such as TIMP-2, TIMP-3, and/or plasminogen activator inhibitor-1 (PAI-1) or by the possibility that inhibition of intrinsic MMP activity does not constitute a profibrogenic event in the kidney. PAI-1 inhibits plasminogen activators such as urinary and tissue plasminogen activators, uPA and tPA, impeding metalloproteases activation by plasmin. B2 bradykinin receptors, which stimulate tPA release, have been involved in MMP activity after UUO in a study where mice deficient for B2 bradikinin receptors, showed less renal fibrosis and less urinary plasminogen activator (uPA) and MMP-2 after UUO [10], probably because B2 bradykinin receptors mediate the signal to activate MMPs through plasmin.

\subsection{Regulatory mechanisms responsible for increased ECM deposition}

\subsubsection{TGF- $\beta$ signaling pathways}

From the first studies published in 1990 demonstrating the fibrogenic effects of TGF- $\beta$, a great body of evidence has been accumulated demonstrating that overexpression of TGF- $\beta$ is a key mediator of fibrotic disease. Its fibrogenic actions include stimulation of matrix synthesis, inhibition of matrix degradation, and modulation of matrix receptor expression to facilitate cell-matrix interactions. Many strategies to block TGF- $\beta$ have been used in animal studies. TGF- $\beta$ antibodies, antisense oligonucleotides, soluble TGF- $\beta$ type II receptor or type III receptor, the TGF- $\beta$ inhibitor decorin, TGF$\beta$ 's latency-associated peptide, the negative regulatory signaling molecule Smad7, blockade of Smad3 and inhibition of TGF- $\beta$ activation have all shown therapeutic efficacy [11]. TGF- $\beta 1$ expression is increased in the kidney with ureteral obstruction and TGF- $\beta 1$ staining is increased markedly in the interstitium of the obstructed kidneys including human obstructive nephropathy [12]. TGF- $\beta$ receptors have been also found 
overexpressed after UUO, including Type I and II [12] and type III receptors [6,13]. 1D11 is a monoclonal antibody which is active against all three isoforms of TGF- $\beta$. It has been used as a single agent in several models of renal disease including UUO, and it has been reported to diminish interstitial fibrosis among other benefic effects in the UUO-induced injury $[14,15]$ thus demonstrating a major role of TGF- $\beta$ in renal interstitial fibrosis after UUO. Also, a recent study report that mice deficient in tissue transglutaminase (TG2), which modifies the stability of extracellular matrix proteins and renders the extracellular matrix resistant to degradation and activates TGF- $\beta$, were protected against development of fibrotic lesions in obstructive nephropathy due to a decreased rate of collagen I synthesis because of decreased TGF- $\beta$ activation [16].

Smad proteins are signaling transducers downstream from TGF- $\beta$ receptors. TGF- $\beta$ activate Smad 2 and Smad 3 through the TGF- $\beta$ receptors type I and II. Nuclear phosphorylated Smad2 and Smad3 have been reported to be increased in the obstructed kidney, whereas the inhibitory Smad7 decreased progressively in UUO kidneys [17]. Targeted deletion of Smad3 markedly prevents from UUO-induced interstitial fibrosis, suggesting that most of the pro-fibrotic activities of TGF- $\beta$ are mediated by Smad3 [18, 19]. Smad transcriptional co-repressors SnoN and Ski were progressively reduced in a time-dependent manner in the obstructed kidney of mice subjected to OUU whereas renal Smad abundance was relatively unaltered. Both SnoN and Ski could block Smadmediated activation of TGF- $\beta 1$-responsive promoter and exhibited additive effect in abrogating the profibrotic actions of TGF- $\beta 1$. In vitro knockdown of SnoN expression in tubular epithelial cells dramatically sensitized their responsiveness to TGF- $\beta 1$ stimulation. This study suggests increased Smad transcriptional co-repressors expression may be effective in antagonizing TGF- $\beta 1$ signaling and thereby blocking the progression of chronic renal fibrosis [20]. As TGF- $\beta$ is major inductor of interstitial fibrosis associated to UUO through smads signalling pathway, probably smads transcriptional repressor could be good targets for attenuate the development of obstructive nephropathy but TGF- $\beta$ also act through other signaling pathways, such as Rho.

Rho and its downstream effector, Rho kinase, have been reported as potential mediators of TGF- $\beta$-associated renal fibrosis [21, 22]. Controversial experimental results have been reported about this assessment. While Rho kinase inhibition showed a decrease in UUO induced-tubulointerstitial fibrosis [21, 23], mice lacking Rho kinase 1 
subjected to UUO showed no protection against increased type I and III collagen and fibronectin expression in the obstructed kidney. Moreover, mice lacking Rho kinase 1 and subjected to OUU showed in the obstructed kidney a further increase in TGF- $\beta 1$ expression associated with a significant increase in the level of $\operatorname{Smad} 2 / 3$ phosphorylation, thus suggesting a crosstalk between the Rho/Rho kinase pathway and the TGF- $\beta /$ Smad signaling pathway in TGF- $\beta$-mediated renal interstitial fibrosis in the UUO model [24].

There is also a close relation between TGF- $\beta$ and Ras signaling pathways. Ras activation is mediated by TGF- $\beta 1[25,26]$ and also by ligands for receptor tyrosine kinases which are soluble or membrane-bound peptide/protein hormones such as platelet-derived growth factor (PDGF) [27], epidermal growth factor (EGF) [28, 29] and fibroblast growth factor (FGF) [30]. Ras activation has been shown to be associated with extracellular matrix deposition in vitro [25] and also we have demonstrated Ras/PI3kinase activation involvement in UUO-induced increase in fibronectin and collagen levels in the obstructed kidneys as the administration of LY294002, a specific PI3Kinase inhibitor, diminished the obstruction-induced fibronectin and collagen I levels [5], p38 MAP kinase pathway inhibition resulted in alpha1(I) collagen mRNA level reduction after UUO [31]. Ras/MAPK activation has been also reported in the obstructed kidney of mice with UUO. ERK inhibition in mice subjected to UUO was associated to reduced interstitial fibrosis [5]. Early ERK activation has been observed initially in medullary collecting ducts and the thick ascending limb of Henle, and then in dilated collecting ducts and in interstitial cells in the cortex and also proliferation of tubular epithelial cells closely followed the same pattern that ERK activation and in addition the inhibition of ERK activation resulted in a reduction in interstitial cell proliferation accompanied by a diminished interstitial macrophage accumulation after UUO [32].

Binding of tyrosine kinase receptors to their ligands also activate JAK/STAT signaling pathway. Signal Transducers and Activator of Transcription proteins (STAT) were activated by phosphorylation in the obstructed kidneys after UUO with a peak in the $7^{\text {th }}$ day [33]. Also STAT6 deficiency mice subjected to UUO showed less accumulation of collagen I than wild-type (WT) mice [34]. These results suggesting STAT pathway may play a role on obstruction-induced renal interstitial fibrosis by activating collagen synthesis. 
In summary Smad, Rho/RhoKinase, Ras/PI3Kinase, Ras/MAPKinase and JAK/STAT pathways have been reported to be involved, at least in part, in profibrotic effects of TGF- $\beta$ during progression of obstructive nephropathy.

Many early papers demonstrate that Angiotensin II (Ang II) seems to play a major role in TGF- $\beta$ overexpression in chronic kidney disease (reviewed in 12). Ang II induces up-regulation of TGF- $\beta$ and TGF- $\beta$ receptor expression. The suppression of angiotensinogen (AGT) gene expression by transferring recombinant adenoviral vectors carrying a transgene expressing AGT antisense mRNA in the kidneys of rats with UUO prevents the formation of renal cortical TGF- $\beta 1$, and of related fibrogenic factors [35]. In a recent study, it was demonstrated that Ang II, both via $\mathrm{AT}_{1}$ and $\mathrm{AT}_{2}$ receptors, activates NF- $\mathrm{KB}$ in response to obstruction in a mouse model [36]. Ang II production is increased in UUO and Ang II receptor blockers reduce TGF- $\beta$ and TGF- $\beta$ receptor expression and renal damage in several models of experimental renal disease, including UUO in adult [37, 38, 39, 40] and in neonatal animals [41, 42]. However, other studies have demonstrated that selective inhibition of $\mathrm{AT}_{1}$ receptors during nephrogenesis exacerbates injury to the obstructed kidney and also injures the contralateral kidney, as $\mathrm{AT}_{1}$ signaling is involved in nephrogenesis. Thus, Ang II receptor blockers should be used with caution in the developing hydronephrotic kidney [43, 44].

Early studies also have demonstrated that angiotensin converting enzyme (ACE) inhibitors reduces renal fibrosis in the obstructed kidney after UUO [45, 46] although other authors have not observed this protection [47]. Even more, other authors have reported a negative effect of treatment with the angiotensin converting inhibitors in neonatal models of UUO, as occurred with the $\mathrm{AT}_{1}$ receptor antagonists [44], thus suggesting that these drugs should be used with caution during the perinatal period.

\subsubsection{Endogenous molecules that modulate TGF- $\beta$ effects and interstitial fibrosis in} UUO

There are many early papers demonstrating that extracellular matrix deposition was attenuated by inhibition of TGF- $\beta$ or TGF- $\beta$ signaling using several pharmacological or genetic strategies. In the last years, there is growing evidence that some endogenous molecules modulate TGF- $\beta$ effects, and could act as anti-fibrotic molecules. These molecules include hepatocyte growth factor (HGF), bone morphogenic proteins (BMPs), decorin, connective tissue growth factor (CTGF), 
decorin and leptin. We will next revise the most recent advances in the knowledge of the effects of these factors on interstitial fibrosis after UUO.

\subsubsection{Hepatocyte groth factor}

There are many early papers describing that exogenous administration of hepatocyte growth factor (HGF) to mice subjected to UUO prevented from interstitial extracellular matrix deposition and myofibroblasts activation in the obstructed kidneys [for review: 48]. HFG administration is effective even when given at a time point when significant renal fibrosis has clearly emerged [49]. The mechanism of HGF-induced protection seems to be the inhibition by HGF of both TGF- $\beta 1$ and its specific type I receptor in the obstructed kidneys in vivo, and producing blockade of Smad nuclear traslocation by HGF on an ERK-MAPKinase dependent manner [48, 50].

\subsubsection{Bone morphogenetic proteins}

The bone morphogenetic proteins (BMPs) are a family of secreted signalling molecules that, although were first identified by their capacity to promote endochondral bone formation, they are involved in the cascades of body patterning and morphogenesis. They are part of the TGF- $\beta$ superfamily that comprises over twenty BMPs, of which BMP-7 (also called osteogenic protein-1 or OP-1) is the most prominent member involved in renal development and disease. BMP-7 is a $35-\mathrm{kDa}$ homodimeric protein, and kidney is its major site of synthesis during embryogenesis as well as in postnatal development. In the adult kidney, BMP-7 is expressed in glomerular podocytes, the thick ascending limb, the distal convoluted tubule, and most strongly in the collecting duct [51]. The function of BMP-7 in the adult kidney has not been revealed completely, but recent evidence suggest that endogenous BMP-7 might function as a regulator of kidney homeostasis and regeneration by maintaining a differentiated epithelial phenotype of tubular epithelial cells [52]. In contrast to the consistent upregulation of TGF- $\beta 1$ in models of experimental and human renal fibrosis, expression of BMP-7 was shown to be markedly reduced in experimental diseases associated with renal fibrosis, including UUO [52]. BMP-7 seems to prevent the profibrotic effects of TGF- $\beta[53,54,55]$. BMP-7 displays protective effects on the kidney by decreasing apoptosis, maintaining and restoring the epithelial phenotype, and displaying antifibrotic activity. Moreover, experimental studies in rodents have demonstrated its ability to stabilize or even reverse renal fibrosis with improved renal 
function [56]. TGF- $\beta$-induced epithelial to mesenchymal transition can be abrogated by upregulation of bone morphogenic protein [57]. Even more, BMP-7 is able to induce formation of epithelial cell aggregates in cultures of adult renal fibroblasts, which was accompanied by acquisition of E-cadherin expression and decreased motility, indicating that true mesenchymal-to-epithelial transition (MET) might be achieved [58]. In fact, the protective effect of rapamicin on interstitial fibrosis in the UUO model seems to be based in an up-regulation of BMP-7 expression in the ligated kidney [59]. Although the mechanism by which BMP-7 antagonizes the pro-fibrotic effect of TGF- $\beta 1$ is not completely known, the protective effect of BMP-7 on preservation of TGF $\beta 1$-induced downregulation of E-cadherin expression in tubular epithelial cells could be mimicked by transfection with the constitutively active general BMP type I receptor ALK3 [57]. The activity of BMP-7 in the kidney can be enhanced or inhibited by extracellular modulators such as kielin/chordin-like protein (KCP) that has been recently identified as a novel enhancer of BMP signaling. $\mathrm{KCP}^{-/-}$mice, developed significantly more renal damage and interstitial fibrosis in the obstructed kidney after induction of UUO [60]. In addition, $\mathrm{KCP}^{-/-}$mice shows have less pSmad1 but increased pSmad2 levels, suggesting that the antifibrotic effect of KCP also included inhibition of TGF- $\beta 1$ activity [61]. Uterine sensitization-associated gene-1 (USAG-1) is an extracellular modulator that inhibit BMP-7 activity, and that is abundantly expressed in the kidney. USAG-1 emerges in developing nephrons and colocalizes with BMP-7 only in differentiated tubules [62]. USAG- $1^{-/}$mice had increased $\mathrm{pSmad1/5}$ protein levels and exhibited a lower profibrotic effect of UUO that can be abolished by administration of a neutralizing antibody against BMP-7, thus demonstrating that this effect is mediated by BMP-7 [63]. Recently, Sclerostin domain-containing-1 or SOSTDC1 was identified as the human ortholog of USAG-1 [64]. Other antagonists of BMP-7 in the kidney include gremlin and noggin, of which overexpression of the latter in podocytes has been shown to result in massive mesangial matrix expansion $[65,66]$. Furthermore, gremlinmediated BMP antagonism is essential to induce the epithelial-mesenchymal feedback necessary for metanephric kidney development [67]. However, the possible role of gremlin or noggin on obstruction-induced renal damage has not been studied. Taken together, these data indicate that BMP-7 plays a major role in regulating EMT and interstitial fibrosis in the kidney after UUO. However, the antifibrotic activity of BMP-7 in the kidney is not only determined by the expression levels of BMP-7, but also by the expression of multiple other BMPs and BMP modulators [68]. 
The expression of thrombospondin-1 (TSP-1), which is the major activator of latent TGF- $\beta 1$ in experimental glomerulonephritis and diabetic nephropathy, was repressed by the prototypical BMP target gene Id1 [69]. These data suggest that the antifibrotic effects of BMP-7 are not entirely specific for this BMP, and that other BMPs might have similar anti-TGF $\beta 1$ activity. In this respect, it is noteworthy that both BMP-4 and BMP-6 were able to functionally substitute for loss of BMP-7 during kidney development [70], and that BMP-6 could inhibit TGF $\beta 1$-induced expression of CTGF and plasminogen activator inhibitor-1 in renal interstitial fibroblasts [71]. The observations that myofibroblast progenitor cells derived from patients with diabetes were deficient in BMP-6 expression [71], and that in renal cortex of diabetic mice, BMP-4, -5, and -6 were decreased to a similar extent as BMP-7, indicate that, in addition to BMP-7, also other BMPs might play an important role as antagonists of renal fibrosis. However, despite apparent overlap in functions of other BMPs with BMP-7, it should be kept in mind that distinct biological effects have been attributed to different BMPs. For instance, BMP-2 and BMP-7 have opposite effects on renal branching morphogenesis [72]. Administration of BMP-2 to rats with UUO has been also reported to prevent obstruction-induced fibrosis [73]. In rat fibroblasts, BMP-2 significantly reversed the TGF- $\beta 1$-induced increase in fibronectin concomitant with a significant decrease in type I TGF- $\beta$ receptors (TGF- $\beta$ RI). Moreover, BMP-2 significantly shortened the half-life of TGF- $\beta$ RI by activating its degradation by the proteasome. Furthermore, t BMP-2 significantly reversed the TGF- $\beta 1$ induced increase in $\mathrm{pSmad} 2 / 3$ and reversed the TGF- $\beta 1$ induced decrease in inhibitory Smad7 whereas Smad7 siRNA abolish the BMP-2-induced decrease in TGF- $\beta$ RI [73]. Thus, we can conclude that other BMPs besides BMP-7 can also regulate interstitial fibrosis after UUO.

\subsubsection{Conective tissue growth factors}

Conective tissue growth factor (CTGF) was first identified in conditioned media of endothelial cells as a $36-38 \mathrm{kDa}$ cysteine-rich polypeptide containing chemotactic and mitogenic activity towards fibroblasts. The biological functions of CTGF are complex and diverse [74]. CTGF is required for most of the increased ECM production and other profibrotic activity generally observed in response to TGF- $\beta 1$ [75]. In addition, CTGF is critically involved in cell growth and differentiation, migration, adherence, apoptosis and survival, as well as in angiogenesis and chondrogenesis [75]. 
Specific effects of CTGF on renal cells include migration, hypertrophy, fibronectin production, and actin disassembly in mesangial cells, EMT and fibronectin production of tubular epithelial cells, and type III collagen and TSP-1 production by renal interstitial fibroblasts [76, 77].

TGF- $\beta 1$ is the earliest recognized inducer of CTGF, and it has remained as one of the most studied regulators of CTGF expression in fibrotic processes [78]. In addition, in vitro studies with renal cells demonstrated that CTGF is also a direct target of gene regulation by TGF- $\beta 1$-independent factors including high glucose, angiotensin II, aldosterone, hypoxia inducible factor-1 $\alpha$, and cyclic mechanical stretch [51]. CTGF is not only induced by TGF- $\beta 1$, but it is also a major enhancer of the biological activity of TGF- $\beta 1$.

CTGF seems to play a role in the obstruction-associated interstitial fibrosis. CTGF, gene expression was prominently upregulated during UUO [79] and the blockade of CTGF by antisense oligonucleotide (ODN) markedly reduced TGF- $\beta$ induced production of fibronectin and type I collagen in cultured renal fibroblasts, whereas treatment with CTGF antisense ODN in rats subjected to OUU inhibits the expression of ECM genes such as fibronectin, fibronectin ED-A, and alpha1(I) collagen in the obstructed kidney. The antisense treatment also reduced interstitial deposition of CTGF, fibronectin ED-A, and type I collagen and the interstitial fibrotic areas, as well as the number of myofibroblasts [79].

\subsubsection{Leptin.}

The peptide hormone leptin is involved not only in the regulation of obesity but also in the regulation of inflammation and fibrosis. Leptin has been reported to be an enhancer of TGF- $\beta$ signaling. In renal interstitial (NRK-49F) fibroblasts leptin administration increased CTGF protein expression. AG-490, aJAK2 inhibitor, abrogated leptin -induced CTGF protein expression at 2 days. AG-490 and CTGF anti-sense ODN abrogated leptin-induced mitogenesis and collagen protein expression by renal interstitial fibroblasts. Thus, leptin induces JAK2 to increase CTGF-induced mitogenesis and type I collagen protein expression in NRK-49F cells. Additionally, AGE-induced mitogenesis and type I collagen protein expression are dependent on leptin-induced CTGF [80]. A role for leptin in regulating obstruction-induced interstitial fibrosis is derived of the fact leptin-deficient mice exposed to UUO showed 
significantly reduced fibrosis and also TGF- $\beta$ levels and TGF- $\beta$-induced activation Smad2/3 were significantly reduced in obstructed kidneys [81].

\section{TUBULAR CELL APOPTOSIS}

Tubular atrophy is the end result of UUO-induced tubular cells apoptosis as initially described Gobe et al. [82]. Afterwards, many authors have established the importance of this process in obstructive nephropathy [83, 84, 85].

Numerous proteins have been found to be related with apoptosis after UUO. DNA fragmentation and cleaved caspases have been considered good markers of cell death. Progressive increase in the intensity of DNA fragmentation was associated with apoptosis during the initial 3 weeks after UUO [86]. Cleaved caspases 1, 2, 3, 6, 7, 8, 9, 11, and 12 expression have been reported to be increased in obstructed kidneys after UUO. Four days after ureter ligation, tubular cell apoptosis peaked (13-fold of control) and remained high between days 4 to 15, and thereafter decreased rapidly [87]. Among all these caspases, increased renal caspase 3 activity seems to play a central role in renal cell apoptosis associated with urinary obstruction [87].

Using in situ hibridization of Sulfated glycoprotein-2 (SGP-2), also designated Clusterin, Apolipoprotein J, SP-40 and testosterone-repressed prostate message 2 (TRPM2), which is related with apoptosis and has been found to be increased after UUO. This study identifies the vascular tissue of the kidney as the initial site of cell death, and increasing time of obstruction resulted in changed the pattern of SGP-2 expression to the collecting ducts and distal tubules [88]. Therefore, localization of cell apoptosis changes with time of obstruction, but also the degree of apoptosis change with the maturity of the kidney. Thus, a study in neonatal and adults rat with UUO revealed that the major content of ceramide, a sphingolipid known to stimulate apoptosis in the kidney, in neonatal obstructed kidneys contributed to the prolonged renal apoptotic response of the neonatal obstructed kidney, as renal apoptosis directly related with ceramide content [89].

Apoptosis is a complex cellular process consisting of multiple steps, each of which is mediated by families of related molecules. These families may include receptor/ligand molecules such as Fas, Fas ligand, tumor necrosis factor receptor-1 (TNFR-1), and TNF-related apoptosis inducing ligand (TRAIL); signal transduction adapter molecules such as Fas-associated death domain (FADD), TNFR-1 associated 
death domain (TRADD), receptor-interacting protein (RIP), Fas-associated factor (FAF), and Fas-associated phosphatase (FAP); or effector molecules such as caspases. Fas and Fas ligand expression were increased in control UUO kidneys compared with sham-operated ones $[90,91]$. Compared with control and contralateral kidneys, the ligated kidneys also displayed an TNF-R1, TRAIL, TNFR-1 TRADD, RIP, and caspase-8, another executer caspase, and an up to twofold increase for FADD and FAP, but there was little change for FAF [91]. Increases in p53 [14] The expression of the cyclin-dependent kinase inhibitory proteins p27KIP1 detected by Western blotting reached a maximum 10 days after UUO in rats, and tubular and interstitial cells contributed to this increase in p27KIP1. p27KIP1-positive cells in the interstitium were macrophages/monocytes or myofibroblasts. Since there was no close correlation between apoptosis and p27KIP1 expression, the authors suggested that the overall number of p27KIP1 expressing cells sets a general restriction point for apoptosis rather than defines an individual level of cell fate [92]. Death-associated protein kinase (DAPK) is a $\mathrm{Ca} 2+/$ calmodulin-dependent serine/threonine kinase that is thought to mediate apoptosis and it has been reported to be increased and associated with apoptosis after UUO. Furthermore, the kinase domain of DAPK is crucial for the induction of renal tubular cell apoptosis in UUO [93]. p53 expression has been increased in obstructed kidneys of rats with UUO [14,94] . It is interesting to note that, using DAPK-mutant mice, Yukawa et al. have demonstrated that deletion of the kinase domain from death-associated protein kinase attenuated both p53 expression and tubular cell apoptosis in mice subjected to UUO, thus demonstrating a major role for p53 in regulating tubular cell apoptosis alter UUO [94]. Furthermore, the treatment with the anti-TGF- $\beta$ antibody 1D11 during UUO almost completely eliminated renal tubular apoptosis and also decreased renal tubular expression of p53 in the obstructed kidney, suggesting that p53 expression in UUO is dependent on TGF- $\beta$ [14]. However, apoptosis in obstructed kidneys involves p53-dependent as well as p53-independent pathways as the lack of p53 in p53 Knockout (KO) mice did not confer complete protection from apoptosis after UUO [95].

\subsection{Signalling of Apoptosis in UUO}

TGB- $\beta$ signaling play a key role in the regulation of apoptosis occurring in obstructed kidneys after ureter ligation as treatment with 1D11 (anti-TGF- $\beta$ ) during UUO, renal tubular apoptosis was almost completely eliminated [14]. It has been also 
reported that Smad3 deficiency reduced UUO-induced apoptosis [19]. CD44, a glycoprotein that is involved in inflammation and cell-cell/cell-matrix interactions, plays an important role in the balance between HGF and TGF- $\beta 1$, because absence of CD44 in vivo diminished HGF-signaling (via its high affinity receptor c-Met) and the signaling of TGF- $\beta 1$ (via phosphorylation and nuclear translocation of Smad-2 and Smad-3) in the obstructed kidney of CD44 ${ }^{-/-}$mice. CD44 may play as protector of apoptosis but also promotes development of fibrosis [96, 97].

The inflammatory process observed after UUO through the release of cytokines and growth factors, also contribute directly to tubular apoptosis caused for the accumulation of interstitial macrophages, which in turn also release many cytokines and growth factors. The role of macrophages regulating tubular apoptosis in obstructive nephropathy was studied by Lange-Sperandio et al. [98] using mice deficient for both E-selectin, P-selectin, L-selectin $\left(\mathrm{EPL}^{-/}\right)$and L-selectin deficient mice $\left(\mathrm{L}^{-/}\right)$and WT mice subjected to complete UUO or sham operation within the first 48 hours of life. Selectin deficient mice showed a marked reduction in macrophage infiltration into the obstructed kidney compared to WT at day 5 and day 12 after UUO. Tubular apoptosis was strongly reduced in $\mathrm{EPL}^{-/-}$at day 5 after $\mathrm{UUO}$, and in $\mathrm{EPL}^{-/-}$and $\mathrm{L}^{-/-}$at day 12 after UUO when compared to WT. The number of apoptotic tubular cells was correlated with macrophage infiltration, suggesting that macrophages stimulate tubular apoptosis in obstructive nephropathy. Furthermore, when mice deficient in colony-stimulating factor-1 (CSF-1), an important chemoattractant, survival, and proliferating factor for macrophages produced by tubular cells during urinary obstruction, were subjected to UUO, the amount of infiltrated macrophages and apoptotic tubular epithelial cells in the obstructed kidney was markedly decreased, compared with the obstructed kidney of WT cells $[99,100]$. Receptors of the P2X7 type have been demonstrated in granulocytes, monocytes/macrophages, $\mathrm{B}$ and $\mathrm{T}$ lymphocytes, and have been involved in several cellular mechanisms including those related to inflammation and immunological response. To investigate the role of these receptors on apoptosis associated to obstructive nephropathy, $\mathrm{P} 2 \mathrm{X} 7 \mathrm{KO}$ mice and C57B16 mice were subjected to UUO. Macrophage infiltration and tubular apoptosis were lower in $\mathrm{P} 2 \mathrm{X} 7 \mathrm{KO}$ mice, thus suggesting that $\mathrm{P} 2 \mathrm{X} 7$ receptors are implicated in macrophage infiltration and apoptosis in response to ureteral obstruction in mice [101]. 
Activation of NF- $\kappa \mathrm{B}$ has been involved in tubular cell apoptosis after UUO [102]. Proinflammatory cytokines, such as TNF- $\alpha$, have been also involved in tubular cell apoptosis after UUO [103]. Moreover, the pro-apoptotic effect of TNF- $\alpha$ in the obstructed kidneys is mediated by NF- $\mathrm{BB}$ activation, as TNF- $\alpha$ neutralization significantly reduced obstruction-induced TNF- $\alpha$ production, NF- $\kappa$ B activation, I- $\kappa \mathrm{B}$ degradation, angiotensinogen expression, and renal tubular cell apoptosis, suggesting that TNF- $\alpha$ pro-inflammatory and cytotoxic effects during renal obstruction is mediated

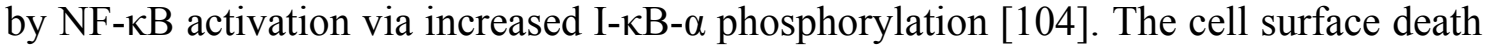
receptor Fas (CD95), a member of the tumor necrosis factor receptor family, is also implicated in the regulation of apoptosis in the UUO model. The absence of functional cell surface Fas in UUO provides distal tubular cells with partial protection from apoptosis but does not affect interstitial cell fate in this model of tubulointerstitial injury [105]. TNF- $\alpha$ stimulates Bid and subsequent intrinsic apoptotic signaling pathway activation during UUO, resulting in mitochondrial cytochrome $\mathrm{C}$ release and apoptotic cell death [106].

Nitric oxide (NO) has emerged as an important endogenous inhibitor of apoptosis. NO can produce resistance to obstruction-induced cell death by mitochondrial apoptotic pathway, through the induction of Hsp70 expression, in neonatal UUO [107]. Power et al. [108] reported that the cellular loss that occurs as a result of UUO is mediated through altered heat shock protein 70 (HSP-70) expression and the caspase cascade. Also upregulation of $\mathrm{HO}-1$ provides protection against renal injury that follows UUO. This effect is dependent on modulation of the antiapoptotic pathway by HO-1 expression [109].

Small GTPases Ras pathway is also implicated in UUO-induced apoptosis. Activated ERK (pERK), an effector of Ras/MAPK pathway, has been associated spatially and temporally with interstitial apoptosis [110]. We have reported that ERK activation is involved in UUO-induced tubular and interstitial cell apoptosis as administration of a MEK inhibitor prevented partially from UUO-induced tubular apoptosis and increased cleaved caspase-3 expression [5]. Also p38 mitogen-activated protein kinase (MAPK) pathway induces apoptosis through MKK3-p38 signaling during UUO in the obstructed kidneys [111]. Akt, an effector of Ras/PI3K pathway involved in cell survival, has been found to be activated after UUO [5]. Furthermore, in mouse embryonic fibroblasts, it has been proposed that Raf-1 binding complex favors 
both the PI3K/Akt and MEK/MAPK signaling pathways leading to phosphorylation of proapoptotic protein $\mathrm{Bad}$ and cell survival [112]. Furthermore, the $\mathrm{Na}(+) / \mathrm{H}(+)$ exchanger-1 (NHE1) in renal tubular epithelial cells regulated cell survival through activating Akt [113].

The transduction and activator transcription (STAT) [34] and Jun N-terminal protein kinases $(\mathrm{JNK})[114]$ pathways exert also a regulatory role on renal cell apoptosis in chronic obstructive uropathy the first preventing apoptosis and the second contributing to apoptosis.

\subsection{Preventing apoptosis in $U U O$}

Numerous studies are searching for targets whose inhibition could ameliorate increased apoptosis after UUO. The favorable effect of EGF in the inhibition of apoptosis during UUO has been very well studied [115, 116, 117]. Insulin-like growth factor-1 (IGF-1) administration also reduced tubular cell apoptosis after UUO [117, $118]$.

HGF also protects tubular cell from apoptosis by inducing cell survival by enhancing Bcl-2 expression [119, 120]. Bcl-2 immunostaining peaked on day 3 and then gradually decreased to baseline by day 11after UUO [121]. This decrease in Bcl-2 expression is accompanied by increased apoptosis after UUO [122]. Both HGF and 1D11 anti-TGF- $\beta$ treatment promoted cell survival and enhanced Bcl-2 expression in the obstructed kidney [14,120], preventing apoptosis after UUO.

Tranilast, a selective inhibitor of collagen synthesis [123] and Etodolac, a cyclooxygenase- 2 inhibitor, [124] reduce tissue TGF- $\beta$ and significantly decreased renal tubular apoptosis in the obstructed kidneys. Furthermore, the treatment with the antiTGF- $\beta$ antibody $1 \mathrm{D} 11$ during UUO, almost completely eliminated renal tubular apoptosis suggesting that apoptosis in UUO is dependent on TGF- $\beta$ [14]. Osteopontin [124, 125, 126], decorin (a small dermatan-sulfate proteoglycan) [127], osteogenic protein-1 (OP-1) [128], NO [129], catalase [130], quercetin [90], atorvastatin [131] have been reported to prevent renal damage associated with ureteral obstruction, in part, by preventing tubular cell apoptosis (Figure 1).

The inhibition of the inflammatory response during UUO also resulted in decreased tubular cell apoptosis in the obstructed kidney. Thus, Rosiglitazone makes this effect through activation of peroxisome proliferator-activated receptor- $\gamma$ (PPAR- $\gamma$ ) 
[132], The administration of dehydroxymethylepoxyquinomicin (DHMEQ), also decreased tubular apoptosis induced by OUU through inhibition of NF- $\kappa \mathrm{B}$ activation [102]. TNF- $\alpha$ neutralization in mice with UUO also significantly decreased tubular cell apoptosis [103, 106].

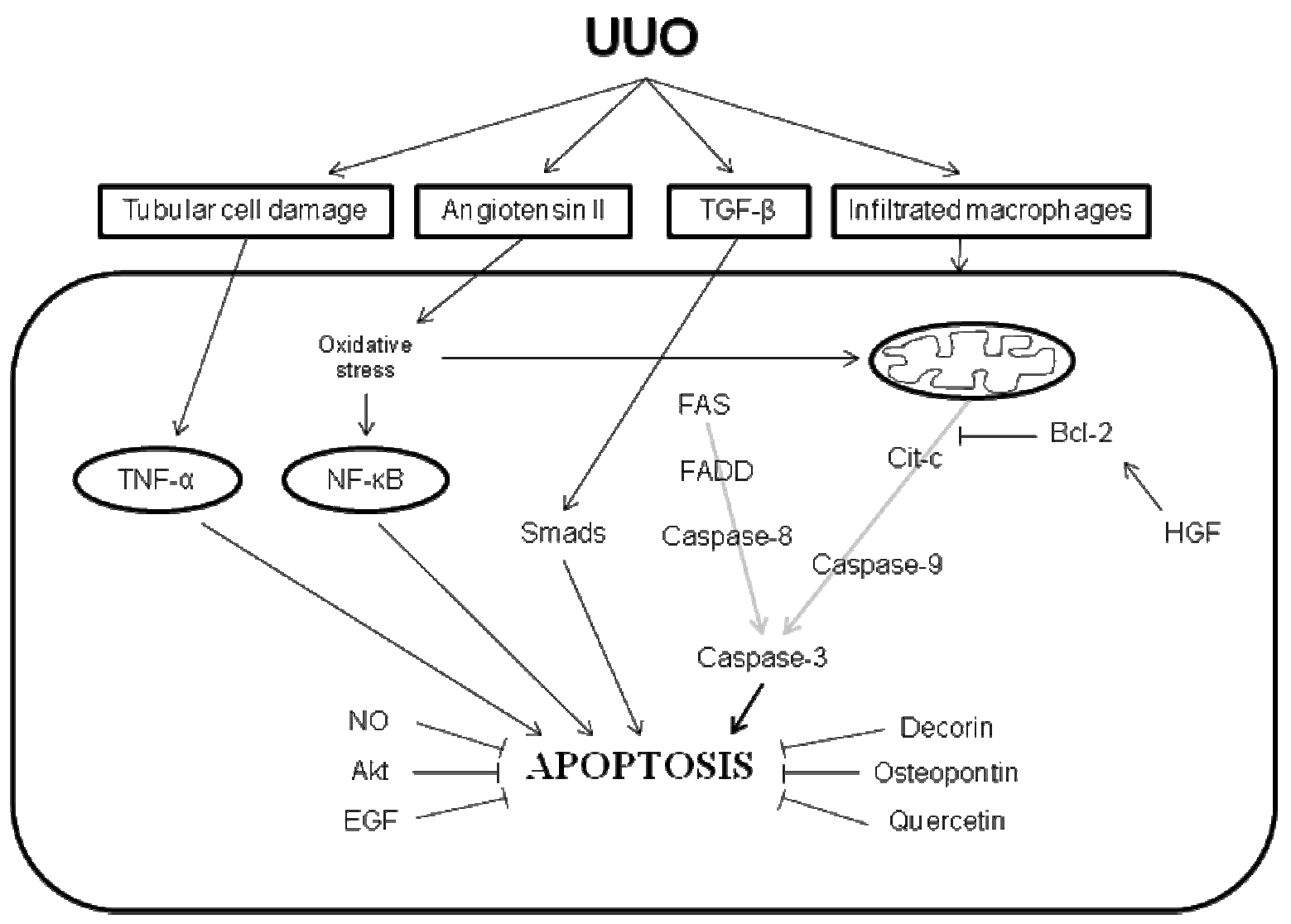

Figure 1. Signalling of apoptosis in UUO. UUO induce tubular cell damage, increased angiotensin and TGF- $\beta$ levels and infiltration of macrophages. All of them contribute to tubular cell apoptosis through different pathways.

As UUO is associated to an increased oxidative stress, and this, in turn activates NF- $\kappa \mathrm{B}$ and inflammatory reaction, another anti-inflammatory and anti-apoptotic approach is the antioxidant therapy. However, administration of antioxidants, including quercetin [90], vitamin E [133], $\alpha$-tocopherol and fluvastatin [134], $\mathrm{N}$-acetylcysteine (NAC), [110] have shown some degree of renal protection in UUO, but only fluvastatin was shown to significantly reduce oxidative markers and tubular apoptosis [134]. The administration of SS-31, a cell permeable antioxidant peptide that concentrate up to 5,000-fold in mitochondria, reduces intracellular free radicals, to rats subjected to UUO significantly attenuated the effects of obstruction on tubular cell apoptosis. Signaling via NF- $\mathrm{B}$ and p38 MAPK pathways were both affected by SS-31 treatment. This study 
demonstrates that peptides which protect mitochondria can provide protection from renal damage in a UUO model [135].

The role of over-activation of the renin-angiotensin system in UUO-induced apoptosis have been previously reviewed [90]. Inhibition of $\mathrm{AT}_{1}[38,42]$, and $\mathrm{AT}_{2}$ receptors [136, 137] decreased UUO-induced apoptosis. However, Radovic et al. have recently reported that losartan administration had no effect on tubular cell apoptosis induced by OUU in rats, whereas the administration of the ACE blocker cilazapril even increased interstitial cell apoptosis after UUO [138]. In the same direction, administration of the ACE blocker enalapril to rats with UUO did not ameliorate tubular apoptosis induced by UUO [47].

Endothelin-1 seems to be also involved in apoptosis induced by ureteral obstruction. After 24 hours of UUO in rats endothelin-1 mRNA expression was increased in the obstructed kidney and decreased in the contralateral kidney. UUOinduced apoptosis was blocked by endothelin inhibition with bosentan [139].

Hyperoxaluria enhances apoptosis induced by UUO in rats [140]. Thus, preventing hyperoxaluria in patients with ureteral obstruction could ameliorate the degree of apoptosis.

The administration of the calcium antagonist verapamil to rabbits with UUO significantly prevents the UUO-induced apoptosis and also the up-regulation of p53, Fas, and PCNA, demonstrating a marked renoprotective effect of verapamil treatment [141]. Something similar was observed in rabbits with partial ureteral obstruction [142].

Thus, although in an early phase of applicability to patients, there are several approaches that have demonstrated to be useful preventing tubular cell apoptosis associated to obstructive nephropathy. Probably this is a promising field to treat or prevent obstruction-induced renal damage

\section{CONCLUSSIONS}

Renal interstitial fibrosis observed after obstructive nephropathy results from of an imbalance between enhanced production and deposition and impaired degradation of extracellular matrix deposition components. Tubular epithelial cell apoptosis also contributes to the loss of functional nephrons and its substitution by extracellular matrix. TGF- $\beta$ is major inductor of interstitial fibrosis and tubular apoptosis in obstructive nephropathy. Angiotensin II overproduction seems to play a major role in 
the activation of the TGF- $\beta$ system. Smad, Rho/RhoKinase, Ras/PI3Kinase, Ras/MAPKinase and JAK/STAT signaling pathways seems to be involved in profibrotic effects of TGF- $\beta$ during progression of obstructive nephropathy. Profibrotic and pro-apoptotic effects of TGF- $\beta$ are modulated by other cytokines including hepatocyte growth factor (HGF), bone morphogenic proteins (BMPs), decorin, connective tissue growth factor (CTGF), decorin and leptin. Activation of NF- $\kappa \mathrm{B}$ and proinflammatory cytokines, such as TNF- $\alpha$, and increased oxidative stress are involved in tubular cell apoptosis induced in obstructive nephropathy. p53 activation seems to play a major role controlling the result of the apoptotic and anti-apoptotic signaling received by the epithelial cells.

There are several approaches that have demonstrated to be useful preventing interstitial fibrosis and tubular cell apoptosis associated to obstructive nephropathy although they are in an early phase of applicability to patients. Probably, this is a promising field to treat or prevent obstruction-induced renal damage. 


\section{Conflict of interest}

No conflict of interests declared

\section{Acknowledgments}

Studies from the authors' laboratories have been supported by grants from Ministerio de Educación, Turismo y Deportes (BFU2004-00285/BFI, and SAF2007-63893), Junta de Castilla y León (SA 001/C05), and Instituto de Salud Carlos III, (RETIC RedIn- Ren $\mathrm{RD} / 0016)$.

\section{References}

[1] Courtoy PJ, Timpl R, Farquhar MG. Comparative distribution of laminin, type IV collagen, and fibronectin in the rat glomerulus. J Histochem Cytochem 1982; 30: 87486.

[2] Monnens LA. The basal membrane of the kidney. Tijdschr Kindergeneeskd 1982; 50: $121-30$.

[3] Sharma AK, Mauer SM, Kim Y, Michael AF. Interstitial fibrosis in obstructive nephropathy. Kidney Int 1993; 44: 774-88.

[4] Wright EJ, McCaffrey TA, Robertson AP, Vaughan ED Jr, Felsen D. Chronic unilateral ureteral obstruction is associated with interstitial fibrosis and tubular expression of transforming growth factor-beta. Lab Invest 1996; 74: 528-37.

[5] Rodríguez-Peña AB, Grande MT, Eleno N, Arévalo M, Guerrero C, Santos E, López-Novoa JM. Activation of Erk1/2 and Akt following unilateral ureteral obstruction. Kidney Int 2008; 74: 196-209.

[6] Prieto M, Rodríguez-Peña AB, Düwel A, Rivas JV, Docherty N, Pérez-Barriocanal F, Arévalo M, Vary CP, Bernabeu C, López-Novoa JM, Eleno N. Temporal changes in renal endoglin and TGF-betal expression following ureteral obstruction in rats. $\mathrm{J}$ Physiol Biochem 2005; 61: 457-67.

[7] Iimura O, Takahashi H, Yashiro T, Madoiwa S, Sakata Y, Asano Y, Kusano E. Effect of ureteral obstruction on matrix metalloproteinase-2 in rat renal cortex. Clin Exp Nephrol 2004; 8: 223-9.

[8] Nishida M, Okumura Y, Ozawa S, Shiraishi I, Itoi T, Hamaoka K. MMP-2 inhibition reduces renal macrophage infiltration with increased fibrosis in UUO. Biochem Biophys Res Commun 2007; 354: 133-9.

[9] Kim H, Oda T, López-Guisa J, Wing D, Edwards DR, Soloway PD, Eddy AA. TIMP-1 deficiency does not attenuate interstitial fibrosis in obstructive nephropathy. J Am Soc Nephrol 2001; 12: 736-48.

[10] Schanstra JP, Neau E, Drogoz P, Arevalo Gomez MA, Lopez Novoa JM, Calise D, Pecher C, Bader M, Girolami JP, Bascands JL. In vivo bradykinin B2 receptor activation reduces renal fibrosis. J Clin Invest 2002; 110: 371-379.

[11] Yu L, Border WA, Anderson I, McCourt M, Huang Y, Noble NA. Combining TGF-beta inhibition and angiotensin II blockade results in enhanced antifibrotic effect. Kidney Int 2004; 66: 1774-84. 
[12] Bascands JL, Schanstra JP. Obstructive nephropathy: insights from genetically engineered animals. Kidney Int 2005; 68: 925-37.

[13] Rodríguez-Peña A, Eleno N, Düwell A, Arévalo M, Pérez-Barriocanal F, FloresO, Docherty N, Bernabeu C, Letarte M, López-Novoa JM. Endoglin upregulation during experimental renal interstitial fibrosis in mice. Hypertension 2002; 40: 713-20.

[14] Miyajima A, Chen J, Lawrence C, Ledbetter S, Soslow RA, Stern J, Jha S, Pigato J, Lemer ML, Poppas DP, Vaughan ED, Felsen D. Antibody to transforming growth factor-beta ameliorates tubular apoptosis in unilateral ureteral obstruction. Kidney Int 2000; 58: 2301-13.

[15] El Chaar M, Chen J, Seshan SV, Jha S, Richardson I, Ledbetter SR, Vaughan ED Jr, Poppas DP, Felsen D. Effect of combination therapy with enalapril and the TGF-beta antagonist 1D11 in unilateral ureteral obstruction. Am J Physiol Renal Physiol 2007; 292: F1291-301.

[16] Shweke N, Boulos N, Jouanneau C, Vandermeersch S, Melino G, Dussaule JC, Chatziantoniou C, Ronco P, Boffa JJ. Tissue transglutaminase contributes to interstitial renal fibrosis by favoring accumulation of fibrillar collagen through TGF-beta activation and cell infiltration. Am J Pathol 2008; 173: 631-42.

[17] Fukasawa H, Yamamoto T, Togawa A, Ohashi N, Fujigaki Y, Oda T, Uchida C, Kitagawa K, Hattori T, Suzuki S, Kitagawa M, Hishida A. Down-regulation of Smad7 expression by ubiquitin-dependent degradation contributes to renal fibrosis in obstructive nephropathy in mice. Proc Natl Acad Sci USA 2004; 101: 8687-92.

[18] Flanders KC. Smad3 as a mediator of the fibrotic response. Int J Exp Pathol 2004; 85: 47-64.

[19] Inazaki K, Kanamaru Y, Kojima Y, Sueyoshi N, Okumura K, Kaneko K, Yamashiro Y, Ogawa H, Nakao A. Smad3 deficiency attenuates renal fibrosis, inflammation, and apoptosis after unilateral ureteral obstruction. Kidney Int 2004; 66: 597-604.

[20] Fukasawa H, Yamamoto T, Togawa A, Ohashi N, Fujigaki Y, Oda T, Uchida C, Kitagawa K, Hattori T, Suzuki S, Kitagawa M, Hishida A. Ubiquitin-dependent degradation of SnoN and Ski is increased in renal fibrosis induced by obstructive injury. Kidney Int 2006; 69: 1733-40.

[21] Satoh S, Yamaguchi T, Hitomi A, Sato N, Shiraiwa K, Ikegaki I, Asano T, Shimokawa H. Fasudil attenuates interstitial fibrosis in rat kidneys with unilateral ureteral obstruction. Eur J Pharmacol 2002; 455: 169-74.

[22] Heusinger-Ribeiro J, Eberlein M, Wahab NA, Goppelt-Struebe M. Expression of connective tissue growth factor in human renal fibroblasts: Regulatory roles of RhoA and cAMP. J Am Soc Nephrol 2001; 12: 1853-61.

[23] Nagatoya K, Moriyama T, Kawada N, Takeji M, Oseto S, Murozono T, Ando A, Imai E, Hori M. Y-27632 prevents tubulointerstitial fibrosis in mouse kidneys with unilateral ureteral obstruction. Kidney Int 2002; 61: 1684-95.

[24] Fu P, Liu F, Su S, Wang W, Huang XR, Entman ML, Schwartz RJ, Wei L, Lan HY. Signaling mechanism of renal fibrosis in unilateral ureteral obstructive kidney disease in ROCK1 knockout mice. J Am Soc Nephrol 2006; 17: 3105-14.

[25] Martinez-Salgado C, Fuentes-Calvo I, Garcia-Cenador B, Santos E, Lopez-Novoa JM. Involvement of $\mathrm{H}$ - and $\mathrm{N}$-Ras isoforms in transforming growth factor-beta1- 
induced proliferation and in collagen and fibronectin synthesis. Exp Cell Res 2006; 312: 2093-106.

[26] Martínez-Salgado C, Rodríguez-Peña AB, López-Novoa JM. Involvement of small Ras GTPases and their effectors in chronic renal disease. Cell Mol Life Sci 2008; 65: 477-92.

[27] Svegliati S, Cancello R, Sambo P, Luchetti M, Paroncini P, Orlandini G, Discepoli G, Paterno R, Santillo M, Cuozzo C, Cassano S, Avvedimento EV, Gabrielli A. Platelet-derived growth factor and reactive oxygen species (ROS) regulate Ras protein levels in primary human fibroblasts via ERK1/2. Amplification of ROS and Ras in systemic sclerosis fibroblasts. J Biol Chem 2005; 280: 36474-82.

[28] Shah BH, Neithardt A, Chu DB, Shah FB, Catt KJ. Role of EGF receptor transactivation in phosphoinositide 3-kinase-dependent activation of MAP kinase by GPCRs. J Cell Physiol 2006; 206: 47-57.

[29] Jeon SH, Jeong WJ, Cho JY, Lee KH, Choi KY. Akt is involved in the inhibition of cell proliferation by EGF. Exp Mol Med 2007; 39: 491-8.

[30] Wu X, Chen H, Parker B, Rubin E, Zhu T, Lee JS, Argani P, Sukumar S. HOXB7, a homeodomain protein, is overexpressed in breast cancer and confers epithelialmesenchymal transition. Cancer Res 2006; 66: 9527-34.

[31] Nishida M, Okumura Y, Sato H, Hamaoka K. Delayed inhibition of p38 mitogenactivated protein kinase ameliorates renal fibrosis in obstructive nephropathy. Nephrol Dial Transplant. 2008; 23: 2520-2524.

[32] Han Y, Masaki T, Hurst LA, Ikezumi Y, Trzaskos JM, Atkins RC, NikolicPaterson DJ. Extracellular signal-regulated kinase-dependent interstitial macrophage proliferation in the obstructed mouse kidney. Nephrology (Carlton) 2008; 13: 411-8.

[33] Kuratsune M, Masaki T, Hirai T, Kiribayashi K, Yokoyama Y, Arakawa T, Yorioka N, Kohno N. Signal transducer and activator of transcription 3 involvement in the development of renal interstitial fibrosis after unilateral ureteral obstruction. Nephrology (Carlton) 2007; 12: 565-71.

[34] Yukawa K, Kishino M, Goda M, Liang XM, Kimura A, Tanaka T, Bai T, OwadaMakabe K, Tsubota Y, Ueyama T, Ichinose M, Maeda M, Takeda K, Akira S.STAT6 deficiency inhibits tubulointerstitial fibrosis in obstructive nephropathy. Int J Mol Med 2005; 15: 225-30.

[35] Shin GT, Kim WH, Yim H, Kim MS, Kim H. Effects of suppressing intrarenal angiotensinogen on renal transforming growth factor-betal expression in acute ureteral obstruction. Kidney Int 2005; 67: .897-908.

[36] Esteban V, Lorenzo O, Ruperez M, Suzuki Y, Mezzano S, Blanco J, Kretzler M, Sugaya T, Egido J, Ruiz-Ortega M. Angiotensin II, via AT1 and AT2 receptors and NFkappaB pathway, regulates the inflammatory response in unilateral ureteral obstruction. J Am Soc Nephrol 2004; 15: 1514-29.

[37] Wamsley-Davis A, Padda R, Truong LD, Tsao CC, Zhang P, Sheikh-Hamad D. $\mathrm{AT}_{1 \mathrm{~A}}$-mediated activation of kidney JNK1 and SMAD2 in obstructive uropathy: preservation of kidney tissue mass using candesartan. Am J Physiol Renal Physiol 2004; 287: F474-F480. 
[38] Kellner D, Chen J, Richardson I, Seshan SV, El Chaar M, Vaughan ED Jr, Poppas D, Felsen D. Angiotensin receptor blockade decreases fibrosis and fibroblast expression in a rat model of unilateral ureteral obstruction. J Urol 2006; 176: 806-12.

[39] Sugiyama H, Kobayashi M, Wang DH, Sunami R, Maeshima Y, Yamasaki Y, Masuoka N, Kira S, Makino H. Telmisartan inhibits both oxidative stress and renal fibrosis after unilateral ureteral obstruction in acatalasemic mice. Nephrol Dial Transplant 2005; 20: 2670-80.

[40] Manucha W, Carrizo L, Ruete C, Molina H, Vallés P. Angiotensin II type I antagonist on oxidative stress and heat shock protein 70 (HSP 70) expression in obstructive nephropathy. Cell Mol Biol 2005; 51: 547-55.

[41] Topcu SO, Pedersen M, Norregard R, Wang G, Knepper M, Djurhuus JC, Nielsen S, Jorgensen TM, Frokiaer J. Candesartan prevents long-term impairment of renal function in response to neonatal partial unilateral ureteral obstruction. Am J Physiol Renal Physiol 2007; 292: F736-F748.

[42] Eskild-Jensen A, Paulsen LF, Wogensen L, Olesen P, Pedersen L, Frøkiaer J, Nyengaard JR. AT1 receptor blockade prevents interstitial and glomerular apoptosis but not fibrosis in pigs with neonatal induced partial unilateral ureteral obstruction. Am J Physiol Renal Physiol 2007; 292: F1771-81.

[43] Coleman CM, Minor JJ, Burt LE, Thornhill BA, Forbes MS, Chevalier RL. Angiotensin AT1-receptor inhibition exacerbates renal injury resulting from partial unilateral ureteral obstruction in the neonatal rat. Am J Physiol Renal Physiol 2007; 293: F262-8.

[44] Chen CO, Park MH, Forbes MS, Thornhill BA, Kiley SC, Yoo KH, Chevalier RL. Angiotensin-converting enzyme inhibition aggravates renal interstitial injury resulting from partial unilateral ureteral obstruction in the neonatal rat. Am J Physiol Renal Physiol 2007; 292: F946-55.

[45] Gonçalves RG, Biato MA, Colosimo RD, Martinusso CA, Pecly ID, Farias EK, Cardoso LR, Takiya CM, Ornellas JF, Leite M Jr. Effects of mycophenolate mofetil and lisinopril on collagen deposition in unilateral ureteral obstruction in rats. Am J Nephrol 2004; 24: 527-36.

[46] Schanstra JP, Duchene J, Desmond L, Neau E, Calise D, Estaque S, Girolami JP, Bascands JL. The protective effect of angiotensin converting enzyme inhibition in experimental renal fibrosis in mice is not mediated by bradykinin B2 receptor activation. Thromb Haemost 2003; 89: 735-40.

[47] Turan T, van Harten JG, de Water R, Tuncay OL, Kok DJ. Is enalapril adequate for the prevention of renal tissue damage caused by unilateral ureteral obstruction and/or hyperoxaluria? Urol Res. 2003; 31: 212-7.

[48] Liu Y. Hepatocyte growth factor in kidney fibrosis: therapeutic potential and mechanisms of action. Am J Physiol Renal Physiol 2004; 287: F7-F16.

[49] Yang J, Liu Y. Delayed administration of hepatocyte growth factor reduces renal fibrosis in obstructive nephropathy.Am J Physiol Renal Physiol 2003; 284: F349-57.

[50] Tan R, Zhang X, Yang J, Li Y, Liu Y. Molecular basis for the cell type specific induction of SnoN expression by hepatocyte growth factor. J Am Soc Nephrol 2007; 18 : 2340-9. 
[51] Nguyen TQ, Goldschmeding R. Bone morphogenetic protein-7 and connective tissue growth factor: novel targets for treatment of renal fibrosis? Pharm Res 2008; 25: 2416-26.

[52] Zeisberg M, Muller GA, Kalluri R. Are there endogenous molecules that protect kidneys from injury? The case for bone morphogenic protein-7 (BMP-7). Nephrol Dial Transplant 2004; 19: 759-61.

[53] Archdeacon P, Detwiler RK. Bone morphogenetic protein 7 (BMP7): a critical role in kidney development and a putative modulator of kidney injury. Adv Chronic Kidney Dis 2008; 15: 314-20.

[54] Mitu G, Hirschberg R. Bone morphogenetic protein-7 (BMP7) in chronic kidney disease. Front Biosci 2008; 13: 4726-39.

[55] Zeisberg M, Kalluri R. Reversal of experimental renal fibrosis by BMP7 provides insights into novel therapeutic strategies for chronic kidney disease. Pediatr Nephrol 2008; 23: 1395-8.

[56] Okada H, Kalluri R. Recapitulation of kidney development paradigms by BMP-7 reverses chronic renal injury. Clin Exp Nephrol 2005; 9: 100-1.

[57] Zeisberg M, Hanai J, Sugimoto H, Mammoto T, Charytan D, Strutz F, Kalluri R. BMP-7 counteracts TGF-betal-induced epithelial-to-mesenchymal transition and reverses chronic renal injury. Nat Med 2003; 9: 964-68.

[58] Zeisberg M, Shah AA, Kalluri R. Bone morphogenic protein-7 induces mesenchymal to epithelial transition in adult renal fibroblasts and facilitates regeneration of injured kidney. J Biol Chem 2005; 280: 8094-8100.

[59] Damião MJ, Bertocchi AP, Monteiro RM, Gonçalves GM, Cenedeze MA, Feitoza CQ, Marques GD, Giannocco G, Mazzali M, Teixeira VP, Dos Reis MA, Pacheco-Silva A, Câmara NO. The effects of rapamycin in the progression of renal fibrosis. Transplant Proc 2007; 39: 457-9.

[60] Lin J, Patel SR, Cheng X, Cho EA, Levitan I, Ullenbruch M, Phan SH, Park JM, Dressler GR. Kielin/chordin-like protein, a novel enhancer of BMP signaling, attenuates renal fibrotic disease. Nat Med 2005; 11: 387-93.

[61]. Lin J, Patel SR, Wang M, Dressler GR. The cysteine-rich domain protein KCP is a suppressor of transforming growth factor beta/activin signaling in renal epithelia. Mol Cell Biol 2006; 26: 4577-85.

[62] Tanaka M, Endo S, Okuda T, Economides AN, Valenzuela DM, Murphy AJ, Robertson E, Sakurai T, Fukatsu A, Yancopoulos GD, Kita T, Yanagita M. Expression of BMP-7 and USAG-1 (a BMP antagonist) in kidney development and injury. Kidney Int 2008; 73: 181-91.

[63] Yanagita M, Okuda T, Endo S, Tanaka M, Takahashi K, Sugiyama F, Kunita S, Takahashi S, Fukatsu A, Yanagisawa M, Kita T, Sakurai T. Uterine sensitizationassociated gene-1 (USAG-1), a novel BMP antagonist expressed in the kidney, accelerates tubular injury. J Clin Invest 2006; 116: 70-9.

[64] Blish KR, Wang W, Willingham MC, Du W, Birse CE, Krishnan SR, Brown JC, Hawkins GA, Garvin AJ, D'Agostino Jr RB, Torti FM, Torti SV. A Human Bone Morphogenetic Protein Antagonist is Down-Regulated in Renal Cancer. Mol Biol Cell 2007; 19: 457-64. 
[65] Dolan V, Murphy M, Sadlier D, Lappin D, Doran P, Godson C, Martin F, O'Meara Y, Schmid H, Henger A, Kretzler M, Droguett A, Mezzano S, Brady HR. Expression of gremlin, a bone morphogenetic protein antagonist, in human diabetic nephropathy. Am J Kidney Dis 2005; 45: 1034-9.

[66] Miyazaki Y, Ueda H, Yokoo T, Utsunomiya Y, Kawamura T, Matsusaka T, Ichikawa I, Hosoya T. Inhibition of endogenous BMP in the glomerulus leads to mesangial matrix expansion. Biochem Biophys Res Commun 2006; 340: 681-8.

[67] Michos O, Panman L, Vintersten K, Beier K, Zeller R, Zuniga A. Gremlinmediated BMP antagonism induces the epithelial-mesenchymal feedback signaling controlling metanephric kidney and limb organogenesis. Development 2004; 131: 340110 .

[68] Yanagita M. Balance between bone morphogenetic proteins and their antagonists in kidney injury. Ther Apher Dial 2007; 11: 38-43.

[69]. Daniel C, Schaub K, Amann K, Lawler J, Hugo C. Thrombospondin-1 is an endogenous activator of TGF-beta in experimental diabetic nephropathy in vivo. Diabetes 2007; 56: 2982-89.

[70] Oxburgh L, Dudley AT, Godin RE, Koonce CH, Islam A, Anderson DC, Bikoff EK, Robertson EJ. BMP4 substitutes for loss of BMP7 during kidney development. Dev Biol 2005; 286: 637-46.

[71] Nguyen TQ, Chon $\mathrm{H}$, van Nieuwenhoven FA, Braam B, Verhaar MC, Goldschmeding R. Myofibroblast progenitor cells are increased in number in patients with type 1 diabetes and express less bone morphogenetic protein 6: a novel clue to adverse tissue remodelling? Diabetologia 2006; 49: 1039-48.

[72] Park SH, Choi MJ, Song IK, Choi SY, Nam JO, Kim CD, Lee BH, Park RW, Park KM, Kim YJ, Kim IS, Kwon TH, Kim YL. Erythropoietin decreases renal fibrosis in mice with ureteral obstruction: role of inhibiting TGF-beta-induced epithelial-tomesenchymal transition. J Am Soc Nephrol 2007; 18: 1497-507.

[73] Yang YL, Liu YS, Chuang LY, Guh JY, Lee TC, Liao TN, Hung MY, Chiang TA. Bone morphogenetic protein-2 antagonizes renal interstitial fibrosis by promoting catabolism of type I TGF-beta receptors. Endocrinology 2009, 150: 727-40.

[74] Perbal B. CCN proteins: multifunctional signalling regulators. Lancet 2004; 363 : 62-64.

[75] Leask A, Abraham DJ. All in the CCN family: essential matricellular signaling modulators emerge from the bunker. J Cell Sci 2006; 119: 4803-10.

[76] Crean JK, Furlong F, Mitchell D, McArdle E, Godson C, Martin F. Connective tissue growth factor/CCN2 stimulates actin disassembly through Akt/protein kinase Bmediated phosphorylation and cytoplasmic translocation of p27(Kip-1). FASEB J 2006; 20: $1712-4$.

[77] Liu C, Zhang JD, Zhang XL, Wu GQ, Li MX. Role of connective tissue growth factor (CTGF) module 4 in regulating epithelial mesenchymal transition (EMT) in HK2 cells. Clin Chim Acta 2006; 373: 144-150.

[78] Leask A, Abraham DJ. TGF-beta signaling and the fibrotic response. FASEB J 2004; 18: 816-27. 
[79] Yokoi H, Mukoyama M, Nagae T, Mori K, Suganami T, Sawai K, Yoshioka T, Koshikawa M, Nishida T, Takigawa M, Sugawara A, Nakao K. Reduction in connective tissue growth factor by antisense treatment ameliorates renal tubulointerstitial fibrosis. $\mathrm{J}$ Am Soc Nephrol 2004; 15: 1430-40.

[80] Lee CI, Guh JY, Chen HC, Lin KH, Yang YL, Hung WC, Lai YH, Chuang LY. Leptin and connective tissue growth factor in advanced glycation end-product-induced effects in NRK-49F cells. J Cell Biochem 2004; 93: 940-50.

[81] Kümpers P, Gueler F, Rong S, Mengel M, Tossidou I, Peters I, Haller H, Schiffer M. Leptin is a coactivator of TGF-beta in unilateral ureteral obstructive kidney disease. Am J Physiol Renal Physiol 2007; 293: F1355-62.

[82] Gobe GC, Axelsen RA. Genesis of renal tubular atrophy in experimental hydronephrosis in the rat. Role of apoptosis. Lab Invest 1987; 56: 273-81.

[83] Cachat F, Lange-Sperandio B, Chang AY, Kiley SC, Thornhill BA, Forbes MS, Chevalier RL. Ureteral obstruction in neonatal mice elicits segment-specific tubular cell responses leading to nephron loss. Kidney Int 2003; 63: 564-75.

[84] Truong LD, Petrusevska G, Yang G, Gurpinar T, Shappell S, Lechago J, Rouse D, Suki WN. Cell apoptosis and proliferation in experimental chronic obstructive uropathy. Kidney Int 1996; 50: 200-7.

[85] Thomas GL, Yang B, Wagner BE, Savill J, El Nahas AM. Cellular apoptosis and proliferation in experimental renal fibrosis. Nephrol Dial Transplant 1998; 13: 2216-26.

[86] Kennedy WA 2nd, Stenberg A, Lackgren G, Hensle TW, Sawczuk IS. Renal tubular apoptosis after partial ureteral obstruction. J Urol. 1994 Aug;152(2 Pt 2):658-64

[87] Truong LD, Choi YJ, Tsao CC, Ayala G, Sheikh-Hamad D, Nassar G, Suki WN. Renal cell apoptosis in chronic obstructive uropathy: the roles of caspases. Kidney Int 2001; 60: 924-34.

[88] Connor J, Buttyan R, Olsson CA, D'Agati V, O'Toole K, Sawczuk IS. SGP-2 expression as a genetic marker of progressive cellular pathology in experimental hydronephrosis. Kidney Int 1991; 39: 1098-103.

[89] Malik RK, Thornhill BA, Chang AY, Kiley SC, Chevalier RL. Renal apoptosis parallels ceramide content after prolonged ureteral obstruction in the neonatal rat. Am $\mathrm{J}$ Physiol Renal Physiol 2001; 281: F56-61.

[90] Jones EA, Shahed A, Shoskes DA. Modulation of apoptotic and inflammatory genes by bioflavonoids and angiotensin II inhibition in ureteral obstruction. Urology. 2000; 56: 346-51.

[91] Choi YJ, Baranowska-Daca E, Nguyen V, Koji T, Ballantyne CM, Sheikh-Hamad D, Suki WN, Truong LD. Mechanism of chronic obstructive uropathy: increased expression of apoptosis-promoting molecules. Kidney Int 2000; 58: 1481-91.

[92] Gerth JH, Kriegsmann J, Trinh TT, Stahl RA, Wendt T, Sommer M, Stein G, Wolf G. Induction of p27KIP1 after unilateral ureteral obstruction is independent of angiotensin II. Kidney Int 2002; 61: 68-79.

[93] Yukawa K, Hoshino K, Kishino M, Mune M, Shirasawa N, Kimura A, Tsubota Y, Owada-Makabe K, Tanaka T, Ichinose M, Maeda M, Takeda K, Akira S. Deletion of the kinase domain in death-associated protein kinase attenuates renal tubular cell apoptosis in chronic obstructive uropathy. Int J Mol Med 2004; 13: 515-20. 
[94] Yukawa K, Hoshino K, Kishino M, Tsubota Y, Owada-Makabe K, Maeda M, Bai $\mathrm{T}$, Tanaka T, Akira S. Deletion of the kinase domain from death-associated protein kinase attenuates p53 expression in chronic obstructive uropathy. Int J Mol Med 2005; 16: 389-93.

[95] Choi YJ, Mendoza L, Rha SJ, Sheikh-Hamad D, Baranowska-Daca E, Nguyen V, Smith CW, Nassar G, Suki WN, Truong LD. Role of p53-dependent activation of caspases in chronic obstructive uropathy: evidence from p53 null mutant mice. J Am Soc Nephrol 2001; 12: 983-92.

[96] Rouschop KM, Sewnath ME, Claessen N, Roelofs JJ, Hoedemaeker I, van der Neut R, Aten J, Pals ST, Weening JJ, Florquin S. CD44 deficiency increases tubular damage but reduces renal fibrosis in obstructive nephropathy. J Am Soc Nephrol 2004; 15: 67486.

[97] Rouschop KM, Claessen N, Pals ST, Weening JJ, Florquin S. CD44 disruption prevents degeneration of the capillary network in obstructive nephropathy via reduction of TGF-betal-induced apoptosis. J Am Soc Nephrol 2006; 17: 746-53.

[98] Lange-Sperandio B, Cachat F, Thornhill BA, Chevalier RL. Selectins mediate macrophage infiltration in obstructive nephropathy in newborn mice. Kidney Int 2002; 61: 516-24.

[99] Lenda DM, Kikawada E, Stanley ER, Kelley VR. Reduced macrophage recruitment, proliferation, and activation in colony-stimulating factor-1-deficient mice results in decreased tubular apoptosis during renal inflammation. J Immunol 2003; 170: 3254-62.

[100] Jang MH, Herber DM, Jiang X, Nandi S, Dai XM, Zeller G, Stanley ER, Kelley VR. Distinct in vivo roles of colony-stimulating factor-1 isoforms in renal inflammation. J Immunol 2006; 177: 4055-63.

[101] Gonçalves RG, Gabrich L, Rosário A Jr, Takiya CM, Ferreira ML, Chiarini LB, Persechini PM, Coutinho-Silva R, Leite M Jr. The role of purinergic P2X7 receptors in the inflammation and fibrosis of unilateral ureteral obstruction in mice. Kidney Int 2006; 70: 1599-606.

[102] Miyajima A, Kosaka T, Seta K, Asano T, Umezawa K, Hayakawa M. Novel nuclear factor kappa B activation inhibitor prevents inflammatory injury in unilateral ureteral obstruction. J Urol 2003; 169: 1559-63.

[103] Misseri R, Meldrum DR, Dinarello CA, Dagher P, Hile KL, Rink RC, Meldrum KK. TNF-alpha mediates obstruction-induced renal tubular cell apoptosis and proapoptotic signaling. Am J Physiol Renal Physiol 2005; 288: F406-11.

[104] Meldrum KK, Metcalfe P, Leslie JA, Misseri R, Hile KL, Meldrum DR. TNFalpha neutralization decreases nuclear factor-kappaB activation and apoptosis during renal obstruction. J Surg Res 2006; 131: 182-8.

[105] Hughes J, Johnson RJ. Role of Fas (CD95) in tubulointerstitial disease induced by unilateral ureteric obstruction. Am J Physiol 1999; 277: F26-32.

[106] Campbell MT, Dagher P, Hile KL, Zhang H, Meldrum DR, Rink RC, Meldrum KK. Tumor necrosis factor-alpha induces intrinsic apoptotic signaling during renal obstruction through truncated bid activation. J Urol 2008; 180: 2694-700.

[107] Manucha W, Vallés PG. Cytoprotective role of nitric oxide associated with Hsp70 expression in neonatal obstructive nephropathy. Nitric Oxide 2008; 18: 204-15. 
[108] Power RE, Doyle BT, Higgins D, Brady HR, Fitzpatrick JM, Watson RW. Mechanical deformation induced apoptosis in human proximal renal tubular epithelial cells is caspase dependent. J Urol 2004; 171: 457-61.

[109] Kim JH, Yang JI, Jung MH, Hwa JS, Kang KR, Park DJ, Roh GS, Cho GJ, Choi WS, Chang SH. Heme oxygenase-1 protects rat kidney from ureteral obstruction via an antiapoptotic pathway. J Am Soc Nephrol. 2006 May;17(5):1373-81

[110] Pat B, Yang T, Kong C, Watters D, Johnson DW, Gobe G. Activation of ERK in renal fibrosis after unilateral ureteral obstruction: modulation by antioxidants. Kidney Int 2005; 67: 931-43.

[111] Ma FY, Tesch GH, Flavell RA, Davis RJ, Nikolic-Paterson DJ. MKK3-p38 signaling promotes apoptosis and the early inflammatory response in the obstructed mouse kidney. Am J Physiol Renal Physiol 2007; 293: F1556-63.

[112] Kebache S, Ash J, Annis MG, Hagan J, Huber M, Hassard J, Stewart CL, Whiteway M, Nantel A. Grb10 and active Raf-1 kinase promote Bad-dependent cell survival. J Biol Chem 2007; 282: 21873-83.

[113] Schelling JR, Abu Jawdeh BG. Regulation of cell survival by $\mathrm{Na}+\mathrm{H}+$ exchanger1. Am J Physiol Renal Physiol 2008; 295: F625-32.

[114] Ma FY, Flanc RS, Tesch GH, Han Y, Atkins RC, Bennett BL, Friedman GC, Fan JH, Nikolic-Paterson DJ. A pathogenic role for c-Jun amino-terminal kinase signaling in renal fibrosis and tubular cell apoptosis. J Am Soc Nephrol 2007; 18: 472-84.

[115] Walton G, Buttyan R, Garcia-Montes E, Olsson CA, Hensle TW, Sawczuk IS. Renal growth factor expression during the early phase of experimental hydronephrosis. J Urol 1992; 148: 510-4.

[116] Kennedy WA 2nd, Buttyan R, Garcia-Montes E, D'Agati V, Olsson CA, Sawczuk IS. Epidermal growth factor suppresses renal tubular apoptosis following ureteral obstruction. Urology 1997; 49: 973-80.

[117] Kiley SC, Thornhill BA, Tang SS, Ingelfinger JR, Chevalier RL. Growth factormediated phosphorylation of proapoptotic BAD reduces tubule cell death in vitro and in vivo. Kidney Int 2003; 63: 33-42.

[118] Chevalier RL, Goyal S, Kim A, Chang AY, Landau D, LeRoith D. Renal tubulointerstitial injury from ureteral obstruction in the neonatal rat is attenuated by IGF-1. Kidney Int 2000; 57: 882-90.

[119] Mizuno S, Matsumoto K, Nakamura T. Hepatocyte growth factor suppresses interstitial fibrosis in a mouse model of obstructive nephropathy. Kidney Int 2001; 59: 1304-14.

[120] Gao X, Mae H, Ayabe N, Takai T, Oshima K, Hattori M, Ueki T, Fujimoto J, Tanizawa T. Hepatocyte growth factor gene therapy retards the progression of chronic obstructive nephropathy. Kidney Int 2002; 62: 1238-48.

[121] Zhang G, Oldroyd SD, Huang LH, Yang B, Li Y, Ye R, El Nahas AM. Role of apoptosis and $\mathrm{Bcl}-2 / \mathrm{Bax}$ in the development of tubulointerstitial fibrosis during experimental obstructive nephtopathy. Exp Nephrol 2001; 9: 71-80.

[122] Chevalier RL, Smith CD, Wolstenholme J, Krajewski S, Reed JC. Chronic ureteral obstruction in the rat suppresses renal tubular Bcl-2 and stimulates apoptosis. Exp Nephrol 2000; 8: 115-22. 
[123] Miyajima A, Asano T, Asano T, Yoshimura I, Seta K, Hayakawa M. Tranilast ameliorates renal tubular damage in unilateral ureteral obstruction. J Urol 2001; 165: 1714-8.

[124] Miyajima A, Ito K, Asano T, Seta K, Ueda A, Hayakawa M. Does cyclooxygenase-2 inhibitor prevent renal tissue damage in unilateral ureteral obstruction? J Urol 2001; 166: 1124-9.

[125] Ophascharoensuk V, Giachelli CM, Gordon K, Hughes J, Pichler R, Brown P, Liaw L, Schmidt R, Shankland SJ, Alpers CE, Couser WG, Johnson RJ. Obstructive uropathy in the mouse: role of osteopontin in interstitial fibrosis and apoptosis. Kidney Int 1999; 56: 571-80.

[126] Yoo KH, Thornhill BA, Forbes MS, Coleman CM, Marcinko ES, Liaw L, Chevalier RL. Osteopontin regulates renal apoptosis and interstitial fibrosis in neonatal chronic unilateral ureteral obstruction. Kidney Int 2006; 70: 1735-41.

[127] Schaefer L, Macakova K, Raslik I, Micegova M, Gröne HJ, Schönherr E, Robenek H, Echtermeyer FG, Grässel S, Bruckner P, Schaefer RM, Iozzo RV, Kresse $\mathrm{H}$. Absence of decorin adversely influences tubulointerstitial fibrosis of the obstructed kidney by enhanced apoptosis and increased inflammatory reaction. Am J Pathol 2002; 160: 1181-91.

[128] Hruska KA, Guo G, Wozniak M, Martin D, Miller S, Liapis H, Loveday K, Klahr S, Sampath TK, Morrissey J. Osteogenic protein-1 prevents renal fibrogenesis associated with ureteral obstruction. Am J Physiol Renal Physiol 2000; 279: F130-43.

[129] Miyajima A, Chen J, Poppas DP, Vaughan ED Jr, Felsen D. Role of nitric oxide in renal tubular apoptosis of unilateral ureteral obstruction. Kidney Int 2001; 59: 1290303.

[130] Sunami R, Sugiyama H, Wang DH, Kobayashi M, Maeshima Y, Yamasaki Y, Masuoka N, Ogawa N, Kira S, Makino H. Acatalasemia sensitizes renal tubular epithelial cells to apoptosis and exacerbates renal fibrosis after unilateral ureteral obstruction. Am J Physiol Renal Physiol 2004; 286: F1030-8.

[131] Mizuguchi Y, Miyajima A, Kosaka T, Asano T, Asano T, Hayakawa M. Atorvastatin ameliorates renal tissue damage in unilateral ureteral obstruction. J Urol 2004; 172: 2456-9.

[132] Efrati S, Berman S, Chachashvili A, Cohen N, Siman-Tov Y, Averbukh Z, Weissgarten J. Rosiglitazone treatment attenuates renal tissue inflammation generated by urinary tract obstruction. Nephrology (Carlton) 2009, in press.

[133] Kuemmerle N, Brandt R, Chan W, Krieg R, Chan J. Inhibition of transforming growth factor beta 1 induction by dietary vitamin $\mathrm{E}$ in unilateral ureteral obstruction in rats. Biochem Mol Med 1997; 61: 82-86.

[134] Moriyama T, Kawada N, Nagatoya K, Takeji M, Horio M, Ando A, Imai E, Hori M. Fluvastatin suppresses oxidative stress and fibrosis in the interstitium of mouse kidneys with unilateral ureteral obstruction. Kidney Int 2001; 59: 2095-2103.

[135] Mizuguchi Y, Chen J, Seshan SV, Poppas DP, Szeto HH, Felsen D. A novel cellpermeable antioxidant peptide decreases renal tubular apoptosis and damage in unilateral ureteral obstruction. Am J Physiol Renal Physiol 2008; 295: F1545-53. 
[136] Ma J, Nishimura H, Fogo A, Kon V, Inagami T, Ichikawa I. Accelerated fibrosis and collagen deposition develop in the renal interstitium of angiotensin type 2 receptor null mutant mice during ureteral obstruction. Kidney Int 1998; 53: 937-44.

[137] Morrissey JJ, Klahr S. Effect of AT2 receptor blockade on the pathogenesis of renal fibrosis. Am J Physiol 1999; 276: F39-45.

[138] Radović N, Cuzić S, Knotek M. Effect of unilateral ureteral obstruction and antiangiotensin II treatment on renal tubule and interstitial cell apoptosis in rats. Croat Med J 2008; 49: 600-7.

[139] Hegarty NJ, Young LS, O'Neill AJ, Watson RW, Fitzpatrick JM. Endothelin in unilateral ureteral obstruction: vascular and cellular effects. J Urol 2003; 169: 740-4.

[140] Turan T, Tuncay OL, Usubütün A, Yonguç T, Aybek Z, Atahan O. Renal tubular apoptosis after complete ureteral obstruction in the presence of hyperoxaluria. Urol Res 2000; 28: 220-2.

[141] Topcu SO, Celik S, Erturhan S, Erbagci A, Yagci F, Ucak R. Verapamil prevents the apoptotic and hemodynamic changes in response to unilateral ureteral obstruction. Int J Urol 2008; 15: 350-5.

[142] Topcu SO, Erbagci A, Erturhan S, Yagci F, Ucak R. Verapamil attenuates renal tubular apoptosis in response to partial unilateral ureteral obstruction. Urol Int 2008; 80: 84-9. 


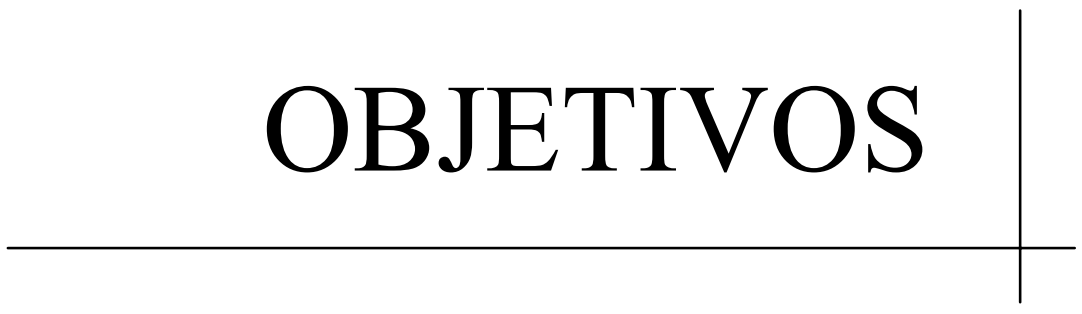



Los objetivos de este trabajo son los siguientes,

1. Evaluar el papel de la activación de Ras y de sus efectores MAPKERK1/2 y PI3K-Akt en la fibrosis tubulointersticial, acumulación de miofibroblastos, apoptosis, proliferación y otras alteraciones de la estructura renal inducida por la obstrucción ureteral unilateral en ratón.

2. Evaluar el papel de las isoformas H-Ras, N-Ras, K-Ras y K-Ras4A en la fibrosis tubulointersticial, acumulación de miofibroblastos, apoptosis, proliferación y otras alteraciones de la estructura renal inducidas por la obstrucción ureteral unilateral en ratón. 


\section{RESULTADOS Y DISCUSIÓN}





\section{Artículo VI}

\section{"Activation of Erk1/2 and Akt following unilateral ureteral obstruction"}

Ana B. Rodríguez-Peña, María T. Grande, Nélida Eleno, Miguel Arévalo, Carmen Guerrero, Eugenio Santos y José M. López-Novoa

Kidney International, 2008, 74,196-209 


\title{
Activation of Erk1/2 and Akt following unilateral ureteral obstruction
}

\author{
Ana B. Rodríguez-Peña $a^{1,2,4}$, Maria T. Grande ${ }^{1,4}$, Nélida Eleno ${ }^{1}$, Miguel Arévalo ${ }^{3}$, Carmen Guerrero ${ }^{2}$, \\ Eugerio Santos ${ }^{2}$ and José M. López-Novoa' \\ 'Departamento de Fisiologia y farmacologia, instituto 'Reina Sofia' de investigación Nefroiógica, Universidad de Salamanca and Red de \\ investigación en Enfermedades Renales (RedinRen) del instituto Carlos it, Salamanca, Spain; ${ }^{2}$ Centro de investigación def Cáncer, \\ Universidad de Salamanca, Salamanca, Spain and ${ }^{3}$ Departamento de Anatomia e Histologia Humanas, Universidad de Salamanca, \\ Salamanca, Spain
}

\begin{abstract}
Chronic unilateral ureteral obstruction is a well characterized model of renal injury leading to tubulointerstitial fibrosis and distinct patterns of cell proliferation and apoptosis in the obstructed kidney. In this study we assessed the contribution of the mitogen activated protein kinase (MAPK)-ERK1/2 and the phosphatidylinositol 3 kinase (PI3K)-Akt pathways to early renal changes following unilateral obstruction. Increased activation of small Ras GTPase and its downstream effectors ERK1/2 and Akt was detected in ligated kidneys. The use of specific pharmacological inhibitors to either ERK1/2 or Akt activation led to decreased levels of fibroblastmyofibroblast markers in the interstitium while inhibition of PI3K reduced the number of proliferating cells and the amount of interstitial extracellular matrix deposition. Treatment with an ERK1/2 inhibitor diminished the number of apoptotic tubule and interstitial cells. Our results suggest a role for the MAPK-ERK1/2 and PI3K-Akt systems in early changes induced by ureteral obstruction and that inhibition of these signaling pathways may provide a novel approach to prevent progression of renal fibrosis.

Kidney international (2008) 74, 196 209; doi 10.1038/ki 2008.160, published online 30 April 2008

KEYWORDS: chronic renal failure, tubulointerstitial fibrosis; ureteral ligation: apoptosis; proliferation; MAPK
\end{abstract}

Correspondence: José M. López-Novoa, Departamento de Fisiojogra y Farmacolagra, Edfificio Departamental, Campus Miguel de Unamuno, Salamanca 37007, Spain. E-mail: iminovoa@usal.es

${ }^{4}$ These authors contributed equally to this work

Received 14 November 2006; revised 30 January 2008; accepted 6 February 2008; published online 30 April 2008
End-stage renal disease is one of the most prevalent complications of hypertension, diabetes, and intrinsic renal diseases. ${ }^{1}$ Depending on the pathology, progressive accumulation of extracellular matrix can occur in the glomeruli (glomerulosclerosis) and/or the interstitial space (tubulointerstitial fibrosis). Several studies suggest that it is the severity of tubulointerstitial fibrosis that best correlates with the risk for renal failure progression. ${ }^{2}$ Chronic unilateral ureteral obstruction (UUO) is a well-characterized model of renal injury leading to tubulointerstitial fibrosis and distinct patterns of cell proliferation and apoptosis in the obstructed kidney. ${ }^{3}$ Interstitial proliferation has been related to development of tubulointerstitial renal fibrosis as obstruction induces differentiation of interstitial fibroblasts into $\alpha$-smooth muscle actin ( $\alpha$-SMA)-positive myofibroblasts, ${ }^{4}$ the principal effector cells responsible for the excess of interstitial extracellular matrix accumulation under pathologic conditions ${ }^{5}$ Apoptosis of tubular epithelial cells has been implicated in the progressive renal atrophy that follows experimental obstruction. ${ }^{6,7}$ Both apoptosis and tubulointerstitial fibrosis culminate in a loss of renal mass and kidney dysfunction in obstructive nephropathy. ${ }^{3}$

Mechanisms by which UUO gives rise to renal damage are gradually being elucidated. They include mechanical stretch from urine accumulation and subsequent tubular distension, ${ }^{8}$ hypoxia caused by reduced renal perfusion, ${ }^{3}$ increased oxidative stress, ${ }^{9}$ and upregulation of inflammatory factors such as monocyte chemoattractant peptide, ${ }^{10}$ vasoconstrictors including angiotensin $\mathrm{II}^{11,12}$ and endothelin, ${ }^{13}$ as well as macrophage-derived cytokines, especially the profibrotic transforming growth factor- $\beta 1,{ }^{14}$ which together contribute to obstruction-induced renal damage. Most of these factors mainly act via two types of membrane receptors: $G$ proteincoupled receptors and tyrosine linase receptors whose downstream signaling involves a range of effectors, including the Ras-mitogen-activated protein kinase (MAPK)/extracellular-regulated signal kinases 1 and 2 (ERK1/2) phosphorylation and the phosphatidyl inositol 3 kinase (PI3K)Alkt pathway activation. ${ }^{15}$ Once active, ERK1/2 and Alkt control fundamental cellular processes such as the cell cycle and cell survival. ${ }^{16,17}$ 
It has been demonstrated that ERK1/2 and Akt are activated in the kidneys of diabetic mice ${ }^{18}$ and rats with glomerulonephritis. ${ }^{19,20}$ Recently, ERK activation has been reported after UUO in rats ${ }^{21,22}$ However, to date no reports have examined the effect of in vivo inhibiting ERK1/2 or Akt activation on ladneys of mice submitted to obstructive nephropathy.

In the present study, we aimed to test whether ERK1/2 and Akt are activated in the early phase of an experimental model of tubulointerstitial renal fibrosis induced by 3 days of UUO in C57BL/6] mice. In addition, we assessed the contribution of either Ras downstream pathways, MAPK-ERK1/2 or PI3K-Akt, to the obstruction-induced renal alterations by in vivo administration of either U0126 or LY 294002 as corresponding inhibitors of ERK1/2 and Akt activation.

\section{RESULTS}

\section{Early renal changes after Uuo in mice}

Three days after UUO, neither contralateral non-ligated (NL) kidneys nor sham-operated ( $\mathrm{SO}$ ) kidneys exhibited morphological alterations. In contrast, ligated (L) kidneys showed typical features of early hydronephrosis including medullar compression toward cortex, flattening of both inner medulla and papillae, together with partial tubular dilation and flattened epithelium in affected tubules mainly circumscribed to the outer cortex.

Figure 1a shows immunohistochemical images for the early fibrosis marker fibronectin in SO, L, and NL kidneys. SO and NL kidneys presented a slight expression of fibronectin that was limited to epithelial basement membranes and around the endothelium of both large vessels and capillaries, whereas no staining was found in the tubular interstitium. Ligated kidneys showed an intense interstitial expression of fibronectin accompanied by a strong subendothelial and adventitial staining in large vessels. In agreement with morphometrical quantifying of interstitial fibronectin expression (Figure $1 \mathrm{~b}$ ), western blot analysis revealed significant higher levels of fibronectin in $L$ kidneys than in NL or SO kidneys (Figure $1 \mathrm{c}$ and $\mathrm{d}$ ).

Figure 2 include immunohistochemical images, morphometrical quantifying, and western blot analysis for the extracellular matrix protein collagen type I in SO, L, and NL kidneys. In SO animals, collagen type I staining was restricted to peritubular and adventitial areas of renal cortex with a very scarce immunostaining detected. Collagen I distribution in NL kidneys was similar to that in SO kidneys, whereas a marked staining was observed in peritubular and pericapillary interstitial areas of $\mathrm{L}$ kidneys (Figure $2 \mathrm{a}$ ), as confirmed by quantitative immunohistochemical determination of interstitial collagen I (Figure 2b). Western blot analysis revealed significant higher levels of collagen I in L kidneys than in NL or SO kidneys (Figure $2 \mathrm{c}$ and d).

The presence of interstitial cells expressing mesenchymal markers such as $\alpha$-SMA and vimentin has been described as additional source of generating fibroblast-myofibroblasts in obstructive nephropathy. ${ }^{4}$ The expression of $\alpha$-SMA was therefore assessed in renal interstitium (Figure 3 ) as a marker of myofibroblasts, the principal cells involved in extracellular matrix production under pathological conditions. ${ }^{4}$ AlphaSMA immunostaining was restricted to the smooth muscle of arterial walls and absent in peritubular interstitium of both SO and NL kidneys (Figure $3 a$ ). In contrast, $\alpha$-SMA staining was additionally expressed by interstitial cells of $L$ kidneys (Figure 3a) as confirmed by immunohistochemical quantifying of interstitial $\alpha$-SMA (Figure 3b). Significant higher levels of $\alpha$-SMA were also detected by western blot in L kidneys when compared with NL or SO kidneys (Figure $3 \mathrm{c}$ and d). As additional feature of the presence of profibrotic cells, vimentin immunodetection was performed in renal tissues. In SO and NL kidneys, vimentin-positive immunostaining was restricted to glomeruli and vascular walls, and no staining was detected in the renal interstitium (Figure 4a). However, like cells expressing $\alpha$-SMA, numerous vimentinpositive cells were found in peritubular interstitium of $\mathrm{L}$ kidneys (Figure $4 \mathrm{a}$ and b). Western blot analysis also revealed increased vimentin expression in L when compared with NL. or SO kidneys (Figure $4 \mathrm{c}$ and d). In addition, the number of CD68-positive cells was determined to assess the contribution of macrophages to the whole of cellular components in the interstitial cortex after UUO. As Figure 5 shows, CD68positive cells were almost absent in SO and NL kidneys. Immunodetection of CD68 was rarely observed in L kidneys, appearing restricted to perivascular areas and in a markedly lower number than in $\alpha$-SMA- or vimentin-positive cells.

Proliferation rate of renal cells was assessed by count of nuclear immunostaining of $\mathrm{Ki}-67$ protein (Figure $6 \mathrm{a}$ and $\mathrm{b}$ ), the expression of which is strictly associated with proliferative process. ${ }^{23}$ Kidneys of SO mice presented scarce positive Ki-67 nuclei in both tubules and interstitium. Ligated kidneys showed a significantly higher number of Ki-67stained tubular and interstitial cells when compared with kidneys of SO mice.

Tubular cell apoptosis is a prominent feature of UUO. ${ }^{6}$ As caspases serve as effector molecules of apoptotic program, and activated caspase- 3 is well known as the principal executioner caspase ${ }^{24}$ with a central role described for this enzyme in UUO-induced renal cell apoptosis in rats, ${ }^{6}$ we have assessed the number of renal cells initiating apoptosis by activated caspase- 3 immunostaining. Renal cells stained with cleaved caspase- 3 were almost absent in SO kidneys (Figure 6a). Several tubules of L kidneys appeared with all the epithelial cells positive for cleaved caspase-3, usually coinciding with dilated tubules (Figure 6a), and counting of stained tubules revealed a significant increase in relation to SO animals ( $7.5 \pm 0.5$ tubules per field in L kidneys vs $<0.1$ tubules per field in SO animals; $P<0.05$ ). When compared with SO kidneys, an appreciable increase was also detected in L kidneys for the area occupied by caspase-3-positive interstitial cells, as confirmed by quantitative immunohistochemical determination (Figure $6 \mathrm{c}$ ). We have also detected DNA fragmentation using the terminal uridine deoxynucleotidyl transferase dUTP nick-end labeling (TUNEL) assay. Tubular cell nuclei stained with this method were almost 
SO

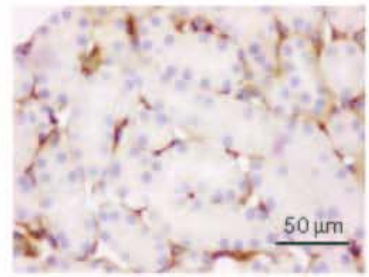

NL

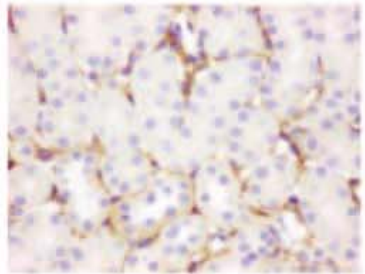

L

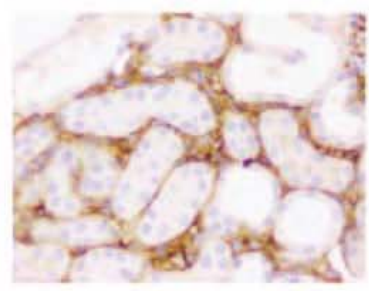

Vehicle
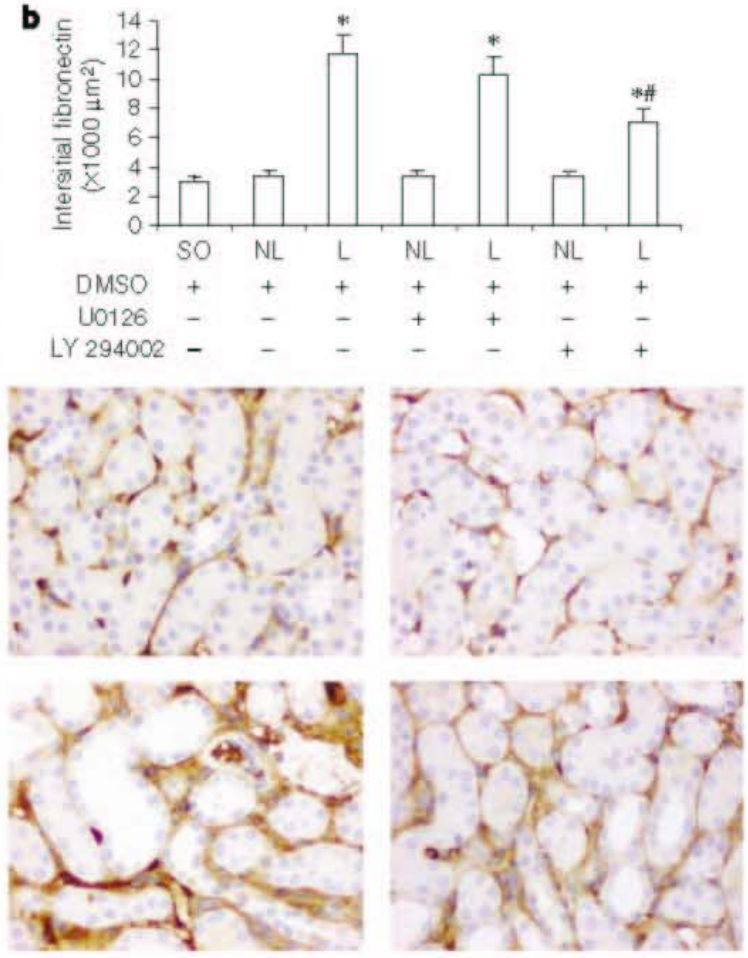

บ0126

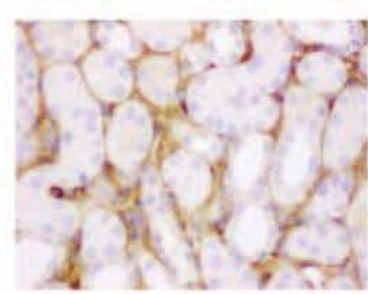

LY 294002

c

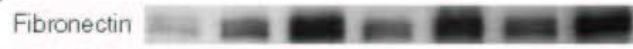

。

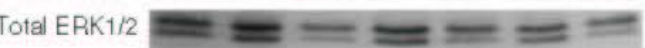

Fibronectin Total ERK $1 / 2$
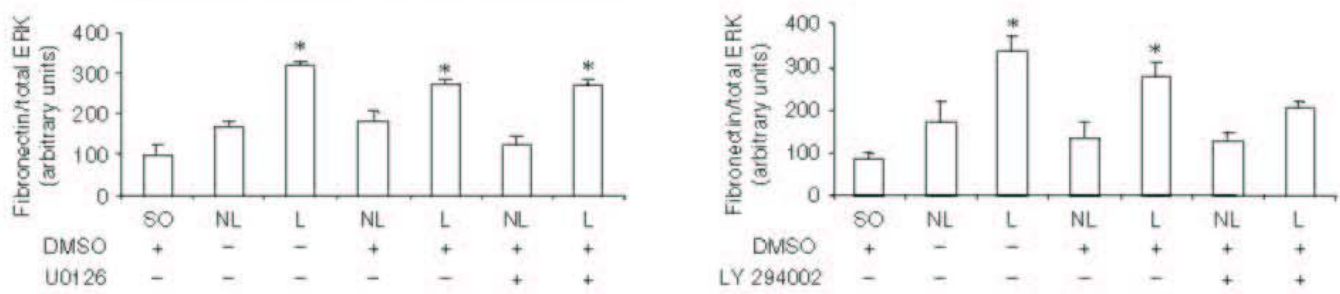

Figure 1 Renal detection of fibronectin 3 days after surgery. (a) Representative images of immunohistochemistry for fibronectin in kidneys of sham-operated ( $\mathrm{SO}$ ), contralateral non-ligated $(\mathrm{NL})$, and ligated (L) groups, and (b) corresponding morphometrical quantifying of fibronectin-immunostained areas in the renal interstitium. Bar $=50 \mu \mathrm{m}$ in all panels. Bars represent the mean \pm s.e.m. of values obtained after quantitative image analysis (see Materials and Methods). ( $\mathbf{c}$ and $\mathbf{d}$ ) Representative western blot analysis of fibronectin expression in kidneys of SO, NL, and L groups. Bars represent the mean \pm s.e.m. of optical density of signals $(n=4$ samples per group). Vehicle-control animals received the solvent dimethyl sulfoxide (DMSO). U0126 and LY 294002 groups respectively received the corresponding inhibitors of ERK1/2 and Akt activation, both dissolved in DMSO. ${ }^{*} P<0.05$ vs SO kidneys. $P<0.05$ vs $L$ untreated group.

absent in SO kidneys, where only scarce interstitial-labeled nuclei were detected (Figure 6a). In contrast, abundant stained nuclei were found both in tubular epithelia, mainly in dilated tubules, and in interstitium of $\mathrm{L}$ kidneys (Figure 6a).

No changes in fibronectin, collagen type I, $\alpha$-SMA, vimentin, $\mathrm{Ki}-67$, or activated caspase-3 expression were found in kidneys of $\mathrm{SO}$ animals receiving the vehicle dimethyl sulfoxide (DMSO) when compared with control SO kidneys (data not shown). In comparison with UUO nontreated animals, kidneys of UUO mice treated with DMSO showed no significant differences for $\mathrm{Ki}-67$ and activated caspase-3 immunostaining (data not shown) as well as for fibronectin, collagen type I, $\alpha$-SMA, and vimentin expression (Figures 1c,d, 2c,d, 3c,d and 4c,d, respectively). 
a

SO

NL

L

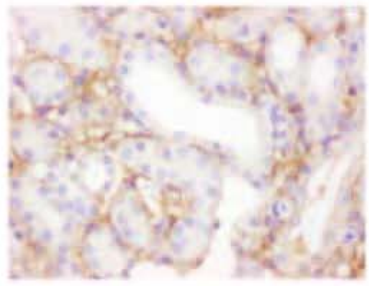

Vehicle

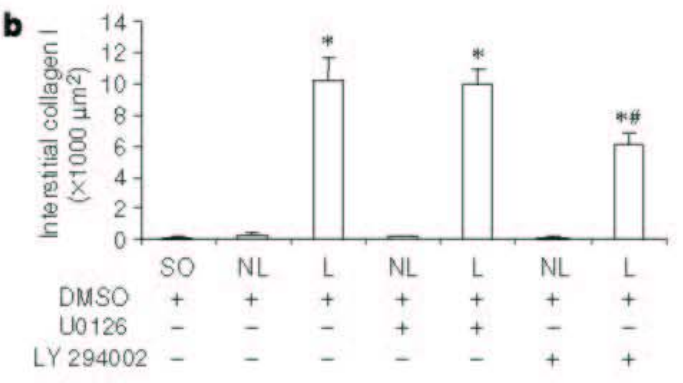

LY294002 - - - - - + +

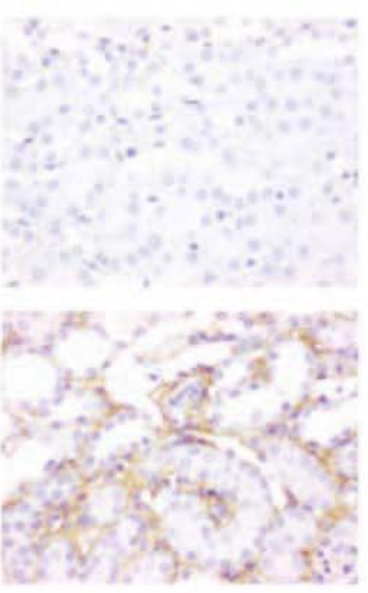

$\cup 0126$

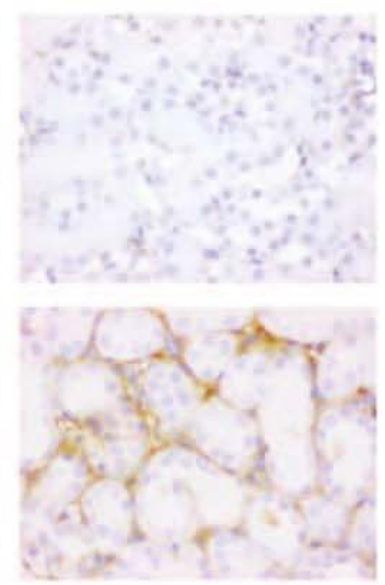

LY 294002
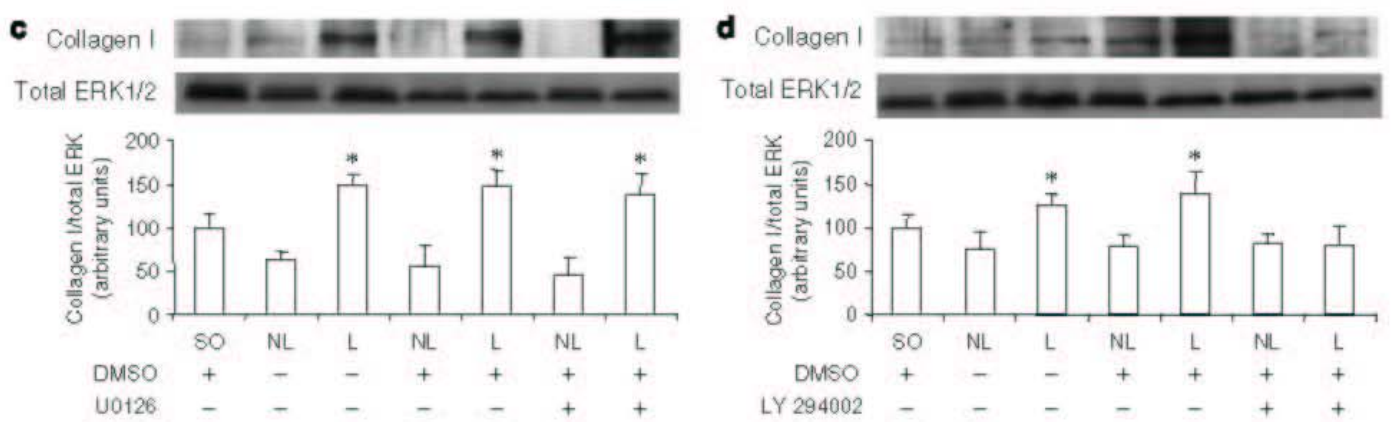

Figure 2 | Renal detection of collagen 13 days after surgery. (a) Representative images of immunohistochemistry for collagen I in kidneys of sham-operated (SO), contralateral non-ligated $(\mathrm{NL})$, and ligated $(\mathrm{L})$ groups, and (b) corresponding morphometrical quantifying of collagen I-immunostained areas in the renal interstitium. Bar $=50 \mu \mathrm{m}$ in all panels. Bars represent the mean \pm s.e.m. of values obtained after quantitative image analysis (see Materials and Methods). ( $c$ and d) Representative western blot analysis of collagen I expression in kidneys of $\mathrm{SO}_{\text {, }} \mathrm{NL}$, and $\mathrm{L}$ groups. Bars represent the mean \pm s.e.m. of optical density of signals $(n=4$ samples per group). Vehicle-control animals received the solvent dimethyl sulfoxide (DMSO). U0126 and LY 294002 groups respectively received the corresponding inhibitors of ERK $1 / 2$ and Akt activation, both dissolved in DMSO. ${ }^{*} P<0.05$ vs 50 kidneys. " $P<0.05$ vs $L$ untreated group.

Activation of the Ras signaling effectors ERK1/2 and Akt after UUO

We next assessed, by detection of phosphorylated forms of ERK1/2 (pERK1/2) and Akt (pAkt), whether the MAP$\mathrm{K}-\mathrm{ERK} 1 / 2$ and PI3K-Akt cascades initiated by Ras activation were also activated after UUO. Phosho-ERK1/2 immunostaining was limited to a faint interstitial expression in the cortex of SO and NL kidneys (Figure 7a). An intense staining for $\mathrm{pERK1} / 2$ was found in cortical tubulointerstitial areas of L kidneys (Figure 7a). Western blot analysis supported immunohistochemical data as it showed the presence of the active phosphorylated form of ERK1/2 in renal lysates from all experimental groups, with significant higher levels of $\mathrm{pERK1} / 2$ in L kidneys than in NL or SO kidneys (Figure $7 \mathrm{~b}$ ). 


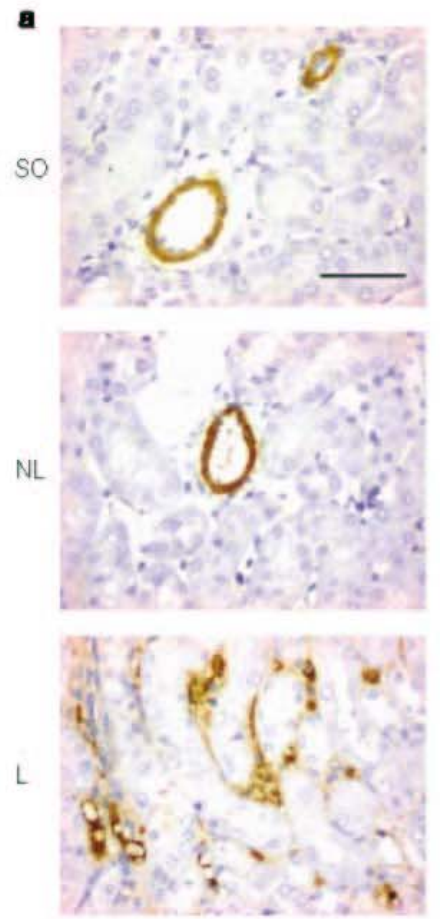

Vehicle
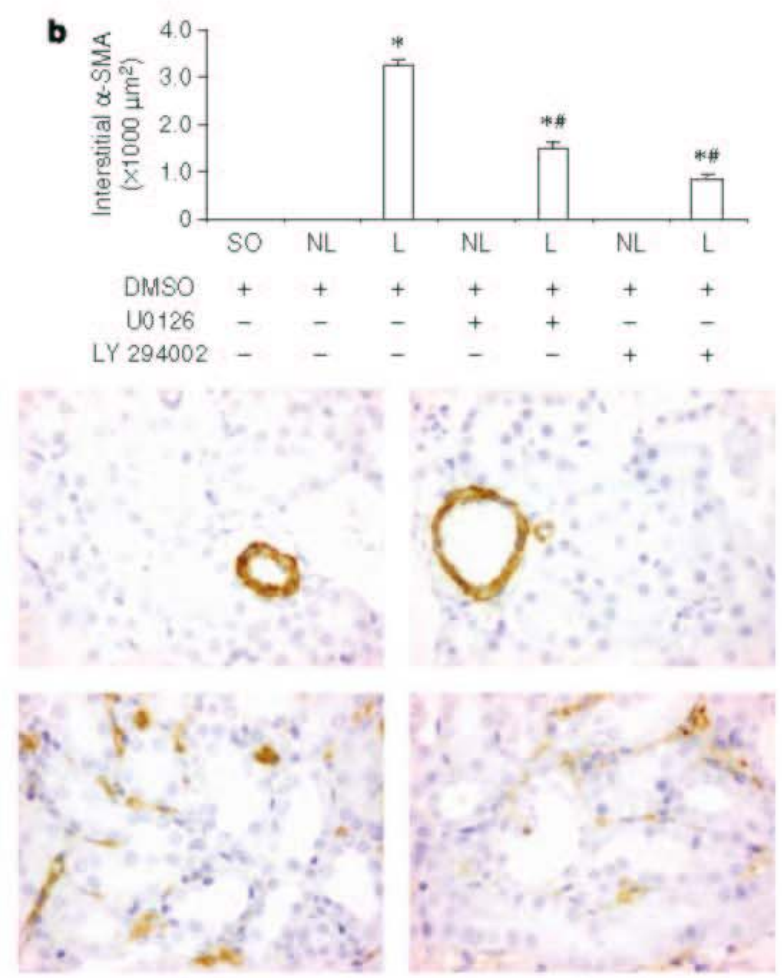

v0126

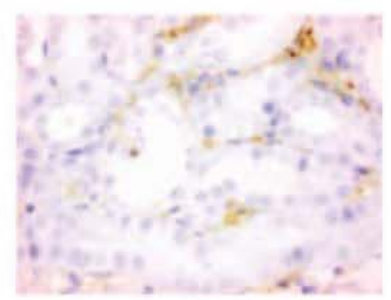

LY 294002
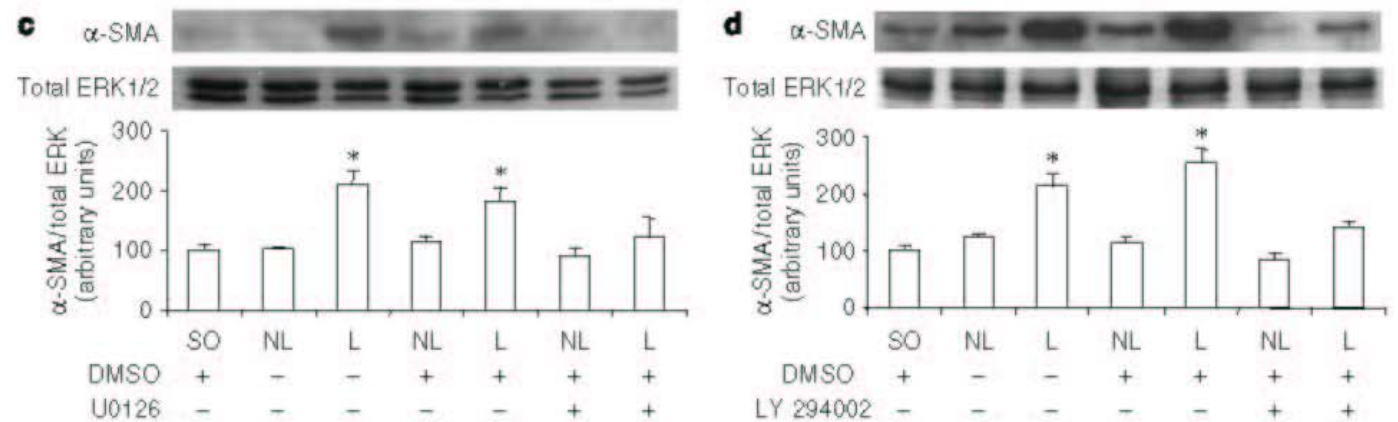

Figure 3 Renal detection of $\alpha$-smooth muscle actin ( $\alpha$-SMA) 3 days after surgery. (a) Representative images of immunohistochemistry for $\alpha$-SMA in kidneys of sham-operated (SO), contralateral non-ligated (NL), and ligated (L) groups, and (b) corresponding morphometrical quantifying of $\alpha$-SMA-immunostained areas in the renal interstitium. Bar $=50 \mu \mathrm{m}$ in all panels. Bars represent the mean \pm s.e.m. of values obtained after quantitative image analysis (see Materials and Methods). (c and d) Representative western blot analysis of $\alpha$-SMA expression in kidneys of SO, NL, and L groups. Bars represent the mean \pm s.e.m. of optical density of signals ( $n=4$ samples per group). Vehicle-control animals received the solvent dimethyl sulfoxide (DMSO). U0126 and LY 294002 groups respectively received the corresponding inhibitors of ERK1/2 and Akt activation, both dissolved in DMSO. $* P<0.05$ vs SO kidneys. " $P<0.05$ vs L untreated group.

Phospho-Akt immunostaining showed a strong granular expression in proximal convoluted tubule cells with the cytoplasmic signal localized to basolateral and medial cell area and scarce or absent staining in both distal and collecting tubules of $\mathrm{SO}$ kidneys (Figure $7 \mathrm{a}$ ). The same pattern of distribution was observed in NL kidneys but with stronger cytoplasmic expression than in SO kidneys in proximal tubules. Ligated kidneys showed an intense expression of pAkt in normal proximal tubular cells, with staining evenly distributed throughout the cytoplasm in most cases. In contrast, low levels of pAkt expression were detected in epithelial tubular cells as a typical feature of altered tubules (Figure 7a). Western blot analysis revealed higher pAkt signal in L kidneys than in NL or SO kidneys (Figure 7c). In 
$\mathbf{a}$

NL.

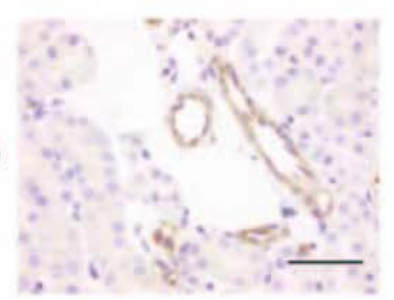

L
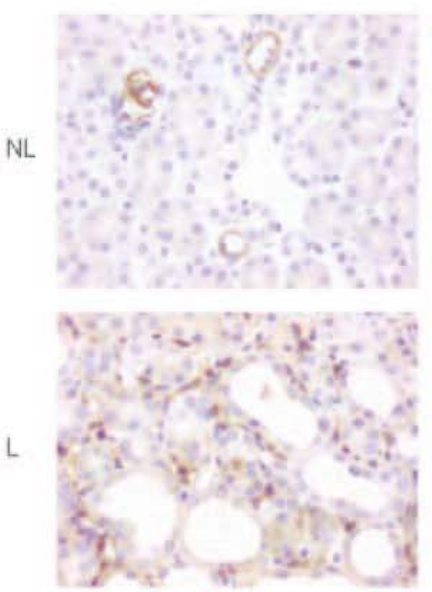

Vehicle
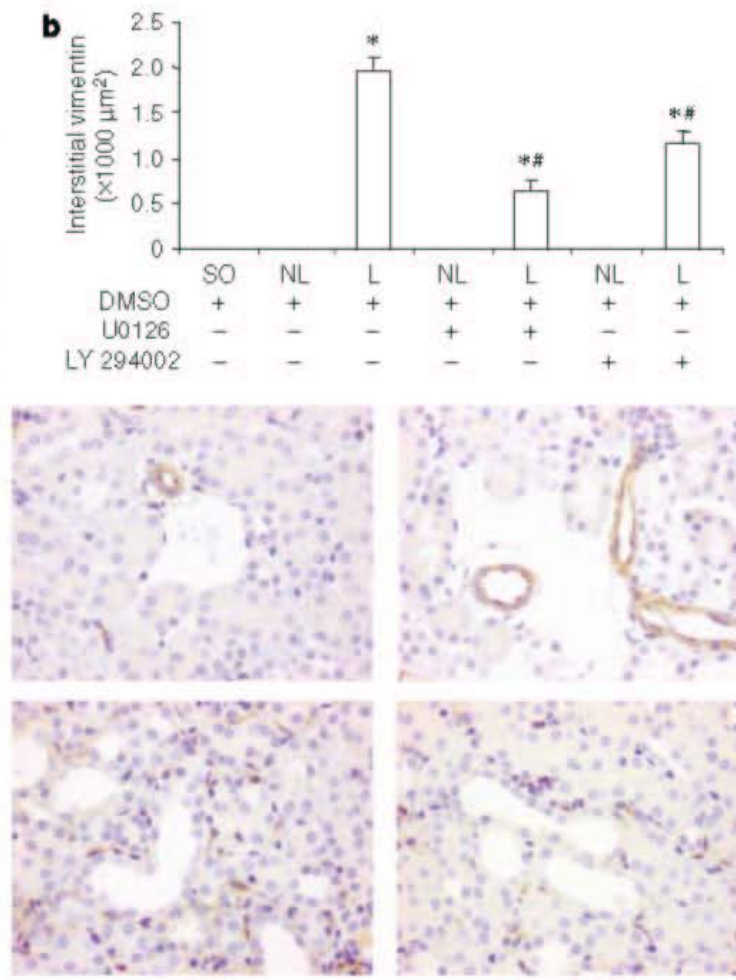

U0126

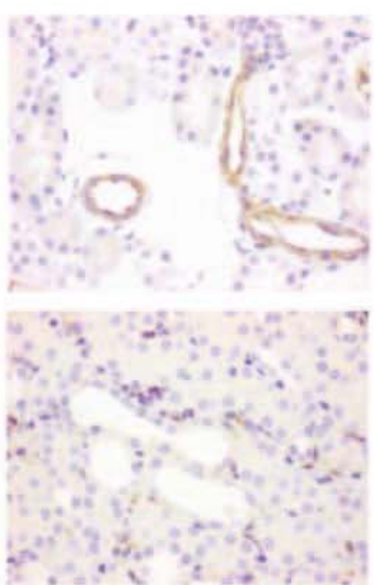

LY 294002

c Vimentin

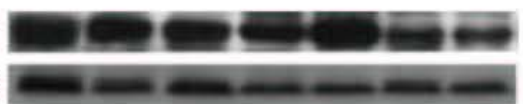

d Vimentin

Total ERK $1 / 2$

Total ERK $1 / 2$
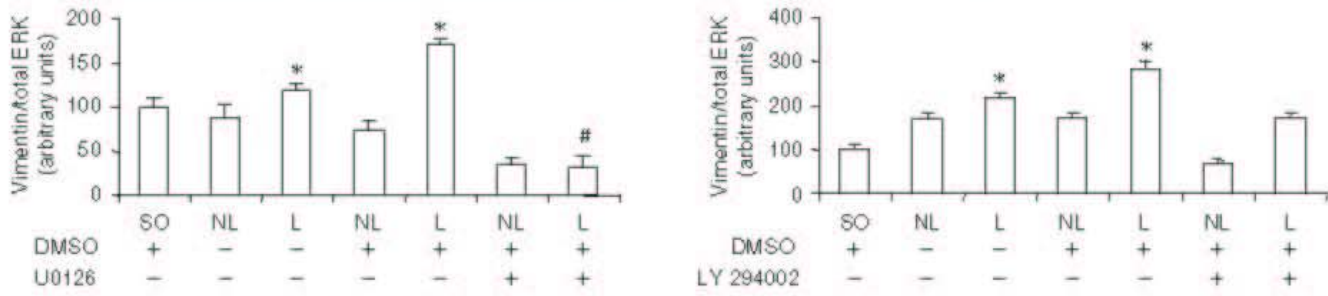

Figure $4 \mid$ Renal detection of vimentin 3 days after surgery. (a) Representative images of immunohistochemistry for vimentin in kidneys of sham-operated (SO), contralateral non-ligated (NL), and ligated (L) groups, and (b) corresponding morphometrical quantifying of vimentin-immunostained areas in the renal interstitium. Bar $=50 \mu \mathrm{m}$ in all panels. Bars represent the mean \pm s.e.m. of values obtained after quantitative image analysis (see Materials and Methods). (c and d) Representative western blot analysis of vimentin expression in kidneys of SO, NL, and L groups. Bars represent the mean \pm s.e.m. of optical density of signals $(n=4$ samples per group). Vehicle-control animals received the solvent dimethyl sulfoxide (DMSO). U0126 and LY 294002 groups respectively received the corresponding inhibitors of ERK1/2 and Akt activation, both dissolved in DMSO. ${ }^{*} P<0.05$ vs 50 kidneys. $P<0.05$ vs $L$ untreated group.

addition, total Akt levels were higher in L kidneys than in NL or SO kidneys as demonstrated by western and northern blot analysis (Figure $8 \mathrm{a}$ and $\mathrm{b}$, respectively).

No differences in ERK1/2 or Akt phosphorylation were detected in kidneys of SO animals receiving DMSO in comparison with kidneys of control SO animals (data not shown). The solvent had no significant effects on PERK1/2 renal expression in UUO mice when compared with the respective control non-treated animals (Figure 7b). Administration of DMSO reduced the obstruction-induced Akt phosphorylation (Figure 7c).

As both MAPK-ERKI/2 and P13K-Akt are downstream effectors of the small Ras GTPase, we assessed Ras activation after UUO. Activated Ras, measured by western blot as the ratio Ras-GTP/total Ras, was markedly higher in the L kidneys compared with NL kidneys or kidneys of SO mice 


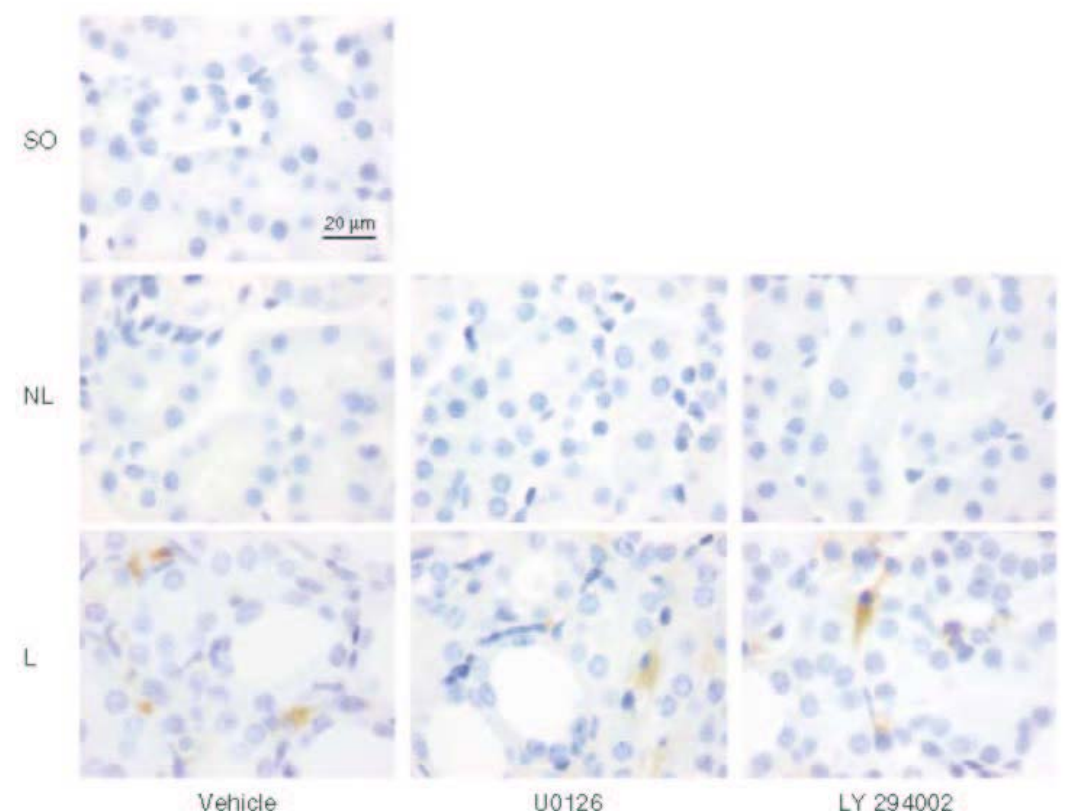

Figure 5 Renal detection of CD68 3 days after surgery. Representative images of immunohistochemistry for CD68 in kidneys of sham-operated (SO), contralateral non-ligated (NL), and ligated (L) groups. Bar- $20 \mu \mathrm{m}$ in all panels. Vehicle-control animals received the solvent dimethyl sulfoxide (DMSO). U0126 and LY 294002 groups respectively received the corresponding inhibitors of ERK1/2 and Akt activation, both dissolved in DMSO.

(Figure 7d). No differences were found between NL and SO kidneys in terms of Ras activation.

\section{Effect of ERK1/2-activation inhibitor on renal changes after ureteral obstruction}

Our next purpose was to assess whether the inhibition of the MAPKK (MEK)1/2-ERK1/2 signaling pathway could modulate the expression of the early fibrosis markers fibronectin and collagen $I$ in kidneys submitted to 3 days of obstruction. Western blot analysis revealed that treatment with U0126 markedly reduced the UUO-induced ERK1/2 activation in L. kidneys (Figure 7b). Administration of U0126 or DMSO did not significantly modify the UUO-induced increase in fibronectin levels (Figure 1c). Furthermore, immunohistochemistry for fibronectin demonstrated a similar distribution in tubulointerstitial areas of both DMSO- and U0126-treated L kidneys (Figure la), and immunohistochemical quantifying also revealed that administration of U0126 does not modify the amount of interstitial fibronectin staining (Figure 1b). Similar results were obtained for collagen I detected by western blot, immunohistochemistry, or semiquantitative immunohistochemical analysis (Figure 2).

Administration of U0126 prevented the UUO-induced $\alpha$-SMA upregulation as demonstrated by western blot analysis (Figure 3c), whereas no significant effect was observed on animals receiving only DMSO. In agreement, reduced $\alpha$-SMA immunostaining was found in the tubulointerstitial areas of L kidneys of U0126-treated mice when compared with L kidneys of DMSO-treated animals (Figure 3a). Quantifying of interstitial $\alpha$-SMA immunostaining revealed a significantly reduced staining in $L$ kidneys of animals treated with U0126 when compared to L kidneys of animals receiving only the vehicle (Figure $3 \mathrm{~b}$ ).

Immunohistochemical analysis demonstrated that the number of vimentin-positive interstitial cells was markedly lower in L kidneys of U0126-treated mice than in L kidneys of DMSO-treated animals (Figure 4a). Morphometrical quantifying revealed that vimentin-stained area was signifcantly lower in L kidneys of U0126-treated mice than in L kidneys of DMSO-treated animals (Figure 4b). Western blot data show that obstruction-induced increase in vimentin expression was completely prevented by treatment with U0126, whereas no effect was observed for the solvent DMSO (Figure 4c).

We have also evaluated the effect of inhibiting MEK1/2ERK1/2 signaling pathway on renal cell proliferation, activated caspase- 3 staining, and TUNEL labeling in obstructed kidneys (Figure 6). Treatment with U0126 induced a slight decrease in the number of $\mathrm{Ki}$-67-stained nuclei in obstructed interstitium whereas the number of stained tubular nuclei was reduced around $50 \%$ in comparison with mice receiving only the vehicle, though these differences did not reach statistical significance (Figure $6 \mathrm{a}$ and $\mathrm{b}$ ).

In L kidneys, U0126 induced a significant decrease in the number of tubules stained with activated caspase- 3 when compared with DMSO-treated animals $(3.7 \pm 0.4$ tubules per 
$\mathbf{8}$

\begin{tabular}{l} 
a \\
$\frac{0}{0}$ \\
$\frac{0}{9}$ \\
\hline
\end{tabular}
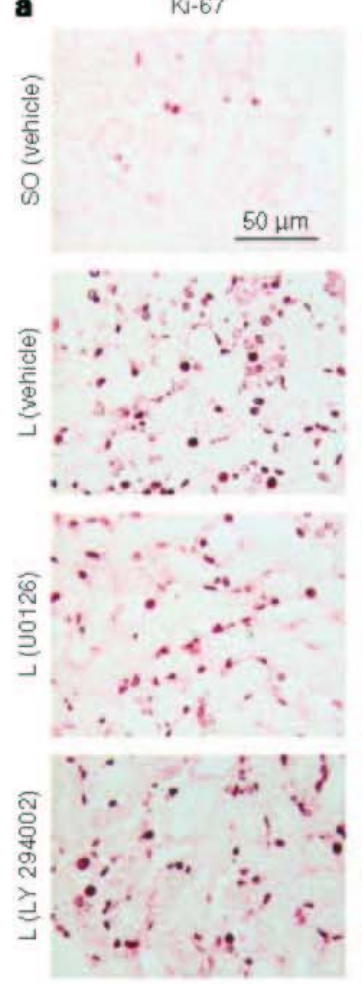

b
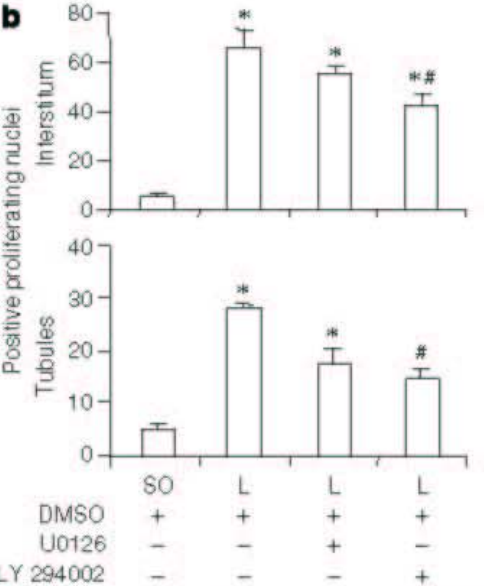

Cleaved-caspase-3
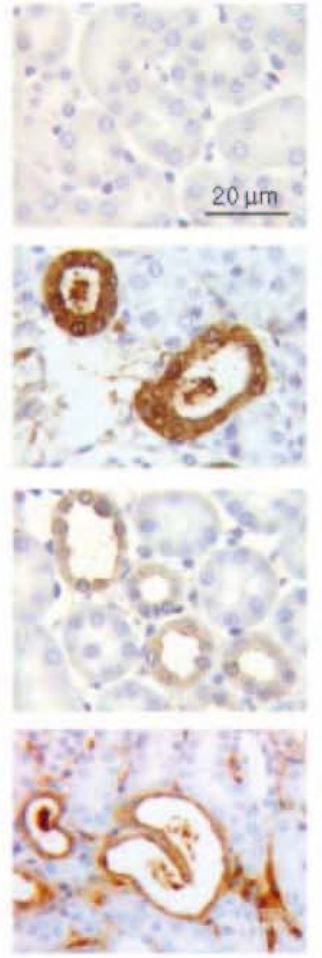

TUNEL
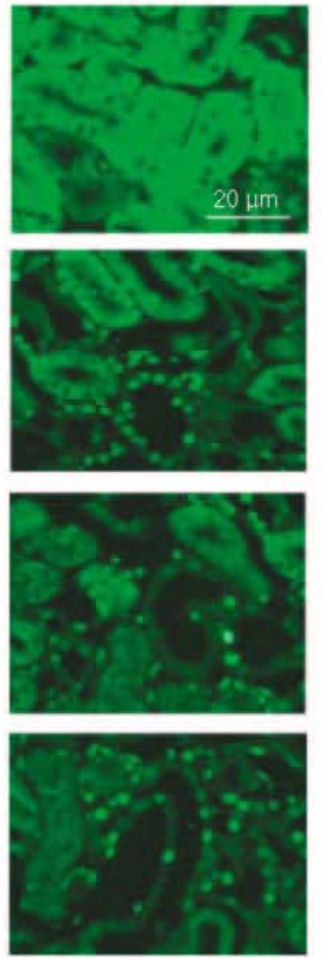

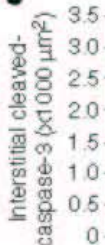

DMSO

U 0126

LY 294002

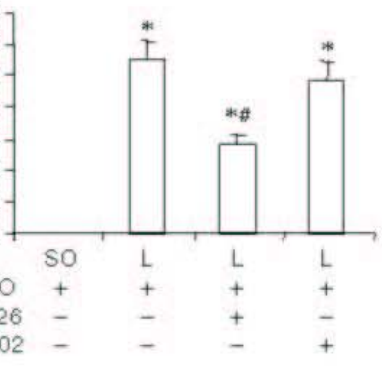

Figure $6 \mid$ Renal detection of Ki-67, cleaved caspase-3, and TUNEL staining 3 days after surgery. (a) Representative renal images of immunohistochemistry for $\mathrm{KL}-67$, deaved caspase-3, and TUNEL assay in kidneys of sham-operated (SO) and ligated (L) groups. Bar - 50 $\mu \mathrm{m}$ for panels of $\mathrm{KI}-67$ and $20 \mu \mathrm{m}$ for panels of caspase-3 and TUNEL staining. (b) Number of either interstitial or tubular Ki-67-positive cells

in the kidneys of SO and L groups. Bars represent the mean \pm s.e.m. of stained cells. (c) Morphometrical quantifying of deaved caspase-3immunostained areas in the renal interstitium. Bars represent the mean \pm s.e.m. of values obtained after quantitative image analysis (see Materials and Methods). Vehicle-control animals received the solvent dimethyl sulfoxide (DMSO). U0126 and LY 294002 groups respectively received the corresponding inhibitors of ERK1/2 and Akt activation, both dissolved in DMSO. * $P<0.05$ vs SO kidneys. "P $<0.05$ vs $L$ untreated group.

field in U0126-treated animals vs $7.8 \pm 0.4$ tubules per field in DMSO-treated animals; $P<0.05$ ). This result correlated with TUNEL assays, which confirmed a decrease in the stained cell nuclei in L kidneys after U0126 treatment (Figure 6a). In contrast to I kidneys of DMSO-treated mice showing the whole tubular epithelia of dilated tubuli strongly stained for cleaved caspase-3, stained tubules of U0126-treated mice presented only a faint staining (Figure 6a). Furthermore, 
a

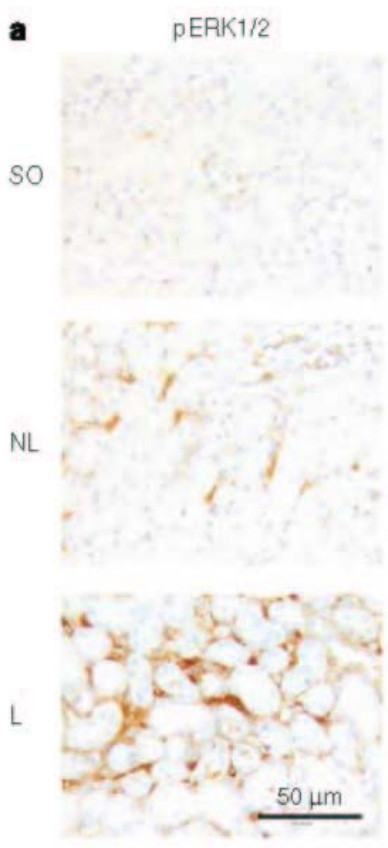

pAkt

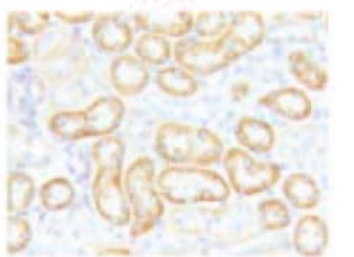

PERK $1 / 2=0=$

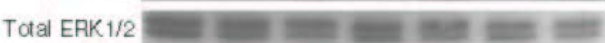

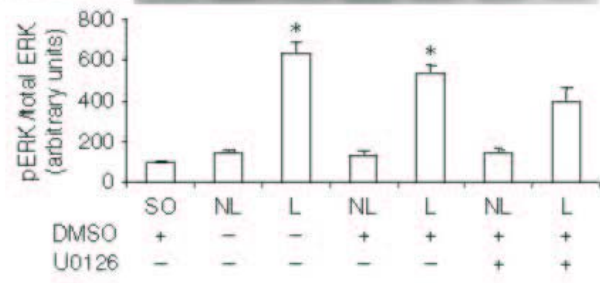

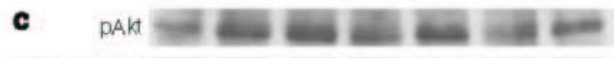

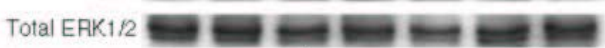

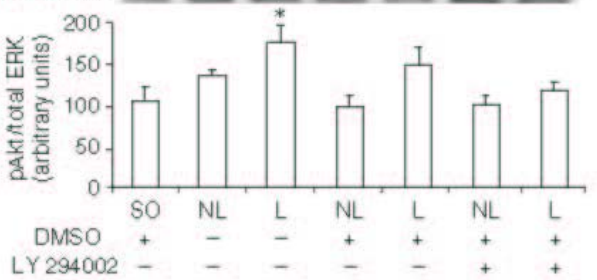

d

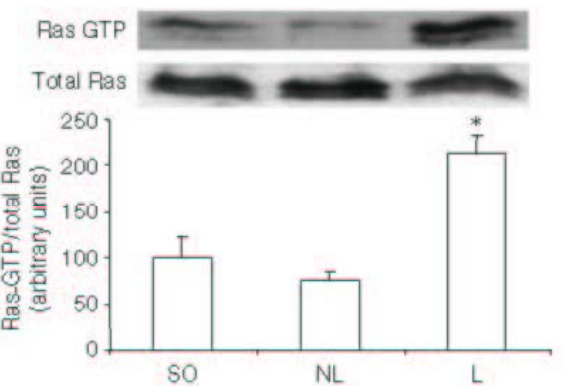

Figure 7 Renal detection of activated forms of ERK1/2, Akt, and Ras 3 days after surgery. (a) Representative immunohistochemical images of activated ERK1/2 (pERK1/2) and Akt (pAkt) in kidneys of sham-operated (SO), contralateral non-ligated (NL), and ligated (L) groups 3 days after surgeny. Asterisk indicates the presence of dilated tubules lacking immunostaining. Bar $=50 \mu m$ in all panels.

(b-d) Representative western blot analysis of pERK1/2, pAkt, and activated Ras (measured as the ratio Ras-GTP/total Ras) expression in kidneys of $\mathrm{SO}, \mathrm{NL}$, and $\mathrm{L}$ groups 3 days after surgery $(n=4$ samples per group, except for Ras detection where at least seven samples per group were used). Bars represent the mean \pm s.e.m. of the optical density of signals. ${ }^{*} p<0.05$ vs SO kidneys. Vehicle-control animals received the solvent dimethyl sulfoxide (DMSO). U0126 and LY 294002 groups respectively received the corresponding inhibitors of ERK1/2 and Akt activation, both dissolved in DMSO.

morphometrical quantifying revealed that $\mathrm{L}$ kidneys treated with U0126 presented a significant lower interstitial area stained for caspase-3 than L kidneys of DMSO-treated mice (Figure 6c).

\section{Effect of PI3K pathway inhibition on renal changes after ligature}

To assess the role of Akt activation in obstruction-induced early renal damage, mice received the specific PI3K inhibitor LY 294002. Western blot analysis revealed that administration of LY 294002 markedly reduced the obstruction-induced Akt activation but not total Alkt (Figures $7 \mathrm{c}$ and $8 \mathrm{a}$, respectively). PI3K inhibitor additionally blunted in a significant manner the ligation-induced increase in both fibronectin (Figure 1d) and collagen I levels (Figure 2d). Immunohistochemistry, as well as corresponding morphometrical quantifying, revealed a significantly lower area occupied by interstitial fibronectin in L kidneys of LY 294002-treated mice than in L kidneys of DMSO-treated animals (Figure $1 \mathrm{a}$ and $\mathrm{b}$ ), with similar results obtained for collagen I expression (Figure 2a and b). Moreover, administration of LY 294002 blunted the obstruction-induced $\alpha$-SMA expression in L kidneys to levels nonsignificantly different from SO mice, as western blot demonstrated (Figure 3d). Reduced tubulointerstitial areas stained with $\alpha$-SMA were also detected in obstructed kidneys of LY 294002-treated mice when compared with DMSOtreated animals (Figure $3 \mathrm{a}$ and $\mathrm{b}$ ).

Similar observations were made for vimentin detection in obstructed lidneys of mice receiving PI3K inhibitor. Immunohistochemical analysis and its corresponding 

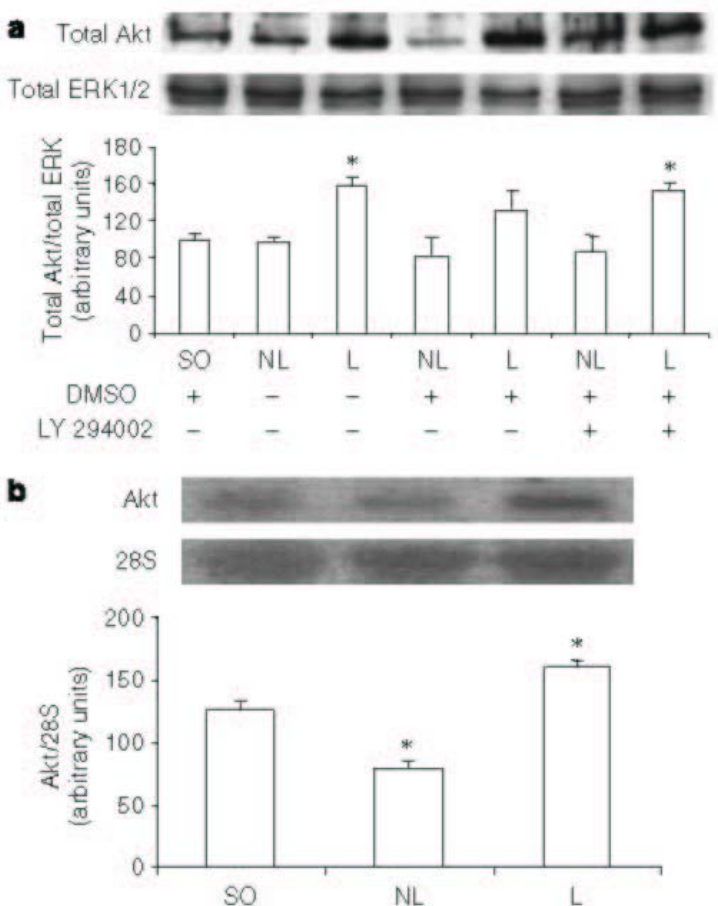

Figure 8 |Renal detection of total Akt protein and Akt mRNA 3 days after surgery. (a) Representative western blot analysis of total Akt expression in kidneys of sham-operated (SO), contralateral non-ligated (NL), and ligated (L) groups 3 days after surgery. (b) Expression of Akt mRNA detected by northem blot analysis in kidneys of SO, NL, and L groups. Bars represent the mean \pm s.e.m. of the optical density of signals $(n=4$ and 7 samples per group in westem and northem blot analysis, respectively). $* p<0.05$ vs $S O$ kidneys, Vehicle-control animals received the solvent dimethyl sulfoxide (DMSO). U0126 and $\mathrm{LY}$ 294002 groups respectively received the corresponding inhibitors of ERK1/2 and Akt activation, both dissolved in DMSO.

interstitial quantifying revealed that the number of vimentinpositive cells were markedly lower in L kidneys of LY 294002treated mice than L in kidneys of DMSO-treated animals (Figure $4 \mathrm{a}$ and $\mathrm{b}$ ). Western blot also demonstrated that administration of LY 294002 clearly reduced the vimentin content in L kidneys, detecting similar levels to those found in SO animals (Figure 4d).

We have also assessed the effect of inhibiting the PI3K-Akt pathway on proliferation, caspase- 3 activation, and TUNEL staining in L kidneys. Inhibition of Akt activation significantly diminished the obstruction-induced increased number of both tubular and interstitial $\mathrm{Ki}$-67-stained nuclei with respect to DMSO-L kidneys (Figure 6a and b). Immunohistochemistry for activated caspase-3 showed a similar number of stained tubules after LY 294002 or vehicle administration in obstructed kidneys ( $7.7 \pm 0.4$ for LY 294002 vs $7.8 \pm 0.4$ tubules per field for DMSO; nonsignificant). TUNEL staining did not show differences in the abundance of tubular stained cell nuclei when images of L kidneys from DMSO- and LY 294002-treated mice were compared (Figure 6a). As morphological quantifying demonstrated, similar interstitial areas occupied by caspase- 3 immunostaining were detected in obstructed kidneys of DMSO- and LY 294002-treated animals (Figure 6c). Though no effects on the number of tubular and interstitial cells stained for cleaved caspase-3 were found, caspase-3-stained dilated tubules showed higher damage degree in kidneys of LY 294002treated animals than in kidneys of DMSO-treated mice as demonstrated by the loss of brush border as well as the flattened and disorganized epithelial tubular cells with frequent tubular denudation (Figure 6a).

\section{DISCUSSION}

\section{Early renal changes in obstructive nephropathy}

In this work, we were interested in the initial mechanisms related to renal damage induced by UUO. Previous studies have already described renal molecular changes as early as $30 \min ^{22}$ and $6 \mathrm{~h}^{12}$ after ureteral ligation. We have observed that renal damage is manifested within 3 days postobstruction by both tubular and interstitial alterations. At this early stage, atrophy and tubular dilation, together with simplification and proliferation of tubular epithelial cells, appeared as pathological features of certain tubules in obstructed kidneys. Our data also showed that tubular cell apoptosis, assessed by TUNEL assay and immunohistochemistry for cleaved caspase-3, was very abundant in L kidneys, whereas only a moderate but significant increase in the amount of interstitial cells expressing cleaved caspase- 3 was observed in obstructed kidneys. These data are in agreement with the proposed role for apoptosis in postobstructive renal damage. 6,7

Fibronectin was included as a marker of early renal fibrosis as previous studies demonstrated that a preformed fibronectin matrix is essential for fibroblasts to form a collagen network, ${ }^{25}$ and an important role in promoting matrix assembly has been described for this protein allowing cells to attach to the matrix. ${ }^{26}$ The increased levels of fibronectin and collagen that we have found in obstructed kidneys revealed that renal changes related to early fibrotic process can be detected as early as 3 days post-UUO. By immunodetection of both $\alpha$-SMA and vimentin, our data also demonstrate that essential changes associated with fibroblast/myofibroblast appearance occur in the obstructed interstitium. In contrast to SO and NL kidneys, where interstitial expression of vimentin or $\alpha$-SMA was not detected, abundant interstitial cells expressing vimentin or $\alpha$-SMA were found in the interstitium of $\mathrm{L}$ kidneys. CD68 immunostaining permitted to discard macrophages as the mainly interstitial cells induced by ligature, as only a very small number of these cells were found positive for $\mathrm{CD} 68$. All these data together suggest that most of interstitial cells appearing 3 days after obstruction present features of fibroblast-myofibroblasts.

Several works based on different animal models have previously reported increased ERK1/2 activation in diseased kidneys. ${ }^{18-22,27-29}$ Here we provide evidence for the increased 
expression of activated ERK1/2 in interstitial areas of kidneys submitted to 3 days of UUO as immunohistochemical and western blot analysis demonstrated. This work also demonstrates that ureteral ligation induced a marked upregulation of both Akt activation and Akt expression, as shown respectively by western blot quantifying of $\mathrm{pAkt}$, and western and northern blot quantifying of total Akt. As revealed with the strong pAlkt immunostaining, normal proximal tubular cell seems to be a main contributor to the obstructioninduced activation of Alct measured by western blot. Our findings suggest that the activation of Ras signaling pathway is likely to be the cause of increased ERK1/2 and Akt phosphorylation in obstructed kidneys, as we have observed an increase in the ratio Ras-GTP/total Ras in the I kidneys when compared with NL or SO kidneys.

\section{Role of ERK1/2 activation in obstructed kidney}

Extra-cellular signal-regulated kinase activation has been related to proliferative response in rats with experimental glomerulonephritis, ${ }^{19,20,29}$ as well as early proliferation of tubular cells in a rat model of UUO. ${ }^{21,22}$ In agreement with UUO studies performed in rat, ${ }^{21,22}$ we have reported a higher activation of $E R K 1 / 2$ in L than in NL kidneys as western blot analysis demonstrated. Immunohistochemical analysis localized this pERK increase to cortical tubulointerstitial areas. This finding is in agreement with a recent report of Zhang et $a L^{30}$, describing that transforming growth factor- $\beta$ induces ERK1/2 activation in cultured immortalized human proximal tubular cells. Treatment with the MEK inhibitor induced a moderate decrease in the number of proliferating interstitial nuclei in L kidneys when compared with L kidneys of mice receiving only the vehicle, whereas the number of proliferating tubular nuclei, though nonsignificant, was reduced to $50 \%$. These data suggest that renal ERK1/2 signaling pathway may partially contribute to early process of tubular cell proliferation induced by obstruction.

In vitro models of oxidative renal injury demonstrated a role for ERK activation in apoptosis of renal fibroblasts ${ }^{31}$ but not in tubular epithelium where it promoted cell survival. ${ }^{28}$ In contrast with previous results, our data suggest that ERK activation is involved in ligation-induced tubular cell apoptosis as it may be deduced from the marked decrease in the number of TUNEL-positive nuclei and the decreased number of tubules as well as total interstitial area stained for activated caspase-3 in L kidneys of U0126-treated mice. In addition, affected tubules presented partial lower staining of epithelial cells and better conservation of tubular structures in contrast to DMSO-obstructed kidneys. It has been recently reported that treatment with U0126 is able to decrease cisplatin-induced tubular cell apoptosis either in vitro ${ }^{32}$ or in vivo. ${ }^{33}$ Taking all these data together, it may be suggested that MEK1/2-ERK1/2 signaling pathway is involved in regulation of obstruction-induced tubular cell apoptosis. Moreover, the reduced levels of interstitial apoptosis that were detected in L kidneys after U0126 also contribute to suggest an important role for ERK1/2 activation in initiating the apoptotic cascade during early UUO. These data are in agreement with previous studies demonstrating that inhibition of ERK1/2 activity in proximal tubular cells prevented cellular apoptosis induced by deprivation of survival factors. ${ }^{34}$

Administration of U0126 gives further proofs of ERK1/2 involvement in UUO-induced renal damage, as demonstrated by the marked interstitial decrease in $\alpha$-SMA and vimentin expression detected in L kidneys treated with U0126 when compared with L kidneys of untreated animals. Interstitial cells expressing $\alpha$-SMA have been related to profibrotic activated fibroblasts at 3 days of UUO; ${ }^{4}$ however, the effect of inhibiting ERK1/2 activation did not modify the increase of interstitial fibronectin or collagen I in I kidneys. The nonsignificant decrease detected in obstruction-induced proliferation of interstitial cells after U0126 treatment may be contributing to this fact. From these data, it could be deduced that activation of MEK $1 / 2-E R K 1 / 2$ cascade is implicated in de novo appearance of myofibroblast-related $\alpha$-SMA- and vimentin-positive cells in the interstitium of obstructed kidneys but, apparently, activated ERK1/2 does not modulate the increased interstitial production of fibronectin and collagen I. Phosphorylation of MAPK-ERK1/ 2 pathway seems also to mediate the initial signaling for apoptotic cascade activation both in interstitium and in tubular epithelium during early renal damage induced by ureteral obstruction.

\section{Role of Akt activation in obstructed kidney}

Tubular apoptosis constitutes a typical feature of renal damage in obstructed kidney, ${ }^{7}$ and the palkt localization that we have reported here may be associated with PI3K/Aktmediated survival mechanisms as the anti-apoptotic role of Akt is well known. ${ }^{17}$ Further support to this hypothesis is given by the fact that dilated tubules of $L$ kidneys presented reduced activity of Alkt and increased staining for activated caspase- 3 as indicative of undergoing apoptosis. Moreover, in vivo inhibition of PI3K-Akt signaling pathway resulted in obstruction-induced increased damage of altered tubules, although no effect on the number of tubular cells stained for cleaved caspase- 3 or in the abundance of TUNEL-labeled nuclei was detected. In vitro experiments have also demonstrated that Alct upregulation prevents apoptosis in proximal tubular cells. ${ }^{34}$ Taking all these data together, it could be suggested that Akt activation after obstruction plays an important role against obstructive injury contributing to survival signaling in renal tubules.

In addition, effects of PI $3 \mathrm{~K}$ inhibition on obstructed interstitium, including the marked decrease in both $\alpha$-SMA and vimentin expression could result in decreased matrix deposition as suggested by the diminished levels of interstitial fibronectin and collagen I detected in L kidney. Alkt activity also appears to be implicated in early mechanisms of cell proliferation in response to renal injury, as decreased levels of $\mathrm{Ki}-67$-positive stained cells were detected in both tubular epithelia and interstitium of L kidney after LY 294002 
treatment. Further evidences of the involvement of the PI3K-Akt signaling pathway in UUO-induced renal damage have been given by a recent study reporting that LY 294002 reduced proliferation and extracellular matrix synthesis in fibroblasts obtained from rat kidney tissue 3 days after UUO. ${ }^{35}$ Furthermore, and also in close agreement with our data, this study also reported that LY 294002 was not able to modify fibroblast apoptosis. ${ }^{35}$ Therefore, early pharmacological downregulation of PI3K-Akt signaling pathway reduces not only the profibrotic interstitial cells but also the potential number of tubular cells that have been described as responsible for excessive interstitial matrix production at later stages of UUO. ${ }^{4}$ All these data suggest that activated Akt plays an essential role in regulating renal cell proliferation, as well as fibroblast activation and matrix production in the interstitium of obstructed kidneys.

\section{Perspectives}

Our results identify a discrete pattern of activation of the RasERK1/2 and -Akt pathways in the kidneys of normal mice and a marked activation of these pathways in lidneys of mice subjected to UUO. As acquisition of mesenchymal features for interstitial cells, such as $\alpha$-SMA and vimentin, has been related to production of interstitial matrix components at early obstruction, the interstitial reduction for these markers observed after U0126 or LY 294002 treatment indicates that inhibition of either MAPK-ERK1/2 or PI3K-Alct signaling pathways could result in an efficient strategy to reduce the number of profibrotic interstitial cells during early fibrosis induced by UUO. Furthermore, we provide evidence that inhibition of PI $3 \mathrm{~K}$ markedly reduced the obstruction-induced increase in both tubular and interstitial proliferating cells, including the profibrotic fibroblast-myofibroblasts in accordance with decreased levels of fibronectin and collagen I detected in the renal interstitium of L kidneys in animals receiving LY 294002. Our study also showed that administration of MEK inhibitor diminishes the increased levels of tubular and interstitial cell apoptosis in obstructed kidneys, and contributes to structural maintenance of renal tubules providing, therefore, a novel strategy to protect epithelial tubular cells from apoptotic renal damage and tubular atrophy induced by obstructive nephropathy.

In conclusion, these results demonstrate that activation of either ERK1/2 or Alk participates in initial changes during early obstructive nephropathy. Pharmacological inhibition of MAPK-ERK1/2 and PI3K-Akt signaling pathways could be a potential target to reduce extracellular matrix deposition in the interstitium of damage kidneys and, therefore, contributes to prevent the development of progressive nephropathy.

\section{MATERIALS AND METHODS}

\section{Animals and disease model}

Surgical procedures were performed in 2-month-old C57BL/6 male mice as previously described. ${ }^{36}$ Animals were kept under controlled ambient conditions (Unidad de Experimentación Animal, University of Salamanca, Spain). The first and third day after ligation, a group of six animals received intraperitoneal administration of U0126 (1,4-diamino-2,3-dicyano-1,4-bis(2-aminophenylthio)-butadiene; LC Laboratories, PKC Pharmaceuticals Inc., Woburn, MA, USA; no. U-6770; $25 \mathrm{mg} / \mathrm{kg} /$ day), which blocks ERK $1 / 2$ activation by inhibiting both active and inactive MEK-1 and MEK-2. Akt activation was blocked by intraperitoneal administration of the PI3K inhibitor LY 294002 (2-(4-morpholino)-8-pheny]-4H-1benzopyran-4-one; LC Laboratories, PKC Pharmaceuticals Inc.; no. L-7962) to a second group of six mice receiving the dose once daily for 3 days after UUO $(50 \mathrm{mg} / \mathrm{kg} /$ day $)$. As $\sim 300 \mu$ of DMSO was required to dissolve each inhibitor, two additional groups of SO $(n=3)$ and UUO mice $(n=4)$ received final equal amounts of this vehicle for 3 days. SO animals $(n=7)$ and animals submitted to 3 days of UUO $(n=7)$ were induded as respective control groups. In all procedures, mice were treated in accordance with the National Institutes of Health Guide for the Care and Use of Laboratory animals.

\section{Renal tissue preparation}

Kidneys of SO animals together with $\mathrm{L}$ and contralateral NL kidneys of UUO mice were recovered 3 days after surgery. Renal samples of animals destined for protein extraction were frozen in liquid nitrogen and stored at $-80^{\circ} \mathrm{C}$ until use. Animals destined for histological studies were perfused with heparinized saline solution$4 \%$ buffered formalin. Kidneys were removed, halved longitudinally, fixed for $24 \mathrm{~h}$ in $4 \%$ buffered formalin, and then embedded in paraffin. Sections 3 - $\mu \mathrm{m}$ thick were cut and mounted on glass slides for immunohistochemical studies and TUNEL assay.

\section{Affinity precipitation of Ras-GTP in renal tissue}

Thirty milligrams of powdered kidney was lysed in $500 \mu l$ of buffer containing $25 \mathrm{~mm}$ 4-(2-hydroxyethyl)-1-piperazineethanesulfonic acid, $\mathrm{pH} 7.5 ; 150 \mathrm{~mm} \mathrm{NaCl}, 1 \%$ igepal CA-630, $10 \mathrm{~mm} \mathrm{MgCl}_{2}$, $1 \mathrm{~mm}$ EDTA, $10 \%$ glycerol, $1 \mathrm{~mm} \mathrm{Na} \mathrm{VO}_{4}, 25 \mathrm{~mm} \mathrm{NaF}, 1 \mathrm{~mm}$ phenylmethanesulfonylfluoride, $10 \mu \mathrm{g} / \mathrm{ml}$ aprotinin, and $10 \mu \mathrm{g} / \mathrm{ml}$ leupeptin. Lysates were cold centrifuged for $10 \mathrm{~min}$ at $4000 \mathrm{~g}$ and the supernatant collected. Following measurement of protein concentration (Biorad, Madrid, Spain), $2 \mathrm{mg}$ of the total protein was added to lysis buffer to yield a final sample volume of $300 \mu$ l. Samples were incubated with $20 \mu \mathrm{g}$ of Raf-1 Ras-binding domain agarose conjugate (Upstate biotechnology, Lake Placid, NY, USA; no. 14-278) and gently rocked at $4^{\circ} \mathrm{C}$ for $30 \mathrm{~min}$. The agarose conjugates were recovered by pulse centrifugation, washed three times with $500 \mu$ l of lysis buffer, resuspended in $40 \mu$ l of Laemmli sample buffer, and boiled for $5 \mathrm{~min}$. Sample supernatants were collected for use in western blot detection of Ras-GTP.

\section{Western blot analyses}

Affinity-precipitated samples described above were used for Ras-GTP detection, whereas total kidney protein lysates $(30 \mu \mathrm{g})$ were employed in the detection of fibronectin, collagen I, $\alpha$-SMA, vimentin, caspase-3, total ERK1/2, pERK, total Akt, pAkt, and total Ras. Samples were electrophoresed in 15\% (Ras), 12\% (ERK1/2, $\alpha$-SMA), $8 \%$ (Akt, vimentin, collagen 1), or $6 \%$ (fibronectin) sodium dodecyl sulfate-polyacrylamide gels and transferred to a nitrocellulose membrane ( $0.45 \mu \mathrm{m}$; BioRad). Membranes were incubated overnight at $4^{\circ} \mathrm{C}$ with following antibodies: anti-Ras (1:1000 dilution; Upstate Biotechnology; no. 05-516), anti-ERK1 (1:1000 dilution; Santa Cruz Biotechnology, Santa Cruz, CA, USA; sc-94), anti-pERK1/2 (1:2000 dilution; Santa Cruz Biotechnology; sc-7383), anti-Akt1/2 (1:1000 dilution; Santa Cruz Biotechnology; sc-8312), 
anti-pAkt (1:1000 dilution; Cell Signaling Technology Inc., Danvers, MA, USA; 9271 no. 172), anti $\alpha$-SMA (1:1000 dilution; Sigma, St Louis, MO, USA; A 2547), anti-vimentin (1:1000 dilution Santa Cruz Biotechnology; no. sc-7557), anti-collagen type I (1:1000 dilution; Chemicon International Inc., Ternecula, CA, USA AB765P), and anti-fibronectin (1:5000 dilution; Chemicon International Inc; AB2033). After incubation with the corresponding horseradish peroxidase-conjugated secondary antibody (1:10,000 dilution; BioRad), membranes were incubated with a chemiluminescent reagent (ECL detection reagents, Amersham, Buckinghamshire, UK) and developed signals recorded on X-ray film (Hyperfilm, Amersham) for densitometric analysis (MacBAS, Fuji, Japan). We have verified by western blot that renal levels of proteins like $\beta$-actin or $\alpha$-tubulin, usually employed as loading control, increased in obstructed kidneys following equal loading of total proteins measured (Supplementary Figure). We have then used total ERK $1 / 2$ as loading control, as no renal changes were detected for this protein after obstruction.

\section{Northern blot analysis}

Total kidney RNA was isolated using the guanidinium thiocyanatephenol-chloroform method, fractionated by electrophoresis $(20 \mu \mathrm{g} /$ lane) in a denaturing $1 \%$ agarose- $2.2 \mathrm{~mol} / 1$ formaldehyde gel, and transferred to a nylon membrane (Hybond, Amersham). The cDNA probe used for Akt was a BamHL/Bgil fragment of murine Akt inserted into the PSG5 plasmid. Forty nanograms of probe were radiolabeled with $\alpha{ }^{32} \mathrm{P}$ dCTP $(3000 \mathrm{Ci} / \mathrm{mmol})$, Results were expressed as $\mathrm{mRNA} / 28 \mathrm{~S}$ relative optical density ratios.

\section{Immunohistochemical studies}

Immunohistochemistry was performed as previously described. ${ }^{36}$ Primary antibodies were anti-fibronectin (1:100 dilution; Sigma; no. F 3648), anti-collagen I (1:200 dilution; Abcam, Cambridge, UK; no. ab6308), anti- $\alpha$-SMA (pre-diluted; DAKO Diagnostics, Copenhagen, Denmark; M0851), anti-vimentin (pre-diluted; Abcam; no. ab8545), anti-CD68 (1:100 dilution; Clone KP1; DAKO Diagnostics; no. M0814), anti-Ki-67 (1:100 dilution; Master Diagnostica, Granada, Spain), anti-cleaved caspase-3 (1:200 dilution; Cell Signaling Technology Inc;; no. 9661), anti-pERK1/2 (1:300 dilution; Santa Cruz Biotechnology; sc-7383), or anti-pAkt (1:50 dilution, Cell Signaling Technology Inc; 9271S no. 172). Following washes in phosphate-buffered saline, sections were incubated with DAKO LSAB2 system + HRP (DAKO), and 3,3'-diaminobenzidine (BioGenex, San Ramon, CA, USA) was used as chromogen. Samples lacking primary antibody, were processed as negative controls.

\section{Semiquantitative immunohistochemical determinations in renal sections}

Quantification of interstitial fibronectin, collagen I, $\alpha$-SMA vimentin, or caspase-3 immunostaining was carried out in a blind trial by using a computer-assisted method based on Visilog 6.5 Professional Imaging software (Noesis, France). At least, 30 consecutive fields of cortical renal interstitium were processed. Automated analysis was performed on individual images saved as 24-bit RGB TIFF file format at Original magnification $\times 20$ by using a specific $\mathrm{C}++$ language program. Our software first transform color images to 256 grey levels, then divide up the image into several areas using intensity of the immunostaining, and last quantify those areas. Final score of each sample was calculated as a mean of the whole scores obtained and expressed in square microns per field.
Counting of renal cells expressing Ki-67 or cleaved caspase-3

The number of tubular or interstitial cells undergoing proliferation (Ki-67-positive immunostaining) or tubular cells expressing the principal executioner caspase of the apoptotic program (cleaved caspase-3-positive immunostaining) was counted under light microscopy at Original magnification $\times 200$ in 6-10 random fields of renal cortex.

\section{TUNEL assay in renal sections}

TUNEL was performed using an in situ cell death detection kit (Roche Molecular Biochemicals, Mannheim, Germany) according to the manufacturer's instructions. The TUNEL labeling was visualized under fluorescence microscopy.

\section{Statistical analysis}

Statistical differences were analyzed by one-way analysis of variance using the NCSS 2000 program. Scheffe's correction test was employed for multiple comparisons. Data were expressed as mean \pm s.e.m., and $P<0.05$ was considered statistically significant.

\section{ACKNOWLEDGMENTS}

We thank Mrs A Pérez for histological assistance. This study was supported by grants from Spanish Ministerio de Ciencia y Tecnología (SAF 2003-04177 and SAF 2007-63893), and instituto Carlos III (RETIC RD/006/0016) and Junta de Castilla y León (SA 001/CO5 and SAN191/ $S A 04 / 06)$. AB Rodríguez Pefia is supported by fondo de imvestigación Sanitaria from Spanish Ministerio de Sanidad y Consumo.

\section{DISCLOSURE}

All the authors declared no competing interests.

\section{SUPPLEMENTARY MATERIAL}

Figure. Representative western blot analysis of total ERK1/2, $\beta$-actin, and $\alpha$-tubulin expression in kidneys of sham-operated $(\mathrm{SO})_{\text {, non- }}$ ligated (NL), and ligated (L) groups 3 days after surgery $(n-4$ samples per group).

Supplementary material is linked to the online version of the paper at http://www.nature.com/ki

\section{REFERENCES}

1. Frolich ED. Hypertension: our major challenges. Hypertension 2001; 38 : 990-991.

2. Bohle A, Müller GA, Wehrmann M et ol. Pathogenesis of chronic renal failure in the primary glomerul opathies, renal vasculopathies and chronic interstitial nephritides. Kodney int 1996; 4: 52-59.

3. Klahr S, Morrissey J. Obstructive nephropathy and renal fibrosis. Am I Physiol Renal Physiol 2002; 283: F861-F875.

4. Liu Y. Epithelial to mesenchymal transition in renal fibrogenesis: pathologic significance, molecular mechanism, and therapeutic intervention. I Am Sor Nephrol 2004; 15: 1-12

5. Powell DW, Mifflin RC, Valentich JD et al. Myofibroblasts. I. Paracrine cells important in health and disease. Am J Physiol 1999; 277: C1-C9.

6. Truong LD, Petrusevska G, Yang $G$ et al. Cell apoptosis and proliferation in experimental thronit obstructive uropathy. Kidney int 1996; 50: $200-207$.

7. Truong LD, Choi YJ, Tsao CC et at. Renal cell apoptosis in chronic obstructive uropathy. The roles of caspases. Kidney int 2001; 60: 924-934.

8. Ricardo S, Ding G, Eufemio $M$ et af. Antioxidant expression in experimental hydronephrosis: Role of mechanical stretch and growth factors. Am J Physiof 1997; 272: F789-F798.

9. Kawada N Moriyama T, Ando A et ol. Increased oxidative stress in mouse Kidneys with unilateral ureteral obstruction. Kidney int 1999; 56: 1004-1013.

10. Diamond JR, Kees-Folts D, Ding $G$ et al Macrophages, monocyte chemoattractant peptide-1, and TGF-beta 1 in experimental hydronephrosis. Am J Physiod 1994; 266: F926-F933. 
11. Kaneto H, Morrissey L, McCracken R et of. Enalapril reduces collagen type IV synthesis and expansion of the interstitium in the obstructed rat kidney. Kidney int 1994; 45: 1637-1647.

12. Pimentel Jr JL, Sundell CL, Wang $S$ et ol. Role of angiotensin II in the expression and regulation of transforming growth factor $\beta$ in obstructive nephropathy. Kidney int 1995; 48: 1233-1246.

13. Reyes AA, Klahr S. Renal function after release of ureteral obstruction. Role of endothelin and the renal artery endothelium. Kidney int 1992; 42: 632-638.

14. Kaneto H, Morrissey J, Klahr S. Increased expression of TGF-beta 1 mRNA in the obstructed kidney of rats with unilateral ureteral ligation. Kidney int 1993; 44: $313-321$

15. Rodriguez Pena $A B$, Santos $E$, Arevalo $M$ et d. Adtivation of small GIPase Ras and renal fibrosis, I Nephrof 2005; 18: 341-349.

16. Pouysségur J, Volmat V, Lenormand P. Fidelity and spatio-temporal control in MAP kinase (ERKs) signaling. Biochem Pharmocol 2002;64 755-763.

17. Osaki M, Oshimura M, ito H. PI3K-Akt pathway. Its functions and alterations in human cancer. Apoptosis 2004; 9: 667-676.

18. Feliers D, Duraisamy S, Faulkner $d$ et of. Activation of renal signaling pathways in db/db mice with type 2 diabetes. Kidney int 2001; 60 : $495-504$.

19. Bokemeyer D, Panek D, Kramer HJ et al, in vivo identification of the mitogen-activated protein kinase cascade as a central pathogenic pathway in experimental mesangioproliferative glomerulonephritis. Am Soc Nephroi 2002: 13: 1473-1480.

20. Bokemeyer D, Ostendorf $\mathrm{T}$, Kunter $\mathrm{U}$ et of. Differential activation of mitogen-activated protein kinases in experimental mesangioproliferative glomerulonephritis. I Am Sor Nephrof 2000; 11: 232-240.

21. Pat $B$, Yang $T$, Kong $C$ et od. Activation of ERK in renal fibrosis after unilateral ureteral obstruction: modulation by antioxidants. Kidney in 2005; 67: $931-943$

22. Masaki T, Foti R, HIll PA et al, Activation of ERK pathway precedes tubular proliferation in the obstructed rat kidney, Kidney int 2003; 63: 1256-1264.

23. Scholzen T, Gerdes J. The Ki-67 protein: from the known and the unknown. J Celf Physiol 2000; 182: 311-322.

24. Budihardjo I, Oliver $\mathrm{H}$, Lutter $\mathrm{M}$ et at, Biochemical pathways of caspase activation during apoptosis. Annu Rev Cett Dev Biol 1999; 15: 269-290.
25. Velling $T$, Risteli I, Wennerberg $K$ et of Polymerization of type I and III collagens is dependent on fibronectin and enhanced by integrins alpha 11 beta 1 and alpha 2beta 1. J Biot Chen 2002; 277: 37377-37381.

26. Morla A, Ruoslahti E. A fibronectin self-assembly site involved in fibronectin matrix assembly: reconstruction in a synthetic peptide. $J$ Celf Brot 1992; 118: $421-429$.

27. Haneda M, Araki S, Togawa M et of. Mitogen-activated protein kinase cascade is activated in glomeruli of diabetic rats and glomerular mesangial cells cultured under high glucose conditions. Diobetes 1997 46: $847-853$.

28. di Mari JF, Davis $R$, Safirstein RL. MAPK activation determines renal epithelial cell survival during oxidative injury. Am J Physiol 1999; 277 : F195-F203.

29. Bokemeyer D, Guglielmi KE, McGinty A et al. Activation of extracellular signal-regulated kinase in proliferative glomerulonephritis in rats. $f$ Chin thvest 1997; 100: 582-588.

30. Zhang $M$, Fraser D, Phillips A. ERK, p38 and smad signaling pathways differentially regulate transforming growth factor- $\beta 1$ autoinduction in proximal tubular epithelial cells. Am J Pathol 2006; 169: 1282-1293.

31. Pat $B K$, Cuttle L, Watters $D$ et at. Fibrogenic stresses activate different mitogen-activated protein kina se pathways in renal epithelial, endothelial or fibroblast cell populations. Nephrology (Cariton) 2003; 8: 196-204.

32. Arany I, Megyesi JK, Kaneto $\mathrm{H}$ et of. Cisplatin-induced cell death is EGFR/src/ERK signaling dependent in mouse proximal tubule cells. Am I Physiol Renal Physiol 2004: 287: F543-F549.

33. Jo SK, Cho WY, Sung SA et ol MEK inhibitor, U0126, attenuates cisplatininduced renal injury by decreasing inflammation and apoptosis. Kidney int 2005; 67 : 458-466.

34. Sinha D, Bannergee S, Schwartz JH et af. Inhibition of lig and-independent ERK1/2 activity in kidney proximal tubular cells deprived of soluble survival factors up-regulates Akt and prevents apoptosis. $f$ Brof Chem 2004; 279: 10962-10972.

35. Winbanks CE, Grimwood L, Gasser A et at Role of the phosphatidylinositol 3-kinase and mTOR pathways in the regulation of renal fibroblast function and differentiation, int 1 Biochem Celf Biol 2007; 39. 206-219.

36. Rodriguez-Pena $A$, Eleno $N$, Duwrell $A$ et at. Endoglin upregulation during experimental renal interstitial fibrosis. Hypertension 2002; 40: 721-728. 


\section{Artículo VII}

"Contribution of Angiotensin II and Ras signalling pathway activation to early renal interstitial changes induced by obstructive nephropathy in mice"

María T. Grande, Ana B. Rodríguez-Peña, Neil Docherty, Miguel Arévalo, y José M. López-Novoa

Clinical Science (enviado) 
Contribution of Angiotensin II and Ras signalling pathway activation to early renal interstitial changes induced by obstructive nephropathy in mice

Ana B. Rodríguez-Peña, ${ }^{{ }^{*}-\& \#}$ María T. Grande,${ }^{{ }^{* \#}}$ Neil Docherty, ${ }^{{ }^{*}}$ Miguel Arévalo, ${ }^{\text {\&*}}$ and José M. López-Novoa ${ }^{\S *}$

${ }^{\S}$ Instituto "Reina Sofia" de Investigación Nefrológica, *Departamento de Fisiología y Farmacología, ${ }^{\&}$ Centro de Investigación del Cáncer, and \&Departamento de Anatomía e Histología Humanas, Universidad de Salamanca, Salamanca, Spain.

\# These authors contributed equally to this manuscript

Short title: Ras activation and early obstructive nephropathy

\section{Key Words:}

Akt, ERK1/2, $\mathrm{AT}_{1}$ inhibition, farnesyl transferase inhibitors, interstitial fibrosis, obstructive nephropathy, statins, ureteral ligation.

\section{Corresponding Author:}

José M. López-Novoa Ph.D.

Departamento de Fisiología y Farmacología;

Edificio Departamental;

Campus Miguel de Unamuno;

37007 Salamanca (Spain)

Phone: (+34) 923294472 ;

Fax: (+34) 923294669 ;

E-mail: jmlnovoa@usal.es 


\begin{abstract}
:
Unilateral ureteral obstruction (UUO) is a model of tubulointerstitial fibrosis in which local early increases in angiotensin II and fibroblast-myofibroblast proliferation play a key role in fibrosis deposition. Activation of the small GTPase Ras and its downstream effectors, extracellular signal-regulated kinases 1 and 2 (ERK1/2) and Akt, has been also reported in the first days after UUO in C57BL/6J mice. The purpose of this study was then to assess the role of Ras signaling pathway upon renal changes induced by 3 days of UUO in mice as well as the possible role of angiotensin II activating Ras pathway after UUO. Angiotensin II induced renal activation of Ras and its downstream effectors ERK1/2 and Akt within 4 hours of administration .Early obstruction-induced activation of Ras, ERK1/2 and Akt, as well as interstitial fibronectin and alpha smooth muscle actin ( $\alpha$-SMA) overexpression were blunted when mice received blockers of Ras activation such as farnesyl transferase inhibitor or atorvastatin. A similar effect on activated Ras, fibronectin and $\alpha$-SMA was observed when the mice received the angiotensin type 1 receptor blocker losartan.

These results suggest the involvement of angiotensin II overexpression in the early activation of Ras signaling pathway after UUO. Furthermore, upstream inhibition of Ras signaling by blocking either angiotensin II pathway or Ras activation can decrease extracellular matrix deposition in the obstructed kidney. Our results also suggest that pharmacological inhibition of Ras activation may hold promise as a future strategy in the prevention of renal fibrosis.
\end{abstract}




\section{Introduction}

Renal interstitial fibrosis is a common histopathological end point in all forms of progressive renal disease independently of its etiology [1]. Unilateral ureteral obstruction (UUO) in mice is a well-established experimental model resulting in tubulointerstitial fibrosis in the obstructed kidney $[2,3]$.

Angiotensin II (Ang II) has been involved in hemodynamic alterations after UUO, such as the increase in renal vasoconstriction and in systolic blood pressure and the decrease in renal plasma flow and glomerular filtration rate [4-6]. Ang II behaves also as a proinflammatory cytokine in the kidney, because it activates the NF-kappaB family of transcription factors, which in turn, fuels at least two autocrine reinforcing loops that amplify Ang II and TNF- $\alpha$ formation [7]. Ang II plays also a major role in the interstitial cell infiltration induced by UUO [8]. Ang II has also profibrotic effects and UUO-induced fibrosis and myofibroblast expression was inhibited by Ang II receptor blockade [9-11]. The role of Ang II in UUO-induced apoptosis is uncertain, as contradictory results of the effects of Ang II receptor blockade and apoptosis have been reported $[10,12,13]$.

Many growth factors are known to activate intracellular signalling pathways that converge on the activation Ras monomeric GTPases, which in turn regulate gene expression, cytoskeleton organization proliferation, and migration by activating the mitogen-activated protein kinase (MAPK) and the phosphatidylinositol-3 kinase (PI3K) signalling pathways [14]. Ras/MAPK pathway has been reported to be stimulated by Ang II $[15,16]$. Recently we have demonstrated that both Ras ant its signaling pathways Erk1/2 and PI3K/Akt were activated early after UUO [17] but there are no data demonstrating the role of Ras activation in the early changes observed in the kidney after UUO. Activation of the Ras requires protein prenylation through farnesyl transferase, allowing the protein anchorage to the cell membrane and the subsequent interaction with its effectors. Thus we aimed to evaluate the effect of farnesyl transferase inhibition and inhibition of the enzyme HMG-CoA reductase, which results in decreased synthesis of farnesyl groups. Furthermore, although the rennin-angiotensin system has been reported to be activated early after UUO [18], and that long-term Ang II administration induced fibrosis in the kidney, no studies have been devoted to assess Ang II over production and early renal damage early after UUO. Thus we have assessed the effects of short-term Ang II administration and the effects of AT1 
antagonist administration on Ras activation, MAPK/ERK and PI3K/Akt pathways activation, accumulation of extracellular matrix components and presence of activated fibroblast markers after 3 days of UUO.

\section{Methods}

\section{Animals}

Two months old male C57BL/6J male mice were kept in a germ-free facility, under controlled environmental conditions (Unidad de Experimentación Animal, University of Salamanca, Spain). Mice were reared on standard chow (Panlab, Barcelona, Spain) and provided with water ad libitum. All procedures were approved by the Committee for Animal Care and Use of the University of Salamanca and complied with the Guide for the Care and Use of Laboratory Animals [19].

\section{Angiotensin II administration}

Mice $(n=5)$ received a single dose of Ang II in a single intraperitoneal dose of 0,8 $\mathrm{mg} / \mathrm{Kg}$ (Sigma, Saint Louis, MO, USA) and control group $(\mathrm{n}=3)$ were treated with a single dose of saline $(\mathrm{NaCl} 0,9 \%)$. After four hours mice were anesthetized and kidneys were removed.

\section{Disease model}

Surgical techniques to produce UUO were performed as previously described [17]. In all procedures, animals were treated in accordance with the National Institutes of Health Guide for the Care and Use of Laboratory Animals.

\section{Inhibitors administration}

Mice in the losartan group $(n=5)$ received a daily intraperitoneal injection of losartan (40 mg/kg; Du Pont, Wilmington, DE, USA) for 4 days, whereas mice in the control group $(\mathrm{n}=3)$ received isotonic saline $(\mathrm{NaCl} 0,9 \%, 0.1 \mathrm{ml})$. UUO was carried out on the second day of treatment.

Mice in the farnesyl transferase inhibitor $(\mathrm{FTI})$ group $(n=5)$ received a subcutaneous injection of the FTI L-744,832 (40 mg/kg/day; Biomol Inc, Plymouth Meeting, PA, USA) whereas the control group $(\mathrm{n}=3)$ received $0.1 \mathrm{ml}$ of vehicle solution $(17 \mathrm{mM}$ sodium citrate, $94 \mathrm{mM}$ sodium chloride; $\mathrm{pH}$ 5.4) daily for 6 days. Ureteral obstruction was performed on the fourth day of treatment. 
Mice in the atorvastatin group $(\mathrm{n}=4)$ received atorvastatin calcium $(70 \mathrm{mg} / \mathrm{kg} / \mathrm{day}$; Pfizer, Madrid, Spain) by oral gavage, whereas control mice $(n=3)$ received carboxymethylcellulose vehicle, once daily for 6 days. Ureteral obstruction was performed at the fourth day after initiating treatment.

\section{Kidney tissue preparation}

Three days after UUO, the ligated (O) and non ligated contralateral (NO) kidneys of each animal and kidneys from sham-operated (SO) animals were recovered. Kidneys destined for protein and RNA extraction were frozen in liquid nitrogen and stored at $80^{\circ} \mathrm{C}$ until use. For histological studies, animals were perfused with heparinized saline solution and $4 \%$ buffered formalin. Kidneys were removed, halved longitudinally, fixed for 24 hours in $4 \%$ buffered formalin and then embedded in paraffin. Sections $3 \mu \mathrm{m}$ thick were cut and mounted on glass slides that were processed either for hematoxylineosin staining or immunohistochemistry.

\section{Affinity precipitation of Ras-GTP in renal tissue}

Thirty milligrams of powdered kidney were lysed in $500 \mu \mathrm{L}$ of buffer containing 25 mmol/L HEPES, pH 7.5; 150 mmol/L NaCl, 1\% igepal CA-630, 10 mmol/L $\mathrm{MgCl}_{2}, 1$ mmol/L EDTA, 10\% g1ycerol, 1 mmol/L Na$V_{3} V_{4}, 25$ mmol/L NaF, 1 mmol/L PMSF, $10 \mu \mathrm{g} / \mathrm{mL}$ aprotinin and $10 \mu \mathrm{g} / \mathrm{mL}$ leupeptin. Lysates were cold centrifuged for $10 \mathrm{~min}$. at $4000 \mathrm{~g}$ and the supernatant collected. Following measurement of protein concentration (Biorad, Madrid, Spain), $2 \mathrm{mg}$ of the total proteins were added to lysis buffer to yield a final sample volume of $300 \mu \mathrm{L}$. Samples were incubated with $20 \mu \mathrm{g}$ of Raf-1 Ras binding domain agarose conjugate (Upstate Biotechnology, Lake Placid, NY; \#14-278) and rocked at $4^{\circ} \mathrm{C}$ for $30 \mathrm{~min}$. The agarose conjugates were recovered by centrifugation, washed 3 times with $500 \mu \mathrm{L}$ of lysis buffer, resuspended in $40 \mu \mathrm{L}$ of Laemmli sample buffer and boiled for $5 \mathrm{~min}$. Sample supernatants were used in Western blot detection of Ras-GTP.

\section{Western blot analyses}

Affinity precipitated samples described above were used for Ras-GTP detection, while total kidney protein lysates $(30 \mu \mathrm{g})$ were employed in the detection of total Ras, pERK1/2, total ERK1/2, pAkt, total Akt, fibronectin and $\alpha$-SMA. Samples were electrophoresed in 15\% (Ras), 12\% (ERK1/2, $\alpha$-SMA), 8\% (Akt) or 6\% (fibronectin) 
SDS-polyacrylamide gels and transferred to a nitrocellulose membrane $(0.45 \mu \mathrm{m}$, BioRad, Madrid, Spain). Membranes were incubated overnight at $4^{\circ} \mathrm{C}$ with the following antibodies: anti-Ras (1:1000 dilution; Upstate Biotechnology, Lake Placid, NY; \#05516), anti-ERK1 (1:1000 dilution; Santa Cruz Biotechnology, Santa Cruz, CA, USA; sc-94), anti-pERK1/2 (1:2000 dilution; Santa Cruz Biotechnology, Santa Cruz, CA, USA; sc-7383), anti-Akt1/2 (1:1000 dilution; Santa Cruz Biotechnology, Santa Cruz, CA, USA; sc-8312), anti-pAkt (1:1000 dilution; Cell Signaling Technology, Beverly, MA, USA; 9271S\#172), anti-fibronectin (1:5000 dilution; Chemicon International, Barcelona, Spain; AB2033) and anti- $\alpha$-SMA (1:1000 dilution; Sigma, St. Louis, MO, USA; A 2547). After incubation with the corresponding horseradish peroxydaseconjugated secondary antibody (1:10000 dilution; Bio-Rad, Madrid, Spain), membranes were incubated for $1 \mathrm{~min}$ with a chemiluminescent reagent (ECL detection reagents, Amersham, Cardiff, UK) and developed signals recorded on x-ray film (Hyperfilm, Amersham, Cardiff, UK) for densitometric analysis (MacBAS V2.5, Fujifilm, Japan).

\section{Immunohistochemical studies}

Immunohistochemistry was performed as previously described [20]. Primary antibodies were: anti-fibronectin (1:100 dilution; Sigma, St. Louis, MO, USA; F 3648), anti- $\alpha-$ SMA (pre-diluted; Dako, Copenhagen, Denmark; M0851). Following washes in PBS, the sections were incubated with the DAKO LSAB2 system +HRP and $\mathrm{f} 3$, 3'diaminobenzidine (DAB, BioGenex, San Ramon, CA, USA) was used as chromogen.

\section{Statistical analysis}

Statistical differences were analysed by one-way analysis of variance (ANOVA) using the NCSS 2000 program (Utah, USA). Data with a normal distribution were analyzed with the Scheffe's multiple-comparison test whereas those without normal distribution were analyzed using the Kruskal-Wallis multiple-comparison test. Data were expressed as mean \pm SEM and $P<0.05$ or $Z>1.96$ were considered statistically significant. 


\section{Results}

Short term Angiotensin II infusion and UUO leads to activation of the renal Ras signaling pathways

Administration of Ang II for 3 hours produced an increase in renal Ras activation (Figure 1A), and also an increase of renal ERK1/2 activation, measured as the ratio of phosphorylated-ERK (p-ERK) and total ERK expression (Figure 1B), and Akt activation measured the amount of phosphorylated-Akt (p-Akt) and total Akt expression (Figure 1C) assessed by western blot, when compared with saline-treated control group.

\section{Effect of AT1 receptor antagonist on renal Ras activation and renal changes after UUO}

Having demonstrated the activation of the Ras signaling pathway in renal tissue, both during UUO [17] and after Ang II administration, we then aimed to determine the effect of administration of the AT1 receptor antagonist losartan on the activation of the Ras/ERK/Akt signaling pathway and the fibronectin and $\alpha$-SMA expression in the kidneys of mice 3 days after UUO. Western blot analyses showed that Ras activation in O kidneys was markedly blunted in losartan-treated animals when compared with control group mice (Figure 2A). After obstruction both ERK1/2 and Akt activation (Figure 2B and 2C) and Akt overexpression (Figure 2D), were slightly lower in losartan-treated mice than in untreated animals. Fibronectin expression levels were significantly lower in $\mathrm{O}$ kidneys of losartan-treated group than in untreated $\mathrm{O}$ kidneys (Figure 2E). Furthermore, $\alpha$-SMA levels in O kidneys of losartan-treated animals waere slightly lower than in saline-treated group (Figure 2F). Immunohistochemical detection of fibronectin revealed a marked attenuation of interstitial fibronectin staining in $\mathrm{O}$ kidneys from losartan group when compared with non-treated animals (Figure 3). Interstitial $\alpha$-SMA immunostaining was also lower in $\mathrm{O}$ kidneys of animals treated with losartan than those from untreated animals (Figure 4).

\section{Effect of Ras activation inhibitors on renal Ras activation and changes after UUO}

Our next purpose was to assess whether inhibition of Ras activation after UUO could modulate its downstream effectors, ERK1/2 and Akt, fibronectin, and $\alpha$-SMA expression. For this purpose we inhibited the enzyme farnesyl transferase that catalyzes the binding of farnesyl groups to Ras, a necessary step for membrane localization and activation [21]. Pull-down and Western blot analysis revealed that O kidneys of FTI- 
treated mice showed a lower Ras activation than $\mathrm{O}$ kidneys of vehicle-treated mice (Figure 5A). FTI administration significantly blunted the obstruction-induced increase in pERK1/2 and only slightly in pAkt or total Akt (Figure 5B, C and D, respectively). The increase in fibronectin levels observed in $\mathrm{O}$ kidneys were markedly reduced after FTI treatment when compared to levels found in O kidneys of untreated mice (Figure 5E). O kidneys from FTI-treated group showed lower levels of $\alpha$-SMA than those from untreated mice (Figure 5F). With respect to the NO kidneys, perk levels were significantly lower in the FTI-treated than in the vehicle-treated group. Immunohistochemistry revealed a lower fibronectin (Figure 3) and $\alpha$-SMA (Figure 4) staining in the renal cortical interstitium of FTI-treated than in the untreated mice.

We also used atorvastatin to inhibit 3-hydroxy-3-methylglutaryl coenzyme A (HMG-CoA) reductase, the enzyme that regulates mevalonic acid synthesis. By inhibiting this rate-limiting step of cholesterol biosynthesis, statins also prevent the synthesis of isoprenoid intermediates required for Ras translocation to the membrane and subsequent activation $[22,23]$. Western blot analysis revealed that $\mathrm{O}$ kidneys from mice that received atorvastatin showed lower levels of Ras-GTP, pERK1/2 and pAkt, when compared with the $\mathrm{O}$ kidneys of mice receiving vehicle (Figure 6A, B and $\mathrm{C}$, respectively). Total Akt expression was also lower in the O kidneys of atorvastatin group than in untreated group (Figure 6D). Once demonstrated that the statin reduced the activation of the major pathways involved in Ras signaling, we assessed whether atorvastatin treatment modified UUO-induced fibronectin and $\alpha$-SMA overexpression. Our data revealed a lower amount of fibronectin and $\alpha$-SMA in the O kidneys from atorvastatin-treated mice than in the $\mathrm{O}$ kidneys from vehicle-treated animals (Figure $6 \mathrm{E}$ and $\mathrm{F}$, respectively). Inmunohistochemical data also revealed a lower amount of $\alpha$ SMA (Figure 4) and fibronectin (Figure 5) in the O kidneys of animals treated with atorvastatin that in the untreated animals.

\section{Discussion}

Increased levels of Ang II have been suggested to play a major role for in the development of experimental UUO [24]. Previous studies have demonstrated increases in both the mRNA and protein levels of renin, angiotensin converting enzyme activity, and Ang II content in the obstructed kidney as early as 1 day after UUO [18]. Additionally, renal Ras/ MAP kinase had been reported to be activated by infusion of 
Ang II, during 6 days in rats $[15,25]$. However, the interpretation of the effects of this long time infusion on the activation of Ras and its effector is difficult due to the effects of Ang II on cell infiltration observed after that time [8]. To our knowledge, the effects of shorter Ang II administration times on Ras activation have not been assessed. Thus we analyzed renal Ras/MAP kinase activation 4 hours after Ang II administration and we observed that both Ras and MAP kinase activities were increased in renal tissue of the animals that received Ang II. Akt activation was also increased by Ang II treatment, thus demonstrating a rapid activation of the Ras/Erk/Akt pathway by Ang II.

It has been previously reported that UUO induced a rapid activation of Ras and its effectors, Raf/ERK and PI3K/Akt pathways [17, 20]. ERK1/2 activation seems to be involved in early proliferation of tubular cells in a rat model of UUO [26, 27] whereas Akt activation seems to be involved in early interstitial cell proliferation and fibronectin and $\alpha$-SMA expression in obstructive nephropathy [17]. Data from the present study demonstrate that short-term Ang II administration induces activation of Ras, assessed as increased levels of Ras-GTP, as well as activation of its effectors, PI3K/Akt and Raf/Erk, assessed by the increase of the levels of pAkt and pErk1/2 respectively.

Next, we aimed to analyze the role of Ang II overproduction on early Ras activation after UUO. For this purpose we have assessed the effects of Ang II type 1(AT1) receptor antagonist on renal Ras activation and renal changes after 3 days of UUO. Blockade of AT1 receptors by losartan, resulted in marked reduction of the levels of Ras-GTP in the obstructed kidney. Erk1/2 and Akt pathways activation were also slightly blunted by losartan administration. Therefore, it could be suggested that the increased renal Ang II levels induced by UUO could exert an autocrine-paracrine effect resulting in the stimulation of Ras signaling activity mediated via AT1 receptor stimulation. As inhibition of obstruction-induced Ras activation by losartan treatment was accompanied by a markedly reduction of fibronectin and $\alpha$-SMA expression, a role for Ang II-induced Ras activation could be suggested in the early stage of renal damage induced by ureteral obstruction in mice. Our results are in agreement with studies reporting that AT1 receptor blockade diminished fibrosis and fibroblast marker expression after 3 weeks of UUO [10]. However, we observe this effect as early as 3 days after UUO, a time period before marked renal fibrosis and myofibroblast infiltration is present. Considering all this data together, it could be suggested that in the 
early stages of UUO, the pro-fibrotic effects of Ang II activation of the AT1 receptor could be mediated by Ras activation.

Results of the present study have also shown that inhibition of Ras activation either by inhibiting farnesyl transferase or inhibiting HMG-CoA reductase were able to elicit reductions in UUO-induced fibronectin accumulation and $\alpha$-SMA immunostaining in the mouse kidney. These results demonstrate that Ras activation participates in the initiating molecular events involved in renal interstitial damage induced by ureteral obstruction in mice.

It should be noted that, although the effect of Ras inhibition on obstructive nephropathy had not been previously reported, it has been reported that Ras activation inhibitors prevent oxidative damage associated to renal diseases [28, 29]. Inhibition of Ras activation has been also reported to reduce post-operative fibrosis [30].

In summary, our results suggest that increased Ang II production in the obstructed kidney could play a role in Ras activation early after UUO, and that Ras activation plays a role in early renal damage induced by UUO in the obstructed kidney. Our data also offer evidence of the pharmacological potential of Ras pathway inhibition in preventing the progression of renal tubulointerstitial fibrosis.

\section{Acknowledgments}

The authors thank Mrs. Angustias Pérez for histological assistance.

The authors declare that they have no conflict of interest.

\section{Funding}

This study was supported by grants from Instituto de Salud Carlos III , Ministerio de Sanidad y Consumo (Retic 06/0016, RedinRen), Comisión Interministerial de Ciencia y Tecnología (grants BFU-2004-00285/BFI and SAF2007-63893) and Junta de Castilla y León (grant SA001/C05 ). 


\section{References}

1 Stahl, P.J. and Felsen, D. (2001) Transforming growth factor-beta, basement membrane, and epithelial-mesenchymal transdifferentiation: implications for fibrosis in kidney disease. Am. J. Pathol. 159, 1187-1192

2 Klahr, S. and Morrissey, J. (2002) Obstructive nephropathy and renal fibrosis. Am. J. Physiol. Renal Physiol. 283, F861-F875

3 Sharma, A.K., Mauer, S.M., Kim, Y. and Michael, A.F. (1993) Interstitial fibrosis in obstructive nephropathy. Kidney Int. 44, 774-788

4 Hernández-Llamas, G., Palafox-Cervantes, G., Borboa-Osuna, A.L., UrrechaManzano, J., Cruz, C., Pedraza-Chaverrí, J. and Cuetos-Martínez, C. (1994) Role of the renin-angiotensin system in arterial hypertension secondary to acute unilateral urinary obstruction. Ren. Fail. 16, 673-679

5 Takihana, Y., Tago, K. and Ueno, A. (1994) Renal functional reserve in obstructive nephropathy. Nippon Jinzo Gakkai Shi. 36, 130-137

6 Shi, Y., Pedersen, M., Li, C., Wen, J.G., Thomsen, K., Stødkilde-Jørgensen, H., Jørgensen, T.M., Knepper, M.A., Nielsen, S., Djurhuus, J.C. and Frøkiaer, J. (2004) Early release of neonatal ureteral obstruction preserves renal function. Am. J. Physiol. Renal Physiol. 286, F1087-F1099

7 Klahr, S. and Morrissey, J. (2002) Comparative effects of ACE inhibition and angiotensin II receptor blockade in the prevention of renal damage. Kidney Int. Suppl. 82, S23-S26

8 Esteban, V., Lorenzo, O., Rupérez, M., Suzuki, Y., Mezzano, S., Blanco, J., Kretzler, M., Sugaya, T., Egido, J. and Ruiz-Ortega, M. (2004) Angiotensin II, via AT1 and AT2 receptors and NF-kappaB pathway, regulates the inflammatory response in unilateral ureteral obstruction. J. Am. Soc. Nephrol. 15, 1514-1529

9 El Chaar, M., Chen, J., Seshan, S.V., Jha, S., Richardson, I., Ledbetter, S.R., Vaughan, E.D. Jr., Poppas, D.P. and Felsen, D. (2007) Effect of combination therapy with enalapril and the TGF-beta antagonist 1D11 in unilateral ureteral obstruction. Am. J. Physiol. Renal Physiol. 292, F1291-F1301

10 Kellner, D., Chen, J., Richardson, I., Seshan, S.V., El Chaar, M., Vaughan, E.D. Jr., Poppas, D. and Felsen, D. (2006) Angiotensin receptor blockade decreases fibrosis and fibroblast expression in a rat model of unilateral ureteral obstruction. J. Urol. 176, 806812 
11 Sugiyama, H., Kobayashi, M., Wang, D.H., Sunami, R., Maeshima, Y., Yamasaki, Y., Masuoka, N., Kira, S. and Makino, H. (2005) Telmisartan inhibits both oxidative stress and renal fibrosis after unilateral ureteral obstruction in acatalasemic mice. Nephrol. Dial. Transplant. 20, 2670-2680

12 Eskild-Jensen, A., Paulsen, L.F., Wogensen, L., Olesen, P., Pedersen, L., Frokiaer, J. and Nyengaard, J.R. (2007) AT1 receptor blockade prevents interstitial and glomerular apoptosis but not fibrosis in pigs with neonatal induced partial unilateral ureteral obstruction. Am. J. Physiol. Renal Physiol. 292, F1771-F1781

13 Radović, N., Cuzić, S. and Knotek, M. (2008) Effect of unilateral ureteral obstruction and anti-angiotensin II treatment on renal tubule and interstitial cell apoptosis in rats. Croat. Med. J. 49, 600-607

14 Barandier, C., Ming, X.F. and Yang, Z. (2003) Small G proteins as novel therapeutic targets in cardiovascular medicine. News Physiol. Sci. 18, 18-22

15 Muthalif, M., Karzoun, N.A., Gaber, L., Khandekar, Z., Benter, I.F., Saeed, A.E., Parmentier, J.H., Estes, A. and Malik, K.U. (2000) Angiotensin II-Induced Hypertension: contribution of Ras GTPase/Mitogen-activated protein kinase and cytochrome P450 metabolites. Hypertension 36, 604-609

16 Schieffer, B., Paxton, W.G., Chai, Q., Marrero, M.B. and Bernstein, K.E. (1996) Angiotensin II controls p21ras activity via pp60c-src. J. Biol. Chem. 271, 10329-10333

17 Rodríguez-Peña, A.B., Grande, M.T., Eleno, N., Arévalo, M., Guerrero, C., Santos, E. and López-Novoa, J.M. (2008) Activation of Erk1/2 and Akt following unilateral ureteral obstruction. Kidney Int. 2008 74, 196-209

18 Pimentel, J.L. Jr., Montero, A., Wang, S., Yosipiv, I., el-Dahr, S. and MartinezMaldonado, M. (1995) Sequential changes in renal expression of renin-angiotensin system genes in acute unilateral ureteral obstruction. Kidney Int 48, 1247-1253

19 National Research Council (NRC) (1996) Commission on Life Sciences, Institute of Laboratory Animal Resources, Guide for the Care and Use of Laboratory Animals, National Academy Press, Washington (DC)

20 Rodríguez-Peña, A.B., Santos, E., Arévalo, M. and López-Novoa, J.M. (2005) Activation of small GTPase Ras and renal fibrosis. J. Nephrol. 18, 341-349

21 Crul, M., de Klerk, G.J., Beijnen, J.H. and Schellens, J.H. (2001) Ras biochemistry and farnesyl transferase inhibitors: a literature survey. Anticancer Drugs 12, 163-184 
22 Jakobisiak, M. and Golab, J. (2003) Potential antitumor effects of statins. Int. J. Oncol. 23, 1055-1069

23 Buemi, M., Senatore, M., Corica, F., Aloisi, C., Romeo, A., Cavallero, E., Floccari, F., Tramontana, D. and Frisina, N. (2002) Statins and progressive renal disease. Med. Res. Rev. 22, 76-84

23 Klahr, S., Ishidoya, S. and Morrissey, J. (1995) Role of angiotensin II in the tubulointerstitial fibrosis of obstructive nephropathy. Am. J. Kidney Dis. 26, 141-146 24 Muthalif, M.M., Benter, I.F., Khandekar, Z., Gaber, L., Estes, A., Malik, S., Parmentier, J.H., Manne, V. and Malik, K.U. (2000) Contribution of Ras GTPase/MAP kinase and cytochrome P450 metabolites to deoxycorticosterone-salt-induced hypertension. Hypertension 35, 457-463

26 Pat, B., Yang, T., Kong, C., Watters, D., Johnson, D.W. and Gobe, G. (2005) Activation of ERK in renal fibrosis after unilateral ureteral obstruction: modulation by antioxidants. Kidney Int. 67, 931-943

27 Masaki, T., Foti, R., Hill, P.A., Ikezumi, Y., Atkins, R.C. and Nikolic-Paterson, D.J. (2003) Activation of ERK pathway precedes tubular proliferation in the obstructed rat kidney. Kidney Int. 63, 1256-1264

28 Song, C.Y., Kim, B.C. and Lee, H.S. (2008) Lovastatin inhibits oxidized low-density lipoprotein-induced plasminogen activator inhibitor and transforming growth factorbetal expression via a decrease in Ras/extracellular signal-regulated kinase activity in mesangial cells. Transl. Res. 151, 27-35

29 Sabbatini, M., Santillo, M., Pisani, A., Paternò, R., Uccello, F., Serù, R., Matrone, G., Spagnuolo, G., Andreucci, M., Serio, V., Esposito, P., Cianciaruso, B., Fuiano, G. and Avvedimento, E.V. (2006) Inhibition of Ras/ERK1/2 signaling protects against postischemic renal injury. Am. J. Physiol. Renal Physiol. 290, F1408-F1415

30 Aarons, C.B., Cohen, P.A., Gower, A., Reed, K.L., Leeman, S.E., Stucchi, A.F. and Becker, J.M. (2007) Statins (HMG-CoA reductase inhibitors) decrease postoperative adhesions by increasing peritoneal fibrinolytic activity. Ann. Surg. 245, 176-184 
$\mathbf{A}$

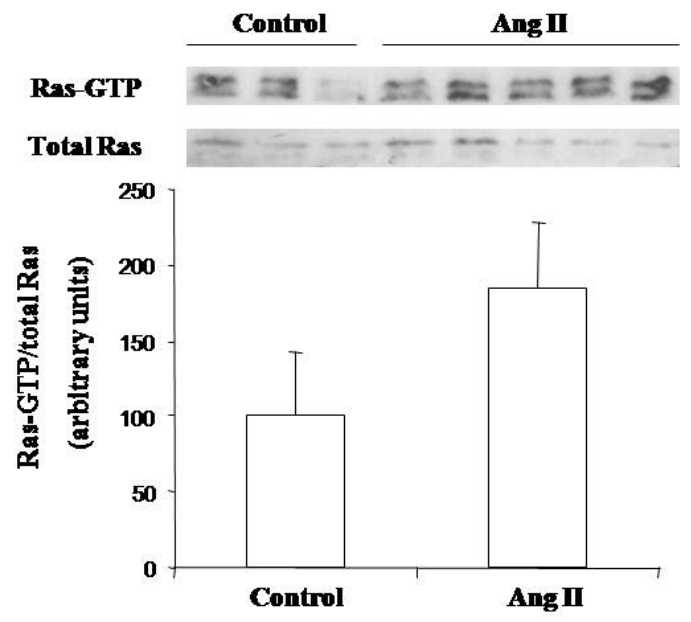

B

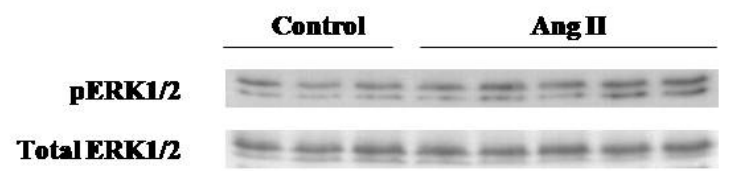

$\mathbf{C}$
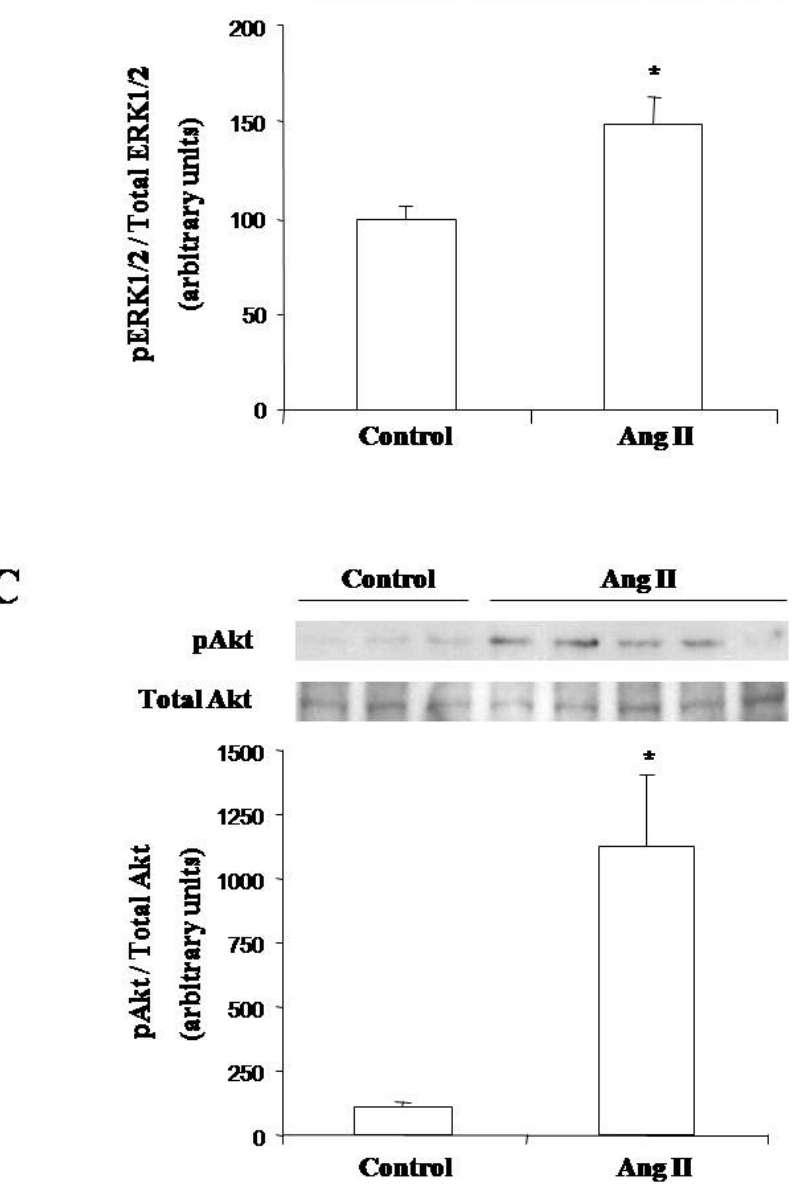

Figure 1. Effect of systemically administrated angiotensin II (Ang II) upon activation of Ras signaling pathway in non obstructed (NO) and obstructed (O) kidneys. Western blot analysis detected the activation of Ras (A), ERK1/2 (B) and Akt (C) measured as the ratio phosphorylated/total proteins. Bars represent the mean \pm SEM of the optical density measured in kidney samples of saline (Control) and angiotensin II-treated animals. $* P<0.05$ vs Control group. 
$\mathbf{A}$

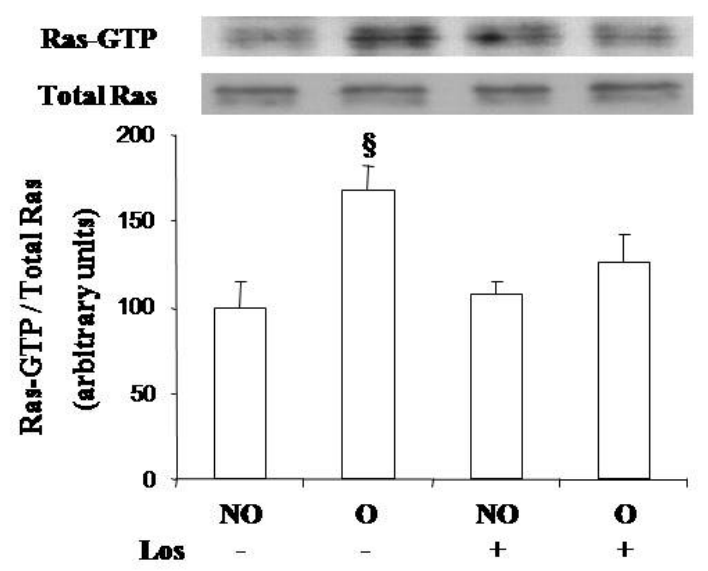

C

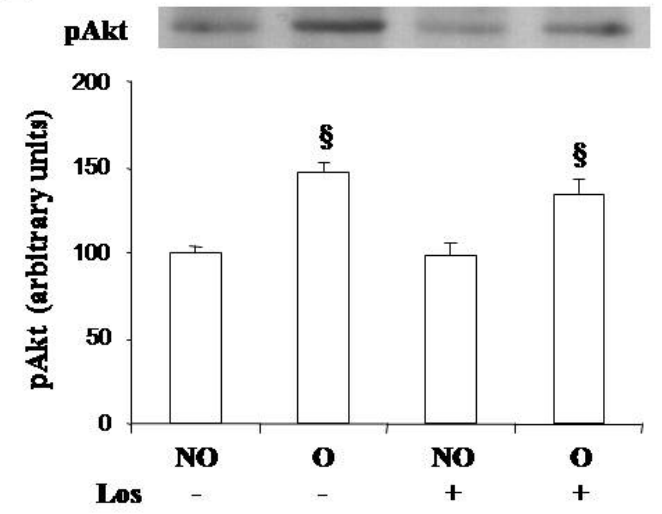

$\mathbf{E}$

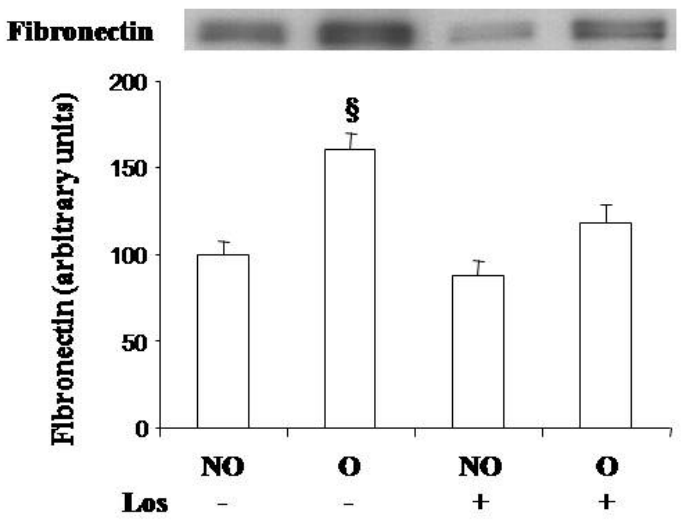

B

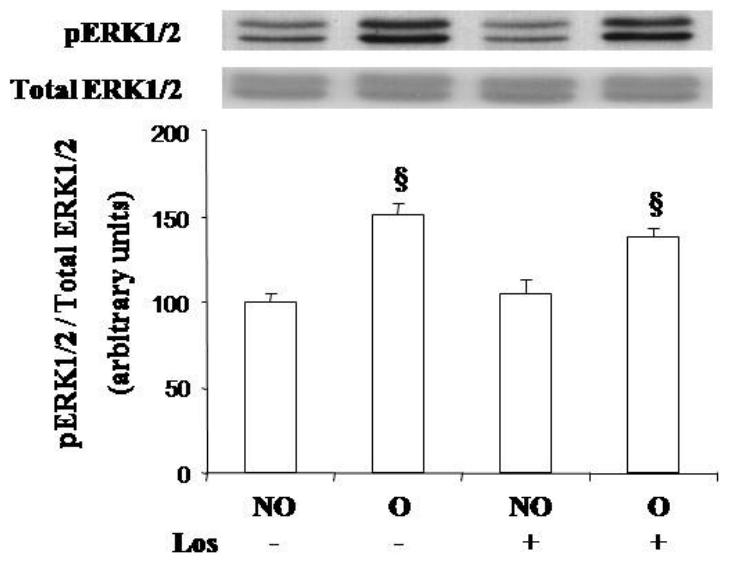

D

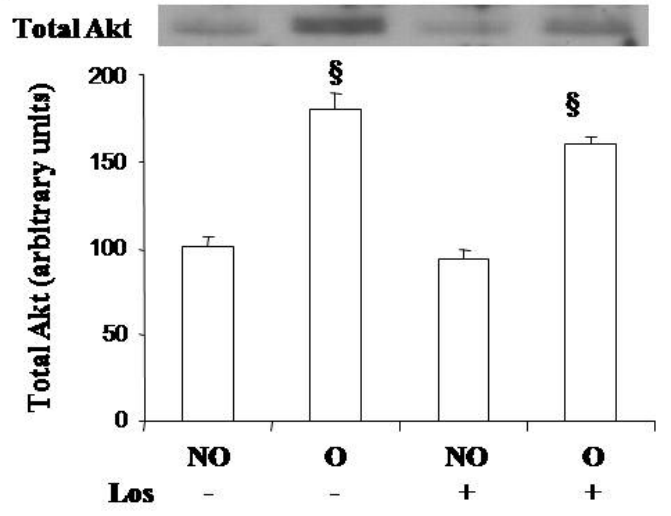

$\mathbf{F}$

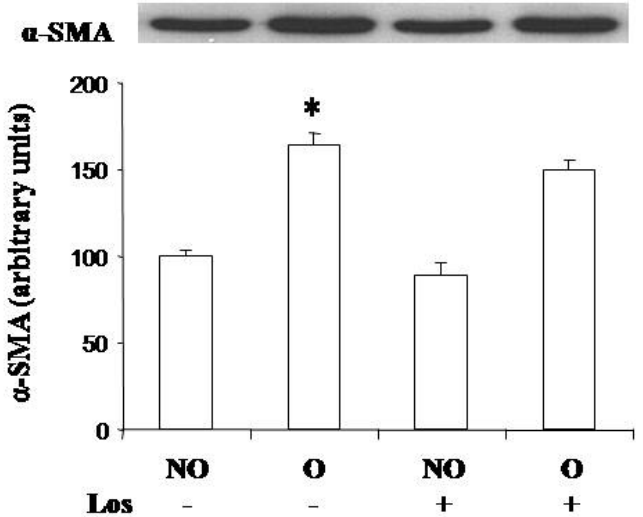

Figure 2. Effect of losartan administration on UUO-induced Ras pathway activation and fibrotic changes analyzed by Western blot. Protein expression of Ras (A), ERK1/2 (B), Akt (C and D), fibronectin (E) and alpha-smooth muscle actin ( $\alpha$-SMA) (F) was detected by immunoblotting. Activation of Ras and ERK1/2 was measured as the ratio phosphorylated/total proteins. Bars represent the mean \pm SEM of the optical density measured in non obstructed $(\mathrm{NO})$ and obstructed $(\mathrm{O})$ kidney samples of vehicle- and losartan (Los)-treated animals. $\S P<$ 0.05 and $* Z>2.6383$ vs NO vehicle-treated kidneys of UUO mice. $\# P<0.05$ vs obstructed (O) vehicle-treated kidneys. 


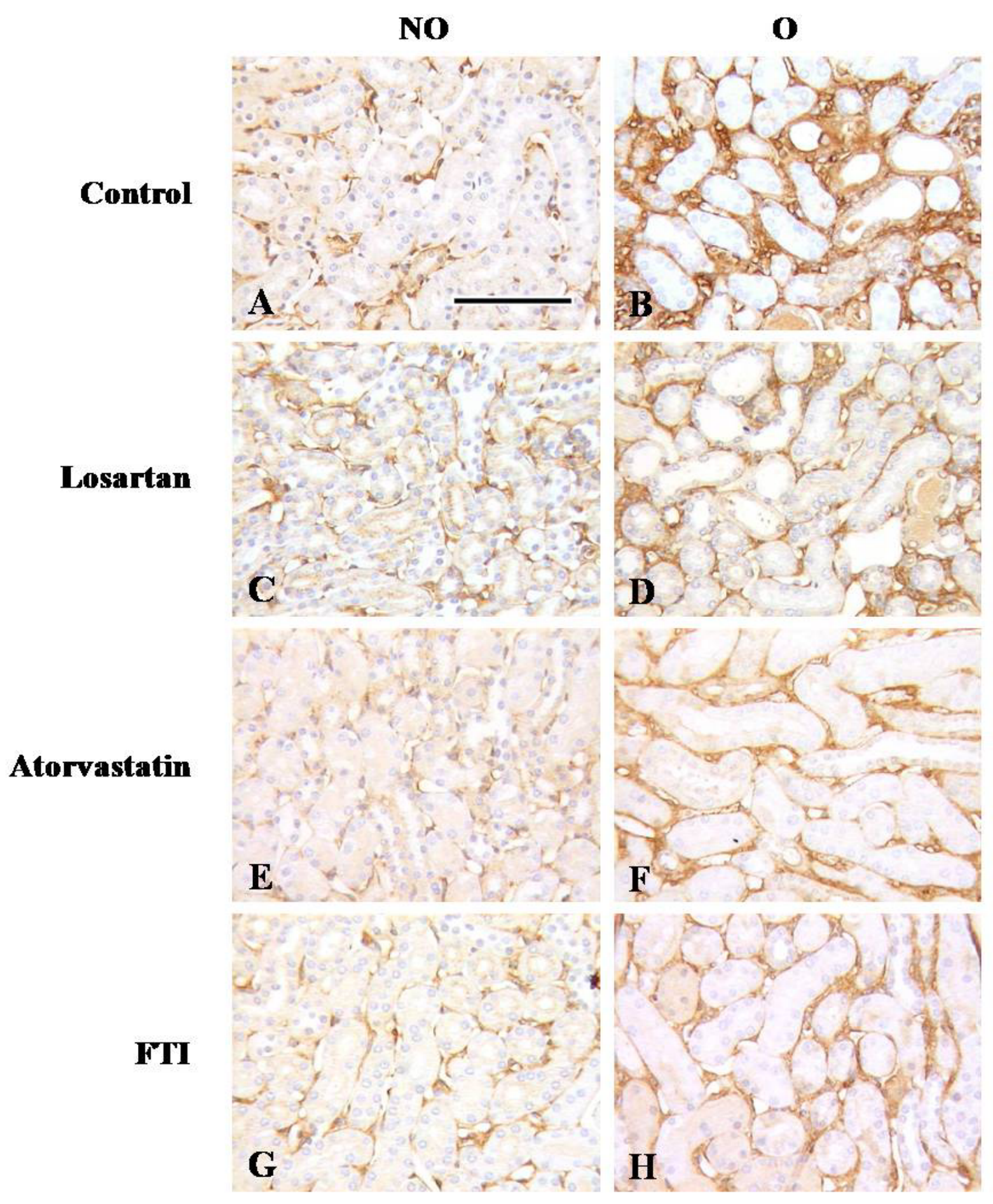

Figure 3. Effect of losartan, atorvastatin or farnesyl transferase inhibitor (FTI) administration on renal fibronectin expression detected by immunohistochemistry in UUO mice. Representative interstitial sections from non-obstructed (NO) and obstructed (O) kidneys of UUO untreated mice (A and B) and UUO mice treated with losartan (C and D), atorvastatin (E and F) or FTI $(\mathrm{G}$ and $\mathrm{H})$. Black bar indicates 100 microns in all panels. 
NO

\section{Control}

\section{Losartan}

\section{Atorvastatin}

\section{FTI}
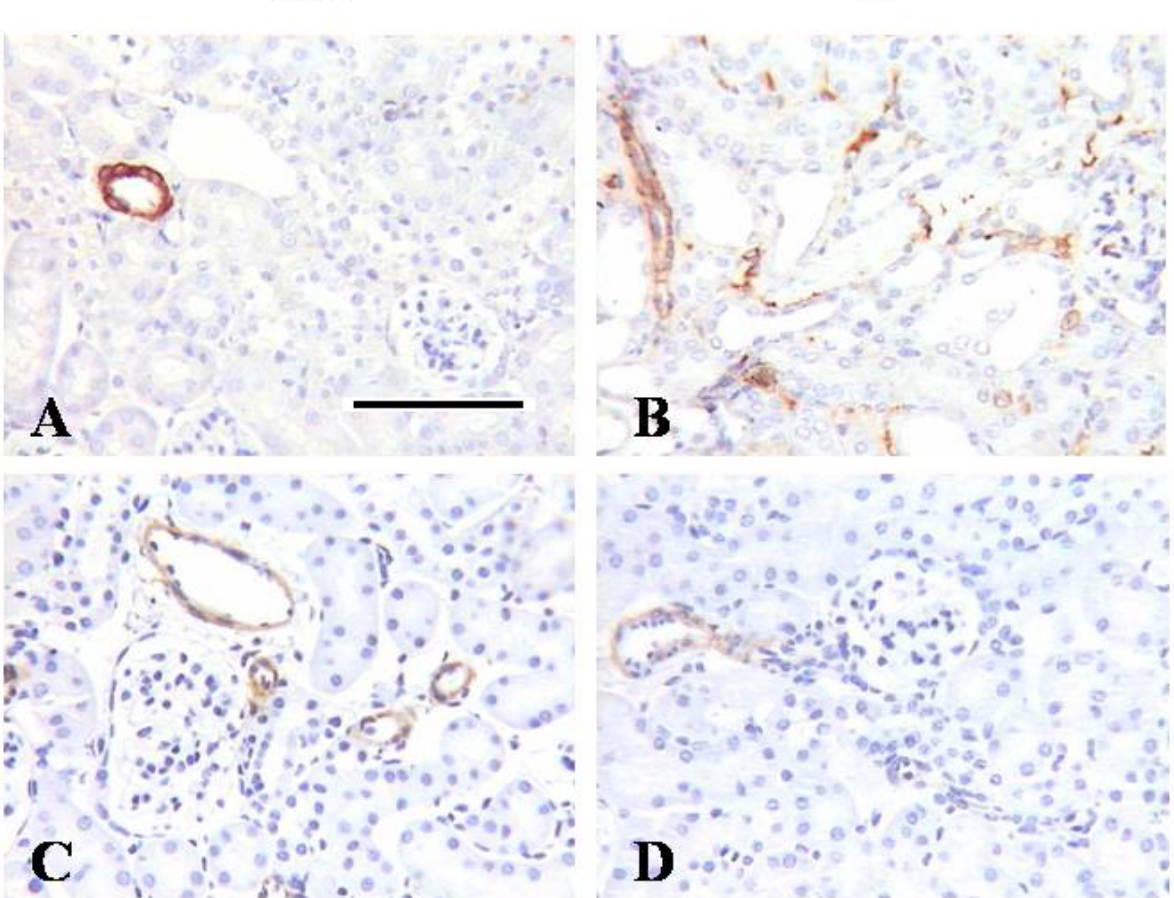

D
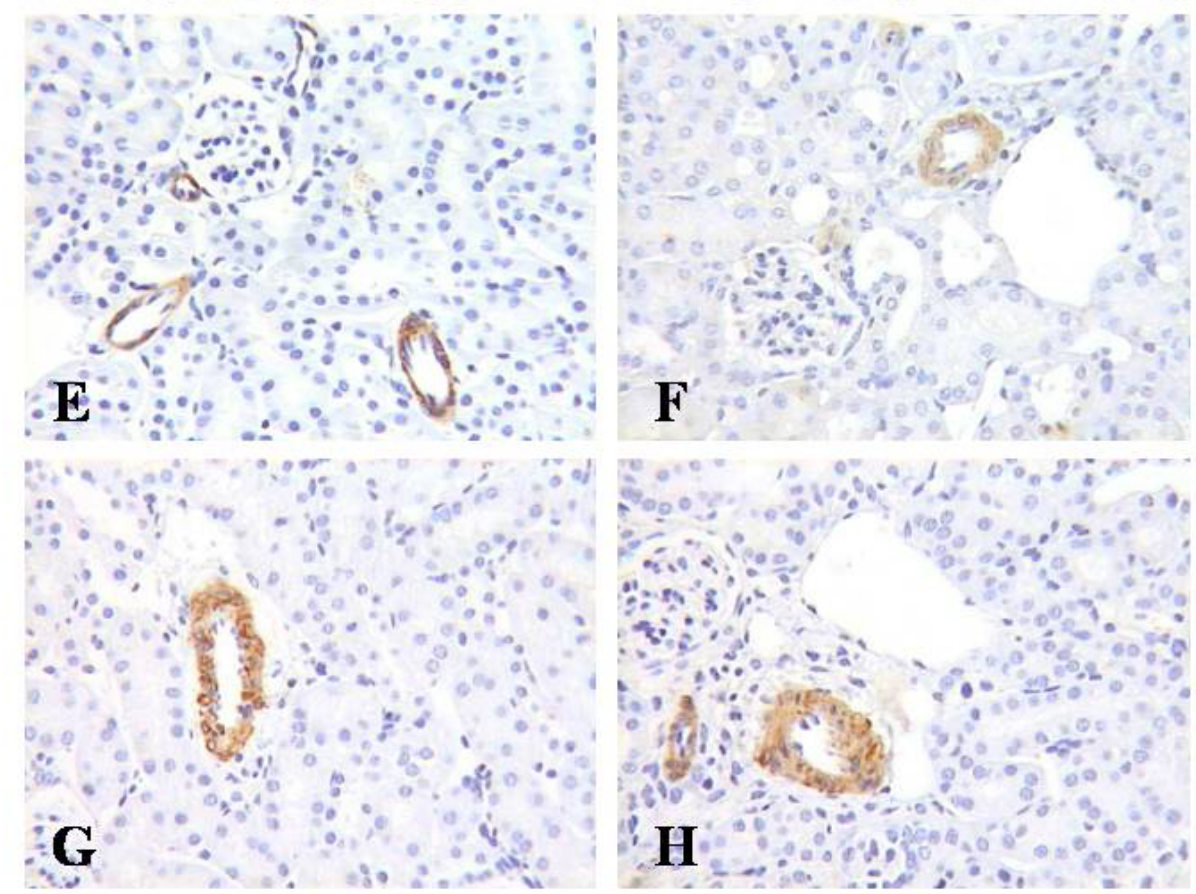

Figure 4. Effect of losartan, atorvastatine or farnesyl transferase inhibitor (FTI) administration on renal alpha-smooth muscle actin (a-SMA) expression detected by immunohistochemistry in UUO mice. Representative interstitial sections from non-obstructed (NO) and obstructed (O) kidneys of UUO untreated mice (A and B) and UUO mice treated with Losartan $(\mathrm{C}$ and $\mathrm{D})$, atorvastatin (E and F) or FTI ( $\mathrm{G}$ and H). Black bar indicates 100 microns in all panels. 
A

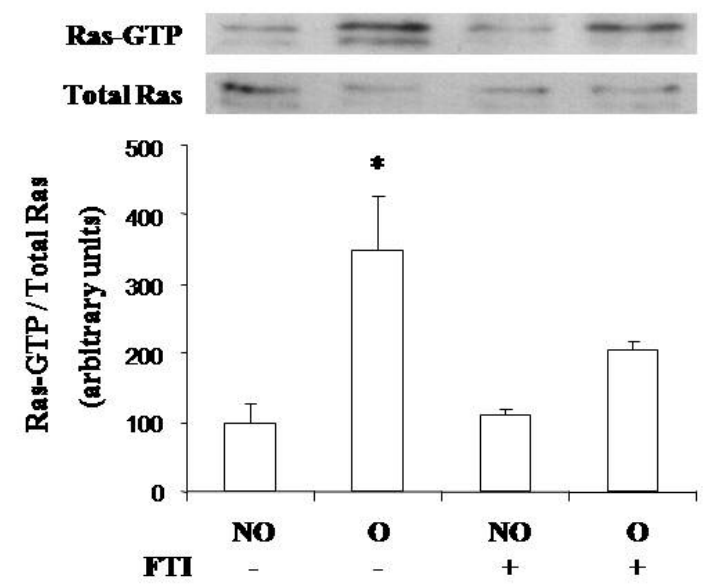

C

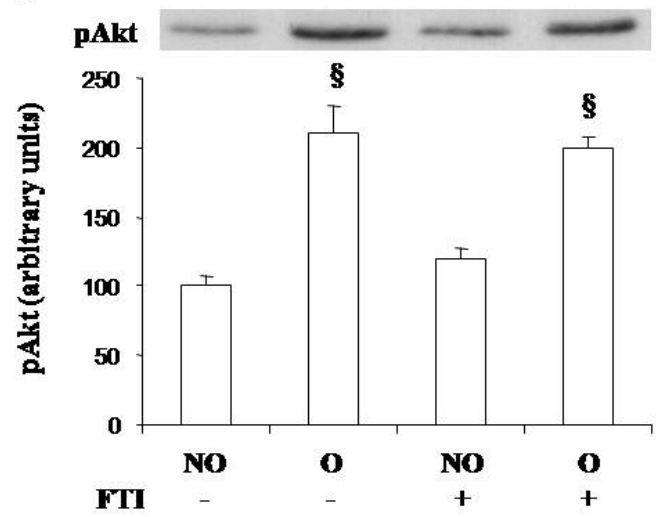

$\mathbf{E}$

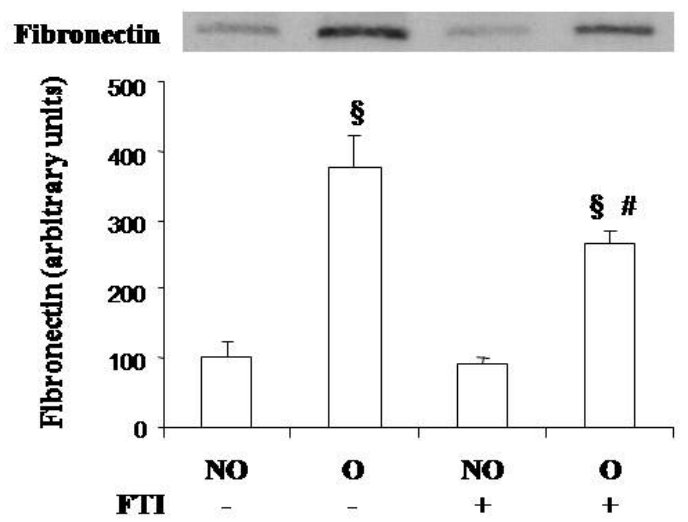

B

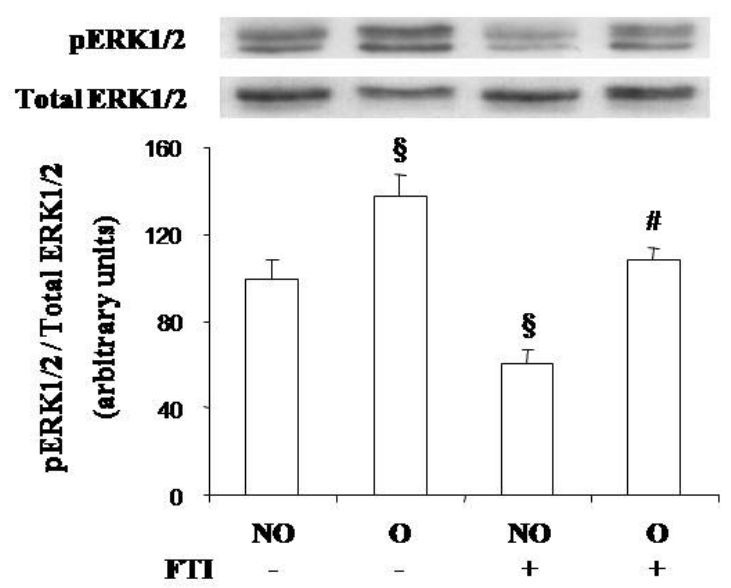

D

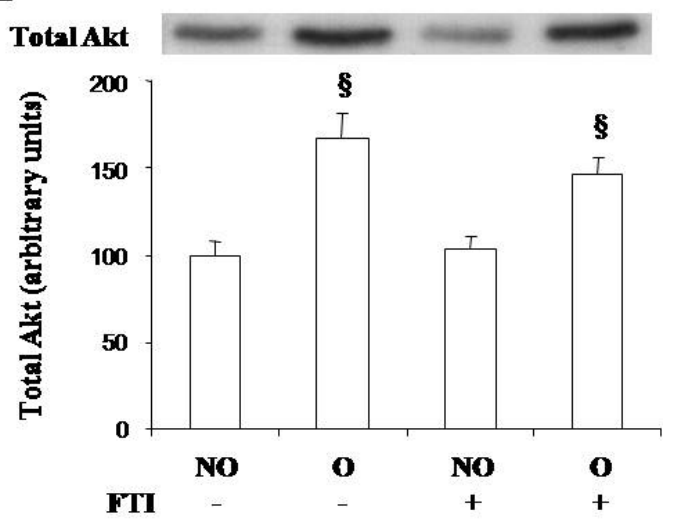

$\mathbf{F}$

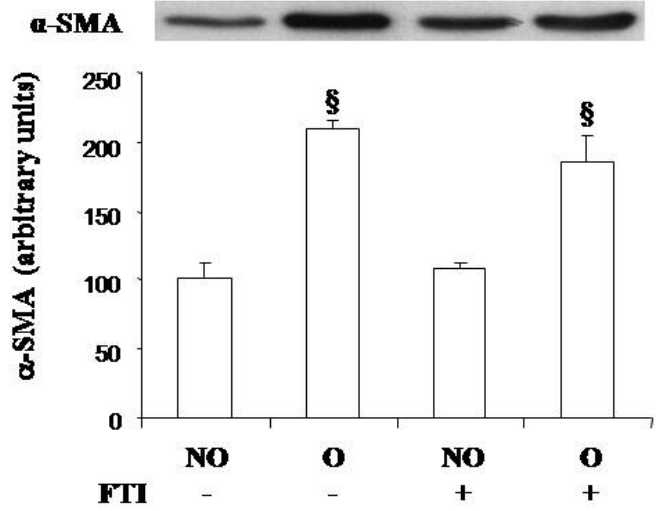

Figure 5. Effect of farnesyl transferase inhibitor (FTI) administration on UUO-induced Ras pathway activation and fibrotic changes analyzed by Western blot. Protein expression of Ras (A), ERK1/2 (B), Akt (C and D), fibronectin (E) and alpha-smooth muscle actin ( $\alpha$-SMA) (F) was detected by immunoblotting. Activation of Ras and ERK1/2 was measured as the ratio phosphorylated/total proteins. Bars represent the mean \pm SEM of the optical density measured in non obstructed (NO) and obstructed (O) kidney samples of vehicle- and FTI-treated animals. $\S P<0.05$ and $* Z>2.6383$ vs NO vehicle-treated kidneys of UUO mice. \#P<0.05 vs $\mathrm{O}$ vehicle-treated kidneys. 
$\mathbf{A}$

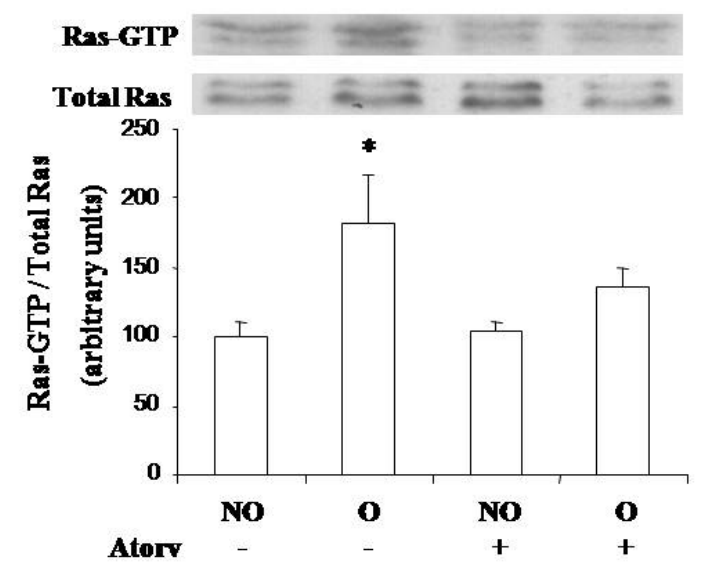

$\mathbf{C}$

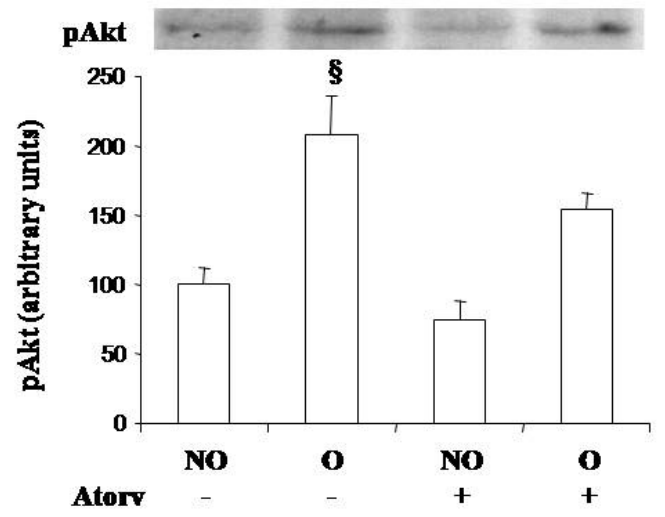

$\mathbf{E}$

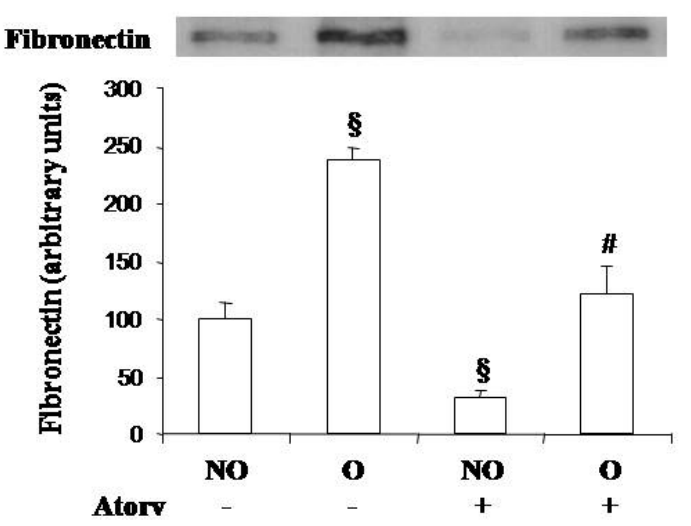

B

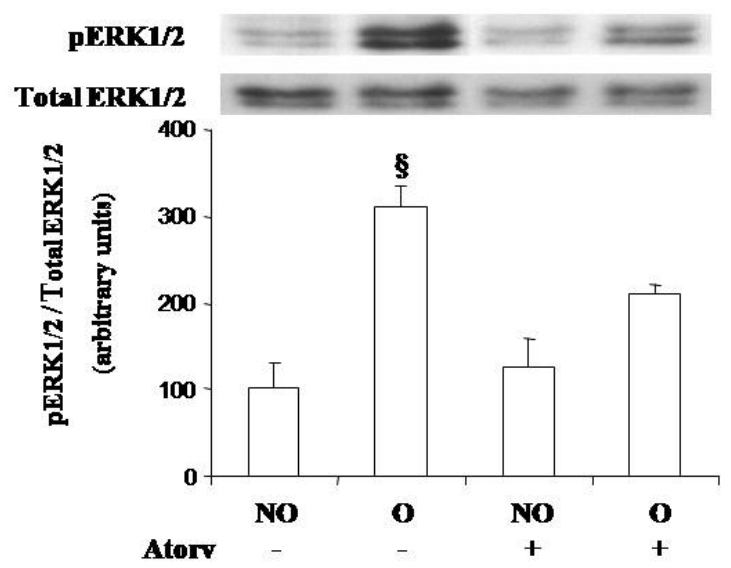

D

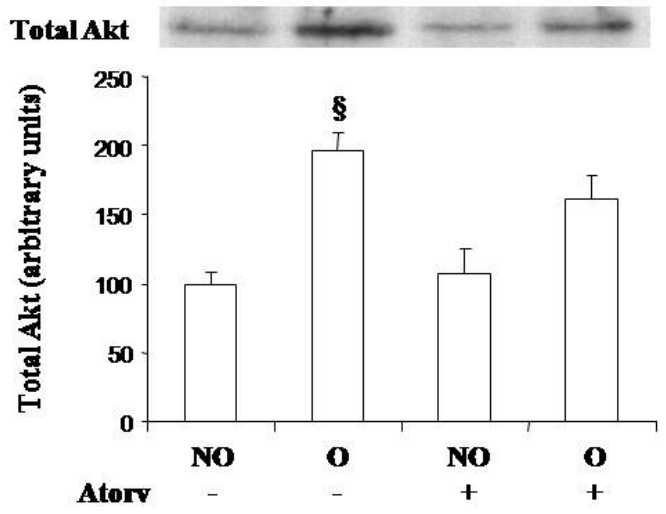

$\mathbf{F}$

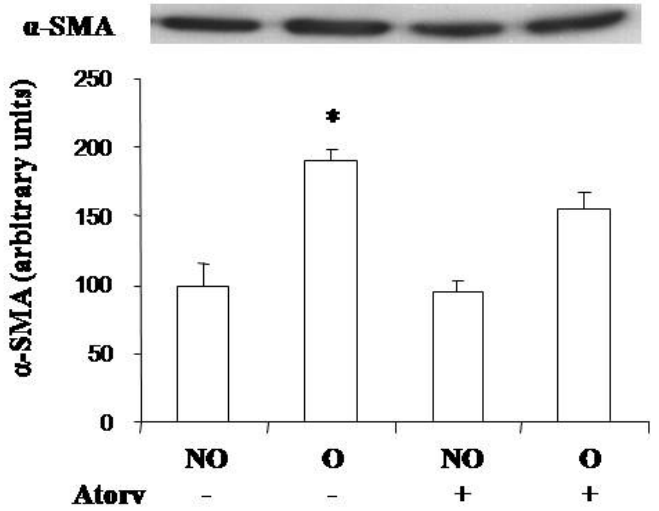

Figure 6. Effect of atorvastatin administration on UUO-induced Ras pathway activation and fibrotic changes analyzed by Western blot. Protein expression of Ras (A), ERK1/2 (B), Akt (C and D), fibronectin (E) and alpha-smooth muscle actin ( $\alpha$-SMA) (F) was detected by immunoblotting. Activation of Ras and ERK1/2 was measured as the ratio phosphorylated/total proteins. Bars represent the mean \pm SEM of the optical density measured in non obstructed $(\mathrm{NO})$ and obstructed $(\mathrm{O})$ kidney samples of vehicle- and atorvastatin (Atorv)-treated animals. $\S P<0.05$ and $* Z>1.9600$ vs NO vehicle-treated kidneys of UUO mice. $\# P<0.05$ vs $\mathrm{O}$ vehicle-treated kidneys. 


\section{Artículo VIII}

"Targeted genomic disruption of $\mathrm{H}$-ras and $\mathrm{N}$-ras has no effect on early renal changes after unilateral ureteral ligation"

María T. Grande, Miguel Arévalo, Alejandro Núñez, Jorge B. Cannata-Andía Eugenio Santos and José M López-Novoa

World Journal of Urology (aceptado) 


\section{Targeted genomic disruption of H-ras and N-ras has no effect on early renal changes after unilateral ureteral ligation.}

María T. Grande ${ }^{1}$, Miguel Arévalo ${ }^{2}$, Alejandro Núñez ${ }^{3}$, Jorge B. Cannata-Andía ${ }^{4}$ Eugenio Santos $^{3}$ and José M López-Novoa ${ }^{1}$

${ }^{1}$ Instituto "Reina Sofía" de Investigación Nefrológica, Departamento de Fisiología y Farmacología, Universidad de Salamanca, Salamanca, Spain. ${ }^{2}$ Departamento de Anatomía e Histología Humanas, ${ }^{3}$ Centro de Investigación del Cáncer CSIC-USAL, and ${ }^{4}$ Mineral, Bone and Mineral Research Unit, Instituto Reina Sofía de Investigación Nefrológica, Hospital Universitario Central de Asturias, Oviedo, Spain.

Concise title: H- and N-ras in early obstructive nephropathy

\section{*Corresponding author:}

Jose M. López-Novoa

Departamento de Fisiología y Farmacología,

Edificio Departamental, Campus Miguel de Unamuno

Universidad de Salamanca

37007 Salamanca,Spain.

Phone: (+34) 923294472

Fax: (+34) 923294669.

E-mail:jimlnovoa@,usal.es 


\begin{abstract}
PURPOSE: To assess the contribution of two different Ras monomeric GTPases isoforms $\mathrm{H}$ - and $\mathrm{N}$ - Ras in the early changes associated to obstructive nephropathy induced by unilateral ureteral obstruction (UUO).

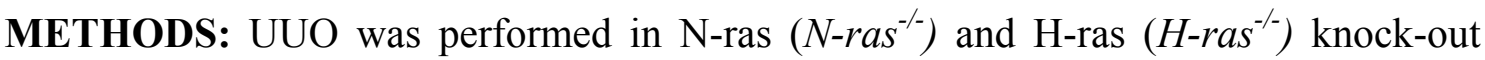

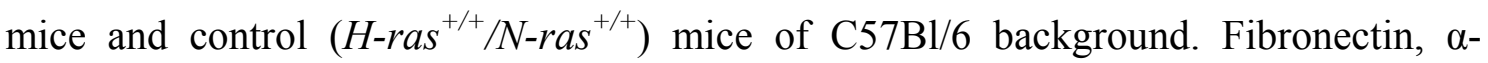
smooth muscle actin, cleaved caspase-3, ki-67, Ras-GTP, pERK, and pAkt expression were analyzed by western blot and/or immunohistochemistry. Ras isoforms activation and caspase activity were determined by both western blot and ELISA.

RESULTS: Three days after UUO, obstructed kidneys of $\mathrm{H}_{-} \mathrm{ras}^{-/}, \mathrm{N}-\mathrm{ras}^{-/}$, and $\mathrm{H}$ $\mathrm{ras}^{+/+} / \mathrm{N}-\mathrm{ras}^{+/+}$mice showed no significant differences in activated total ras, pERK1/2, pAkt, total Akt levels, fibronectin, $\alpha$-SMA expression, cell proliferation and activated caspase 3. The morphological alterations in the O kidneys, revealed by histological and immunohistochemical studies, were also similar in $\mathrm{H}-\mathrm{ras}^{-/-}, \mathrm{N}-\mathrm{ras}^{-/-}$and $\mathrm{H}-\mathrm{ras}^{+/+} / \mathrm{N}-$ $\operatorname{ras}^{+/+}$mice.
\end{abstract}

CONCLUSIONS: These data suggest that activation of $\mathrm{H}$-ras and $\mathrm{N}$-ras isoforms does not play a major role in the early renal damage induced by UUO.

Keywords: Akt, MAPK, obstructive nephropathy, Ras-GTPases, ureteral obstruction. 


\section{Introduction}

Obstructive nephropathy, resulting from urinary tract obstruction is a common and significant urological problem both in children and in adults. Evidence from clinical studies and animal models indicates that, even with acute recovery following relief of obstruction, function may be compromised in the long term by progressive renal fibrosis and other renal structural and functional alterations [1].Unilateral ureteral obstruction (UUO) in mice is a well-established experimental model of obstructive nephropathy characterized by epithelial tubular cell apoptosis, proliferation and accumulation of myofibroblasts, and increased deposition of extracellular matrix leading to tubulointerstitial fibrosis [2].

Injury to the kidney is associated with growth factors such as TGF- $\beta$, EGF, and FGF-2 that facilitate by binding epithelial receptors with ligand-inducible intrinsic kinase activity. As a result of ligand-inducible receptor kinase activation there is a downstream engagement of GTPases from the Ras superfamily functioning as molecular switches in essential cellular processes [3]. In mammals the Ras subfamily includes three functional Ras genes which are expressed ubiquitously. These genes are located on different chromosomes and encode four highly homologous $21 \mathrm{kDa}$ proteins: H-ras, N-ras, K-ras4A, and K-ras4B [3]. However, the different Ras isoforms seem to have different function. $\mathrm{H}$-ras and $\mathrm{N}$-ras gene expression is dispensable for mouse development, growth, and fertility [5]. Only K-ras appears to be critical for normal mouse development based on the observation that $K$-ras deficiency results in embryonic lethality [6].

Ras GTP transmits its signal through interactions with a large number of target proteins, such as phosphatidylinositol 3-kinase (PI3K) and Ras/Raf/MEK-extracellular signal-regulated kinases (ERK1 and ERK2) [7]. The mitogen-actived protein kinase (MAPK) ERK1/2 are key signal-transducing enzymes that are activated by a wide range of extracellular stimuli, they are responsible for the induction of a number of cellular responses, such as changes in gene expression, proliferation, differentiation and apoptosis [8]. Akt kinase is activated by phosphorylation at Thr308 and Ser473 mediated by PI3K and is involved in the regulation of diverse cellular processes, as well as cell growth, survival and motility [9].

In previous studies, we have demonstrated the activation of total Ras and its effectors PI3K/Akt and ERK1/2 3 days after UUO [10, 11]. One of these studies 
reported a specific pattern of distribution of Ras isoforms in the kidney after UUO: NRas staining was detected in NO (non-obstructed) kidneys, but its expression was dramatically increased in $\mathrm{O}$ (obstructed) kidney both in terms of intensity and extension with diffuse pattern in both cortical and medullar tubulointerstitium areas [11]. In NO kidneys, K-Ras showed a specific interstitial expression in areas of the inner cortex and the medulla, being its expression higher in O kidneys. NO kidneys also showed a marked granular H-Ras immunostaining in proximal and distal convoluted tubular cells and lower intensity staining in collecting tubules, but no staining was detected in the interstitial areas of cortex or medulla. In O kidneys, staining intensity was notably lower than in NO kidneys, with the same pattern of distribution [11]. However, the contribution of the different Ras isoforms activation to early changes in the kidney after UUO has not been studied. Thus, the purpose of the present study is to assess the effect of UUO on Ras-dependent signaling pathways and early renal damage in mice lacking $\mathrm{N}$ or H-ras isoforms. We have not studied K-ras KO mice because they die before birth. Specifically we have assessed Ras isoform activation, PI3K and ERK1/2 activation and renal injury markers of extracellular matrix deposition, alpha-SMA positive cells, apoptosis and proliferation, all of them early major processes which lead to tubular atrophy and tubulointerstitial fibrosis characteristic of the obstructive nephropathy. Studies have been performed at 3 days after UUO because this is the time period in which ras activation has been already observed $[10,11]$. In addition, most of the renal alterations characteristics of urinary tract obstruction such as initial interstitial fibrosis, increase in the number of interstitial myofibroblasts, tubular dilation and atrophy, epithelial cells proliferation and apoptosis, can be already observed 3 days after ligation, whereas at later times, early changes could be masked by massive tubulointerstitial fibrosis.

\section{Materials and Methods}

\section{Animals and disease model}

All procedures were approved by the Committee for Animal Care and Use of the University of Salamanca and complied with the Guide for the Care and Use of Laboratory Animals [12]. Studies were performed in 8 weeks old male N-ras deficient

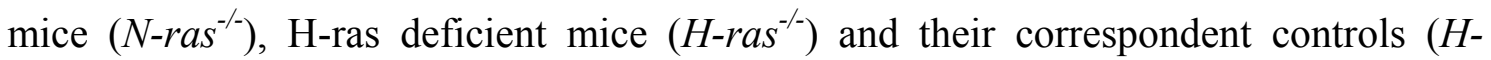
$\mathrm{ras}^{+/+} / \mathrm{N}-\mathrm{ras}^{+/+}$) that were obtained as previously reported [5] and maintained under 
standard conditions. A breeding colony of adult $\mathrm{H}_{-\mathrm{ras}^{-/}}$and $\mathrm{N}-\mathrm{ras}^{-/-}$animals has been maintained in our laboratory for more than 7 years. The animals appeared healthy and normal with no signs of any apparent associated lesions. The growth rates of these animals were indistinguishable from those of wild-type (WT) animals, and mutant mice reproduced normally. Routine genotyping of DNA isolated from mouse tail biopsies were performed by PCR using the primers previously reported [5]. For unilateral ureteral obstruction (UUO), after a 24 hours fasting period, mice were anesthetized with ketamine and valium, the abdomen was opened, and the left ureter was ligated two times with 5-0 silk. The abdomen was closed with running sutures and the skin was closed with interrupted sutures. After surgery, the mice were maintained in a temperature controlled room with a 12 hours light/dark cycle, and were reared on standard chow (Panlab, Spain) and water ad libitum. UUO was maintained for three days.

For histological studies $3 \mathrm{H}_{-\mathrm{ras}^{+/+}} / \mathrm{N}-\mathrm{ras}^{+/+}$mice, $3 \mathrm{~N}_{\mathrm{ras}^{-/}}$mice and $3 \mathrm{H}-\mathrm{ras}^{-/-}$ mice were used. All animals were perfused with heparinized saline solution and then with $4 \%$ buffered formalin. Obstructed (O) and non-obstructed (NO) kidneys were removed, halved longitudinally, fixed for 24 hours in $4 \%$ buffered formalin and then embedded in paraffin. Sections $3 \mu \mathrm{m}$ thick were cut and mounted on glass slides that were used either for hematoxylin-eosin staining or immunohistochemistry. Kidneys

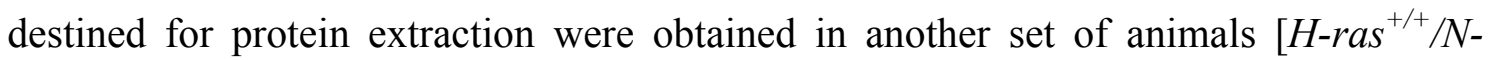
$\mathrm{ras}^{+/+}(\mathrm{n}=4), \mathrm{N}-\mathrm{ras}^{-/-}(\mathrm{n}=6)$ and $\mathrm{H}-\mathrm{ras}^{-/-}(\mathrm{n}=5)$ mice] after perfusion with saline solution, frozen immediately in liquid nitrogen and stored at $-80^{\circ} \mathrm{C}$ until use.

\section{Western blot analysis}

To obtain protein extracts from mouse kidneys, tissues were homogenized in lysis buffer (25mM HEPES pH7,5, 150mM NaCl, 1\% Igepal CA-630, 10mM MgCl 2 , $1 \mathrm{mM}$ EDTA, $10 \%$ glycerol, $10 \mu \mathrm{g} / \mathrm{mL}$ aprotinin, $10 \mu \mathrm{g} / \mathrm{mL}$ leupeptin, $100 \mathrm{mM}$ PMSF, $25 \mathrm{mM} \mathrm{NaF}, 1 \mathrm{mM} \mathrm{Na} \mathrm{VO}_{4}$ ) and centrifuged at $14,000 \mathrm{~g}$ for $30 \mathrm{~min}$. Supernatant was recovered and proteins were quantified. Lysates $(60 \mu \mathrm{g} / \mathrm{lane})$ were loaded onto SDSpolyacrylamide gels, and the proteins were transferred to nitrocellulose membranes (Bio-Rad) by electroblotting. Membranes blocked in TTBS (10mM Tris pH 7.5, $150 \mathrm{mM} \mathrm{NaCl}, 0.1 \%$ Tween 20 plus $2 \%$ bovine serum albumin) were incubated overnight at $4^{\circ} \mathrm{C}$, as appropriate, with: anti-ERK1 (1:2000, Santa Cruz Biotechnology, Santa Cruz, Ca, USA), anti-phospho-ERK (1:2000, Santa Cruz Biotechnology), anti- 
phospho-Akt (1:1000, Santa Cruz Biotechnology), anti-Akt1/2 (1:1000, Santa Cruz Biotechnology), anti-fibronectin (1:1000, Chemicon International, USA), anti-alphaSMA (1:1000, Sigma, St. Louis, USA), and anti cleaved caspase-3 (1:500, Cell Signalling Inc, Danvers, MA, USA). For detection of Ras-GTP expression, lysates $(1000 \mu \mathrm{g})$ were incubated with $20 \mu \mathrm{g}$ of Raf-1 Ras binding domain agarose conjugate (Upstate biotechnology, Lake Placid, NY, USA) and rocked at $4^{\circ} \mathrm{C}$ for $30 \mathrm{~min}$. After transference, membranes were incubated with anti-H-Ras (1:500), anti-N-Ras (1:500), anti-K-Ras (1:500), all from Santa Cruz Biotechnology, Santa Cruz, Ca, USA. Membranes were incubated with corresponding horseradish peroxidase-conjugated secondary antibody $(1: 10,000)$ and were developed using a chemiluminescent reagent (ECL detection reagent Amersham Biosciences). Developed signals were recorded on X-ray film (Fujifilm) for densitometric analysis (Scion Image).

\section{ELISA for Ras GTP}

Total kidneys lysates $(50 \mu \mathrm{g})$ were employed for the detection of RasGTP. RasGTP levels were determined by an ultra sensitive commercial ELISA kit (Active Motif, RasGTPase Chemi ELISA, Rixensart, Belgium) according to the manufacturer's instruction. Raf-RBD is used to isolate Ras-GTP from samples, then a primary antibody specific for Ras followed by an HRP-conjuged secondary antibody and developing reagent results in a chemiluminescent reaction which was determined with the Fluoroskan Ascent FL luminometer.

\section{Caspase activity assay}

Caspase activity was determined with an EnzoLyte Homogeneous Rh110 Caspase-3/7 Assay Kit (AnaSpec, Inc., San Jose, CA, USA), in which cleavage of (AspGlu-Val-Asp)2-rhodamine (Rh) 110 by caspases-3 and - 7 liberates Rh110 to generate a fluorescence signal. Fluorescence intensity is proportional to caspase-3/7 activity. Total kidneys lysates $(50 \mu \mathrm{g})$ were employed for this assay. Fluorescence was determined with the Fluoroskan Ascent FL fluorometer with excitation and emission wavelengths of 485 and $510 \mathrm{~nm}$, respectively.

\section{Immunohistochemical studies}

Immunohistochemistry was performed on buffered formalin fixed, paraffinembedded tissues. Briefly, $3 \mu \mathrm{m}$ sections were deparaffined in xylene and rehydrated in graded ethanols before staining with the peroxidase-anti peroxidase method. 
Endogenous peroxidase was blocked by incubation in 3\% hydrogen peroxide. Primary antibodies were: monoclonal mouse anti-human fibronectin, (clone 568, 1:50 dilution; Biogenex, CA, USA), mouse monoclonal anti-alpha smooth muscle actin (clone HHF35, Novocastra, MA, USA; dilution 1:50), rabbit monoclonal anti-Ki67 (clone SP6, LabVision Corp. Ca. USA, 1:100 dilution), rabbit polyclonal anti-caspase-3 (Cell Signaling Technology, Ma.USA, 1:50 dilution), rabbit polyclonal anti-phospho-Akt (Cell Signalling Technology, Ma. USA, 1:50 dilution) and mouse monoclonal antiPhospho-ERK (E-4, Santa Cruz Biotechnology, Ca. USA. 1:50 dilution). Following washes in PBS, the sections were sequentially incubated with the Novolink Polymer Detection System (Novocastra, MA, USA) using 3,3'diaminobenzidine (DAB) as chromogen. Sections were lightly counterstained with hematoxylin and were dehydrated and cover slipped. Negative controls were prepared without primary antibody.

\section{Statistical analysis}

Statistical differences were analyzed by two way ANOVA using the SPSS 12.0 program. Data were expressed as mean \pm SEM and $p<0.05$ was considered statistically significant.

\section{Results}

Ras activation after UUO

Activated H-Ras levels, detected by Ras GTPase Chemi ELISA were higher in $\mathrm{O}$ than in NO kidneys in $\mathrm{H}-\mathrm{ras}^{+/+} / \mathrm{N}-\mathrm{ras}^{+/+}$mice. O kidneys did not differ in terms of $\mathrm{H}-$ RasGTP levels between $\mathrm{H}-\mathrm{ras}^{+/+} / \mathrm{N}-\mathrm{ras}^{+/+}$, and $\mathrm{N}_{-\mathrm{ras}^{-/}}$mice (Fig. 1a). As Ras GTPase Chemi ELISA specifically detects activated H-ras in rodent samples, we were not able to detect activated ras levels in $\mathrm{H}_{-\mathrm{ras}^{-/}}$mice (Fig. 1a). Also activated levels of H-Ras, $\mathrm{N}-$ Ras, K-Ras and Pan-Ras were evaluated by western blot in NO and O kidneys from $\mathrm{H}-\mathrm{ras}^{+/+} / \mathrm{N}-\mathrm{ras}^{+/+}, \mathrm{H}-\mathrm{ras}^{-/-}$and N-ras${ }^{-/-}$mice (Fig. 1b). H-Ras, N-Ras, K-Ras and PanRas GTP levels were higher in O kidneys compared NO kidneys in $\mathrm{H}-\mathrm{ras}^{+/+} / \mathrm{N}-\mathrm{ras}^{+/+}$ mice. No differences were observed in total H, N, K nor Pan-Ras levels in O kidneys compared NO kidneys in $\mathrm{H}_{-\mathrm{ras}^{+/+}} / \mathrm{N}-\mathrm{ras}^{+/+}$mice (Fig. 1b). Predictably neither expression of H-RasGTP nor total H-Ras was observed in $\mathrm{H}-\mathrm{ras}^{-/}$mice, and neither activated N-Ras nor total N-Ras were detected in $\mathrm{O}$ and NO kidneys from $\mathrm{N}-\mathrm{ras}^{-/-}$mice 
(Fig. 1b). The expression of the other isoforms were apparently similar in all groups (Fig. 1b).

\section{ERK1/2 and Akt activation after UUO}

Western blot analysis revealed that the content of the active, phosphorylated form of ERK1/2, pERK1/2 was higher in O than in NO kidneys of $\mathrm{H}-\mathrm{ras}^{+/+} / \mathrm{N}-\mathrm{ras}^{+/+}$ mice. No significant differences were observed between $\mathrm{H}-\mathrm{ras}^{+/+} / \mathrm{N}-\mathrm{ras}^{+/+}, \mathrm{N}-\mathrm{ras}^{-/-}$and

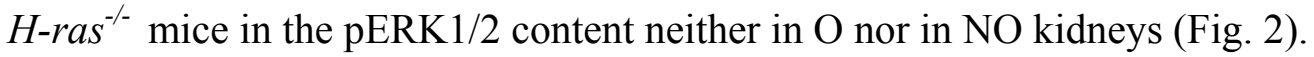

In $\mathrm{O}$ kidneys, phosphorilated ERK $1 / 2$ immunohistochemistry showed antigen expression located in collecting ducts and, to a lesser extent in thick ascending limbs of Henle's loop. pERK was present in both the nucleus and cytoplasm of tubular epithelial cells. A light expression of the antibody is detected in some interstitial cells in renal cortex and medulla. This pattern can be observed in the three groups of study with no significant differences among them (Fig. 2).

Western blot analysis also revealed that both the total Akt levels and the levels of the active phosphorylated form of Akt, pAkt were higher in O kidneys than in NO kidneys of $\mathrm{H}-\mathrm{ras}^{+/+} / \mathrm{N}-\mathrm{ras}^{+/+}$mice. In addition no differences were observed between $\mathrm{H}$ $\mathrm{ras}^{+/+} / \mathrm{N}-\mathrm{ras}^{+/+}, \mathrm{N}-\mathrm{ras}^{-/-}$and $\mathrm{H}-\mathrm{ras}^{-/-}$in the pAkt or total Akt content neither in the O nor in the NO kidney (Fig. 2).

Immunohistochemistry study of phosphorilated Akt in O kidneys showed pAkt expression restricted to collecting ducts and ascending limbs of Henle's loop. A remarkable Akt immunoexpression can be observed in renal interstitium. No differences were detected between $\mathrm{H}-\mathrm{ras}^{+/+} / \mathrm{N}-\mathrm{ras}^{+/+}, \mathrm{N}-\mathrm{ras}^{-/-}$and $\mathrm{H}-\mathrm{ras}^{-/-}$animals (Fig. 3).

\section{Acute renal morphological changes after UUO}

After three days of ureteral obstruction, O kidneys from all groups, showed focal tubular dilation with flattened epithelium circumscribed to the outer renal cortex. Hyaline casts were frequently observed in both renal cortex and medulla. The medulla was compressed towards the cortex and the inner medulla and papillae appeared flattened. No significant differences in the histological appearance were observed between the $\mathrm{H}-\mathrm{ras}^{+/+} / \mathrm{N}-\mathrm{ras}^{+/+}$and $\mathrm{H}-\mathrm{ras}^{-/}$or $\mathrm{N}-\mathrm{ras}^{-/}$groups (Fig. 4). NO kidneys did not exhibit overt morphological alterations. 
Fibronectin expression after UUO

Immunohistochemistry revealed that NO kidneys presented a slight expression of fibronectin in both epithelial basement membranes and glomerular mesangium as well as around the endothelium of large intrarenal vessels and capillaries. However, no staining was found in the renal interstitium of NO kidneys. Obstructed kidneys showed an intense interstitial fibronectin expression in renal cortex and medulla, with no significant differences among the $\mathrm{H}-\mathrm{ras}^{+/+} / \mathrm{N}-\mathrm{ras}^{+/+}$and $\mathrm{H}-\mathrm{ras}^{-/-}$or $\mathrm{N}-\mathrm{ras}^{-/}$groups (Fig. 5a). Western blot analysis revealed that fibronectin content was significantly higher in O kidneys than NO kidneys. The effect of UUO on fibronectin content in the O kidney was similar in control, $\mathrm{H}-\mathrm{ras}^{+/+} / \mathrm{N}-\mathrm{ras}^{+/+}$mice and in $\mathrm{H}_{-\mathrm{ras}^{-/}}$and $\mathrm{N}-\mathrm{ras}^{-/-}$mice (Fig. 5b).

\section{$\alpha-S M A$ expression after $U U O$}

Whereas in NO kidneys, $\alpha$-smooth muscle actin ( $\alpha$-SMA) immunoexpression was restricted to smooth muscle cells in vessel walls, immunohistochemical studies in $\mathrm{O}$ kidneys showed that, in addition to vessel walls, cells with $\alpha$-SMA positive staining, most probably corresponding to myofibroblasts, were found widely along the renal interstitium. The number and distribution of $\alpha$-SMA-positive cells was similar in $H$ $\mathrm{ras}^{+/+} / \mathrm{N}-\mathrm{ras}^{+/+}, \mathrm{H}-\mathrm{ras}^{-/-}$and $\mathrm{N}-\mathrm{ras}^{-/-}$mice (Fig. 5a). Western blot analysis reveals that $\alpha-$ SMA content was significantly higher in O kidneys than in NO kidneys. No significant

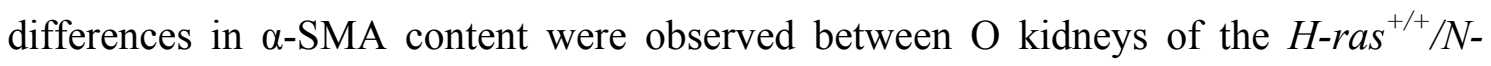
$\mathrm{ras}^{+/+}, \mathrm{H}-\mathrm{ras}^{-/-}$and $\mathrm{N}$-ras ${ }^{-/}$mice (Fig. 5b).

\section{Cell proliferation after UUO}

Proliferating cells, detected as cells with nuclei positive for Ki-67 immunostaining, were clearly observable in both tubules and interstitium of ureteral obstructed kidneys, but no differences were observed among $\mathrm{H}$-ras ${ }^{+/+} / \mathrm{N}-\mathrm{ras}^{+/+}, \mathrm{N}-\mathrm{ras}^{-/-}$ and $\mathrm{H}_{-\mathrm{ras}^{-/}}$mice in the number of nuclei stained with $\mathrm{Ki}-67$ neither in tubules nor in the interstitium (Fig. 6). NO kidneys presented scarce positive Ki-67 nuclei in both tubules and interstitium (Fig. 6).

\section{Caspase-3 activation after UUO}

In the obstructed kidneys, a strong immunostaining for cleaved caspase-3 was observed in epithelial tubular cells, mainly in the collecting ducts and thick ascending limbs of Henle's loop. An intense cleaved caspase-3 staining was also detected in cells located in the renal interstitium. The pattern of cleaved caspase- 3 staining was similar in 


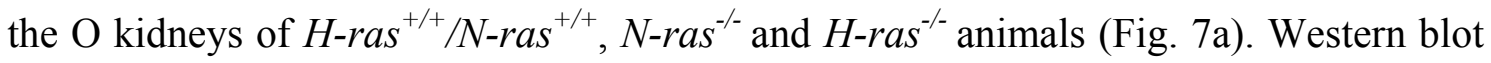
analysis also revealed higher levels of cleaved caspase-3 in O kidneys than in NO kidneys without significant differences among the O kidneys of $\mathrm{H}-\mathrm{ras}^{+/+} / \mathrm{N}-\mathrm{ras}^{+/+}, \mathrm{N}$ $\mathrm{ras}^{-/-}$and $\mathrm{H}_{-\mathrm{ras}^{-/}}$animals (Fig. 7b). To assess whether the increase in the cleavage of caspase-3 induced by UUO correlated with an increase in his activity, the proteolytic cleavage of (Z-DEVD) $)_{2}$-Rh110 (that is cleaved by both caspases 3 and 7) was also measured. Results show that caspase-3/7 activity is significantly higher in $\mathrm{O}$ that in $\mathrm{NO}$ kidneys, without significant differences obstructed kidneys in $\mathrm{H}-\mathrm{ras}^{+/+} / \mathrm{N}-\mathrm{ras}^{+/+}, \mathrm{N}-\mathrm{ras}^{-/-}$ and $\mathrm{H}_{-\mathrm{ras}^{-/}}$mice, (Fig. 7c) a result that is similar to that obtained with western blot.

\section{Discussion}

In previous studies we have observed the activation of Ras and its signaling pathways PI3K/Akt and ERK1/2 in the kidneys of mice after ureteral obstruction [10, 11]. The purpose of the present study has been to assess the possible role of the activation of H-ras and N-ras isoforms in the early changes that occurs in the kidney. For this purpose we have assessed the effect of unilateral ureteral obstruction on activated total Ras, activated Ras isoforms, pERK1/2, pAkt, total Akt levels, fibronectin, $\alpha$-SMA, cell proliferation, activated caspase 3 and morphological

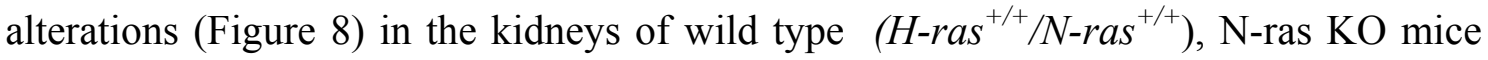
$\left(\mathrm{N}^{-\mathrm{ras}^{-/}}\right)$and H-ras KO mice $\left(\mathrm{H}-\mathrm{ras}^{-/}\right)$animals.

The present study shows that total Ras activation after UUO was similar in $H$ $\mathrm{ras}^{+/+} / \mathrm{N}-\mathrm{ras}^{+/+}, \mathrm{N}-\mathrm{ras}^{-/-}$and $\mathrm{H}-\mathrm{ras}^{-/-}$animals. Ras activation by UUO was accompanied by increases in the ERK pathway activation, measured as the ratio pERK/ERK content. Renal ERK activation has been also reported after UUO in mice [10] and rats [15].No significant differences in the ratio $\mathrm{pERK} / \mathrm{ERK}$ ratio in the $\mathrm{O}$ kidney were observed

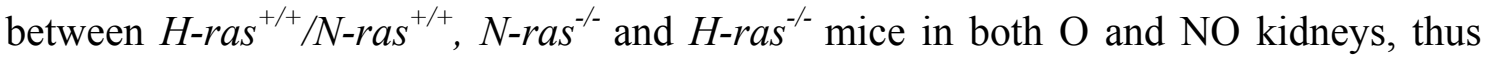
suggesting that neither N-ras nor H-ras activation do play a major role in the ERK pathway activation after UUO. After UUO, no significant differences were observed between WT, $\mathrm{N}-\mathrm{ras}^{-/}$and $\mathrm{H}-\mathrm{ras}^{-/-}$mice in both $\mathrm{O}$ and NO kidneys, thus suggesting that neither N-ras nor H-ras activation do play a major role in the Akt pathway activation after UUO.

Fibronectin has been measured as a marker of early renal fibrosis since previous studies demonstrated that a preformed fibronectin matrix is essential for fibroblasts to 
form a collagen network and it plays a major role in promoting matrix assembly, and that fibronectin increases early after UUO in mice [10]. The expression of fibronectin in the obstructed kidney did not differ between $\mathrm{H}-\mathrm{ras}^{+/+} / \mathrm{N}-\mathrm{ras}^{+/+}, \mathrm{N}-\mathrm{ras}^{-/}$and $\mathrm{H}-\mathrm{ras}^{-/-}$ animals thus suggesting than neither N-ras nor H-ras play a major role in the genesis of early fibrosis after UUO.

$\alpha$-SMA is a marker of activated myofibroblasts and it has been reported that in obstructive nephropathy there is a marked fibroblast activation, that plays a major role in extracellular matrix deposition [13]. Previous studies reveals $\alpha$-SMA abundance increases early after UUO in mice [10]. The expression of $\alpha$-SMA in the obstructed kidney, assessed by immunohystochemistry and western blot was similar in $\mathrm{H}_{-\mathrm{ras}^{+/+}} / \mathrm{N}$ $\mathrm{ras}^{+/+}, \mathrm{N}-\mathrm{ras}^{-/-}$and $\mathrm{H}-\mathrm{ras}^{-/}$animals, thus suggesting than neither N-ras nor H-ras play a major role in the myofibroblast activation after UUO. Sharpe et al. detected in cultured rat fibroblasts mRNA for $\mathrm{H}-\mathrm{Ras}, \mathrm{Ki}(\mathrm{B})$-Ras, and $\mathrm{N}-\mathrm{Ras}$, but not for $\mathrm{Ki}(\mathrm{A})-\mathrm{Ras}$ and showed that K-Ras was the predominantly expressed isoform $(>95 \%$ of total Ras protein), with $\mathrm{N}$ - and H-Ras being detected only in small amounts. They also showed different roles for K- and H-Ras in the control of fibroblast proliferation [14]. Thus, it is possible that myofibroblast activation and the subsequent renal damage after UUO is mediated exclusively by activation of the K-ras isoform, thus explaining the lack of differences between fibronectin and $\alpha$-SMA between $\mathrm{H}$-ras ${ }^{+/+} / \mathrm{N}-\mathrm{ras}^{+/+}, \mathrm{N}-\mathrm{ras}^{-/-}$and $\mathrm{H}$ $\mathrm{ras}^{-/-}$mice.

Proliferation of tubular epithelial cells and interstitial cells is also a characteristic feature of the obstructed kidney. In the present study we have not observed significant differences neither in tubular nor in interstitial cell proliferation of the $\mathrm{O}$ kidney between $\mathrm{H}-\mathrm{ras}^{+/+} / \mathrm{N}-\mathrm{ras}^{+/+}, \mathrm{N}-\mathrm{ras}^{-/-}$and $\mathrm{H}-\mathrm{ras}^{-/-}$mice, thus suggesting that neither N-ras nor H-ras activation do play a major role in regulating cell proliferation after UUO. ERK activation has been related to tubular proliferation in the obstructed kidney [16]. We have also observed that treatment with the MEK inhibitor U0126 induced a 50\% decrease in the number of proliferating tubular cells in $\mathrm{O}$ kidneys when compared with O kidneys of mice receiving only the vehicle [10], thus suggesting a role for ERK 1/2 signalling pathway activation in early obstruction-induced tubular cell proliferation. Thus, the lack of differences in proliferation between $\mathrm{H}-\mathrm{ras}^{+/+} / \mathrm{N}-\mathrm{ras}^{+/+}, \mathrm{N}-\mathrm{ras}^{-/-}$and $\mathrm{H}$ $\mathrm{ras}^{-/-}$mice is compatible with the lack of differences in ERK activation also observed in this study. Activation of PI3K/Akt pathway after UUO seems to be also related with cell 
proliferation, as inhibition of Akt activation significantly diminished the obstructioninduced increased number of both tubular and interstitial Ki-67-stained nuclei [10]. Further proves of the involvement of the PI3K-Akt signalling pathway in UUO induced cell proliferation has been given by a recent study reporting that the specific PI3K inhibitor LY294002 reduced proliferation and extracellular matrix synthesis in fibroblasts obtained from rat kidney tissue 3 days after UUO [17]. Thus, the lack of differences in proliferation between $\mathrm{H}-\mathrm{ras}^{+/+} / \mathrm{N}-\mathrm{ras}^{+/+}, \mathrm{N}-\mathrm{ras}^{-/-}$and $\mathrm{H}-\mathrm{ras}^{-/-}$mice is compatible with the lack of differences in Akt activation also observed in this study.

Tubular apoptosis constitutes a typical feature of renal damage in obstructed kidney and caspase 3 seems to be the major executive caspase in this process [18]. In the present study we have not found any significant difference in caspase-3 activation in the O kidneys between $\mathrm{H}-\mathrm{ras}^{+/+} / \mathrm{N}-\mathrm{ras}^{+/+}, \mathrm{N}-\mathrm{ras}^{-/-}$and $\mathrm{H}-\mathrm{ras}^{-/-}$mice, suggesting that none of these two isoforms play a role in the early activation of this pathway after UUO. PI3K/Akt pathway seems to be involved in the survival mechanisms of the epithelial cells, since is well known the anti-apoptotic role of Akt [19], and in vitro experiments have also demonstrated that Akt upregulation prevents apoptosis in proximal tubular cells [20]. Further support to this hypothesis is given by the fact that dilated tubules of $\mathrm{O}$ kidneys presented reduced activity of Akt and increased staining for activated caspase-3 as indicative of apoptosis. Moreover, in vivo inhibition of PI3K-Akt signalling pathway with LY 294002 resulted in obstruction-induced increased damage of altered tubules [10]. Taking all these data together, it could be suggested that Akt activation plays an important role against obstructive injury contributing to survival signalling in renal tubules of obstructed kidney. In the present study we have not found any significant difference neither in Akt activation nor in caspase-3 activation in the $\mathrm{O}$ kidneys between $\mathrm{H}-\mathrm{ras}^{+/+} / \mathrm{N}-\mathrm{ras}^{+/+}, \mathrm{N}-\mathrm{ras}^{-/-}$and $\mathrm{H}-\mathrm{ras}^{-/-}$mice, suggesting that none of these two isoforms plays a role in the early activation of these pathways after UUO.

Thus, the observation that removal of either $\mathrm{H}$-ras or $\mathrm{N}$-ras gene expression did not induce any changes in the UUO-induced ERK and Akt pathways activation, fibronectin or $\alpha$-SMA expression, caspase 3 activation and cell proliferation suggest that neither H-ras nor N-ras activation plays a major role in the early changes observed in that kidney after ureteral obstruction. Although we can speculate that the K-ras isoform probably is the isoform involved in these changes, further experimental studies are needed to demonstrate this fact. 


\section{Conclusions}

In summary, our results demonstrate that neither N-ras nor H-ras isoforms activation play a major role in the early changes observed in the obstructed kidney after unilateral ureteral obstruction in mice.

\section{Acknowledgments}

The authors wish to thank Ms. Angustias Pérez for his invaluable skilful technical assistance in histology procedures. This study was supported by grants from Spanish Ministerio de Ciencia y Tecnología (BFU2004-00285/BFI and SAF 2003-04177), Instituto de Salud Carlos III (RD06/0016/013: RedinRen) and Junta de Castilla y León (SA 001/C05).

\section{Conflict of interest}

The authors declare that they have no conflict of interest.

\section{References}

1. Klahr S, Morrissey J (2002) Obstructive nephropathy and renal fibrosis. Am J Physiol Renal Physiol 283(5):F861-75.

2. Bascands JL, Schanstra JP (2005) Obstructive nephropathy: insights from genetically engineered animals. Kidney Int 68(3):925-37.

3. Santos E, Nebreda AR (1989) Structural and functional properties of ras proteins. FASEB J 3(10):2151-63.

4. Leon J, Guerrero I, Pellicer A (1987) Diferential expression of the ras gene family in mice. Mol Cell Biol 7(4):1535-40.

5. Esteban LM, Vicario-Abejón C, Fernández-Salguero P et al (2001) Targeted genomic disruption of H-ras and N-ras, individually or in combination, reveals the dispensability of both loci for mouse growth and development. Mol Cell Biol 21(5):1444-52.

6. Koera K, Nakamura K, Nakao K et al (1997) K-ras is essential for the development of the mouse embryo. Oncogene 4:15(10):1151-9.

7. Dhanasekaran N, Premkumar Reddy E (1998) Signaling by dual specificity kinases. Oncogene 17:17:1447-55. 
8. Marshall CJ (1994) MAP kinase kinase kinase, MAP kinase kinase and MAP kinase. Curr Opin Genet Dev 4(1):82-9.

9. Malumbres M, Pellicer A (1998) RAS pathways to cell cycle control and cell transformation. Front Biosci 6:3:d887-912.

10. Rodríguez-Peña AB, Grande MT, Eleno N et al (2008) Activation of Erk1/2 and Akt following unilateral ureteral obstruction. Kidney Int 74(2):196-209.

11. Rodriguez-Peña AB, Santos E, Arevalo M et al (2005) Activation of small GTPase Ras and renal fibrosis. J Nephrol 18(3):341-9.

12. National Research Council (NRC) (1996) Commission on Life Sciences, Institute of Laboratory Animal Resources, Guide for the Care and Use of Laboratory Animals, National Academy Press, Washington (DC).

13. Bani-Hani AH, Campbell MT, Meldrum DR et al (2008) Cytokines in epithelialmesenchymal transition: a new insight into obstructive nephropathy. J Urol 180(2):4618.

14. Sharpe CC, Dockrell ME, Noor MI et al (2000) Role of Ras isoforms in the stimulated proliferation of human renal fibroblasts in primary culture. J Am Soc Nephrol 11(9):1600-6.

15. Pat B, Yang T, Kong $\mathrm{C}$ et al (2005) Activation of ERK in renal fibrosis after unilateral ureteral obstruction: modulation by antioxidants. Kidney Int 67(3):931-43.

16. Masaki T, Foti R, Hill PA et al (2003) Activation of ERK pathway precedes tubular proliferation in the obstructed rat kidney. Kidney Int 63(4):1256-64.

17. Winbanks CE, Grimwood L, Gasser A et al (2007) Role of the phosphatidylinositol 3-kinase and mTOR pathways in the regulation of renal fibroblast function and differentiation. Int J Biochem Cell Biol 39(1):206-19.

18. Truong LD, Choi YJ, Tsao CC et al (2001) Renal cell apoptosis in chronic obstructive uropathy: The roles of caspases. Kidney Int 60(3):924-34.

19. Osaki M, Oshimura M, Ito H (2004) PI3K-Akt pathway: Its functions and alterations in human cancer. Apoptosis 9(6):667-76.

20. Sinha D, Bannergee S, Schwartz JH et al (2004) Inhibition of ligand-independent ERK1/2 activity in kidney proximal tubular cells deprived of soluble survival factors up-regulates Akt and prevents apoptosis. J Biol Chem 19:279(12):10962-72. 
a

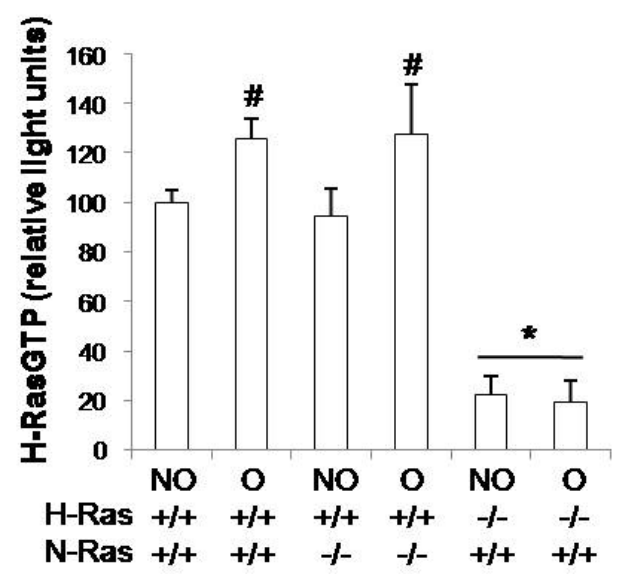

b

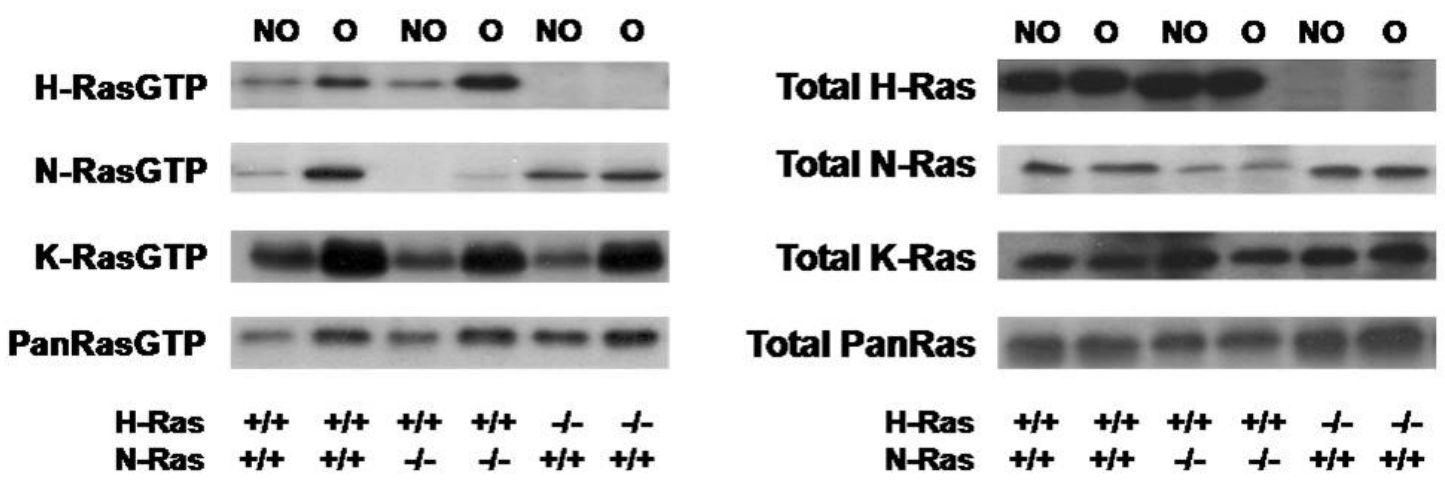

Fig.1 Ras activation in NO and $\mathrm{O}$ kidneys of $\mathrm{H}-\mathrm{ras}^{+/+} / \mathrm{N}-\mathrm{ras}^{+/+}, \mathrm{N}-\mathrm{ras}^{-/-}$and $\boldsymbol{H}$-ras ${ }^{-/-}$mice. (a) RasGTP levels were determined by ELISA. Data represent the average \pm SEM of the relative light units. $\# \mathrm{P}<0,01$ vs NO kidneys. * $\mathrm{P}<$ 0,01 vs $\mathrm{H}-\mathrm{ras}^{+/+} / \mathrm{N}-\mathrm{ras}^{+/+}$and $\mathrm{N}-\mathrm{ras}^{-/-}$(b) H, N, K and Pan-Ras activation (left) and total expression (right) in $\mathrm{NO}$ and $\mathrm{O}$ kidneys from $\mathrm{H}-\mathrm{ras}^{+/+} / \mathrm{N}-\mathrm{ras}^{+/+}, \mathrm{N}-$ $\mathrm{ras}^{-/ .}$and $\mathrm{H}$-ras ${ }^{-/}$mice analyzed by western blot. 

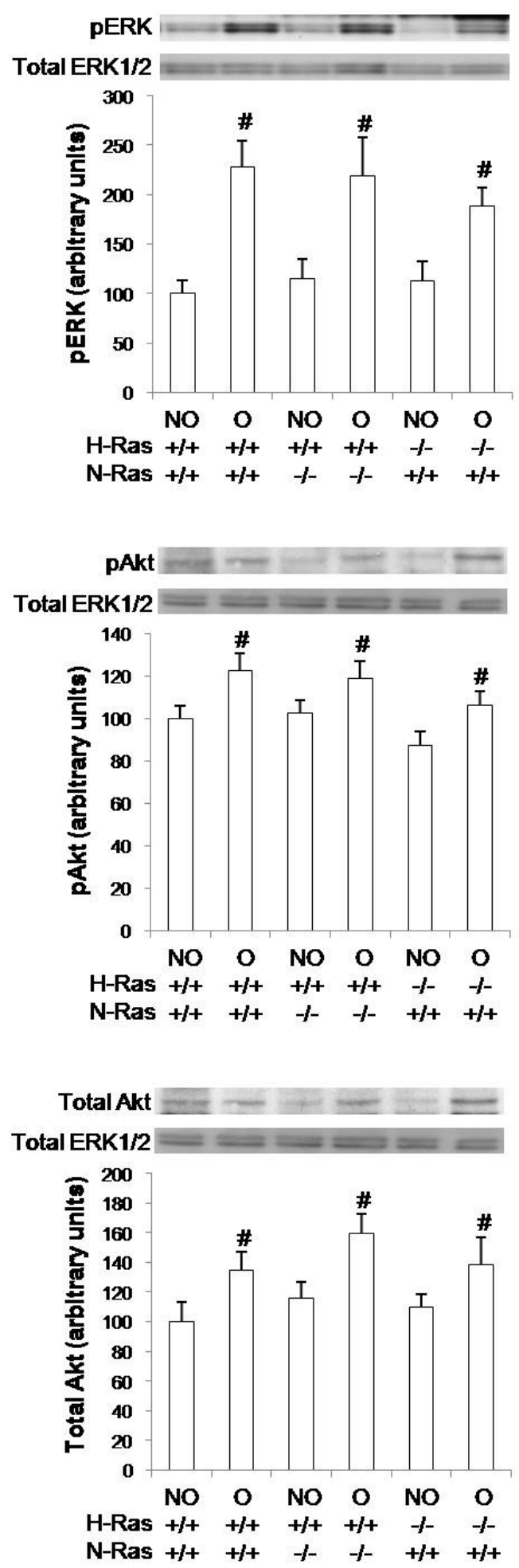

Fig. 2 ERK activation, phospho-Akt expression and total Akt expression in NO and $\mathrm{O}$ kidneys of $\mathrm{H}-\mathrm{ras}^{+/+} / \mathrm{N}-\mathrm{ras}^{+/+}, \mathrm{N}-\mathrm{ras}^{-/-}$and $\mathrm{H}_{-\mathrm{ras}^{-/}}$mice. All proteins were evaluated by western blot. Data represent the average \pm SEM of the optical density. \# $\mathrm{P}<0,01$ vs corresponding NO kidneys. 

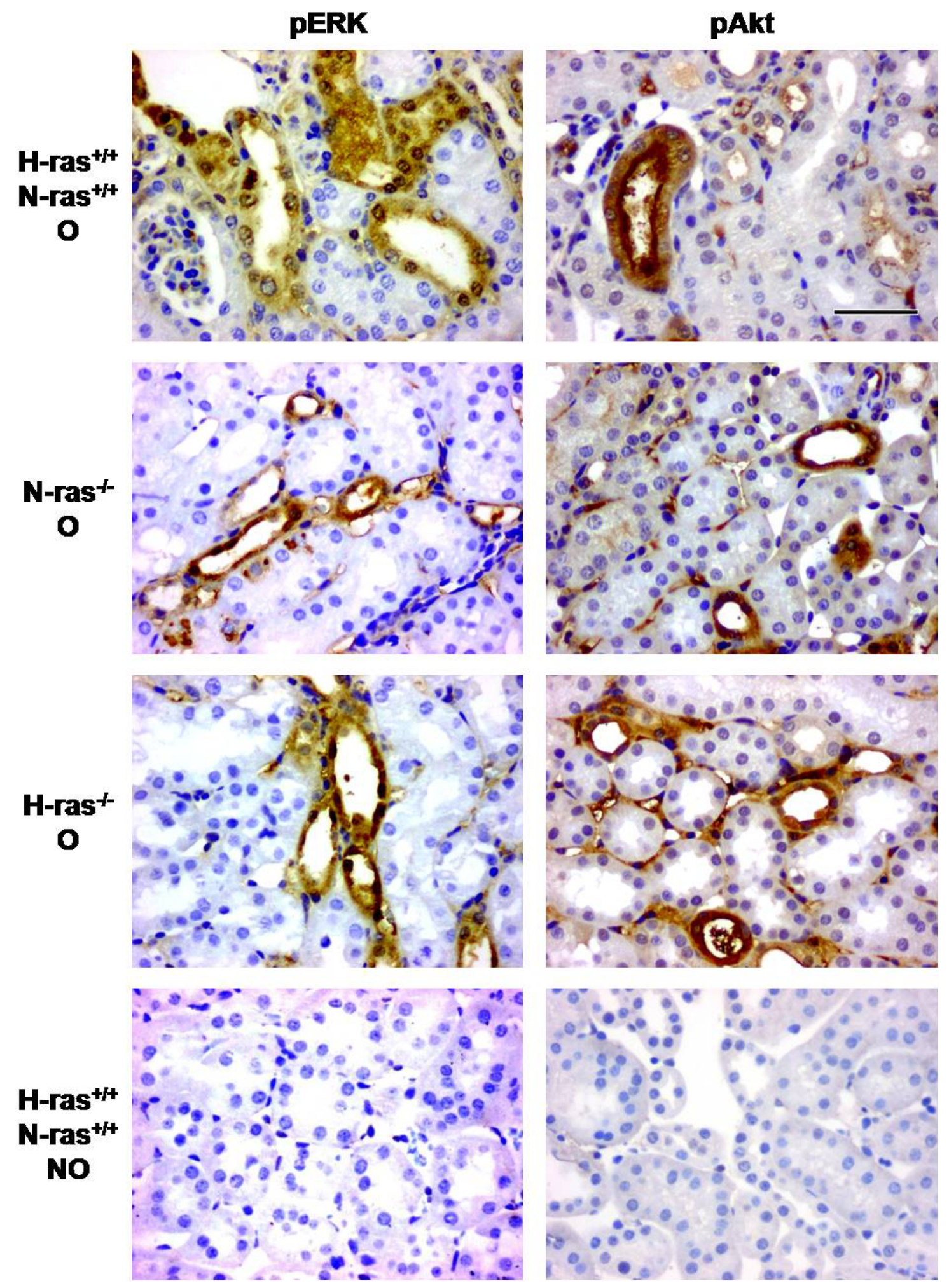

Fig.3 Inmunohistochemistry for phospho-ERK and phospho-Akt in NO

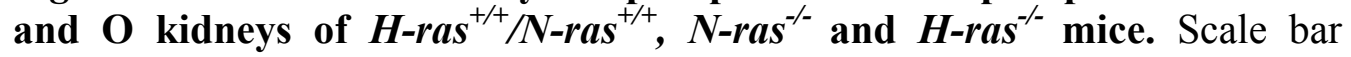
indicates 100 microns in all panels. 


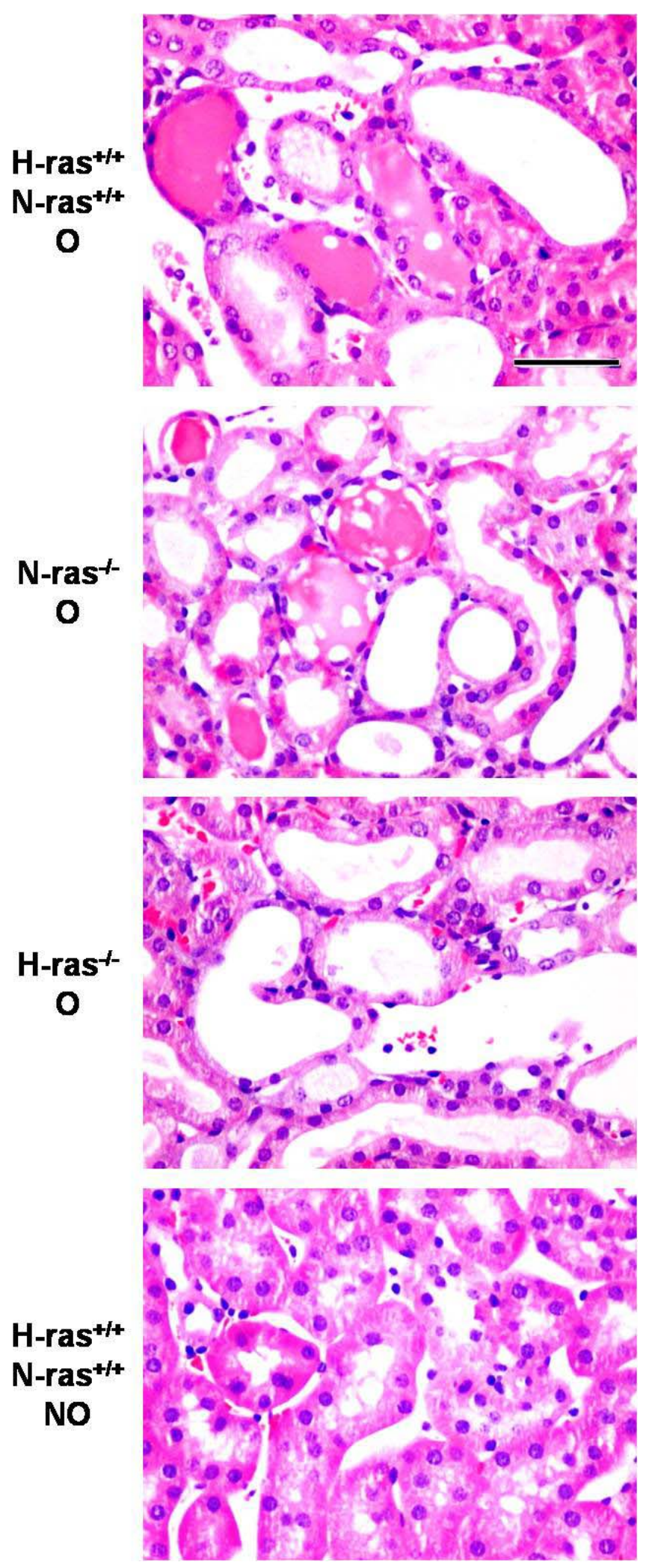

Fig.4 Hematoxylin-eosin staining of non-obstructed (NO) and obstructed

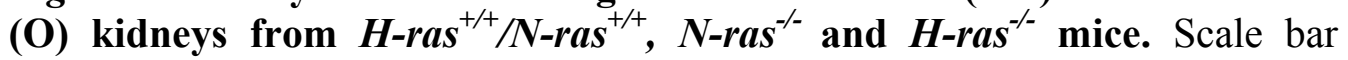
indicates 100 microns in all panels. 


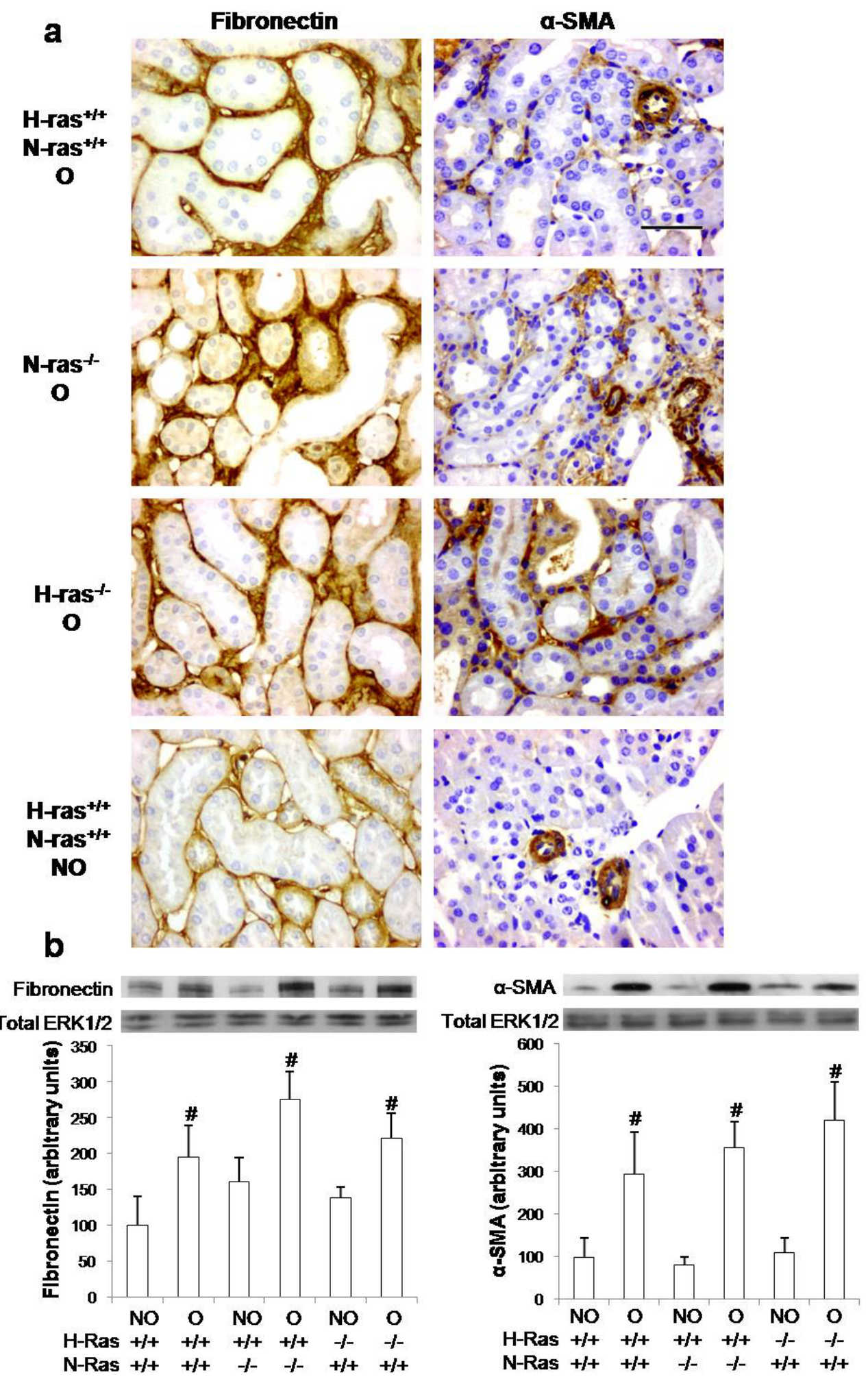

Fig.5 Inmunohistochemistry for fibronectin and $\alpha$-SMA (a) in NO and O kidneys of $\mathrm{H}-\mathrm{ras}^{+/+} / \mathrm{N}-\mathrm{ras}^{+/+}, \mathrm{N}-\mathrm{ras}^{-/-}$and $\mathrm{H}-\mathrm{ras}^{-/-}$mice. Scale bar indicates 100 microns in all panels. (b) Western blot analysis of fibronectin and $\alpha$-SMA levels in $\mathrm{NO}$ and $\mathrm{O}$ kidneys of $\mathrm{H}-\mathrm{ras}^{+/+} / \mathrm{N}-\mathrm{ras}^{+/+}, \mathrm{N}-\mathrm{ras}^{-/-}$and $\mathrm{H}-\mathrm{ras}^{-/-}$mice. Data represent the average $\pm \mathrm{SEM}$ of the optical density. $\# \mathrm{P}<0,01$ vs corresponding NO kidneys. 


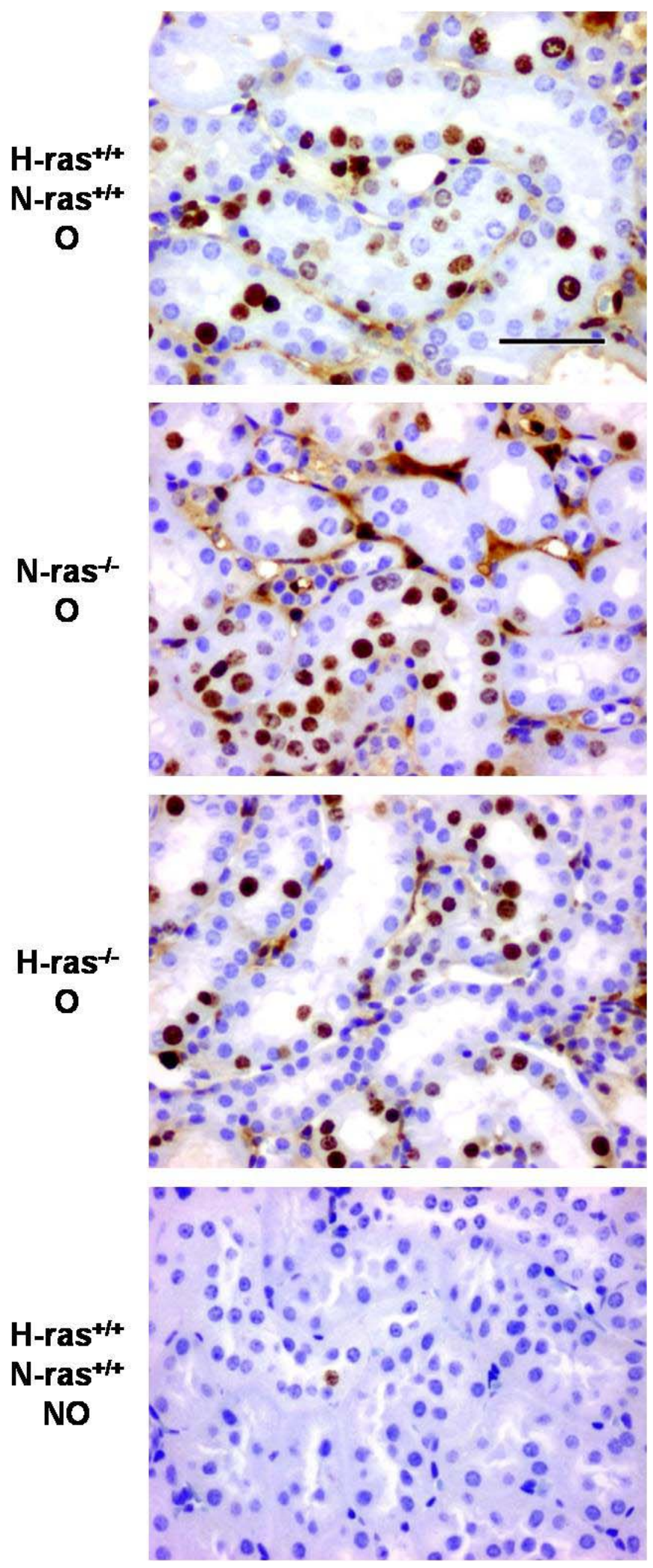

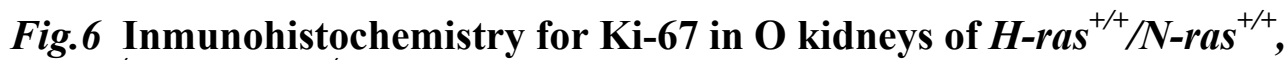
$\mathrm{N}-\mathrm{ras}^{-/-}$and $\mathrm{H}$-ras ${ }^{-/-}$mice. Scale bar indicates 100 microns in all panels. 
a

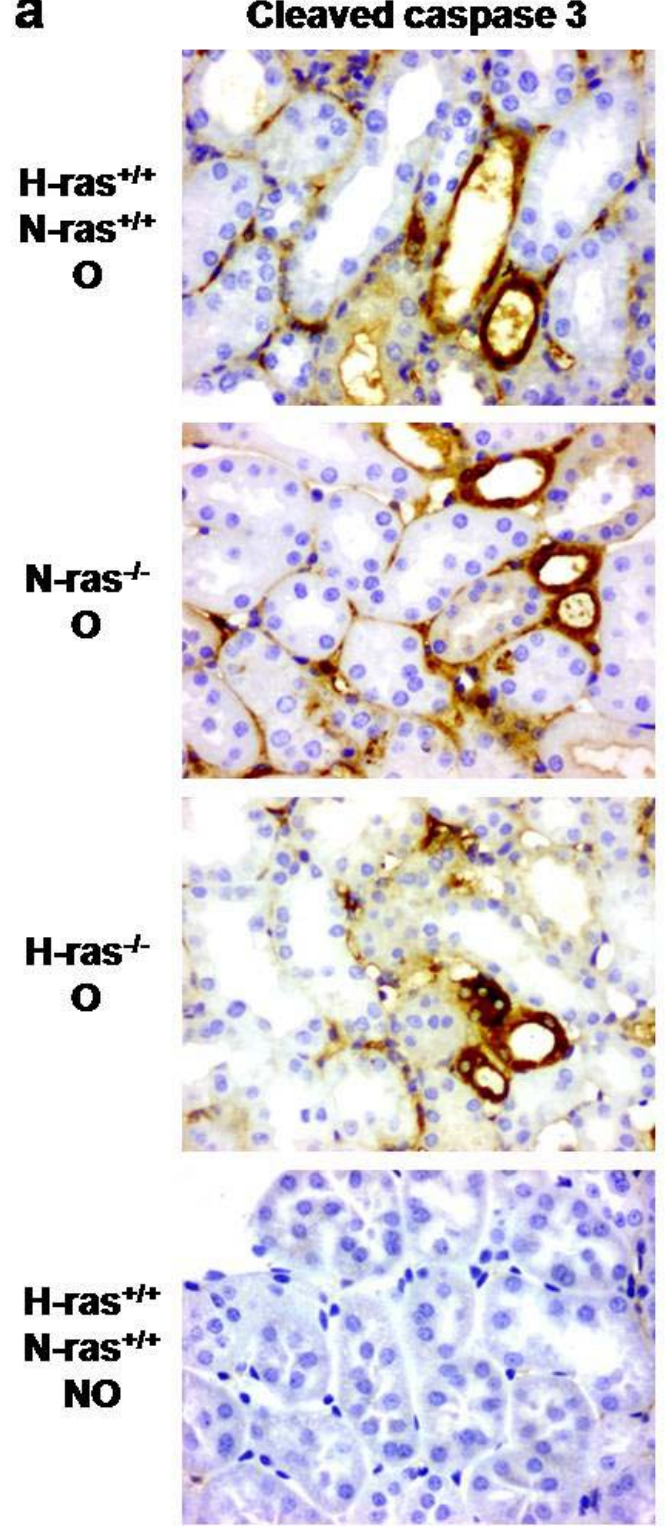

b

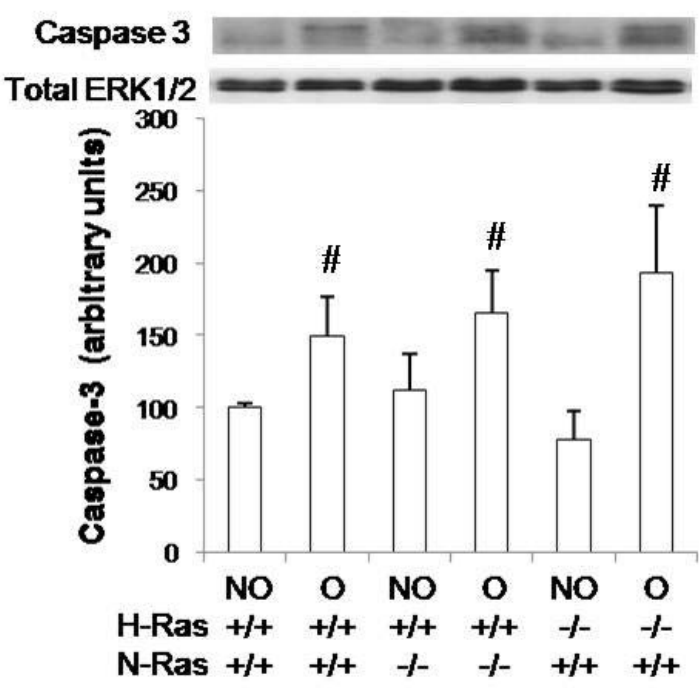

C

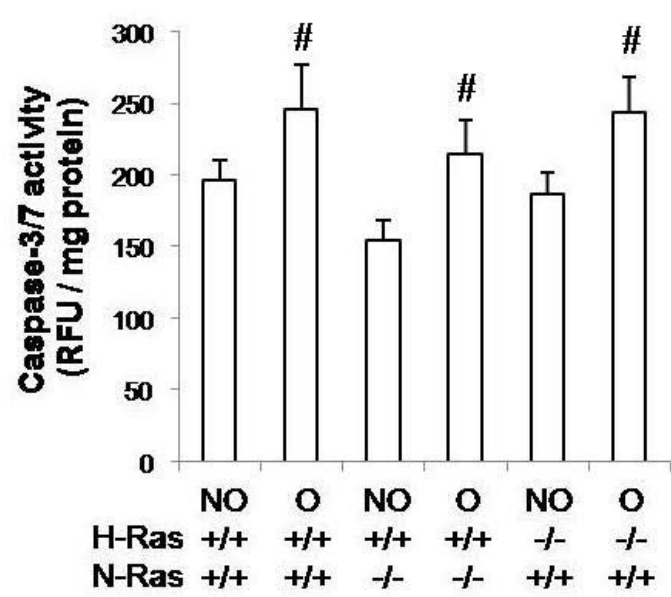

Fig.7 (a) Inmunohistochemistry for cleaved caspase 3 in O kidneys of $\mathrm{H}$ $\mathrm{ras}^{+/+} / \mathrm{N}-\mathrm{ras}^{+/+}, \mathrm{N}-\mathrm{ras}^{-/-}$and $\mathrm{H}$-ras ${ }^{-/-}$mice. Scale bar indicates 100 microns in all panels. (b) Western blot of cleaved caspase-3 expression in $\mathrm{NO}$ and $\mathrm{O}$ kidneys from $\mathrm{H}-\mathrm{ras}^{+/+} / \mathrm{N}-\mathrm{ras}^{+/+}, \mathrm{N}-\mathrm{ras}^{-/-}$and $\mathrm{H}-\mathrm{ras}^{-/-}$mice. (c) Caspase-3/7 activity assay in $\mathrm{NO}$ and $\mathrm{O}$ kidneys from $\mathrm{H}-\mathrm{ras}^{+/+} / \mathrm{N}-\mathrm{ras}^{+/+}, \mathrm{N}-\mathrm{ras}^{-/-}$and $\mathrm{H}-\mathrm{ras}^{-/-}$mice. Data represent the average \pm SEM of the optical density. \# $\mathrm{P}<0,01$ vs corresponding NO kidneys. 


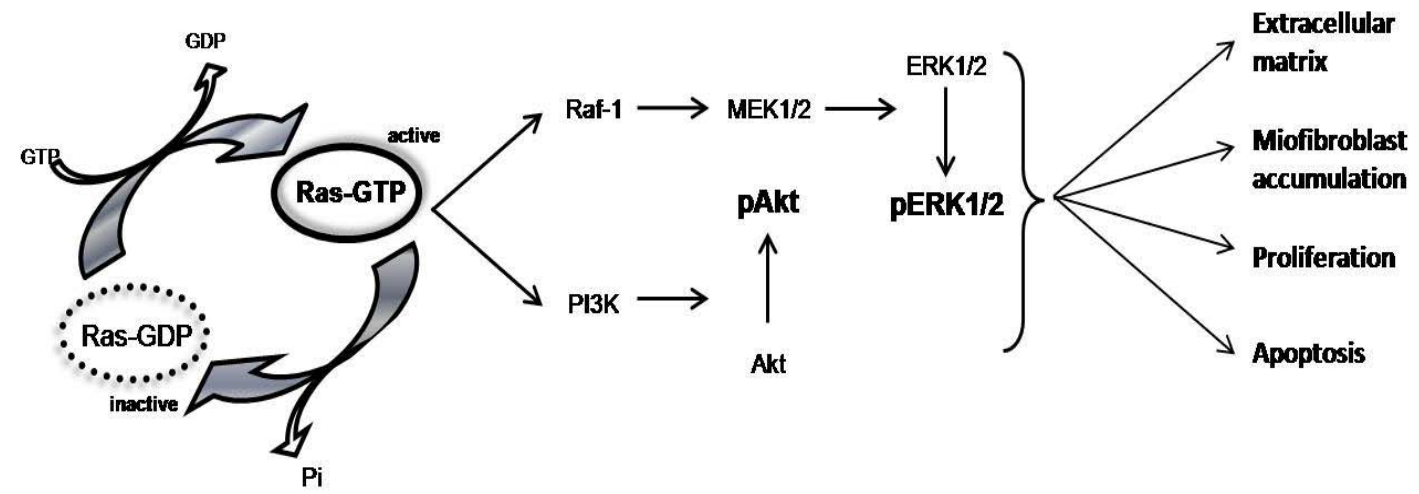

Fig. 9 Schematic diagram of the pathways involved in early damage in the obstructed kidney after unilateral ureteral ligation evaluated in the present study. 


\section{Artículo IX}

\section{"Targeted genomic disruption of H-Ras decreases renal fibrosis and myofibroblast activation after unilateral ureteral obstruction in mice"}

M. Teresa Grande, Isabel Fuentes-Calvo, Miguel Arévalo,

Eugenio Santos, Carlos Martínez-Salgado, Diego Rodríguez-Puyol, y

José M López-Novoa

Kidney International (enviado) 
Targeted genomic disruption of H-Ras decreases renal fibrosis and myofibroblast activation after unilateral ureteral obstruction in mice.

M. Teresa Grande ${ }^{1}$, Isabel Fuentes-Calvo ${ }^{1}$, Miguel Arévalo ${ }^{2}$, Eugenio Santos ${ }^{3}$, Carlos MartinezSalgado $^{4}$, Diego Rodríguez-Puyol ${ }^{5}$ and José M López-Novoa ${ }^{1}$

${ }^{1}$ Instituto "Reina Sofía" de Investigación Nefrológica, Departamento de Fisiología y Farmacología, Universidad de Salamanca, 37007 Salamanca, Spain. ${ }^{2}$ Departamento de Anatomía e Histología Humanas, ${ }^{3}$ Centro de Investigación del Cáncer CSIC-USAL, 37007 Salamanca, Spain. ${ }^{4}$ Unidad de Investigación, Hospital Universitario de Salamanca, 37007 Salamanca, Spain. ${ }^{5}$ Unidad de Investigación, Hospital Universitario Principes de Asturias, Alcalá de Henares, Spain.

\section{*Corresponding author:}

Jose M. López-Novoa

Departamento de Fisiología y Farmacología,

Edificio Departamental,

Campus Miguel de Unamuno

Universidad de Salamanca

37007 Salamanca, Spain.

Phone: (+34) 923294472

Fax: (+34) 923294669.

E-mail: jmlnovoa@usal.es 
Abstract.

Previous studies reveal that RasGTPases contribute to changes associated to obstructive nephropathy induced by unilateral ureteral obstruction (UUO). The purpose of this study was to asses the contribution of the H-Ras isoform to UUO-induced renal

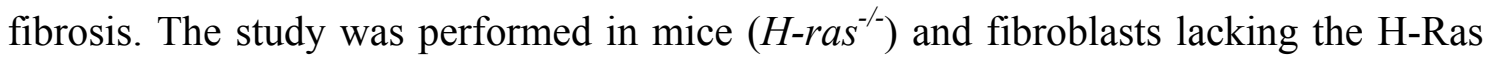
isoform. Fifteen days after UUO, interstitial fibrosis, fibronectin and collagen I accumulation, and myofibroblast abundance markers were lower in obstructed kidneys from $\mathrm{H}_{-\mathrm{ras}^{-/}}$compared with $\mathrm{H}-\mathrm{ras}^{+/+}$mice. This can be explained by a lower activation of myofibroblasts in renal tissue, as a lower proliferation rate and migration ability but similar amounts of $\alpha$-SMA and vimentin were observed in fibroblasts deficient for $\mathrm{H}$ Ras compared with WT fibroblasts. Another possible explanation is a reduced

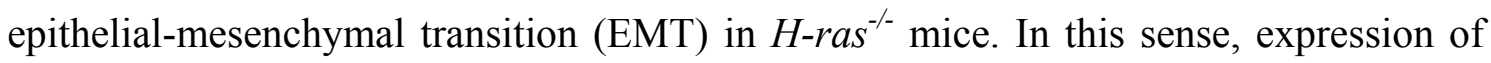
E-cadherin repressors, Snail and Slug, were also diminished in O kidneys from $\mathrm{H}_{-\mathrm{ras}^{-/}}$ mice, compared with ${\mathrm{H}-\mathrm{ras}^{+/+}}$mice, thus suggesting a decreased EMT. Moreover lower levels of activated Akt and activated GSK3 $\beta$ were found in the kidneys from $\mathrm{H}$-ras ${ }^{-/}$ than in $\mathrm{H}-\mathrm{ras}^{+/+}$and in cultured fibroblasts, in which TGF- $\beta 1$-induced Akt activation was markedly lower in $\mathrm{H}$-ras ${ }^{-/-}$than in $\mathrm{H}-\mathrm{ras}^{+/+}$fibroblasts.

Taken all results together, lower fibrosis observed in obstructed kidneys from $\mathrm{H}$ $\mathrm{ras}^{-/-}$seems to be based in a lower number of activated myofibroblasts, because both a reduction in the proliferation of resident fibroblasts, and a reduced EMT. 


\section{Introduction}

Interstitial renal fibrosis, the common end point of progressive kidney disease, is a complex process involving not only derangements in both the synthesis and degradation of extracellular matrix (ECM), but also cell infiltration, apoptosis, accumulation of activated myofibroblasts and increased deposition of extracellular matrix [1, 2]. Unilateral ureteral obstruction (UUO) in mice is a well-established experimental model resulting in tubulointerstitial fibrosis in the obstructed kidney [2, 3].

Among the cells that accumulate in the renal interstitium, myofibroblasts play a major role mediating tubulointerstitial fibrosis as they are the source of several components of ECM and many cytokines that contributes to renal damage [1]. Active myofibroblasts seems to derive from resident fibroblasts and from tubular epithelial cells by a process called epithelial-mesenchymal transition (EMT) [1, 4].

Small GTPases Ras are key mediators in signalling pathways that convey extracellular signals from the surface receptors to inside the cell, functioning as molecular switches in essential cellular processes [5,6]. There are three major isoforms of Ras: H-Ras, K-Ras, and N-Ras sharing a high degree of sequence homology. The only region that exhibits significant sequence divergence is the final 24 residues, constituting the hypervariable $\mathrm{COOH}$ terminus. However, studies have demonstrated that the Ras isoforms may have different biological effect [7]. $\mathrm{H}$-ras and $\mathrm{N}$-ras gene expression are dispensable for mouse development, growth, and fertility [8]. Only K-ras appears to be critical for normal mouse development based on the observation that $K$-ras deficiency results in embryonic lethality $[9,10]$. Transforming growth factor- $\beta 1$ (TGF$\beta 1)$ plays a major role in the origin and maintenance of fibrosis $[11,12]$ as a consequence of the regulatory role of TGF- $\beta 1$ in cell proliferation $[13,14]$ and in renal ECM synthesis and degradation [15].

There is a close relation between TGF- $\beta$ and Ras signalling pathways, which has been previously described in the literature. The family of Ras GTPases function as transducers of extracellular signals regulating cell survival, growth and differentiation, and it is particularly well known their prooncogenic effect [16, 17]. Ras alters the expression of TGF- $\beta 1$ type II receptor, counteracting TGF- $\beta$ signalling [18], and on the other hand, TGF- $\beta 1$ overcomes Ras mitogenic effects [19, 20, 21$]$.

Ras GTP transmits its signal through interactions with a large number of target proteins, being phosphatidylinositol 3-kinase (PI3K)/Akt and Raf/MEK-extracellular 
signal-regulated kinase (ERK1 and ERK2) the most studied pathways [22]. The activation of Ras and its effectors pathways has been demonstrated to play an important role in renal fibrosis $[23,24]$. In previous studies, we have demonstrated the activation of Ras and its effectors PI3K/Akt and ERK1/2 pathways 3 days after UUO [25]. However, the contribution of the activation of the different Ras isoforms activation to kidney damage after UUO has not been studied. Thus, in the present study we aimed to examine the role of $\mathrm{H}$-Ras isoform in tubular and interstitial proliferation, myofibroblast abundance, EMT and deposition of extracellular matrix, key processes in UUO-induced interstitial fibrosis. The study has been performed in an in vivo model, unilateral ureteral ligation in $\mathrm{H}-\mathrm{ras}^{+/+}$and $\mathrm{H}-\mathrm{ras}^{-/-}$mice, and in an in vitro model, cultured fibroblasts lacking the H-Ras isoform. We have chosen to study $\mathrm{H}$-Ras because $\mathrm{H}$-ras ${ }^{-/-}$mice are viable [8], and we have developed a line of fibroblasts lacking H-Ras [26].

\section{Results}

\section{In vivo studies}

\section{Morphological and biochemical characteristics of obstructed kidneys}

After fifteen days of ureteral obstruction, the obstructed (O) kidney in wild-type mice showed the typical features of obstructive nephropathy: tubular dilatation, flattened epithelium and widespread renal tubulointerstitial damage (Figure 1A) and fibrosis, as evidenced by increases in fibronectin and sirius red staining (Figure 1A). Western blot analysis of renal tissue also revealed higher content of collagen I and fibronectin in $\mathrm{O}$ than in NO kidney (Figure 1B). O kidney showed also increased myofibroblast number, as demonstrated by increased $\alpha$-SMA and vimentin immunostaining and expression by immunohystochemistry and western blot (Figure 2 A y B). $\alpha$-SMA and FSP-1 (S100A4) interstitial localization was also assessed by double immunofluorescence. In the NO kidney, $\alpha$-SMA-positive cells (green) were observed only in the blood vessels wall (figure $2 \mathrm{~B}$ ), but in the O kidney, many $\alpha$-SMApositive cells were observed in the peritubular space (Figure 2B). FSP-1 positive cells (red) were very scarce in the NO kidney, but abundant in the interstitial space of the $\mathrm{O}$ kidney. In general, FSP-1 positive cells were bigger and more circular than $\alpha$-SMApositive cells. No cells showing both $\alpha$-SMA and FSP-1 staining were observed (figure $2 \mathrm{~B}$, inserts). 
H-ras deficiency reduces interstitial fibrosis, myofibroblast number and EMT markers after UUO

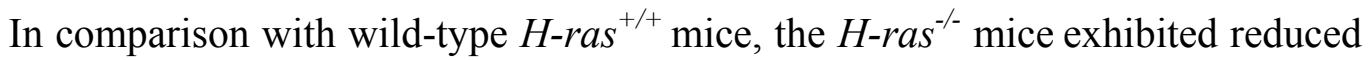
renal cortical scarring as assessed by hematoxilin-eosine, sirius red staining, and fibronectin immunostaining (Figure 1A). Western blot analysis of renal tissue revealed that fibronectin and type I collagen expression was significantly lower in O kidneys from $\mathrm{H}-\mathrm{ras}^{-/-}$than in those from $\mathrm{H}-\mathrm{ras}^{+/+}$mice (Figure 1B).

Compared with wild-type mice, the $\mathrm{H}-\mathrm{ras}^{-/-}$mice expressed significantly less renal cortical $\alpha$-SMA and vimentin staining than $\mathrm{H}_{-} \mathrm{ras}^{+/+}$mice (Figures 2A and B), in O kidneys. The number of both $\alpha$-SMA and FSP-1 positive cells were also markedly lower in O kidneys from $\mathrm{H}$-ras ${ }^{-/-}$mice than in O kidneys from $\mathrm{H}$-ras ${ }^{+/+}$mice (Figure 2C). Both $\alpha$-SMA and vimentin content, analyzed by western blot, was significantly lower in $\mathrm{O}$ kidneys of $\mathrm{H}_{-\mathrm{ras}^{-/}}$than in those from $\mathrm{H}-\mathrm{ras}^{+/+}$mice (Figure 3A and 3B). The same pattern was observed with FSP-1 (S100A4) expression (Figure 3C).

As both Snail and Slug activation have been demonstrated to be involved in EMT [27], analyses of Snail and Slug expression were also performed. Snail and Slug expression, assessed by RT-PCR, revealed an increased expression in $\mathrm{O}$ than in NO kidneys. Furthermore, Snail and Slug expression was lower in O kidneys from $\mathrm{H}_{-\mathrm{ras}^{-/}}$ compared with O kidneys from $\mathrm{H}_{-} \mathrm{ras}^{+/+}$mice (Figure 3D).

Effect of H-Ras defficiency on Ras, ERK1/2 and Akt activation after UUO

Activated H-Ras levels were higher in O kidneys compared NO kidneys in $\mathrm{H}$ ras $^{+/+}$mice. Ras GTPase Chemi ELISA specifically detects activated H-Ras in rodent samples, but it was unable to detect activated Ras levels in $\mathrm{H}-\mathrm{ras}^{-/}$mice (Figure 4A).

As we have previously demonstrated that ras activation after UUO was associated to ERK1/2 and Akt activation [25], we assessed the activation of these two pathways after UUO in $\mathrm{H}_{-\mathrm{ras}^{-/}}$and $\mathrm{H}_{-} \mathrm{ras}^{+/+}$mice. Western blot analysis revealed that the content of the active, phosphorylated form of ERK1/2, pERK1/2 was higher in O than in NO kidneys of $\mathrm{H}_{-\mathrm{ras}^{+/+}}$mice. Both $\mathrm{O}$ and $\mathrm{NO}$ kidneys from $\mathrm{H}-\mathrm{ras}^{-/-}$mice shown higher levels of pERK1/2 than $\mathrm{H}_{-\mathrm{ras}^{+/+}}$mice (Figure 4B). Western blot studies revealed that both total Akt levels and the levels of pAkt were higher in O kidneys than in NO

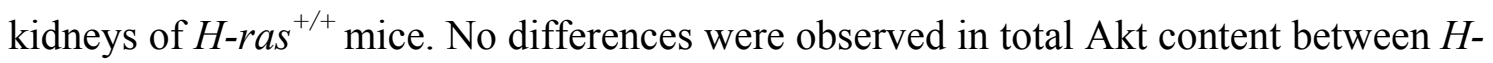
$\mathrm{ras}^{+/+}$and $\mathrm{H}-\mathrm{ras}^{-/-}$neither in the O nor in the NO kidney (Figure 4B), however pAkt 
levels were significantly lower in O kidneys from $\mathrm{H}_{-\mathrm{ras}^{-/}}$than in those from $\mathrm{H}$-ras ${ }^{+/+}$ mice (Figure 4B).

Immunohistochemistry showed an increase in pERK in $\mathrm{O}$ compared with NO kidneys. No differences in pERK staining was observed in O kidneys from $\mathrm{H}_{-\mathrm{ras}^{-/}}$and $\mathrm{H}_{-\mathrm{ras}^{+/+}}$mice (Figure 5) Immunohistochemistry also revealed that the expression of the active phosphorylated form of Akt, pAkt, was higher in $\mathrm{O}$ than in NO kidneys after UUO. In addition, kidneys from $\mathrm{H}$ - $\mathrm{ras}^{-/-}$mice showed lower pAkt staining than kidneys from $\mathrm{H}-\mathrm{ras}^{+/+}$mice (Figure 5). In order to further study the PI3-Kinase pathway, we assessed by immunohistochemistry and western blot the expression of GSK3 $\beta$, a substrate of Akt who inhibit the activity of GSK3 $\beta$ through phosphorilation of the Ser9. Immunohistochemistry revealed that pGSK3 $\beta$ immunostaining was almost absent in NO kidneys, but many cells positive for pGSK3 $\beta$ appeared in the O kidney (Figure 5). By western blot, we observed pGSK3 $\beta$ levels higher in O than in NO kidneys of $\mathrm{H}_{-\mathrm{ras}^{+/+}}$ mice, but this increment was significantly lower in the kidneys from $\mathrm{H}$-ras ${ }^{-/}$mice (Figure 4B). As in the case of total Akt levels, total GSK3 $\beta$ levels were also increased in the O kidneys from $\mathrm{H}-\mathrm{ras}^{+/+}$and $\mathrm{H}_{-\mathrm{ras}^{-/}}$mice compared with NO kidneys (Figure 4B).

Effect of H-Ras deficiency on cell proliferation after UUO.

Ki-67 expression assessed by immunohistochemistry, revealed higher Ki67 staining in O kidneys than in NO kidneys (Figure 6A). After 15 days of UUO Ki67 was localized more frequently in interstitial cell nuclei than in tubular cell nuclei. The number of Ki-67-possitive interstitial cells were significantly lower in $\mathrm{O}$ kidneys from $\mathrm{H}_{-\mathrm{ras}^{-/}}$mice than in O kidneys from $\mathrm{H}-\mathrm{ras}^{+/+}$mice (Figure 6B).

\section{In vitro studies}

Effect of H-Ras deficiency on basal and TGF- $\beta$-induced extracellular matrix synthesis and vimentin and $\alpha-S M A$ expression

Western blot analysis showed that fibronectin expression was higher in H-Ras KO fibroblasts than in WT fibroblasts; TGF- $\beta 1$ treatment increases fibronectin expression in WT fibroblasts, without any increase in $\mathrm{H}-\mathrm{ras}^{-/}$fibroblasts (Figure 7A). Western blot quantification showed that collagen type I expression was significantly higher in $\mathrm{H}_{-\mathrm{ras}^{-/}}$fibroblasts than in WT fibroblasts. TGF- $\beta 1$ treatment stimulated collagen type I expression in both WT and H-Ras KO fibroblasts (figure 7B). 
Both vimentin and $\alpha$-SMA expression were similar in WT and $\mathrm{H}-\mathrm{Ras} \mathrm{KO}$ fibroblasts either with or without incubation with TGF- $\beta 1$ (figure 7C and 7D).

\section{Effect of H-Ras deficiency on ERK $1 / 2$ and PI3K activation}

The expression of pERK, as well as total ERK1/2 expression, was analyzed by western blot. pERK expression was significantly higher in H-Ras KO than in WT fibroblasts in basal conditions. TGF- $\beta 1$ treatment increased pERK expression in WT fibroblasts, but did not induce any significant change in pERK expression in $\mathrm{KO}$ fibroblasts (Figure 7E);

PI3K pathway activation was analyzed evaluating pAkt and total Akt expression by western-blot. pAkt expression was significantly increased in basal conditions in $H$ $\mathrm{ras}^{-/-}$fibroblasts, but TGF- $\beta 1$ treatment increased Akt activation only in WT fibroblasts but not in $\mathrm{H}_{-\mathrm{ras}^{-/}}$fibroblasts (Figure 7F).

\section{Effect of H-Ras deficiency on fibroblast proliferation and migration}

Cell proliferation was evaluated by nuclei staining with crystal violet and by immunocytochemistry with Ki67. In basal conditions, cell proliferation was reduced in $H-$ ras $^{-/}$fibroblasts. TGF- $\beta 1$-induced fibroblast proliferation was significantly lower in H-Ras KO fibroblasts with respect to WT cells (Figure 8A). Nuclei staining with Ki67 antibody corroborated the crystal violet data: the percentage of cells stained for Ki67 after TGF- $\beta 1$ treatment was reduced in H-Ras KO fibroblasts with respect to WT cells (Figure 8B).

We have also analyzed the existence of alterations in cell cycle in $\mathrm{KO}$ fibroblasts by flow cytometry. Our results showed that there are a significant reduction in the percentage of cells in phases S, G2 and M of the cell cycle in $\mathrm{H}-\mathrm{ras}^{-/-}$fibroblasts with respect to WT fibroblasts (Figure $8 \mathrm{C}$ ).

Fibroblast migration was analyzed by wound-healing assay and by cell migration through a Boyden chamber. Analysis of wounds half-closure time shows that cell movement in H-Ras KO fibroblasts was notably slower with respect to WT cells (Figure 8D); moreover, fibroblast migration in Boyden chamber after $24 \mathrm{~h}$ was significantly lower in $\mathrm{H}_{-\mathrm{ras}^{-/}}$fibroblasts compared with WT fibroblasts (figure 8E).

\section{Discussion}

In the present study, we report that UUO induces lower interstitial fibrosis, lower fibronectin and collagen I accumulation and lower amount of myofibroblast abundance 


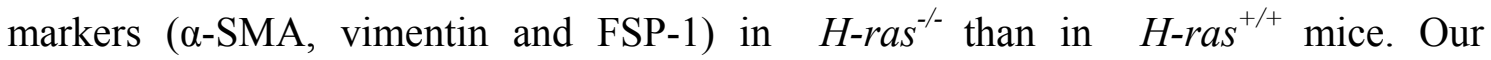
hypothesis is that this could be due to a lower number of myofibroblasts in renal tissue, as we have observed a lower density of cells positive for either $\alpha$-SMA, vimentin or FSP-1 in O kidneys of $\mathrm{H}$-ras ${ }^{-/-}$than in those of $\mathrm{H}_{-\mathrm{ras}^{+/+}}$mice. $\alpha$-SMA, vimentin or FSP-1 have been widely used as markers of activated myofibroblasts [28]. Interestingly, no cells were observed positive for both $\alpha$-SMA, and FSP-1. This observation is in agreement with the data of Picard $\mathrm{N}$ et al. [29] which also reported the lack of costainning of interstitial cells with $\alpha$-SMA and FSP-1/S100A4. This observation and the bigger and more circular shape of FSP-1-possitive cells could suggest that FSP$1 / \mathrm{S} 100 \mathrm{~A} 4$ is not an exclusive fibroblast marker as have been reported that FSP1/S100A4 also co-localizes with macrophages markers [30], and thus, FSP-1 positive cells could be also macrophages. Alternatively, these data could suggest that the different phenotypes of myofibroblasts observed in the obstructed kidneys represent different functional stages of the same cell type, depending of the specific mechanical or biochemical stimulus received [29].

Activated myofibroblasts may originate from the differentiation of resident fibroblasts, from bone marrow-derived precursors, which infiltrated the injured tissue, or from EMT $[2,4,31]$. The lower resident fibroblasts proliferation and migration as a cause of the lower number of activated myofibroblasts in $\mathrm{H}_{-} \mathrm{ras}^{-/}$compared with $\mathrm{H}$ $\mathrm{ras}^{+/+}$mice is compatible with the in vitro data of the present study showing a lower proliferation rate and migration ability in the fibroblasts deficient for H-Ras than in WT fibroblasts, but with similar amounts of $\alpha$-SMA and vimentin in fibroblasts from both origins, either in presence or absence of TGF- $\beta 1$. This is also compatible with the lower rate of interstitial cell proliferation observed in O kidneys of $\mathrm{H}-\mathrm{ras}^{-/-}$compared with $\mathrm{H}$ $\mathrm{ras}^{+/+}$mice. This hypothesis is in agreement with a recent report [29] describing that after UUO resident fibroblasts progressively gain the phenotype of myofibroblasts and massively increase their rate of cell division, participating actively in the development of renal fibrosis.

Other possible origin for interstitial myofibroblasts after UUO is EMT. The mechanism by which tubular epithelial cells undergo EMT is complex and involves both early and late cellular events. Early events include rapid Akt activation and GSK$3 \beta$ phosphorylation, associated with early disruption of E-cadherin- $\beta$-catenin membrane colocalization, with translocation of E-cadherin to endosomes and $\beta$-catenin to the 
nucleus, and with an increase in Snail expression. TGF- $\beta 1$, on the other hand, induced early activation of Smad3 and its translocation to the nucleus, ERK1/2 phosphorylation, and early disruption of membrane E-cadherin localization. The late consequences of these events included a phenotypic transformation of the cells to a mesenchymal morphology with associated increase in vimentin and $\alpha$-SMA protein expression and a decrease in total cellular E-cadherin expression [32]. In the kidney suffering EMT, epithelial cells acquire fibroblast-like properties and show reduced intercellular adhesion and increased motility. This process is associated with the functional loss of Ecadherin [33]. Several transcription factors have been implicated in this repression, including zinc-finger proteins of the Snail/Slug family [34], EF1/ZEB1, SIP1 [35] and the basic helix-loop-helix E12/E47 factor [27]. Our data of lower expression of $\alpha$-SMA FSP-1 and and vimentin in O kidneys from H-Ras deficient mice suggest that in these mice there is a lower EMT than in WT mice after ureteral obstruction. The fact that both Snail and Slug expression are clearly lower in the O kidney of $\mathrm{H}$-ras ${ }^{-/-}$compared with $\mathrm{H}-\mathrm{ras}^{+/+}$mice, gives further support to the fact that EMT is clearly reduced in $\mathrm{H}-\mathrm{ras}^{-/-}$ mice, and that H-ras plays a major role in EMT. To our knowledge, this is the first in vivo study demonstrating a relationship between H-Ras and EMT in the kidney. In in vitro studies, it has been already reported that H-Ras is involved in EMT, inducing MMP-9 transcription and expression synergistically with Snail and through nuclear accumulation of Smad2 [36], both of which are essential for EMT [37] and inducing strongly enhanced vimentin expression through the MAPK-ERK pathway [38]. Snail and Slug are strong repressors of transcription of the E-cadherin gene [34, 39]. Furthermore, it has been already reported that H-Ras activation induces upregulation of the transcriptional repressor Slug and subsequent downregulation of the junctional protein E-cadherin in rat intestinal epithelial (RIE) cells [40]. A major demonstration of the role of snail in renal fibrosis "in vivo" is the fact that constitutive Snail activation in transgenic mice induces renal fibrosis [41].

We have also found that Ras and the Raf/MEK/ERK, PI3K/Akt pathways are activated in O kidneys compared with NO kidneys after 15 days of obstruction in $\mathrm{H}$ $\mathrm{ras}^{+/+}$mice with C57BL/6J background. These data is in agreement with previous studies from our laboratory $[23,25]$. In addition, both $\mathrm{O}$ and NO kidneys from $\mathrm{H}$-ras ${ }^{-/}$ mice showed higher levels of pERK1/2 than $\mathrm{H}_{-\mathrm{ras}^{+/+}}$mice. This is in agreement with the data obtained in cultured fibroblasts, where phospho-ERK expression was 
significantly higher in H-Ras $\mathrm{KO}$ than in WT fibroblasts in basal conditions. Whereas total Akt levels were increased similarly after UUO in ${\mathrm{H}-\mathrm{ras}^{-/}}^{-}$and $\mathrm{H}-\mathrm{ras}^{+/+}$mice, pAkt

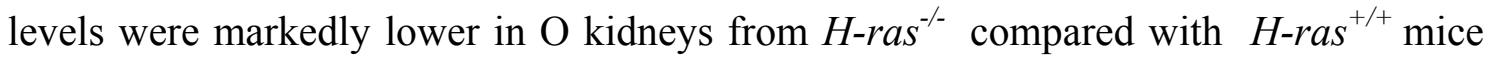
after 15 days of ureteral obstruction. This is in agreement with data obtained in cultured fibroblasts, in which TGF- $\beta 1$-induced Akt activation was markedly lower in $\mathrm{H}$-ras ${ }^{-/}$ than in $\mathrm{H}_{-\mathrm{ras}^{+/+}}$fibroblasts. It should be noted that H-Ras is a potent activator of PI3K [42].

PI3K-Akt signalling cascade is essential for FGF-induced EMT and cell survival. FGF-dependent PI3K-Akt signalling activation leads to GSK3 $\beta$ inactivation depending

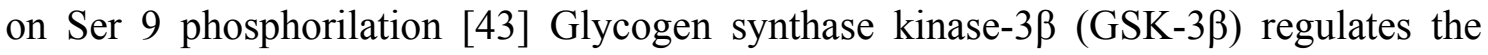
Snaill level by degrading Snaill protein. The level of the phosphorylated inactive form of GSK-3 $\beta$ was increased in the tubular epithelial cells of the obstructed kidney [44]. The elevated level of GSK-3 $\beta$ phosphorylation seemed to be correlated with Snaill accumulation, since phosphorylated GSK-3 $\beta$ is the inactive form and cannot recruit a protein degradation system for Snaill [44]. In our data, and in accordance with the changes in pAkt, the levels of pGSK3 $\beta$, the inactive form of the enzyme, were lower in the kidneys of $\mathrm{H}_{-\mathrm{ras}^{--}}$than in $\mathrm{H}-\mathrm{ras}^{+/+}$animals after 15 days of ureteral obstruction. These data is also in agreement with the lower amount of Snail accumulation in the kidneys of $\mathrm{H}_{-\mathrm{ras}^{-/}}$than in $\mathrm{H}$-ras ${ }^{+/+}$animals.

Taken together our results show that, after UUO, the kidneys of $\mathrm{H}$-ras ${ }^{-/}$mice shows a lower interstitial fibrosis than those of $\mathrm{H}_{-\mathrm{ras}^{+/+}}$animals. This lower fibrosis seems to be based in a lower number of activated myofibroblasts that could be based in a reduction in the proliferation of resident fibroblasts and a reduced EMT. This paper demonstrates, for the first time, a role for H-Ras in tubulo-interstitial fibrosis.

\section{Methods}

Mice and disease model

Generation and genotyping of $\mathrm{H}-\mathrm{ras}^{-/-}$mice was previously described [8]. A breeding colony of adult $\mathrm{H}-\mathrm{ras}^{-/}$and animals has been maintained in our laboratory for more than 8 years. The animals appeared healthy and normal with no signs of any apparent associated lesions. The growth rates of these animals were indistinguishable from those of wild-type (WT) animals, and mutant mice reproduced normally. All procedures were approved by the Committee for Animal Care and Use of the University 
of Salamanca and complied with the Guide for the Care and Use of Laboratory Animals of the USA National Research Council. Routine genotyping of DNA isolated from mouse tail biopsies were performed by PCR using the primers previously reported [8]. All studies were performed in parallel in $\mathrm{H}_{-\mathrm{ras}^{-/}}$and $\mathrm{H}$-ras ${ }^{+/+}$littermates male mice aged 8 weeks $(20 \mathrm{~g})$ and were maintained in ventiled rooms under standard conditions. For unilateral ureteral obstruction, mice were anesthesized with ketamine and valium, the abdomen was opened, and the left ureter was ligated with 5-0 silk. The abdomen was closed with running sutures and the skin was closed with interrupted sutures. After surgery, the mice were maintained in a temperature controlled room with a 12 hours light/dark cycle, and were reared on standard chow (Panlab, Spain) and water ad libitum. UUO was maintained for fifteen days.

For histological studies, after anesthesia with pentobarbital, animals were perfused with heparinized saline solution and then with $4 \%$ buffered formalin. Obstructed (O) and non-obstructed (NO) kidneys were removed from $3 \mathrm{H}-\mathrm{ras}^{+/+}$mice and $3{\mathrm{H}-\mathrm{ras}^{-/}}^{-/}$mice, halved longitudinally, fixed for 24 hours in $4 \%$ buffered formalin and then embedded in paraffin. Sections $3 \mu \mathrm{m}$ thick were cut and mounted on glass slides that were used either for hematoxylin-eosin staining or immunohistochemistry. Additional $5 \mu \mathrm{m}$ sections were cut and processed for Sirius red staining, as previously reported [45]. Kidneys destined for protein extraction were obtained in another set of animals (5 $\mathrm{H}-$ ras $^{+/+}$mice and $4 \mathrm{H}-\mathrm{ras}^{-/-}$mice) and after perfusion with saline solution, kidneys were frozen immediately in liquid nitrogen and stored at $-80^{\circ} \mathrm{C}$ until use.

\section{Immunohistochemical studies}

Immunohistochemistry was performed on buffered formalin fixed, paraffinembedded tissues. Briefly, $5-\mu \mathrm{m}$ sections were cut and stained with Syrius red and $3 \mu \mathrm{m}$ sections were deparaffined in xylene and rehydrated in graded ethanols before staining with the peroxidase-anti peroxidase method. Endogenous peroxidase was blocked by incubation in 3\% hydrogen peroxide. Primary antibodies were: polyclonal rabbit antifibronectin (F 3648, Sigma-Aldrich Corp. St. Louis, MO, USA, 1:100 dilution), mouse monoclonal anti- $\alpha$ smooth muscle actin (M0851, DAKO Diagnostics, Copenhagen, Denmark, pre-diluted), mouse monoclonal anti-vimentin (ab8545, Abcam, Cambridge, UK, pre-diluted), rabbit polyclonal anti-phospho-Akt (\#9271, Cell Signaling Technology, Ma. USA, 1:50 dilution), mouse monoclonal anti-phospho-ERK (E-4, sc7383, Santa Cruz Biotechnology, Ca. USA. 1:300 dilution), rabbit monoclonal anti- 
phospho-GSK-3 $\beta$ (\#9323, Cell Signaling Technology, Ma. USA, 1:50 dilution) and rabbit monoclonal anti-Ki-67 (Master Diagnostica, Granada, Spain. 1:100 dilution). Following washes in PBS, the sections were sequentially incubated with the Novolink Polymer Detection System (Novocastra, MA, USA) using 3,3'diaminobenzidine (DAB) (Biogenez, San Ramón, CA, USA) as chromogen. Sections were lightly counterstained with haematoxylin and were dehydrated and cover slipped. Negative controls were prepared without primary antibody. The number of tubular and interstitial renal cells undergoing proliferation (Ki-67-positive immunostaining) was counted under light microscopy at x 200 magnification in 6-10 random fields of cortex.

\section{Double-immunofluorescence staining}

Paraffin-embedded tissues were cut in $3 \mu \mathrm{m}$ sections. Heat-induced antigen retrieval was performed incitrate buffer $(\mathrm{pH} 9.00)$. Sections were incubated in the mixture of anti-S100A4 (1:100, Abcam, Cambridge, UK) and anti- $\alpha$-SMA (1:300, Sigma, St. Louis, USA) during 1 hour at room temperature. Following washes in PBS, sections were incubated in the mixture of two fluorescent conjugated secondary antibodies (anti-mouse FITC and anti-rabbit $\mathrm{Cy} 3$ ) for 40 minutes at room temperature, washed in PBS and sequently counterstain with DAPI for 20 minutes at room temperature. Slides were rinsed in PBS and mounted in Vectashield (Vector Laboratories, Burlingame, CA,USA).

\section{ELISA for Ras GTP}

Total kidneys lysates $(50 \mu \mathrm{g})$ were employed for the detection of RasGTP. RasGTP levels were determined by an ultra sensitive commercial ELISA kit (Active Motif, RasGTPase Chemi ELISA, Rixensart, Belgium) according to the manufacturer's instruction.

\section{Western blot analysis}

Total cell extracts and tissue protein extracts were homogenized in lysis buffer (25mM HEPES pH7,5, 150mM NaCl, 1\% Igepal CA-630, $10 \mathrm{mM} \mathrm{MgCl}_{2}, 1 \mathrm{mM}$ EDTA, $10 \%$ glycerol, $10 \mu \mathrm{g} / \mathrm{mL}$ aprotinin, $10 \mu \mathrm{g} / \mathrm{mL}$ leupeptin, $100 \mathrm{mM}$ PMSF, $25 \mathrm{mM}$ $\mathrm{NaF}, 1 \mathrm{mM} \mathrm{Na}_{3} \mathrm{VO}_{4}$ ) and centrifuged at $14,000 \mathrm{~g}$ for $30 \mathrm{~min}$. Supernatant was recovered and proteins were quantified. Lysates (60 $\mu \mathrm{g} /$ lane for tissue, $30 \mu \mathrm{g} / \mathrm{lane}$ for cells) were loaded onto SDS-polyacrylamide gels, and the proteins were transferred to nitrocellulose membranes (Bio-Rad) by electroblotting. Membranes blocked in TTBS (10mM Tris $\mathrm{pH} 7.5,150 \mathrm{mM} \mathrm{NaCl}, 0.1 \%$ Tween 20 plus $2 \%$ bovine serum albumin) 
were incubated overnight at $4^{\circ} \mathrm{C}$, as appropriate, with: anti-ERK1 (1:2000), antiphospho-ERK (1:2000), anti-phospho-Akt (1:1000), anti-Akt1/2 (1:1000), all from Santa Cruz Biotechnology, Santa Cruz, Ca, USA, anti-fibronectin (1:1000 for tissue, 1:10000 for cells) anti-collagen type I (1:1000 for tissue, 1:20000for cells), from Chemicon International, USA, anti-S100A4 (1:500, Abcam, Cambridge, UK), anti- $\alpha$ SMA (1:1000, Sigma, St. Louis, USA), anti-vimentin (1:1000, DAKO, Copenhagen, Denmark) and anti-phospho-GSK $3 \beta$ (Ser9) (1:500) and anti -GSK $3 \beta$ (1:1000) from Cell Signalling Inc, Danvers, MA, USA. Membranes were incubated with corresponding horseradish peroxidase-conjugated secondary antibody $(1: 10,000)$ and were developed using a chemiluminescent reagent (ECL detection reagent Amersham Biosciences). Developed signals were recorded on X-ray film (Fujifilm) for densitometric analysis (Scion Image).

\section{Reverse Transcription-PCR Analysis}

Tissue RNA was isolated from kidneys using Tri-reagent (Molecular Research Center). RT was carried out oligo dT primers (Isogen), dNTP (Applied Byosistems), MMLV-RT (Promega), whereas PCR reactions were performed using mouse specific primers for Snail, Slug and ribosomal protein S13 as follows: Snail forward, 5'GCAGCTGGCCAGGCTCTCGGTGGC 3'; Snail reverse, 5'GTAGCTGGGTCA GCGAGGGCCTCC 3'; Slug forward, 5'GCCTCCAAGAAGCCCAACTA 3'; Slug reverse, 5'CACAGTGCAGCTGCTTGTGT 3'; RPS13 forward, 5'GATGCTAAATTC GCGCTGAT 3' ; RPS13 reverse 5'TAGAGCAGAGGCTGTGAATG 3'

Cell culture and growth factor stimulation

$\mathrm{H}_{-\mathrm{ras}^{+/+}}$and $\mathrm{H}-\mathrm{ras}^{-/-}$fibroblasts were obtained as previously described [26, 24]. Cell were seeded in $100 \mathrm{~mm}$ Petri dishes for Western blot and cell cycle analysis, and at 20000 or 9000 cells/well in 24 well plates for total collagen measurements and proliferation studies, respectively.

Cells were grown in DMEM containing 10\% FCS and $100 \mathrm{U} / \mathrm{ml}$ penicillin/streptomycin at $37^{\circ} \mathrm{C}$ in the presence of $5 \% \mathrm{CO}_{2}$. When cultures achieved 80 $90 \%$ confluence, cells were serum-starved for $24 \mathrm{~h}$ and treated with active human recombinant TGF- $\beta 1(1 \mathrm{ng} / \mathrm{ml})$ or control vehicle during $24 \mathrm{~h}$ in the absence of serum.

\section{Crystal violet staining}

The number of cells was measured using a colorimetric method previously described [46]. In brief, cells subcultured to subconfluence in 24 well plates were 
incubated for $24 \mathrm{~h}$ under the experimental conditions described above. Then, cells were fixed with $10 \%$ glutaraldehyde for 10 minutes, and washed twice with phosphate buffered saline solution (PBS: 0.81\% ClNa, $2.6 \mathrm{mM} \mathrm{PO}_{4} \mathrm{H}_{2} \mathrm{~K}, 4.1 \mathrm{mM} \mathrm{PO} \mathrm{HNa}_{2}$ ). Cellular nuclei were dyed by incubating the cells for $30 \mathrm{~min}$ in a $1 \%$ crystal violet solution. Wells were washed exhaustively with PBS, and left overnight to dry. Finally, 2 $\mathrm{ml}$ of $10 \%$ acetic acid were added in each well. Optical density at $595 \mathrm{~nm}$ was proportional to the number of viable cells in each well.

\section{Immunofluorescence analysis of Ki67 expression}

Cell proliferation was also assessed as the percentage of cells stained for Ki-67 [47]. Cells in cover slips were fixed with $4 \%$ paraformaldehyde, washed with PBS with calcium and magnesium (PBS Ca-Mg: $1 \mathrm{mM} \mathrm{CaCl}_{2}, 1 \mathrm{mM} \mathrm{MgSO}$, 0.81\% ClNa, 2.6 $\mathrm{mM} \mathrm{PO} \mathrm{H}_{2} \mathrm{~K}, 4.1 \mathrm{mM} \mathrm{PO}_{4} \mathrm{HNa}_{2}$ ), permeabilized with $0.1 \%$ Triton $\mathrm{X}-100,0.2 \%$ BSA and $0.5 \%$ sodium azide, quenched with $\mathrm{NH}_{4} \mathrm{Cl} 50 \mathrm{mM}$ in PBS Ca-Mg, blocked with $10 \%$ normal goat serum (NGS) in PBS Ca-Mg for $30 \mathrm{~min}$, and incubated during 2 hours with rabbit anti-human Ki67 (dilution 1/50) in PBS Ca-Mg with 2\% NGS. Later, cells were incubated $30 \mathrm{~min}$ with goat anti-rabbit Cy3 (Jackson Immunoresearch, West Grove PA, USA) (dilution 1/1000) in PBS Ca-Mg with $2 \%$ NGS in a dark chamber. Nuclei staining was performed by 5 min incubation with $2 \mu \mathrm{M}$ Hoechst 33258 in a dark chamber. Coverslips were mounted on slides using Prolong gold antifade. Confocal images were made using a Zeiss Axiovert 200M microscope with a HeNe laser with 543-excitation for rhodamine and Hg laser with 365-excitation for DAPI. All images were obtained with identical parameters for intensity, pinhole aperture, etc.

\section{Cell cycle determination by flow citometry}

Fibroblasts were seeded to subconfluence in $100 \mathrm{~mm}$ Petri dishes, cells were washed twice with PBS, trypsin was added during 2 min. and cells were resuspended in PBS in a concentration of $10^{6}$ cells $/ \mathrm{ml}$. Fibroblasts were incubated for $10 \mathrm{~min}$. with 1.8 $\mathrm{ml}$ solution A $(60 \mathrm{mg} / \mathrm{L}$ trypsin in $0.5 \mathrm{mM}$ Tris-hydroximethylaminemethane, $3.4 \mathrm{mM}$ trisodium citrate, $0.1 \% \mathrm{NP} 40,1.5 \mathrm{mM}$ spermin, $\mathrm{pH}$ 7.6) in order to break the cell membrane and to digest the protein content of the cells. Then, cell extracts were incubated during $10 \mathrm{~min}$ at room temperature with $1.5 \mathrm{ml}$ of solution B $(1 \mathrm{~g} / \mathrm{L}$ RNAse and $0.2 \mathrm{~g} / \mathrm{L}$ trypsin inhibitor in $0.5 \mathrm{mM}$ Tris-hydroximethylaminemethane, $3.4 \mathrm{mM}$ trisodium citrate, $0.1 \%$ Nonidet $\mathrm{P} 40,1.5 \mathrm{mM}$ spermin, $\mathrm{pH}$ 7.6). After this incubation, $1.5 \mathrm{ml}$ of solution $\mathrm{C}$ were added $(0.416 \mathrm{~g} / \mathrm{L}$ propidium iodide in $0.5 \mathrm{mM}$ Tris- 
hydroximethylaminemethane, $3.4 \mathrm{mM}$ trisodium citrate, $0.1 \%$ Nonidet P40, $1.5 \mathrm{mM}$ spermin, $\mathrm{pH}$ 7.6). Finally, cells were introduced in a flow cytometer; both data acquisition and analysis were performed using the computer software Cell QUEST and Paint-A-gate, respectively.

\section{Cell migration assay}

Fibroblast migration was assessed by wound-healing assay. For this purpose, cells were grown in $100 \mathrm{~mm}$ culture plates until confluence, and in vitro scratched wounds were created with a straight incision on the cell monolayers with a sterile disposable pipette tip. Cell migration into denuded area was monitored over a time course using digital video-microscopy, and the rate of cell movement was calculated by the time when half of the wound was occupied by cells.

Fibroblast migration was also assayed was performed in a Boyden chamber. Briefly, cell suspension is loaded into the upper chamber in 2\% FCS medium, and invading cells migrate through and attach to the bottom of the membrane (bottom chamber with $10 \%$ FCS medium), while non-invading cells remain above. After 12-24 $\mathrm{h}$, inserts were washed with PBS, fixed with $10 \%$ glutaraldehyde, and the number of migrated cells was determined by the previously described crystal violet method.

\section{Statistical analysis}

Statistical differences were analyzed by two way ANOVA using the SPSS 12.0 program. Data were expressed as mean \pm SEM and $p<0.01$ was considered statistically significant.

\section{Disclosure}

The authors declared they have no competing interests.

\section{Acknowledgments}

The authors wish to thank Ms. Angustias Pérez for his invaluable skilful technical assistance in histology procedures. This study has been supported by grants from Instituto de Salud Carlos III (Ministerio de Sanidad y Consumo, CP03/00094, PI041817 and Retic 06/0016, RedinRen), Comisión Interministerial de Ciencia y Tecnología (BFU-2004-00285/BFI) and Junta de Castilla y León (SA001/C05; SA029A05). 


\section{References}

1. Stahl PJ, Felsen D. Transforming growth factor-beta, basement membrane, and epithelial-mesenchymal transdifferentiation: implications for fibrosis in kidney disease. Am J Pathol 2001; 159: 1187-1192.

2. Iwano M, Neilson EG. Mechanisms of tubulointerstitial fibrosis. Curr Opin Nephrol Hypertens 2004; 13: 279-284.

3. Klahr S, Morrissey J. Obstructive nephropathy and renal fibrosis. Am J Physiol Renal Physiol 2002; 283: F861-875.

4. Iwano M, Plieth D, Danoff TM, Xue C, et al. Evidence that fibroblasts derive from epithelium during tissue fibrosis. J Clin Invest 2002; 110: 341-350.

5. Crespo P, Leon J. Ras proteins in the control of the cell cycle and cell differentiation. Cell Mol Life Sci 2000; 57: 1613-1636.

6. Malumbres M, Pellicer A. RAS pathways to cell cycle control and cell transformation. Front Biosci 1998; 3: d887-912.

7. Santos E, Nebreda AR. Structural and functional properties of ras proteins. FASEB J 1989; 3: 2151-2163.

8. Esteban LM, Vicario-Abejon C, Fernandez-Salguero P, Fernandez-Medarde A, et al. Targeted genomic disruption of H-ras and N-ras, individually or in combination, reveals the dispensability of both loci for mouse growth and development. Mol Cell Biol 2001; 21: $1444-1452$.

9. Johnson L, Greenbaum D, Cichowski K, Mercer K, et al. K-ras is an essential gene in the mouse with partial functional overlap with N-ras. Genes Dev 1997; 11: 2468-2481. 10. Koera K, Nakamura K, Nakao K, Miyoshi J, et al. K-ras is essential for the development of the mouse embryo. Oncogene 1997; 15: 1151-1159.

11. Tamaki K, Okuda S, Ando T, Iwamoto T, et al. TGF-beta 1 in glomerulosclerosis and interstitial fibrosis of adriamycin nephropathy. Kidney Int 1994; 45: 525-536. 12. Eddy AA. Molecular insights into renal interstitial fibrosis. J Am Soc Nephrol 1996; 7: 2495-2508.

13. Sharma K, Ziyadeh FN. The transforming growth factor-beta system and the kidney. Semin Nephrol 1993; 13: 116-128.

14. Haberstroh U, Zahner G, Disser M, Thaiss F, et al. TGF-beta stimulates rat mesangial cell proliferation in culture: role of PDGF beta-receptor expression. Am J Physiol 1993; 264: F199-205. 
15. Ketteler M, Noble NA, Border WA. Transforming growth factor-beta and angiotensin II: the missing link from glomerular hyperfiltration to glomerulosclerosis? Annu Rev Physiol 1995; 57: 279-295.

16. Downward J. Targeting RAS signalling pathways in cancer therapy. Nat Rev Cancer 2003; 3: 11-22.

17. Colicelli J. Human RAS superfamily proteins and related GTPases. Sci STKE 2004; 2004: RE13.

18. Alcock RA, Dey S, Chendil D, Inayat MS, et al. Farnesyltransferase inhibitor (L744,832) restores TGF-beta type II receptor expression and enhances radiation sensitivity in K-ras mutant pancreatic cancer cell line MIA PaCa-2. Oncogene 2002; 21: 7883-7890.

19. Kretzschmar M, Doody J, Timokhina I, Massague J. A mechanism of repression of TGFbeta/ Smad signaling by oncogenic Ras. Genes Dev 1999; 13: 804-816.

20. Park BJ, Park JI, Byun DS, Park JH, et al. Mitogenic conversion of transforming growth factor-betal effect by oncogenic Ha-Ras-induced activation of the mitogenactivated protein kinase signaling pathway in human prostate cancer. Cancer Res 2000; 60: $3031-3038$.

21. Iglesias M, Frontelo P, Gamallo C, Quintanilla M. Blockade of Smad4 in transformed keratinocytes containing a Ras oncogene leads to hyperactivation of the Ras-dependent Erk signalling pathway associated with progression to undifferentiated carcinomas. Oncogene 2000; 19: 4134-4145.

22. Dhanasekaran N, Premkumar Reddy E. Signaling by dual specificity kinases. Oncogene 1998; 17: 1447-1455.

23. Rodriguez-Pena AB, Santos E, Arevalo M, Lopez-Novoa JM. Activation of small GTPase Ras and renal fibrosis. J Nephrol 2005; 18: 341-349.

24. Martinez-Salgado C, Rodriguez-Pena AB, Lopez-Novoa JM. Involvement of small Ras GTPases and their effectors in chronic renal disease. Cell Mol Life Sci 2008; 65: $477-492$

25. Rodriguez-Pena AB, Grande MT, Eleno N, Arevalo M, et al. Activation of Erk1/2 and Akt following unilateral ureteral obstruction. Kidney Int 2008; 74: 196-209.

26. Castellano E, De Las Rivas J, Guerrero C, Santos E. Transcriptional networks of knockout cell lines identify functional specificities of H-Ras and N-Ras: significant involvement of N-Ras in biotic and defense responses. Oncogene 2007; 26: 917-933. 
27. Bolos V, Peinado H, Perez-Moreno MA, Fraga MF, et al. The transcription factor Slug represses E-cadherin expression and induces epithelial to mesenchymal transitions: a comparison with Snail and E47 repressors. J Cell Sci 2003; 116: 499-511.

28. Le Hir M, Hegyi I, Cueni-Loffing D, Loffing J, et al. Characterization of renal interstitial fibroblast-specific protein 1/S100A4-positive cells in healthy and inflamed rodent kidneys. Histochem Cell Biol 2005; 123: 335-346.

29. Picard N, Baum O, Vogetseder A, Kaissling B, et al. Origin of renal myofibroblasts in the model of unilateral ureter obstruction in the rat. Histochem Cell Biol 2008; 130: 141-155.

30. Inoue $\mathrm{T}, \mathrm{Plieth} \mathrm{D}$, Venkov $\mathrm{CD}, \mathrm{Xu} \mathrm{C}$, et al. Antibodies against macrophages that overlap in specificity with fibroblasts. Kidney Int 2005; 67: 2488-2493.

31. Hinz B, Phan SH, Thannickal VJ, Galli A, et al. The myofibroblast: one function, multiple origins. Am J Pathol 2007; 170: 1807-1816.

32. Ivanova L, Butt MJ, Matsell DG. Mesenchymal transition in kidney collecting duct epithelial cells. Am J Physiol Renal Physiol 2008; 294: F1238-1248.

33. Peinado H, Portillo F, Cano A. Transcriptional regulation of cadherins during development and carcinogenesis. Int J Dev Biol 2004; 48: 365-375.

34. Cano A, Perez-Moreno MA, Rodrigo I, Locascio A, et al. The transcription factor snail controls epithelial-mesenchymal transitions by repressing E-cadherin expression. Nat Cell Biol 2000; 2: 76-83.

35. Comijn J, Berx G, Vermassen P, Verschueren K, et al. The two-handed E box binding zinc finger protein SIP1 downregulates E-cadherin and induces invasion. $\mathrm{Mol}$ Cell 2001; 7: 1267-1278

36. Jorda M, Olmeda D, Vinyals A, Valero E, et al. Upregulation of MMP-9 in MDCK epithelial cell line in response to expression of the Snail transcription factor. J Cell Sci 2005; 118: 3371-3385.

37. Oft M, Akhurst RJ, Balmain A. Metastasis is driven by sequential elevation of H-ras and Smad2 levels. Nat Cell Biol 2002; 4: 487-494.

38. Andreolas C, Kalogeropoulou M, Voulgari A, Pintzas A. Fra-1 regulates vimentin during Ha-RAS-induced epithelial mesenchymal transition in human colon carcinoma cells. Int J Cancer 2008; 122: 1745-1756.

39. Moreno-Bueno G, Cubillo E, Sarrio D, Peinado H, et al. Genetic profiling of epithelial cells expressing E-cadherin repressors reveals a distinct role for Snail, Slug, and E47 factors in epithelial-mesenchymal transition. Cancer Res 2006; 66: 9543-9556. 
40. Schmidt CR, Gi YJ, Patel TA, Coffey RJ, et al. E-cadherin is regulated by the transcriptional repressor SLUG during Ras-mediated transformation of intestinal epithelial cells. Surgery 2005; 138: 306-312.

41. Boutet A, De Frutos CA, Maxwell PH, Mayol MJ, et al. Snail activation disrupts tissue homeostasis and induces fibrosis in the adult kidney. EMBO J 2006; 25: 5603 5613.

42. Yan J, Roy S, Apolloni A, Lane A, et al. Ras isoforms vary in their ability to activate Raf-1 and phosphoinositide 3-kinase. J Biol Chem 1998; 273: 24052-24056. 43. Katoh M. Cross-talk of WNT and FGF signaling pathways at GSK3beta to regulate beta-catenin and SNAIL signaling cascades. Cancer Biol Ther 2006; 5: 1059-1064. 44. Yoshino J, Monkawa T, Tsuji M, Inukai M, et al. Snaill is involved in the renal epithelial-mesenchymal transition. Biochem Biophys Res Commun 2007; 362: 63-68. 45. Rodriguez-Pena A, Eleno N, Duwell A, Arevalo M, et al. Endoglin upregulation during experimental renal interstitial fibrosis in mice. Hypertension 2002; 40: 713-720. 46. Gillies RJ, Didier N, Denton M. Determination of cell number in monolayer cultures. Anal Biochem 1986; 159: 109-113.

47. Bryant RJ, Banks PM, O'Malley DP. Ki67 staining pattern as a diagnostic tool in the evaluation of lymphoproliferative disorders. Histopathology 2006; 48: 505-515. 


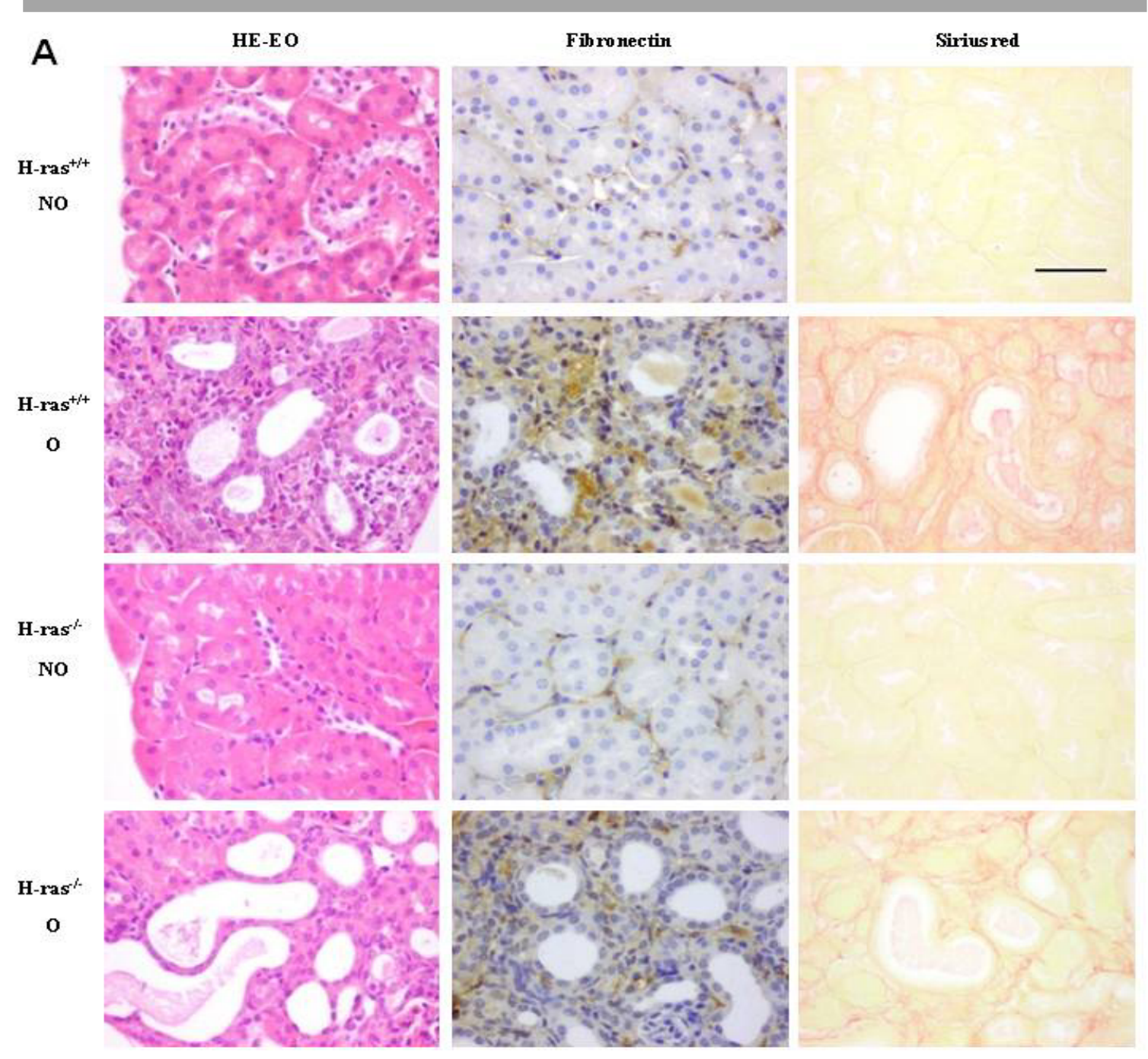

B
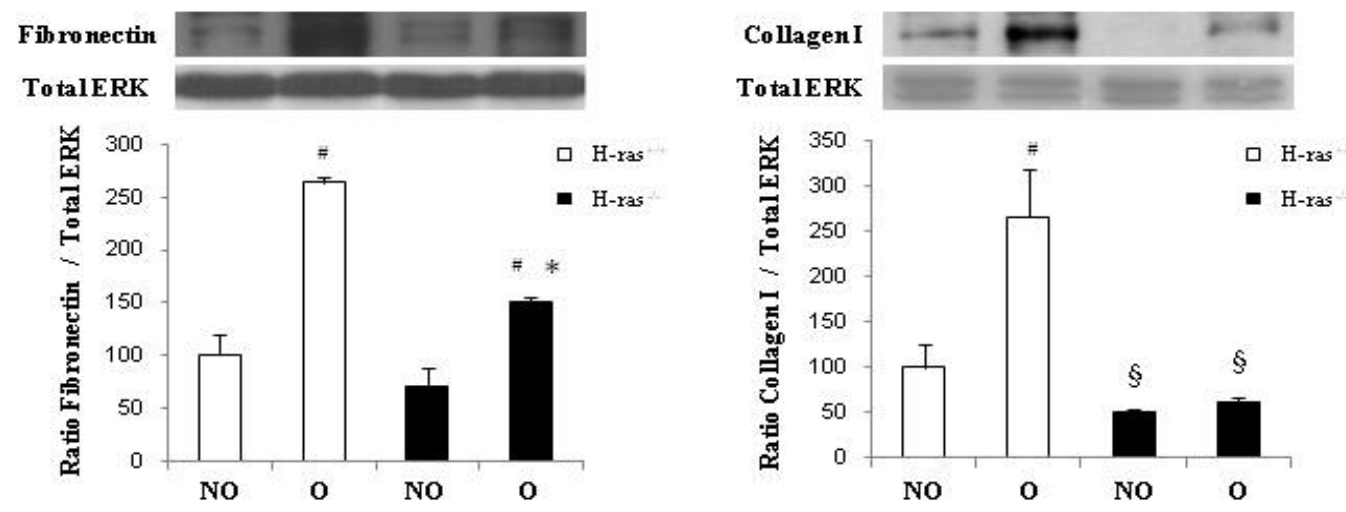

Figure 1: Effects of deficiency of H-Ras in interstitial fibrosis after UUO. A) Hematoxylineosin staining, inmunohistochemistry for fibronectin and sirius red staining in non-obstructed (NO) and obstructed (O) kidneys from $\mathrm{H}_{-\mathrm{ras}^{+/+}}$and $\mathrm{H}_{-} \mathrm{ras}^{-/-}$mice. Scale bar indicates 100 microns in all panels. B) Western blot analysis of fibronectin and collagen type I levels in NO and $\mathrm{O}$ kidneys of $\mathrm{H}-\mathrm{ras}^{+/+}$and $\mathrm{H}-\mathrm{ras}^{-/-}$mice. In the upper part of this figure, a characteristic western blot is shown, whereas in the lower part data represent the average \pm SEM of the optical density. $\# \mathrm{p}<0,01 v s$ corresponding NO kidneys. ${ }^{*} \mathrm{p}<0,01 v s \mathrm{O}$ kidneys from $\mathrm{H}$-ras ${ }^{+/+}$mice. $\S \mathrm{p}<0,01$ vs $\mathrm{NO}$ and $\mathrm{O}$ kidneys from $\mathrm{H}_{-} \mathrm{ras}^{+/+}$mice. $\square \mathrm{H}-\mathrm{ras}^{+/+}$mice $\square \mathrm{H}_{-} \mathrm{ras}^{-/-}$mice. 

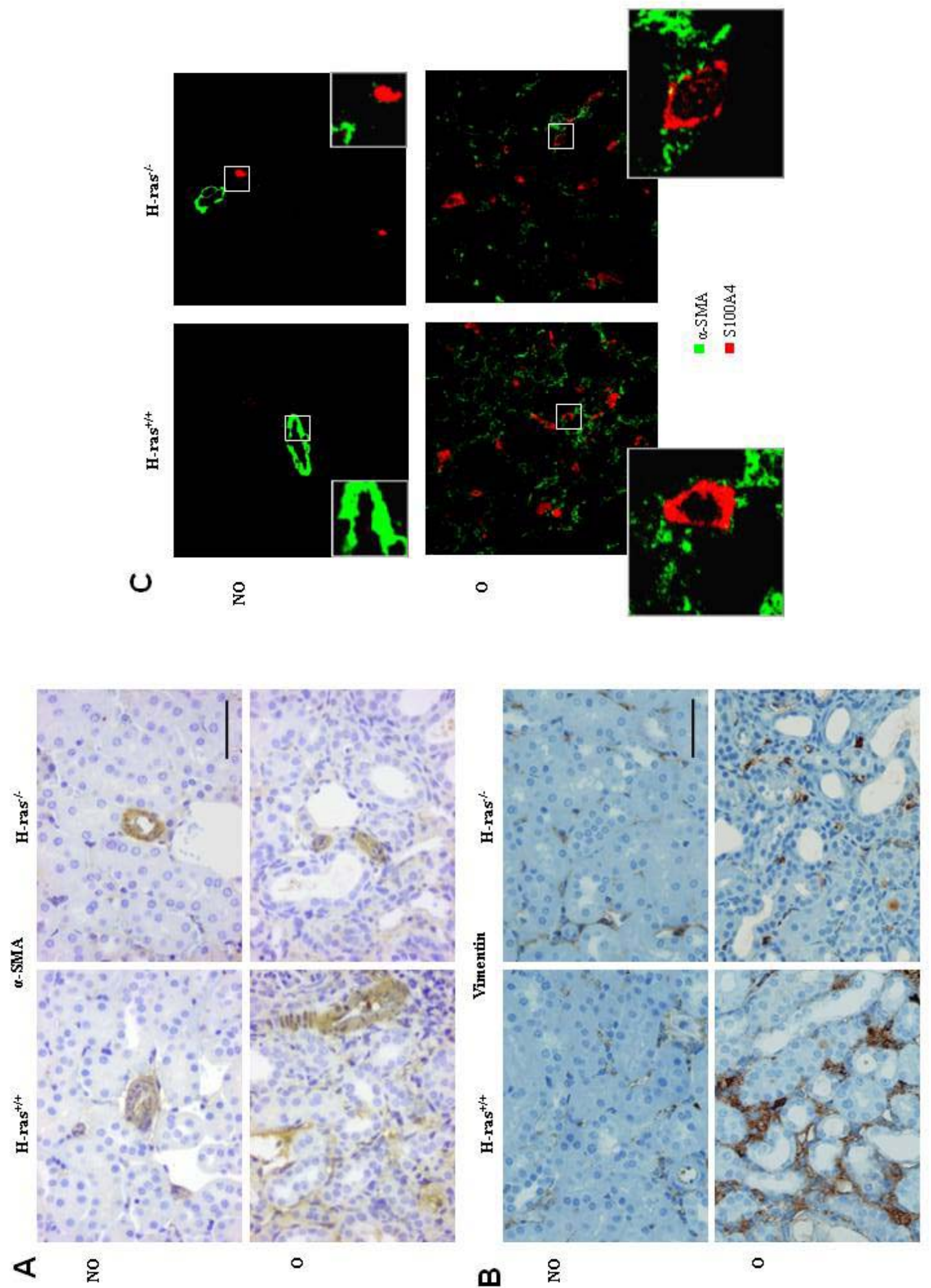

Figure 2: Effects of deficiency of H-Ras in myofibroblast activation and EMT after UUO. A) Representative inmunohistochemistry for $\alpha$-smooth muscle actin in non-obstructed (NO) and obstructed (O) kidneys from $\mathrm{H}_{-\mathrm{ras}^{+/+}}$and $\mathrm{H}-\mathrm{ras}^{-/}$mice. B) Representative inmunohistochemistry for vimentin in $\mathrm{NO}$ and $\mathrm{O}$ kidneys from $\mathrm{H}-\mathrm{ras}^{+/+}$and $\mathrm{H}-\mathrm{ras}^{-/-}$mice. Scale bar indicates 100 microns in all panels. C) Double immunofluorescence of $\alpha$-SMA (green) and

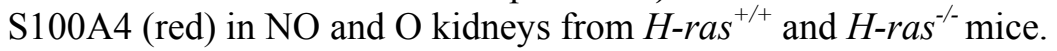


A

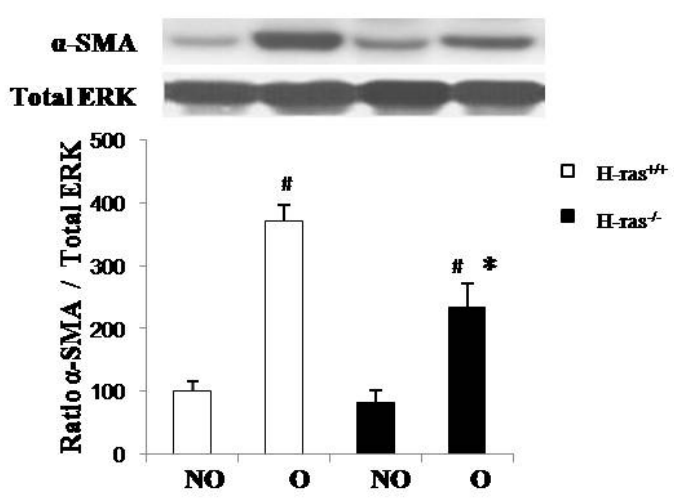

B
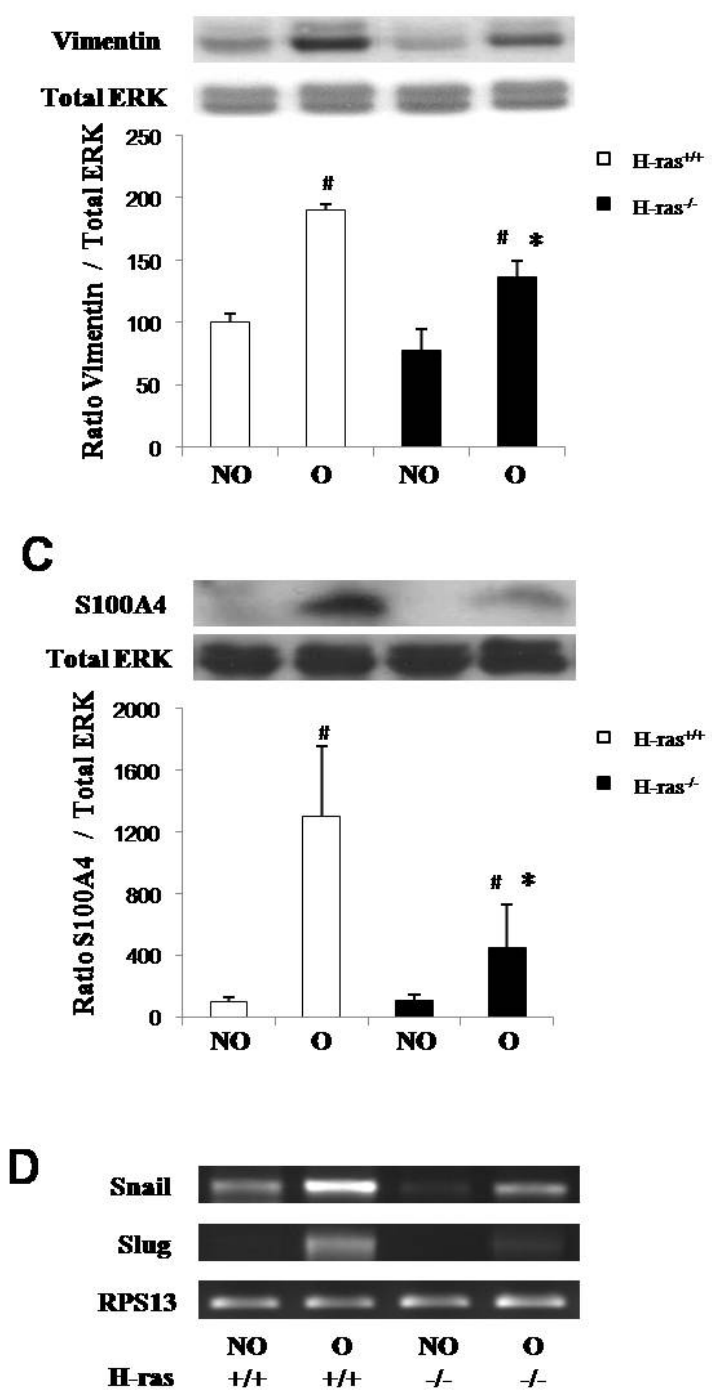

Figure 3: Effects of deficiency of H-Ras in myofibroblast activation and EMT after UUO. $\alpha$ SMA (panel A), vimentin (panel B) and S100A4 (panel C) levels were evaluated by Western blot, whereas Snail and Slug expression (panel D) was analyzed by RT-PCR in non-obstructed (NO) and obstructed (O) kidneys from $\mathrm{H}_{-\mathrm{ras}^{+/+}}$and $\mathrm{H}-\mathrm{ras}^{-/-}$mice. In the western blot experiments, in the upper part of this figure, a characteristic western blot is shown, whereas in the lower part data represent the average \pm SEM of the optical density. \#P $<0,01 v s$ corresponding NO kidneys. ${ }^{*} \mathrm{p}<0,05$ vs O kidneys from $\mathrm{H}_{-\mathrm{ras}^{+/+}}$mice. $\square \mathrm{H}$-ras ${ }^{+/+}$mice $\mathbf{\square} \mathrm{H}$ $\mathrm{ras}^{-1 /}$ mice. The RT-PCR analysis is representative of 4 independent experiments. 
A

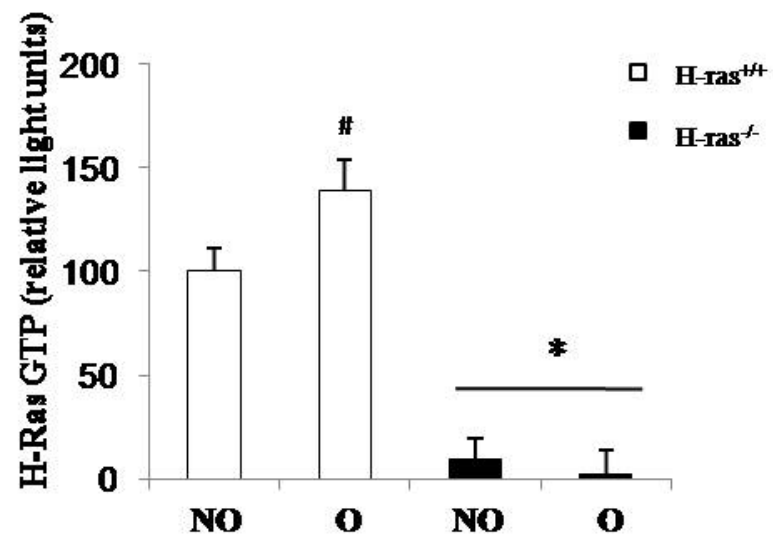

B

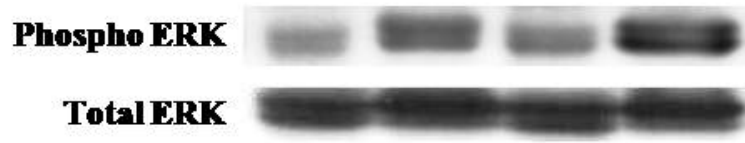

Phospho Akt

Total Akt

Total ERK

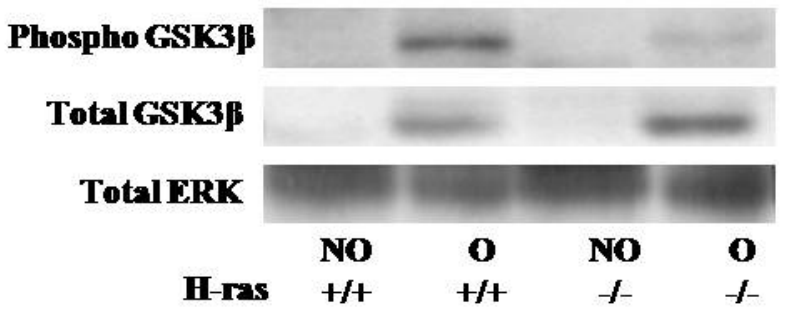

Figure 4: Effects of deficiency of H-Ras in Ras, ERK and Akt activation after UUO. A) Ras activation in non-obstructed (NO) and obstructed (O) kidneys of $\mathrm{H}_{-} \mathrm{ras}^{+/+}$and $\mathrm{H}-\mathrm{ras}^{-/}$mice. HRasGTP levels were determined by ELISA. Data represent the average \pm SEM of relative light units. $\# \mathrm{p}<0,01 v s$ corresponding NO kidneys. ${ }^{*} \mathrm{p}<0,05$ vs NO and O kidneys from $\mathrm{H}$-ras ${ }^{+/+}$ mice. $\square \mathrm{H}-\mathrm{ras}^{+/+}$mice $\square \mathrm{H}-\mathrm{ras}^{-/}$mice. B) Representative images of western blot analysis of ERK activation, Akt activation and GSK3 $\beta$ activation in $\mathrm{NO}$ and $\mathrm{O}$ kidneys from $\mathrm{H}-\mathrm{ras}^{+/+}$and $\mathrm{H}_{-\mathrm{ras}^{-/}}$mice. 

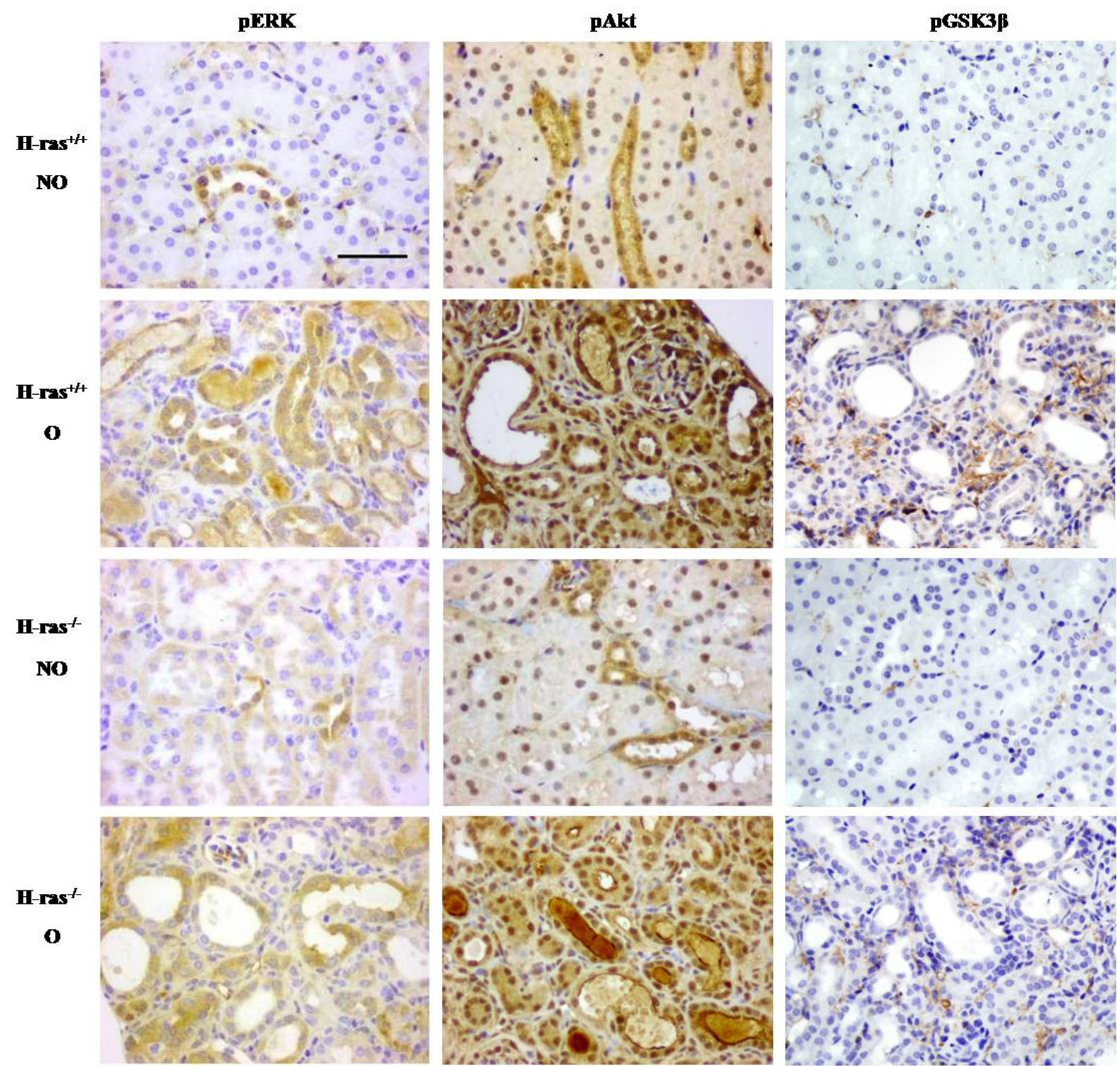

Figure 5: Inmunostaining for $p E R K$, $p A k t$ and $p G S K-3 \beta$. Representative staining in the cortex of non-obstructed (NO) and obstructed (O) kidneys of $\mathrm{H}_{-\mathrm{ras}^{+/+}}$and $\mathrm{H}_{-} \mathrm{ras}^{-/-}$mice 15 days after UUO. Scale bar indicates 100 microns in all panels. 

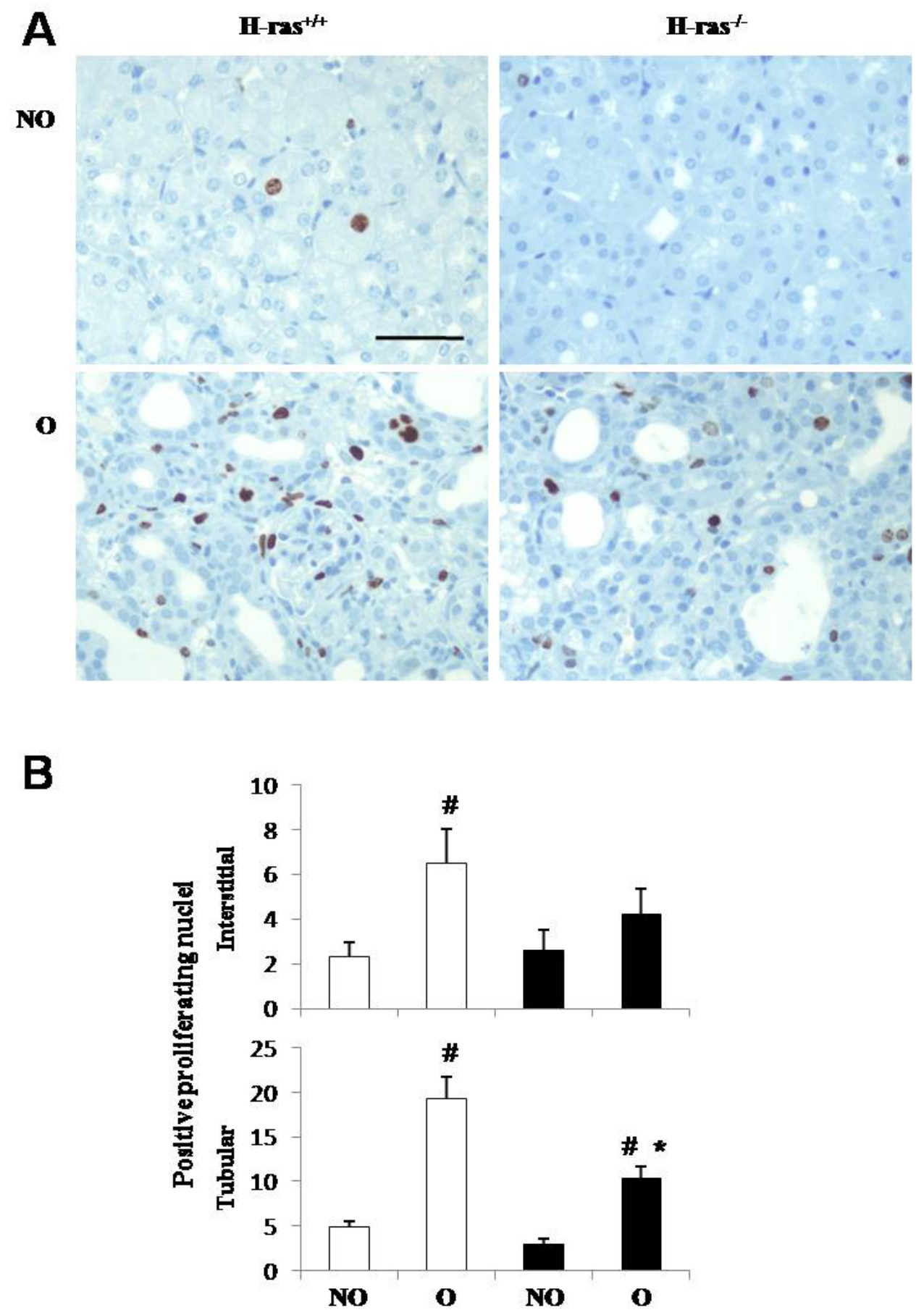

Figure 6: Effects of deficiency of H-Ras in proliferation after UUO. A) Representative staining of Ki-67 in non-obstructed (NO) and obstructed (O) kidneys from $\mathrm{H}-\mathrm{ras}^{+/+}$and $\mathrm{H}-\mathrm{ras}^{-/-}$mice 15 days after UUO. B) Number of Ki-67 positive of interstitial and tubular cells in $\mathrm{NO}$ and $\mathrm{O}$ kidneys from $\mathrm{H}-\mathrm{ras}^{+/+}$and $\mathrm{H}-\mathrm{ras}^{-/-}$mice 15 days after UUO. \#p $<0,01$ vs corresponding NO kidneys. ${ }^{*} \mathrm{p}<0,01$ vs $\mathrm{O}$ kidney from $\mathrm{H}-\mathrm{ras}^{+/+}$mice. 

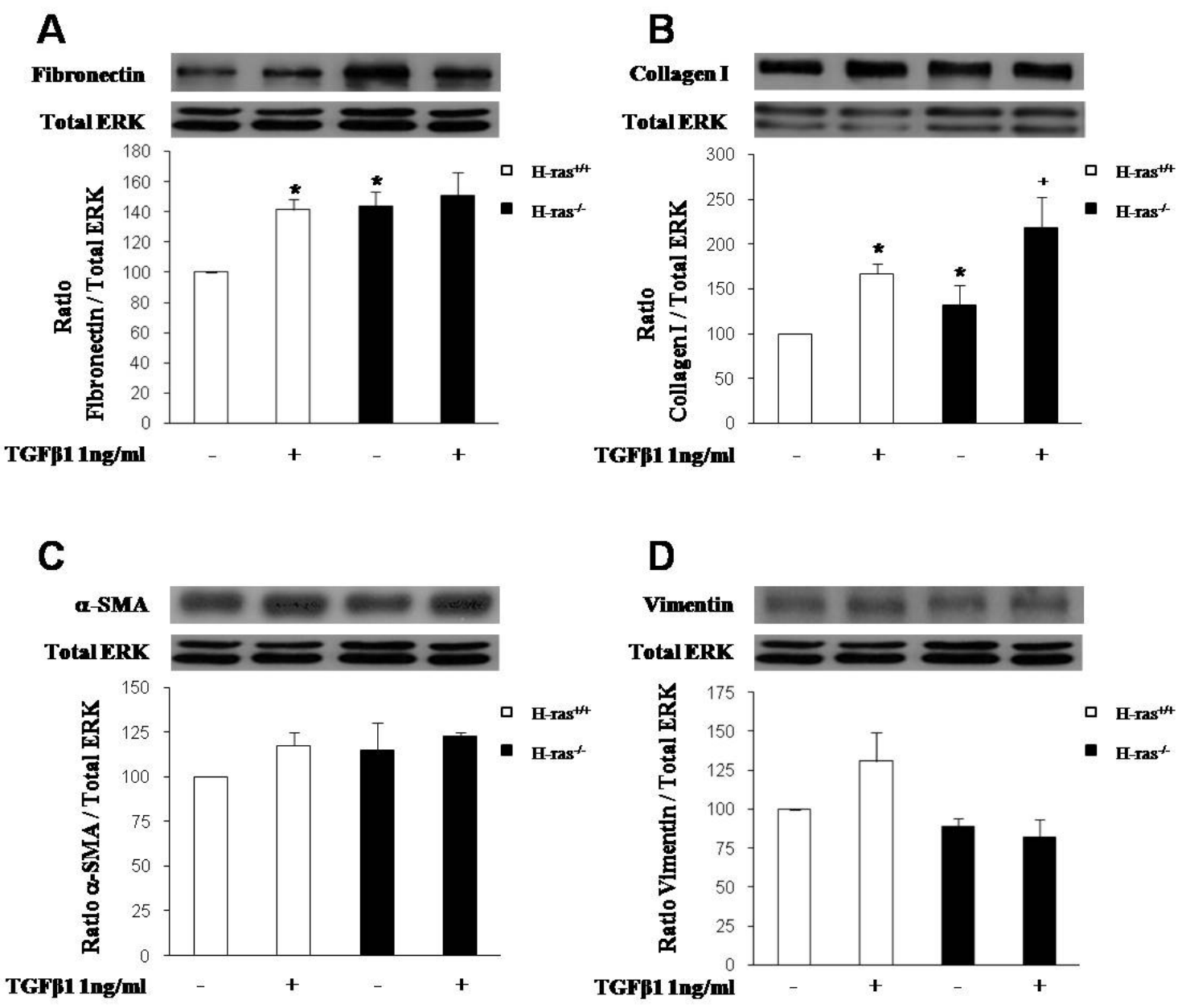

E

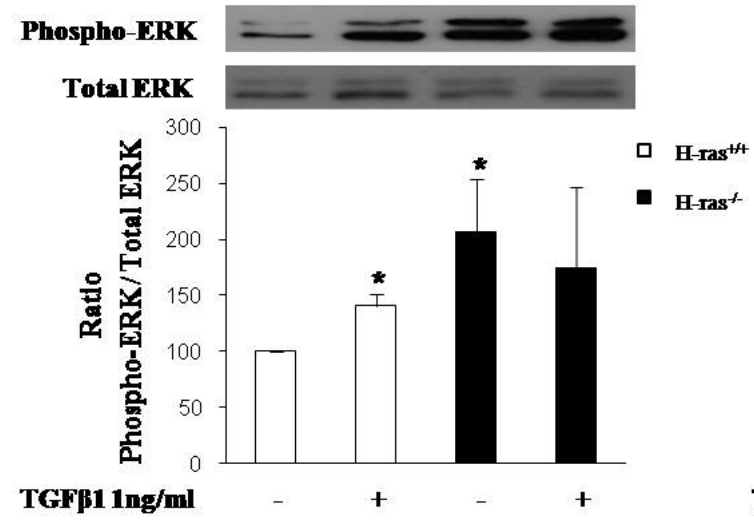

$\mathbf{F}$
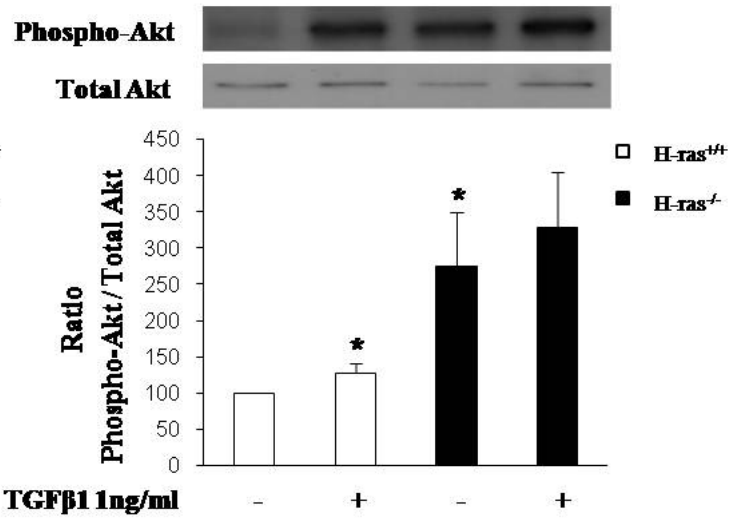

Figure 7: Effects of the absence of H-Ras isoform on extracellular matrix synthesis and EMT markers expression on embrionary fibroblasts. A) Effect of TGF- $\beta 1$ treatment $(1 \mathrm{ng} / \mathrm{ml})$ on A) fibronectin expression, B) collagen type I expression, C) $\alpha$-smooth muscle actin expression, D) vimentin expression, E) phospho-ERK / total ERK expression, F) phospho-Akt / total Akt expression, evaluated by western blot in $\mathrm{H}-\mathrm{ras}^{+/+}$and $\mathrm{H}-\mathrm{ras}^{-/}$fibroblasts. Upper panels show a representative blot from 8 different experiments, performed in similar conditions. Histograms represent the mean \pm SEM of the optical density of the bands, expressed as \% over basal values $\left(\mathrm{H}_{-\mathrm{ras}^{+/+}}\right.$fibroblasts with outh TFG- $\left.\beta 1,100 \%\right)$; ERK1/2 expression was used as loading control in A-F. ${ }^{*} \mathrm{p}<0.01$ vs. $\mathrm{H}-\mathrm{ras}^{+/+}$fibroblasts in basal conditions; $+\mathrm{p}<0.05$ vs $\mathrm{H}$-ras ${ }^{-/}$ fibroblasts in basal conditions. $\square \mathrm{H}-\mathrm{ras}^{+/+}$fibroblasts $\square{\mathrm{H}-\mathrm{ras}^{-/}}^{-/}$fibroblasts. 

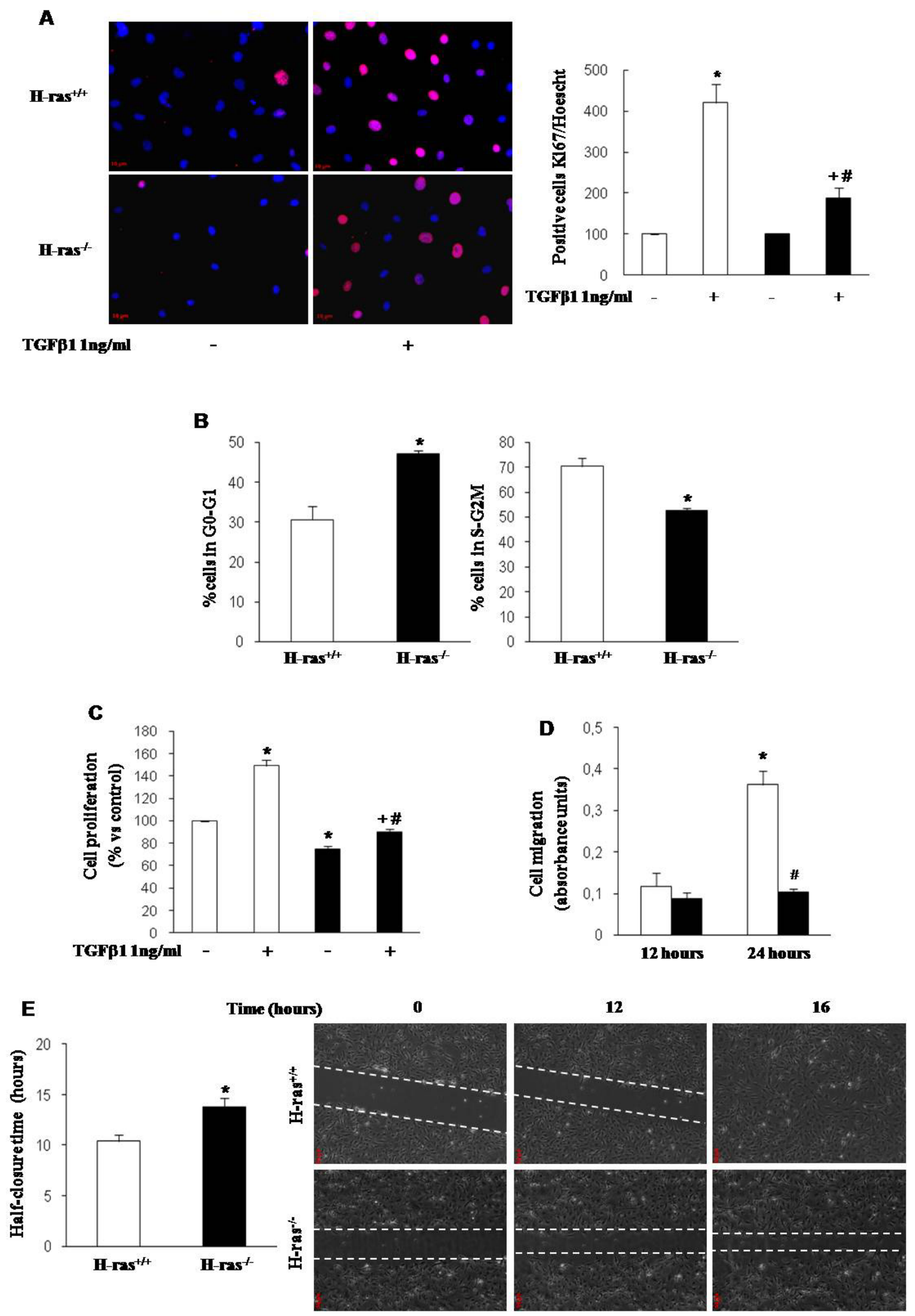
Figure 8: Effects of the absence of H-Ras isoform on cell proliferation, cell migration and apoptosis on embrionary fibroblasts. A) Effect of TGF- $\beta 1$ treatment on cell proliferation in $\mathrm{H}$ $\mathrm{ras}^{+/+}$and $\mathrm{H}$-ras ${ }^{-/}$fibroblasts evaluated by Ki67 immunostaining (and by crystal violet staining) Upper panel shows representative pictures of 8-16 experiments, histogram represents the mean \pm SEM, expressed as \% of Ki67 stained cells / Hoechst stained cells over basal values $\left(\mathrm{H}-\mathrm{ras}^{+/+}\right.$ and $\mathrm{H}_{-\mathrm{ras}^{-/}}$fibroblasts in $0 \% \mathrm{FCS}, 100 \%$ ). ${ }^{*} \mathrm{p}<0.01 \mathrm{vs} . \mathrm{H}$ - $\mathrm{ras}^{+/+}$fibroblasts in basal conditions; $+\mathrm{p}<0.05$ vs. $\mathrm{H}$-ras ${ }^{-/}$fibroblasts in basal conditions; \#p $<0.01 v^{2} . \mathrm{H}_{-} \mathrm{ras}^{+/+}$ fibroblasts treated TGF- $\beta 1$ B) Percentage of WT and $\mathrm{H}_{-\mathrm{ras}^{-/}}$fibroblasts in each phase of cell cycle evaluated by flow citometry. ${ }^{*}: \mathrm{p}<0.01 \mathrm{vs}$. $\mathrm{H}_{-\mathrm{ras}^{+/+}}$fibroblasts C) Effect of TGF- $\beta 1$ treatment on cell proliferation in $\mathrm{H}-\mathrm{ras}^{+/+}$and $\mathrm{H}-\mathrm{ras}^{-/}$fibroblasts evaluated by crystal violet staining. Histogram represents the mean \pm SEM of $80\left({\mathrm{H}-\mathrm{ras}^{+/+}}^{2}\right)$ and 14 experiments $\left({\mathrm{H}-\mathrm{ras}^{-/}}^{-}\right)$, performed in triplicate, expressed as \% over basal values (WT fibroblasts in $0 \% \mathrm{FCS}, 100 \%$ ). ${ }^{*} \mathrm{p}<0.01$ vs. $\mathrm{H}-\mathrm{ras}^{+/+}$fibroblasts in basal conditions; $+\mathrm{p}<0.05$ vs. $\mathrm{H}$-ras ${ }^{-/-}$fibroblasts in basal conditions; \#p $<0.01$ vs. $\mathrm{H}-\mathrm{ras}^{+/+}$fibroblasts treated with TGF- $\beta 1$. D) $\mathrm{H}-\mathrm{ras}^{+/+}$and $\mathrm{H}-\mathrm{ras}^{-/-}$ migration evaluated by the analysis of migration through trans-wells. Histogram represents the mean \pm SEM of 3 experiments quantifying the number of crystal violet stained cells that go through the migration chamber in absorbance units. ${ }^{*} \mathrm{p}<0.01 \mathrm{vs} . \mathrm{H}-\mathrm{ras}^{+/+}$fibroblasts after 12 h. $\# \mathrm{p}<0.01$ vs. $\mathrm{H}-\mathrm{ras}^{+/+}$fibroblasts after $24 \mathrm{~h}$. E) $\mathrm{H}-\mathrm{ras}^{+/+}$and $\mathrm{H}-\mathrm{ras}^{-/-}$fibroblasts migration evaluated by the analysis of wounds half-closure time. Lines in the micrographs represent the migration front after wound. Histogram represents the time in hours needed to close half of the wound expressed as mean \pm SEM of 18 experiments. ${ }^{*}: \mathrm{p}<0.01 v s . \mathrm{H}_{-} \mathrm{ras}^{+/+}$fibroblasts. $\square \mathrm{H}-$ $\mathrm{ras}^{+/+}$fibroblasts $\mathrm{H}-\mathrm{ras}^{-/-}$fibroblasts. 


\section{Artículo X}

"K-ras is involved in renal cell apoptosis and proliferation induced by unilateral ureteral obstruction in mice"

María T. Grande, Miguel Arévalo, Fernando Pérez-Barriocanal, Charles E. Patek y José M. López-Novoa

Molecular Medicine (enviado) 
Title: K-ras is involved in renal cell apoptosis and proliferation induced by unilateral ureteral obstruction in mice

\section{Running head: K-ras in ureteral obstruction model}

María T. Grande ${ }^{1}$, Miguel Arévalo ${ }^{2}$, Fernando Pérez-Barriocanal ${ }^{1}$, Charles E. Patek ${ }^{3}$ and José M. López-Novoa ${ }^{1}$

1 Instituto "Reina Sofía" de Investigación Nefrológica, Departamento de Fisiología y Farmacología, Universidad de Salamanca, Salamanca, Spain. ${ }^{2}$ Departamento de Anatomía e Histología Humanas, Universidad de Salamanca, Salamanca, Spain. ${ }^{3}$ Sir Alastair Currie Cancer Research UK Laboratories, Molecular Medicine Centre, The University of Edinburgh, Western General Hospital, Crewe Road, Edinburgh, EH4 2XU, UK

\section{*Corresponding author:}

Jose M. López-Novoa

Departamento de Fisiología y Farmacología,

Edificio Departamental, Campus Miguel de Unamuno

Universidad de Salamanca

37007 Salamanca,Spain.

Phone: (+34) 923294472

Fax: (+34) 923294669.

E-mail:jmlnovoa@usal.es 


\begin{abstract}
Ras proteins are membrane-associated molecular switches which regulate cell growth, differentiation, proliferation and apoptosis through interactions with a large number of target proteins, such as phosphatidylinositol-3 kinase (PI3K)/Akt and Raf/Erk signalling pathways. K-ras, the only Ras isoform to be essential for normal mouse development as K-ras deficiency embryos die before birth, has been reported to play a role in stimulated proliferation of renal fibroblasts. The aim of the study is to reveal the possible role of K-ras isoform in renal changes induced by unilateral ureteral obstruction in mice. For this purpose we have used mice heterozygous for a null

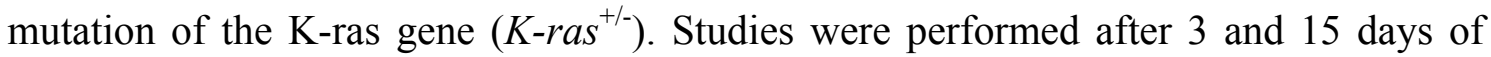
ureteral obstruction to analyze early and long-term changes. $\mathrm{K}_{-\mathrm{ras}}{ }^{+/-}$mice showed a higher UUO-induced H-Ras activation although no differences were observed Erk1/2 and Akt activation. After UUO, vimentin expression was lower in obstructed kidneys from $\mathrm{K}_{-\mathrm{ras}^{+/-}}$than in kidneys from $\mathrm{K}-\mathrm{ras}^{+/-}$mice, whereas no differences were observed in $\alpha$-SMA expression. $\mathrm{K}$-ras ${ }^{+/-}$mice showed also a lower expression of cleaved caspase3 and PARP, markers of cell apoptosis, and a lower expression of PCNA, marker of cell proliferation. These results suggest that K-ras activation plays a major role in UUOinduced apoptosis and proliferation and regulates vimentin expression.
\end{abstract}

\title{
Key words
}

Apoptosis, K-Ras, proliferation, ureteral obstruction, tubulointerstitial fibrosis 


\section{Introduction}

Interstitial renal fibrosis is the common pathologic end point of progressive forms kidney diseases, including obstructive nephropathy. The identification of mediators that are involved in this process could lead to novel therapeutic approaches Unilateral ureteral obstruction (UUO) in mice is a well-established experimental model of obstructive nephropathy whose most prominent changes include progressive accumulation of extracellular matrix, interstitial cell infiltration, tubular cell apoptosis, epithelial-to-mesenchymal transition and local proliferation and accumulation of myofibroblasts $(1,2)$.

Ras proteins are membrane-associated molecular switches which regulate cell growth, differentiation, proliferation and apoptosis (3) through interactions with a large number of target proteins, such as phosphatidylinositol 3-kinase (PI3K) and Ras/Raf/MEK-extracellular signal-regulated kinase (ERK1 and ERK2) (4). The three functional ras genes, $\mathrm{H}$-ras, K-ras and N-ras show a very similar structure and function although there are several differences between the mammalian ras isoforms (4). K-ras gene encodes two protein isoforms, K-ras4A and K-ras4B, of 189 and 188 residues respectively by alternative splicing and differs significantly at the $\mathrm{C}$ termini which is the region involved in membrane association. Whereas $\mathrm{K}$-ras4A, like $\mathrm{H}$-ras and $\mathrm{N}$-ras, is palmitoylated at cysteine residues, K-ras4B is methylated because has a polybasic domain of six lysine residues which impede the palmitoylation (5). These variations results in that different Ras isoforms have different traffic ways to the plasma membrane via different routes and different localization to distint plasma microdomains which influences Ras function (6).

Targeted deletion of ras family genes in mice demonstrates that only K-ras appears to be critical for normal mouse development, based on the observation that K-ras deficient embryos die between day 12 and term due to fetal liver defects, ventricular walls extremely thin, anemia and increased cell death of motoneurons $(7,8)$. In contrast $\mathrm{H}$-ras and N-ras are dispensable for development both individually or in combination (9, 10). K-ras4A deficient mice revealed that K-ras4A is also dispensable for normal mouse development, at least in the presence of functional K-ras4B (11).

Ras proteins have been related to be involved in development of renal fibrosis (12). Previously, we demonstrated the activation of ras and its effectors PI3K and ERK1/2 
after 3 days of UUO $(13,14)$. H-ras and N-ras activation have been reported to regulate extracellular matrix synthesis and proliferation in fibroblasts (15), and K-ras activation plays a role in stimulated proliferation of renal fibroblasts (16). However, the involvement of the different ras isoforms activation on changes in the kidney after UUO has not been studied. The purpose of our study was to assess the role of K-ras activation in the renal damage induced by UUO.

\section{Material and Methods}

\section{Animals and disease model}

All procedures were approved by the Committee for Animal Care and Use of the University of Salamanca and complied with the Guide for the Care and Use of

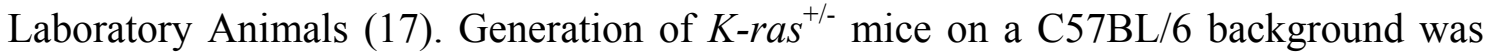
previously described (7). Animals appeared healthy and normal with no signs of any apparent associated lesions. The growth rates of these animals were indistinguishable from those of wild-type (WT) animals, and mutant mice reproduced normally. Routine genotyping of DNA isolated from mouse tail biopsies were performed by PCR using two sets of primers amplifying a 360-bp wild-type fragment for the $K$-ras ${ }^{+/+}$mice and a 270-bp mutant specific fragment (Figure 1) as previously described (7). Studies were

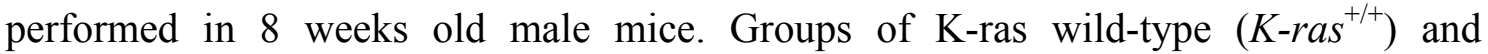

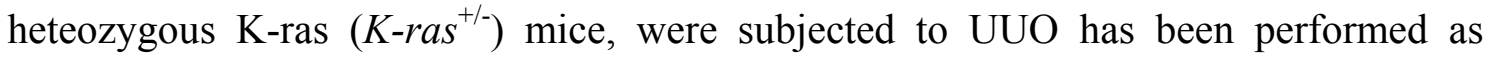
previously described (14).

After 3 or 15 days after surgery, animals intended to histological analysis were anesthetized with pentobarbital $(40 \mathrm{mg} / \mathrm{Kg})$ and perfused with heparinized saline solution followed by $4 \%$ buffered formalin. Obstructed $(\mathrm{O})$ and non-obstructed (NO) kidneys were removed, halved longitudinally, fixed for 24 hours in $4 \%$ buffered formalin and then embedded in paraffin. Sections $3 \mu \mathrm{m}$ thick were cut and mounted on glass slides that were used either for hematoxylin-eosin staining or immunohistochemistry. Kidneys destined for protein extraction were obtained in another set of animals after anesthesia and perfusion with heparinized saline solution. Kidneys were removed and frozen immediately in liquid nitrogen and stored at $-80^{\circ} \mathrm{C}$ until use. 
Immunohistochemical studies

Immunohistochemistry was performed on buffered formalin fixed, paraffinembedded tissues. Briefly, $3 \mu \mathrm{m}$ sections were deparaffined in xylene and rehydrated in graded ethanols before staining with the peroxidase-anti peroxidase method. Endogenous peroxidase was blocked by incubation in 3\% hydrogen peroxide, followed by primary antibody incubation. Primary antibodies were rabbit monoclonal anti-Ki67 (clona SP6, LabVision Corp. Ca. USA, 1:100 dilution), rabbit polyclonal anti-caspase_3 (Cell Signaling Technology, Ma. USA, 1:50 dilution). Following washes in PBS, the sections were sequentially incubated with the Novolink Polymer Detection System (Novocastra, MA, USA) using 3,3'diaminobenzidine (DAB) as chromogen. Sections were lightly counterstained with haematoxylin and were dehydrated and cover slipped. Negative controls were prepared without primary antibody.

\section{ELISA for Ras GTP}

Total kidneys lysates $(50 \mu \mathrm{g})$ were employed for the detection of RasGTP. RasGTP levels were determined by an ultra sensitive commercial ELISA kit (Active Motif, RasGTPase Chemi ELISA, Rixensart, Belgium) according to the manufacturer's instruction.

\section{Western blot analysis}

Tissue protein extracts were homogenized in lysis buffer (25mM HEPES pH7,5, $150 \mathrm{mM} \mathrm{NaCl}, 1 \%$ Igepal CA-630, 10mM MgCl2, 1mM EDTA, 10\% glycerol, $10 \mu \mathrm{g} / \mathrm{mL}$ aprotinin, $10 \mu \mathrm{g} / \mathrm{mL}$ leupeptin, 100mM PMSF, 25mM NaF, $1 \mathrm{mM} \mathrm{Na3VO} 4)$ and centrifuged at $14,000 \mathrm{~g}$ for $30 \mathrm{~min}$. Supernatant was recovered and proteins were quantified. Lysates (60 $\mu \mathrm{g} / \mathrm{lane})$ were loaded onto SDS-polyacrylamide gels, and the proteins were transferred to nitrocellulose membranes (Bio-Rad) by electroblotting. Membranes blocked in TTBS (10mM Tris pH 7.5, 150mM NaCl, 0.1\% Tween 20 plus $2 \%$ bovine serum albumin) were incubated overnight at $4{ }^{\circ} \mathrm{C}$ with correspondent primary antibody, as appropriate. Membranes were incubated with corresponding horseradish peroxidase-conjugated secondary antibody $(1: 10,000)$ and were developed using a chemiluminescent reagent (ECL detection reagent Amersham Biosciences). Developed signals were recorded on X-ray film (Fujifilm) for densitometric analysis (Scion Image). Western blot antibodies were: anti-ERK1 (1:2000), anti-phospho-ERK 
(1:2000), anti-phospho-Akt (1:1000), anti-Akt1/2 (1:1000), all from Santa Cruz Biotechnology, Santa Cruz, Ca, USA, anti-fibronectin (1:1000, Chemicon International, USA) and anti-alpha-SMA (1:1000, Sigma, St. Louis, USA) and anti cleaved caspase-3 (1:500) from Cell Signalling Inc, Danvers, MA, USA.

\section{Results}

\section{Renal Ras activation in non-obstructed and obstructed kidneys}

Renal Ras activation was analyzed by Ras GTPase Chemi ELISA which specifically detects activated $\mathrm{H}-$ ras in rodent samples. H-Ras activation was higher in $\mathrm{O}$

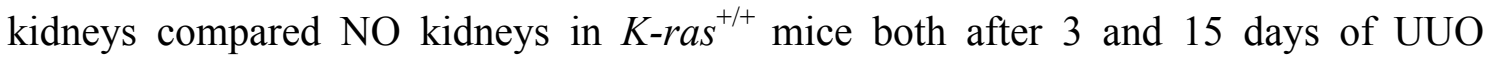
(Figure 2A). After 3 days of obstruction, $\mathrm{H}$-ras activation was higher in kidneys from $K$ $\mathrm{ras}^{+/-}$mice in both $\mathrm{NO}$ and $\mathrm{O}$ kidneys compared with those from $\mathrm{K}_{-} \mathrm{ras}^{+/+}$mice. The same pattern was observed after 15 days of obstruction, as both $\mathrm{NO}$ and $\mathrm{O}$ kidneys from $\mathrm{K}-\mathrm{ras}^{+/-}$mice showed a higher content in activated H-ras compared respectively with $\mathrm{NO}$ and $\mathrm{O}$ kidneys from $\mathrm{K}-\mathrm{ras}^{+/+}$mice.

To asses possible different expression of three Ras isoforms in early changes after UUO, in K-ras-deficient mice, western blot analysis of Ras isoforms was performed in

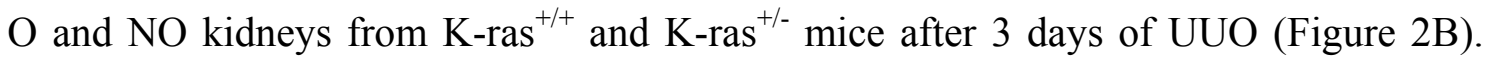
PanRasGTP levels were higher in O kidneys than in NO kidneys in both $\mathrm{K}_{-\mathrm{ras}^{+/+}}$and $\mathrm{K}_{-\mathrm{ras}^{+/}}{ }^{+-}$mice, but PanRas total expression was similar in O kidneys and NO kidneys from both groups. The pattern of expression of the different Ras isoforms were divergent, whereas total H-ras did not show differences between $\mathrm{NO}$ and $\mathrm{O}$ kidneys, total N- and K-ras expression were slightly increased in O kidneys compared with NO kidneys in both K-ras ${ }^{+/-}$and K-ras ${ }^{+/}$(Figure 2B). Expression of the three activated GTP-bound Ras isoforms were always higher in O kidneys than in NO kidneys independently of the mice type, although K-RasGTP and total K-ras levels were lower in both $\mathrm{O}$ and $\mathrm{NO}$ kidneys from $\mathrm{K}_{-\mathrm{ras}^{+/-}}$mice compared with $\mathrm{O}$ and NO kidneys from $\mathrm{K}-\mathrm{ras}^{+/+}$mice.

\section{Activation of the MAPK and PI3K in ureteral obstruction}

To determine whether deficiency in K-ras modifies the activation of ras pathways after UUO, Erk1/2 and Akt activation were compared in $\mathrm{O}$ and NO kidneys from Kras $^{+/-}$, and $\mathrm{K}-$ ras ${ }^{+/+}$mice at 3 and 15 days after UUO. 
When analyzing ERK activation in $\mathrm{O}$ and NO kidneys after ureteral obstruction, we observed that phosphorylated ERK (pERK) levels were higher in O than in NO kidneys both at day 3 and 15 after UUO in either $\mathrm{K}_{-\mathrm{ras}^{+/}}$and $\mathrm{K}$-ras $^{+/+}$mice. When O kidneys from $\mathrm{K}$ - $\mathrm{ras}^{+/-}$mice were compared with $\mathrm{O}$ kidneys from wild-type littermates, no differences in pERK levels were observed neither 3 days (Figure 3A) nor 15 days (Figure 3A), after UUO.

Akt activation was also assessed after ureteral obstruction. We observed that levels of phosphorylated Akt, pAkt, were higher in O kidneys than in NO kidneys in both $K$ $\mathrm{ras}^{+/+}$and $\mathrm{K}$-ras ${ }^{+/}$mice. This pattern was similar after 3 and 15 days after UUO (Figure 3B), and no differences were observed between $\mathrm{O}$ kidneys from K-Ras ${ }^{+/-}$and $\mathrm{K}-\mathrm{Ras}^{+/+}$ mice (Figure 3B). UUO also induced an increased Akt expression in $\mathrm{O}$ kidneys compared with NO kidneys. This fact was observed in both $\mathrm{K}-\mathrm{ras}^{+/+}$and $\mathrm{K}$-ras ${ }^{+/-}$mice, both 3 and 15 days after ureteral obstruction (Figure 3C).

\section{Extracellular matrix accumulation after ureteral obstruction}

To asses if K-ras activation plays a role in the extracellular matrix accumulation induced by UUO, we analyzed collagen expression with syrius red staining and fibronectin and collagen I expression by western blot analysis in the $\mathrm{O}$ and NO kidneys from $\mathrm{K}_{-\mathrm{ras}^{+/-}}$and $\mathrm{K}-\mathrm{ras}^{+/+}$mice after 3 and 15 days of UUO. Syrius red studies showed a lack of interstitial fibrosis in NO kidneys from both groups. However, O kidneys from both groups revealed focal interstitial fibrosis 3 days after OUU, and a marked and diffused interstitial fibrosis 15 days after ligation (Figure 4), without differences between $\mathrm{K}_{-\mathrm{ras}^{+/-}}$and $\mathrm{K}_{-\mathrm{ras}^{+/+}}$mice (Figure 4). As it was expected, fibronectin and collagen I expression were higher in O kidneys compared with NO kidneys in samples from all groups of mice. Partial deficiency of K-ras $\left({\left.\mathrm{K}-\mathrm{ras}^{+/}\right)}^{+-}\right.$did not affect to UUOinduced expression of fibronectin (Figure 5A) and collagen I (Figure 5B) in the $\mathrm{O}$ kidney neither after 3 days nor after 15 days of UUO.

\section{Activation of fibroblasts after UUO}

Abundance of renal interstitial myofibroblasts was assessed by the expression of $\alpha$ SMA and vimentin. Both proteins expression were analyzed by western blot in $\mathrm{O}$ and NO kidneys from K-ras ${ }^{+/}$and $\mathrm{K}-$ ras $^{+/+}$mice.

The expression of both $\alpha$-SMA (Figure 6A) and vimentin (Figure 6B) were higher in $\mathrm{O}$ kidneys than in NO kidneys from $\mathrm{K}-\mathrm{ras}^{+/+}$mice, after 3 and 15 days of obstruction. 
$\alpha$-SMA UUO-induced expression were similar in O kidneys of $\mathrm{K}^{-\mathrm{ras}^{+/-}}$and $\mathrm{K}-\mathrm{ras}^{+/+}$ mice after either 3 days or 15 days of obstruction (Figure 6A). After 3 days of UUO, no differences in vimentin UUO-induced expression were observed between $\mathrm{O}$ kidneys

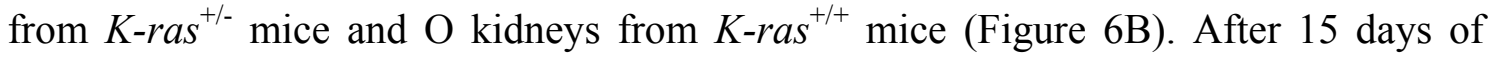
obstruction, increase in vimentin expression was lower in O kidneys from $\mathrm{K}_{-} \mathrm{ras}^{+/-}$than in O kidneys from $\mathrm{K}$-ras ${ }^{+/+}$mice (Figure 6B).

\section{Proliferation and apoptosis after UUO}

Cleaved caspase- 3 expression, assessed by western blot, was higher in $\mathrm{O}$ than in NO kidneys 3 and 15 days after UUO in both types of mice (Figure 7). O kidneys from $\mathrm{K}_{-\mathrm{ras}^{+/}}$mice showed lower cleaved caspase-3 expression than O kidneys from $\mathrm{K}$-ras ${ }^{+/+}$ mice both 3 days and 15 days after UUO (Figure 7A). Also immunohistochemistry of cleaved caspase-3 revealed major expression in O kidneys than in NO kidneys and also

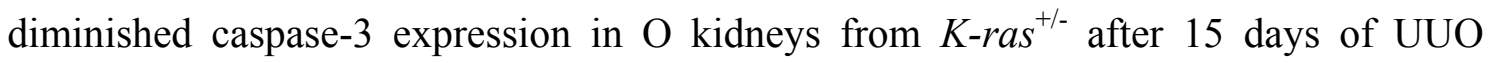
(Figure 8). These results were corroborated by the amount of poly-ADP-ribose polymerase (PARP), a substrate of active caspases which is cleaved from the full-length intact form of $116 \mathrm{kDa}$ into $85 \mathrm{kDa}$ form during apoptosis. In $\mathrm{O}$ kidneys both full-length and cleaved PARP expression was significantly higher than in NO kidneys (Figure 7B). Cleaved PARP expression was lower in $\mathrm{O}$ kidneys from $\mathrm{K}-\mathrm{Ras}^{+/-}$mice compared with $\mathrm{O}$ kidney from $\mathrm{K}-\mathrm{Ras}^{+/+}$mice on days 3 and 15 after UUO (Figure 7B).

PCNA and Ki67 expression are well known proliferation markers. UUO-induced a markedly increase in PCNA expression in O kidneys compared with NO kidneys (Figure 9A). O kidneys from $\mathrm{K}$-ras ${ }^{+-}$mice showed a lower PCNA expression, analyzed

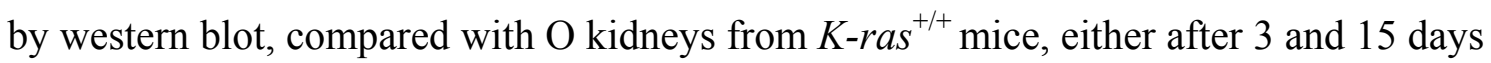
of UUO (Figure 9A). Ki67 immunohistochemistry studies also revealed increased cell proliferation in O kidneys compared with NO kidneys. Ki-67 stained nuclei were lower in O kidneys from $\mathrm{K}$-ras ${ }^{+/-}$mice than in O kidneys from $\mathrm{K}_{-} \mathrm{ras}^{+/+}$mice (Figure 9B).

\section{Discussion}

Previous studies have involved Ras activation on renal fibrosis $(12,13)$. We have previously demonstrated that Ras and its effectors Erk1/2 and Akt were activated after ureteral obstruction in mice (14). Furthermore, inhibition of Erk1/2 or Akt activation prevented in a differential form some of the early changes observed in the obstructed kidney after UUO (14). As different actions have been assigned to the different Ras 
isoforms, in the present study we aimed to analyze the role of K-ras activation in the changes observed after UUO.

K-ras expression has been assessed in normal human kidney. Ki-ras was expressed in mesangial cells, interstitial cells and in proximal convoluted tubule cells (PCT) (particularly localized at brush borders) and in collecting duct cells (CD) (localized to cell membranes) but not in podocytes (18). Primate renal fibroblasts have been reported to predominantly express the $\mathrm{Ki}$ isoform of Ras. Our results show K-ras activation induced by UUO in control mice and, as it was expected, a lower expression of both activated and total K-ras in kidneys from $\mathrm{K}$ - $\mathrm{ras}^{+/-}$mice after UUO.

The partial deficiency in K-ras did not produced differences in the activation of Ras effectors, ERK and Akt. This fact can be explained by the fact that Ras isoforms can differentially activate Akt and ERK because the differences in the mechanisms of membrane attachment of the Ras isoforms $(19,20)$.

Tubulointerstitial fibrosis is characterized by accumulation of components of extracellular matrix in the interstitial space $(21,22)$. No differences in the expression of fibronectin and type I collagen were observed in kidneys from $\mathrm{K}$-ras ${ }^{+/-}$mice compared with kidneys from $\mathrm{K}_{-\mathrm{ras}^{+/+}}$mice after 3 and 15 days of ureteral obstruction, thus suggesting that K-ras activation does not play a major role in the accumulation of interstitial extracellular matrix proteins. The most important cells producers of extracellular matrix after UUO are activated fibroblasts or myofibroblasts which can derive from local resident fibroblasts, bone marrow derived cells and tubular epithelial cells (23). $\alpha$-SMA and vimentin are frequently used as activated fibroblasts. $\alpha$-SMA expression in the $\mathrm{O}$ kidney was the same in $\mathrm{K}-\mathrm{ras}^{+/-}$mice and $\mathrm{K}$-ras ${ }^{+/+}$mice either 3 or 15 days after UUO, but unexpectedly, vimentin expression was lower on day 15 after UUO in O kidneys of $\mathrm{K}_{-\mathrm{ras}^{+/-}}$mice compared with $\mathrm{O}$ kidneys in $\mathrm{K}$-ras ${ }^{+/+}$mice. K-ras has been reported to be a potent activator of the Rac pathway, more than H-ras (20), and activation of Rac pathway promotes vimentin activation and reorganization (24). Possibly, lower K-ras activation in O kidneys from $\mathrm{K}$ - $\mathrm{ras}^{+/-}$mice results in lower Rac activation and consequently a diminished vimentin reorganization and expression, whereas $\alpha$-SMA expression seems to be regulated through a different pathway. However, further studies are needed to elucidate the precise role of K-Ras in regulating vimentin expression. 
Ureteral obstruction has been reported to induce apoptosis of both tubular and interstitial cells in the obstructed kidneys. This is accompanied with increased caspase activation (25). Cleaved caspase-3 leads to burst of PARP, which is required for apoptosis (26). We have also observed higher expression of both cleaved caspase-3 and cleaved PARP in O kidneys than in NO kidneys both on days 3 and 15 after UUO. O kidneys from $\mathrm{K}_{-\mathrm{ras}^{+/}}$mice showed less cleaved caspase-3 and cleaved PARP abundance compared with O kidneys from WT mice. Several studies have proposed K-ras as promoter of apoptosis $(27,28)$. Our results suggest K-ras activation is involved in obstruction-induced apoptosis as partial deficiency of K-ras is associated to lower caspase-3 activation and cleavage of PARP in the obstructed kidney, and therefore, lower tubular atrophy as apoptosis has been considered the major cause of UUOinduced tubular atrophy (29).

Ureteral obstruction induced interstitial and tubular epithelial cell proliferation which continuous increases with time and approximately parallel the increase in the interstitial damage (29). Our results also show higher levels of PCNA expression in O kidneys compared with NO kidneys. Previous results have reported that K-ras isoform activation plays a role in the stimulated proliferation of primate renal fibroblasts, as inhibition of K-ras through using transfection with specific phosphorothioate oligodeoxynucleotides inhibited EGF- and FGF-induced proliferation (16). This result is in agreement with our result that $\mathrm{O}$ kidneys from $\mathrm{K}-\mathrm{ras}^{+/-}$mice had lower levels of cell proliferation, measured by PCNA expression, than $\mathrm{O}$ kidneys from $\mathrm{K}$-ras ${ }^{+/+}$mice. Thus K-ras activation seems to modulate UUO-induced proliferation in the obstructive nephropathy.

In conclusion, our results suggest that K-ras activation plays a major role in early and long term apoptosis and proliferation induced by UUO in mice. Also K-ras activation seems to be involved in increased vimentin expression in the obstructed kidneys. This study should provide the impetus for further exploration on the role of Kras isoform on the mechanisms of cell death and cell proliferation associated to UUO. 


\section{Acknowledgements}

The authors thank Mrs. Angustias Pérez for technical histological assistance. This study has been partially supported by grants from Instituto de Salud Carlos III , Ministerio de Sanidad y Consumo (Retic 06/0016, RedinRen), Comisión Interministerial de Ciencia y Tecnología (grantsBFU-2004-00285/BFI and SAF2007-63893) and Junta de Castilla y León (grant SA001/C05 ).

\section{Disclosure}

The authors declared they have no competing interests.

\section{References}

1. Iwano M, Neilson EG. (2004) Mechanisms of tubulointerstitial fibrosis. Curr Opin Nephrol Hypertens. 13: 279-84.

2. Klahr S, Morryssey J. (2002) Obstructive nephropathy and renal fibrosis. Am $J$ Physiol Renal Physiol. 283: F861-F875.

3. Malumbres M, Barbacid M. (2003) RAS oncogenes: the first 30 years. Nat Rev Cancer. 3: 459-65.

4. Malumbres M, Pellicer A. (1998) RAS pathways to cell cycle control and cell transformation. Front Biosci. 3: d887-912.

5. Silvius JR. (2002) Mechanisms of Ras protein targeting in mammalian cells. $J$ Membr Biol. 190: 83-92.

6. Prior IA, Hancock JF. (2001) Compartmentalization of Ras proteins. J Cell Sci. 114: $1603-8$.

7. Johnson L, et al.(1997) K-ras is an essential gene in the mouse with partial functional overlap with N-ras. Genes Dev. 11: 2468-81.

8. Koera K, et al. (1997) K-ras is essential for the development of the mouse embryo. Oncogene. 15: 1151-9. 
9. Esteban LM, et al. (2001) Targeted genomic disruption of H-ras and N-ras, individually or in combination, reveals the dispensability of both loci for mouse growth and development. Mol Cell Biol. 21: 1444-52.

10. Umanoff H, Edelmann W, Pellicer A, Kucherlapati R. (1995) The murine N-ras gene is not essential for growth and development. Proc Natl Acad Sci U S A. 92: 1709-13.

11. Plowman SJ, et al. (2003) While K-ras is essential for mouse development, expression of the K-ras 4A splice variant is dispensable. Mol Cell Biol. 23: 924550.

12. Martínez-Salgado C, Rodríguez-Peña AB, López-Novoa JM. (2008) Involvement of small Ras GTPases and their effectors in chronic renal disease. Cell Mol Life Sci. 65: 477-92.

13. Rodríguez-Peña AB, Santos E, Arévalo M, López-Novoa JM. (2005) Activation of small GTPase Ras and renal fibrosis. J Nephrol. 18: 341-9.

14. Rodríguez-Peña AB, Grande MT, Eleno N, Arévalo M, Guerrero C, Santos E, López-Novoa JM. (2008) Activation of Erk1/2 and Akt following unilateral ureteral obstruction. Kidney Int. 74: 196-209.

15. Martínez-Salgado C, Fuentes-Calvo I, García-Cenador B, Santos E, LópezNovoa JM. (2006) Involvement of H- and N-Ras isoforms in transforming growth factor-beta1-induced proliferation and in collagen and fibronectin synthesis. Exp Cell Res. 312: 2093-106.

16. Sharpe CC, et al. (1999) Evidence of a role for Ki-Ras in the stimulated proliferation of renal fibroblasts. J Am Soc Nephrol. 10: 1186-92.

17. National Research Council (NRC) (1996) Commission on Life Sciences, Institute of Laboratory Animal Resources, Guide for the Care and Use of Laboratory Animals, National Academy Press, Washington (DC).

18. Kocher HM, et al. (2003) Expression of Ras GTPases in normal kidney and in glomerulonephritis. Nephrol Dial Transplant. 18: 2284-92. 
19. Yang JJ, Kang JS, Krauss RS. (1998) Ras signals to the cell cycle machinery via multiple pathways to induce anchorage-independent growth. Mol Cell Biol. 18: 2586-95.

20. Walsh AB, Bar-Sagi D. (2001) Differential activation of the Rac pathway by Ha-Ras and K-Ras. J Biol Chem. 276: 15609-15615.

21. Wright EJ, McCaffrey TA, Robertson AP, Vaughan ED Jr, Felsen D. (1996) Chronic unilateral ureteral obstruction is associated with interstitial fibrosis and tubular expression of transforming growth factor-beta. Lab Invest. 74: 528-537.

22. Sharma AK, Mauer SM, Kim Y, Michael AF. (1993) Interstitial fibrosis in obstructive nephropathy. Kidney Int. 44: 774-788.

23. Strutz F (2008) How many different roads may a cell walk down in order to become a fibroblast? J Am Soc Nephrol 19: 2246-2248

24. Chang L, Goldman RD. (2004) Intermediate filaments mediate cytoskeletal crosstalk. Nat Rev Mol Cell Biol. 5: 601-613.

25. Truong LD, et al. (2001) Renal cell apoptosis in chronic obstructive uropathy: the roles of caspases. Kidney Int. 60: 924-34.

26. Boulares AH, et al. (1999) Role of poly(ADP-ribose) polymerase (PARP) cleavage in apoptosis. Caspase 3-resistant PARP mutant increases rates of apoptosis in transfected cells. J Biol Chem. 274: 22932-40.

27. Quatela SE, Sung PJ, Ahearn IM, Bivona TG, Philips MR. (2008) Analysis of K-Ras phosphorylation, translocation, and induction of apoptosis. Methods Enzymol. 439: 87-102.

28. Bivona TG, et al. (2006) PKC regulates a farnesyl-electrostatic switch on K-Ras that promotes its association with Bcl-XL on mitochondria and induces apoptosis. Mol Cell. 21: 481-93.

29. Truong LD, et al. (1996) Cell apoptosis and proliferation in experimental chronic obstructive uropathy. Kidney Int. 50: 200-7. 

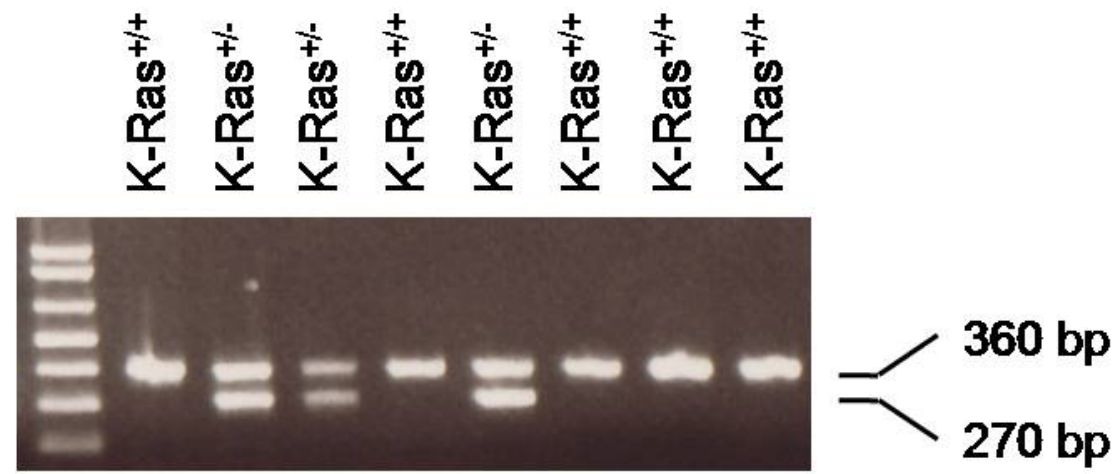

Figure 1. Routine genotyping of mice by PCR analysis. Tail biopsies from $\mathrm{K}-\mathrm{ras}^{+/+}$ mice amplified a 360-bp fragment and tail biopsies from $\mathrm{K}$-ras ${ }^{+/-}$mice amplified a 270-bp mutant specific fragment.

A

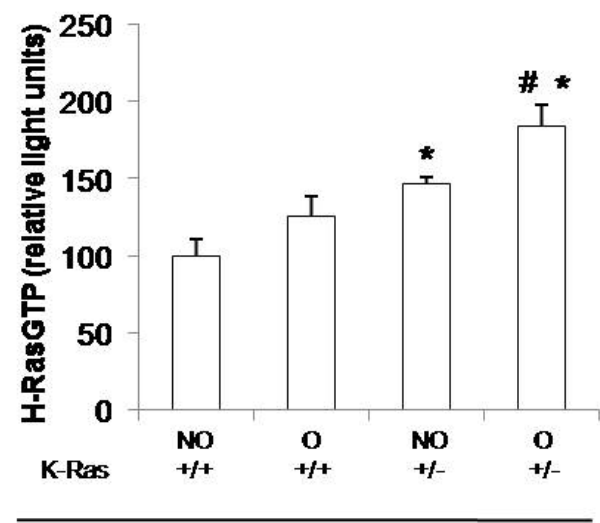

3d UUO

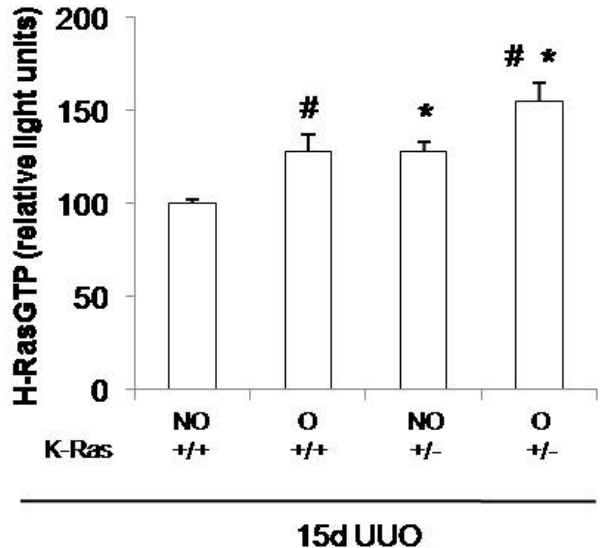

15d UUO

B
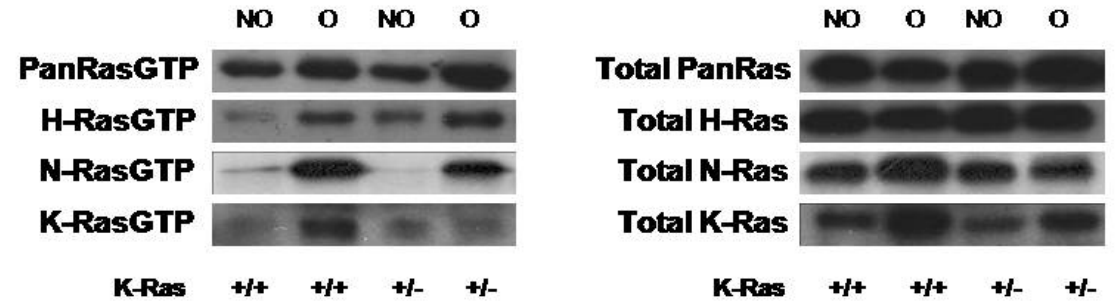

Figure 2. Activation of Ras isoforms after UUO. A) H-ras activation determined by ELISA 3 days (left) and 15 days (right) after UUO. Data represent the average \pm SEM

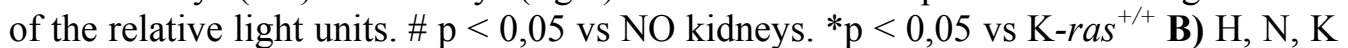
and Pan-Ras activation (left) and total expression (right) in NO and O kidneys from K$\operatorname{Ras}^{+/+}$and K-Ras ${ }^{+/-}$mice analyzed by western blot. 

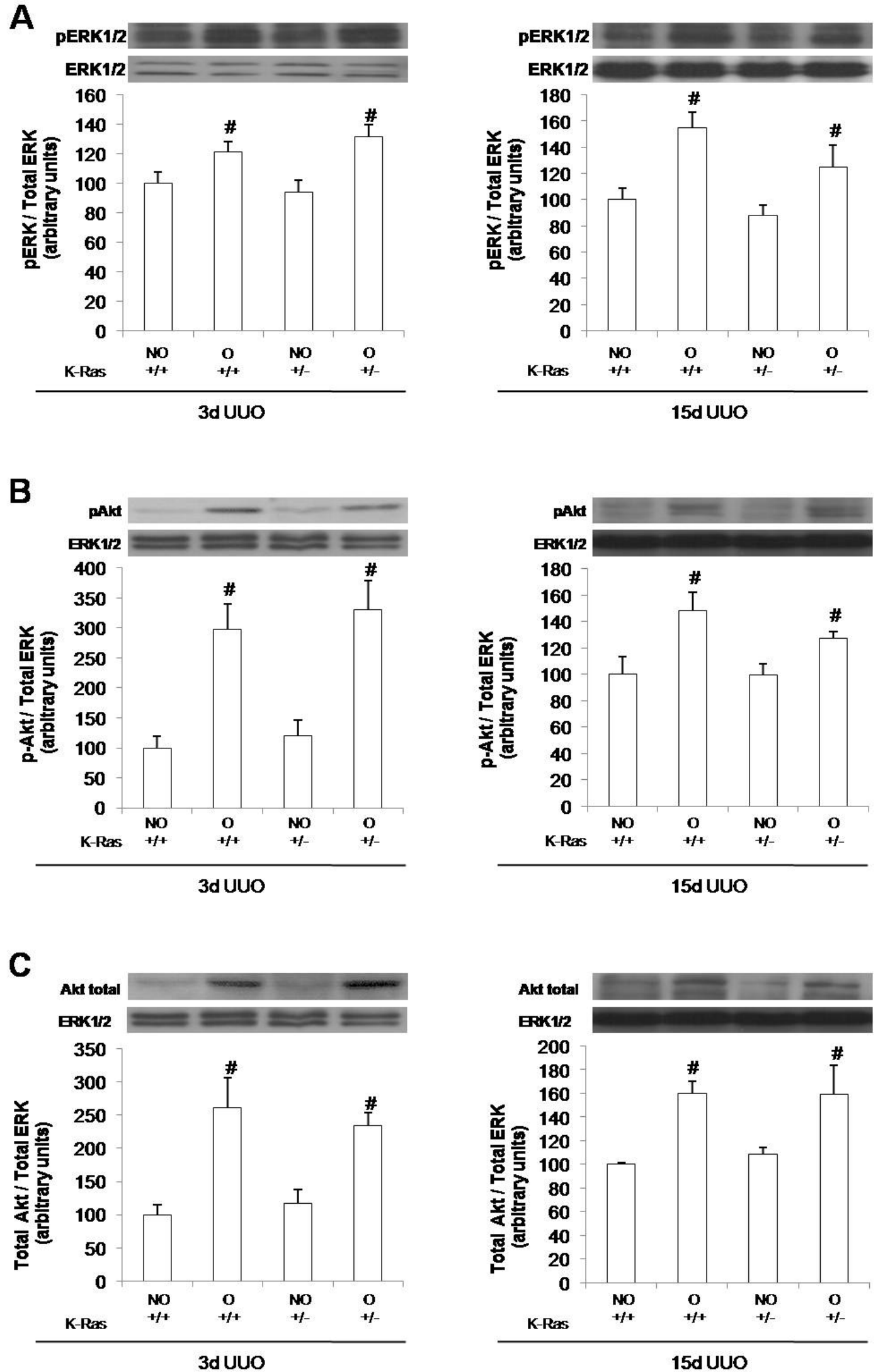

Figure 3. Activation of Ras effectors after UUO. A) ERK activation, B) phospho-Akt expression and C) total Akt expression in NO and O kidneys from $\mathrm{K}_{-\mathrm{ras}^{+/+}}$and $\mathrm{K}$-ras ${ }^{+-}$mice 3 days (left) and 15 days (right) after UUO. All proteins were evaluated by western blot. Data represent the average \pm SEM of the optical density. \# $\mathrm{P}<0,01$ vs corresponding NO kidneys. 


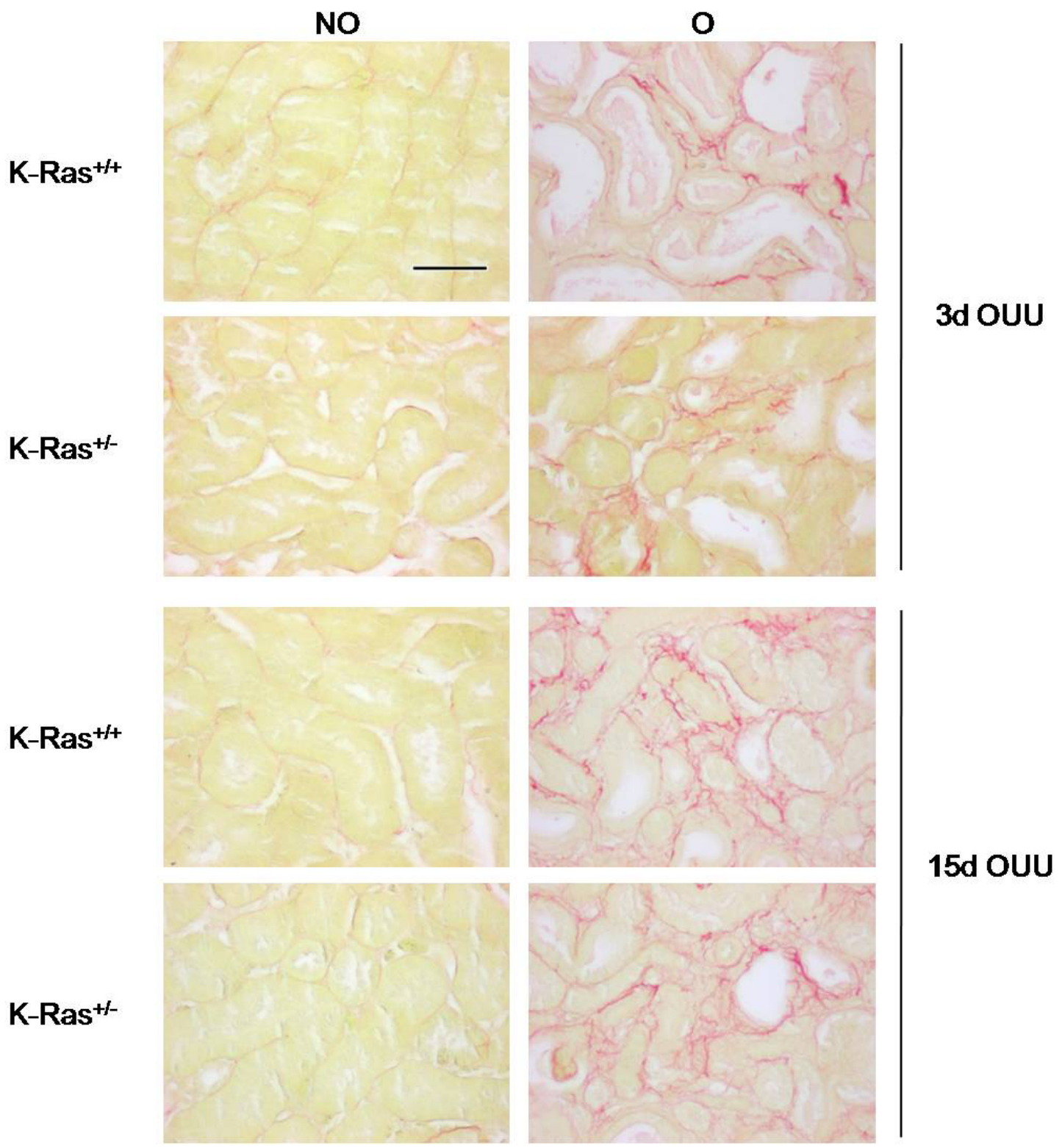

Figura 4. Syrius red staining. Syrius red staining of NO and O kidneys from $\mathrm{K}_{-\mathrm{ras}^{+/+}}$and $K-\mathrm{ras}^{+/-}$mice after 3 and 15 days of UUO. Scale bar indicates 50 microns in all panels. 
A
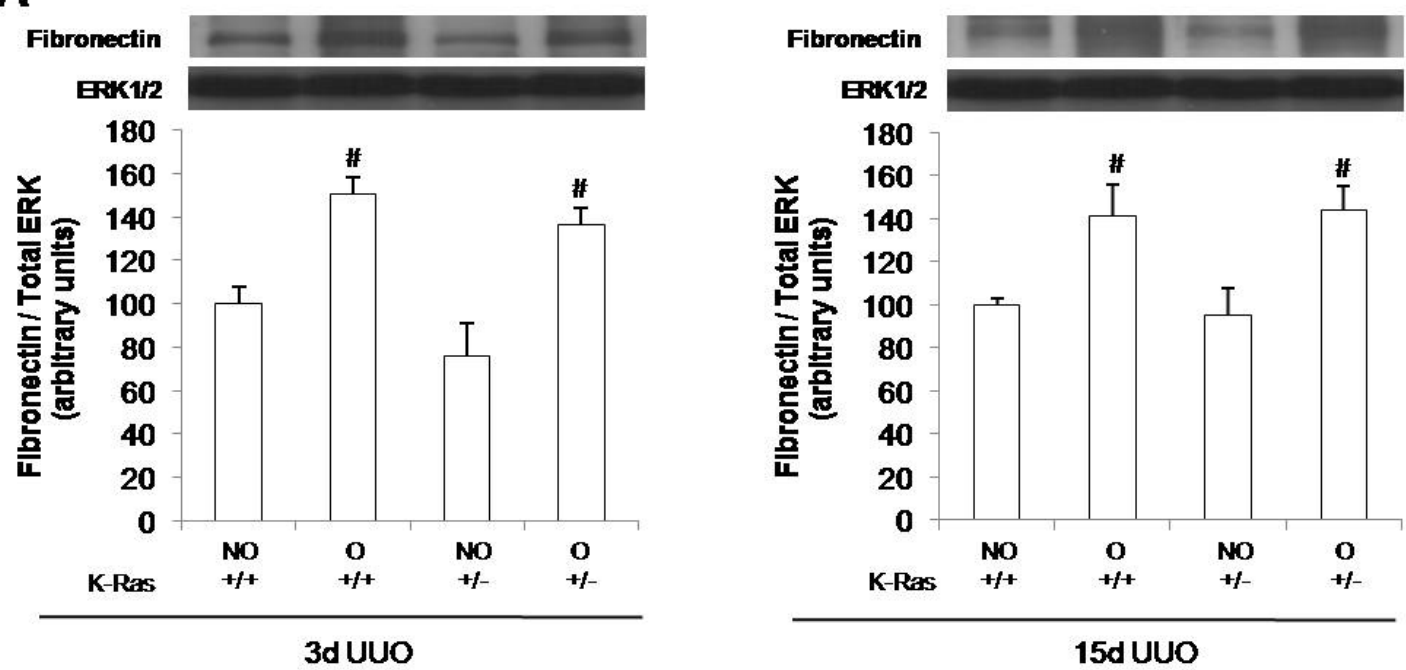

B
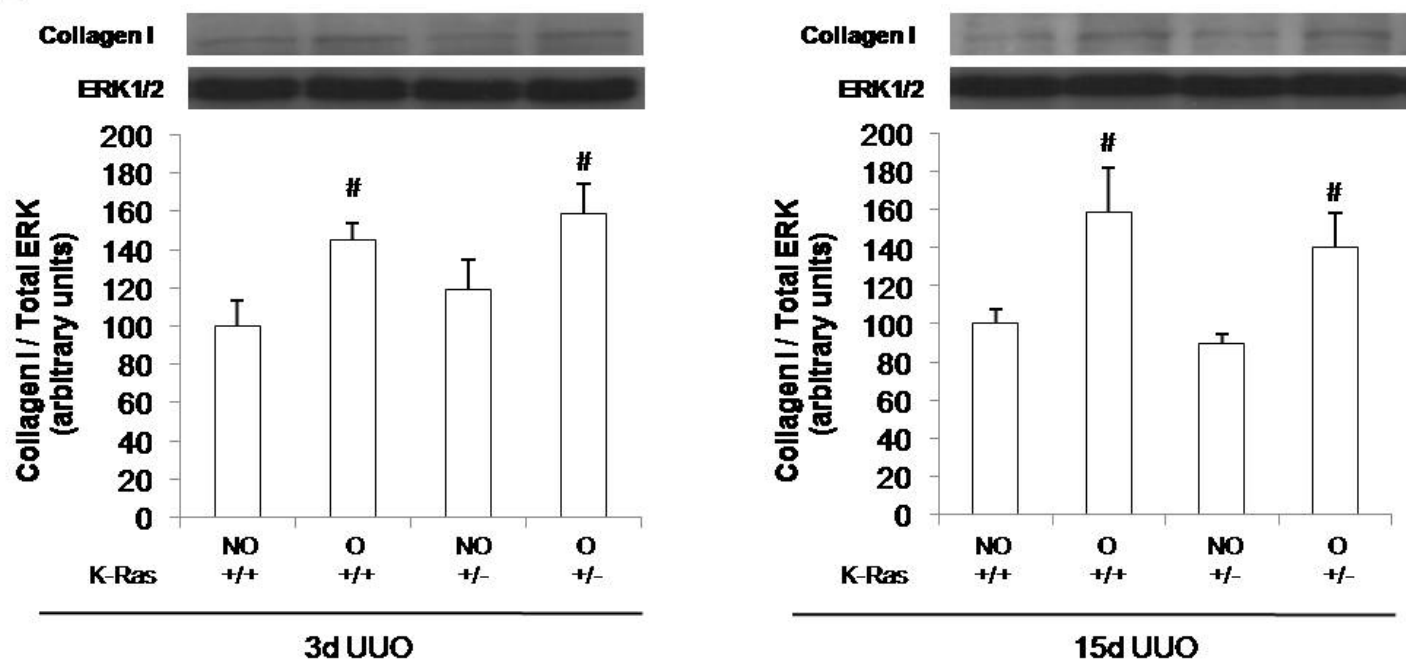

15d UUO

Figure 5. Extracellular matrix deposition markers after UUO. Western blot analysis of A) fibronectin and B) type I collagen levels in NO and O kidneys from $\mathrm{K}-\mathrm{ras}^{+/+}$and $\mathrm{K}$-ras ${ }^{+/-}$mice 3 days (left) and 15 days (right) after UUO. Data represent the average \pm SEM of the optical density. \# $\mathrm{P}<0,01$ vs corresponding NO kidneys. 

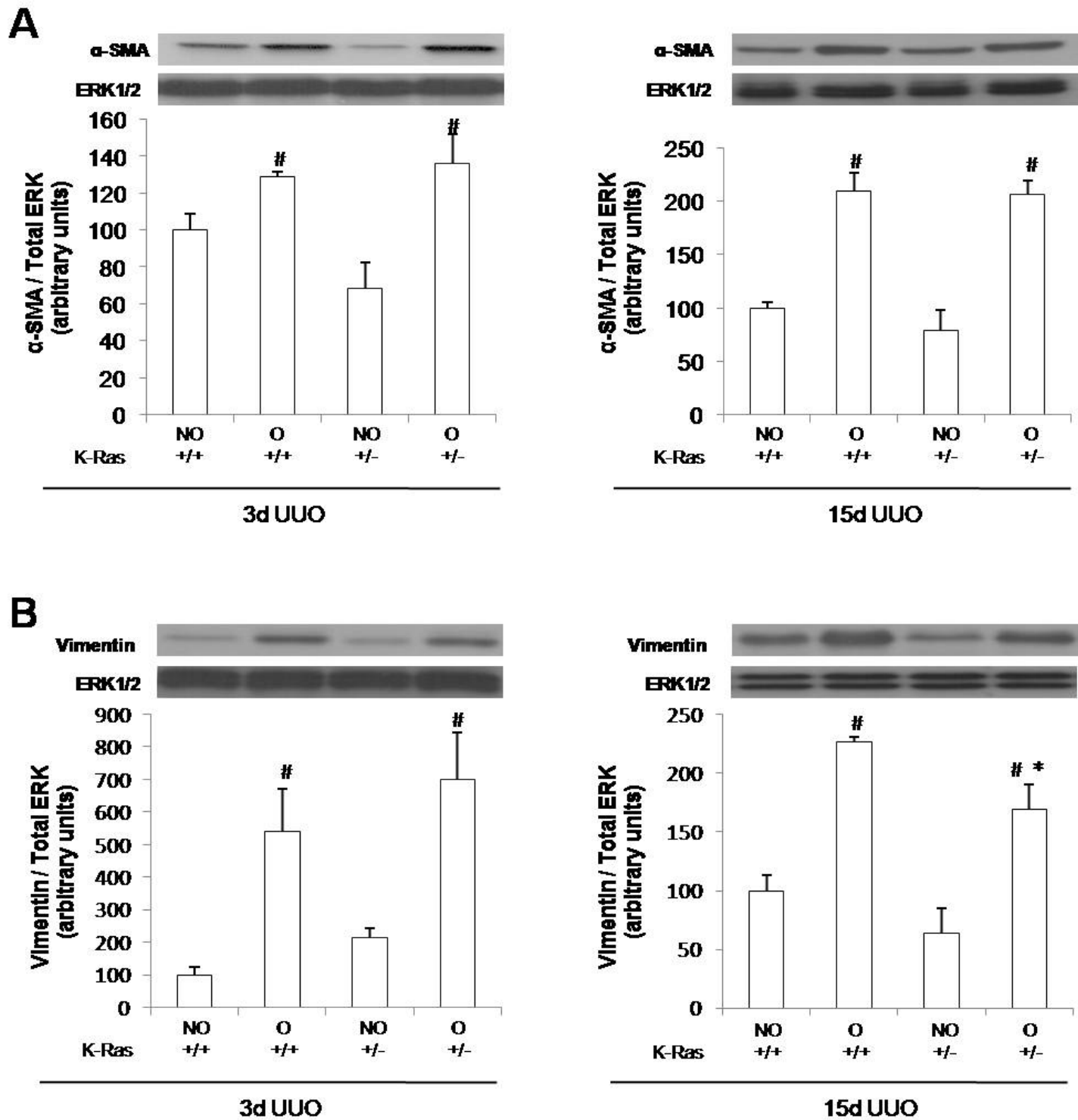

Figure 6. Markers of myofibroblasts after UUO. Western blot analysis of A) $\alpha$-SMA and B) vimentin levels in $\mathrm{NO}$ and $\mathrm{O}$ kidneys from $\mathrm{K}_{-\mathrm{ras}^{+/+}}$and $\mathrm{K}$-ras ${ }^{+/-}$mice 3 days (left) and 15 days (right) after UUO. Data represent the average \pm SEM of the optical density. \# P $<0,01$ vs corresponding NO kidneys. 

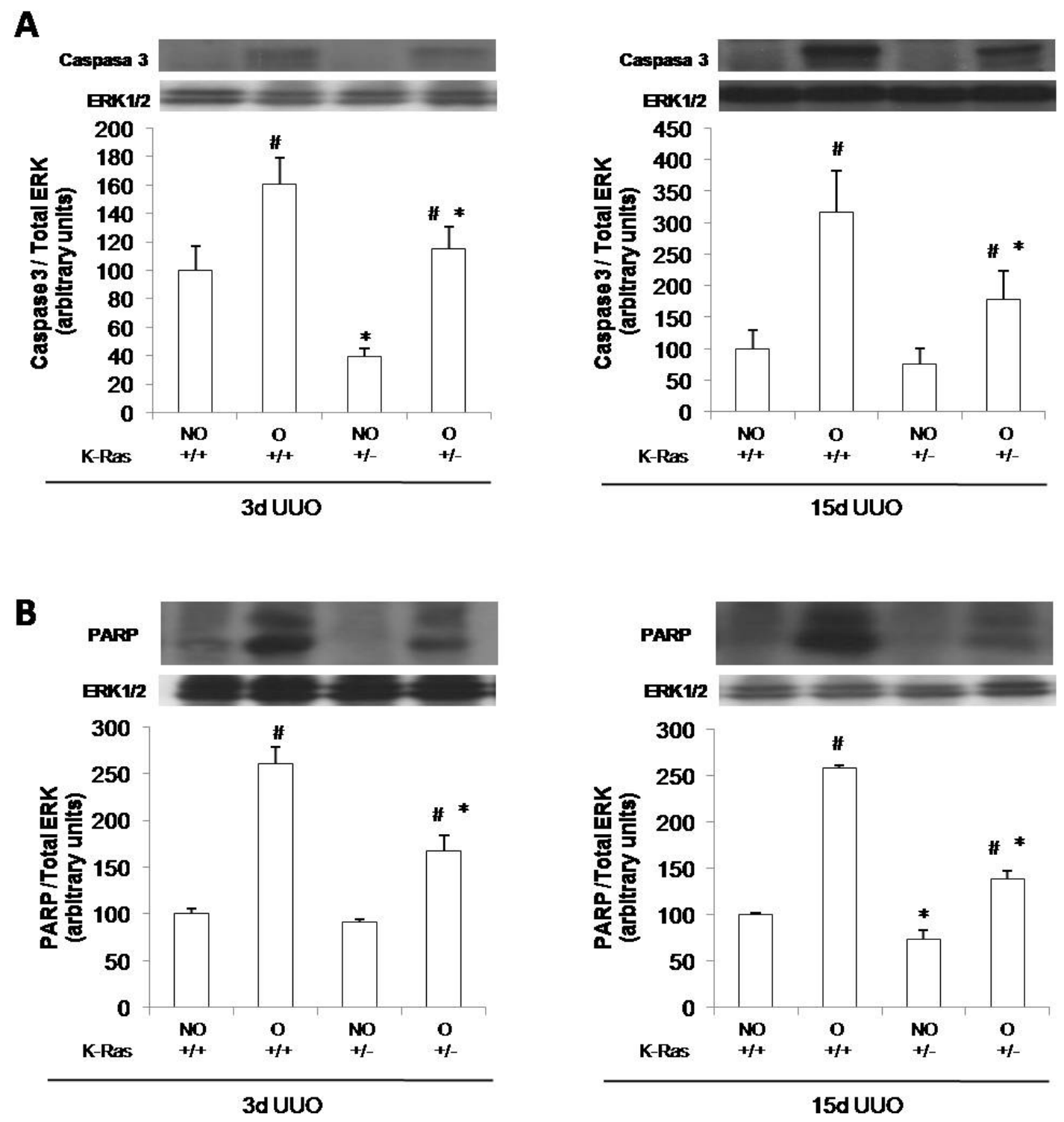

Figure 7. Apoptosis markers expression after UUO. Western blot analysis of A) cleaved caspase-3 and B) PARP levels in NO and O kidneys from $\mathrm{K}_{\text {-ras }}{ }^{+/+}$and $\mathrm{K}$-ras ${ }^{+/-}$mice 3 days (left) and 15 days (right) after UUO. Data represent the average \pm SEM of the optical density. \# $\mathrm{P}<0,01$ vs corresponding NO kidneys. 


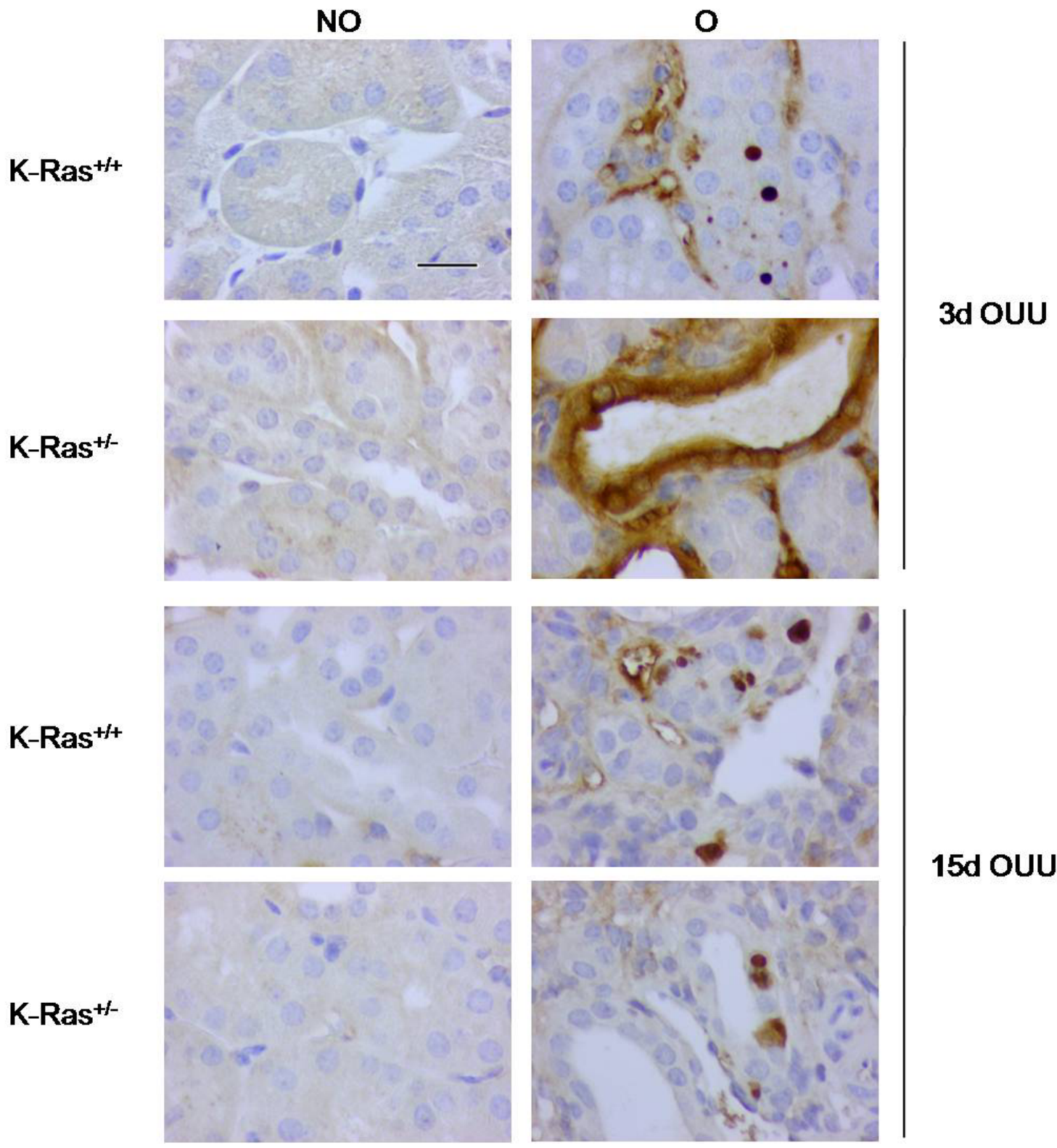

Figure 8. Immunohistochemistry for cleaved caspase 3. Inmunohistochemistry for cleaved caspase 3 in NO and O kidneys from $\mathrm{K}-\mathrm{ras}^{+/+}$and $\mathrm{K}_{\text {-ras }}{ }^{+/}$mice after 3 and 15 days of UUO. Scale bar indicates 20 microns in all panels. 


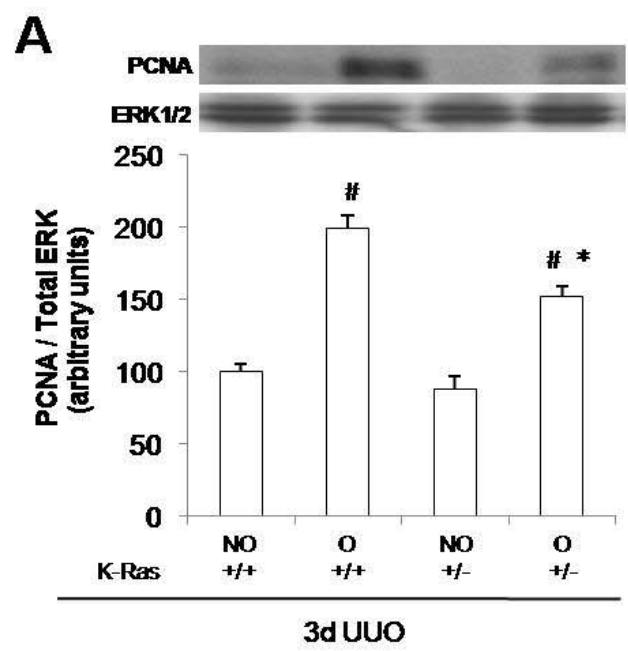

B
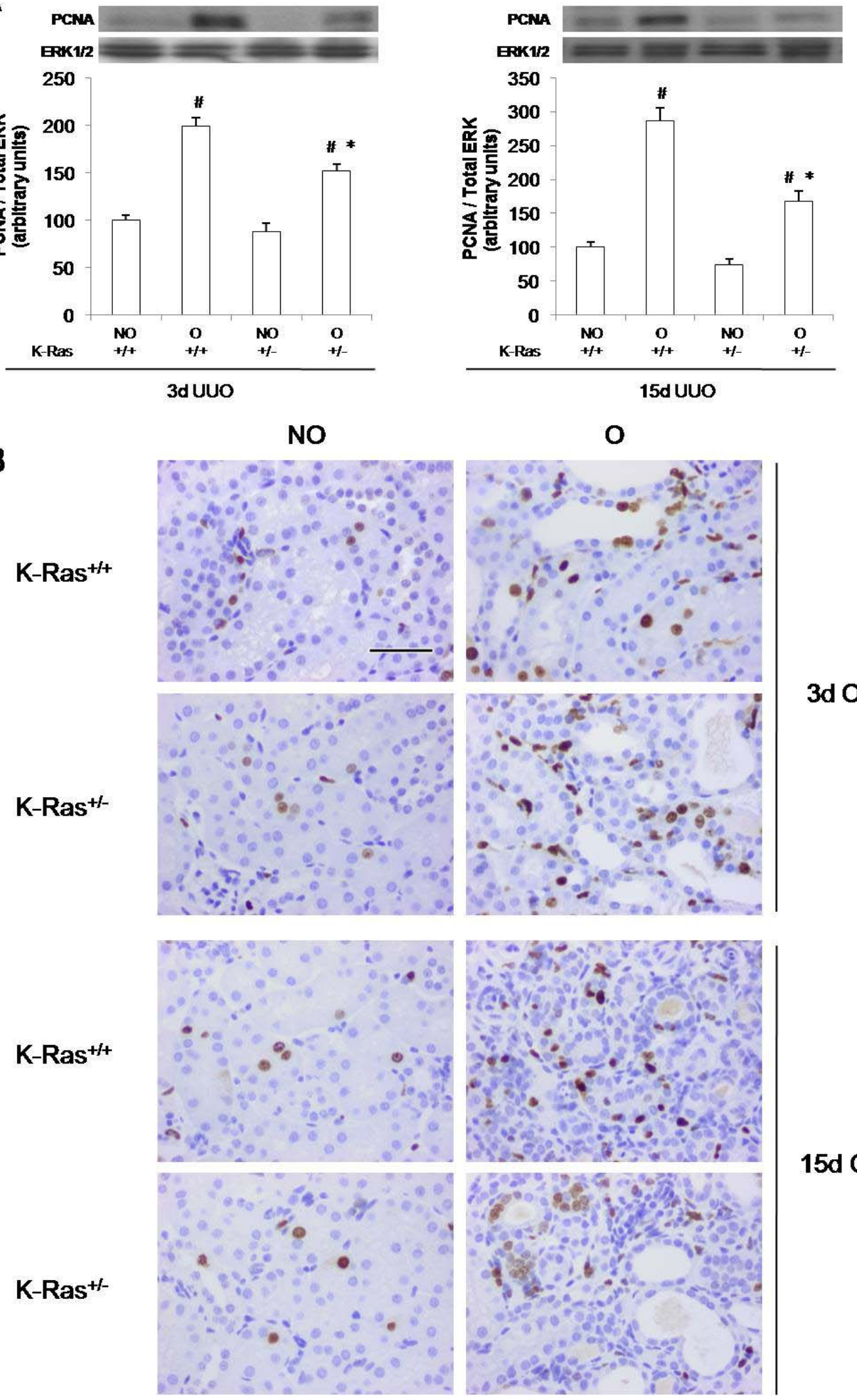

3d OUU

15d OUU

Figure 9. Markers of proliferation after UUO. A) Western blot analysis of PCNA expression in $\mathrm{NO}$ and $\mathrm{O}$ kidneys from $\mathrm{K}-\mathrm{ras}^{+/+}$and $\mathrm{K}-\mathrm{ras}^{+/-}$mice 3 days (left) and 15 days (right) after UUO.B) Inmunohistochemistry for Ki67 in NO and O kidneys from $\mathrm{K}$-ras ${ }^{+/+}$and $\mathrm{K}$-ras ${ }^{+/-}$mice after 3 and 15 days of UUO. Scale bar indicates 50 microns in all panels. 


\section{Artículo XI}

"Papel de la isoforma K-ras4A en la fibrosis tubulointersticial inducida por la obstrucción ureteral en ratón"

María T. Grande, Miguel Arévalo, Fernando Pérez-Barriocanal, Charles E. Patek y José M. López-Novoa

Nefrología (enviado) 
Título: PAPEL DE LA ISOFORMA K-RAS4A EN LA FIBROSIS TUBULOINTERSTICIAL INDUCIDA POR LA OBSTRUCCIÓN URETERAL EN RATÓN

Title: ROLE OF K-RAS4A ISOFORM IN THE TUBULOINTERSTITIAL FIBROSIS INDUCED BY URETERAL OBSTRUCTION IN MICE

Título corto: K-RAS4A EN LA NEFROPATÍA OBSTRUCTIVA

M. Teresa Grande ${ }^{1}$, Miguel Arévalo ${ }^{2}$, Fernando Perez-Barriocanal ${ }^{1}$, Charles Patek ${ }^{3}$ and José M. López-Novoa ${ }^{1}$.

${ }^{1}$ Instituto "Reina Sofía" de Investigación Nefrológica, Departamento de Fisiología y Farmacología, Universidad de Salamanca, Salamanca, España. ${ }^{2}$ Departamento de Anatomía e Histología Humanas, Universidad de Salamanca, Salamanca, España. ${ }^{3}$ Sir Alastair Currie Cancer Research UK Laboratories, Molecular Medicine Centre, The University of Edinburgh, Western General Hospital, Crewe Road, Edinburgh, EH4 2XU, UK.

Correspondencia:

Dr. José M. Lopez-Novoa.

Departamento de Fisiología y Farmacología,

Universidad de Salamanca,

Avda. Campo Charro s/n, 37007 Salamanca, Spain.

Phone: (+34) 923 294472,

fax: (+34) 923294669 ,

e-mail: jmlnovoa@usal.es 


\section{RESUMEN}

Las proteínas de la familia Ras regulan numerosos procesos celulares como la migración, deposición de matriz extracelular, apoptosis y proliferación celular, pasos clave en el desarrollo de la fibrosis tubulointersticial inducida por la obstrucción ureteral unilateral (OUU). Las proteínas Ras, aunque presentan un elevado grado de homología, parecen tener distintas funciones. El objetivo de este trabajo es conocer el posible papel de la isoforma K-Ras4A en los procesos que conllevan a la pérdida de función renal en la OUU.

Métodos: El estudio se llevó a cabo en ratones deficientes en K-Ras4A (K-Ras4A ${ }^{-/-}$), parcialmente deficientes en K-Ras4A $\left(\mathrm{K}-\operatorname{Ras} 4 \mathrm{~A}^{+/-}\right)$y en ratones control $\left(\mathrm{K}-\operatorname{Ras} 4 \mathrm{~A}^{+/+}\right)$. Los ratones fueron sometidos a OUU. Los riñones obstruidos y sus respectivos contralaterales no obstruidos fueron recogidos en el día 3 y 15 después de la OUU. La activación de Ras y de sus efectores, la expresión de marcadores de matriz extracelular (fibronectina y colágeno tipo I), de miofibroblastos ( $\alpha$-SMA y vimentina), de apoptosis (caspasa 3) y de proliferación (PCNA), mediante western blot. Además la activación de Ras se determinó también por ELISA, y la expresión de también por ELISA, y la expresión de alfa actina de músculo liso, fibronectina, caspasa 3 y Ki67 mediante inmunohistoquímica. Igualmente, se realizó un estudio histológico para detectar las lesiones renales y la fibrosis con hematoxilina-eosina, tricrómico de Masson y rojo sirio.

Resultados: La falta de K-Ras4A se asocia a un aumento en la activación de ERK, un aumento temprano en la expresión de marcadores de miofibroblastos y un aumento en la apoptosis y en la proliferación intersticial, y una disminución de la proliferación tubular observada después de la OUU.

Conclusión: K-Ras4A regula la acumulación de miofibroblastos, la apoptosis y la proliferación celular en un modelo de OUU en ratones.

Palabras clave: Obstrucción ureteral, K-Ras4A, miofibroblastos, apoptosis, proliferación. 
SUMMARY

Ras proteins family modulate numerous cellular processes such as cell migration, extracellular matrix accumulation, cell apoptosis and proliferation. All of them are key stages in the development of tubulointerstitial fibrosis induced by unilateral ureteral obstruction (UUO). Although Ras proteins show a high degree of homology, they are supposed to have different functions. The aim of this study is to reveal the role of the $\mathrm{K}$ Ras4A isoform in the stages that culminate with the loss of renal function in the UUO model.

Methods: This study was performed in deficient mice for K-Ras4A (K-Ras4A ${ }^{-/-}$), partly deficient mice for K-Ras4A (K-Ras4A $\left.{ }^{+/}\right)$and in control mice $\left(\mathrm{K}-\mathrm{Ras} 4 \mathrm{~A}^{+/+}\right)$. Mice were subjected to UUO and kidneys were removed on days 3 and 15 after UUO. Ras and its effectors activation, extracellular matrix deposition (fibronectin and type I collagen), myofibroblasts ( $\alpha$-SMA and vimentin), apoptotic (caspase 3 ) and proliferation (PCNA) markers were analyzed by western blot. Ras activation was also analyzed by ELISA and expression of alpha smooth mucle actin, fibronectin, caspase 3 and Ki67 were analyzed by immunohistochemistry. To detect kidney alterations and fibrosis, a histology study was performed with hematoxilyn-eosin, Masson's trichrome and siryus red.

Results: K-Ras4A deficiency showed increased ERK activation, increased expression of myofibroblasts markers and increased apoptosis and interstitial proliferation whereas decreased tubular proliferation observed after UUO.

Conclusion: K-Ras4A modulates myofibroblasts accumulation, apoptosis and proliferation after UUO in mice.

Key words: Ureteral obstruction, K-Ras4A, myofibroblast, apoptosis, proliferation. 


\section{INTRODUCCIÓN}

La obstrucción de las vías urinarias produce una acumulación de orina en los uréteres y en la pelvis renal (hidronefrosis) y alteraciones de la función renal y de la estructura renal que no se revierten completamente tras la resolución de la obstrucción si ésta dura un tiempo suficiente. La obstrucción ureteral unilateral (OUU) consiste en una obstrucción aguda y completa del uréter que mimetiza de forma acelerada los diferentes estados de la nefropatía obstructiva dando lugar a fibrosis tubulointersticial ${ }^{1}$. Este es el modelo experimental más utilizado para estudiar los mecanismos de daño en la nefropatía obstructiva ${ }^{2}$.

En la patogénesis del daño renal están involucrados procesos de migración celular, deposición de matriz extracelular, apoptosis y proliferación celular y estos procesos están regulados por numerosas citocinas, factores de crecimiento e integrinas que se activan o aumentan en respuesta al daño uniéndose a sus correspondientes receptores de membrana con actividad tirosina kinasa, acopladas a proteínas $\mathrm{G}$ y de integrinas para producir sus efectos a través de una serie de efectores. La pequeña GTPasa Ras puede constituir un punto convergente en la transducción de señales extracelulares inducidas por el daño renal, desde los receptores hasta el núcleo, como la cascada Raf-MAPK (mitogen-activated proteín kinase) que termina en la activación de ERK1/2 (extracellular signal regulated kinases 1 and 2) y la vía PI3K-Akt (phosphatidylinositol-3-kinasa). Trabajos previos de nuestro laboratorio han observado múltiples relaciones entre activación de la pequeña GTPasa Ras y la fibrosis renal ${ }^{3-6}$.

En humanos existen 3 genes de Ras con estructura y funciones parecidas: $N$-Ras, H-Ras y K-Ras y sus homólogos en ratón respectivamente, Hras1, Kras2, y Nras. Aunque la falta de $N$-Ras y H-Ras no modifique el desarrollo normal del ratón, la deficiencia en el gen $K$-Ras es letal, ya que se produce la muerte del ratón en el estado embrionario $^{7-9}$. El gen $K$-Ras da lugar a dos proteínas diferentes: K-Ras4A y K-Ras4B. La deficiencia en la producción de la proteína K-Ras4A tampoco afecta al desarrollo normal del ratón, al menos en presencia de K-Ras4 $\mathrm{B}^{10}$.

Se sabe que las distintas isoformas de Ras tienen funciones diferentes. De esta manera se conoce que las isoformas H-ras y N-ras regulan la síntesis de matriz extracelular y la proliferación en fibroblastos ${ }^{3}$ y que K-ras juega un papel en la proliferación de los fibroblastos renales ${ }^{11}$. Se ha descrito que tanto Ras como sus 
efectores Erk1/2 y Akt, están activados en un modelo experimental de obstrucción ureteral en ratones ${ }^{6}$. Sin embargo, aún se desconoce el papel de las distintas isoformas de Ras en los cambios renales producidos por la obstrucción ureteral. El objetivo de nuestro trabajo fue conocer el posible papel de K-Ras4A en la acumulación de matriz extracelular, la proliferación, apoptosis y aparición de miofibroblastos tras la OUU.

\section{MATERIALES Y MÉTODOS}

\section{Animales y técnica quirúrgica}

Este estudio se llevó a cabo en ratones deficientes en K-Ras4A (K-Ras4A ${ }^{-/}$), en ratones haploinsuficientes $\left(\mathrm{K}-\operatorname{Ras} 4 \mathrm{~A}^{+/}\right)$y en ratones control $\left(\mathrm{K}-\operatorname{Ras} 4 \mathrm{~A}^{+/+}\right)$. Todos los procedimientos fueron aprobados por el Comité Ético de Experimentación Animal de la Universidad de Salamanca de acuerdo a la Guía para el Cuidado y Uso de los Animales de Laboratorio ${ }^{12}$.

La producción de los ratones deficientes en K-Ras4A se ha descrito previamente $^{10}$. El análisis rutinario de genotipado de ratones se realiza en biopsias de cola mediante PCR. La presencia del alelo del gen deleccionado K-ras tmdelta4A se comprueba con los primers NB1 (GCC TGA AGA ACG AGA TCA GC) y el Int4AR1 (TCC CAA GTT CAC ACT AGA GTC) que generan un fragmento de $450 \mathrm{pb}$. Los primers Int3F (AGC TCA TGT TTT AAC GCT GC) y Px4AA (TCA CAC AGC CAG GAG TCT TTT CTT C) localizados en el exón 4A generan un fragmento de 290 bp que corresponde al gen intacto. Los fragmentos amplificados se analizan mediante electroforesis en gel de agarosa $2 \%$ (Figura 1).

La OUU se llevó a cabo en ratones anestesiados vía intraperitoneal (Ketamina $78 \mathrm{mg} / \mathrm{Kg}$, Diazepam $6 \mathrm{mg} / \mathrm{kg}$, Atropina $0,15 \mathrm{mg} / \mathrm{kg}$ disuelto en cloruro sódico 0,9\%). Una vez anestesiados, se abre el abdomen mediante una incisión media, se localiza el uréter izquierdo y se realiza una ligadura de doble nudo, con seda 6/0, en dos puntos separados $0,3 \mathrm{~cm}$ entre sí. Se cierra la incisión mediante sutura.

Todos los estudios se realizaron en ambos riñones, no obstruido (NO) y obstruido (O), a corto plazo, 3 días de obstrucción, y largo plazo, 15 días de obstrucción. Los grupos se distribuyeron de la siguiente forma: K-Ras4A ${ }^{+/+}(n=3), K-$ $\operatorname{Ras}_{4} \mathrm{~A}^{+/-}(\mathrm{n}=3)$ y $\mathrm{K}-\operatorname{Ras} 4 \mathrm{~A}^{-/-}(\mathrm{n}=4)$ para determinación de expresión de proteínas mediante western blot, y K-Ras4A ${ }^{+/+}(n=3), K-\operatorname{Ras} 4 A^{+/-}(n=3)$ y K-Ras $4 A^{-/-}(n=3)$ para estudios histológicos a los 3 días de obstrucción. K-Ras4A ${ }^{+/+}(n=4), K-R a s 4 A^{+/-}(n=4)$ y 
K-Ras4A $\mathrm{A}^{-/}(\mathrm{n}=3)$ para determinación de expresión de proteínas mediante western blot, $\mathrm{y}$ $\mathrm{K}_{-} \operatorname{Ras} 4 \mathrm{~A}^{+/+}(\mathrm{n}=3), \mathrm{K}-\operatorname{Ras} 4 \mathrm{~A}^{+/-}(\mathrm{n}=3)$ y K-Ras4A $\mathrm{K}^{-/-}(\mathrm{n}=3)$ para estudios histológicos a los 15 días de obstrucción.

Análisis de expresión de proteínas

Para los estudios histológicos se procedió a la perfusión del animal con formaldehído 3,7-4\% tamponado a $\mathrm{pH} 7$ y estabilizado con metanol. Una vez extraídos los riñones, se descapsularon y se cortaron sagitalmente. Tras 24 horas de fijación en formaldehido, las piezas fueron deshidratadas e incluidas en parafina, tras lo cual se realizaron los correspondientes bloques que se cortaron con un microtomo de parafina en secciones de $3 \mu \mathrm{m}$ ( $5 \mu \mathrm{m}$ para la técnica de rojo sirio) depositándolas en portaobjetos de cristal esmerilado. Las secciones así obtenidas, una vez desparafinadas, se tiñeron con las técnicas de hematoxilina-eosina, tricrómico de Masson y rojo sirio. Los estudios inmunohistoquímicos se realizaron sobre secciones de $3 \mu \mathrm{m}$ que fueron desparafinadas y rehidratadas posteriormente. La peroxidasa endógena fue bloqueada mediante incubación en peróxido de hidrógeno al 3\% en etanol. Los anticuerpos primarios fueron: Anti-fibronectina (clona 568, Biogenex, CA, USA. Dilución 1:50); Anti-Alfa actina de músculo liso (clona HHF35, Novocastra, MA, USA. Dilución 1:50); Anti-Caspasa 3 (policlonal de conejo, (Cell Signaling Technology, Ma. USA. Dilución 1:50) y AntiKi67 (clona MIB-1, Masterdiagnóstica, Granada, España. Dilución 1:100). El resto de la inmunohistoquímica se realizó mediante el sistema Novolink Polymer Detection System (Novocastra, MA, USA) utilizando diaminobencidina (DAB) como cromógeno.

Para la determinación de expresión de proteínas mediante western blot se lisó el tejido renal en un tampón de lisis con el detergente Igepal CA-630 en presencia de diversos inhibidores de proteasas y metaloproteasas. Se cuantificó la cantidad de proteína, se realiza electroforesis, cargando $60 \mu \mathrm{g}$ de proteína por carril, seguido de electrotransferencia a membranas de PVDF para procesarlas utilizando anticuerpos específicos para las proteínas a analizar. anti-ERK1 (1:2000, Santa Cruz Biotechnology, Santa Cruz, Ca, USA), anti-fosfo-ERK (1:2000, Santa Cruz Biotechnology), anti-fosfo-Akt (1:1000, Santa Cruz Biotechnology), anti-Akt1/2 (1:1000, Santa Cruz Biotechnology), anti-fibronectina (1:1000, Chemicon International, USA), anti-alpha-SMA (1:1000, Sigma, St. Louis, USA), anti-PCNA (1:1000, BD Transduction laboratorios, San José, CA, USA) y anti caspasa-3 activada (1:500, Cell Signalling Inc, Danvers, MA, USA). Para el análisis de la expresión de RasGTP, 1000 
$\mu \mathrm{g}$ de lisado se incubaron con $20 \mu \mathrm{g}$ de Raf-1 RBD agarosa (Upstate biotechnology, Lake Placid, NY, USA) en agitación a $4^{\circ} \mathrm{C}$ durante $30 \mathrm{~min}$. A continuación se procede a la electroforesis seguida de electrotransferencia y se incuban con los anticuerpos correspondientes: anti-H-Ras (1:500), anti-N-Ras (1:500), anti-K-Ras (1:500) (Santa Cruz Biotechnology, Santa Cruz, Ca, USA) y anti-Ras (1:500, Upstate biotechnology, Lake Placid, NY, USA). Las membranas se revelaron con anticuerpo secundario acoplado a peroxidasa de rábano picante mediante quimioluminiscencia.

Para la detección de los niveles de RasGTP activado se ha utilizado el kit comercial Active Motif, RasGTPase Chemi ELISA (Active Motif, RasGTPase Chemi ELISA, Rixensart, Belgium), siguiendo el protocolo detallado del kit ELISA suministrado por el vendedor.

\section{Análisis estadístico}

El análisis estadístico de los datos se efectuó con el programa SPSS 12.0 para Windows. Los valores se expresan como la media \pm error estándar de la media. Las diferencias entre las medias se han analizado mediante el análisis de la varianza (ANOVA), con comparaciones múltiples post hoc de Bonferroni. Se consideraron estadísticamente significativas las diferencias con una probabilidad de error tipo I inferior al $5 \%$.

\section{RESULTADOS}

Activación de las isoformas de Ras y de sus efectores tras la OUU

En estudios previos hemos observado una activación de Ras y de sus efectores, MAPK/ERK y PI3K/Akt, tras la obstrucción ureteral ${ }^{6}$. En el presente estudio hemos analizado la activación de Ras y de las 3 isoformas de Ras a los 3 días de obstrucción en los riñones $\mathrm{NO}$ y $\mathrm{O}$ de ratones $\mathrm{K}-\mathrm{Ras} 4 \mathrm{~A}^{-/-}, \mathrm{KRas} 4 \mathrm{~A}^{+/-}$y K-Ras4A $\mathrm{K}^{+/+}$(Figura 2A). La OUU produce un aumento de la expresión de las 3 isoformas activadas, N-RasGTP, HRasGTP y K-RasGTP, en los riñones O respecto a los riñones NO en todos los grupos de ratones, aunque la expresión de K-RasGTP es mucho menor en los riñones $\mathrm{NO}$ y O de los ratones $\mathrm{KRas}_{4} \mathrm{~A}^{+/-}$y K-Ras $4 \mathrm{~A}^{-/-}$que en los ratones K-Ras $4 \mathrm{~A}^{+/+}$. La expresión de $\mathrm{N}$-Ras y H-Ras total es igual en ambos riñones, $\mathrm{NO}$ y $\mathrm{O}$, en todos los grupos de ratones, sin embargo la expresión de K-Ras total aumenta en los riñones O respecto a los NO, aunque la expresión de K-Ras total es menor en los ratones K-Ras4A ${ }^{-/}$(Figura 2A). También medimos la activación de Ras mediante un ELISA que sólo reconoce la 
isoforma H-Ras a los 3 y 15 días de obstrucción ureteral y observamos siempre un aumento de H-Ras activado (H-RasGTP) en los riñones $\mathrm{O}$ comparados con los riñones NO, sin observar diferencias significativas entre los grupos de ratones (Figura 2B).

Analizamos la activación de la ruta MAPK/ERK mediante el análisis de ERK activado (p-ERK) y ERK total en riñones NO y O después de 3 días y 15 días de OUU en ratones K-Ras $4 \mathrm{~A}^{-/}$, $\mathrm{KR} \mathrm{Ras} 4 \mathrm{~A}^{+/-}$y K-Ras $4 \mathrm{~A}^{+/+}$(Figure 3A). Para analizar la activación de la ruta PI3K/Akt, medimos la expresión de Akt activado o fosforilado (p-Akt) y Akt total en los riñones $\mathrm{NO}$ y $\mathrm{O}$ después de 3 y 15 días de OUU en ratones $\mathrm{K}-\mathrm{Ras} 4 \mathrm{~A}^{-/}$, $\mathrm{KRas}_{4} \mathrm{~A}^{+/-}$y K-Ras4A ${ }^{+/+}$(Figure 3B y 3C). Como en estudios anteriores la obstrucción ureteral originó una activación de los efectores de Ras, pERK/ERK total, pAkt y Akt total en los riñones $\mathrm{O}$ comparados con los $\mathrm{NO}$ en los animales control así como en los ratones $\mathrm{K}-\mathrm{Ras} 4 \mathrm{~A}^{-/-}$y $\mathrm{KRas}_{4} \mathrm{~A}^{+/-}$tanto a los 3 días como a los 15 días de OUU (Figura 3). También se observó que los ratones deficientes en K-Ras4A tienen mayor activación de ERK tras la OUU comparados con los ratones control K-Ras4A ${ }^{+/+}$(Figura 3A).

\section{Alteraciones morfológicas fibrosis tubulointersticial tras la OUU}

A los tres días de la ligadura, los riñones NO de los animales de todos los grupos no tenían alteraciones histológicas aparentes. Sin embargo, en los riñones O se aprecian alteraciones debidas a la obstrucción ureteral. Los riñones $\mathrm{O}$ del grupo de animales $\mathrm{K}$ Ras $4 \mathrm{~A}^{+/+}$, la médula renal aparecía comprimida contra la corteza. En la corteza, de manera focal, se observaron numerosos túbulos dilatados con aplanamiento de células epiteliales tubulares. Igualmente, se aprecian numerosos cilindros hialinos intratubulares. En los animales pertenecientes a los grupos $\mathrm{KRas}^{+} \mathrm{A}^{+-}$y $\mathrm{K}-\mathrm{Ras} 4 \mathrm{~A}^{-/-}$se observaron las lesiones citadas para los ratone $\mathrm{K}-\mathrm{Ras} 4 \mathrm{~A}^{+/+}$pero la extensión de las mismas era mayor y se apreciaba un evidente infiltrado inflamatorio, fundamentalmente perivascular (Figura 4).

A los 15 días de la ligadura tampoco se apreciaron lesiones destacables en los riñones $\mathrm{NO}$ en ninguno de los grupos. En los riñones $\mathrm{O}$ se observó un incremento de la extensión de las lesiones descritas para los animales de 3 días de ligadura. De esta manera la papila renal había desaparecido prácticamente. En la corteza, una gran parte de los túbulos estaban dañados bien con aplanamiento y dilatación tubulares, bien con destrucción total de los mismos. El infiltrado inflamatorio era aun más evidente y 
aparecía no solo perivascularmente sino también a nivel intersticial. No se encontraron diferencias en los riñones ligados entre los diferentes grupos experimentales (Figura 4).

La fibrosis tubulointersticial asociada a la nefropatía obstructiva consiste en un aumento de la acumulación de proteínas de la matriz extracelular en el espacio tubulointersticial. En repuesta a la OUU, la expresión de fibronectina evaluada mediante western blot aumenta en los riñones $\mathrm{O}$ respecto a los riñones $\mathrm{NO}$ en todos los genotipos diferentes de ratones, sin observar diferencias entre ellos, tanto a los 3 días de obstrucción como a los 15 días de obstrucción, (Figura 5A). Mediante inmunohistoquímica de fibronectina (Figura 6) se observa como a los 15 días de obstrucción en los riñones $\mathrm{O}$ de los ratones $\mathrm{K}-\mathrm{Ras} 4 \mathrm{~A}^{+/-}$y $\mathrm{K}-\mathrm{Ras} 4 \mathrm{~A}^{-/-}$se produce un incremento evidente de la expresión de fibronectina, También se observa mediante western blot un aumento de la expresión de colágeno tipo I en los riñones $\mathrm{O}$ de los ratones $\mathrm{K}-\mathrm{Ras} 4 \mathrm{~A}^{-/-}, \mathrm{KRas} 4 \mathrm{~A}^{+/-}$y $\mathrm{K}-\operatorname{Ras} 4 \mathrm{~A}^{+/+}$en comparación con los riñones NO después de 3 y 15 días de OUU, sin observar diferencias en la expresión de colágeno tipo I entre los diferentes genotipos (Figura 5B).

El estudio con rojo sirio reveló que en los riñones $\mathrm{NO}$ de todos los grupos de animales después de 3 días de OUU, la tinción en el área tubulointersticial se limitaba a las membranas basales y adventicias vasculares. Sin embargo, en los riñones O de todos los grupos de animales se aprecia un reforzamiento de las membranas basales tubulares y un ligero incremento intersticial de la fibrosis (Figura 7). Después de 15 días de OUU tampoco se aprecia incremento de rojo sirio en los riñones NO de ninguno de los grupos de animales. No ocurre lo mismo en los riñones $\mathrm{O}$, donde sí se observa una fibrosis intersticial evidente en los animales del grupo $\mathrm{K}-\mathrm{Ras} 4 \mathrm{~A}^{+/+}$, que se incrementa en cantidad y en extensión en el grupo K-Ras $4 \mathrm{~A}^{+/-}$y aun más en los animales K-Ras $4 \mathrm{~A}^{-/-}$ (Figura 7).

Expresión de marcadores de miofibroblastos tras la OUU.

Otra característica de la nefropatía obstructiva es la aparición en el intersticio tubular renal de células productoras de matriz extracelular, llamadas miofibroblastos. La expresión de vimentina y $\alpha$-SMA se ha usado frecuentemente como marcadores de miofibroblastos. La expresión de $\alpha$-SMA y vimentina fue mayor en los riñones $\mathrm{O}$ comparados con los riñones NO de los ratones $\mathrm{K}-\mathrm{Ras} 4 \mathrm{~A}^{-/-}, \mathrm{KRas} 4 \mathrm{~A}^{+/-}$y sus respectivos controles, K-Ras $4 \mathrm{~A}^{+/+}$tras 3 y 15 días de OUU (Figura 8). Además, la deficiencia total o parcial en K-Ras4A produce un aumento de expresión de $\alpha$-SMA y vimentina en los 
riñones $\mathrm{O}$ de los ratones $\mathrm{K}-\mathrm{Ras} 4 \mathrm{~A}^{+/-}$y $\mathrm{K}_{-}$Ras $4 \mathrm{~A}^{-/-}$comparados con los ratones control, en el día 3 de OUU (Figura 8A y B, izquierda), aunque a los 15 días de OUU este fenómeno no observamos diferencias significativas en la expresión de a-SMA y vimentina entre los diferentes genotipos de ratones (Figura 8A y B, derecha). La inmunohistoquímica de $\alpha$-SMA muestra también un aumento en la expresión intersticial en los riñones $\mathrm{O}$ de los ratones $\mathrm{K}-\mathrm{Ras} 4 \mathrm{~A}^{+/-}$y K-Ras $4 \mathrm{~A}^{-/-}$comparados con los ratones $\mathrm{K}$ Ras $4 \mathrm{~A}^{+/+}$después de 3 días de OUU, aunque tras 15 días de OUU esta diferencia entre los grupos de ratones desaparece (Figura 9). En los riñones NO de todos los grupos de ratones se observa a los 15 días de OUU un ligero incremento de la expresión de $\alpha$ SMA intersticial (Figura 9).

\section{Apoptosis y proliferación tras la OUU}

El daño tubulointersticial renal inducido por la OUU también se caracteriza por un aumento en la apoptosis y en la proliferación celular en el riñón obstruido. Para analizar el grado de apoptosis celular analizamos la expresión de caspasa 3 activada, marcador de células en apoptosis, y observamos una mayor expresión de caspasa 3 activada en los riñones $\mathrm{O}$ comparados con los riñones NO fundamentalmente y significativamente a los 15 días de la OUU (Figura 10A). Además los ratones haploinsuficientes en K-Ras4A y KO en K-Ras4A muestran mayor expresión de caspasa 3 activada en los riñones $\mathrm{O}$ en el día 3 y 15 después de la obstrucción ureteral que los riñones $\mathrm{O}$ de los ratones WT. Mediante inmunohistoquímica de caspasa 3 activada también podemos observar como los ratones $\mathrm{K}_{-} \operatorname{Ras} 4 \mathrm{~A}^{+/-}$y $\mathrm{K}-\operatorname{Ras} 4 \mathrm{~A}^{-/-}$ presentan mayor expresión de caspasa 3 activada en los riñones $\mathrm{O}$ que los ratones $\mathrm{K}$ Ras $4 \mathrm{~A}^{+/+}$en sus riñones O (Figura 11).

Para analizar el grado de proliferación celular medimos la expresión de antígeno nuclear de proliferación celular (PCNA). La expresión de PCNA fue mucho mayor en los riñones $\mathrm{O}$ que en los riñones $\mathrm{NO}$ en lisados totales renales de ratones de todos los genotipos. Este aumento es 2 veces mayor en el día 3 de obstrucción y 2,7 veces mayor en el día 15 de obstrucción en los ratones $\mathrm{K}-\operatorname{Ras} 4 \mathrm{~A}^{+/+}, \mathrm{y}$ Ras $4 \mathrm{~A}^{+/-}$. Además, la falta total de K-Ras4A produce un aumento significativamente mayor en los riñones NO con respecto a NO, siendo 2,5 y 3,5 veces mayor a los 3 y 15 días de obstrucción ureteral respectivamente (Figura 10B). 
Para saber que tipos celulares renales contribuyen al aumento de la proliferación inducida por OUU, se estudiaron las células teñidas positivamente para Ki67, un marcador de células en proliferación. Se observó que los riñones NO de todos los grupos experimentales el número de núcleos marcados era muy pequeño, sin deferencias entre los tres grupos, y correspondían casi exclusivamente a células epiteliales tubulares. El numero de núcleos marcados era menos a los 15 de aías que a los tres días tras la ligadura (Figura 12). En los riñones O de los ratones K-Ras $4 \mathrm{~A}^{+/+}$, a los tres días de la obstrucción, el numero de núcleos marcados era mucho mayor que en el riñón NO, y aunque correspondían mayoritariamente a células tubulares, también había un número substancial de células intersticiales marcadas. En el caso de los riñones $\mathrm{O}$ de los ratones K-Ras4 $\mathrm{A}^{+/}$, a los tres días de la obstrucción, se observó que el número de células tubulares marcadas era menor, mientras que el de células intersticiales era mayor que en los riñones $\mathrm{O}$ de los ratones $\mathrm{K}-\mathrm{Ras} 4 \mathrm{~A}^{+/+}$. En los riñones $\mathrm{O}$ de los ratones $\mathrm{K}-\mathrm{Ras} 4 \mathrm{~A}^{-/-}$, a los tres días de la obstrucción, el numero de células tubulares cuyo núcleo estaba marcado con Ki67 era todavía menor, mientras que era mayor el de células intersticiales. En conjunto, podemos decir que en el riñón obstruido, la deficiencia de KRas4A induce una menor proliferación celular y una mayor proliferación intersticial. A los 15 días de la OUU, el número de células marcadas con Ki67 en los riñones O de todos los grupos era menor que a los 3 días de la OUU. En los ratones K-Ras $4 \mathrm{~A}^{+/+}$había un mayor número de células intersticiales, mientras que en los ratones $\mathrm{K}_{-} \mathrm{Ras}_{4} \mathrm{~A}^{+/}$y KRas $4 \mathrm{~A}^{-/-}$, las células marcadas parecían ser casi exclusivamente tubulares.

\section{DISCUSIÓN}

La pequeña GTPasa Ras parece jugar un papel muy importante en la transducción de señales extracelulares inducidas por el daño renal. Previamente nuestro laboratorio ha observado la existencia de múltiples relaciones entre la activación de la pequeña GTPasa Ras y la fibrosis renal $^{3-6}$. En el presente estudio hemos observado también una activación de Ras y de sus efectores después de la obstrucción ureteral. La falta parcial o total de K-Ras4A no disminuyó la activación de Ras ni de sus efectores MAPK/ERK y PI3K/Akt. Nuestros resultados muestran un mayor aumento de la activación de la ruta MAPK/ERK en el riñón ligado en ausencia de K-Ras4A que en los ratones controles. Estos resultados son compatibles con los obtenidos por Yan y cols, que demuestran que las distintas isoformas de Ras muestran distinta afinidad por sus efectores PI3K/Akt o Raf/MAPK/ERK, siendo K-Ras más eficiente y más potente en la 


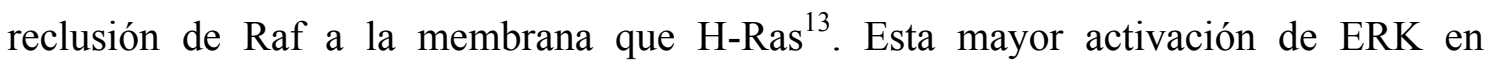
ausencia de K-Ras4A puede ser debida a la mayor afinidad que tiene K-Ras4B sobre la activación de Raf/MAPK/ERK comparada con la afinidad de K-Ras4A ${ }^{14}$. Nuestro estudio demuestra además que la falta total o parcial de K-Ras4A no modifica la expresión de Akt activado ni la expresión de Akt total, al menos en presencia de KRas4B.

Numerosos estudios se han centrado en la acumulación de matriz extracelular inducida por la OUU en el espacio tubulointersticial renal ${ }^{15,16}$. Nuestros resultados muestran que la expresión de fibronectina y colágeno 1, medida medida mediante western blot, era similar en los riñones obstruidos de los ratones parcial o totalmente deficientes en K-Ras4A y en los ratones control. Sin embargo la inmunohistoquímica de fibronectina y la tinción de rojo sirio muestran mayor grado de fibrosis en riñones obstruidos de los ratones K-Ras $4 \mathrm{~A}^{+/-}$y K-Ras $4 \mathrm{~A}^{-/}$que en los controles Aunque existen estudios que relacionan la isoforma K-Ras con la función de los fibroblastos, no existen trabajos que relacionen la expresión de K-Ras con la expresión de componentes de la matriz extracelular en estudios in vivo. Nuestros resultados parecen mostrar que KRas4A ejerce un papel en la acumulación de matriz extracelular inducida por la OUU.

Otra característica de la patogénesis de la nefropatía obstructiva en el riñón obstruido es el aumento de la población celular de miofibroblastos y fibroblastos activados que se originan a partir de diferentes células como los propios fibroblastos renales residentes, células progenitoras infiltradas derivadas de médula ósea y células tubulares epiteliales que se transforman, mediante un proceso conocido como transición epitelial-mesenquimal ${ }^{17}$. Vimentina y $\alpha$-SMA se han considerado como marcadores de miofibroblastos. Nuestros resultados demuestran que la expresión de ambos marcadores está aumentada en los riñones obstruidos y que la falta de K-Ras4A incrementa la expresión de ambos a los 3 días de OUU, sin encontrar diferencias a los 15 días de obstrucción. Este resultado puede sugerir que la presencia de K-Ras4A retrasa la expresión de estos marcadores ya que la deficiencia en K-Ras4A produce mayor expresión a tiempos cortos de la OUU, igualándose la expresión con el paso del tiempo. Hasta ahora no se ha relacionado la regulación de la expresión de marcadores de miofibroblastos con la regulación de K-Ras4A. Esta regulación puede estar mediada a través de la activación de Rac, ya que se ha demostrado la alta capacidad de K-Ras para 
activar $\operatorname{Rac}^{18}$. Además la ruta de Rac activa y promueve la reorganización de vimentina $^{19}$.

La obstrucción ureteral induce apoptosis y proliferación de las células tubulares e intersticiales renales. Nuestros resultados muestran un aumento a lo largo del tiempo de la apoptosis tubular en los riñones obstruidos medidos a los 3 y 15 días de obstrucción. Con respecto a la proliferación, esta aumenta a los tres días pero disminuye parcialmente a los 15 días de la obstrucción, Además, la deficiencia en K-Ras4A parece inhibir la proliferación de las células del epitelio tubular pero estimula la proliferación de las células intersticiales, en un proceso que se observa sobre todo a los tres días de la obstrucción. Estos resultados están de acuerdo con los obtenidos por nosotros y por otros autores demostrando un aumento de proliferación celular, tanto tubular como intersticial tras la ligadura ${ }^{6,20}$. Además, la falta de K-Ras4A aumenta aún más la expresión de marcadores de apoptosis y proliferación, sugiriendo que en la proliferación y apoptosis inducida por la OUU, K-Ras4A juega un papel anti-apoptótico y antiproliferativo de las células tubulares en el riñón obstruido. Los datos de apoptosis están de acuerdo con estudios previos que demuestran que la activación de $\mathrm{K}$ ras protege alas células epiteliales de cáncer de colon contra la apoptosis ${ }^{21}$. Algo similar se ha visto con células madre, con un estudio realizado en células madre donde se observó que la deficiencia de K-Ras4A protegía de la apoptosis ${ }^{22}$.

\section{PEQUEÑO RESUMEN}

Se ha demostrado que Ras juega un papel importante en la transducción de señales en el desarrollo de la enfermedad renal crónica. Es importante desglosar las diferentes funciones que tienen las isoformas de Ras; H-Ras, N-Ras, K-Ras4A y KRas4B, para conocer posibles dianas terapéuticas. Este trabajo atribuye, por primera vez, a la isoforma K-Ras4A, un papel en la regulación de la proliferación celular y de la apoptosis tubular, inducidas por la obstrucción ureteral, durante el desarrollo de la nefropatía obstructiva. 


\section{AGRADECIMIENTOS}

Los autores agradecen a la Sra. Angustias Pérez la ayuda prestada en la realización de las técnicas histológicas. Este estudio ha sido financiado por proyectos del Instituto de Salud Carlos III, Ministerio de Sanidad y Consumo, Retic 06/0016, RedinRen), Comisión Interministerial de Ciencia y Tecnología (BFU-2004-00285/BFI and SAF2007-63893) y Junta de Castilla y León (SA001/C05).

\section{BIBLIOGRAFÍA}

1. Bascands JL, Schanstra . Obstructive nephropathy: insights from genetically engineered animals. Kidney Int 2005; 68: 925-937.

2. Klahr S, Morrissey J. Obstructive nephropathy and renal fibrosis. Am J Physiol Renal Physiol 2002; 283: F861-F875.

3. Martínez-Salgado C, Fuentes-Calvo I, García-Cenador B, Santos E, López-Novoa JM. Involvement of H- and N-Ras isoforms in transforming growth factor-beta1induced proliferation and in collagen and fibronectin synthesis. Exp Cell Res 2006; 312: 2093-2106.

4. Martínez-Salgado C, Rodríguez-Peña AB, López-Novoa JM. Involvement of small Ras GTPases and their effectors in chronic renal disease. Cell Mol Life Sci 2008; 65: 477-492.

5. Rodríguez-Peña AB, Santos E, Arévalo M, López-Novoa JM. Activation of small GTPase Ras and renal fibrosis. J Nephrol 2005; 18: 341-349.

6. Rodríguez-Peña AB, Grande MT, Eleno N, Arévalo M, Guerrero C, Santos E, López-Novoa JM. Activation of Erk1/2 and Akt following unilateral ureteral obstruction. Kidney Int 2008; 74: 196-209.

7. Esteban LM, Vicario-Abejon C, Fernandez-Salguero P, Fernandez-Medarde A, Swaminathan N, Yienger K, Lopez E, Malumbres M, McKay R, Ward JM, Pellicer A, Santos E. Targeted genomic disruption of H-ras and N-ras, individually or in combination, reveals the dispensability of both loci for mouse growth and development. Mol Cell Biol 2001; 21: 1444-1452.

8. Johnson L, Greenbaum D, Cichowski K, Mercer K, Murphy E, Schmitt E, Bronson RT, Umanoff H, Edelmann W, Kucherlapati R, Jacks T. K-ras is an essential gene 
in the mouse with partial functional overlap with N-ras. Genes Dev 1997; 11: 24682481.

9. Koera K, Nakamura K, Nakao K, Miyoshi J, Toyoshima K, Hatta T, Otani H, Aiba A, Katsuki M. K-ras is essential for the development of the mouse embryo. Oncogene 1997; 15: 1151-1159.

10. Plowman SJ, Williamson DJ, O'Sullivan MJ, Doig J, Ritchie AM, Harrison DJ, Melton DW, Arends MJ, Hooper ML, Patek CE. While K-ras is essential for mouse development, expression of the K-ras 4A splice variant is dispensable. Mol Cell Biol 2003; 23: 9245-9250.

11. Sharpe CC, Dockrell ME, Scott R, Noor MI, Cowsert LM, Monia BP, Hendry BM. Evidence of a role for Ki-RAS in the stimulated proliferation of human fibroblasts. $J$ Am Soc Nephrol 1999; 10: 1186-1192.

12. National Research Council (NRC) (1996) Commission on Life Sciences, Institute of Laboratory Animal Resources, Guide for the Care and Use of Laboratory Animals, National Academy Press, Washington (DC).

13. Yan J, Roy S, Apolloni A, Lane A, Hancock JF. Ras isoforms vary in their ability to activate Raf-1 and phosphoinositide 3-kinase. J Biol Chem 1998; 273: 24052-24056.

14. Voice JK, Klemke RL, Le A, Jackson JH. Four human ras homologs differ in their abilities to activate Raf-1, induce transformation, and stimulate cell motility. $J$ Biol Chem 1999; 274: 17164-17170.

15. Wright EJ, McCaffrey TA, Robertson AP, Vaughan ED Jr, Felsen D. Chronic unilateral ureteral obstruction is associated with interstitial fibrosis and tubular expression of transforming growth factor-beta. Lab Invest 1996, 74: 528-537.

16. Sharma AK, Mauer SM, Kim Y, Michael AF. Interstitial fibrosis in obstructive nephropathy. Kidney Int 1993; 44: 774-788.

17. Strutz F. How many different roads may a cell walk down in order to become a fibroblast? J Am Soc Nephrol 2008; 19: 2246-2248.

18. Walsh AB, Bar-Sagi D. Differential activation of the Rac pathway by Ha-Ras and K-Ras. J Biol Chem 2001; 276: 15609-15615. 
19. Chang L, Goldman RD. Intermediate filaments mediate cytoskeletal crosstalk. Nat Rev Mol Cell Biol 2004; 5: 601-613.

20. Truong LD, Petrusevska G, Yang G, Gurpinar T, Shappell S, Lechago J, Rouse D, Suki WN. Cell apoptosis and proliferation in experimental chronic obstructive uropathy. Kidney Int 1996; 50: 200-207.

21. Escandell JM, Kaler P, Recio MC, Sasazuki T, Shirasawa S, Augenlicht L, Ríos JL, Klampfer L. Activated kRas protects colon cancer cells from cucurbitacin-induced apoptosis: the role of p53 and p21. Biochem Pharmacol 2008;76:198-207.

22. Plowman SJ, Arends MJ, Brownstein DG, Luo F, Devenney PS, Rose L, Ritchie AM, Berry RL, Harrison DJ, Hooper ML, Patek CE. The K-Ras 4A isoform promotes apoptosis but does not affect either lifespan or spontaneous tumor incidence in aging mice. Exp Cell Res 2006; 312: 16-26. 


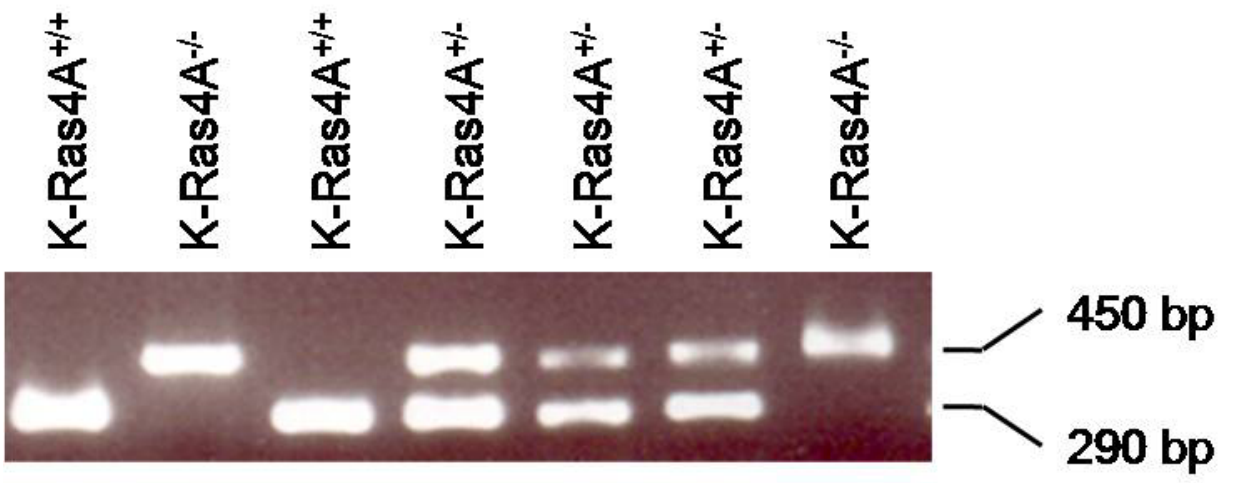

Figura 1. Análisis rutinario de genotipado de ratones mediante PCR. Las muestras de ratones K-Ras $4 \mathrm{~A}^{+/+}$presentan una única banda de $290 \mathrm{pb}$ que corresponde a la amplificación de la región correspondiente del gen intacto. Las biopsias de ratones K-Ras4A-/- presentan una única banda de $450 \mathrm{pb}$ que corresponde a la amplificación de la región correspondiente del gen mutado. Los ratones $\mathrm{K}-\mathrm{Ras} 4 \mathrm{~A}^{+/-}$presentan ambas bandas cuando se amplifica el DNA de sus biopsias de cola de ratón.

A
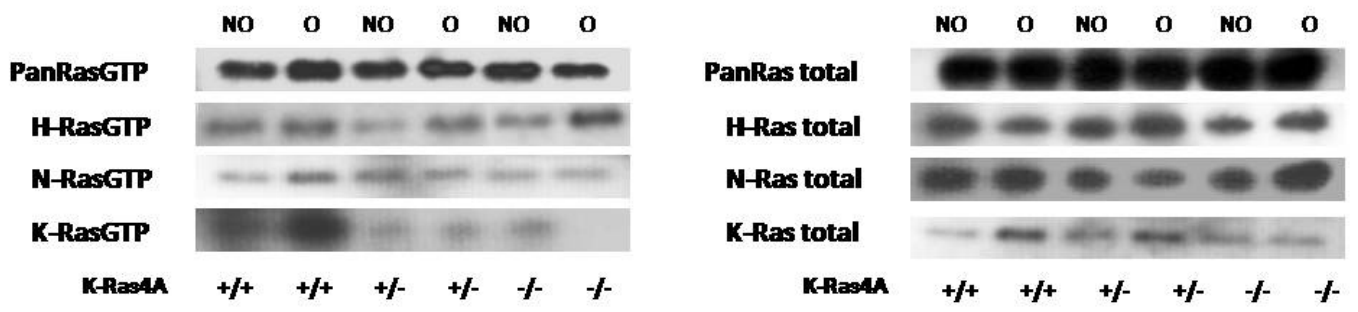

B
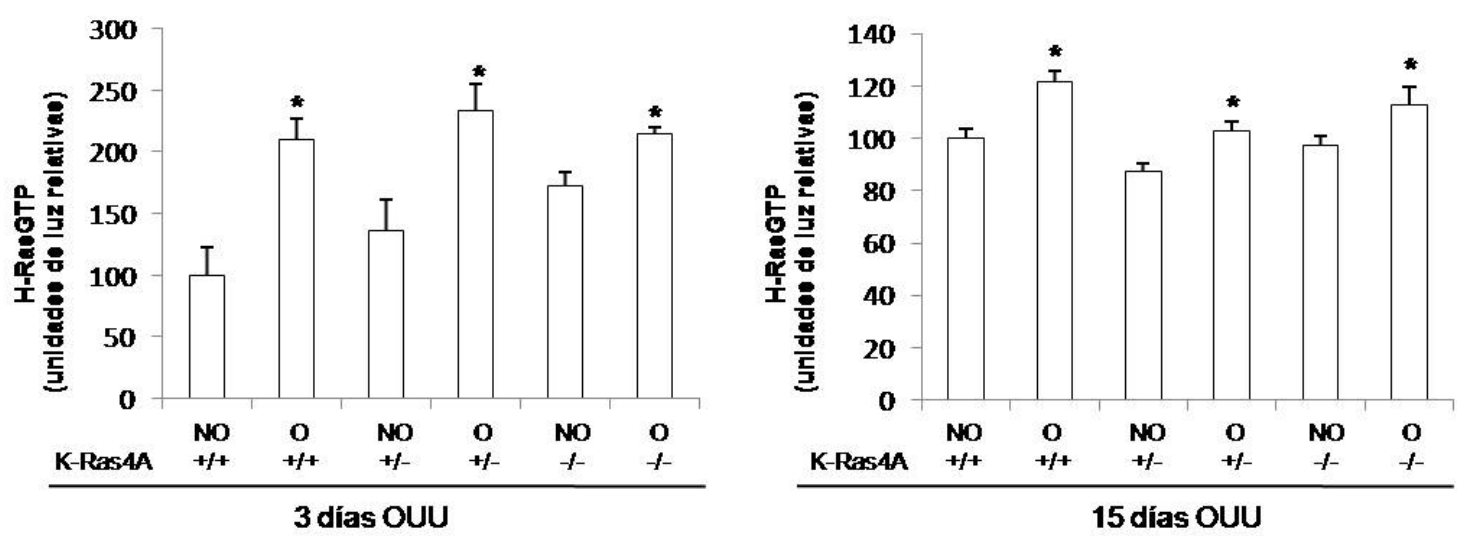

Figura 2. Activación de las isoformas de Ras tras la OUU. A) Activación (izquierda) y expresión total (derecha) de $\mathrm{H}, \mathrm{N}, \mathrm{K}$ y Pan-Ras en riñones $\mathrm{NO}$ y O de ratones $\mathrm{K}-\mathrm{Ras} 4 \mathrm{~A}^{+/+}, \mathrm{K}-$ Ras $4 \mathrm{~A}^{+/-}$y K-Ras $4 \mathrm{~A}^{-/}$analizados mediante western blot. B) H-Ras activado determinado mediante ELISA en riñones $\mathrm{NO}$ y O de ratones $\mathrm{K}-\mathrm{Ras} 4 \mathrm{~A}^{+/+}$, $\mathrm{K}^{-R a s} 4 \mathrm{~A}^{+/-}$y $\mathrm{K}-\mathrm{Ras} 4 \mathrm{~A}^{-/-}$después de 3 días (izquierda) y de 15 días (derecha) de OUU.*p $<0,05$ vs riñones NO. 
A
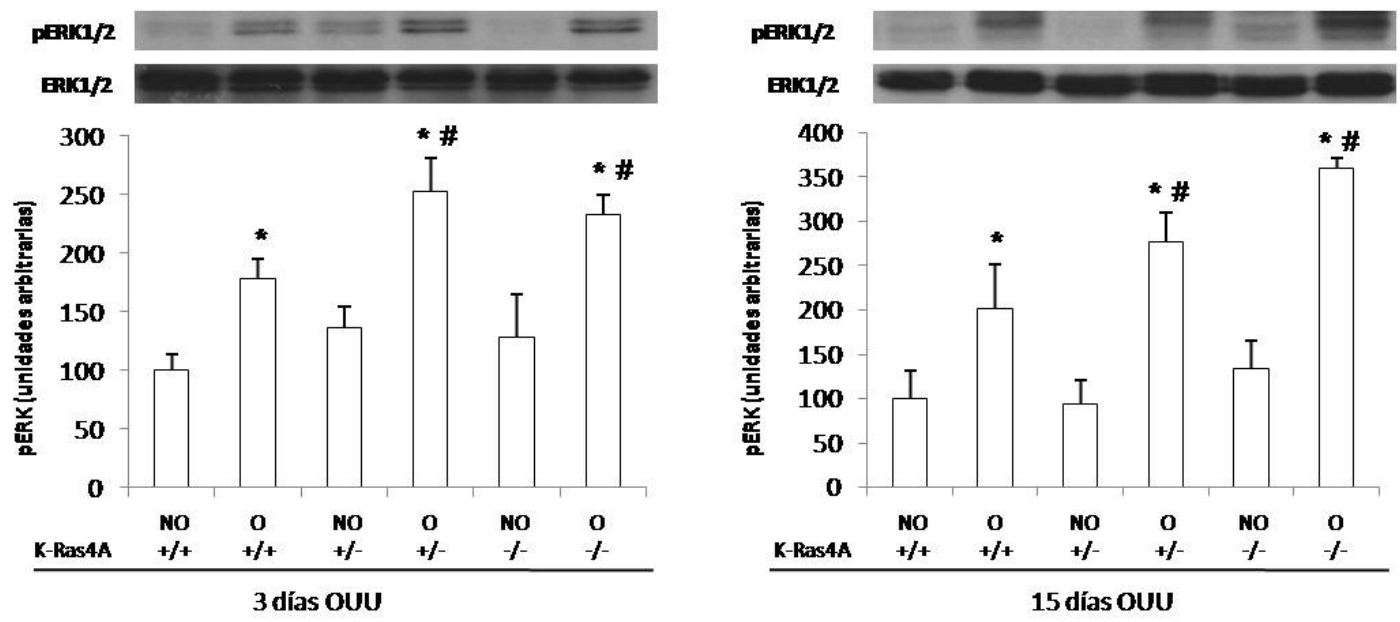

B
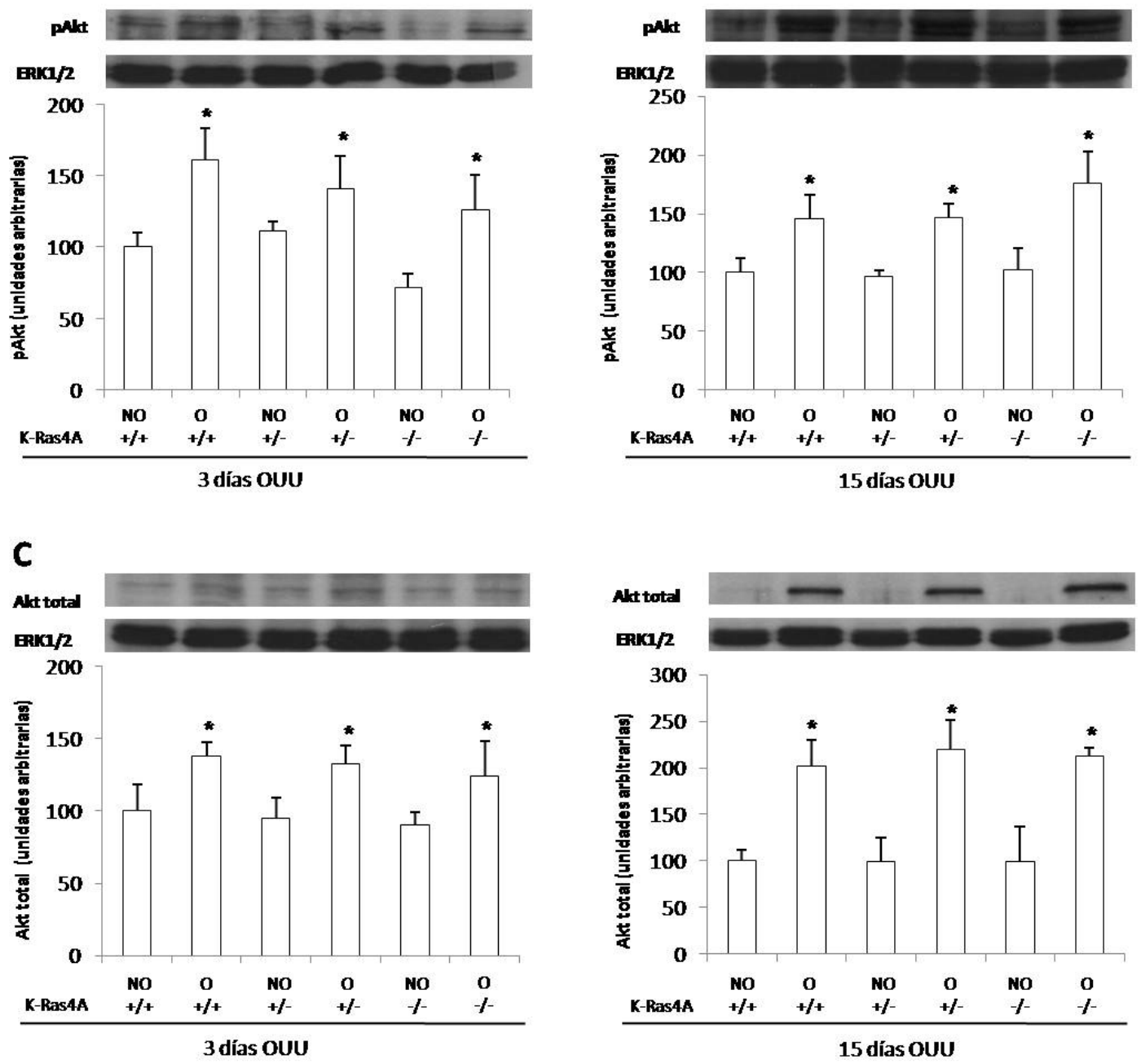

Figura 3. Activación de los efectores de Ras tras la OUU. A) Activación de ERK B) Expresión de pAkt C) Expresión de Akt total analizado mediante western blot en riñones $\mathrm{NO}$ y $\mathrm{O}$ de ratones K-Ras $4 \mathrm{~A}^{+/+}$, K-Ras $4 \mathrm{~A}^{+/-}$y K-Ras $4 \mathrm{~A}^{-/-}$a los 3 (izquierda) y 15 (derecha) días de OUU. ${ }^{*} \mathrm{p}<0,05$ vs riñones NO. $\# \mathrm{p}<0,05$ vs riñones $\mathrm{O}$ de ratones $\mathrm{K}-\mathrm{Ras} 4 \mathrm{~A}^{+/+}$. 

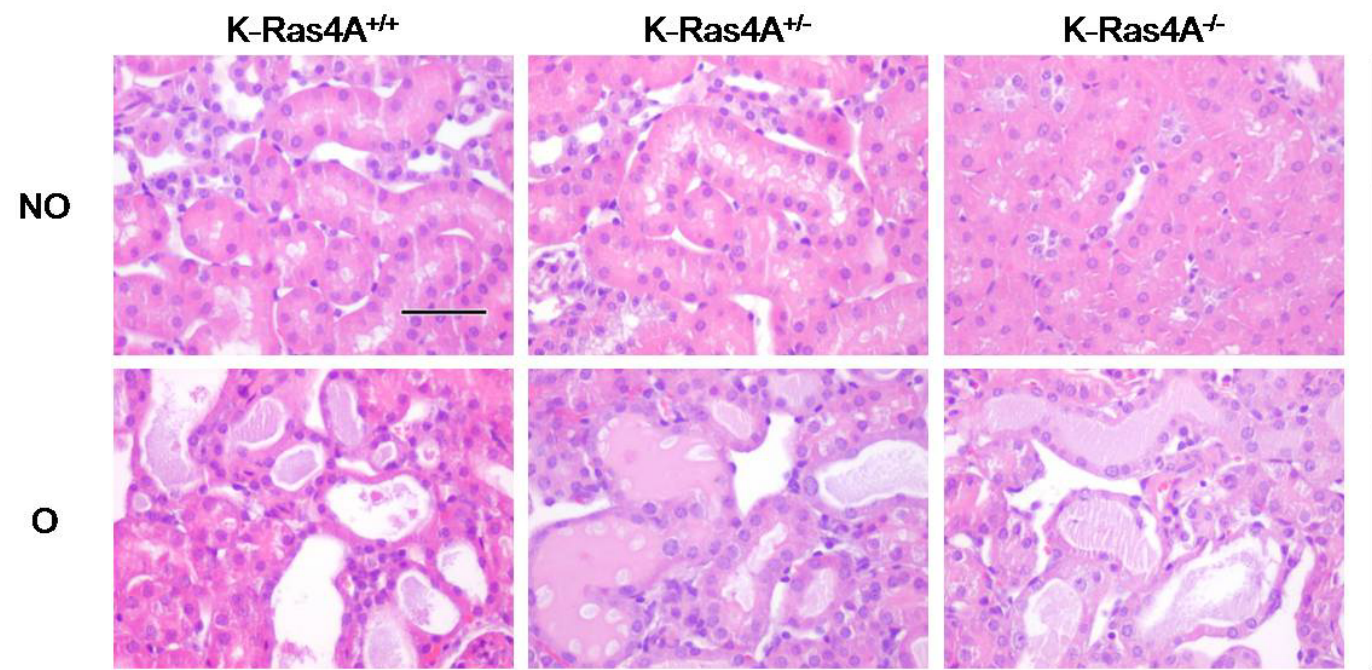

3d OUU

\section{o}
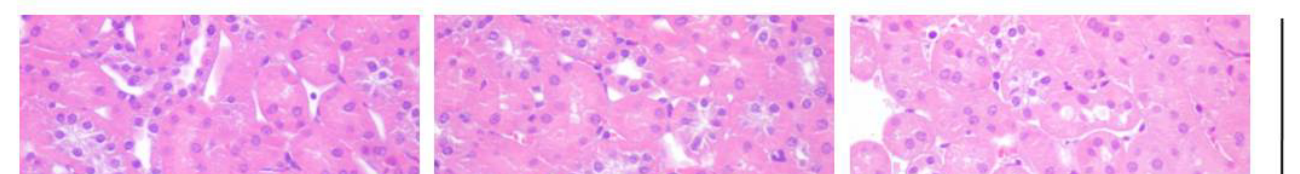

NO

O
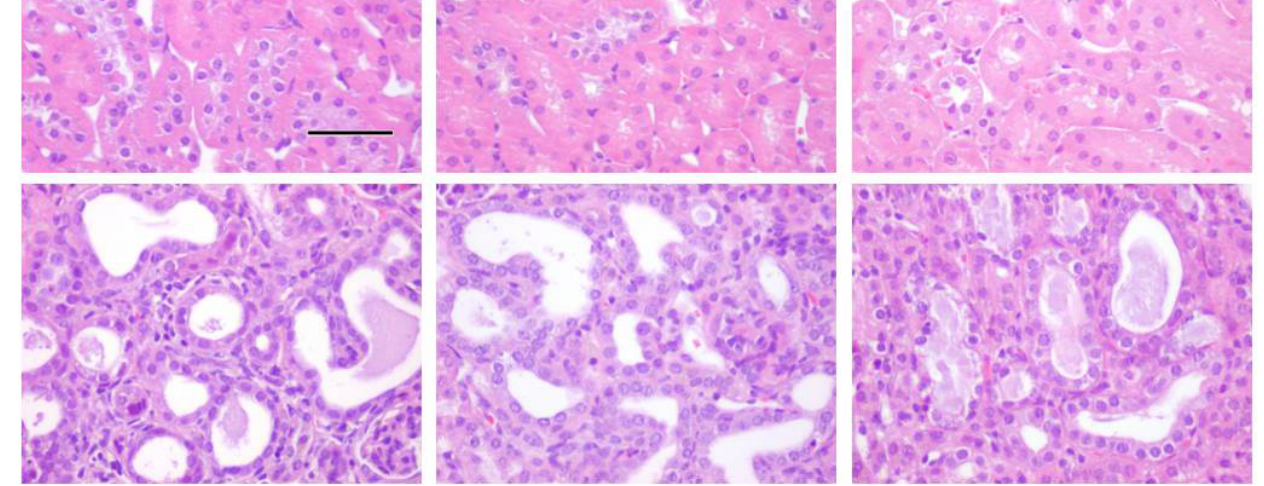

15d OUU

Figura 4. Tinción de Hematoxilina-Eosina. Tinción de hematoxilina-eosina de los riñones NO y O de ratones K-Ras4A ${ }^{+/+}$, K-Ras4A $\mathrm{A}^{+/}$y K-Ras $4 \mathrm{~A}^{-/-}$a los 3 y 15 días de OUU. La barra indica 50 micras en todas las imágenes. 

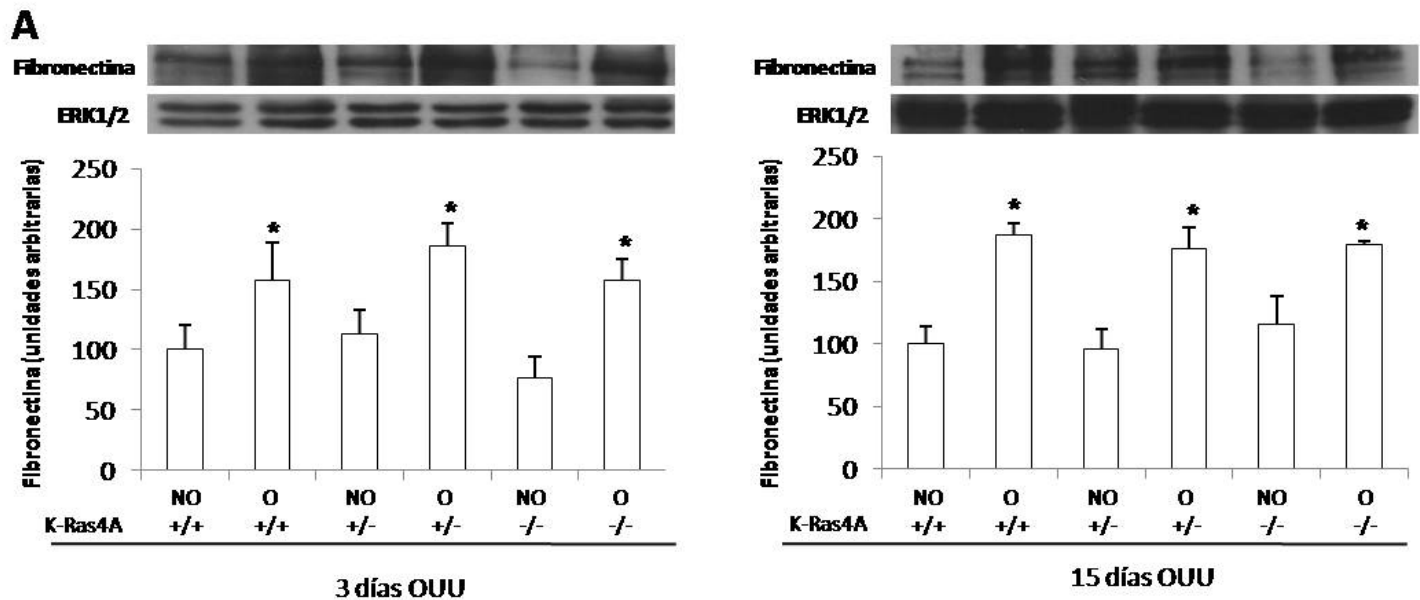

B
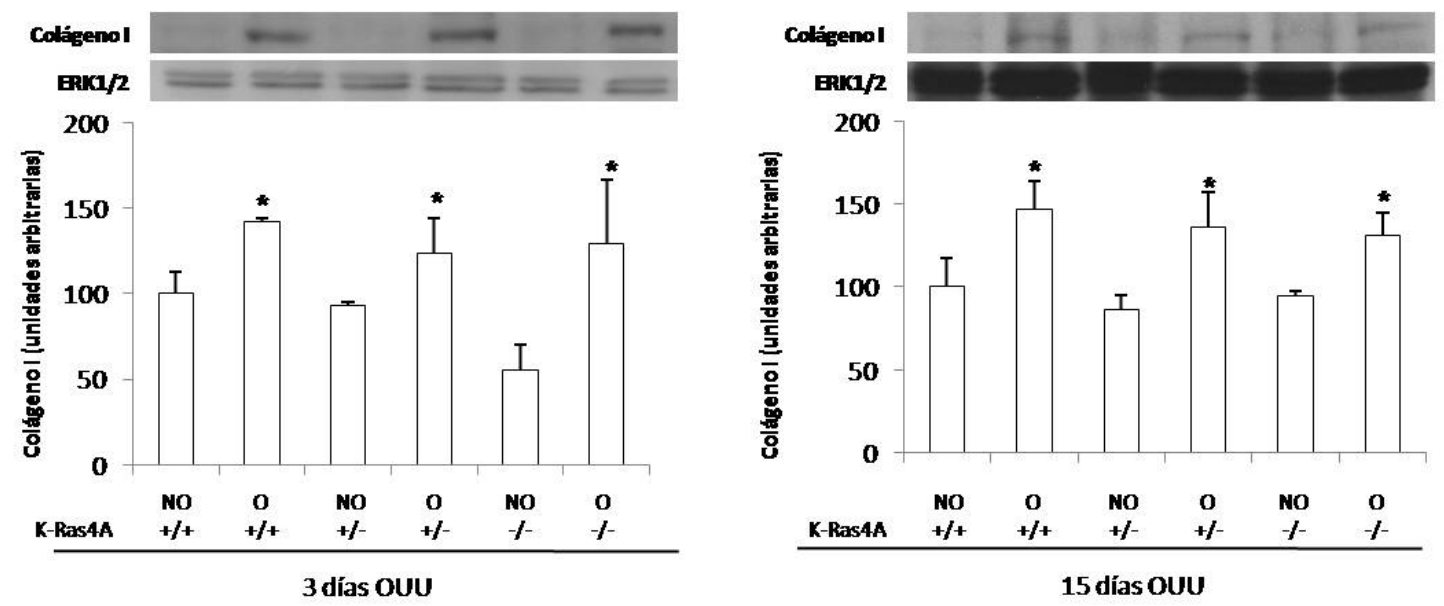

Figura 5. Expresión de proteínas de matriz extracelular tras la OUU. A) Expresión de fibronectina evaluada por western blot en riñones $\mathrm{NO}$ y O de ratones $\mathrm{K}-\mathrm{Ras} 4 \mathrm{~A}^{+/+}$, K-Ras $4 \mathrm{~A}^{+/-}$y $\mathrm{K}-\operatorname{Ras} 4 \mathrm{~A}^{-/-}$a $\operatorname{los} 3$ (izquierda) y 15 (derecha) días de OUU. B) Expresión de colágeno I determinado por western blot en riñones $\mathrm{NO}$ y $\mathrm{O}$ de ratones $\mathrm{K}-\mathrm{Ras} 4 \mathrm{~A}^{+/+}, \mathrm{K}_{-} \mathrm{Ras} 4 \mathrm{~A}^{+-}$y $\mathrm{K}$ Ras $4 \mathrm{~A}^{-/ /}$a los 3 (izquierda) y 15 (derecha) días de OUU. ${ }^{*} \mathrm{p}<0,05$ vs riñones NO. 


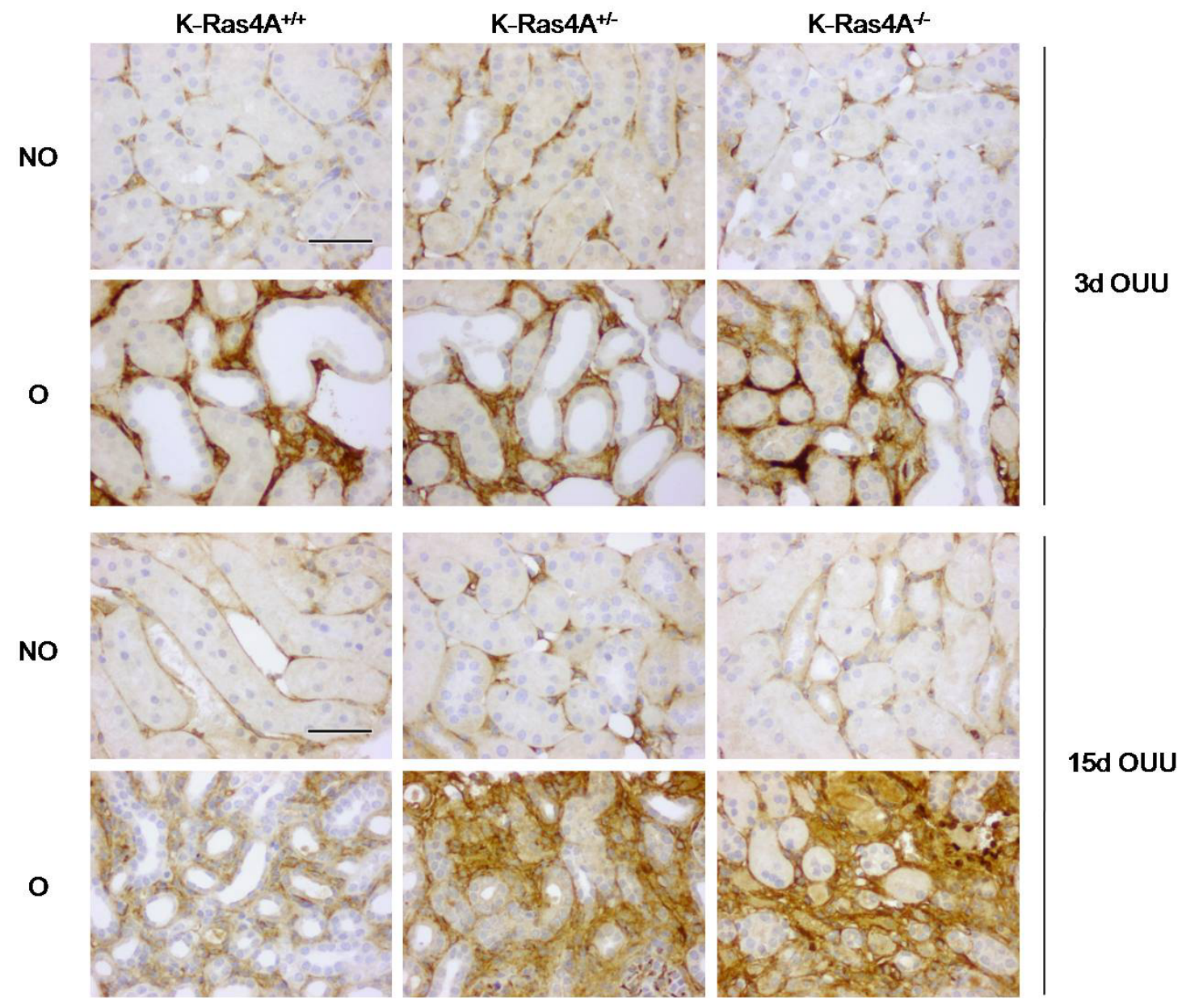

Figura 6. Inmunohistoquímica de fibronectina. Inmunohistoquímica de fibronectina en riñones $\mathrm{NO}$ y $\mathrm{O}$ de ratones $\mathrm{K}-\mathrm{Ras} 4 \mathrm{~A}^{+/+}$, $\mathrm{K}-\operatorname{Ras} 4 \mathrm{~A}^{+/-}$y $\mathrm{K}-\mathrm{Ras}_{4} \mathrm{~A}^{-/}$a los 3 y 15 días de OUU. La barra indica 50 micras en todas las imágenes. 


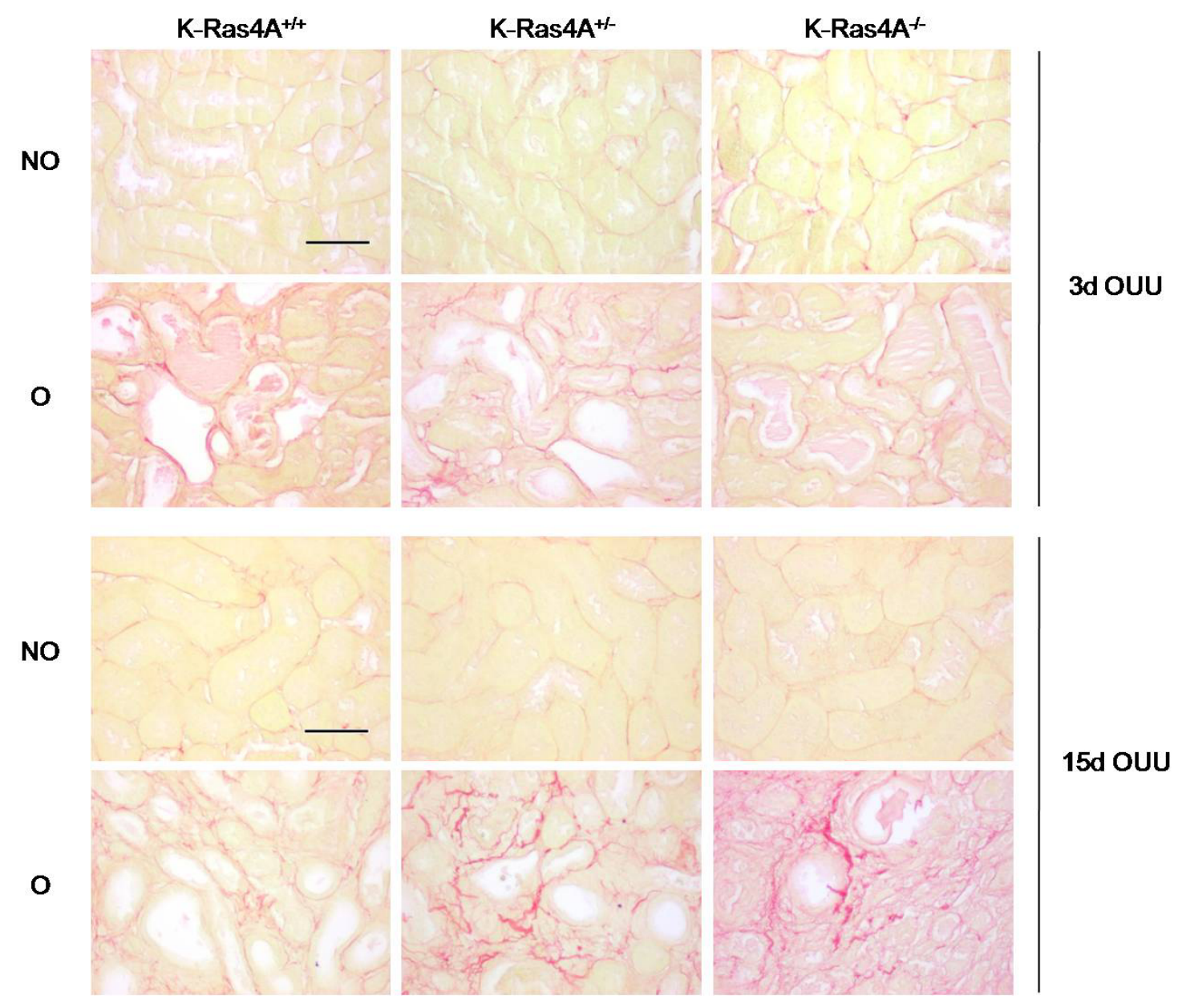

Figura 7. Tinción con rojo sirio. Tinción con rojo sirio en los riñones $\mathrm{NO}$ y $\mathrm{O}$ de ratones $\mathrm{K}-$ Ras $4 \mathrm{~A}^{+/+}$, K-Ras $4 \mathrm{~A}^{+/-}$y K-Ras $4 \mathrm{~A}^{-/}$a los 3 y 15 días de OUU. La barra indica 50 micras en todas las imágenes. 
A
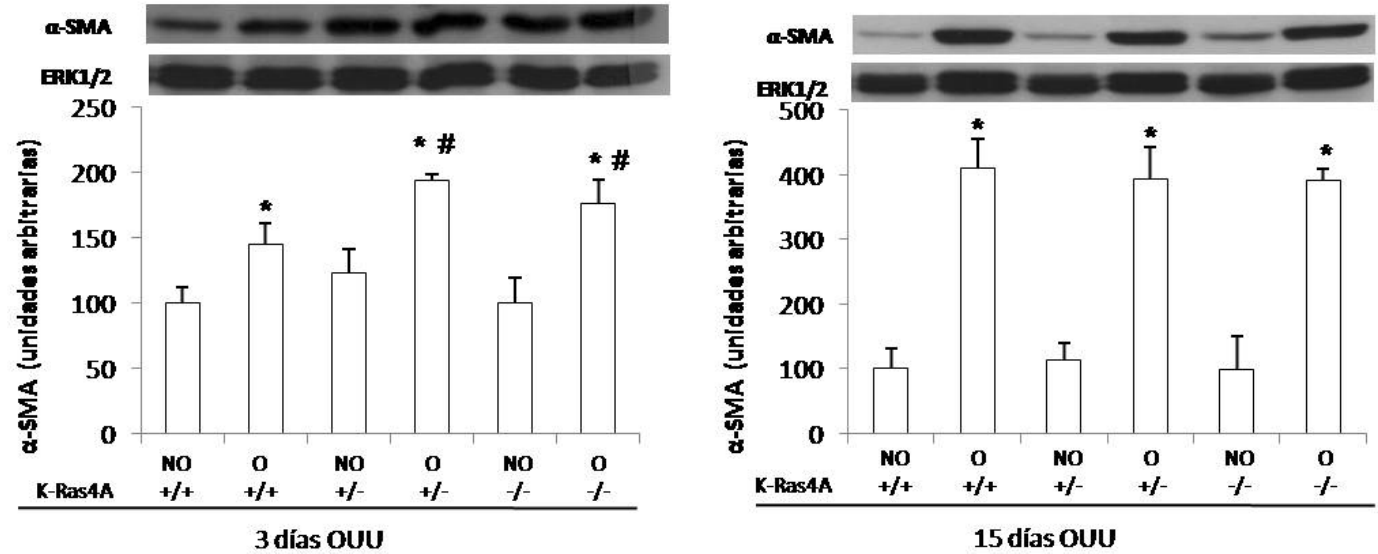

B
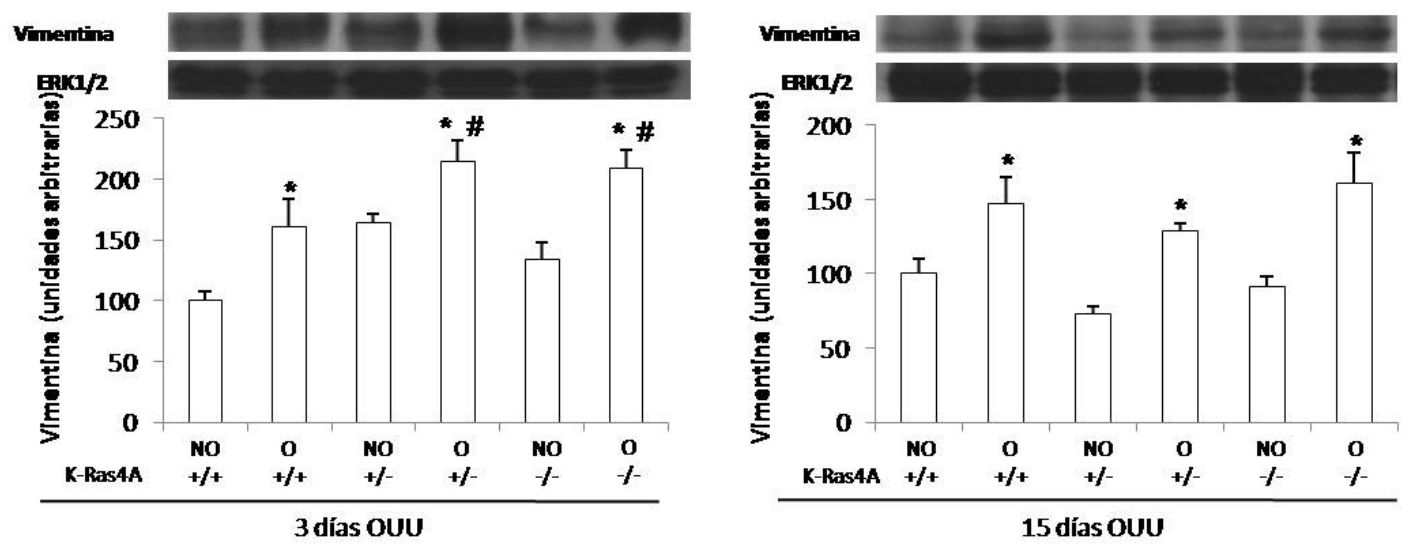

Figura 8. Expresión de marcadores de miofibroblastos tras la OUU. A) Expresión de $\alpha$ SMA evaluada por western blot en riñones $\mathrm{NO}$ y $\mathrm{O}$ de ratones $\mathrm{K}_{-R a s} 4 \mathrm{~A}^{+/+}$, $\mathrm{K}_{-} \operatorname{Ras}_{4} \mathrm{~A}^{+/-}$y KRas $4 \mathrm{~A}^{-/-}$a los 3 (izquierda) y 15 (derecha) días de OUU. B) Expresión de vimentina analizada mediante western blot en riñones $\mathrm{NO}$ y O de ratones $\mathrm{K}-\mathrm{Ras} 4 \mathrm{~A}^{+/+}, \mathrm{K}_{-} \mathrm{Ras} 4 \mathrm{~A}^{+/-}$y K-Ras $4 \mathrm{~A}^{-/-}$a los 3 (izquierda) y 15 (derecha) días de OUU. *p $<0,05$ vs riñones NO. \#p $<0,05$ vs riñones O de ratones $\mathrm{K}-\mathrm{Ras} 4 \mathrm{~A}^{+/+}$. 


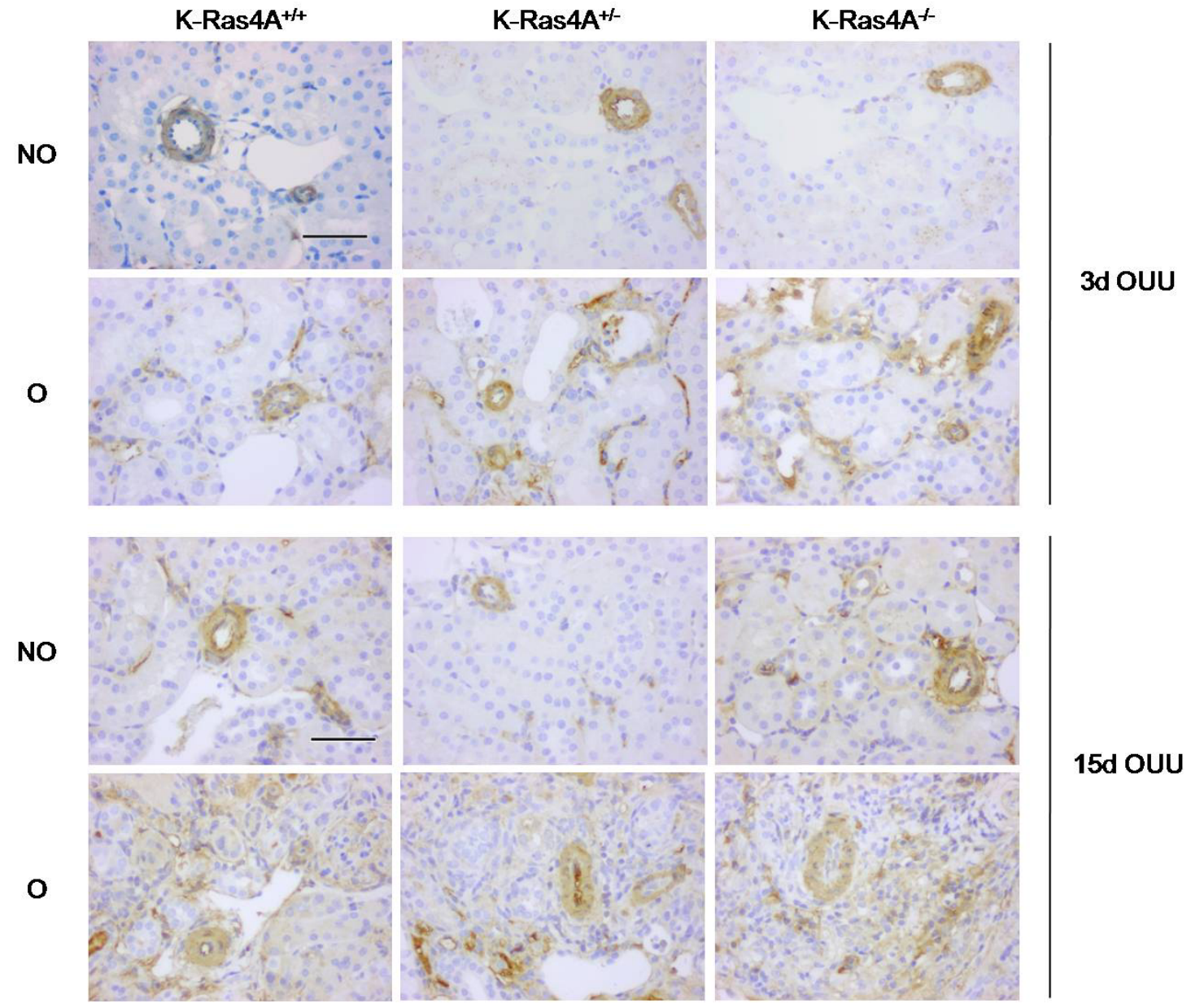

Figura 9. Inmunohistoquímica de $\alpha$-SMA. Inmunohistoquímica de $\alpha$-SMA en riñones NO y $\mathrm{O}$ de ratones K-Ras $4 \mathrm{~A}^{+/+}$, K-Ras $4 \mathrm{~A}^{+/}$y K-Ras $4 \mathrm{~A}^{-/-}$a los 3 y 15 días de OUU. La barra indica 50 micras en todas las imágenes. 
A
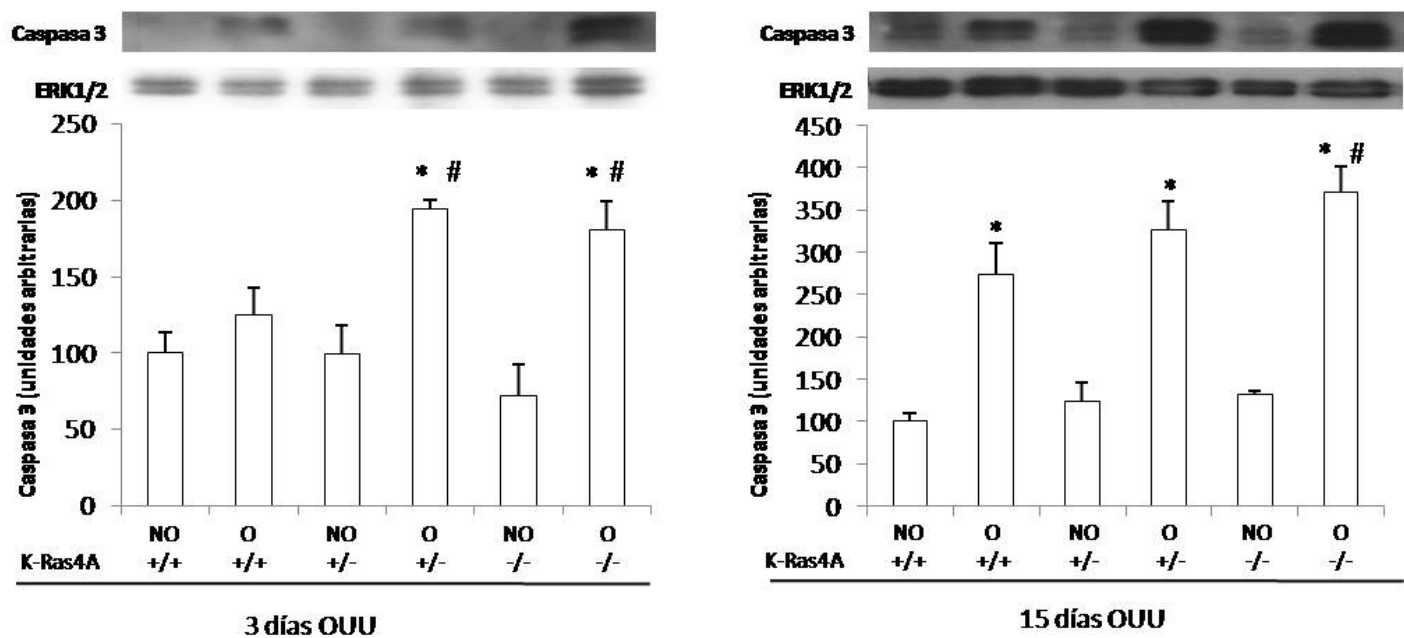

B
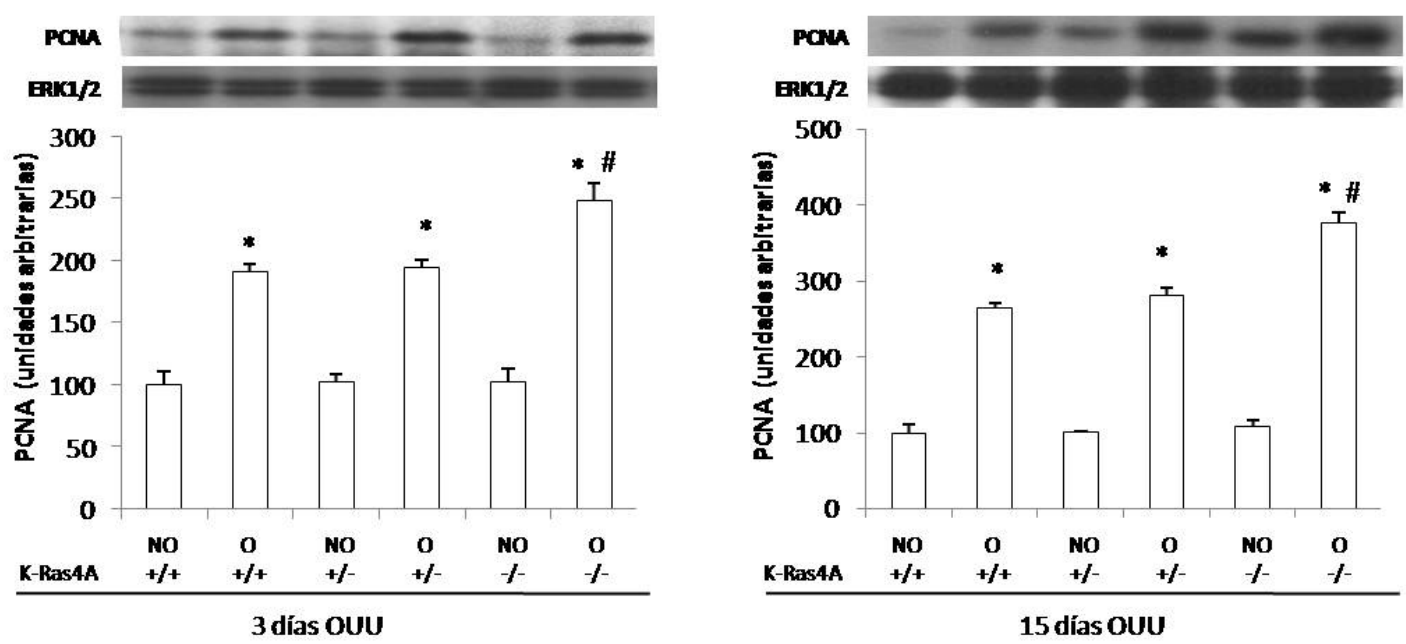

Figura 10. Expresión de proteínas marcadoras de apoptosis y proliferación tras la OUU. A) Expresión de caspasa 3 activada evaluada por western blot en riñones $\mathrm{NO}$ y $\mathrm{O}$ de ratones $\mathrm{K}$ Ras $4 \mathrm{~A}^{+/+}$, K-Ras $4 \mathrm{~A}^{+/}$y K-Ras $4 \mathrm{~A}^{-/-}$a los 3 (izquierda) y 15 (derecha) días de OUU. B) Expresión de PCNA analizada mediante western blot en riñones $\mathrm{NO}$ y $\mathrm{O}$ de ratones $\mathrm{K}$ Ras $4 \mathrm{~A}^{+/+}, \mathrm{K}-\operatorname{Ras} 4 \mathrm{~A}^{+/-}$y K-Ras $4 \mathrm{~A}^{-/ /}$a los 3 (izquierda) y 15 (derecha) días de OUU. *p $<0,05$ vs riñones NO. $\# \mathrm{p}<0,05$ vs riñones $\mathrm{O}$ de ratones $\mathrm{K}$-Ras $4 \mathrm{~A}^{+/+}$. 


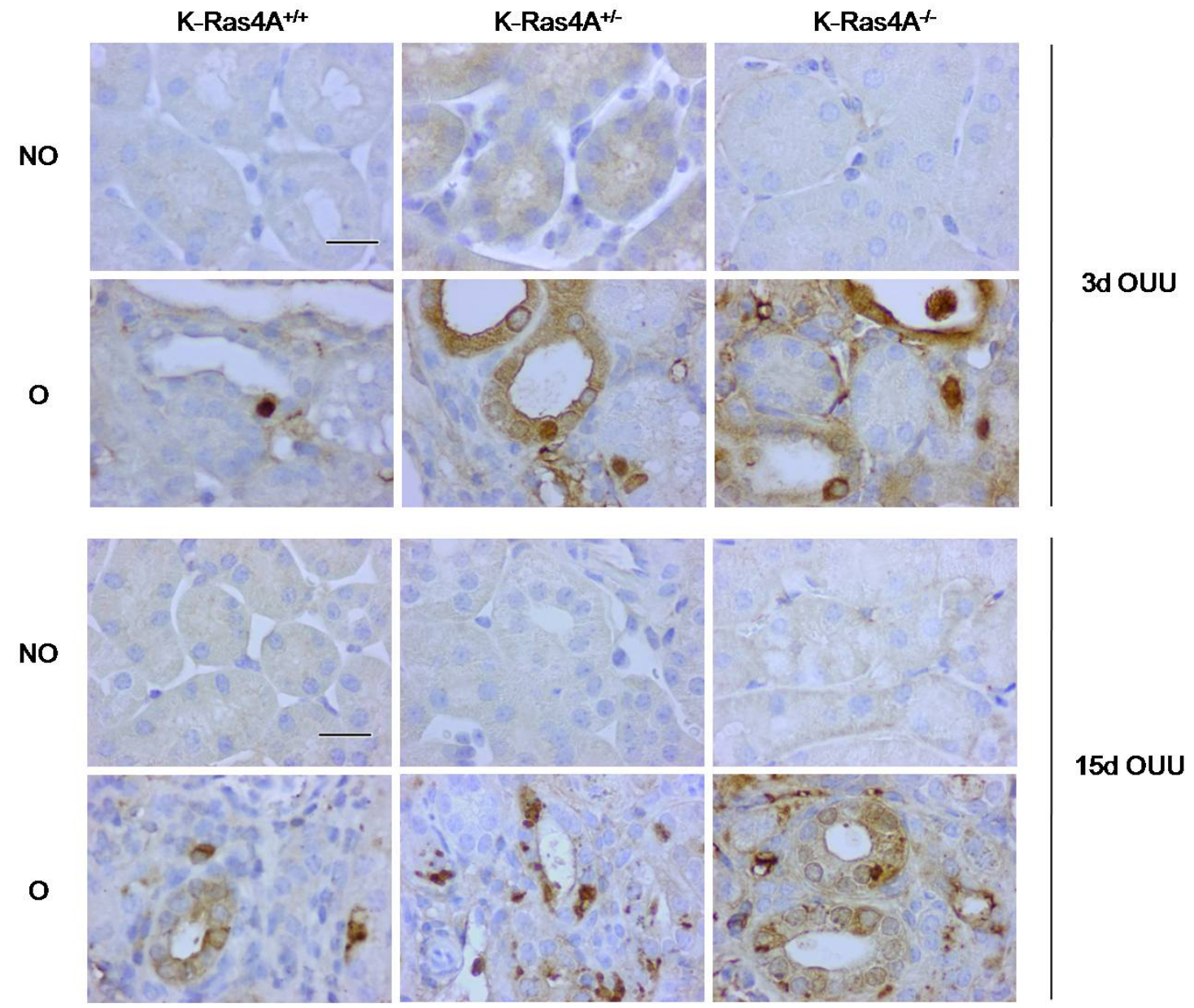

Figura 11. Inmunohistoquímica de caspasa 3 activada. Inmunohistoquímica de caspasa 3 activada en riñones $\mathrm{NO}$ y $\mathrm{O}$ de ratones $\mathrm{K}-\operatorname{Ras} 4 \mathrm{~A}^{+/+}$, K-Ras $4 \mathrm{~A}^{+/-}$y $\mathrm{K}-\mathrm{Ras} 4 \mathrm{~A}^{-/-}$a $\operatorname{los} 3$ y 15 días de OUU. La barra indica 20 micras en todas las imágenes. 


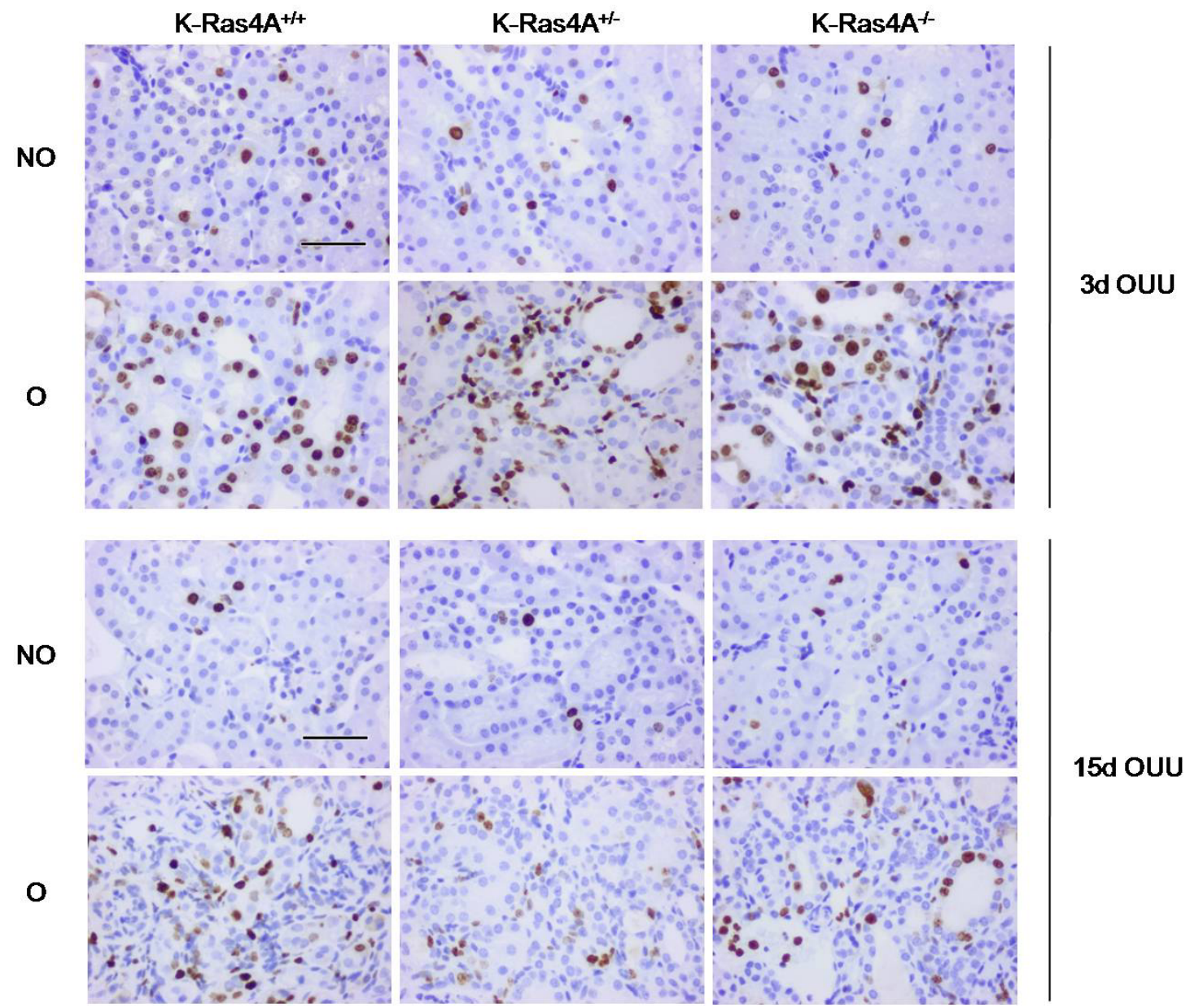

Figura 12. Inmunohistoquímica de Ki-67. Inmunohistoquímica de Ki-67 en riñones $\mathrm{NO}$ y $\mathrm{O}$ de ratones K-Ras $4 \mathrm{~A}^{+/+}$, K-Ras $4 \mathrm{~A}^{+/-}$y K-Ras $4 \mathrm{~A}^{-/}$a los 3 y 15 días de OUU. La barra indica 50 micras en todas las imágenes. 


\section{DISCUSIÓN GENERAL}




\section{DISCUSIÓN GENERAL}

\section{Introducción}

El objetivo general de este estudio ha sido el papel de la activación de la pequeña GTPasa Ras y de sus efectores MAPK-ERK1/2 y PI3K-Akt y el papel de las distintas isoformas de Ras: H-Ras, K-Ras y N-Ras en los cambios que se inducen en la estructura renal por la nefropatía obstructiva, utilizando el modelo de obstrucción ureteral unilateral en el ratón. La base de la que partimos para estudiar la activación de Ras es que numerosas citoquinas que se encuentran aumentadas en numerosos modelos experimentales de fibrosis renal, como Angiotensina II, factor de crecimiento transformante $\beta$ (TGF- $\beta$ ), factor de crecimiento derivado de las plaquetas (PDGF), factor de crecimiento epidérmico (EGF), endotelina y trombina, son capaces de activar $\operatorname{Ras}[1]$.

Para nuestros estudios en la nefropatia obstructiva, hemos utilizado la obstrucción unilateral del ureter (OUU), que se ha convertido en el modelo estándar para estudiar los mecanismos de inducción de fibrosis tubulo-intersticial de causa no inmune, ya que es un modelo normoproteinúrico, sin hipertensión ni hiperlipidemia, y sin que exista aparentemente un daño toxico o inmunológico El modelo consiste en la ligadura bajo anestesia de uno de los uréteres $\mathrm{y}$, dependiendo del tiempo de duración de la obstrucción, el modelo va imitando los diferentes estadíos de la nefropatía obstructiva, acabando en una fibrosis intersticial masiva del riñón obstruido, pero sin comprometer la vida del animal ni su entorno metabólico ya que el riñón contralateral mantiene su función, o incluso la aumenta debido a la hipertrofia compensadora tanto funcional como anatómica [2]

Hemos utilizado dos tiempos de duración de la obstrucción, 3 días, un tiempo en el cual la fibrosis intersticial es muy pequeña, y 15 días, un periodo en el que ya está bien desarrollada, ya que los fenómenos que ocurren agudamente y más tardíamente tras la obstrucción urinaria son probablemente muy diferentes.

Después de tres días de obstrucción ureteral los riñones obstruidos mostraban dilatación tubular y atrofia parcial con el epitelio aplanado en los túbulos afectados. También se observa proliferación y apoptosis celular, tanto en las células epiteliales tubulares como en células intersticiales, aparición de miofibroblastos (células mesenquimales con aspecto de propiedades de fibroblastos y capaces de sintetizar una 
gran cantidad de matriz extracelular) y aumento de la expresión de proteínas de matriz extracelular, como fibronectina y colágeno 1 .

La fibronectina se ha propuesto como la primera proteína de matriz extracelular que aparece durante la patogénesis de la fibrosis tubulointersticial inducida por OUU. Sus propiedades quimioatrayentes y adhesivas facilitan la agrupación de fibroblastos y la deposición de las otras proteínas extracelulares [3].

La $\alpha$-SMA es una isoforma de la actina específica de músculo liso vascular y miofibroblastos. En los riñones no obstruidos la expresión de $\alpha$-SMA se limita al músculo liso de las paredes arteriales, por el contrario, en los riñones obstruidos, la expresión de $\alpha$-SMA se encuentra además en células del intersticio renal. En riñones no ligados la expresión de vimentina, marcador de células de origen mesenquimal, se limita a los glomérulos y en las paredes vasculares, sin expresión en las células tubulares o en el intersticio. Sin embargo, en los riñones obstruidos hay muchas células positivas para vimetina en el intersticio peritubular, en la misma zona donde se observan células $\alpha$ SMA positivas. Los miofibroblastos positivos para $\alpha$-SMA son admitidos como los principales responsables de la deposición en exceso de matriz extracelular intersticial en condiciones patológicas [4,5]. Mediante inmunohistoquímica de CD68, marcador específico de macrófagos, observamos en los riñones obstruidos después de tres días de obstrucción, que existen células positivas CD68 en el intersticio de estos riñones mientras que no aparecen en los riñones no obstruidos. La acumulación tubulointersticial de macrófagos se correlaciona con la progresión de la enfermedad renal y éstos, directa o indirectamente, participan en la fibrosis tubulointersticial [6,7]. Estos resultados indican que en el espacio intersticial de los riñones obstruidos parece que coexisten macrófagos con células $\alpha$-SMA positivas y vimentina positivas y que todas ellas contribuyen al desarrollo de la fibrosis tubulointersticial.

Otro fenómeno observado después de tres días de obstrucción ureteral en los riñones obstruidos es un aumento de la proliferación celular, evaluada mediante inmunotinción nuclear de la proteína Ki67, siendo mayor la proliferación intersticial que la tubular Además se observa una gran cantidad de células tubulares en apoptosis analizada mediante inmunotinción con caspasa 3 activada, sin observar a penas apoptosis de células intersticiales. Estudios previos han señalado la importancia que juegan la proliferación y apoptosis en el desarrollo de la nefropatía obstructiva $[8,9]$. 
Cuando los riñones se estudian a los quince días de la obstrucción, algunos fenómenos son mucho más intensos que a los tres días, incluyendo la fibrosis intersticial o la acumulación de miofibroblastos, mientras que otros son menos intensos, como la proliferación epitelial.

\section{La activación de Ras y sus efectores ¿está involucrada en las alteraciones} observadas tras la OUU?

En nuestros estudios hemos observado un aumento significativo en la activación de Ras en el riñón obstruido así como un aumento de la activación de ERK y de Akt, así como un aumento de la expresión de Akt total, que sugiere que la OUU induce un aumento de la activación de Ras, y de sus rutas de señalización MAPK/ERK y PI3K/Akt. La activación de ERK parece relacionada con el aumento de proliferación celular observado tras la OUU, ya que al administrar el inhibidor de la activación de ERK, U0126, se produce una disminución de la proliferación celular inducida por la OUU. Nuestros resultados concuerdan con otros estudios de OUU realizados en rata que también sugieren que ERK regula, al menos en parte, la proliferación inducida por este modelo de nefropatía obstructiva $[10,11]$.

Nuestros resultados sugieren que la activación de ERK está involucrada en la apoptosis inducida por la OUU, ya que la administración de U0126 produce una disminución de núcleos positivos teñidos por TUNEL y de inmunotinción con caspasa 3 activada. Ya se ha descrito que la administración de U0126 disminuye la apoptosis inducida por cisplatino tanto in vitro [12] como in vivo [13]. Por otro lado la activación de Akt parece relacionada con la supervivencia celular tubular, ya que la administración del inhibidor de la activación de Akt, LY 294002, produce además de una disminución en la activación de Akt en el riñón obstruido, un aumento del daño en los túbulos afectados después de la obstrucción ureteral, aunque no aumente la activación de caspasa ni el número de núcleos teñidos con TUNEL. La función anti-apoptótica de Akt es bien conocida [14] y existen experimentos in vitro que demuestran que la activación de Akt previene la apoptosis en células tubulares renales [15]. Sin embargo y de acuerdo con nuestros resultados, se ha publicado que la inhibición de la activación de Akt no produce modificación alguna en apoptosis en fibroblastos de rata obtenidos a los 3 días de la OUU [16]. Además la inhibición de la activación de Akt produce la disminución de la expresión de $\alpha$-SMA y vimentina, una reducción significativa en los niveles de fibrosis tubulointersticial y también una disminución en la proliferación 
inducida por la OUU. Previamente se ha descrito que el tratamiento de fibroblastos renales obtenidos tras 3 días de OUU, reduce la proliferación y la síntesis de matriz extracelular [16]. Todos estos datos en conjunto sugieren que la activación de MAPKERK1/2 y PI3K-Akt participa en los cambios tempranos de la obstrucción ureteral unilateral en ratón.

La angiotensina II parece jugar un papel muy importante en el desarrollo de la patología renal asociada a la nefropatía obstructiva [17]. Después de la OUU se ha demostrado que hay aumento de renina, de la actividad de la enzima convertidora de angiotensina II en el riñón obstruido [18]. Por otra parte también se ha demostrado que la infusión de Angiotensina II en ratas durante 6 días produce la activación renal de Ras y MAPK/ERK [19, 20]. Nosotros analizamos la activación renal de Ras y de sus efectores a las 4 horas de la administración de Ang II y observamos un aumento en la activación renal de Ras, de ERK y de Akt. Para conocer el papel del aumento de Ang II en la activación de Ras y en los cambios renales inducidos por la OUU, administramos losartán, inhibidor de receptor tipo I de angiotensina, durante la OUU y observamos una disminución en la activación de Ras y una ligera reducción de la activación de sus efectores ERK y de Akt. Estos resultados sugieren que la activación de Ras observada tras la OUU, puede estar mediada por el aumento de Ang II a través de su receptor tipo I. La administración de losartán durante la OUU también causó una disminución en la expresión de fibronectina y de $\alpha$-SMA. Esto coincide con otros estudios que han observado una disminución de marcadores de fibrosis y de miofibroblastos después de 3 semanas de OUU cuando inhiben el receptor tipo I de angiotensina [21]. Todos estos resultados sugieren que los efectos profibróticos de Ang II a través del receptor tipo I de angiotensina, pueden estar mediados por la activación de Ras.

Para conocer si la activación renal de Ras tras la OUU está implicada en los cambios observados como la fibrosis intersticial y aparición de miofibroblastos, inhibimos la activación de Ras con y con inhibidores de la hidroximetilglutaril-CoA reductasa, enzimas implicada en la síntesis de grupos prenilo, [22], inhibidores de la farnesiltransferasa, enzima que cataliza la prenilación de Ras, un proceso necesario para su anclaje a la membrana y su activación. La inhibición de la activación de Ras dio como resultado una disminución de la expresión temprana de de fibronectina y de $\alpha$ SMA en el riñón obstruido, demostrando así que la activación de Ras participa en los cambios iniciales del daño renal inducidos por la OUU. Aunque la inhibición de la 
activación de Ras no se había estudiado en el modelo de nefropatía obstructiva, si se había observado que la inhibición de la activación de Ras previene el daño oxidativo asociado a las enfermedades renales y que además reduce la fibrosis post-operativa [2325].

En conjunto, los resultados sugieren que la activación de Ras y de sus efectores está involucrada en los cambios tempranos inducidos por la obstrucción ureteral.

\section{¿Qué papel juega la activación de las diferentes isoformas de Ras en la} UUO?

Aunque las proteínas Ras tienen un alto grado de homología en sus primeros 164 aminoácidos, la heterogeneidad observada en los últimos 25 aminoácidos está relacionada con diferencias en la funcionalidad de las isoformas de las proteínas Ras. Además, mientras la falta de H-Ras y N-Ras no afecta en el desarrollo vital del ratón, KRas sí parece ser fundamental para el desarrollo del ratón ya que la deficiencia de K-ras produce la muerte de los embriones [26-28]. Utilizando ratones deficientes en H-Ras, NRas y K-Ras evaluamos el desarrollo de la patología renal inducida por la obstrucción ureteral para dilucidar el posible papel que puede estar ejerciendo cada una de las isoformas de Ras.

Cuando realizamos la OUU a ratones deficientes en la isoforma H-Ras y en la isoforma N-Ras, y los estudiamos a los tres días, no observamos diferencias en el daño renal temprano inducido por la obstrucción ureteral, ni en la expresión de marcadores de matriz extracelular, como fibronectina, ni en la expresión de marcadores de miofibroblastos como $\alpha$-SMA, ni en marcadores de apoptosis ni en la proliferación.

Posiblemente la falta de diferencias entre los ratones controles y los deficientes en H-Ras y N-Ras podían deberse a que la isoforma K-Ras era responsable del daño agudo observado tras la OUU, pero podría ser que estas isoformas si tuvieran un papel en la regulación de los cambios tardíos observados tras la OUU. Para estudiar el posible papel de la activación de la isoforma Hras en los cambios tardíos asociados a la OUU, realizamos la OUU a ratones deficientes en la isoforma H-Ras y los estudiamos después de 15 días de OUU. Observamos que los riñones obstruidos de los ratones

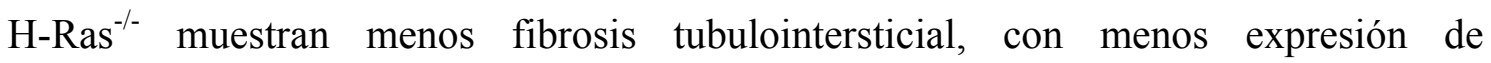
fibronectina y colágeno I y menos expresión de marcadores de miofibroblastos, $\alpha$-SMA, vimentina y FSP-1 que los riñones obstruidos de los ratones $\operatorname{Ras}^{+/+}$. Estos resultados 
sugieren que en los riñones obstruidos de los ratones deficientes en H-Ras había menos miofibroblastos que en los correspondientes riñones de los ratones controles. Por otro lado observamos que no existe co-expresión de $\alpha$-SMA y de la proteína específica de fibroblastos (FSP-1), que se había propuesto como la proteína más específica para marcar los miofibroblastos. Estos resultados, que ya se ha habían observado anteriormente [31]. sugieren que posiblemente FSP-1 no sea un marcador exclusivo de fibroblastos, sino también de macrófagos, ya que se ha observado que existe colocalización con marcadores de macrófagos [32] y en nuestros estudios, la morfología de las células positivas para FSP-1 era similar a la de los macrófagos infiltrados.

Las diferencias observadas entre los estudios agudos y los estudios a más largo plazo en los ratones carentes de H-ras pueden explicarse por que los fenómenos que estamos estudiando son diferentes. En los primeros días tras OUU, los miofibroblastos derivan probablemente de la activación de fibroblastos residentes. En los estados tardíos de la OUU, se ha demostrado que los miofibroblastos pueden tener su origen en un proceso denominado transición epitelio-mesenquimal (TEM) [33], un proceso complejo por el cual las células tubulares se transforman en celulas mesemquimales con características de miofibroblastos y en el que participan numerosos factores [34]. Nuestros resultados mostraron una menor activación de Akt y de GSK-3 $\beta$, en los riñones obstruidos de los ratones deficientes en H-Ras y una disminución de la expresión de los factores de transcripción Snail y Slug, factores de transcripción represores de E-cadherina implicados en la regulación de la TEM [34]. Estos resultados sugieren que la isoforma H-Ras está involucrada en la regulación de la TEM, además de que también está implicada en la proliferación celular inducida por la OUU.

Para conocer el posible papel que puede jugar la activación de K-Ras en los cambios inducidos por la nefropatía obstructiva, estudiamos los cambios tempranos y a largo plazo de la OUU en ratones haploinsuficientes en K-Ras $\left(\mathrm{K}-\mathrm{Ras}^{+/-}\right)$y deficientes y haploinsuficientes en la isoforma K-Ras4A (K-Ras4 $\mathrm{A}^{-/}$y $\left.\mathrm{K}-\operatorname{Ras} 4 \mathrm{~A}^{+-}\right)$ya que la deficiencia en el gen $K$-Ras es letal porque produce la muerte del ratón en el estado embrionario [35-37] mientras que la deficiencia en la producción de la proteína KRas4A no afecta al desarrollo normal del ratón, al menos en presencia de K-Ras4B [38]. Observamos que la deficiencia parcial de K-Ras regula la proliferación y apoptosis inducida por la OUU, porque los ratones K-Ras+/- presentan menos caspasa 3 activada y PARP activado y también menos proliferación celular que los ratones control K- 
$\operatorname{Ras}^{+/+}$. Nuestros resultados sugieren que la activación de K-Ras induce apoptosis y proliferación celular tras la OUU. Previamente se ha descrito que K-Ras promueve apoptosis [39,40] y proliferación en fibroblastos renales [41].

Por otro lado la OUU en ratones deficientes y parcialmente deficientes en la isoforma K-Ras4A produce un aumento de la apoptosis de las células epiteliales tubulares mayor que en los ratones control K-Ras $4 \mathrm{~A}^{+/+}$, sugiriendo que en la en el riñón obstruido, la activación de la isoforma K-Ras4A juega un papel anti-apoptótico. Estos están de acuerdo con los obtenidos en células madre donde se observó que la deficiencia de K-Ras4A protegía de la apoptosis [42]. En el riñón obstruido, a los tres días de OUU, la falta de K-Ras4A además se asoció a una menor proliferación de las células epiteliales tubulares y una mayor proliferación de las células intersticiales, probablemente miofibroblastos. Estos datos sugieren que la activación de K-Ras4A regula de forma diferencial la proliferación de distintos tipos celulares en el riñón. En los riñones obstruidos, a falta de K-Ras4A se asoció una mayor activación de ERK, que puede deberse a la mayor afinidad de K-Ras4B para activar la ruta Raf/MAPK/ERK comparada con la de K-Ras4A [43]. También se observó en los riñones obstruidos de los animales deficientes en K-Ras4A una menor expresión de vimentina después de 3 días de OUU, comparados con losa riñones obstruidos de los animales controles KRas $4 \mathrm{~A}^{+/+}$. Esto sugiere que K-Ras4A puede ejercer algún tipo de regulación en la expresión de marcadores de miofibroblastos, aunque hasta ahora no se ha relacionado la la expresión de marcadores de miofibroblastos con K-Ras4A. Esta regulación puede estar mediada a través de la activación de Rac, ya que se ha demostrado la alta capacidad de K-Ras para activar Rac y además la ruta de Rac activa y promueve la reorganización de vimentina $[44,45]$.

Todos estos resultados muestran por primera vez diferentes papeles para la activación de las diferentes isoformas de Ras en el desarrollo del daño renal inducido por la UUO en ratón. 


\section{Referencias}

[1] Martínez-Salgado C, Rodríguez-Peña AB, López-Novoa JM. Involvement of small Ras GTPases and their effectors in chronic renal disease. Cell Mol Life Sci 2008; 65: 477-492.

[2] Chevalier RL (2006) Pathogenesis of renal injury in obstructive uropathy. Curr Opin Pediatr 18: 153-60.

[3] Gharaee-Kermani M, Wiggins R, Wolber F, Goyal M, Phan SH. Fibronectin is the major fibroblast chemoattractant in rabbit anti-glomerular basement membrane disease. Am J Pathol. 1996; 148(3): 961-7.

[4] Kim S, Iwao H. Molecular and cellular mechanisms of angiotensin II-mediated cardiovascular and renal diseases. Pharmacol Rev. 2000, 52(1):11-34.

[5] Satoh M, Kashihara N, Yamasaki Y, Maruyama K, Okamoto K, Maeshima Y, Sugiyama H, Sugaya T, Murakami K, Makino H. Renal interstitial fibrosis is reduced in angiotensin II type 1a receptor-deficient mice. J Am Soc Nephrol. 2001 12(2):317-25.

[6] Eddy AA. Progression in chronic kidney disease. Advances in Chronic Kidney Disease. 2005;12(4):353-365.

[7] Young BA, Burdmann EA, Johnson RJ, et al. Cellular proliferation and macrophage influx precede interstitial fibrosis in cyclosporine nephrotoxicity. Kidney Int. 1995;48(2):439-448.

[8] Truong LD, Petrusevska G, Yang G, Gurpinar T, Shappell S, Lechago J, Rouse D, Suki WN. Cell apoptosis and proliferation in experimental chronic obstructive uropathy. Kidney Int. 1996 Jul;50(1):200-7

[9] Kim JH, Yang JI, Jung MH, Hwa JS, Kang KR, Park DJ, Roh GS, Cho GJ, Choi WS, Chang SH. Heme oxygenase-1 protects rat kidney from ureteral obstruction via an antiapoptotic pathway. J Am Soc Nephrol. 2006 17(5):1373-81.

[10] Pat B, Yang T, Kong C et al. Activation of ERK in renal fibrosis after unilateral ureteral obstruction: modulation by antioxidants. Kidney Int. 2005; 67: 931-43.

[11] Masaki T, Foti R, Hill PA et al. Activation of ERK pathway precedes tubular proliferation in the obstructed rat kidney. Kidney Int 2003; 63: 1256-1264.

[12] Arany I, Megyesi JK, Kaneto $\mathrm{H}$ et al. Cisplatin-induced cell death is EGFR/src/ERK signaling dependent in mouse proximal tubule cells. Am J Physiol Renal Physiol 2004; 287: F543-49.

[13] Jo SK, Cho WY, Sung SA et al. MEK inhibitor, U0126, attenuates cisplatininduced renal injury by decreasing inflammation and apoptosis. Kidney Int 2005; 67: 458-66.

[14] Okada M, Oshimura M, Ito H. PI3K-Akt pathway: Its functions and alterations in human cancer. Apoptosis 2004; 9: 667-676.

[15] Sinha D, Bannergee S, Schwartz JH, Lieberthal W, Levine JS. Inhibition of ligandindependent ERK1/2 activity in kidney proximal tubular cells deprived of soluble survival factors up-regulates Akt and prevents apoptosis. J Biol Chem. 2004 Mar 19;279(12):10962-72. 
[16] Winbanks CE, Grimwood L, Gasser A, Darby IA, Hewitson TD, Becker GJ. Role of the phosphatidylinositol 3-kinase and mTOR pathways in the regulation of renal fibroblast function and differentiation. Int J Biochem Cell Biol. 2007;39(1):206-19.

[17] Klahr, S., Ishidoya, S. and Morrissey, J. (1995) Role of angiotensin II in the tubulointerstitial fibrosis of obstructive nephropathy. Am. J. Kidney Dis. 26, 141-146

[18] Pimentel, J.L. Jr., Montero, A., Wang, S., Yosipiv, I., el-Dahr, S. and MartinezMaldonado, M. (1995) Sequential changes in renal expression of renin-angiotensin system genes in acute unilateral ureteral obstruction. Kidney Int 48, 1247-1253

[19] Muthalif, M., Karzoun, N.A., Gaber, L., Khandekar, Z., Benter, I.F., Saeed, A.E., Parmentier, J.H., Estes, A. and Malik, K.U. (2000) Angiotensin II-Induced Hypertension: contribution of Ras GTPase/Mitogen-activated protein kinase and cytochrome P450 metabolites. Hypertension 36, 604-609.

[20] Muthalif, M.M., Benter, I.F., Khandekar, Z., Gaber, L., Estes, A., Malik, S., Parmentier, J.H., Manne, V. and Malik, K.U. (2000) Contribution of Ras GTPase/MAP kinase and cytochrome P450 metabolites to deoxycorticosterone-salt-induced hypertension. Hypertension 35, 457-463

[21] Kellner, D., Chen, J., Richardson, I., Seshan, S.V., El Chaar, M., Vaughan, E.D. Jr., Poppas, D. and Felsen, D. (2006) Angiotensin receptor blockade decreases fibrosis and fibroblast expression in a rat model of unilateral ureteral obstruction. J. Urol. 176, 806-812

[22] Crul, M., de Klerk, G.J., Beijnen, J.H. and Schellens, J.H. (2001) Ras biochemistry and farnesyl transferase inhibitors: a literature survey. Anticancer Drugs 12, 163-184

[23] Song, C.Y., Kim, B.C. and Lee, H.S. (2008) Lovastatin inhibits oxidized lowdensity lipoprotein-induced plasminogen activator inhibitor and transforming growth factor-betal expression via a decrease in Ras/extracellular signal-regulated kinase activity in mesangial cells. Transl. Res. 151, 27-35

[24] Sabbatini, M., Santillo, M., Pisani, A., Paternò, R., Uccello, F., Serù, R., Matrone, G., Spagnuolo, G., Andreucci, M., Serio, V., Esposito, P., Cianciaruso, B., Fuiano, G. and Avvedimento, E.V. (2006) Inhibition of Ras/ERK1/2 signaling protects against postischemic renal injury. Am. J. Physiol. Renal Physiol. 290, F1408-F1415

[25] Aarons, C.B., Cohen, P.A., Gower, A., Reed, K.L., Leeman, S.E., Stucchi, A.F. and Becker, J.M. (2007) Statins (HMG-CoA reductase inhibitors) decrease postoperative adhesions by increasing peritoneal fibrinolytic activity. Ann. Surg. 245, 176-184.

[26] Esteban LM, Vicario-Abejon C, Fernandez-Salguero P, Fernandez-Medarde A, Swaminathan N, Yienger K, Lopez E, Malumbres M, McKay R, Ward JM, Pellicer A, Santos E. Targeted genomic disruption of H-ras and N-ras, individually or in combination, reveals the dispensability of both loci for mouse growth and development. Mol Cell Biol 2001; 21: 1444-1452.

[27] Johnson L, Greenbaum D, Cichowski K, Mercer K, Murphy E, Schmitt E, Bronson RT, Umanoff H, Edelmann W, Kucherlapati R, Jacks T. K-ras is an essential gene in the mouse with partial functional overlap with N-ras. Genes Dev 1997; 11: 2468-2481.

[28] Koera K, Nakamura K, Nakao K, Miyoshi J, Toyoshima K, Hatta T, Otani H, Aiba A, Katsuki M. K-ras is essential for the development of the mouse embryo. Oncogene 1997; 15: 1151-1159. 
[29] Sharpe CC, Dockrell ME, Noor MI et al (2000) Role of Ras isoforms in the stimulated proliferation of human renal fibroblasts in primary culture. J Am Soc Nephrol 11(9):1600-6.

[30] Rodríguez-Peña AB, Grande MT, Eleno N et al (2008) Activation of Erk1/2 and Akt following unilateral ureteral obstruction. Kidney Int 74(2):196-209.

[31] Picard N, Baum O, Vogetseder A, Kaissling B, et al. Origin of renal myofibroblasts in the model of unilateral ureter obstruction in the rat. Histochem Cell Biol 2008; 130: 141-155.

[32] Inoue T, Plieth $\mathrm{D}$, Venkov $\mathrm{CD}, \mathrm{Xu} \mathrm{C}$, et al. Antibodies against macrophages that overlap in specificity with fibroblasts. Kidney Int 2005; 67: 2488-2493.

[33] Zeisberg M and Kalluri R (2008) Fibroblasts emerge via epithelial-mesenchymal transition in chronic kidney fibrosis. Front Biosci 13: 6991-6998

[34] Iwano $\mathrm{M}$ et al. (2002) Evidence that fibroblasts derive from epithelium during tissue fibrosis. $J$ Clin Invest 110: 341-350

[35] Esteban LM, Vicario-Abejon C, Fernandez-Salguero P, Fernandez-Medarde A, Swaminathan N, Yienger K, Lopez E, Malumbres M, McKay R, Ward JM, Pellicer A, Santos E. Targeted genomic disruption of H-ras and N-ras, individually or in combination, reveals the dispensability of both loci for mouse growth and development. Mol Cell Biol 2001; 21: 1444-1452.

[36] Johnson L, Greenbaum D, Cichowski K, Mercer K, Murphy E, Schmitt E, Bronson RT, Umanoff H, Edelmann W, Kucherlapati R, Jacks T. K-ras is an essential gene in the mouse with partial functional overlap with N-ras. Genes Dev 1997; 11: 2468-2481.

[37] Koera K, Nakamura K, Nakao K, Miyoshi J, Toyoshima K, Hatta T, Otani H, Aiba A, Katsuki M. K-ras is essential for the development of the mouse embryo. Oncogene 1997; 15: 1151-1159.

[38] Plowman SJ, Williamson DJ, O'Sullivan MJ, Doig J, Ritchie AM, Harrison DJ, Melton DW, Arends MJ, Hooper ML, Patek CE. While K-ras is essential for mouse development, expression of the K-ras 4A splice variant is dispensable. Mol Cell Biol 2003; 23: 9245-9250.

[39] Quatela SE, Sung PJ, Ahearn IM, Bivona TG, Philips MR. (2008) Analysis of KRas phosphorylation, translocation, and induction of apoptosis. Methods Enzymol. 439: 87-102.

[40] Bivona TG, et al. (2006) PKC regulates a farnesyl-electrostatic switch on K-Ras that promotes its association with Bcl-XL on mitochondria and induces apoptosis. Mol Cell. 21: 481-93.

[41] Sharpe CC, et al. (1999) Evidence of a role for Ki-Ras in the stimulated proliferation of renal fibroblasts. J Am Soc Nephrol. 10: 1186-92.

[42] Plowman SJ, Arends MJ, Brownstein DG, Luo F, Devenney PS, Rose L, Ritchie AM, Berry RL, Harrison DJ, Hooper ML, Patek CE. The K-Ras 4A isoform promotes apoptosis but does not affect either lifespan or spontaneous tumor incidence in aging mice. Exp Cell Res 2006; 312: 16-26.

[43] Voice JK, Klemke RL, Le A, Jackson JH. Four human ras homologs differ in their abilities to activate Raf-1, induce transformation, and stimulate cell motility. J Biol Chem 1999; 274: 17164-17170. 
[44] Walsh AB, Bar-Sagi D. Differential activation of the Rac pathway by Ha-Ras and K-Ras. J Biol Chem 2001; 276: 15609-15615.

[45] Chang L, Goldman RD. Intermediate filaments mediate cytoskeletal crosstalk. Nat Rev Mol Cell Biol 2004; 5: 601-613. 
CONCLUSIONES 

Las conclusiones de este trabajo son,

1. La obstrucción ureteral unilateral en ratón induce la activación renal de Ras y de sus vías efectoras de señalización.

2. La activación de MAPK-ERK1/2 y PI3K-Akt participa en los cambios tempranos de la obstrucción ureteral unilateral en ratón. La activación de MAPK-ERK1/2 contribuye al mantenimiento de la estructura tubular renal protegiendo a las células tubulares de la apoptosis inducida por la obstrucción ureteral unilateral. La activación de PI3K-Akt contribuye en la supervivencia celular, proliferación celular, activación de fibroblastos y producción de matriz extracelular intersticial.

3. La administración de Angiotensina II en ratones aumenta la activación renal de Ras y de sus vías efectoras de señalización, MAPK-ERK1/2 y PI3K-Akt. La activación de Ras y el aumento de Angiotensina II inducido por la obstrucción ureteral unilateral, sugieren un papel importante de Angiotensina II en la mediación de Ras y sus vías efectoras MAPK-ERK1/2 y PI3K-Akt en el daño renal inducido por la obstrucción ureteral unilateral.

4. La activación de las isoformas H-Ras y N-Ras no participa en los cambios tempranos inducidos por la obstrucción ureteral unilateral, sin embargo la activación de la isoforma H-Ras participa en la proliferación y activación de miofibroblastos inducidos por la obstrucción ureteral unilateral a largo plazo.

5. La activación de la isoforma K-Ras participa en la proliferación y apoptosis inducida por la obstrucción ureteral unilateral a corto y largo plazo.

6. La activación de la isoforma K-Ras4A regula la expresión de marcadores la infiltración de miofibroblastos, la apoptosis y la proliferación celular en el modelo de obstrucción ureteral unilateral en ratones. 
